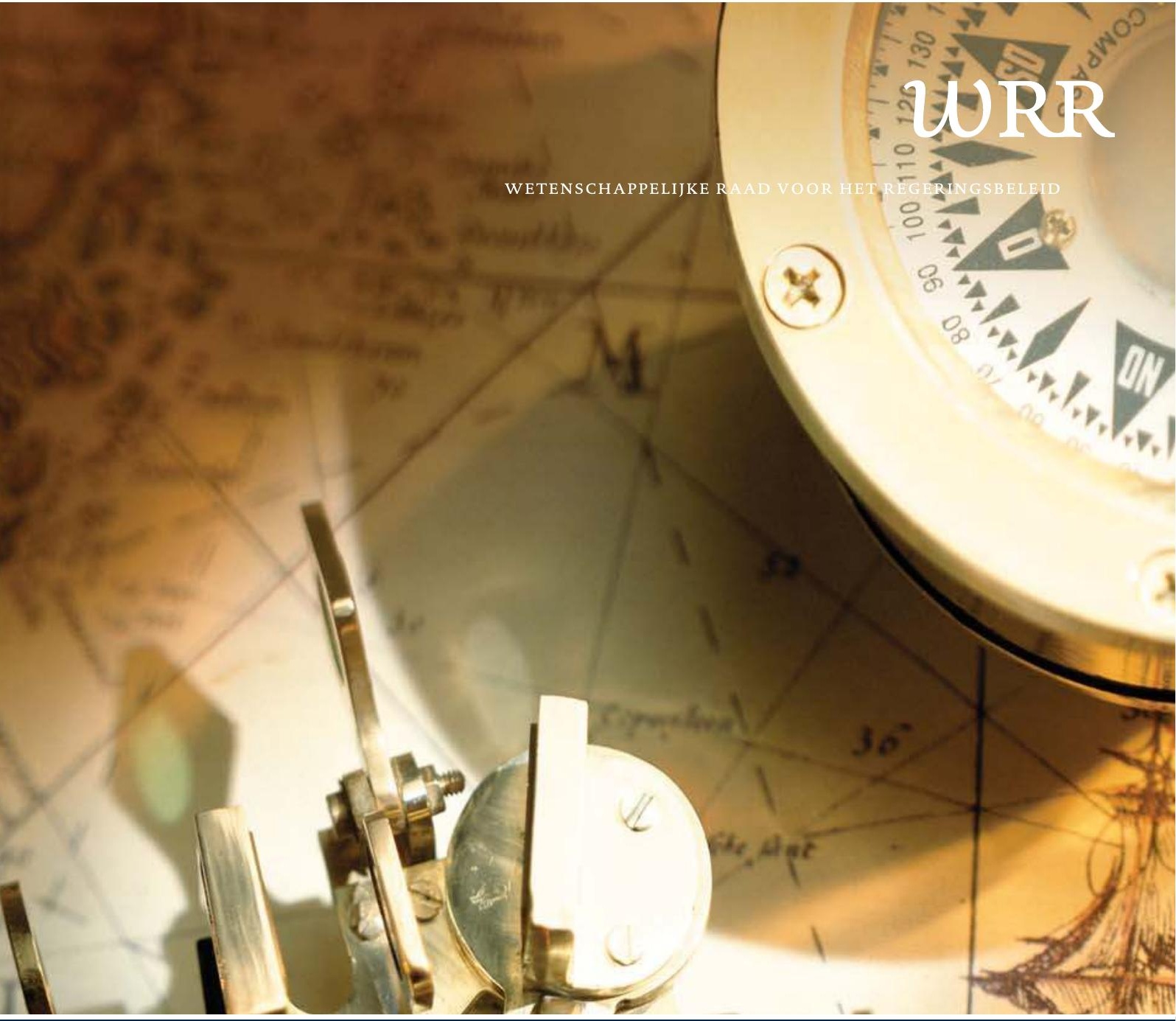

De verzorgingsstaat herwogen

OVER VERZORGEN, VERZEKEREN,

VERHEFFEN EN VERBINDEN

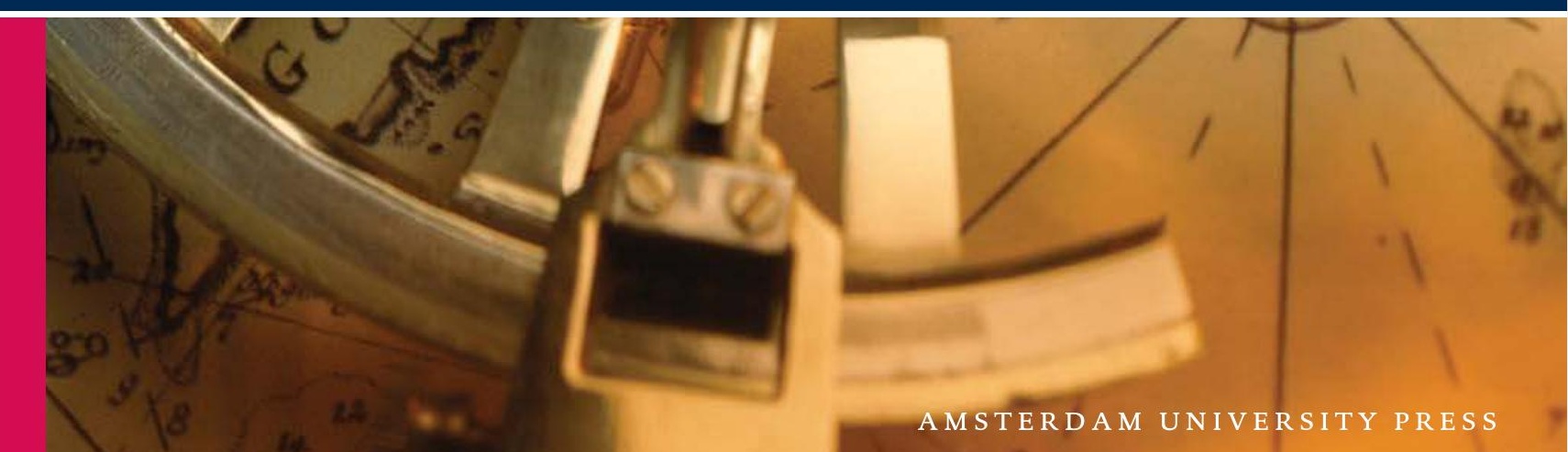


De verzorgingsstaat herwogen 
De Wetenschappelijke Raad voor het Regeringsbeleid werd in voorlopige vorm ingesteld in 1972. Bij wet van 30 juni 1976 (Stb. 413) is de positie van de raad definitief geregeld. De huidige zittingsperiode loopt tot 31 december 2007.

Ingevolge de wet heeft de raad tot taak ten behoeve van het regeringsbeleid wetenschappelijke informatie te verschaffen over ontwikkelingen die op langere termijn de samenleving kunnen beïnvloeden. De raad wordt geacht daarbij tijdig te wijzen op tegenstrijdigheden en te verwachten knelpunten en zich te richten op het formuleren van probleemstellingen ten aanzien van de grote beleidsvraagstukken, alsmede op het aangeven van beleidsalternatieven.

Volgens de wet stelt de WRR zijn eigen werkprogramma vast, na overleg met de minister-president die hiertoe de Raad van Ministers hoort.

De samenstelling van de raad is (tot 31 december 2007):

prof. dr. W.B.H.J. van de Donk (voorzitter)

mw. prof. dr. L. Hancher

prof. dr. P.A.H. van Lieshout

mw. prof. dr. P.L. Meurs

prof. dr. J.L.M. Pelkmans

drs. I.J. Schoonenboom

prof. dr. J.J.M. Theeuwes

prof. dr. P. Winsemius

Secretaris: prof. dr. A.C. Hemerijck

Plaatsvervangend secretaris: dr. R.J. Mulder

De WRR is gevestigd:

Lange Vijverberg 4-5

Postbus 20004

2500 EA Den Haag

Telefoon 070-356 46 oo

Telefax 070-356 4685

E-mailinfo@wrr.nl

Website http://www.wrr.nl 


\section{De verzorgingsstaat}

\section{herwogen}

OVER VERZORGEN, VERZEKEREN, VERHEFFEN

EN VERBINDEN 
Omslagafbeelding: (C) ANP Photo

Omslagontwerp: Studio Daniëls, Den Haag

Vormgeving binnenwerk: Het Steen Typografie, Maarssen

$\begin{array}{ll}\text { ISBN-13 } & 9789053569269 \\ \text { ISBN-1O } & 905356926 \mathrm{x} \\ \text { NUR } & 754\end{array}$

(C) WRR/Amsterdam University Press, Den Haag/Amsterdam 2006

Alle rechten voorbehouden. Niets uit deze uitgave mag worden verveelvoudigd, opgeslagen in een geautomatiseerd gegevensbestand, of openbaar gemaakt, in enige vorm of op enige wijze, hetzij elektronisch, mechanisch, door fotokopieën, opnamen of enige andere manier, zonder voorafgaande schriftelijke toestemming van de uitgever.

Voor zover het maken van kopieën uit deze uitgave is toegestaan op grond van artikel 16B Auteurswet $1912 j^{\circ}$ het Besluit van 20 juni 1974, Stb. 351, zoals gewijzigd bij het Besluit van 23 augustus 1985, Stb. 471 en artikel 17 Auteurswet 1912, dient men de daarvoor wettelijk verschuldigde vergoedingen te voldoen aan de Stichting Reprorecht (Postbus 3051, $2130 \mathrm{~KB}$ Hoofddorp). Voor het overnemen van gedeelte(n) uit deze uitgave in bloemlezingen, readers en andere compilatiewerken (artikel 16 Auteurswet 1912) dient men zich tot de uitgever te wenden. 
Aan de Minister-president

Voorzitter van de Ministerraad

De heer mr.dr. J.P. Balkenende

Postbus 20001

2500 EA Den Haag

ons kenmerk

2006130/wvdd/lt

onderwerp

WRR-rapport 76 'De

verzorgingsstaat herwogen' doorkiesnummer

070-356 4691

email

voorzitter@wrr.nl telefax

070-356 4685

\section{datum}

27 september 2006

Het doet mij genoegen $U$ hierbij te mogen aanbieden rapport nummer 76 van de WRR: 'De verzorgingsstaat herwogen. Over verzorgen, verzekeren, verheffen en verbinden.' 'De verzorgingsstaat' is een veelgehanteerd begrip waarachter een veelvoudige en heterogene verzameling van instituties, voorzieningen en regelgeving schuilgaat, en waarin ook maatschappelijke organisaties en burgers de nodige verantwoordelijkheden dragen. De verzorgingsstaat is, eigenlijk al sinds de eerste wetten die gericht waren op de bescherming tegen risico's van arbeid en gezondheid, voortdurend in debat en verandering. Dat is ook bij de hervormingen van de afgelopen jaren wel gebleken en dat zal de komende jaren niet anders zijn. De raad beschrijft en analyseert in dit rapport de wijze waarop ontwikkelingen als mondialisering en Europeanisering, sociaal-culturele en demografische ontwikkelingen en zelfstandige veranderingen in de sfeer van arbeidsmarkt en onderwijs, de verzorgingsstaat voor belangrijke nieuwe uitdagingen stelt. De raad laat zien hoe een benadering in termen van functies - verzorgen, verzekeren, verheffen en verbinden - mogelijkheden biedt voor een meer op de toekomst gerichte afweging van inhoudelijke prioriteiten en vormgeving van verantwoordelijkheden.

Naar het oordeel van de raad zal, gezien de geschetste uitdagingen, de komende jaren een sterk accent op de verheffings- en verbindingsfunctie noodzakelijk zijn, waarbij met name verbeteringen in het functioneren van de arbeidsmarkt en het onderwijs een zekere urgentie zouden moeten hebben.

Ingevolge de Instellingswet ziet de raad graag de bevindingen van de ministerraad tegemoet,

De voorzitter,

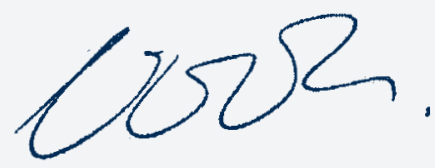

Prof.dr. W.B.H.J. van de Donk
De secretaris,

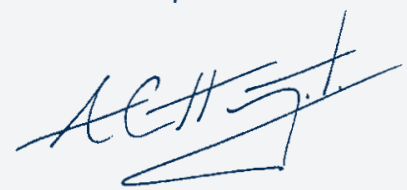

Prof.dr. A.C. Hemerijck 


\title{
INHOUDSOPGAVE
}

\author{
Samenvatting
}

1 De verzorgingsstaat: permanente discussie? 21

$\begin{array}{ll}1.1 & \text { Strijd om de verzorgingsstaat }\end{array}$

$\begin{array}{ll}1.2 & \text { Dertig jaar debat }\end{array}$

1.3 Een overgedetermineerd begrip 23

1.4 Geen grand design, maar historisch product 24

1.5 Van instituties naar functies $\quad 26$

$\begin{array}{ll}\text { 1.6 Opbouw van het rapport } & 27\end{array}$

2 De functies van de verzorgingsstaat 31

2.1 De verzorgingsstaat op de agenda 31

$\begin{array}{lll}2.2 & \text { Verzorgingsstaat in functies } & 35\end{array}$

$\begin{array}{lll}2.3 & \text { Verzorgen } & 38\end{array}$

$\begin{array}{lll}2.4 & \text { Verzekeren } & 40\end{array}$

$\begin{array}{lll}2.5 & \text { Verheffen } & 43\end{array}$

$\begin{array}{lll}2.6 & \text { Verbinden } & 45\end{array}$

$3 \quad$ Uitdagingen voor de verzorgingsstaat 53

3.1 Inleiding 53

3.2 Externe uitdaging: economische internationalisering 54

3.2.1 Gevolgen voor werkgelegenheid en sociale zekerheid 56

3.2.2 Budgettaire en fiscale gevolgen 60

3.3 Externe uitdaging: Europese economische en politieke integratie 62

3.4 Interne uitdaging: vergrijzing en ontgroening 66

3.5 Interne uitdaging: sociaal-culturele differentiatie en individualisering $\quad 68$

$\begin{array}{lll}3.6 & \text { Conclusie } & 72\end{array}$

$4 \quad$ De Nederlandse verzorgingsstaat in Europees-vergelijkend $\begin{array}{ll}\text { perspectief } & 75\end{array}$

$\begin{array}{ll}4.1 & 75\end{array}$

4.2 Verzorgingsstaten tussen economische doelmatigheid en rechtvaardigheid $\quad 76$

$\begin{array}{lll}\text { 4.2.1 Overheidsuitgaven } & 78\end{array}$

4.2.2 Economische prestaties en werkgelegenheid 82

$\begin{array}{ll}\text { 4.2.3 Nederland in perspectief } & 88\end{array}$

$\begin{array}{lll}4.3 & \text { Op functies vergeleken } & 92\end{array}$

4.3.1 Verzorgen 93

$\begin{array}{lll}4.3 .2 & \text { Verzekeren } & 95\end{array}$

$\begin{array}{ll}4 \cdot 3 \cdot 3 \text { Verheffen } & 99\end{array}$

$\begin{array}{ll}4 \cdot 3 \cdot 4 \text { Verbinden } & 104\end{array}$

4.4 Conclusie 110 
$5 \quad$ Verzorgen: veilig stellen van verzorgingscapaciteit $\quad 115$

$\begin{array}{ll}5.1 & \text { Inleiding } \\ 5.15\end{array}$

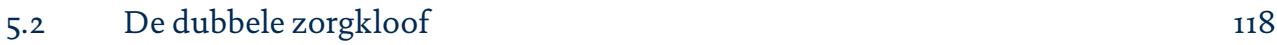

$\begin{array}{lll}5.3 & \text { De opgaven } & 126\end{array}$

5.4 Informele zorg 130

5.4.1 Informele zorg: niet altijd (een) ideaal 131

5.4.2 Informele zorg verwaarloosd? 131

5.4.3 Minder formele zorg, meer informele zorg? 132

$\begin{array}{ll}\text { 5.4.4 Arbeid en zorgbeleid } & 135\end{array}$

$\begin{array}{ll}\text { 5.4.5 Enkele subconclusies } & 140\end{array}$

5.5 De bijdrage van volkshuisvesting aan de zorgagenda $\quad 141$

5.6 Conclusie: de verzorgende verzorgingsstaat 144

6 Verzekeren: balanceren tussen onder- en oververzekering $\quad 147$

$\begin{array}{lll}6.1 & \text { Inleiding } & 147\end{array}$

6.2 Het risicomanagement in de Nederlandse verzorgingsstaat: mate en

$\begin{array}{ll}\text { 6.2.1 Verzekeren: publiek en privaat } & 147\end{array}$

$\begin{array}{ll}\text { 6.2.2 Sociale verzekeringen } & 150\end{array}$

6.2.3 Subconclusie: veranderende uitdagingen; geëvalueerde

6.3 Welke risico's zijn hoe verzekerd; een plaatsbepaling $\quad 152$

$\begin{array}{ll}\text { 6.3.1 Inleiding } & 152\end{array}$

6.3.2 Een historische plaatsbepaling naar risico's en groepen: oud

6.3.3 Een internationaal-vergelijkende plaatsbepaling $\quad 155$

$\begin{array}{lll}6.3 .4 & \text { Subconclusie } & 156\end{array}$

6.4 Ontwikkelingen in het denken over de verzekeringsfunctie 157

$\begin{array}{ll}\text { 6.4.1 Inleiding } & 157\end{array}$

6.4.2 Van groei naar beheersing van de verzekeringsfunctie 157

6.4.3 Hoe om te gaan met nieuwe risico's? 158

6.4.4 Van werkloosheidsbestrijding naar participatiebevordering als

6.4.5 De rol van informatie in relatie tot de legitimiteit van regelingen $\quad 161$

6.4.6 Subconclusie: verzekeringsfunctie meer verbinden met de andere $\begin{array}{ll}\text { functies } & 164\end{array}$

6.5 Beïnvloedbaarheid, verantwoordelijkheidsverdeling en besturing $\quad 165$

$\begin{array}{ll}\text { 6.5.1 Inleiding } & 165\end{array}$

$\begin{array}{ll}\text { 6.5.2 De sociale verzekeringsfunctie in relatie tot de collectieve } & \\ \text { sector } & \end{array}$

6.5.3 Verzekeringsfunctie is eerst verstatelijkt en later deels gepriva-
tiseerd

6.5.4 Nieuwe verantwoordelijkheden voor het middenveld? 168 
6.6 De verzekeringsfunctie geëvalueerd $\quad 168$

$\begin{array}{lll}\text { 6.6.1 Inleiding } & 168\end{array}$

6.6.2 De verzekeringsfunctie in een welvarender samenleving $\quad 169$

6.6.3 De noodzakelijke veranderingen in de vorm van de verzekeringsfunctie 171

6.7 Conclusie: naar meer preventie als de beste verzekering 173

$7 \quad$ Verheffen: investeren in een zachtmoedige meritocratie 181

$\begin{array}{ll}7.1 & \text { Inleiding } \\ 7.2 & 181\end{array}$

$\begin{array}{lll}7.2 & \text { Verheffen in het onderwijs } & 184\end{array}$

$\begin{array}{lll}\text { 7.2.1 } & \text { De prestaties van het Nederlandse onderwijs } & 187\end{array}$

$\begin{array}{lll}\text { 7.2.2 } & \text { Voorschoolse educatie: voorbij de opvang } & 187\end{array}$

7.2.3 Primair onderwijs: over ongelijkheid en diversiteit $\quad 189$

7.2.4 Voortgezet onderwijs: over doorstroom en uitval 191

7.2.5 Hoger onderwijs: tussen kwantiteit en kwaliteit 196

7.2.6 Postinitieel onderwijs: naar een leven lang leren? 199

7.3 Verheffing op de Nederlandse arbeidsmarkt 201

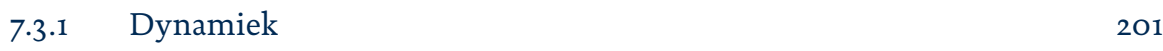

$\begin{array}{lll}7 \cdot 3 \cdot 2 & \text { Instroom } & 203\end{array}$

$\begin{array}{lll}7 \cdot 3 \cdot 3 & \text { Doorstroom } & 205\end{array}$

7.3.4 De Nederlandse arbeidsmarktprestaties gewogen 206

$\begin{array}{lll}7.4 & \text { Verbeteren van de verheffingsfunctie } & 208\end{array}$

$\begin{array}{ll}\text { 7.4.1 Betere verheffing in het onderwijsbestel } & 208\end{array}$

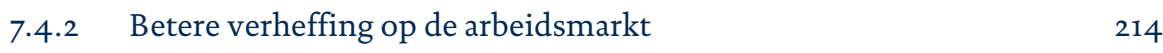

$\begin{array}{lll}7.5 & \text { Conclusie: naar een zachtmoedige meritocratie } & 217\end{array}$

$8 \quad$ Verbinden: overbruggen van sociale afstand 219

$\begin{array}{ll}8.1 & \text { Inleiding } \\ 8.219\end{array}$

8.2 De verbindingsfunctie nader beproefd 222

8.3 Rijk en arm in Nederland $\quad 225$

8.3.1 Wat te doen? 228

8.4 Oud en jong in Nederland 229

8.4.1 Oud en jong op de arbeidsmarkt 230

8.4.2 Inkomen en vermogen van oud en jong 232

8.4.3 Wat te doen? 234

8.5 Interetnische verbindingen $\quad 236$

8.5.1 De school als ontmoetingsplaats 237

8.5.2 Wat te doen? 240

8.5.3 Verbinden op de werkvloer $\quad 242$

8.5.4 Wat te doen? $\quad 242$

8.5.5 Verbinden in wijk en buurt 244

8.6 Conclusie: de verbindende verzorgingsstaat 246 
9 Conclusie $\quad 249$

9.1 Andere beleidsoriëntatie $\quad 249$

9.2 Andere weging van functies van de verzorgingsstaat 251

9.3 Andere verwachtingen en ambities $\quad 257$

9.4 Andere verantwoordelijkheidsverdeling 260

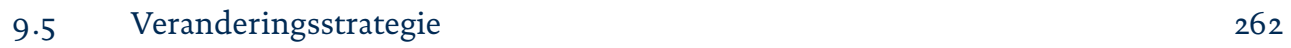

$\begin{array}{ll}\text { Literatuur } & 265\end{array}$ 


\section{SAMENVATTING}

\section{Elan}

De manier waarop Nederland in de twintigste eeuw een stelsel van bescherming en participatie heeft opgezet, is over de hele linie een indrukwekkende prestatie. Een goed huis, goede voeding, goede kleding, goede gezondheidszorg en goed onderwijs zijn in principe voor iedereen bereikbaar geworden. Zeker sinds de jaren zeventig is de precieze vormgeving van de verzorgingsstaat echter permanent onderwerp van discussie en strijd. Dat heeft geleid tot een veelheid van incrementele aanpassingen. Het is nu nodig om verder te kijken dan kleine aanpassingen. De verzorgingsstaat krijgt te maken met uitdagingen die een verderstrekkend perspectief vergen. Dit advies schetst hoe een verzorgingsstaat eruitziet die past bij de uitdagingen van de eenentwintigste eeuw en die voldoende open is om om te gaan met een nieuwe internationale orde en een nieuw type burger.

Bij een verderstrekkend perspectief hoort een aansprekend vocabulaire. Het is noch productief noch nodig om de verzorgingsstaat slechts in defensieve termen te benaderen. Te veel worden de ontwikkelingen die op de verzorgingsstaat afkomen gezien als bedreigingen. Zo lijkt globalisering bijvoorbeeld vooral problemen met zich mee te brengen; dat globalisering ook een groeiende welvaart met zich meebrengt, wordt te gemakkelijk veronachtzaamd. Hetzelfde geldt voor vergrijzing, die vooral als een dreigende strijd tussen generaties beleefd lijkt te worden, zodat de essentie over het hoofd wordt gezien: een langer leven, vaak in goede gezondheid. Dit advies wil een schets geven van een uitgedaagde, maar ook uitdagende verzorgingsstaat die toekomstbestendig is - al dekt het woord 'verzorgingsstaat' daarbij steeds minder de lading.

\section{Verzorgingsstaat in functies}

Bij een principiële benadering van (de toekomst van) de verzorgingsstaat past een perspectief dat vertrekt vanuit de vraag wat een verzorgingsstaat eigenlijk verondersteld wordt te doen. Niet de institutionele tekortkomingen, maar de vraag of de gestelde doelen gehaald worden, dient voorop te staan. Vandaar dat in dit advies de verzorgingsstaat geanalyseerd wordt aan de hand van de functies die hij vervult. Een historische analyse leert dat de verzorgingsstaat vier hoofdfuncties vervult: verzorgen, verzekeren, verheffen en verbinden. De zwaarte van die functies wisselt in de tijd, net als de instrumenten die worden ingezet om ze te realiseren. In dit rapport analyseren we de manier waarop en de mate waarin die functies vervuld worden in het licht van externe en interne uitdagingen. Globalisering zal, zo is een gewettigde verwachting, de snelle opmars die ze sinds de jaren tachtig maakt, doorzetten. Tot op heden bleek de Nederlandse economie die ontwikkeling echter goed te accommoderen, maar het vergt inspanningen om die situatie vast te houden. In politieke zin zal globalisering, vooral door de processen binnen de EU, ertoe leiden dat Nederland steeds meer een semi-soeverein land wordt, met maar beperkte mogelijkheden voor eigen beleid. Binnen Nederland zullen een veranderende demografie (vergrijzing en ontgroening) en de 
behoefte van burgers om zich in psychologische en culturele zin indivueler te kunnen uiten - wat niet betekent dat ze ook in sociale zin atomiseren - hun eisen stellen aan de verzorgingsstaat van de toekomst.

De consequentie van deze veranderingen is dat er een nieuwe invulling moet worden gegeven aan de verzorgingsstaat. De afgelopen decennia is er ruimschoots aandacht besteed aan hervormingen van de onderdelen van de verzorgingsstaat die vooral gericht zijn op verzekeren en verzorgen; het wordt nu tijd om de beleidsinspanningen te concentreren op die onderdelen die gericht zijn op verheffen en verbinden. Het streven om verheffen en verbinden te voorzien van een eigentijdse en hoogwaardige invulling, moet nadrukkelijk herkenbaar worden in de toekomstige beleidsontwikkeling. Laten we dat per functie toelichten.

\section{Verzekeren: balanceren tussen onder-en oververzekering}

De verzekeringsfunctie houdt in dat mensen onder condities en tot op zekere hoogte zich verzekerd weten tegen bepaalde vormen van inkomensverlies. Die functie heeft voor een belangrijk gedeelte gestalte gekregen via het stelsel van sociale zekerheid. De transformaties die in het stelsel mogelijk en wenselijk waren, zijn voor het grootste deel gerealiseerd. De kosten zijn verminderd, de doelmatigheid van het stelsel is verhoogd en een beter evenwicht in rechten en plichten is tot stand gebracht. Zo is het budgettaire beslag dat de WW, WAO, en Bijstand op het bruto binnenlands product leggen, fors gedaald: dat percentage is sinds medio jaren tachtig bijna gehalveerd. Van een land dat gekenmerkt werd door een relatief hoge mate van inactiviteit en een ruimhartig stelsel van sociale zekerheid, is Nederland een land geworden dat in arbeidsparticipatie in personen gemeten alleen voorbij gestreefd wordt door Denemarken. De afgelopen twintig jaar wisten we het aantal werkzame mensen met twee miljoen te verhogen, terwijl het aantal inactieven in absolute zin niet toenam.

Tegelijk is de werking van de verzekeringen wezenlijk gewijzigd: ze omvatten nu allemaal substantiële prikkels om het beroep op voorzieningen te beperken (denk aan de loondoorbetaling in de eerste twee ziektejaren, de risicodragende rol van de gemeenten bij de Bijstand en de herziening van de ww). In de uitvoering van al deze wetten valt wellicht nog het een en ander te verbeteren, en een enkele regeling behoeft nog nadere aandacht, maar de belangrijkste systeemtransformaties in de sociale zekerheid naderen voor dit moment hun voltooiing. Socialezekerheidsbeleid kan in het teken van de implementatie komen te staan, in plaats van in het teken van stelselwijzigingen.

Bij die implementatie valt overigens nog winst te boeken. In het bijzonder zijn er in de sociale zekerheid nog mogelijkheden om verzekeren meer in het kader te plaatsen van verheffen. In de vormgeving en uitvoering van de verzekeringsfunctie is het accent de afgelopen jaren al steeds meer verschoven van inkomenscompensatie naar tegenprestatie. $\mathrm{Nu}$ is een volgende stap mogelijk: voor wie werkloos wordt, is werk of scholing beschikbaar. Omdat het organiseren van een dergelijke omslag tijd kost, zou begonnen kunnen worden door voor de groep jongeren tot 
25 jaar het recht op een bijstandsuitkering te vervangen door het recht op werk of scholing. Een dergelijke maatregel zou vastleggen wat in veel steden in het kader van Wet Werk en Bijstand gaandeweg al vorm aan het krijgen is.

\section{Verzorgen: veiligstellen van verzorgingscapaciteit}

De verzorgingsstaat biedt zorg voor wie door fysieke of cognitieve beperkingen onvoldoende meekomt - dat is een oerfunctie van de verzorgingsstaat. De verzorgingscapaciteit komt de komende jaren onder druk te staan vanwege de vergrijzing. Zorgbeleid moet in het licht van de vergrijzing echter niet teruggebracht worden tot een primair financieel vraagstuk - dat is vooral een kwestie van wijs beleid dat heel wel mogelijk is als er een politiek breed gedragen langetermijnperspectief ontwikkeld wordt. Bovendien gaat het eerder om een verdelingsprobleem tussen rijke en minder rijke ouderen dan om een financieringsprobleem. De personele en infrastructurele opdrachten die aan de vergrijzing kleven, zijn echter taaier. De toekomstige generatie ouderen is niet alleen omvangrijk, maar ziet zorg bovendien steeds minder als een gunst en steeds meer als een recht. Dat betekent dat niet alleen de kwantiteit maar ook de kwaliteit van de professionele zorg aan hoge eisen zal moeten voldoen, en aan deze eisen kan alleen tegemoet worden gekomen als in het komende decennium alle schoolverlaters in de zorg gaan werken en alle nieuwbouw speciaal op ouderen wordt afgestemd. Dat is wenselijk noch realiseerbaar. Geen enkele maatregel is op zichzelf afdoende, zelfs geen grootscheepse arbeidsmigratie. Een samenhangend pakket van maatregelen is daarom nodig: adequatere mogelijkheden om werk en zorg te combineren, technologische innovatie, een financieringsstructuur die meer prikkelt tot differentiatie en klantoriëntatie, en meer ruimte voor informele zorg. 'Tijdspolitiek' zal een nadrukkelijker thema in het beleid moeten worden.

\section{Verheffen: investeren in een zachtmoedige meritocratie}

De verheffingsfunctie behoeft een nadrukkelijke impuls. Nederland heeft in de opbouw van zijn verzorgingsstaat het accent gelegd op ouderen. Zij hebben verhoudingsgewijs genereuze voorzieningen en inkomensregelingen. Dat geldt voor publieke regelingen, zoals blijkt uit de omvang van de ouderenzorg en de AOW, en vooral voor (semi-)private bezittingen, zoals huizenbezit, vermogen en pensioenaanspraken. Vergeleken met andere Europese landen kennen Nederlandse ouderen ook significant minder armoede. De zorg voor kinderen steekt daar, in internationaal opzicht, echter mager bij af. De omvang van verlofregelingen voor ouders is beperkt en kinderopvang is in Nederland beperkt en met weinig inhoudelijke ambitie van de grond gekomen. Het Nederlandse onderwijs presteert alleszins redelijk, maar publieke uitgaven aan onderwijs en gezinsbeleid liggen hier lager dan in vrijwel alle EU-15 landen. In vergelijkend perspectief is het opleidingsniveau van de Nederlandse bevolking gemiddeld niet hoog en blijft de duur van onderwijsdeelname achter bij de ons omringende landen. Nederland staat met enkele mediterrane landen bovenaan de OECD-lijst als het gaat om het aantal jongeren dat zonder startkwalificatie de school verlaat. Alhoewel veel van deze jongeren op enig moment toch wel werk weten te vinden - zeker in perioden van hoogconjunctuur - blijft de kwaliteit van de banen waar ze toegang tot 
hebben beperkt, zeker omdat tweede- en derdekansonderwijs in Nederland onvoldoende ontwikkeld is. Nederland investeert - na de mediterrane landen het minste in bedrijfsspecifieke opleidingen. Meer nog dan hoge schooluitval is in Nederland de lage schoolterugkeer het probleem. Kortom, onze ambitie op dit vlak moet en kan omhoog.

De meeste aandacht dient te worden gegeven aan kinderen, vaak van allochtone afkomst, die aan de basisschool beginnen met leerachterstanden van vaak meer dan een jaar. Goede stimuleringsprogramma's blijken voorschoolse achterstand met de helft tot twee derde terug te kunnen brengen. De inzet moet dan ook zijn om te zorgen dat kinderen die voor voorscholing in aanmerking komen er ook gebruik van gaan maken. Integratie van de stimuleringsprogramma's (voor- en vroegschoolse educatie) in de reguliere kinderopvang is daar de meest geëigende vorm voor. Daartoe dient kinderopvang voor minstens een aantal dagen per week voor alle kinderen een basisvoorziening te worden.

Er moet ook meer ambitie voor kinderen in de basisschoolleeftijd aan de dag worden gelegd. Investeringen in het onderwijs zijn daarvoor een eerste vereiste. De kwaliteit van docenten moet worden verbeterd en het aantal uren dat les wordt gegeven moet omhoog. Bovendien kan tussen- en naschoolse opvang beter in het teken van vorming worden geplaatst dan in het teken van opvang. Kinderen zouden een breed palet aan sociale, culturele, sportieve en cognitieve mogelijkheden aangeboden moeten krijgen. Het gaat er immers om niet alleen een oudervriendelijk land te worden, maar ook een kindvriendelijk land.

Menselijk talent wordt ook onderbenut in het (voorbereidend) beroepsonderwijs. Het vmbo en mbo kunnen verder worden verbeterd. De belangrijkste ingrediënten daarvoor zijn: meer ruimte voor soepele doorstroom en voor differentiatie zowel door variatie in intensiteit, niveau en inhoud van het onderwijsaanbod als door flexibilisering van eindtermen. De jongeren waarop dit onderwijs zich richt, bevinden zich in een lastige en turbulente levensfase. Dat brengt met zich mee dat scholen naast kennisoverdracht ook individuele begeleiding moeten kunnen bieden. Het (weer) overbruggen van de afstand tussen school en ouders enerzijds, en tussen de school en instanties op het gebied van de jeugdzorg anderzijds, vergt aandacht en creatieve oplossingen.

Ook universiteiten en het hoger beroepsonderwijs schieten tekort in het vervullen van hun verheffingsopdracht. Universiteiten hebben de spanning tussen hun twee kerntaken, het opleiden van wetenschappers en het opleiden van professionals, nooit goed tot een oplossing weten te brengen. Meer differentiatie in inhoud en niveau zal nadrukkelijker gezocht moeten worden. In dat kader verdient ook de studiefinanciering bijstelling. Wanneer men de verheffingsfunctie serieus neemt is de studiefinanciering zo ingericht dat zij studeren - ook op latere leeftijd en ook als het gaat om een tweede of derde studie - maximaal bevordert en bijbaantjes ontmoedigt. 
Verheffen is een functie die vorm kan krijgen via het onderwijs, maar ook langs andere wegen. De arbeidsmarkt en de sociale zekerheid zouden meer in dit teken moeten komen te staan. Vrouwen zijn even goed opgeleid, maar werken minder uren buitenshuis dan mannen en vrouwelijk talent is nog steeds scheef verdeeld over de Nederlandse economie. Voor jongeren uit allochtone kring speelt het tegenovergestelde. Ze zijn niet overschoold, maar onderschoold en worden bovendien onvoldoende snel opgenomen in de arbeidsmarkt. Een strakker antidiscriminatiebeleid, vormen van naming and shaming, goede voorbeeldwerking en een stevige inzet van onderhandelingsinstrumenten van de overheid in overleg met werkgevers zijn een deel van het antwoord.

\section{Verbinden: overbruggen van sociale afstand}

Wellicht de lastigste opgave waar de Nederlandse verzorgingsstaat voor staat, is een nieuwe invulling te geven aan de verbindingsfunctie. Het heterogener en individueler worden van de Nederlandse bevolking maken dat 'de' Nederlandse samenleving minder vanzelfsprekend geworden is, en ook minder vanzelfsprekend zal blijven. Het streven moet zijn om voor iedereen mogelijkheden te scheppen om bindingen aan te gaan, dan wel zich eruit los te maken en ze in te wisselen voor andere. In de termen van dit rapport: 'zware gemeenschappen' moeten 'licht' gemaakt worden, en 'lichte gemeenschappen' voldoende 'zwaar'.

Verbinden is bij uitstek een functie die niet alleen als overheidstaak aangemerkt kan worden. Ook van andere actoren - binnen het maatschappelijk middenveld mag verwacht worden dat zij zich inzetten. De overheid kan daaraan bijdragen door te zorgen dat tegenstellingen niet zo structureel worden dat ze op termijn ontwrichten. Dat stelt zware eisen aan de instituties van het onderwijs en de arbeidsmarkt. Die moeten leren omgaan met nieuwe tegenstellingen. De oorspronkelijke tegenstelling die de verzorgingsstaat hielp overbruggen, die tussen arm en rijk, heeft veel van haar scherpte verloren. Het overbruggen van nieuwe tegenstellingen komt daarvoor in de plaats. De verbinding tussen hoogen laagopgeleiden is daarbij nog het geringste probleem. Anders dan veel ons omringende landen slaagt de Nederlandse verzorgingsstaat er redelijk in om groeiende ongelijkheden in de primaire inkomensverdeling via belasting- en premieheffing te neutraliseren. De verbinding tussen generaties is lastiger. Dat valt weliswaar mee op de arbeidsmarkt, die zeker niet vriendelijker is voor ouderen dan voor jongeren, maar op een aantal andere terreinen voelen jonge generaties zich wel degelijk uitgesloten. Zo zijn de bezuinigingen in de sociale zekerheid in belangrijke mate wel van toepassing op jongeren, maar niet op mensen die nu ouder zijn dan vijftig. Verder is de toegang tot de koopwoningmarkt voor jongeren zeer moeilijk geworden. Dat kan gaan knagen aan de verhouding tussen de generaties.

Het overbruggen van verschillen langs etnische lijnen is echter ongetwijfeld de grootste opgave. Samen met België en Frankrijk scoort Nederland in Europa het hoogst als het gaat om de spanning die mensen voelen tussen allochtonen en autochtonen. Veel allochtonen in Nederland percipiëren de klassieke instituties 
(scholing, huisvesting, arbeid) als ondoordringbaar, en voor een deel van hen zijn ze dat ook. Dat kan zich vertalen in een (versterkt) zoeken naar eigen identiteiten of in het terugtrekken in eigen kring, wat de verbindingsopgave alleen maar lastiger maakt. Voor een tweezijdige verbinding tussen allochtonen en autochtonen is een brede strategie nodig. Aandacht voor de culturele dimensie van verbinding is, zo is in de jaren tachtig en negentig gebleken, een onvoldoende voorwaarde voor integratie - het gaat er ook om verbinding te realiseren in 'harde' aspecten van de samenleving. Arbeidsorganisaties zijn in dat kader van evident belang. Evenzeer is het voorschoolse en (basis)onderwijs een cruciale factor, omdat dit in de huidige samenleving de plaats bij uitstek is waar kinderen (en hun ouders) elkaar kunnen ontmoeten zodat stereotypering vermindert.

Het ligt voor de hand om gemeenten nadrukkelijker een verbindingsopdracht te geven, en om ze daartoe ook wettelijk en financieel in staat te stellen. Het komt daarbij vooral aan op het ontwikkelen van lokale, op specifieke situaties toegesneden oplossingen. In kleinere gemeenten zou het zwaartepunt kunnen liggen op voldoende gemengd onderwijs. In de grote steden, met een hoge concentratie van allochtone en een gebrek aan voldoende autochtone kinderen, zal het antwoord vooral gevonden moeten worden in interetnisch mengen en extra aandacht voor de kwaliteit van het onderwijs; verheffen is immers ook een sleutel tot verbinden. Zo wordt aangesloten op de manier waarop de laatste jaren op lokaal niveau burgemeesters en wethouders het als hun taak definieerden om verbinding tot stand te brengen en wordt inhoud gegeven aan het concept 'verbindingsstad'.

\section{Hoe te veranderen}

De kernboodschap van dit advies is dat de functies van de verzorgingsstaat herwogen moeten worden. Het is tijd voor een verschuiving van aandacht van de functies verzekeren en verzorgen naar de functies verheffen en verbinden. Hoe is een dergelijke doorontwikkeling van de verzorgingsstaat vorm te geven? Van belang is allereerst om een voldoende ambitieus klimaat te creëren. De transformatie van de verzorgingsstaat vergt een specifieke stijl: de stijl van wenkende idealen. Incrementele, bijna technische aanpassingen, met een hoog no-regretgehalte en een lage mate van politieke kleuring werken onvoldoende. Bovendien is een strategie vereist die gericht is op langetermijnveranderingen en die deze ook weet door te voeren in een politieke arena die vaak gericht is op de korte termijn. Zo ontstaat een toekomstgericht, toekomstbestendig en breed gedragen programma voor de verzorgingsstaat van de eenentwintigste eeuw. 




\section{TEN GELEIDE}

Dit rapport is voorbereid door een interne projectgroep van de WRR. Voorzitter was prof.dr. Peter van Lieshout, lid van de raad. Verder bestond deze projectgroep uit de volgende stafleden: dr. Ewald Engelen, dr. Cock Hazeu (tevens projectcoördinator), prof. dr. Anton Hemerijck, dr. Monique Kremer, Cindy Kroon, drs. Peter Sleegers en dr. Gerard de Vries. Hiernaast hebben dr. Wendy Asbeek Brusse, mr. dr. Ton van den Brink en drs. Dennis Broeders, alsmede een aantal andere raads- en stafleden, bijdragen geleverd.

Statistisch materiaal op Europees-vergelijkend terrein is in opdracht van de WRR verzameld door het Centrum voor Sociaal Beleid van de Universiteit Antwerpen (Bea Cantillon, Ive Marx); materiaal dat met name in hoofdstuk 4 van dit rapport is gebruikt.

Bij de voorbereiding zijn op verschillende manieren inzichten verzameld. Zo zijn verschillende bezoeken gebracht aan buitenlandse 'denktanks', omdat in de meeste Europese landen de verzorgingsstaat op dit moment hevig bediscussieerd wordt. Bijzondere vermelding verdient het bezoek dat de projectgroep in april 2005 bracht aan de Ierse National Economic and Social Council om te discussiëren over hun ideeën over een 'Developmental welfare state'. In Nederland heeft onder meer een gedachtewisseling plaatsgevonden met de Sociaal-Wetenschappelijke Raad van de KNAW. Inspiratie is ook opgedaan in het kader van de WRRlezing en aansluitende workshops van prof. Gøsta Esping-Andersen en prof. Saskia Sassen in december 2005.

Verder hebben in de voorbereiding van dit rapport leden van de projectgroep met vele deskundigen gesproken. Een aantal externe deskundigen heeft bovendien commentaar geleverd op conceptteksten. De projectgroep heeft dankbaar gebruik gemaakt van hun kennis en deskundigheid. De raad is hen erkentelijk voor hun bijdrage - al geldt ook nu dat voor de inhoud van het rapport alleen de raad verantwoordelijk is. De volgende personen - bijna allen hoogleraar - wil de raad in het bijzonder bedanken: Paul de Beer, Jos de Beus, Lans Bovenberg, Gabriël van den Brink, Jan-Willem Duyvendak, Godfried Engbersen, Han Entzinger, Kees van Kersbergen, Trudie Knijn, Frans Leijnse, Paul Leseman, Robert Maier, Marc van der Meer, Wim Meijnen, Ruud de Mooij, Wim van Oorschot, Kees van Paridon, Paul Schnabel, Romke van der Veen en Maykel Verkuyten. Inspirerende input kwam eveneens van Tony Atkinson (vK), Keith Banting (Canada), Marcel Canoy (EU), Jane Jenson (Canada), Jon Kvist (Denemarken), Janet Newman (VK), Bart van Riel (SER) en Günther Schmid (Duitsland). 


\section{DE VERZORGINGSSTAAT: PERMANENTE DISCUSSIE?}

\subsection{STRIJD OM DE VERZORGINGSSTAAT}

De verzorgingsstaat anno 2006: in Frankrijk gaan studenten de straat op om te protesteren tegen een wet die werkgevers moet verlokken meer jongeren een baan te geven door arbeidscontracten van tijdelijke duur voor jongere werknemers mogelijk te maken. Dat wetsvoorstel was een antwoord op de opstand van een half jaar daarvoor van een andere groep jongeren; jongeren die eerder in de banlieus van de grote steden rellen ontketend hadden omdat ze helemaal geen baan konden krijgen, ook geen tijdelijke. In Duitsland blijkt het al evenzeer moeilijk om hervormingen door te voeren. Daar moeten enkele grote bedrijven dreigen met het verplaatsen van werkgelegenheid naar landen in Oost-Europa om concessies af te dwingen. En het lukt de nieuwe, brede coalitie alleen na zware onderhandelingen om een beperkt aantal transformaties in gang te zetten. In Nederland zette het kabinet-Balkenende-II in op een drastische reductie van de VUT- en prepensioenvoorzieningen, en stuitte daarbij op groot verzet; de plannen kunnen uiteindelijk alleen worden doorgezet door de bestaande regelingen (en de WAO) in stand te houden voor de groep mensen die nu 50 jaar of ouder zijn, en ze voor een belangrijk deel te laten betalen door de leeftijdsgroep daaronder.

Deze ontwikkelingen lijken de moderne verzorgingsstaat te karakteriseren: veranderingen blijken moeilijk; gevestigden en buitenstaanders voeren een hevige strijd, of dat nu om de strijd tussen de kansarme allochtone en kansrijke autochtone jongeren gaat in Frankrijk, tussen insiders en outsiders in Duitsland, of tussen jongeren en de oudere werknemers in Nederland. De manier waarop er over de verzorgingsstaat gesproken wordt, kent dan ook een sterk defensief vocabulaire. Het gaat over strijd en er wordt al snel gesproken in termen van winnaars en verliezers. Het gaat ook over bedreigingen: globalisering is bijvoorbeeld iets wat vooral problemen met zich mee lijkt te brengen. Hetzelfde geldt voor de vergrijzing, die ook vooral als problematisch - een dreigende strijd tussen generaties - beleefd lijkt te worden, en waar de essentie dat het primair een vergroting van levensmogelijkheden van mensen betekent, maar al te gemakkelijk veronachtzaamd wordt. Om de richting van herzieningen te onderbouwen, lijkt een wervend, toekomstgericht, open en meeslepend 'verhaal' te ontbreken.

Het is de vraag of het debat over de toekomst van de verzorgingsstaat in een positieve sleutel gezet kan worden. De manier waarop westerse landen in de twintigste eeuw een stelsel van bescherming en participatie hebben opgezet, is, hoeveel kritiek men ook op onderdelen kan hebben, over de hele linie een indrukwekkende prestatie. Een goed huis, goede voeding, goede kleding, goede gezondheidszorg en goed onderwijs zijn nu in principe voor iedereen bereikbaar (Schnabel 2004). Zou het dan niet mogelijk zijn om een perspectief op de verzor- 
gingsstaat te ontwikkelen dat past bij de eenentwintigste eeuw, dat voldoende open is om om te gaan met een nieuwe internationale orde, en een nieuw type burger, en dat getoonzet is in een aansprekend vocabulaire? Een perspectief dat lessen uit het verleden trekt en durft te leren van de momenten waarop het niet goed ging? Een schets van een dergelijk programma en een bijpassend vocabulaire voor de verzorgingsstaat van de eenentwintigste eeuw staat centraal in dit advies.

\subsection{DERTIG JAAR DEBAT}

Het zoeken naar een wervend perspectief voor de verzorgingsstaat brengt al meer dan drie decennia veel mensen in beweging. Zoals Powell en Hewitt (2002) het uitdrukken: "The welfare state has been in crisis (Mischra 1984), under threat (Lowe 1999), in transition (Johnson 1987; Esping-Andersen 1996), resilent or robust (Le Grand 1991), reshaped (Johnson 1990), refashioned (Wicks 1987), restructured (Sullivan 1992), retrenched (Mischra 1990), reconstructed (Johnson 1990), residualized (Digby 1989), rolled back (Hay 1996), recast (Fererra and Rhodes 2000), recalibrated (Ferrera et al. 2001), transformed (Squires 1990) and even dismantled (Community Development Project 1977). (. . .) In short, it is generally agreed that "something happened" (...) but there is little consensus beyond this point." Het beeld van een verzorgingsstaat die steeds weer ter discussie wordt gesteld, geldt ook voor Nederland. Al in 1977 verschijnt er een spraakmakende bundel artikelen onder de titel De stagnerende verzorgingsstaat (Van Doorn en Schuyt 1977). In 1983 heette een invloedrijke studie van Idenburg c.s. De nadagen van de verzorgingsstaat (Idenburg et al. 1983), terwijl een vergelijkbare studie ruim twintig jaar later de ambigue titel Verzorgingsstaat vaar wel meekrijgt (Arts et al. 2004). In 1999 kwam Zijderveld met een cultuurkritiek op de verzorgingsstaat onder de titel The waning of the welfare state.

Wie de nationale en internationale literatuur over de verzorgingsstaat overziet, moet constateren dat er vanaf de tweede helft van de jaren zeventig bijna alleen studies zijn verschenen die de vraag stellen in welke mate de verzorgingsstaat (nog) functioneert - alle constateren ze tekortkomingen, niet alleen in termen van efficiencytekorten en een te groot beslag op de macro-economische ruimte, maar vaak ook in termen van ongewenste effecten en tekortschietende morele principes. Tegelijkertijd kan geconstateerd worden dat diezelfde verzorgingsstaat veel van de stormen beter doorstaan heeft dan vele auteurs hebben voorspeld. Dertig jaar na een stroom van kritische studies en een aantal economische crises, is er nog steeds sprake van een vitale verzorgingsstaat, die ook, zo blijkt keer op keer uit opinieonderzoek, kan rekenen op een grote aanhang onder de bevolking (SCP 2003). De verzorgingsstaat is here to stay in de beleving van het overgrote deel van de bevolking. Die constatering geldt voor Nederland, en gaat ook op voor alle westerse landen; nergens is tot op heden besloten tot een drastische afbouw van de verzorgingsstaat als zodanig; wél zijn er overal substantiële aanpassingen tot stand gebracht in afzonderlijke regelingen en arrangementen. 
De verzorgingsstaat mag dan weerbaarder gebleken zijn dan velen voorspeld hebben, daarmee is nog niet gezegd dat ze ook de komende decennia vanzelfsprekend zal blijven. Wat betekent een globaliserende wereldorde voor de verzorgingsstaat? Ooit gebaseerd op de notie van sociale verzekeringen en voorzieningen binnen de natiegrens, wordt de verzorgingsstaat steeds meer geconfronteerd met de effecten van internationalisering: arbeid verplaatst zich sneller over de wereld, zowel in de vorm van migranten die in westerse landen werk hopen te vinden, als in de vorm van de verplaatsing van productie van westerse landen naar het oosten van Europa en naar Azië. Die tendens zet zich waarschijnlijk voort; ze wordt immers aangedreven door 'normale' economische principes van kosten- en batenverschillen die voor ruimtelijke economische dynamiek zorgen. Ook het Europese integratieproces leidt ertoe dat de verzorgingsstaat steeds minder bepaald wordt binnen de eigen landsgrens. En binnen de eigen landsgrens heeft de verzorgingsstaat te maken gekregen met een ander type burger: welvarender, beter opgeleid, diverser van achtergrond, en met een duidelijke behoefte om zich individueel te uiten. Normatieve oriëntaties die ten grondslag lagen aan de verzorgingsstaat die sterk was gebaseerd op een kwestbare arbeider met weinig economisch, sociaal en cultureel kapitaal, zijn gaandeweg geëvolueerd. Ook die veranderingen stellen eisen aan het type verzorgingsstaat dat mogelijk en wenselijk is. De toekomstbestendigheid van de verzorgingsstaat spreekt zeker niet voor zich.

In dit advies gaat de WRR uitgebreid in op deze en aanverwante ontwikkelingen. Centraal staat daarbij de vraag hoe de Nederlandse verzorgingsstaat zich de komende decennia moet ontwikkelen. $\mathrm{Nu}$ zijn er verschillende manieren om een dergelijke vraag te beantwoorden. Jaarlijks verschijnen er de nodige studies die daar ook blijk van geven. Dit betekent dat de manier waarop met deze vraag wordt omgegaan, moeten worden gespecificeerd. Dit inleidende hoofdstuk gaat daar nader op in en schetst op welke manier de raad meent dat een vruchtbaar perspectief ontwikkeld kan worden op de toekomst van de verzorgingsstaat. De daaropvolgende hoofdstukken zullen elk een deel van dat antwoord proberen te geven.

\subsection{EEN OVERGEDETERMINEERD BEGRIP}

Het is verleidelijk om te spreken van 'de' verzorgingsstaat, en deze dan vervolgens de maat te nemen. Dat heeft zeker retorische voordelen, maar het werkt vooral vertroebelend. Veel van de debatten over de toekomst van de verzorgingsstaat bestaan uit voor- en tegenstanders die langs elkaar heen praten, omdat ze allemaal hun eigen definitie van de verzorgingsstaat hanteren. Voor sommigen is de verzorgingsstaat in essentie het stelsel van sociale verzekeringen en voorzieningen dat de afgelopen honderd jaar gegroeid is. In ieder geval worden de ww, de WAO en de Bijstandsregelingen daartoe gerekend, maar soms ook andere inkomensregelingen zoals pensioenen, ziektekostenverzekeringen, studiefinanciering en huurtoeslag. Het is dan nog maar één stap verder om ook de fiscale aftrekmogelijkheden in de beschouwingen te betrekken die eigen woningbezit of (private) 
pensioenopbouw stimuleren. Steeds meer worden ook de instrumenten van de arbeidsmarkt tot de verzorgingsstaat gerekend; denk aan regelingen rond arbeidsmarkttoeleiding, arbeidsomstandigheden en ontslag, maar ook aan het functioneren van CAO's en de rol van sociale partners in de overlegeconomie. Voor weer anderen is het minder de sociale zekerheid die vanaf het eind van de negentiende eeuw vorm kreeg, die de essentie van de verzorgingsstaat uitmaakt, dan wel het geheel aan (semi-)collectieve regelingen dat na de Tweede Wereldoorlog is ontstaan. Het gaat dan om alles wat gericht is op inkomensbescherming, maar ook om onderwijs, gezondheidszorg, jeugdzorg, kinderopvang, welzijnswerk en arbeidsbemiddeling. Het feit dat deze arrangementen voor een belangrijk deel uniform geregeld en op een relatief hoog kwaliteitsniveau voor iedereen toegankelijk zijn, kenmerkt deze beleving van de verzorgingsstaat. Behalve om verzekeringen, gaat het hierbij dus vooral ook om 'diensten' die de verzorgingsstaat aanbiedt. Nog anderen leggen het accent op het feit dat de verzorgingsstaat ook een moreel concept is: het is de uitdrukking van de bereidheid van burgers om in hoge mate onderlinge betrokkenheid vorm te geven en risico's met elkaar te delen op een hoog schaalniveau.

1.4 GEEN GRAND DESIGN, MAAR HISTORISCH PRODUCT

Niet alleen de verschillende associaties bij het begrip verzorgingsstaat kunnen tot verwarring leiden in het debat; dat geldt ook voor de vaak onuitgesproken veronderstelling dat de verzorgingsstaat gemaakt is vanuit één consistente visie. Dat is echter niet het geval. Verzorgingsstaten zijn gegroeid uit een beperkte opzet, primair erop gericht om economisch achtergebleven groepen grond onder de voeten te geven (Van Doorn 1977). En met die verdere groei vanuit dat startpunt zijn ze het product van (politieke) strijd tussen verschillende partijen en benaderingswijzen. De verzorgingsstaat is ook niet op één moment ontworpen: het is de resultante van meer dan een eeuw investeren, ontwikkelen, duwen, trekken, en incrementeel aanpassen. Het resultaat is daarmee bijna per definitie een grootheid die de kenmerken van verschillende doelstellingen kent, een vorm van patchwork zo men wil, waarin de restanten van verschillende uiteenlopende strevingen en belangen terug te vinden zijn: die van verschillende politieke partijen, maar ook van belangenorganisaties, professionals, bureaucraten, boeren en arbeiders, mannen en - in mindere mate - vrouwen, volwassenen en - in nog mindere mate - kinderen, en van ouderen en jongeren. Aan de verzorgingsstaat heeft geen blauwdruk ten grondslag gelegen. Wel zijn er om de zoveel tijd pogingen gedaan om het bestaande palet van regelingen en voorzieningen van een systematisch kader te voorzien. Die systematiek gaat dan soms een tijd mee, zeker als er sprake was van een politiek stabiele situatie, maar daarna is er altijd weer sprake van nieuwe ideeën over hoe de dan gegroeide situatie weer bij te stellen.

In Nederland was het net na de Tweede Wereldoorlog de commissie-Van Rhijn die met een uitgewerkt concept kwam voor iets wat je een verzorgingsstaat zou kunnen noemen. Het concept was voor een belangrijk deel gebaseerd op het 
Beveridge-rapport uit Engeland. Maar het duurde nog geen twee jaar voordat duidelijk werd dat de centrale rol die in het rapport aan de overheid was toebedacht, niet kon rekenen op ruime steun in de Nederlandse samenleving. Drees (1945-1958) is vervolgens gaan werken aan een invulling waarin een brede groep maatschappelijke actoren een substantiële rol kreeg. Gaandeweg werd zo de conceptuele helderheid van het rapport-Van Rhijn ingeruild voor een pragmatisch zoeken naar haalbare modellen. En toen in de jaren zestig de KVP'er Veldkamp als minister van Sociale Zaken (1961-1967) werkte aan de uitbouw van een aantal sociale zekerheidsregelingen, leidde dit aanvankelijk tot een breed draagvlak voor enkele nieuwe wetten, maar toen diezelfde Veldkamp in de jaren zeventig in opdracht van de regering het geheel aan sociale zekerheidsregelingen in één (wets)systematiek mocht proberen onder te brengen, strandde zijn poging uiteindelijk en werd zijn opdracht ingetrokken, omdat de inzichten in de loop van dat (lange) proces gewijzigd waren.

\section{Historisch product}

Dat de verzorgingsstaat een ingewikkeld historisch 'product' is, kan ook nog op een andere wijze geillustreerd worden. Wie ooit geprobeerd heeft om aan buitenlanders een belangrijk onderdeel van het Nederlandse stelsel uit te leggen - of het nu gaat om de wetgeving op het terrein van de gezondheidszorg, de sociale zekerheid of de volkshuisvesting - heeft ervaren dat veel van de regelingen aan buitenlanders onlogisch voorkomen. In de praktijk moet dan ook vaak de specifieke wordingsgeschiedenis erbij gehaald worden om duidelijk te maken waarom iets is zoals het is. De regels in de gezondheidszorg, die dan weer gebaseerd waren op aanbodregulering en dan weer op vraagsturing; de regels in sociale zekerheid die dan weer de verantwoordelijkheid legden bij sociale partners, dan weer bij de overheid, en dan weer bij tripartiete tussenvormen; de regels in de volkshuisvesting die dan weer uitgingen van private partijen en dan weer centrale kaderstelling voorop stelden: het zijn allemaal evenzovele uitdrukkingen van het feit dat de verzorgingsstaat niet vanuit een blauwdruk ontstaan is, maar door permanente strijd en het zoeken naar compromissen.

Het feit dat verzorgingsstaten historische producten zijn, heeft nog meer implicaties. Het betekent bijvoorbeeld ook dat verzorgingsstaten in de loop van de tijd uiteen kunnen gaan lopen in hun architectuur, niet omdat er wezenlijk verschillende concepten aan ten grondslag liggen, maar omdat een aantal 'kleine' keuzen achter elkaar een bepaald pad uitzetten waarop nieuwe keuzen vervolgens geënt worden. Door dergelijke 'padafhankelijkheden' kunnen kleine verschillen in startpositie gaandeweg uitgroeien tot grotere verschillen in uitkomsten. Neem het verschil tussen de Nederlandse en Deense verzorgingsstaat. Tegenwoordig wordt dat wel geduid als een verschil tussen een continentale en een Scandinavische verzorgingsstaat (zie uitgebreider hoofdstuk 4), waarbij het lijkt alsof er ooit heel verschillende systemen ontworpen zijn. Dat is echter niet het geval. Toen in de eerste decennia van de twintigste eeuw zowel in Nederland als Denemarken de strijd woedde rond de vormgeving van sociale verzekeringen, werd in Nederland na een lange strijd uiteindelijk gekozen voor een model waarin sociale part- 
ners een belangrijke rol speelden, terwijl in Denemarken het accent op de centrale overheid kwam te liggen. Dat had alles te maken met het feit dat Denemarken weinig grote industrie kende, maar wel veel kleine bedrijven, waardoor de rol van werkgeversorganisaties minder stevig was aangezet, terwijl daarentegen de politieke betekenis van de boerenpartij groter was dan in Nederland. De boeren verzetten zich heftig tegen het idee dat sociale zekerheid tussen werkgevers en werknemers geregeld ging worden, want zij wensten zich niet in dit (industriële) schema te persen, en dus werden de regelingen meer geënt op een centrale rol voor de overheid, waarbij de vakbeweging een meer aanvullende rol kreeg. Op basis van dit uitgangpunt zijn er vervolgens nieuwe stappen gezet toen er nieuwe regelingen gemaakt moesten worden, bijvoorbeeld op het terrein van kinderopvang. Uiteindelijk zijn we dat als het verschil tussen twee modellen gaan begrijpen.

De verzorgingsstaat is dus een historische grootheid die in de loop van de tijd op basis van wisselende, en soms zelfs strijdige principes gaandeweg vorm heeft gekregen: het is niet een 'af' product dat op basis van een enkel idee ontworpen is - en bovendien hebben mensen een meer of minder ruime definitie van de verzorgingsstaat. De vraag is wat dat betekent voor de wijze waarop we de verzorgingsstaat moeten analyseren en beoordelen.

\subsection{VAN INSTITUTIES NAAR FUNCTIES}

Het is heel wel mogelijk, en in de praktijk ook vaak beproefd, om als startpunt van een redenering een operationele opsomming te geven van de voorzieningen die we tot de verzorgingsstaat rekenen, om die vervolgens te beoordelen op basis van een aantal criteria, zoals betaalbaarheid, bestuurbaarheid, houdbaarheid en draagvlak. Dit kan leiden tot een interessant palet aan inzichten; veel studies zijn ook beschikbaar die op deze wijze inzicht geven in het functioneren van allerlei instituties van de verzorgingsstaat.

De raad probeert in dit rapport een andere benadering te beproeven: een benadering die niet uitgaat van instituties, maar van functies. Dat wil zeggen dat we vertrekken vanuit de vraag: welke expliciete en impliciete opdrachten liggen er besloten in de verzorgingsstaat? Wat willen we eigenlijk dat de verzorgingsstaat doet? Vanuit een dergelijk perspectief zijn instituties ondergeschikt aan functies: het zijn manieren waarop een specifieke functie vorm kan krijgen. Institutionele arrangementen zijn van groot belang, maar een grondige analyse van de verzorgingsstaat hoort in de ogen van de raad niet te beginnen met een herontwerp van deze voorzieningen, maar met een analyse van hun bestaansrecht. In dit advies wordt daarom niet een institutioneel, maar een functioneel vertrekpunt genomen: begonnen wordt met de vraag welke functies de verzorgingsstaat vervult, vervolgens wordt nagegaan hoe die functies gewogen moeten worden - mede in het licht van de toekomstige veranderingen in de context van de verzorgingsstaat - en hoe adequaat ze vervuld worden, om pas daarna de consequenties te trekken voor de instituties van de verzorgingsstaat. 
Een dergelijke benadering heeft een aantal consequenties. Door niet te beginnen met instituties, ligt het accent van de beschouwing niet onmiddellijk bij praktische beleidsvoorstellen voor aanpassingen in ingewikkelde stelsels. Dergelijke bijstellingen zijn relevant, maar relevanter is de vraag in welke richting te veranderen. Vervolgens kan een veelheid van praktische argumenten meegewogen worden bij de precieze maatvoering en vormgeving. Een te nadrukkelijk accent op de laatste aspecten leidt vaak af van de startvraag: wat beogen we?

Een consequentie is ook dat de verzorgingsstaat niet onmiddellijk gelijkgesteld wordt met het stelsel van sociale zekerheid. In het debat dat de afgelopen dertig jaar over de verzorgingsstaat gevoerd is, is die gelijkschakeling maar al te vaak gemaakt, en dan vooral vanuit het perspectief dat de sociale zekerheid een actieve opstelling van mensen afremt. De vraag hoe activerend een verzorgingsstaat is, wordt echter ook bepaald door andere instituties, bijvoorbeeld de manier waarop het onderwijs of de arbeidsmarkt in elkaar zit. Een functioneel perspectief probeert dus 'over de instituties heen' te redeneren. Het omgekeerde is overigens ook waar: instituties kunnen meerdere functies vervullen. Neem het onderwijs: het is een manier om mensen mogelijkheden voor later te bieden, maar ook een manier om sociale verbanden te creëren en maatschappelijke en culturele waarden over te dragen. Op de ene dimensie is een bepaalde herziening van het onderwijssysteem wellicht een groot goed, in het licht van een andere misschien juist niet. De weging van systeemtransformaties is dan ook afhankelijk van de functie die je aan een institutie toedicht, of, beter gezegd, van de verzameling van functies.

Het redeneren in termen van functies opent nog een perspectief: het maakt de vraag mogelijk hoe we de verschillende functies wegen ten opzichte van elkaar. Juist dat is het type afweging dat relatief weinig plaatsvindt - waar beleidsherzieningen vaak sterk gekoppeld zijn aan institutionele systemen, wordt een herziening van de verzorgingsstaat de optelsom van deze herzieningsplannen, die pas met elkaar in verband worden gebracht als de totale som van de transformatiekosten berekend moet worden. Maar ook functies verdienen het ten opzichte van elkaar gewogen te worden.

\subsection{OPBOUW VAN HET RAPPORT}

Redeneren in termen van functies vereist een idee over wat de functies van de verzorgingsstaat zijn. $\mathrm{Nu}$ is het niet mogelijk om die in abstracto te deduceren uit een vooraf gegeven idee over wat de verzorgingsstaat eigenlijk is. We zagen al dat er geen 'eigenlijke' bedoeling aan de verzorgingsstaat ten grondslag ligt, want er is geen archimedisch punt, geen startdatum en geen blauwdruk. Wat wel kan, is nagaan welke functies er in de loop van de afgelopen eeuw aan de verzorgingsstaat zijn toegeschreven. Het is wat economen de revealed preferences noemen: datgene wat in brede kring klaarblijkelijk leeft als wens of doel. In hoofdstuk 2 wordt dit perspectief op de functies van de verzorgingsstaat verder uitgewerkt door een historische reconstructie. Met de opbouw van de Nederlandse verzor- 
gingsstaat in de twintigste eeuw is de vraag naar haar functies, zij het vaak impliciet, voor een deel al van een antwoord voorzien. In hoofdstuk 2 wordt geschetst wat, achteraf bezien, blijkbaar de functies waren die de verzorgingsstaat verondersteld werd te vervullen.

Vervolgens wordt een kader ontworpen waarlangs deze functies op waarde kunnen worden geschat. Dat gebeurt in de twee volgende hoofdstukken. In hoofdstuk 3 wordt dat gedaan door de vraag op te werpen hoe deze functies gewogen moeten worden in het licht van de ontwikkelingen die de komende decennia op de verzorgingsstaat afkomen. Hoe past de verzorgingsstaat bij burgers die veel mondiger zijn dan de slecht opgeleide en afhankelijke fabrieksarbeider die honderd jaar geleden voor de introductie van de sociale zekerheid model stond? De huidige (diensten)economie, met een grote mate van betrokkenheid van werknemers, is bovendien niet te vergelijken met het gevaarlijke en fysiek zware werk dat de fabrieken van honderd jaar geleden kenmerkte. En past het hoe dan ook nog wel om te redeneren in termen van een hoog beschermingsniveau binnen de grenzen van een natiestaat, waar die natiestaat zelf onder druk staat? Werk en werkenden kunnen zich immers steeds makkelijker over grenzen heen verplaatsen. Zoals zal blijken, is het niet altijd eenvoudig om ontwikkelingen voldoende trefzeker te schetsen om er een precieze voorspelling aan te ontlenen, maar het is wel mogelijk een trend zichtbaar te maken.

Een andere manier om de functies te ijken, is door de wijze waarop ze in Nederland vervuld worden af te zetten tegen de wijze waarop ze in andere westerse verzorgingsstaten worden vervuld. Die plaatsbepaling (in hoofdstuk 4) krijgt vorm door gegevens over Nederland te vergelijken met die van andere landen een vorm van benchmarking, al moeten uitkomsten op dat vlak altijd zorgvuldig gewogen worden, want altijd speelt de vraag hoe vergelijkbaar de cijfers zijn. De vergelijking zal dan ook verder reliëf krijgen door deze gegevens te plaatsen naast de debatten die de afgelopen jaren in de andere Europese verzorgingsstaten zijn gevoerd. In die landen speelt de vraag hoe de verzorgingsstaat zich kan en moet ontwikkelen immers evenzeer.

Zo ontstaat er een kader van waaruit kan worden ingezoomd op de verschillende functies van de verzorgingsstaat. Daarbij kunnen vier (hoofd)functies worden onderscheiden, en aan iedere functie is een hoofdstuk gewijd (hoofdstukken 5 $\mathrm{t} / \mathrm{m} 8$ ). Begonnen wordt met wat wellicht de oerfunctie van de verzorgingsstaat genoemd kan worden: verzorgen. Al ver voor de twintigste eeuw zorgden mensen voor elkaar, en gaandeweg is die functie steeds meer onder invloed komen te staan van statelijke bemoeienis. In de loop van de twintigste eeuw is zorgen zelfs voor een belangrijk deel een activiteit geworden die in professioneel verband uitgeoefend wordt, binnen een in hoge mate verstatelijkt kader (financiering, regelgeving, enzovoorts). Zorg is echter niet louter een professionele aangelegenheid: in hoofdstuk 5 wordt daarom ook de vraag behandeld hoe het zorgvermogen in Nederland er de komende decennia uitziet, zowel in professionele als in niet-professionele zin. 
Hoofdstuk 6 richt zich vervolgens op wat voor velen de kernfunctie van de verzorgingsstaat bij uitstek geworden is: verzekeren, dat wil zeggen: je onder condities en tot op zekere hoogte verzekerd mogen weten tegen bepaalde vormen van inkomensverlies. Het is de functie die in de twintigste eeuw met name vorm kreeg via een uitgebreid stelsel van sociale zekerheid. Welke risico's werden en worden er verzekerd, en welke niet? En in hoeverre gaat het nog om (door externe factoren bepaalde) risico's waarvoor een verzekering past, dan wel om te beïnvloeden kansen? En wat betekent dat voor de structuur en legitimiteit van de verzekeringen en voorzieningen die gewenst zijn? Dit zijn de vragen die centraal staan in hoofdstuk 6.

Hoofdstuk 7 is gewijd aan een functie die de laatste decennia wellicht wat minder als zodanig is benoemd, maar die onmiskenbaar ook diepe wortels heeft in de Nederlandse verzorgingsstaat: verheffen. De verzorgingsstaat is altijd ook een 'verheffingsproject' geweest, in de eerste helft van de twintigste eeuw vooral gericht op de verheffing van groepen (arbeiders, katholieken, 'kleine luyden'...) en in de tweede helft steeds meer gericht op de verheffing van individuen. Hoe goed slagen de instituties van de verzorgingsstaat er echter nog in te verheffen, en volstaat die verheffing gegeven de uitdagingen waar we op dit moment en in de toekomst voor komen te staan?

Daarna wordt in hoofdstuk 8 ingegaan op een functie die steeds meer expliciete benoeming behoeft: verbinden. Nederland was ooit een land waarin verbindingen voor zich spraken - in relatief homogene gemeenschappen konden relatief heldere culturele codes doorgegeven worden en kon onderlinge betrokkenheid vorm krijgen. Bovendien werden sociale tegenstellingen gemitigeerd door een herverdeling van inkomen. Sommige van die verbindingen zijn er nog, maar ze zijn minder vanzelfsprekend geworden, en ze zijn diverser van aard. Bovendien spreken ze minder voor zich; ze behoeven explicitering en onderhoud. De vraag in welke mate en op welke wijze de verzorgingsstaat daaraan bijdraagt, vormt de leidraad van hoofdstuk 8.

Ten slotte worden in hoofdstuk 9 de lijnen bij elkaar gebracht: hoe die analyses per functie in onderlinge samenhang te zien? Wat ontstaat er voor een totaalbeeld? Waar zijn er 'tekorten' of juist 'overschotten'? En wat betekent dit voor gewenste veranderingen, voor het veranderingsproces, en voor het soort ambitie dat gekoesterd kan worden? Aan de hand van die vragen probeert het slothoofdstuk een aanzet te geven voor het programma en het vocabulaire van de verzorgingsstaat van de eenentwintigste eeuw. In het centrum van die zoekrichting staat dat we (verder) op weg moeten naar nieuwe ambities en nieuwe accenten voor de verzorgingsstaat - waarbij het overigens de vraag is of die nieuwe constellatie nog het beste aangeduid kan worden met de term 'verzorgingsstaat'. 


\subsection{DE VERZORGINGSSTAAT OP DE AGENDA}

\section{Van vanzelfsprekendheid naar onderwerp van debat}

De afgelopen drie decennia, zo zagen we al in hoofdstuk 1, zijn tal van aspecten van regelingen van de verzorgingsstaat en daarmee ook de verzorgingsstaat als zodanig permanent onderwerp van debat geworden. Blijkbaar spreekt het niet meer voor zich wat in de periode nog maar kort daarvoor juist wél vanzelfsprekend aan het worden was: dat de staat bepaalde zekerheden aan zijn burgers garandeert. Sinds de structurele economische crisis van de jaren zeventig echter wordt meer en vaker in twijfel getrokken of en in hoeverre dit mogelijk is. En volgens sommigen is het niet alleen onmogelijk, het is ook onwenselijk. Zij bekritiseren dan de verzorgingsstaat: hij zou leiden tot anonimisering van menselijke verhoudingen, uitholling van spontane menselijke solidariteit ('warme solidariteit') en mensen te weinig aanspreken op hun eigen verantwoordelijkheid. Of, zoals Van Doorn (Van Doorn 1977, p. 40) het ooit uitdrukte: een schaduw die de verzorgingsstaat begeleidt, is het koesteren van te hoge verwachtingen van het systeem en van te lage verwachtingen van mensen.

Het crescendo uitbouwen van de verzorgingsstaat is sinds eind jaren zeventig in ieder geval stil komen te staan. Dat was een breuk met de dertig jaar die daaraan voorafgingen. Vanaf het einde van de Tweede Wereldoorlog was er sprake van een relatief snelle op- en uitbouw van overheidstaken; stap voor stap, ononderbroken en weinig omstreden. Daarbij leefde direct na de oorlog enkele jaren het idee om het model van Beveridge voor Nederland te kopiëren. Vanaf eind jaren veertig krijgt de Nederlandse verzorgingsstaat (avant la lettre) echter zijn eigen gezicht. Dan lukt het ook om een politiek spoor te trekken waarin overheidsbemoeienis en particulier initiatief elkaar op een constructieve wijze weten te vinden. Tot in de jaren zestig gaat dit nog traag en beperkt; in bijna alle westerse landen wordt er in de tweede helft van de jaren vijftig al meer aan sociaal beleid uitgegeven dan in Nederland. Het voorzieningenniveau is vooral nog gericht op het realiseren van een minimumniveau. In de jaren zestig, met het snel stijgen van de private welvaart, wordt vervolgens de grote opdracht om het niveau van publieke voorzieningen op te trekken naar de normen van de middenklasse. Zo wordt het verzorgingsstaatproject bijna synoniem aan 'beschaving': het wordt zijn opdracht om aan alle burgers bescherming op dit niveau te bieden. Er wordt gewerkt aan een dekkend stelsel van verzekeringen en voorzieningen.

\section{De verzorgingsstaat als ideaaltype}

Zo ontstaat ook geleidelijk, en deels volgend op de feitelijke ontwikkelingsgang, het concept of ideaaltype van de 'verzorgingsstaat' - af te zetten tegen bijvoorbeeld het concept van de 'nachtwakersstaat'. De term verzorgingsstaat werd in 1957 gemunt door de sociologe Verwey-Jonker. Ze zag het als een betere vertaling van het Engelse welfare state dan het alternatief welvaartsstaat. Immers: er is niet 
per se veel welvaart voor nodig om wat er is goed te verdelen en om zorgvoorzieningen op te zetten voor de mensen die ze nodig hebben, zo benadrukte ze. Begin jaren zestig is de term verzorgingsstaat verder uitgewerkt door de socioloog Thoenes. De verzorgingsstaat staat bij hem voor een maatschappijvorm met een centrale positie voor de staat als regelaar van die maatschappij. Dat past in een tijd waarin het keynesiaanse paradigma het economische beleid is gaan domineren. Het idee is dat (de groei van) de welvaart gemaakt en gepland kan worden door speciaal opgeleide deskundigen die beschikken over geëigende technieken en modellen (denk aan de oprichting van het СРB). Die deskundigen vormen de 'functionarissenelite' die de rol van dominees en pastors moeten overnemen en de besturing van de samenleving als totaliteit ondersteunen (Thoenes 1962). De term verzorging verwees naar het beter kunnen voorzien van onwelkome gebeurtenissen en het tijdig kunnen treffen van beschermende maatregelen, en niet naar de letterlijke betekenis van zorg, zoals dat bijvoorbeeld in de jaren tachtig in het woord zorgzame samenleving terug kwam.

Met het begrip verzorgingsstaat als ideaaltypische omschrijving van de zich ontplooiende samenleving brachten sociologen ook zaken met elkaar in verband die eerder niet zo met elkaar in verband werden gebracht, zoals industriepolitiek, loonpolitiek, onderwijspolitiek, gezondheids- en armenzorg. Mede als gevolg daarvan kan nu het onderscheid tussen de ideaaltypische notie van de 'verzorgingsstaat' en de nationale staat met zijn feitelijke taken niet meer scherp gemaakt worden. Daarvoor is verzorgingsstaat inmiddels een (te) breed en overgedetermineerd begrip (geworden): alles wat de overheid doet in een land als Nederland, is 'verzorgingsstaat' geworden, of kan daarmee in verband worden gebracht.

\section{De Kaderwet Specifiek Welzijn (1974) als symbool van zijn tijd}

Tot in de jaren zeventig is het credo van de zich ontwikkelende verzorgingsstaat 'verantwoord uitbouwen'. De Kaderwet Specifiek Welzijn (1974) had het meesterstuk moeten worden, een wet met een wat onduidelijke naam, maar met een enorme ambitie. De naam verwijst naar het feit dat sommige terreinen, zoals het basisonderwijs, al wettelijk geregeld waren, en er een aparte Wet Voorzieningen Gezondheidszorg op komst was. Een groot aantal specifieke welzijnsvoorzieningen en werksoorten behoefden nog een eigen wettelijk onderdak als voltooiing van het systeem. De wet was daarmee vooral een kaderwet, waarin allerlei vormen van wetgeving op het terrein van (specifiek) welzijn met elkaar in verband werden gebracht. Welzijn werd in de Kaderwet breed opgevat. Het ging om veel meer dan wetgeving op het terrein van klassieke welzijnsvoorzieningen zoals het sociaal-cultureel werk of het opbouwwerk. Hoewel de wet zich formeel vooral richtte op de bestuurlijke en procesmatige kanten van de wetgeving op de uiteenlopende terreinen van 'specifiek welzijn', zouden uiteindelijk ook (grote delen van) de wetgeving op het terrein van gezondheidszorg, onderwijs, volkshuisvesting en sociale zekerheid onder de wet moeten gaan vallen. Op ten minste twee manieren was de wet daarmee ook een symbool. 
Allereerst suggereerde de notie van een kaderwet dat de wetgeving op de specifieke terreinen gaandeweg tot een voltooiing aan het komen was. Alle levensterreinen leken voor het eerst in de geschiedenis onder een dekkend stelsel van wetten en regels te vallen. Voor heel de gezondheidszorg ontstond gaandeweg specifieke wetgeving; de verzekeringen waren al geregeld via de Ziekenfondswet uit 1941 en de AW BZ uit 1968, en begin jaren zeventig waren ook de plannen gereed voor een dekkend stelsel van wetten dat de planning, de bouw en bekostigingssystematiek moest regelen: de Wet Voorzieningen Gezondheidszorg. Nadat onder minister (-president) Drees (1945-1958) de ouderen en nabestaanden al van wettelijke inkomensgaranties waren voorzien, en dankzij minister van Sociale Zaken Veldkamp (1961-1967) het minimumloon, de wW en de arbeidsongeschiktheidsregelingen voor werknemers op een 'passend niveau' waren gebracht, leek nu als slot de arbeidsongeschiktheidsverzekering voor zelfstandigen tot stand te komen. Huursubsidie en studiefinanciering hadden eveneens niveaus bereikt die ervoor zorgden dat het overgrote deel van de Nederlandse bevolking toegang had tot adequate huisvesting en tot goed secundair en tertiair onderwijs. Nu deze 'deelprojecten' alle hun min of meer definitieve slot leken te bereiken, was de tijd gekomen voor een laatste, overkoepelend perspectief: de Kaderwet Specifiek Welzijn.

Deze wet was op een tweede manier symbool voor het einde van de periode van de uitbouw van de verzorgingsstaat: welzijn werd door velen gezien als een wezenlijk doel van de overheid. De verzorgingsstaat was, met andere woorden, meer dan een economisch project. De economische doelstelling was ondergeschikt aan een bredere beschavingsdoelstelling. In de jaren vijftig was economisch herstel de voorwaarde geweest voor het kunnen opbouwen van verzorgingsarrangementen. Het was een periode met een strak geleide loonpolitiek. De lonen in Nederland werden (nog) lager gehouden dan in de meeste omringende landen om zo de kosten te drukken en de export te bevorderen. Zodra in de jaren zestig die lage lonen en de bijbehorende soberheid van de jaren vijftig resulteren in een loonexplosie en een langdurige periode van volledige werkgelegenheid, is ook de voedingsbodem gelegd voor een uitbouw van de niet-primair-economische kant van de verzorgingsstaat. Het streven was gericht op het verhogen van alle aanspraken van een net-geen-armoede-niveau naar een middenklassenniveau. En het aanbod van voorzieningen die aan iedereen geleverd moesten worden op het niveau van de middenklasse, was breed (onderwijs, zorg en andere dienstverlening).

\section{De omslag in de jaren zeventig}

De vanzelfsprekendheid van een overheid die behoorlijke uitkerings- en voorzieningenniveaus garandeert op alle mogelijke terreinen, heeft, zoals gezegd, maar kort geduurd. Medio jaren zeventig treedt er een diepe economische crisis op, waarna het 'project' van de verzorgingsstaat in een andere sleutel komt te staan. Van een breed aanvaard uitgangspunt wordt de verzorgingsstaat onderwerp van discussie. De economische omstandigheden lijken die heroriëntatie af te dwingen. Aanvankelijk is de reactie op de oliecrisis van 1973 en oplopende werkloosheid, een keynesiaans beleid - dat echter niet goed uitpakt. Immers, de economi- 
sche crisis blijkt niet conjunctureel, maar structureel van aard. Het overheidstekort loopt, ondanks de toenemende aardgasbaten, snel op, en vanaf eind jaren zeventig gaat een nieuw credo gelden: versoberen. Aanvankelijk neemt die versobering een eenvoudiger vorm aan, te weten minder uitgaven. De overheersende economische analyse luidde dat de arbeidskosten in Nederland te hoog zijn opgelopen, en dat daarom onder andere de premie- en belastingdruk verlaagd moeten worden. Dit vereiste het afslanken van de achterliggende socialezekerheidsregelingen. Voorstellen voor en ingrepen in de Ziektewet (1982) en de WAO beheersten het debat. In het debat kwam in plaats van de aanvankelijke focus op eenvoudige bezuinigingen meer nadruk te liggen op doelmatigheid. De voorgestelde wijzigingen kwamen steeds meer in het teken te staan van een grotere mate van doelmatigheid: de aandacht voor de 'prikkelstructuur' van het palet aan sociale regelingen en voorzieningen groeide sterk. Uitkeringen moesten niet (alleen) lager worden, daarnaast moest er ook gezorgd worden dat mensen minder in de verleiding kwamen om een aanvraag in te dienen, en dat de aandrang om regelingen te verlaten werd vergroot. Het streven wordt om alle openeinderegelingen 'dicht te schroeien'.

\section{Activering}

Vanaf begin jaren negentig krijgt de herziening van de prikkelstructuur een duidelijk label, activering. In lijn met de beleidsontwikkelingen in bijna alle westerse landen wordt activering een dominant uitgangspunt van overheidsbeleid. Dit betekent ook dat de sociale zekerheid - en de daarbij passende aanbodkant van de arbeidsmarkt - het maatschappelijk debat domineert. Terreinen als volkshuisvesting, onderwijs en zorg verliezen aandacht en scherpte. Het beleid op deze terreinen is primair gericht op kostenbeheersing. In de volkshuisvesting leidt de afbouw van een stelsel van bouwsubsidiëring tot een verzelfstandiging van de woningbouwcorporaties. In de zorg wordt aanbodbeheersing geïntroduceerd in de vorm van een budgettair kader, in het onderwijs is vooral sprake van decentralisatie, schaalvergrotings- en efficiencyoperaties.

'Activering' is geen geheel nieuw inzicht of doel van de verzorgingsstaat. Veel van de sociale verzekeringswetten hebben altijd al mede ten doel gehad mobiliteit en dynamiek op de arbeidsmarkt te behouden. Ze staan in het licht van 'je beschermd voelen' enerzijds, en het 'zelf verder kunnen komen' anderzijds. Voor de werkende bevolking was de Bijstand hooguit bedacht als een tijdelijke voorziening. Zo heeft in de Bijstandswet (terugkeer naar) arbeid als doel altijd voorop gestaan. Dat geldt nog sterker voor de WW. In de uitvoeringspraktijk kwam dat echter in veel te geringe mate tot uitdrukking.

\section{Ideologiekritiek}

Onvrede over het functioneren van socialezekerheidsregelingen vertaalt zich niet alleen in pogingen regelingen aan te passen; ook in meer principiële bedenkingen. Burgers worden steeds minder tolerant ten aanzien van fraude en oneigenlijk gebruik, maar blijven verzorgingsstaatarrangementen in essentie koesteren. In opiniërende en beleidsmakende gremia wordt de vraag steeds nadrukkelijker geagendeerd of de sociale zekerheid ook niet een uitdrukking is 
van een principieel fout ingerichte samenleving. De roep groeit om individuele verantwoordelijkheid, sociale verbanden en maatschappelijke middenveldorganisaties een grotere rol te geven. Het effect is geen abrupte koerswijziging, maar een einde aan de vanzelfsprekendheid dat de verzorgingsstaat alsmaar verder uitgebouwd moet worden. De verzorgingsstaat heet vanaf dat moment permanent 'in crisis', of minstens 'in revisie'. Inrichting en omvang zijn principieel controversieel geworden.

\section{De verzorgingstaat anno nu}

Aan het begin van de eenentwintigste eeuw lijkt het zoeken naar mogelijkheden om de verzorgingsstaat 'bij de tijd' te brengen, nog steeds het overheersende streven. Hervormingen in de sociale zekerheid blijven op de agenda staan en het activeringsprogramma wordt inmiddels steeds breder onderschreven. De ontwikkelingen in onderwijs en zorg staan sterk in het teken van vormen van aanbodbeheersing die het afgelopen decennium tot ontwikkeling zijn gekomen. Hierbij zijn naast bezuinigingen ook allerlei afgeleide beheersingsinstrumenten ontstaan. De vraag of die instrumenten nog passen bij de aard van de sectoren en de wijze waarop professionals hun opdracht zien is zich gaandeweg meer op gaan dringen (vgl. WRR 2004). Op deze manier omschreven zijn (herzieningen in) regelingen van onderwijs, zorg en sociale zekerheid dertig jaar lang vooral een operationeel probleem. Hoe kunnen verzekeringen en voorzieningen worden gefinancierd? Hoe kan het stelsel van prikkels adequaat in elkaar worden gezet? Hoe moet aan toezicht en verantwoording vormgegeven worden? Hoe kan fraude en oneigenlijk gebruik bestreden worden, en waar kan de efficiency omhoog? Hoe begrijpelijk ook, een dergelijke benaderingswijze gaat voorbij aan de vraag wat we eigenlijk van een verzorgingsstaat verwachten: wat zijn de functies die de verzorgingsstaat moet en kan vervullen? Die vraag lijkt, aan het begin van de eenentwintigste eeuw na meer dan dertig jaar van incrementele aanpassingen, meer dan ooit aan de orde. In het licht van de vanzelfsprekendheid van de uitbouw van de verzorgingsstaat in de periode daarvoor, was dit incrementalisme alleszins begrijpelijk. Nu is het tijd om ons weer af te vragen welke doelen de instituties van de verzorgingsstaat hebben en zouden moeten hebben. In dit hoofdstuk trachten we te reconstrueren wat de functies zijn die de instituties van de verzorgingsstaat vervullen, en hoe die in de loop van de tijd inhoud hebben gekregen. Functies zijn geen van bovenaf gegeven grootheden, zij geven uitdrukking aan de doelen die een samenleving erop na houdt. Door de functies van de verzorgingsstaat voorop te stellen wordt het mogelijk na te gaan of het bestaande grondpatroon ook bij de toekomst past, en welke moderniseringen gewenst zijn in het licht van huidige en toekomstige uitdagingen. Die vraag komt in de volgende hoofdstukken aan bod. In dit hoofdstuk analyseren we eerst het grondpatroon van de verzorgingsstaat zoals die zich tot op heden ontwikkelde.

\subsection{VERZORGINGSSTAAT IN FUNCTIES}

Wie de ontwikkeling van de westerse verzorgingsstaten op zich laat inwerken, kan daarin een viertal functies herkennen die steeds terugkeren: verzorgen, 
verzekeren, verheffen en verbinden. Mensen mogen van de samenleving waarin ze terechtkomen verwachten dat die hen kansen biedt om vooruit te komen, zo lijkt een diep gedeeld uitgangspunt: verheffing is een breed gedragen doel. De omstandigheden daarvoor zijn echter niet altijd en voor iedereen gunstig; dat impliceert vormen van verzekering tegen inkomensverlies, en verzorging waar cognitieve of fysieke vermogens tekortschieten door ziekte of leeftijd. Dit alles vindt plaats in een context waarin individuele kansen slechts betekenis krijgen in relatie tot anderen - en ook de vormgeving van die relaties behoeft onderhoud: verbinden. Verbinden en verheffen zijn de as van het positief inhoud geven aan het leven. Verzorgen en verzekeren vormen de as van de opvang bij problemen. Verzekeren en verbinden zijn daarbij vooral tweezijdige activiteiten; verzorgen en verheffen vooral eenzijdig.

Deze vier onderscheiden functies hebben diepe fundamenten in de Nederlandse samenleving. Verzorgen betekent hulp voor mensen die (al dan niet tijdelijk) niet voor zichzelf kunnen zorgen. Die zorg kan bestaan uit: aandacht, geld, begeleiding, ondersteuning of medische handelingen. Het is de prototypische taak van de verzorgingsstaat en heeft diepe wortels. Verzekeren is van recentere datum - al sloten Nederlanders al in de zestiende eeuw lijfrenteverzekeringen af - zeker als het gaat om grote collectieve verzekeringen tegen armoede door het wegvallen van werk of het vermogen om te werken. De sociale zekerheid die hieruit resulteerde, vormt het boegbeeld van de verzorgingsstaat van de twintigste eeuw. Verheffen gaat over het aanreiken van vaardigheden aan individuen en groepen die hen in staat stellen om in economische en culturele zin hun eigen weg beter te gaan. Verbinden ten slotte is de opdracht om vormen van onderlinge verbondenheid tussen verschillende individuen en groepen tot stand te brengen of te bevorderen. Dat kan uiteindelijk bijdragen aan een grotere maatschappelijke stabiliteit, betrokkenheid en economische vooruitgang.

De laatste twee functies - verheffen en verbinden - worden de laatste decennia wel af en toe genoemd, maar zelden in deze brede betekenis, en zelden ook als opdracht van de verzorgingsstaat. De sociale zekerheid kleurt tegenwoordig het beeld van de verzorgingsstaat in veel grotere mate. In historisch opzicht is dat niet volledig terecht. Wie terugleest hoe oorspronkelijke plannen voor Europese verzorgingsstaten eruitzagen, wordt gefrappeerd door het relatief beperkte belang van sociale zekerheid. Het Beveridge-rapport uit 1942 ziet als ultieme doel van de verzorgingsstaat: To slay the five giants of want, disease, ignorance, squalor and idleness (unemployment) - let op de volgorde! Aan onderwijs wordt in dat rapport dan ook veel aandacht besteed. Wie verder teruggaat in de geschiedenis, ziet dat ook de introductie van de sociale zekerheid in Nederland pas vorm kon krijgen toen de hogere standen zich ermee verzoenden dat hiermee een instrument voor verheffing en verbinding werd gecreëerd.

Dit laatste voorbeeld maakt ook duidelijk dat functies niet precies samenvallen met instituties en regelingen. Per periode neemt de manier waarop een dergelijk doel praktische inhoud krijgt in de vorm van een regeling, een wet of een institu- 
tie, andere vormen aan. Bovendien dienen regelingen, wetten en instituties vaak meerdere doelen tegelijk. Bij het debat over de introductie van de kinderbijslag in Nederland in de jaren dertig bijvoorbeeld was voor velen een verzorgingsideaal uitgangspunt: te veel kinderen leefden in armoede, en er moest voor hen een vorm van zorg komen. Voor anderen was de kinderbijslag vooral een instrument om Nederland te verzekeren van voldoende kinderen. Weer anderen zagen het als een manier om gezinnen in staat te stellen om zich te verheffen, omdat ze nu in de gelegenheid werden gesteld hun kinderen een gedegen opvoeding te geven. De introductie van de kinderbijslag had ook tot doel desintegratie tegen te gaan die het gevolg was van een grote mate van verpaupering onder gezinnen met kinderen. Verschillende doelstellingen, hetzelfde instrument - al zal duidelijk zijn dat het antwoord op de vraag of de kinderbijslag bij een oplopend kindertal juist progressief of degressief moest zijn verschilde al naar gelang het doel dat men aanhing.

\section{Meer dan vier functies}

De identificatie van deze vier hoofdfuncties van de verzorgingsstaat impliceert geen uitputtende opsomming. Ze blijken een sterk fundament te vormen van de Nederlandse samenleving als we de geschiedenis van de Nederlandse verzorgingsstaat nader analyseren. Maar soms zijn er ook andere functies herkenbaar. Zo heeft de verzorgingsstaat soms expliciet een economische functie. In Nederland is de WAO gebruikt om verouderde industrietakken te saneren. Roosevelts New Deal uit de jaren dertig had al een economische aanjaagfunctie: na de Great Depression via overheidsinvesteringen in publieke werken en via de introductie van socialezekerheidsregelingen de vraag van consumenten stimuleren. Soms ook liggen er bevolkingspolitieke noties aan verzorgingsstaatarrangementen ten grondslag. De family allowances die Engeland en Australië na de Tweede Wereldoorlog introduceerden, hadden die functie, net als de regelingen die Frankrijk in het huidige decennium treft. Weer andere functies zijn minder manifest, maar wel degelijk traceerbaar. Zo heeft de verzorgingsstaat een grote bijdrage geleverd aan de veiligheid van de samenleving - een functie die vaak primair in verband wordt gebracht met politie en rechterlijke macht, maar die in de praktijk ook in belangrijke mate gevoed is door de aanwezigheid van stabiliserende instituties als de sociale zekerheid.

Soms wordt aan de verzorgingsstaat ook een verdelende functie toegeschreven, meestal gaat het dan om de verdeling tussen arm en rijk. In sommige perioden, bijvoorbeeld in de jaren zeventig van de vorige eeuw, werd verdeling vaak zelfs als functie bij uitstek gepresenteerd. Bij nadere analyse blijkt de motivatie voor 'verdelen' meestal te zijn gebaseerd op ideeën over de noodzaak van het voorkomen van onhanteerbare spanningen in de samenleving - iets wat valt onder de functie 'verbinden'. Verdelen staat meestal ten dienste van verbinden, en daarom wordt de verdelingsfunctie hier behandeld als een onderdeel van de verbindingsfunctie.

In dit advies zullen we ons verder concentreren op wat we als de vier funderende functies van de verzorgingsstaat beschouwen: verzorgen, verzekeren, verheffen 
en verbinden. In de volgende vier paragrafen worden deze functies stuk voor stuk vanuit hun historische ontwikkeling verder toegelicht. Uit die reconstructie blijkt dat de zwaarte van de doelstellingen wisselt in de tijd, net als de instrumenten die worden ingezet om die doelen na te streven. Veel regels, wetten en instituties krijgen daarbij vorm op basis van meer dan één doelstelling. De onderlinge weging van die doelstellingen varieert ook. Naar tijd en naar de positie die mensen innemen.

\subsection{VERZORGEN}

De eerste, meest manifeste functie van de verzorgingsstaat zit al besloten in het woord: verzorging. Mensen in kwetsbare posities behoeven zorg. Dat uitgangspunt is veel ouder dan de verzorgingsstaat, maar het vormt wel een van de duidelijkste motieven voor het ontstaan van verzorgingsarrangementen. Dat fenomeen is van alle tijden: onderlinge steunbetuiging in de kring van de familie en in het dorp waarin men leefde. In institutionele zin kent het in de vorm van caritas ook een eeuwenoude traditie.

Pas de laatste twee eeuwen is er sprake van een expliciete rol van de overheid. Voor ons land is de eerste codificatie van grondrechten de Staatsregeling voor het Bataafsche Volk uit 1798. Het eerste hoofdstuk 'Algemeene Beginselen: burgerlijke en staatkundige grondregels' bevat in de vorm van artikel 62 een opdracht aan de overheid betreffende de gezondheidszorg: “Zij strekt, insgelijks, door heilzaame wetten, haare zorg uit tot alles, wat in het algemeen de gezondheid der Ingezetenen kan bevorderen, met wegruiming, zoveel mooglijk, van alle belemmeringen" (Bannier 1936, p. 52). In latere staatsregelingen kwamen de grondrechten in een bescheidener opmaak voor. In de eerste grondwet van Nederland van 1814 was geen aparte afdeling meer aan grondrechten gewijd, maar zijn de verschillende grondrechten ondergebracht in verschillende hoofdstukken, in het bijzonder het achtste hoofdstuk - 'Van den Godsdienst, het openbaar onderwijs en het arm-bestuur' - met daarin artikel 141: “Als eene zaak van hoog belang wordt ook het armbestuur en de opvoeding der arm-kinderen der aanhoudende zorg der Regering aanbevolen. De Souvereine Vorst doet insgelijks van de inrigtingen dienaangaande jaarlijks een uitvoerig verslag aan de Staten Generaal geven" (Oud 1970, p. 691).

Dergelijke bepalingen hebben echter nog weinig praktische betekenis. Koning Willem I werd aan het begin van de negentiende eeuw geconfronteerd met een verdeeld Nederland. Er was geen sterk centraal gezag. Gemeenten en provincies gingen in veel opzichten hun eigen gang. Fysieke verbindingen en meer centrale controlemogelijkheden moesten nog tot ontwikkeling komen (Knippenberg en De Pater 2002). Pas nadat er na 1840 een aantal aardappeloogsten na elkaar mislukte, het percentage bedeelden van tien naar vijftien procent van de bevolking steeg, de politieke onrust in de landen om ons heen fors groeide en er her en der opstanden uitbraken, was de tijd rijp voor een verdere uitwerking van de overheidsverantwoordelijkheid op het gebied van armenzorg. Met de grondwets- 
herziening van 1848 werd in hoofdstuk 10 'Van het onderwijs en het armbestuur' de rol van de overheid strakker geformuleerd: "Het armbestuur is een onderwerp van aanhoudende zorg der Regering, en wordt door de wet geregeld. De Koning doet van de verrigtingen dienaangaande jaarlijks een uitvoering verslag aan de Staten-Generaal geven."

Vanaf de tweede helft van de negentiende eeuw krijgen deze algemene grondwettelijke bepalingen nader inhoud in specifieke wetten. Hierbij blijft overigens tot aan de grondwetsherziening van 1983 het bovengenoemde hoofdstuk 1o van de grondwet op hoofdpunten onveranderd. De Gemeentewet van 1851 werkt de opdracht op het terrein van armenzorg nader uit door dit een expliciete gemeentelijke verantwoordelijkheid te maken. In dit wetsvoorstel wordt zelfs bepaald dat de gemeenten toezicht moeten houden op de kerkelijke armenzorg. In de definitieve wet van 1854 wordt die bepaling echter geschrapt en krijgt het particulier initiatief een initiërende rol. In een land waarin de centrale overheid nog nauwelijks een uitvoeringsstructuur kende, was dat ook de enige mogelijkheid. Het eenvoudigweg aan gemeenten opdragen van de armenzorg betekende nog niet dat deze ook op ruime schaal tot ontwikkeling kwam. De armenzorg kwam grotendeels neer op particulier initiatief, gemeenten vulden hun rol maar beperkt in.

De noodzaak voor specifieke aandacht voor armoede nam in deze periode sterk toe. Dat komt voor een deel door de structuur van de arbeidsmarkt die was ontstaan in de tijd van de gilden. Daar lagen de lonen vast, dus economische recessies werden opgevangen door massale uitstoot van arbeid. Zo ontstonden grote groepen die gingen zwerven en een beroep deden op bedeling. De Fransen schaften de gilden echter af. Economische schokken werden daardoor steeds meer gereguleerd door loonaanpassing voor alle werkenden. Armoede werd bovendien een stadsprobleem in plaats van een plattelandsprobleem. In een verstedelijkend Nederland ontstond zo een 'sociale kwestie' die gemeenten maar beperkt konden oplossen. In de laatste kwart van de negentiende eeuw is dan ook de opkomst en groei van allerlei verenigingen voor onderwijs, zorg, woningbouw, liefdadigheid en cultuur waar te nemen. Daaromheen komen landelijke politieke partijen: de 'verzuiling' maakt zo van een heterogene en lokalistische samenleving geleidelijk een eenheidsstaat.

\section{Openbare en particuliere zorgtaken}

De verhouding tussen openbare en particuliere zorg was gedurende lange tijd gespannen. In de loop van de tijd zou die realiteit ook uitgangspunt worden voor de wetgeving. In de Armenwet van 1912 geldt het principe dat pas wanneer kerkelijke en particuliere armenzorg geen of te weinig hulp boden, de (plaatselijke) overheid de arme bijstand kon verlenen (Mannoury en Asscher-Vonk 1987, p. 49). In de periode tot de Tweede Wereldoorlog steeg het aantal particuliere instanties dat zich richtte op de zorg voor de armen. Er ontstond een steeds grotere financiële afhankelijkheid van de subsidiërende rijksoverheid. Na de Tweede Wereldoorlog werd armenzorg gaandeweg in overwegende mate een overheidsverant- 
woordelijkheid. Het streven was om iedereen die onder een bepaald inkomensniveau zakt, een adequaat financieel vangnet te bieden. Nadat in 1949 een nieuwe Werkloosheidswet was aangenomen, in 1956 met de AOW en in 1959 met de AWW ook alle ouderen, weduwen en wezen van een inkomensbescherming waren voorzien, en in 1962 via de nieuwe Algemene Kinderbijslagwet voor iedereen kinderbijslag was geregeld, was in 1963 de Algemene Bijstandswet - gericht op iedereen voor wie geen bijzondere inkomensdervingsregelingen gelden - het voorlopige sluitstuk.

In een kleine twee eeuwen is er zo een sluitend stelsel van uitkeringen en voorzieningen ontstaan voor mensen die onvoldoende in hun eigen bestaan kunnen voorzien. Dat roept de vraag op: waarom? Lang werd het antwoord op die vraag in termen van morele beginselen gegeven. Al dan niet religieus geïnspireerde principes leidden ertoe dat in brede kring altruïsme als een wenselijke levenshouding werd gezien. Maar dergelijke nobele motieven vormden, zo blijkt uit historisch onderzoek, zeker niet de enige basis waarop de zorg voor armen was gestoeld. Angst voor landlopers, angst voor verkrotting, en voor armoede als broedplaats van criminaliteit speelden evenzeer mee. Verzorgingsarrangementen zijn, in termen van De Swaan (1989), mede gebaseerd op het welbegrepen eigenbelang van de burgerij. Economen noemen dat ook het bestrijden van negatieve externe effecten. Dit alles neemt niet weg dat er, tot op de dag van vandaag, een breed gedeeld gevoel bestaat dat een moderne samenleving mensen die onvoldoende voor zichzelf kunnen zorgen, een adequate mogelijkheid tot bestaan moet bieden.

\subsection{VERZEKEREN}

De eerste onderscheiden functie van de verzorgingsstaat - verzorgen - kan worden aangeduid met de term 'eenzijdige solidariteit'. Het gaat om betrokkenheid bij anderen. Er wordt in anderen geïnvesteerd in termen van geld, tijd of aandacht, zonder dat daar een directe tegenprestatie tegenover staat. Daarnaast is een andere vorm van solidariteit ontstaan die kan worden aangeduid als 'tweezijdige solidariteit', en die primair een vorm van onderlinge verzekering is. Daarbij gaat het niet om betrokkenheid bij mensen die vooral beleefd worden als 'anders', maar mensen die behoren tot dezelfde groep.

\section{Onderlinge verzekering}

De oorsprong van onderlinge verzekeringen gaat in Nederland terug tot het midden van de achttiende eeuw. De gilden begonnen toen fondsen te vormen voor die leden die om een specifieke reden - meestal ziekte - niet mee konden doen. Dit idee krijgt verder vorm als aan het eind van de negentiende eeuw ook arbeiders onderlinge kassen oprichten. Vakbonden spelen daarbij een belangrijke rol. Zo ontstaan er kassen die hun leden moeten verzekeren tegen de loonderving bij ziekte, arbeidsongevallen en ouderdom, en tegen de kosten van medische zorg. Deze ontwikkeling is ook in de ons omringende landen terug te vinden in de vorm van friendly societies, Krankenkassen en sociétés de secours mutuel. Veel daarvan vinden hun oorsprong in de ontluikende industriële sector. In Nederland 
- dat nooit een industrieland is geweest: op het hoogtepunt werkte maar een derde van de bevolking in de industrie - toont ook de landbouw zich erg actief in het ontwikkelen van collectieven (denk aan de Raiffeisen Boerenleenbanken, gericht op onderlinge kredietverlening). In eerste instantie zijn het vooral lokale fondsen, die daarmee ook kwetsbaar zijn. Gaandeweg treedt er echter schaalvergroting op en daarmee ook een verdere risicopooling, die de fondsen weerbaarder maakt. De financiële basis blijft echter wankel. Vanaf het eind van de negentiende eeuw is er een permanente roep om meer overheidsbemoeienis met deze vorm van verzekering. In een periode die in totaal zo'n tachtig jaar zal duren, wordt de rol van de overheid stapsgewijs steeds groter, door een deel van de te verzekeren risico's als overheidsverantwoordelijkheid te definiëren, en door bij te dragen aan de kassen voor de andere risico's.

Risico's ten gevolge van slechte arbeidsomstandigheden zijn een manifest en politiek geladen onderwerp rond 1900. Het begint aan het eind van de negentiende eeuw met een roep om meer bemoeienis met (de gevolgen van slechte) arbeidsomstandigheden. De industriële revolutie, die in Nederland laat van de grond komt, leidt tot lang, zwaar en ongezond werk in fabrieken. De nieuw ontstane vakbeweging en de nieuw ontstane politieke partijen worden pleitbezorgers van landelijke maatregelen. Het kinderwetje van Van Houten uit 1874 is daar een eerste antwoord op, maar omdat die wet vooral een papieren aangelegenheid blijft, houdt het probleem aan. In 1886 wordt daarom een parlementaire enquête gehouden naar arbeidsomstandigheden in fabrieken. Dat leidt in 1889 tot een Arbeidswet die de arbeidsduur voor vrouwen en kinderen maximeert en die voorziet in het instellen van drie inspecteurs voor heel Nederland. In $1895 \mathrm{komt}$ daar nog een Veiligheidswet bij. Bedrijven met meer dan tien werknemers moeten een veiligheidsplan hebben. Dit alles lost echter het probleem van inkomensderving bij arbeidsongevallen niet op. In 1898 beveelt een staatscommissie daarom aan een verplichte verzekering voor werknemers voor invaliditeit en ouderdom in te stellen. Dit blijkt echter op dat moment nog te ver te gaan. Uiteindelijk komt er in 1901 een Ongevallenwet, een publieke regeling voor inkomensderving en medische kosten. Werknemers kunnen deze kosten op de staat - en niet op de werkgever - verhalen. Aanvankelijk geldt de wet alleen voor heel grote bedrijven (de 'gevaarlijke industrie') en is de premiehoogte gerelateerd aan de mate van gevaar in de fabriek. In 1921 zou ze gaan gelden voor alle werknemers.

Zo ontstaat de eerste vorm van verzekering waarbij de overheid de primaire verantwoordelijkheid heeft, omdat zij premies int, voorwaarden bepaalt en uitkeringen verricht. Bereidheid om ook andere verzekeringen onder overheidsregime te brengen, is minder aanwezig. Het verzekeren tegen werkloosheid blijft voorlopig een verantwoordelijkheid voor de onderlinge kassen. Die zijn echter onvoldoende in staat de economische crisis van de jaren dertig op te vangen. Aarzelend besluit de overheid dan om extra gelden in de kassen te storten om toch nog enige vorm van verzekering te garanderen, en vooral om het ontstaan van nieuwe kassen te stimuleren. 
Ook de verzekering tegen ziektekosten komt moeizaam tot stand: de onderlinge kassen ('ziekenfondsen') groeien, maar pas in 1930 wordt er een voorzichtig wettelijk kader voor geschapen, dat controversieel blijkt. Het is de Duitse bezetter die in 1941 de knoop doorhakt en besluit om er een verplichte verzekering van te maken - net zoals overigens de Duitsers een einde maakten aan een al even slepend debat uit de jaren dertig, dat over de kinderbijslag.

Ondertussen wordt het verzekeren ook op een andere manier vormgegeven, niet als stelsel van sociale zekerheid maar in de vorm van het reguleren van de arbeidsverhoudingen. In de jaren twintig en dertig worden allerlei maatregelen genomen om de pacificatie van arbeid en kapitaal in banen te leiden. Zo komt er in 1925 een Arbeidsgeschillenwet, en even later een Hoge Raad voor de Arbeid, waarin werkgevers en werknemers op landelijk niveau met elkaar overleggen. In 1927 wordt de CAO wettelijk geregeld, zij het eerst nog zonder algemeenverbindendverklaring (AVV). Het AVv'en wordt pas in 1936 wettelijk geregeld, nota bene onder druk van de werkgevers, die geen free riders in eigen kring wilden hebben. Ondertussen is in 1932 de Bedrijfsradenwet ingevoerd, waarin op lager niveau overleg geregeld wordt. De wet zal weinig succesvol zijn, en overleg krijgt pas een nieuwe impuls als in 1950 de Wet op de Ondernemingsraden van kracht wordt.

\section{Versnelde verstatelijking}

$\mathrm{Na}$ de Tweede Wereldoorlog worden de onderlinge verzekeringen in snel tempo verstatelijkt. De Duitsers hadden namelijk - naast hun introductie van het ziekenfonds en de kinderbijslag - ook besloten om de vakbondskassen af te schaffen. In Duitsland kenden ze al sinds 1874 - dat willen zeggen driekwart eeuw eerder - een vorm van verplichte verzekering tegen werkloosheid en inkomensderving bij ziekte. Die vorm van modernisering stond hen ook voor Nederland voor ogen. Aan het bijpassende wetgevingsprogramma kwamen ze echter niet toe, maar vanaf de jaren vijftig wordt dit gat gevuld. Nederland besluit om de Ziekenfondsverzekering te houden, al zou die in 1966 in een nieuw jasje worden gegoten. De werkloosheidsregeling komt er in 1952, in de vorm van een algemeen fonds, maar uit te voeren door de bedrijfsverenigingen waarin werkgevers en werknemers zijn vertegenwoordigd. In 1967 komt daar de wAo bij, in 1968 de AWBZ en in 1976 de arbeidsongeschiktheidsverzekering voor zelfstandigen (AAW).

De kosten lopen navenant op. Werd in 1950 nog vier procent van het bbp aan de sociale zekerheid uitgegeven, in 1970 is dat aandeel al verdrievoudigd. Tegelijkertijd trad er een proces op waarbij de uitvoering van de verzekeringen meer en meer de verantwoordelijkheid van de overheid werd. In het begin van de jaren vijftig lag het zwaartepunt van de uitvoering nog sterk bij sociale partners, zij het vaak in een 'tripartite' gezamenlijke structuur met de rijksoverheid. Bedrijfsverenigingen speelden daarbij een belangrijke rol, maar uiteindelijk wordt in 1996 besloten om de uitvoering de facto volledig in handen van de overheid te leggen, en wordt de rol van sociale partners beperkt tot die van adviseur via de SociaalEconomische Raad. 
Wat duidelijk is uit deze korte schets, is dat onderlinge verzekeringen een belangrijk onderdeel van de verzorgingsstaat zijn geworden, maar ook dat er steeds controverse is geweest over de vraag wie daar nu verantwoordelijk voor moet zijn. Sommige verzekeringen (bijvoorbeeld voor weduwen en wezen, en voor kosten bij langdurige ziekte) zijn bijna een exclusieve overheidsverantwoordelijkheid geworden (de 'volksverzekeringen'). In formele zin geldt dat er een premie voor geheven wordt, maar in de praktijk zien mensen het onderscheid niet met andere overheidsvoorzieningen die uit de algemene middelen (belastingopbrengsten) worden betaald. De andere verzekeringen, in het bijzonder die voor werkloosheid en arbeidsongeschiktheid (de 'werknemersverzekeringen'), hebben meer het karakter van een verzekering, maar zijn in feite een hybride vorm, omdat de overheid de verzekering verplicht stelt, de polisvoorwaarden vaststelt, de aanspraken toetst, de uitbetaling regelt en de premies int. Daarom worden ook de werknemersverzekeringen volledig gerekend tot de collectieve sector van de economie, en telt het saldo van de fondsen mee voor de berekening van het financieringstekort van de overheid (zie verder hoofdstuk 6).

\subsection{VERHEFFEN}

Het bieden van inkomensgaranties aan wie zelf onvoldoende in eigen inkomen kan voorzien - of dat nu op basis van eenzijdige inkomensoverdrachten is, die via de belasting worden geregeld, zoals in het geval van de Bijstand, of als er sociale premies voor zijn betaald, zoals bij de WW en WAO - vormen een belangrijk onderdeel van de verzorgingsstaat. Veel studies beschouwen ze zelfs als de kern van de verzorgingsstaat. Ze zijn er in ieder geval een gemakkelijk te bestuderen deel van. Het gaat om traceerbare regels die vervat liggen in een beperkt aantal wetten, en om vormen van inkomensoverdracht die goed in een getal vallen uit te drukken. Het is ook gemakkelijk om verzorgingsstaten aan de hand van deze parameters te vergelijken. Toch is, zoals gezegd, de verzorgingsstaat meer dan een 'project' gericht op inkomensbescherming. Niet altijd even expliciet, en ook niet altijd ondubbelzinnig, is het project van de verzorgingsstaat er ook een van verheffing: het streven om mensen de mogelijkheden te bieden om op een zinvolle en verantwoorde wijze invulling aan hun leven te geven en hun talenten te kunnen ontplooien.

\section{Emancipatieproject}

De verzorgingsstaat is ook, en soms vooral, een emancipatieproject. De precieze inkleuring daarvan loopt uiteen. Emancipatie betekent daarbij bijna altijd: zorgen dat mensen niet op een allesoverheersende wijze bezig zijn in hun meest elementaire levensbehoeften te voorzien, en zorgen dat ze ook over voldoende cultureel kapitaal beschikken om hun eigen leven verder inhoud te geven. Soms ligt het accent vooral op het idee dat materiële omstandigheden niet te beperkend moeten zijn; soms gaat het meer om het overdragen van kennis en inspiratie.

In dit licht is een socialezekerheidsstelsel, net als inkomensvooruitgang, een belangrijke maar niet voldoende voorwaarde voor emancipatie van (groepen van) mensen. Het zorgen dat mensen voldoende cultureel kapitaal hebben om hun 
eigen levensproject inhoud te geven, veronderstelt ook een actieve publieke investering in een bijpassende bagage. De belangrijkste institutie die daarin moet voorzien is het onderwijs. Onderwijs heeft dan ook van begin af aan een opdracht gehad die verderging dan het overdragen van vaardigheden op het gebied van rekenen, taal of aardrijkskunde. Er ligt ook een vormende opdracht in besloten.

Dit krijgt al contouren aan het eind van de achttiende eeuw. Verontrusting over 'het volk', en de overtuiging dat het noodzakelijk is om dat via onderwijs en opvoeding in goede banen te leiden, vormen steeds meer de opinio communis van de bourgeoisie. Mede in het zadel geholpen door de Fransen, gaat in 1800 de Agent van Nationale Opvoeding aan de slag en ontwerpt een wettelijke basis voor volksopvoeding. Daarmee wordt onderwijs al aan het begin van de negentiende eeuw als staatstaak gedefinieerd, en dat is het sindsdien gebleven. Dit in tegenstelling tot bijvoorbeeld de armenzorg die lang een kerkelijke en lokale aangelegenheid bleef. Geredeneerd dus vanuit de basiswetten van de Nederlandse eenheidsstaat (vanaf het eind van de achttiende eeuw) heeft onderwijswetgeving zeer oude papieren: in 1803 komt de eerste Lager Onderwijswet tot stand. Er komt ook een stelsel van schoolopzieners, de Onderwijsinspectie, en er wordt geïnvesteerd in de opleiding van een onderwijzerscorps. Inhoudelijk is het onderwijs er sterk op gericht om kinderen deugden bij te brengen. In Nederland krijgt het onderwijs vorm voordat de industrialisatie serieuze vormen aanneemt. Dat maakt het begrijpelijk dat het vormende aspect belangrijker werd gevonden dan het kwalificerende. Pas in de tweede helft van de negentiende eeuw komt naar voren dat onderwijs ook loon zou kunnen opbrengen.

Vanaf de tweede helft van de negentiende eeuw treedt ook een verbreding op van het onderwijsstelsel. De Wet op het Lager Onderwijs uit 1857 vormt - net als de Gemeentewet die de armenzorg regelt - een belangrijke invulling die al besloten ligt in de grondwet van 1848 . Het aantal kinderen dat naar school gaat, stijgt sterk, al zijn de scholen aanvankelijk nog nauwelijks voor hun taak toegerust en zijn de klassen enorm. Verder zijn er grote regionale verschillen. Zo verschijnen, zeker buiten Holland, nog decennialang de meeste kinderen in de oogstmaanden niet op school. Pas rond 1900 gaat ieder kind naar de lagere school en maakt die ook af, al gaat minder dan één op tien daarna nog door met vervolgonderwijs.

De wet laat het aan de gemeenten over om schoolgeld te heffen, waarmee de kiem voor de schoolstrijd wordt gelegd, want gemeenten hanteren dit instrument om onderscheid te maken naar type school. Het niveau van de scholen loopt dan ook sterk uiteen. Met de Lager Onderwijswet en de pacificatie van 1917 ontstaat een stelsel dat althans op papier de privileges van de standenscholen afschaft en een over de hele linie gelijkvormig onderwijs stimuleert - zij het in beperkte mate, want de financiering wordt landelijk geregeld, de leerstof en het leerplan zijn nog lang gemeentelijke aangelegenheden.

Ondertussen ontstaan zo vanaf 1860 ook de eerste ambachtsscholen. Onderwijs begint functioneel te worden in het bijbrengen van beroepskwalificaties. In 1863 
maakt de Wet op het Middelbaar Onderwijs de introductie van de hbs mogelijk een opleiding alleen voor jongens, gericht op de vaardigheden die nodig zijn voor het bemensen van kantoren en het bedrijven van moderne handel, waarin papierwerk een niet meer weg te denken element is. Juist waar vrouwen anders gevormd moeten worden, ontstaan iets later, en in een trager tempo, voor hen speciale scholen. Als tegenhanger van de ambachtsschool ontstaat de huishoudschool en als tegenhanger van de hbs de mms, al vrezen velen dat ook deze speciale scholen nog zullen leiden tot een te eenzijdige verstandelijke ontwikkeling bij meisjes. In het onderwijssysteem dat vorm krijgt manifesteert zich zo steeds een subtiele strijd tussen de meer 'verheffende' motieven, vaak gegoten in morele of culturele termen, en de meer economische motieven: onderwijs kwalificeert voor banen op de arbeidsmarkt, of voor het goed kunnen doen verlopen van het gezinsleven. Vanuit het eerste motief is het vaak de aristocratie, en later de gegoede burgerij die voldoende onderwijs bepleit. Vanuit het tweede motief zijn het ook de werkgevers die in de loop van de tijd steeds actiever voor onderwijs pleiten. De curricula van alle genoemde opleidingen laten deze dubbele motivatie ook steeds zien.

Het vormingsmotief gaat gaandeweg ook leven als het om kleine kinderen gaat. Pedagogische noties doen hun intrede. Het idee van een 'bewaarschool' wordt minder acceptabel, en concepten als die van Fröbel en Montessori beginnen hun ingang te vinden.

Zo ontwikkelt zich in de twintigste eeuw een onderwijssysteem dat voor grote groepen in de samenleving een belangrijk instrument wordt om zich te verheffen, zowel voor de middenklasse als voor de arbeidersklasse. De wijze waarop, en met name de mate waarin dat op een uniforme wijze vorm moet krijgen, blijft daarbij steeds onderwerp van debat. Nederland kiest daarbij een middenweg: al vroeg in de jaren zestig van de twintigste eeuw komt met de Mammoetwet een beperkte vorm van segmentering tot stand, die door zijn doorstroommogelijkheden overigens karakteristieken van een meer omvattend systeem kent. Verdergaande varianten als de middenschool worden wel in discussie gebracht, maar halen het uiteindelijk niet.

Het hoger onderwijs ten slotte raakt ook zijn standskarakter kwijt en wordt een middenklassevoorziening - pas met de massale toestroom in de jaren zestig en zeventig, en de komst van een stelsel van studiefinanciering, waarvan de contouren terug te vinden zijn in de plannen uit 1957 voor een combinatie van een renteloze lening en beurzen.

\subsection{VERBINDEN}

In wisselende perioden en met wisselende instrumenten zijn verzorgingsstaten ook bedoeld om de binding tussen burgers te versterken. Aan deze vierde hoofdfunctie die we onderscheiden, liggen op zichzelf weer verschillende motieven ten grondslag. 


\section{Verbinden en de natiestaat}

Allereerst is de ontwikkeling van de verzorgingsstaat als stelsel van rechten en voorzieningen verbonden geweest met de vorming van de natiestaat. In Nederland is dat proces van natiestaatvorming tot de Tweede Wereldoorlog heel geleidelijk gegaan en niet zo manifest; we zijn immers altijd een op handel en op de wereld gericht land aan de zee geweest. De vorming van de natiestaat beperkte zich hier aanvankelijk tot culturele harmonisatie (taalpolitiek, ABN, mediapolitiek: afschaffing dagbladzegel en dergelijke) en fysieke integratie (kanalen, spoorwegen en wegen, en de gelijkschakeling van de kloktijd in 1909 in het hele land) (Knippenberg en De Pater 2002).

Elders werd het proces van natiestaatvorming al eerder ondersteund door de opbouw van sociale voorzieningen en regelingen. Denk aan landen als het Verenigd Koninkrijk, Duitsland of Noorwegen. Een katalyserende rol daarbij speelden oorlogen (1870, 1914-1918) die een grote mate van maatschappelijke dynamiek met zich meebrachten. De meest manifeste poging tot verbinden is het eerste socialezekerheidsarrangement in Europa: het Duitse systeem dat onder Bismarck tot stand kwam. Bismarcks beleid om Duitsland te verenigen was drieledig: (1) imperialistische buitenlandse politiek, (2) importtarieven en economische steun om agrarische belangen veilig te stellen en economische groei te stimuleren, en (3) sociale zekerheid om de opkomende arbeidersklasse te integreren. Bismarck was vooral een representant van de Duitse landadel, groot geworden in een traditie die wil dat een landheer goed voor zijn personeel en pachters zorgt. Dit maakte hem tot een verklaard tegenstander van de opkomende arbeidersbeweging en de daarbij horende sociaal-democratische partijen - en overigens ook van de katholieken. Hij ontwikkelde dan ook uitdrukkelijk wetgeving gericht op het terugdringen van de invloed van deze groepen. Tegelijkertijd wilde hij het recent gevormde Duitsland een duidelijke machtsbasis geven en tot een eenheid smeden. Dit bracht uitgerekend de autoritaire Bismarck ertoe als eerste in Europa een socialezekerheidsstelsel te ontwikkelen - zonder er overigens ooit formeel met arbeidersorganisaties over te overleggen. In 1871 introduceerde hij een ongevallenverzekering, in 1883 een ziektekostenverzekering en in 1889 een ouderdoms- en arbeidsongeschiktheidsverzekering. De introductie was revolutionair, de omvang beperkt. Een ouderdomspensioen was beschikbaar voor wie 71 jaar was geworden - iets wat in die jaren overigens slechts voor achttien procent van de mannelijke bevolking was weggelegd (Metzler 2003). (In Nederland heeft het idee postgevat dat de leeftijdsgrens van 65 jaar op Bismarck is terug te voeren, maar de verlaging tot die leeftijd vond, althans voor fabrieksarbeiders, in Duitsland pas plaats in 1917.) De regelingen zouden model staan voor wat er verder in West-Europa in de decennia daarna zou gebeuren. Dat vooral autoritaire regimes aan de wieg stonden van socialezekerheidsarrangementen, ging daarbij ook op voor andere landen. De eerste maatregelen voor verplichte verzekeringen werden vaak geïntroduceerd door liberale en/of conservatieve elites, en niet door vertegenwoordigers uit kringen van de vakbonden of sociaal-democratie. Dat geldt voor Duitsland, Oostenrijk, Italië en zelfs voor de Scandinavische landen (Pierson 1998). Het bevestigt de stelling dat socialezekerheidsarrangementen 
primair te maken hebben met de ontwikkeling van de economie in een land; het belang van politieke stromingen en voorkeuren zijn eerder een tweede ordefactor.

Dat sociale maatregelen genomen worden terwille van de natievorming is ook in het Verenigd Koninkrijk terug te vinden. De sociale programma's die daar aan het begin van de twintigste eeuw opkomen, worden expliciet gelegitimeerd met de stelling dat het Verenigd Koninkrijk zijn leidende rol in de wereld, gegeven zijn vele koloniën, niet kon waarmaken zonder een ander type arbeiders- (en soldaten)populatie. In de lange Victoriaanse periode (1837-1901) was het Verenigd Koninkrijk altijd wel ergens in oorlog om de grenzen van zijn enorme koloniale rijk te kunnen handhaven. Dat vergde aanhoudende beschikbaarheid van een potentieel aan jonge, gezonde mannen, iets wat bij omvangrijke golven van besmettelijke ziekten problematisch was. Dat heeft op zijn beurt uiteindelijk weer de aanzet gegeven voor de oprichting van de voorloper van de National Health Service. In de befaamde woorden van Lloyd George uit 1917: "You can not maintain an A-1 empire with a C-3 population." In Frankrijk en de vs speelden oorlogen een nadrukkelijke rol bij de ontwikkeling van de pensioensystemen die daar aan het begin van de twintigste eeuw tot ontwikkeling kwamen: de overheden waren door de publieke opinie gedwongen om voorzieningen in het leven te roepen voor oorlogsveteranen. In het Duitsland tijdens de Eerste Wereldoorlog besloot men in het kader van de Kriegswohlfahrtpflege om uitkeringen bij arbeidsongeschiktheid niet langer op het niveau van armenzorg te verstrekken, maar zo hoog te maken dat iemand "in seiner sozialen Schicht" blijven kan, om zo de harmonische samenhang van het volk te waarborgen.

Nederland - een nog weinig geïndustrialiseerd land - volgde tot de Tweede Wereldoorlog een veel terughoudender beleid. De moeizame introductie van een socialezekerheidsstelsel werd vooral bepaald door wat er in landen om ons heen gebeurde, waarbij de regering bij voorkeur niet al te ver wilde gaan, maar ook niet al te ver uit de pas wilde lopen. Aristocraten, boeren en middenstanders houden vergaande sociale regelingen tegen. Tegelijkertijd is hetgeen wat langzaam en deels contre coeur wél tot stand komt een compromis waar alle richtingen aan hebben bijgedragen: confessionelen (katholieken en protestant-christelijken), socialisten, vrijzinnig-democraten en liberalen. In die zeer geleidelijke ontwikkeling komt een eerste versnelling als er aan het eind van de jaren dertig een katholiek-socialistisch pact ontstaat dat betekenisvolle vormen van sociale zekerheid wil introduceren. Maar daar zouden ze door de Duitse bezetting echter nog even mee moeten wachten (Hoogenboom 2003).

Een verzorgingsstaat als instrument om een natie te verbinden wordt in Nederland vooral bepleit in de periode kort na de Tweede Wereldoorlog. Tijdens de oorlog is de regering in aanraking gekomen met het Beveridge-plan dat in de eerste jaren van de oorlog in het Verenigd Koninkrijk was opgesteld om te komen tot een 'offensieve' vorm van sociale politiek. Het plan ademt de geest van de New Deal die in 1932 door Roosevelt voor de vs was ontwikkeld, een vorm van 
sociale zekerheid die in die periode nog ruimhartiger was dan wat er in Nederland beschikbaar was, en die sterk lijkt op de verzorgingsstaat die op dat moment in Zweden ontwikkeld wordt. In alle gevallen ging het om een actieve economische en sociale politiek, gericht op arbeidsmarktbeleid, publieke werken, centrale loonafspraken en extra overheidsinvesteringen. In Nederland wordt kort na de oorlog de commissie-Van Rhijn geïnstalleerd die een offensieve keynesiaanse economische politiek bepleit. Het zwaartepunt verschuift van werknemersverzekeringen naar volksverzekeringen, en de uitvoering van de sociale zekerheid krijgt vorm via een combinatie van ideeën van Bismarck en Beveridge: uitvoering via bedrijfsverenigingen, maar aangestuurd door de Sociale Verzekeringsraad.

\section{Sociale grondrechten}

Wezenlijk is ook dat nu voor het eerst wordt geredeneerd in termen van sociale grondrechten die vertaald worden in minimumstandaarden voor onderwijs, huisvesting en zorg. Het redeneren in termen van sociale grondrechten komt op dat moment in alle westerse landen op, met als bekendste resultaat de Universele Verklaring van de Rechten van de Mens. Dit type redenering brengt met zich mee dat de verzorgingsstaat meer is dan een stelsel van verzekeringen; het wordt een samenhangend arrangement van voorzieningen die tezamen voor alle burgers op alle wezenlijke terreinen van het leven op een adequate wijze tegemoetkomen aan hun behoeften. In de beleving van velen is het daarmee een slotakkoord van een beschavingsproces dat eeuwen heeft geduurd. Marshall - de man die verbonden is met het begrip 'sociale rechten' - benadrukte dat die rechten geen middel zijn, maar een doel. Het ging om: "The whole range from the right to a modicum of economic welfare and security to share to the full in the social heritage and to live the life of a civilised being, according to the standard prevailing in society." Sociale grondrechten zijn voor hem: "Admission tickets for membership and participation in society." En wie mensenrechten niet als sluitstuk van een geschiedenis zag, zag ze tenminste als de beste garantie tegen een wereld van onophoudende oorlog en armoede. Het tevredenstellen van alle burgers, hen voorzien van wat ze nodig hebben, vormde een cruciale voorwaarde om nog een oorlog te voorkomen. In het Angelsaksische taalgebied staat de welfare state kort na de oorlog dan ook voor de belofte en ambitie van de geallieerden een alternatief te bieden voor de power state van nazi-Duitsland.

\section{Beschavingsideaal}

Het ideaal om een beschaafde natie te vormen, bleef ook in de jaren vijftig nadrukkelijk aanwezig, al nam het transcendente karakter in de beleving van velen wel wat af. Het visionaire karakter van de plannen verloor aan glans. Zo gingen de plannen van de commissie-Van Rhijn ook voor Drees een brug te ver. Al snel raakte het maken van een totaalplan op de achtergrond; het bestaande werd weer uitgangspunt en aan de hand daarvan werden er steeds kleine stapjes gezet, al bleef het doel om een dekkend systeem te maken overeind. Het was uiteindelijk in de jaren zestig minister Veldkamp die het systeem compleet mocht maken. Met het idee van sociale grondrechten en een dekkend stelsel werd ook een andere belangrijke stap gezet, het idee van een universeel systeem is geïntrodu- 
ceerd. Daarbij gaat het niet langer om een systeem dat zich slechts richt op mensen met geen of te weinig inkomen, maar om een systeem dat evenzeer betekenis heeft voor de middenklasse.

Al stond natievorming hier maar kort prominent op de agenda, het idee dat mensen verbonden moeten worden, dat een opdracht vormt voor de verzorgingsstaat, heeft in Nederland een stevigere traditie op een minder hoog schaalniveau: dat van praktische interventies om sociale cohesie te bevorderen en disfunctioneel gedrag te corrigeren in wijken, buurten, dorpen en steden. Het was daarbij vooral zaak om te voorkomen dat kleine groepen zich buiten de reguliere orde zouden plaatsen. Vanaf de laatste decennia van de negentiende eeuw werd daartoe vormgegeven aan 'volksopvoeding'. Als inspiratie dienden daarbij de beschavingsidealen van de hogere middenklasse. Uitbreidingen van de klassieke armenzorg, zoals volksgaarkeukens, waren op allerlei manieren bedoeld om met name arbeiders beschaving bij te brengen. Woningopzichteressen deden hun intrede, een beroep dat spoedig geprofessionaliseerd zou worden tot maatschappelijk werkster, ook het bibliotheekwezen kwam op. Binnen de opkomende zuilen werd veel energie gestoken in vormende activiteiten. In socialistische, katholieke en protestants-christelijke kring werden voorlichtings-, discussie- en studiebijeenkomsten georganiseerd. In de jaren na de Eerste Wereldoorlog werd dit systeem van volksontwikkeling uitgebouwd. Binnen de vakbeweging professionaliseerden de scholingsinstituten. In steden verschenen volksuniversiteiten, volkshogescholen en volkshuizen (de latere buurthuizen) gericht op de 'opvoeding tot gemeenschapsmens'. Voor 'onmaatschappelijke gezinnen' werden in die jaren in de grote steden aparte (delen van) wijken en 'woonscholen' ingericht en in Drenthe zelfs kampen. De professies differentieerden zich verder en er kwamen opbouwwerkers en sociaal-cultureel werkers. Ook de gezinszorg ontwikkelt zich op grote schaal, meestal eveneens op verzuilde basis.

Na de Tweede Wereldoorlog komt dit proces gaandeweg steeds meer onder overheidsregie te staan. In 1952 wordt er zelfs een apart ministerie voor ingericht: het ministerie van Maatschappelijk Werk. De terminologie verandert in de loop der tijd, maar het gaat vooral om 'samenlevingsopbouw'. Voor mensen die niet meekunnen, komt er het social casework, een vorm van interventie die onder Angelsaksische invloed een sterk individugebonden inslag krijgt. De verontrusting blijft, al geldt die steeds minder de onmaatschappelijken, en steeds meer de 'verwilderde' of de 'massajeugd'. De 'onmaatschappelijkheidsbestrijding' boet in de jaren zestig aan betekenis in, en wordt dan in het publieke discours zelfs getransformeerd tot een 'lof der onaangepastheid'. Waar het welzijnswerk zijn opdracht om sociale samenhang tot stand te brengen geleidelijk inwisselt voor een ontplooiings- en bevrijdingsideaal, neemt ook de legitimiteit van het werk af. Begin jaren tachtig is het werk in kwantitatieve zin sterk teruggebracht en is het ministerie van Maatschappelijk Werk slechts nog een directie van het ministerie van Welzijn, Volksgezondheid en Cultuur. Maatschappelijke integratievraagstukken lijken op dat moment niet of nauwelijks meer aan de orde. Alleen van de zijde van politie en justitie valt bij tijd en wijle een pleidooi te horen voor het heruit- 
vinden van met name het jeugd- en jongerenwerk, maar gebrek aan sociale samenhang wordt toch vooral als probleem voor de strafrechtketen beschouwd.

Voor het uitdrukkelijk nastreven van de functie verbinden ontstaat zo vanaf de jaren zeventig een leemte. De institutionele kaders zijn er niet langer op toegesneden. Als in de jaren zeventig niet meer onmaatschappelijken, maar vrouwen volop in de aandacht komen te staan, zijn de instituties van de verzorgingsstaat vooral reactief. Aparte scholing (moedermavo, vrouwenvakschool) komt mondjesmaat van de grond, en de ontwikkeling van de kinderopvang verloopt in Nederland trager dan in de meeste andere landen. Nog lastiger wordt het als aan het eind van de jaren negentig het integratievraagstuk in het teken van de integratie van allochtonen komt te staan. De oude (welzijns-)infrastructuur is te verzwakt om hier een substantiële rol in te kunnen vervullen. De vraag rijst hoe andere maatschappelijke systemen (arbeidsmarkt, onderwijs, huisvesting) de functie verbinden op zich kunnen nemen. Vooralsnog is er echter een grote aarzeling om categoraal beleid in welke vorm dan ook te ontwikkelen. Bovendien blijken er weinig toereikende instrumenten.

\section{Verbinding en ontzuiling}

Verbinden was een manifest doel van de verzorgingsstaat, met name in periodes gericht op het opbouwen of herstellen van de natiestaat. Verbinden was evenzeer een manifest doel in de vele praktijken die erop waren gericht om (groepen) mensen met een afwijkende levensstijl te verbinden met de hoofdstroom. Verbinden was juist op de achtergrond geraakt, terwijl de laatste decennia van de vorige eeuw nieuwe verschillen ontstonden. Tegelijkertijd mag niet onderschat worden hoe sterk de verbindende functie van de verzorgingsstaat toch steeds geweest is - al dan niet bedoeld. Op alle mogelijke manieren heeft de verzorgingsstaat eraan bijgedragen dat mensen in materieel opzicht meer met elkaar verbonden raakten, en dat ook als zodanig gingen beleven en waarderen.

Als illustratie van deze ontwikkeling kan het onderscheid in zuilen dienen. Aan het begin van de twintigste eeuw is het sociale leven in Nederland nog sterk gesegmenteerd in zuilen. Maar met de komst van verzorgingsstaatarrangementen zoals een systeem van sociale zekerheid en een onderwijs- en hulpverleningsstelsel, komt de overheid steeds meer in het vizier. Aanvankelijk stelt die overheid slechts algemene kaders, maar al snel ontstaat er ook een financiële betrokkenheid, vooral in de vorm van bijdragen en subsidies. Waar die bijdragen aanvankelijk vooral aanvullend waren, worden ze in de loop van de tijd maatgevend. Vijftig jaar later is de financiering van de sociale zekerheid, het onderwijs en de zorg niet meer gebaseerd op een zuilenstelsel, maar op publieke middelen. In de uitvoering spelen de voormalige zuilen nog wel een rol, maar in beperkte mate, want de polisvoorwaarden in de sociale zekerheid, het curriculum in het onderwijs en de kwaliteitsbepalingen in de zorgverlening zijn onlosmakelijk gekoppeld geraakt aan de sturende rol van de financier. Dat heeft een groot effect gehad op de invulling van de sociale cohesie in Nederland.

Hetzelfde geldt voor het onderscheid tussen arm en rijk, in klassen en standen. 
Nederland was ooit een land waarin standen duidelijk herkenbaar waren. Enerzijds was er binnen de steden het onderscheid tussen de aristocratie, de middenstand en de fabrieksarbeiders. Anderzijds waren het buiten de steden de boeren en landarbeiders die verschilden van de stedelingen. Die onderscheiden hebben sterk aan betekenis ingeboet. Voor een deel is dat terug te voeren op het herverdelende karakter van de verzorgingsstaat, zoals dat bijvoorbeeld via de belastingen vorm krijgt. Voor een minstens zo groot deel is dat echter terug te voeren op wat de eigen normstelling van de instituties en professies van de verzorgingsstaat zou kunnen worden genoemd. Voor onderwijzers, maar ook voor artsen, belastinginspecteurs en uitvoerders van de sociale zekerheid, bestaat er geen onderscheid in rang en stand. De beroepsethiek van deze groepen schrijft voor dat iedereen naar vermogen onderwijs krijgt, dat artsen zich bij hun beslissingen slechts laten leiden door de mate van ziekte, en dat rechtsgelijkheid het hoogste goed is in de uitvoering van de sociale zekerheid en de fiscaliteit. En waar deze professies en instituties van de verzorgingsstaat een belangrijk deel van het dagelijkse leven zijn gaan uitmaken, heeft het traditionele onderscheid in klassen en standen sterk aan betekenis ingeboet.

Het was dus een van de functies van de verzorgingsstaat om verbindingen tussen verschillende groepen tot stand te brengen, maar hij heeft ongetwijfeld zelf nieuwe verschillen tussen sociale groepen gemaakt en versterkt. Allerlei 'oude' sociale onderscheidingen, zoals die tussen standen, hebben aan betekenis ingeboet. Tegelijkertijd zijn er nieuwe ontstaan, zoals tussen 'zwarte' en 'witte' scholen.

\section{Elkaar veronderstellen en versterken}

De Nederlandse verzorgingsstaat, zo blijkt uit deze historische reconstructie, kent niet alleen diepe wortels, maar ook brede. Waar tegenwoordig verzorgingsstaat bijna gelijkgesteld wordt met sociale zekerheid, blijkt bij nadere analyse dat het adequater is om te spreken over verschillende perioden waarin dan weer de ene functie sterk in de belangstelling stond, en dan weer de andere. Andere functies zijn in zo'n periode niet weg, maar blijven wat op de achtergrond. Verzekeren mag de afgelopen decennia sterk op de voorgrond treden, in eerdere perioden wisselden verzorgen, verheffen en verbinden elkaar af als meest dominante functie in het maatschappelijk debat en het beleidsdiscours.

De vier functies, zo ligt ook besloten in de beschrijving, zijn functies die elkaar veronderstellen en versterken. Publieke verzekeringen kunnen alleen bestaan als er ook een vorm van verbondenheid gevoeld wordt - en omgekeerd produceren verzekeringen ook verbondenheid. Paupers verheffen was een doel op zichzelf, maar het droeg ook bij aan vormen van verbinding - en was daarmee bovendien een manier om 'de samenleving' bij elkaar te houden. Het verzorgen van zieken en armen was eveneens een manier om ze 'erbij te houden'. Verheffen was ook een manier om mensen te leren beter in hun levensonderhoud te voorzien, en daarmee tegelijk een vorm van verzekeren. De zorg voor kinderen heeft altijd ook in het teken van verheffen gestaan. Verzorgen, verzekeren, verheffen en verbin- 
den zijn kortom functies die analytisch te onderscheiden zijn. Ze zijn echter niet te scheiden. Ze vormen juist in hun samenhang het raster waarlangs (het functioneren van) een verzorgingsstaat gelegd kan worden. 


\section{UITDAGINGEN VOOR DE VERZORGINGSSTAAT}

\section{$3.1 \quad$ INLEIDING}

De uitdagingen waar de Nederlandse verzorgingsstaat - en in verschillende gradaties ook andere verzorgingsstaten - op dit moment voor staat, zijn het gevolg van een samenspel van factoren. Van buitenaf wordt de verzorgingsstaat geconfronteerd met een verheviging van de internationale concurrentie. Van binnenuit doen zich geleidelijke maar ingrijpende veranderingen in arbeidsmarktpatronen, levensstijlen en in de demografische opbouw van de bevolking voor. Reageren op de nieuwe eisen die deze veranderingen aan de verzorgingsstaat stellen kan slechts onder inachtneming van collectieve verwachtingen die zijn gegroeid en verplichtingen die in het verleden zijn aangegaan. Veranderingen worden daardoor meestal met vertraging doorgevoerd. De 'erfenis van het verleden' kleurt in de beleidspraktijk de ruimte voor nieuwe beleidsoriëntaties. En in dat verleden is de verzorgingsstaat geënt op de toenmalige demografische gegevenheden, industriële productiewijze, internationale concurrentieverhoudingen, arbeidspatronen en gezinssamenstelling. Al die zaken zijn veranderd. Dat laat echter onverlet dat waar je naartoe gaat in belangrijke mate bepaald wordt door waar je vandaan komt.

Dit hoofdstuk gaat in op de externe en interne uitdagingen waar de verzorgingsstaat een antwoord op moet zien te vinden. Hoe, zo luidt de vraag, beïnvloeden die uitdagingen de vier in het vorige hoofdstuk onderscheiden hoofdfuncties van de verzorgingsstaat: verzorgen, verzekeren, verheffen en verbinden. De slotconclusie zal zijn dat, terwijl er zeker nieuwe eisen gesteld worden aan verzekeren en verzorgen, het toch vooral de verbindings- en de verheffingsfuncties van de verzorgingsstaat zijn die meer aandacht moeten krijgen. De vier genoemde functies worden in het vervolg van dit rapport (hoofdstukken $5 \mathrm{t} / \mathrm{m} 8$ ) verder uitgediept. De analyse van de externe en interne uitdagingen waar de verzorgingsstaat voor staat geven echter al een eerste indicatie voor die hoofdconclusie van dit rapport.

In dit hoofdstuk wordt een onderscheid gemaakt tussen externe en interne uitdagingen. Beide hebben een tweeledig karakter. De externe uitdaging vloeit voort uit economische globalisering en liberalisering van markten (par. 3.2), en de Europese economische eenwording (par. 3.3). Aan de interne maatschappelijke uitdagingen kan een structurele en een culturele dimensie worden onderscheiden. In paragraaf 3.4 wordt de structurele uitdaging, de vergrijzing en de ontgroening - met hun gevolgen voor arbeidsmarkt en gezinsleven, behandeld. In paragraaf 3.5 is de vraag aan de orde hoe culturele veranderingen - individualisering, veranderende burgers, toenemende heterogeniteit - de verzorgingsstaat uitdagen. In paragraaf 3.6 worden de belangrijkste conclusies met betrekking tot de uitdagingen getrokken en in verband gebracht met de functies van de verzorgingsstaat. 
3.2 EXTERNE UITDAGING: ECONOMISCHE INTERNATIONALISERING

De Nederlandse verzorgingsstaat heeft allerlei verbindingen met de wereld om Nederland heen. Die zijn voor een deel van economische aard. De economie wordt in toenemende mate internationaal. Dat geldt voor de handel in goederen en diensten, voor de productie, voor financieel kapitaal en ondernemerschap, en ook voor informatie en technologie. Die economische internationalisering gaat gepaard met het ontstaan en belangrijker worden van internationale politieke organisaties. De EU springt daarbij het meest in het oog, maar er zijn ook andere organen die op wereldniveau zaken reguleren die direct ingrijpen in nationale verzorgingsstaten, of de speelruimte van nationale overheden inperken. Al met al kunnen deze internationale ontwikkelingen voor verzorgingsstaten als mogelijkheid en als inperking geduid worden.

\section{Globalisering in historische context}

Globalisering heeft het afgelopen decennium duidelijk momentum gekregen. Het proces van globalisering is echter beslist geen rechte lijn in de geschiedenis. Aan het eind van de negentiende eeuw was de omvang van de handel met het buitenland als aandeel van het bbp niet lager dan nu. Tot ver in de negentiende eeuw was handel vooral internationaal georiënteerd. De verschuiving van handels- naar industrieel kapitalisme bracht met zich mee dat de grenzen waarbinnen geproduceerd werd, meer van belang werden. Bedrijven - fabrieken en handelsorganisaties - gaan vanaf eind negentiende eeuw vooral produceren voor en handelen in het eigen land. Daarvoor zijn wegen, communicatie en energie vereist, en dat vraagt om een nationale overheid die meer doet dan het garanderen van rechtspraak en leger. Voor de overheid is de negentiende eeuw dan ook de eeuw van de infrastructuur. Gaandeweg groeit de noodzaak om ook een structuur te maken voor de politieke articulatie van de behoeften en wensen van de bevolking. Die structuur wordt eveneens nationaal georganiseerd, net als het stelsel van sociale voorzieningen dat daar weer op volgt. Na de Eerste Wereldoorlog breekt dan ook een periode aan van sterkere natiestaten: paspoorten worden verplicht, tariefmuren opgetrokken en de buitenlandse handel wordt verhoudingsgewijs minder belangrijk. Het staatsgezag wordt uitgebreid, centralistischer en democratischer. Het is ook de periode van een verdichting van de verhoudingen binnen de natiestaat. De twintigste eeuw is dan ook een periode met een sterke nadruk op economische productie binnen de grenzen van een natiestaat, gekoppeld aan een stelsel van verzorgings- en verzekeringsarrangementen die nationaal zijn georganiseerd. Het is die betrekkelijk jonge toestand die eind twintigste, begin eenentwintigste eeuw met de dan opnieuw opkomende globalisering onder druk staat.

\section{De huidige globaliseringsfase als nieuwe uitdaging}

Sinds de jaren tachtig van de vorige eeuw zijn we een nieuwe fase van globalisering ingegaan. Na enkele decennia van sterke natiestaten, zien we toenemende grensoverstijgende concurrentie op de markten van kapitaal, arbeid, goederen en diensten. De sterke toename van het aantal internationale economische transac- 
ties en de herschikking van het internationale productiesysteem zijn in belangrijke mate te herleiden tot de wereldwijde handelsliberalisatie, het hogere tempo van technologische vooruitgang, de daling van transport- en communicatiekosten, en de stijging van inkomens. Bij elkaar maken die de productiefactoren kapitaal en arbeid mobieler dan ooit tevoren. Hoever is deze ontwikkeling voortgeschreden? Om die vraag te kunnen beantwoorden is een nadere specificatie van globalisering vereist. Globalisering heeft op verschillende gebieden een verschillend tempo en verschillende vorm aangenomen. Laten we het proces daarom in een aantal deelprocessen uiteenleggen.

Allereerst verandert in de huidige globaliseringsfase de structuur van de handel. Handelsstromen worden internationaler. Het aandeel van de export in het bbp verdubbelde in alle OECD-landen van tien naar twintig procent in de periode 1960-200o. Voor het grootste deel gaat het daarbij om goederen, maar gaandeweg wordt ook dienstverlening steeds meer een internationale aangelegenheid. Daarbij tellen in het bijzonder de grensoverschrijdende financieringstransacties mee, die in de afgelopen dertig jaar naar schatting met een factor vijftig zijn gegroeid. Alleen al de deviezenmarkt groeide in de jaren tachtig en negentig met een factor twintig.

Ook de structuur van de productie verandert. Producten worden in het ene land ontworpen, in het volgende samengesteld, uit deelproducten die uit diverse delen van de wereld kunnen komen, om ten slotte weer elders te worden vermarkt. De honderd grootste internationale bedrijven hebben ongeveer vijftig procent van hun werknemers in hun thuisland in dienst en dus ook ongeveer vijftig procent elders. Het eigendom van (delen van) bedrijven wisselt ook sneller. Grote bedrijven groeien niet langer primair door zelf aan onderzoek en ontwikkeling te doen, maar veeleer door nieuwe kleine bedrijven te kopen. Het kopen en verkopen van (delen van) een bedrijf is bovendien steeds vaker een grensoverschrijdende aangelegenheid. Nieuwe landen dienen zich aan op de wereldmarkt. Het meest spectaculair is wel de opkomst van China met in het kielzog - zij het nog met achterstand - India. In 1990 was China de veertiende exporteur ter wereld. De Chinese uitvoer bedroeg nog niet de helft van die van Nederland. In 2005 stond China op het punt om de vs als tweede exporteur ter wereld te passeren en heeft het de ambitie om de grootste exporteur, Duitsland, spoedig in te halen.

Naast de liberalisering van productmarkten is de liberalisering van kapitaalmarkten van groot belang in de huidige globaliseringsgolf. Met de liberalisering van kapitaalmarkten in de tweede helft van de jaren tachtig heeft het regime van 'ingebed liberalisme' plaatsgemaakt voor de integratie van internationale product- en kapitaalmarkten. Markteconomieën hebben zich in toenemende mate aan nationale controles ontworsteld.

\section{Globalisering en de verzorgingsstaat}

Liberalisering, flexibilisering, privatisering en hervorming van de regulering vormen een wereldwijde ontwikkeling. Daarom typeren we ze als externe uitda- 
gingen voor de Nederlandse verzorgingsstaat. Dat betekent nog niet dat ze als een 'natuurontwikkeling' op samenlevingen als de onze zijn afgekomen. Overheden hebben deze processen bewust gestimuleerd in de hoop dat ze bijdragen aan een verdere groei van de welvaart. Maar welke gevolgen hebben ze voor de verzorgingsstaat? Veel auteurs zijn van mening dat het voortschrijdende proces van economische internationalisering de beleidsruimte voor nationale overheden en sociale partners voor arbeidsmarktbeleid aanzienlijk heeft ingeperkt. De vrees daarbij is dat landen steeds meer zullen moeten concurreren op het punt van lonen, belastingen en (sociale) regelgeving. Dit om hun aandeel op de internationale markt voor goederen en diensten te behouden, aantrekkelijk te blijven als vestigingsplaats voor bedrijven, en dus voldoende banen en belastinginkomsten te blijven genereren (Scharpf 200o, p. 4; Scharpf en Schmidt 200o). Doen ze dat niet, dan zou dat direct of indirect de financiële ruimte voor de verzorgingsstaat ondergraven. Hoe reëel deze vrees is, bespreken we hierna aan de hand van (1) de gevolgen voor de werkgelegenheid en de sociale zekerheid, en (2) de budgettaire en fiscale gevolgen.

\subsubsection{GEVOLGEN VOOR WERKGELEGENHEID EN SOCIALE ZEKERHEID}

Wanneer we naar de werkgelegenheid kijken, zien we dat er in de afgelopen jaren inderdaad op mondiale schaal een verplaatsing van productie heeft plaatsgevonden. Daarbij zijn delen van het productieproces uitbesteed naar andere, niet-gelieerde buitenlandse bedrijven (verticale specialisatie of outsourcing) of naar buitenlandse dochterondernemingen (offshoring). Ten dele was dit een kwestie van internationale specialisatie. In Europese landen is het verlies van banen in de industrie gecompenseerd door banengroei in de dienstensector. Uit onderzoek van de Europese Commissie komt echter ook de conclusie naar voren dat de effecten van dit proces voor de vijftien 'oude' lidstaten van de EU (EU-15) in de afgelopen tien tot vijftien jaar niet onverdeeld positief waren. Dit komt omdat een aantal lidstaten door hun te rigide instituties de kansen die economische globalisering biedt voor productiviteitsverbetering en groei niet hebben gegrepen. Een vergelijking van de Europese en Amerikaanse arbeidsproductiviteit en van de totale factorproductiviteit in de periode 1960-1990 laat zien dat beide regio's te kampen hebben met verouderde industrieën. Anders dan de vs, is Europa in de jaren negentig niet in staat geweest dat voldoende te compenseren door de groei van nieuwe hoogproductieve branches in de ICT-sector en de dienstverlening. Juist het Europese marktaandeel en de Europese comparatieve voordelen in hoogwaardig technologische uitvoerproducten (waaronder vooral ICT-producten) zijn achtergebleven bij die van de vs en Zuidoost-Azië. De EU-15 is nu nog marktleider in een groot aantal kapitaalintensieve sectoren en sectoren met een gemiddeld niveau van technologie-input, maar de Aziatische landen kunnen die marktpositie op termijn bedreigen. Als dat gebeurt, kan dat op lange termijn leiden tot een toename van de invoer van goederen en tot een uitstroom van kapitaal, en daarmee tot een verlies aan werkgelegenheid (Europese Commissie 2005, p. 63-64, 137). 


\section{Outsourcing én insourcing}

Tegelijkertijd verdient het gevaar van verlies aan werkgelegenheid door outsourcing enige relativering. Ten eerste blijkt dat, ondanks de outsourcing naar lagelonenlanden, en ondanks de enorme groei van de directe investeringen in China en India, verreweg het grootste deel van de investeringen nog altijd wordt gedaan in de EU en de vs. Productieverplaatsingen en specialisatie zijn bovendien van alle tijden. Zo heeft ons land in de afgelopen decennia afscheid genomen van een breed opgezette scheepsbouw en textielindustrie met een sterke regionale oriëntatie. Deze markten zijn ingeruild voor een rol op wereldschaal in enkele nichemarkten op het terrein van scheepsbouw (zoals luxejachten) en textiel (zoals hoogwaardige stoffen voor bijvoorbeeld kogelvrije vesten).

Parallel aan de outsourcing van zakelijke dienstverlening, zo kan worden geconstateerd, vindt ook insourcing plaats (Europese Commissie 2005, p. 173). Het voordeel van lage loonkosten is vooral in de meer traditionele, zware industrieën een factor van betekenis. Hoogtechnologische bedrijfstakken (met een hogere kapitaalintensiteit) en de dienstensector laten zich sterker leiden door stedelijke en regionale agglomeratievoordelen, zoals de aanwezigheid van verwante ondernemingen, de kwaliteit van infrastructuur, onderwijs en onderzoek, en regelgeving op het terrein van intellectueel eigendom. De problemen die voortkomen uit andere arbeidsculturen en andere wet- en regelgeving zijn bovendien vaak zo groot dat veel bedrijven terugschrikken voor het vestigen van een productielocatie in China, India of een ander land met een jongere traditie van industrialisatie.

\section{Open economieën}

Er zijn geen indicaties dat globalisering in relatief open economieën als vanzelf leidt tot hogere werkloosheid of uitholling van de sociale zekerheid. Onderzoek naar het verband tussen economische openheid, concurrentiepositie en sociale uitgaven laat zien dat welvarende landen die relatief veel uitgeven aan sociale bescherming, juist goed scoren in concurrentietoetsen (zie verder hoofdstuk 4). Dit positieve verband zou erop kunnen duiden dat deze open economieën investeren in sociale zekerheid om hun werknemers te beschermen tegen de nadelige gevolgen van internationale marktfluctuaties en economische aanpassingsprocessen. Het kan ook betekenen dat een hoger niveau van sociale zekerheid bijdraagt aan een hogere productiviteit en daarmee aan een groter concurrentievermogen, bijvoorbeeld doordat goed beschermde werknemers flexibeler kunnen zijn en meer risico's durven te nemen. Katzenstein heeft in 1985 in een studie naar zeven kleine Europese landen gevonden dat deze 'gecoördineerde' politieke economieën uitgebalanceerde strategieën van flexibele aanpassing hebben ontwikkeld als reactie op de eerste golf van internationalisering na de eerste oliecrisis van de jaren zeventig. Zij deden mee aan de liberalisering van de wereldhandel, terwijl zij binnenslands een strategie van sociale compensatie ontwikkelden, opdat er een acceptabele verdeling van de 'kosten' van de internationalisering tot stand kwam. Deze strategie heeft bijgedragen aan zowel het relatieve economische succes van deze kleine economieën als aan hun relatief ruimhartige verzorgingsstaten. Deze redenering is later gestaafd door onderzoek 
van Rodrik (Rodrik 1997; Katzenstein 1985). Kortom, in beginsel is toenemende internationalisering van de economie niet onverenigbaar met een goede concurrentiepositie én een fatsoenlijk niveau van sociale zekerheid. Van sociale dumping onder invloed van globalisering lijkt dan ook geen sprake te zijn (SER 2004, p. 125-126; Europese Commissie 2005, p. 173; СРВ/De Mooij 2006, p. 192-194).

Uit tal van studies blijkt dat protectionistische scenario's, waarmee overheden zouden kunnen proberen om de globalisering tegen te gaan, op termijn negatief uitwerken voor de productiviteit en de welvaart. De kansen die globalisering biedt blijven dan onbenut. De 'pijn' van globalisering zit in de negatieve gevolgen voor de werkgelegenheid in specifieke sectoren en regio's, en voor kwetsbare groepen zoals laaggeschoolde starters op de arbeidsmarkt, laaggeschoolde oudere werknemers en laaggeschoolde allochtonen. Outsourcing leidt tot een relatieve daling van de vraag naar laaggeschoolde arbeid in de industrie. Anders dan in de vs heeft dat in Europa tot dusverre nog geen grote toename van de loonverschillen tussen laag- en hoger opgeleiden veroorzaakt. Evenmin heeft het geleid tot een structurele verslechtering van de arbeidsomstandigheden. Dat neemt niet weg dat de positie van laaggeschoolden op de arbeidsmarkt het meest kwetsbaar is in de kenniseconomie. In de nabije toekomst zal de vraag naar arbeid alleen maar verder verschuiven in de richting van hoger opgeleiden en weg van lager opgeleiden. De problematiek van de laaggeschoolden zal in de Europese verzorgingsstaten dan ook een prominentere plaats innemen op de agenda. Dit is een belangrijke reden waarom de verheffings- en de verbindingsfuncties van de verzorgingsstaat aandacht behoeven.

\section{En Nederland?}

Vooralsnog lijkt het erop dat Nederland als kleine open economie meer dan evenredig geprofiteerd heeft van de economische globalisering. Uit veel parameters blijkt dat Nederland het goed is blijven doen. In de WTO-ranglijst van grootste exporteurs ter wereld bevond ons land zich in 2004 op de zesde plaats, dezelfde positie als in 1975. Onze handelsbalans vertoont al decennia een surplus, dat een opgaande lijn vertoont. De samenstelling van onze handelsoverschotten is daarbij verrassend stabiel. In vergelijking met ondernemingen uit andere OECD-landen deden Nederlandse ondernemingen op internationale markten en op het terrein van de mondiale kennisdeling (aandeel in buitenlandse R\&D, eigendom van buitenlandse innovaties, enzovoort) het de afgelopen jaren niet veel beter, maar ook niet veel slechter. Ook de scores op het gebied van groeivermogen (samengestelde indexen voor menselijk kapitaal, innovatie, ICT-gebruik en ondernemerschap) geven aan dat Nederland redelijk presteert en alleen op het terrein van ondernemerschap minder scoort.

Het leeuwendeel van de investeringen door Nederlandse bedrijven in het buitenland gaat nog steeds naar andere 'oude' industrielanden. De nadruk ligt daarbij op de vs, de EU en Zwitserland. Investeringen in bijvoorbeeld China, India of Midden-Europa groeien, maar nemen een ondergeschikte plaats in. Opvallend is dat Nederland de afgelopen tien jaar niet zozeer meer is gaan investeren in Azië - dat 
is maar beperkt het geval geweest - maar dat er vooral een verschuiving heeft plaatsgevonden van investeringen in de vs naar investeringen in Europa. Onderzoek van Bureau Berenschot laat zien dat 84 procent van de ondervraagde Nederlandse ondernemingen de afgelopen tien jaar geen bedrijfsactiviteiten hebben verplaatst en ook niet van plan zijn om dat in de nabije toekomst te doen. Berenschot meldt ook dat jaarlijks zo'n 9.000 banen verloren gaan als gevolg van outsourcing; een fractie van de totale dynamiek op de arbeidsmarkt, waar in de periode 1991-1997 jaarlijks gemiddeld 939.00o banen bijkwamen, terwijl er 856.ooo banen verloren gingen. Van de bedrijven die wel aan outsourcing hadden gedaan, bleek 52 procent Midden- en Oost-Europa te hebben gekozen als nieuwe locatie, 42 procent West- en Zuid-Europa, 16 procent China, en 11 procent India. Voor 62 procent van de ondernemingen bleken kostenoverwegingen de doorslaggevende factor te zijn voor outsourcing (Europese Commissie 2005, p. 9, 98).

Toch bestaat er bezorgdheid over het structurele groeivermogen van de Nederlandse economie. Mede dankzij de sterke toestroom van vrouwen en jongeren op de arbeidsmarkt zijn welvaart en werkgelegenheid in de jaren negentig sterk gestegen, maar dat was voor een belangrijk deel een inhaalslag. Daarnaast staan het vestigingsklimaat en de concurrentiepositie onder permanente concurrentiedruk (Ministerie van Economische Zaken 2004). Dit betekent dat er bedrijven zijn die moeten inkrimpen of die failliet gaan als gevolg van de buitenlandse concurrentie. De gevolgen daarvan zijn groter dan de negenduizend banen die jaarlijks verloren gaan als gevolg van bedrijfsverplaatsing naar het buitenland. De kans is aanwezig dat het aantal bedrijfsverplaatsingen de komende jaren toeneemt, zeker nu de EU in 2004 met tien nieuwe lidstaten is uitgebreid. In het algemeen is de beroepsbevolking in die nieuwe lidstaten goed opgeleid en sommige van de betrokken landen kennen een sterke industriële traditie. Weliswaar blijkt een en ander nog niet uit de cijfers, maar naarmate de nieuwe lidstaten beter geïntegreerd raken in de interne Europese markt, valt niet uit te sluiten dat sommige delen van het Nederlandse bedrijfsleven alsnog in versneld tempo werk naar Midden-Europa gaan verplaatsen. Dit leidt vooral tot maatschappelijke problemen in perioden van laagconjunctuur en als bijzondere groepen werknemers getroffen worden, zoals oudere, laagopgeleide mannen die elders moeilijk aan de slag komen. Minstens zo belangrijk voor de beoordeling van de slagkracht van de Nederlandse economie is echter de gebrekkige aansluiting van vraag en aanbod op de arbeidsmarkt voor technisch geschoold personeel in Nederland zelf. De Nederlandse industrie kampt met een relatief oud personeelsbestand. Dit betekent dat er als gevolg van pensionering een flinke vervangingsvraag naar technisch personeel zich kan gaan voordoen.

\section{Arbeidsmigratie}

Naast verplaatsing van de productie heeft ook de verplaatsing van arbeid in de vorm van migratie gevolgen voor de werkgelegenheid. Hoewel mondiaal gezien de afgelopen decennia de vrijheid om geld en productie te verplaatsen stukken groter was dan de vrijheid om te migreren, valt migratie niet meer weg te denken uit een globaliserende wereld. Nederland zal dan ook voortdurend te maken 
hebben met migratie. Een deel daarvan betreft emigratie - Nederlanders die naar elders vertrekken, vaak tijdelijk; een volgend deel betreft remigratie, voormalige migranten of hun kinderen die terug willen naar het land van herkomst. Maar ook migratie naar Nederland zal in de toekomst blijven bestaan, al valt te verwachten dat door de open grenzen binnen Europa de migratiestroom minder van zuid naar noord zal gaan en meer van oost naar west. Waarschijnlijk zal deze migratie bovendien tijdelijker zijn, denk bijvoorbeeld aan Polen die slechts enkele maanden per jaar in Nederland komen werken.

Zal arbeidsmigratie inderdaad, zoals soms gevreesd wordt, leiden tot verdringing van arbeid, loonconcurrentie en 'economisch toerisme'? Of kunnen migranten in de toekomst juist een bijdrage leveren aan de economische groei en aan het verlichten van het vergrijzingsprobleem? Onderzoek naar deze vragen levert geen ondubbelzinnige conclusies op, alleen al omdat veel afhangt van de individuele kenmerken van de arbeidsmigrant, de duur van het verblijf, de aard van arbeidsmarktinstituties en de (conjunctuur)fase waarin de migratie plaatsvindt. In theorie kunnen arbeidsmigranten de collectieve welvaart vergroten door het verhogen van de productie, het produceren tegen lagere (loon)kosten en het oplossen van specifieke knelpunten op de arbeidsmarkt. Tegelijkertijd kunnen echter negatieve gevolgen ontstaan voor de welvaartsverdeling, de overheidsfinanciën en de maatschappelijke verhoudingen tussen nieuwkomers en ingezetenen, en tussen degenen die van arbeids- en volgmigratie vooral de voordelen dan wel de nadelen ondervinden. In ieder geval is duidelijk dat als arbeidsmigratie vooral zou bestaan uit immigratie van laag- en ongeschoolden, de positie van laag- en ongeschoolde ingezetenen verslechtert.

Mag verwacht worden dat met de komst van nieuwe arbeidsmigranten het vergrijzingprobleem kan worden opgelost? Het antwoord hierop lijkt een ondubbelzinnig 'neen' te zijn (Entzinger 2002; Europese Commissie 2005, p. 119-123; De Beer 2006). Het stabiel houden van de 'grijze druk' tot 2040 op het huidige niveau, zou vragen om een hypothetische immigratiestroom van acht miljoen mensen. Zelfs een dergelijke massale additionele vestiging in Nederland zou het vergrijzingsprobleem hier niet oplossen, maar hooguit uitstellen, want ook onder migranten is er op termijn sprake van vergrijzing.

\subsubsection{BUDGETTAIRE EN FISCALE GEVOLGEN}

Welke gevolgen heeft de concurrentiedruk en de toenemende mobiliteit van productiefactoren voor de belastingopbrengsten in Europa en Nederland, en daarmee voor de collectieve uitgaven? Kan het leiden tot een belastingconcurrentie die uitmondt in een race to the bottom? Deze vrees is in het achterliggende decennium vaak geopperd. Steeds meer overheden kregen te maken met bedrijven en burgers die aan tax planning doen. Dit mede dankzij de toenemende ruimtelijke spreiding van productieprocessen, de opkomst van de elektronische handel en de toegenomen arbeidsmobiliteit. Overheden worstelen met de vraag hoe daarop een geschikt antwoord te vinden. Aan de ene kant willen ze hun land 
niet in een ongunstige concurrentiepositie manoeuvreren, aan de andere kant behoren al te grote belastingverlagingen meestal niet tot de reële mogelijkheden.

In de jaren tachtig en negentig zijn diverse Europese verzorgingsstaten inderdaad de belastingconcurrentie aangegaan: landen probeerden met behulp van verlaging van de tarieven bedrijven aan te trekken zonder rekening te houden met de belastinggrondslag van andere Europese landen. Het meest zichtbaar is die neerwaartse spiraal in de formele tarieven voor de vennootschapsbelasting, die in de OECD-landen van vijftig procent in 1983 naar gemiddeld dertig procent in 2003 werden teruggebracht. Ook Nederland volgde en volgt nog steeds dat patroon. De netto-opbrengsten van de vennootschapsbelasting bleven echter bijna overal op peil, omdat er gelijktijdig ook een grondslagverbreding plaatsvond door vermindering van vrijstellingen, en omdat bovendien de accountancyregels strenger zijn geworden. Al met al heeft er in de EU vanaf 1980 een kleine stijging van totale belastingopbrengsten plaatsgevonden: tot zo'n veertig 40 procent van het bbp. Daarbij zijn de verhoudingen tussen verschillende belastingsoorten niet substantieel veranderd. De kapitaalbelasting levert ongeveer 7 procentpunt op, de belasting op consumptie 12 procentpunt, en de belasting op arbeid 21 procentpunt. Bovendien is de lastendrukquote in de verschillende landen geconvergeerd. De quote is het meest aangetrokken in landen die laag zaten, en het meest gedaald in landen die hoog zaten. Nederland is van een land met een hoge collectieve lastendruk een kwart eeuw geleden veranderd in een gemiddeld OECD-land.

Verdere dalingen van de (effectieve) belastingtarieven zijn mede door de toenemende kapitaalmobiliteit en de uitbreiding van de EU naar Midden- en OostEuropa en Cyprus niet ondenkbaar. In de aanloop tot, en ook na hun toetreding, hebben verschillende nieuwe EU-lidstaten hun wettelijke en effectieve belastingtarieven verlaagd, in de hoop daarmee nieuwe investeringen aan te trekken en/of de concurrentiestrijd om de 'papieren winsten' van holdings en financieringsmaatschappijen aan te gaan. Deze praktijken spoorden de oude lidstaten van de EU aan om op hun beurt te reageren met tariefverlagingen.

Toch kunnen we in het algemeen concluderen dat belastingconcurrentie tot op heden niet de voorspelde race to the bottom is geworden. Er zijn ook redenen om aan te nemen dat ook in toekomst de vennootschapsbelasting niet volledig zal (hoeven te) verdwijnen. Ten eerste worden de kapitaalinvesteringen in Europa voor een deel bepaald door agglomeratievoordelen. Landen, zoals Nederland, die tot de kern van Europa behoren kunnen dankzij hun locatievoordelen hogere belastingtarieven handhaven dan meer perifere Europese landen. Ten tweede, en daarmee samenhangend, hangt het vestigingsklimaat van een land van meer factoren af dan van het belastingtarief. Voor moderne hoogwaardige industrieën en diensten zijn de aanwezigheid van aanverwante ondernemingen en de kwaliteit van grotendeels publiek gefinancierde zaken, zoals infrastructuur, onderwijs en onderzoek, en culturele voorzieningen, minstens zo belangrijk. Naarmate bedrijven meer waarde hechten aan de kwaliteit van deze publieke goederen zal ook de bereidheid groter zijn om hier via belastingen aan mee te 
betalen. Ten derde hebben hoogontwikkelde verzorgingsstaten nu eenmaal te maken met een politiek gewenst voorzieningenniveau dat beperkingen oplegt aan hun mogelijkheden om mee te doen aan belastingconcurrentie. Waar het niveau van die voorzieningen steeds meer op elkaar gaat lijken, iets wat in hoofdstuk 4 nog verder geadstrueerd zal worden, is er ook een vanzelfsprekende impuls om belastingen meer op elkaar af te stemmen.

\section{Conclusie}

Belastingconcurrentie heeft geleid tot convergentie. Tegelijkertijd is er sprake van een reële convergentie van sociale systemen. Dat heeft verschillende consequenties. Allereerst zal de roep toenemen om verdere multilaterale coördinatie van belastingbeleid binnen de OECD en de EU (Griffiths en Klemm 2004).

Belangrijker echter is dat deze convergentie in de praktijk betekent dat de eigen budgettaire en fiscale manoeuvreerruimte van landen beperkter is geworden. Er vindt dan wel niet de gevreesde race to the bottom plaats, maar er is in de overzienbare toekomst ook weinig ruimte voor een substantiële groei van de publieke uitgavenquote.

\subsection{EXTERNE UITDAGING: EUROPESE ECONOMISCHE EN POLITIEKE INTEGRATIE}

Economische internationalisering biedt kansen voor welvaartsvergroting, maar beperkt ook de mogelijkheden om door nationale sturing nadelige neveneffecten van toenemende economische verwevenheid op te vangen. Het internationaliseringsproces heeft daarmee ook invloed op de vormgeving van nationale verzorgingsstaten. Dankzij de economische en politieke internationalisering is het traditioneel sterk nationaal getinte overheidsgezag zich geleidelijk en deels sluipenderwijs gaan verspreiden over meer verschillende publieke, en ook private, actoren op lokale, regionale, nationale, inter- en bovennationale niveaus. Er zijn meer uiteenlopende vormen en lagen van bestuur (governance) ontstaan. Op meerdere niveaus wordt beleid gemaakt en het beeld van relevante institutionele kaders en netwerken is aanzienlijk complexer geworden (Held en McGrew 2004, p. 9; WRR 2003, p. 25).

De EU springt daarbij het meest in het oog als regulerend kader. Maar ook op andere, vooral mondiale niveaus dienen zich politieke en juridische verbanden aan die de toekomst van verzorgingsarrangementen kunnen beïnvloeden (denk aan de doorwerking van internationale boekhoudregels, dekkingsgrondslagen voor pensioenfondsen, Europese aanbestedingsregels, etc.)(vgl. Sassen 2005). In het kader van dit hoofdstuk richten we ons in het bijzonder op de invloed van de EU op de (ruimte die er is voor een Nederlandse) verzorgingsstaat. We zullen de invloed analyseren langs vier sporen die deze invloed volgt: budgettaire spelregels, bindende regelgeving, uitspraken van Europese Hof en 'open' beleidscoördinatie.

\section{Budgettaire regels}

In de EU zijn met de totstandkoming van de interne markt nationale economische grenzen goeddeels verdwenen, en met de introductie van de Europese Monetaire 
Unie (EMU) is het instrumentarium van nationale wisselkoers- en renteaanpassing verdwenen. Op grond van het Stabiliteits- en Groeipact (SGP) is de maximale omvang van het financieringstekort bepaald. Dat was een duidelijke beleidskeuze. Veel politici waren (en zijn) van mening dat 'harde' wetgeving te verkiezen is boven meer flexibelere vormen van open beleidscoördinatie, nauwere samenwerking en kopgroepvorming. In een omgeving van vrij kapitaalverkeer zijn harde munten, lage inflatie, en budgettaire discipline noodzakelijke voorwaarden voor een stabiele economie. Daarmee is echter nog niet gezegd dat het kader van EMU en SGP onder alle omstandigheden een optimaal groeibevorderend macro-economisch regime is. De EMU en het SGP zijn gedurende de jaren negentig tot stand gekomen terwijl de economie in de EU-lidstaten sterk groeide. Binnen het kader van het SGP is destijds gekozen voor een beperkte bandbreedte voor nationaal budgettair beleid: het overheidstekort mag maximaal drie procent bedragen. Hiernaast richt de Europese Centrale Bank (ЕСB) zijn rentebeleid op de gemiddelden in de conjunctuurontwikkeling van de eurolanden. Dit brengt spillover-problemen met zich mee voor landen die afwijken van deze gemiddelden in groei en inflatie.

Deze versmalling van de marges voor nationaal monetair en budgettair beleid kunnen in de eerste plaats beschouwd worden als beneficial constraints (Streeck 1997), die stevig verankerde randvoorwaarden vastleggen die nationale beleidsmakers stimuleren om zich te concentreren op de modernisering van de arbeidsverhoudingen en de sociale zekerheid. De vastgestelde beleidsruimte voor een nationaal monetair en budgettair beleid onder de EMU en het SGP heeft nationale beleidsmakers ertoe aangezet om sociale akkoorden tussen werkgevers- en werknemersorganisaties te stimuleren, om binnenlandse arbeidsverhoudingen te moderniseren, de arbeidsmarkt te flexibiliseren, en socialezekerheidsarrangementen meer te richten op activering. Voor Nederland is zo'n bestuurlijke constellatie niet zo bijzonder, voor een aantal andere Europese landen was het een noviteit. Ze gingen ook een beetje 'polderen'.

\section{Bindende regels}

De politieke gevolgen van het proces van Europese integratie gaan verder dan de gevolgen van de Europese interne markt en de EMU. De aanpassingsproblemen die in diverse landen op verregaande economische integratie volgen, kunnen aanleiding vormen voor Europees beleid dat probeert de negatieve sociale gevolgen van de intensivering van de economische concurrentie in de eurozone tegen te gaan. Politieke elites in Europa beseffen in toenemende mate dat om de steun van de bevolking voor het 'Europese project' te behouden, de EU met de intensivering van de economische integratie zich ook aan haar burgers moet tonen als een geloofwaardig arrangement van sociale cohesie, en niet louter als een bedreiging van bestaande rechten. Het coördineren van zoveel verschillende nationale systemen van sociale zekerheid en arbeidsmarktbeleid, en politieke stijlen van besluitvorming, is niet eenvoudig. Hier en daar is bindende Europese sociale wetgeving tot stand gekomen, met name op het gebied van gezondheids- en veiligheidswetgeving. Richtlijnen met betrekking tot gelijke behandeling en 
kansen, en de jurisprudentie van het Europese Hof dat zich op deze wetgeving baseert, hebben bovendien geleid tot een uitgebreid stelsel van bindende rechten dat geldt in alle lidstaten. Sinds het midden van de jaren zeventig worden zaken geregeld zoals collectief ontslag van werknemers, overname van bedrijven, en de rechten van werknemers van onvermogende werkgevers.

\section{Uitspraken van het Europese Hof}

Omdat verschillende markten een gelijk en voor iedereen in dezelfde mate toegankelijk speelveld moesten gaan vormen (vergelijk de notie van vrijheid van verkeer uit het Verdrag van Rome) is onder leiding van het Europese Hof regelgeving tot stand gekomen die de nationale begrensdheid van (verzorgings)staten ter discussie stelt. Die uitspraken van het Hof betreffen met name de rechten van burgers, bijvoorbeeld op Bijstand en medische vergoedingen. Vooralsnog is dit nog niet van invloed op het aanbod van voorzieningen in verschillende landen. De invloed van uitspraken van het Europese Hof zou in de toekomst wel verder kunnen voortschrijden. Het zou kunnen dat lidstaten sociale voorzieningen zoals de Bijstand niet langer zonder meer mogen voorbehouden aan hun eigen inwoners. Ook kunnen overheden wellicht niet langer eisen dat sociale uitkeringen binnen het eigen territorium worden gebruikt. De vraag is ook wanneer burgers binnen hun eigen staatsgrenzen verzekerd dienen te zijn, en wanneer dit ook elders kan (bijvoorbeeld waar het gaat om ziekte- en arbeidsongeschiktheidsverzekeringen). Op termijn zullen ook constructies als een algemeen-verbindendverklaring van een CAO tegen het licht van de mededingingsbepalingen worden gehouden. Ook het Hof zal dus een voorzichtige maar wezenlijke harmoniserende werking hebben op sociale stelsels.

\section{Europees werkgelegenheidsbeleid en open coördinatie}

Naast monetaire afspraken, juridisch bindende richtlijnen en uitspraken van het Hof is 'open beleidscoördinatie' een vierde kanaal waarlangs de invloed van de EU op nationale verzorgingsstaten zich doet gelden. In 1989 werd in de EU het Sociale Handvest aanvaard, dat in 1991 werd opgenomen in het Verdrag van Maastricht. Met dit compromis over een nauwere samenwerking tussen elf landen (het Verenigd Koninkrijk wilde daar niet bijhoren) werd een belangrijke stap in een nieuwe richting gezet. Doordat het compromis werd aanvaard door alle twaalf toenmalige lidstaten, was het mogelijk voor een kopgroep van elf om richtlijnen met gekwalificeerde meerderheid op te stellen ten aanzien van arbeidsomstandigheden, medezeggenschap en gelijke kansen voor mannen en vrouwen. Een tweede institutionele vernieuwing die voortkwam uit het Sociaal Protocol, is de formalisering van de sociale dialoog tussen de sociale partners op Europees niveau, waarmee gemeenschappelijke overeenkomsten tussen de Europese sociale partners door de Commissie kunnen worden bekrachtigd.

De invoering van een apart hoofdstuk over werkgelegenheid in het Verdrag van Amsterdam (1997) was een volgende belangrijke stap: hiermee werd toename van de werkgelegenheid verheven tot een van de doelen van Europees economisch beleid. 
De hierop volgende Europese werkgelegenheidsstrategie vormde de eerste toepassing van de zogeheten 'methode van open coördinatie' (OMC). In het kader van de OMC vinden er nationale en Europese beleidsevaluaties plaats. Die maken het mogelijk om een aantal voorzichtige conclusies te trekken over de merites van deze nog betrekkelijk nieuwe beleidsontwikkeling binnen de EU. In de eerste plaats is in de meeste landen van de EU duidelijk sprake van een inhoudelijke transformatie van een passief beleid gericht op inkomenscompensatie (uitkeringen op grond van inactiviteit) naar een meer activerende benadering in nationaal arbeidsmarkt- en sociaal beleid (zie uitgebreid hoofdstuk 4). Verder zijn sinds 1997 de nationale werkgelegenheidsambities opgevoerd en vertaald in een groot aantal concrete doelen voor opleiding, training, en preventieve aanpassingen van werk en huishoudelijke taken in jonge gezinnen.

\section{EU: economisch en sociaal beleid meer in elkaars verlengde}

De pogingen tot economische en beleidsmatige integratie zijn niet zonder neveneffecten gebleven. Een kenmerk van de geleidelijke wording van de huidige EU is dat er onder burgers en beleidsmakers allengs een zekere onvrede is gerezen die vooral het primaat van de markt in de Eu betrof. De politieke vertaling van die onvrede is terug te vinden in het besef dat de EU naast 'markt en munt' ook een sociaal gezicht moet hebben om niet aan legitimiteit in te boeten (WRR 2003). Om blijvende maatschappelijke steun te behouden of te verwerven, moet de EU meer sociale geloofwaardigheid uitstralen. Nu bestaat het gevaar dat ze louter als een bedreiging wordt gezien. Economische doelstellingen dienen dan ook niet als doel op zichzelf, maar als voertuig van sociale vooruitgang vorm te krijgen. De europeanisering van het sociale beleid werd aanvankelijk vooral gedreven door de behoefte van sociale partners aan een 'gelijk speelveld' (level playing field) op de interne markt, en door de vrees voor sociale dumping. Maar geleidelijk is scherper op het netvlies gekomen dat economisch en sociaal beleid ten principale meer in elkaars verlengde moeten worden gebracht en niet meer los van elkaar kunnen worden gezien. Consequentie van deze veranderende optiek in en op de EU is ook dat het een meer open en politieke opvatting veronderstelt van het subsidiariteitsbegrip dat de verhouding tussen de EU en de deelnemende landen regelt, met consequenties van dien voor nationale verzorgingsstaten.

In dit proces kunnen beleidsconvergentie, zelfbinding en leereffecten op regionale schaal in theorie fungeren als buffermechanismen tegen het verlies aan nationaal bestuurlijk handelingsvermogen. Naar verwachting zullen de komende jaren de politiek-maatschappelijke condities in de verschillende EU-lidstaten minder direct wijzen in de richting van een versterkte ontwikkeling van deze mechanismen; daarvoor mist het project Europa in de ogen van veel burgers voldoende geloofwaardigheid en daarmee draagvlak. Tegelijkertijd wijst er nog steeds veel op dat dit een fase is die gevolgd zal worden door een fase waarin de verdere ontwikkeling van deze buffermechanismen weer voldoende legitimiteit heeft. Als die veronderstelling klopt mogen we ervan uitgaan dat de ontwikkelingen op EU-niveau de komende decennia de ruimte van de lidstaten voor een eigenstandige invulling van hun verzorgingstaat nog verder inperken. Nederland wordt in 
dat opzicht in toenemende mate een semi-soeverein land in de EU waar sociale stelsels in steeds grotere mate op elkaar gaan lijken. Veel hangt af van de vraag of de ontwikkeling doorzet waarin EU-lidstaten veel meer oog hebben voor elkaars problemen en institutionele geschiedenis. Daarmee zou een basis ontstaan voor een verdere emancipatie van Europees sociaal beleid.

\subsection{INTERNE UITDAGING: VERGRIJZING EN ONTGROENING}

De uitdagingen waarmee verzorgingsstaten zich geconfronteerd zien, vinden niet alleen hun oorsprong in de beperkingen die worden opgelegd door economische internationalisering en de verregaande europeanisering van economisch beleid, maar ook in ontwikkelingen van vergrijzing en ontgroening en veranderde arbeidsmarkt-, gezins- en samenlevingspatronen in Nederland zelf. De meer sociaal-culturele aspecten van deze veranderingen behandelen we in de volgende paragraaf (par. 3.5). Deze paragraaf behandelt vergrijzing en ontgroening.

In alle Europese verzorgingsstaten doen zich ingrijpende demografische veranderingen voor. Ten eerste verandert de bevolkingsopbouw als gevolg van de daling van het kindertal en de verlenging van de levensduur. Zo is de vervangingsfactor in bijna heel Europa onder de twee gedaald (vrouwen krijgen gemiddeld minder dan twee kinderen). Hierdoor zal de bevolking op termijn in aantal afnemen, iets wat in een aantal landen al begonnen is. Daarmee is een van de grootste problemen van de Europese verzorgingsstaten gegeven: de bevolking wordt niet alleen ouder, maar op termijn ook kleiner. Tussen 2000 en 2050 zal de bevolkingsomvang in de EU naar verwachting dalen van 482 naar 452 miljoen mensen. Al vanaf 2010 zullen er in de EU meer mensen overlijden dan geboren worden. In $2050 \mathrm{zal}$ de gemiddelde leeftijd in de EU 49 jaar zijn, tegen nu 38 jaar. Dat heeft vooral consequenties voor de 'grijze druk', de verhouding tussen het aantal 65-plussers en het aantal 20-64-jarigen. De grijze druk stijgt van 24 procent in 2000 tot 49 procent in 2050. Dankzij een relatief hoog geboortecijfer zal de absolute daling van de (beroeps)bevolking in Nederland wat later optreden, maar het vergrijzingstempo wijkt niet veel af van het EU-gemiddelde. In Nederland zullen in 2050 naar verwachting voor elke tien werknemers 4,1 gepensioneerden zijn bijna het dubbele van het huidige aantal van 2,2.

De consequenties van deze demografische trends zijn groot. In economische zin ontstaan er twee problemen voor de overheid: ceteris paribus zullen er minder inkomsten zijn, want er zijn minder (werkende) mensen om sociale zekerheidspremies en belastingen af te dragen, en met die geringere bijdragen moeten de uitgaven voor meer mensen betaald worden, vooral op het gebied van de gezondheidszorg en oudedagsvoorzieningen. De groei van de kosten van pensioenen, gezondheidszorg en ouderenzorg zal beduidend groter zijn dan de terugloop van uitgaven op het terrein van werkloosheid, onderwijs en andere jeugdgerelateerde uitgaven. Ramingen van het СРВ voor Nederland gaan bijvoorbeeld uit van een stijging van de collectieve uitgaven met ruim 7 procentpunt van het bbp tussen 
Figuur 3.1 Toekomstige omvang van de beroepsbevolking en de totale werkgelegenheid in de EU-25

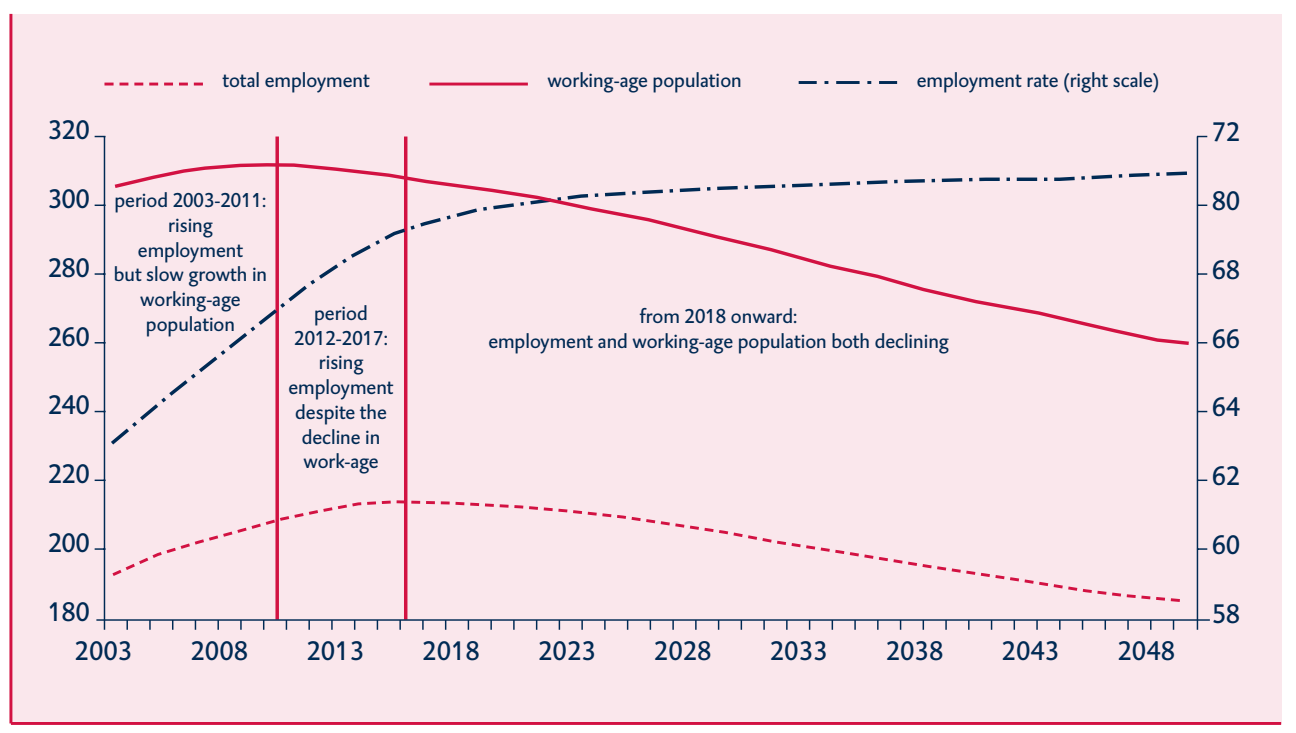

Bron: EC-DG ECFIN/EPC (2006) The Impact of ageing on public expenditure, European Economy special report $1 / 2006$

nu en 2040 indien de huidige arrangementen gehandhaafd blijven. De uitgaven voor de pensioenen zouden volgens die veronderstellingen stijgen van 4,7 naar 9 procent van het bbp (СРв/De Mooij 2006, p. 145). Zelfs als Nederland en de andere lidstaten erin zouden slagen de Lissabondoelstellingen voor het verhogen van de arbeidsparticipatie te halen, zou dat onvoldoende zijn om de gevolgen van de vergrijzing op te vangen. Figuur 3.1 laat zien dat tussen 2012 en 2017 de stijging van de werkgelegenheid de daling van de beroepsbevolking nog zal compenseren. Daarna zullen de effecten van de vergrijzing zich echter in volle omvang vertalen in een daling van de beroepsbevolking. Al eerder zal de ontgroening leiden tot structurele arbeidstekorten, die in ieder geval pregnant worden in de zorgsector (zie verder hoofdstuk 5).

De demografische ontwikkelingen zijn ook merkbaar in de verhoudingen tussen generaties en de samenstelling van gezinnen. Van een samenleving met hoge sterfte- en geboortecijfers zijn we veranderd in een samenleving met lage sterfteen geboortecijfers: dat betekent meer levende generaties, maar minder familieleden binnen een generatie. De trend dat vrouwen hun kinderen op een latere leeftijd krijgen, leidt tot een grotere 'afstand' tussen de generaties. In de loop van de afgelopen decennia zijn gezinsverbanden bovendien minder stabiel geworden. Gemiddeld eindigt in Europa een op de drie huwelijken in een scheiding, maar dit percentage ligt in de Zuid-Europese landen rond de tien procent en in de noordelijke rond de veertig procent. In Scandinavië zal inmiddels ongeveer de helft van de kinderen niet (volledig) opgroeien in een omgeving met hun twee oorspronkelijke ouders. 
Al deze ontwikkelingen hebben consequenties voor de verdeling van de financiële lusten en lasten van de verzorgingsstaat. Handhaving van de status quo in het huidige Nederlandse omslagstelsel voor de AOw betekent bijvoorbeeld dat de extra kosten van de vergrijzing door de jongere generaties werkenden moeten worden opgebracht (Esping-Andersen 2006, p. 14). Vandaar dat er indringende (politieke) 'verdelingsdebatten' (kunnen) ontstaan. De demografische ontwikkelingen stellen dan ook niet alleen eisen aan de verzorgings- en de verzekeringsfuncties van de verzorgingsstaat, maar zeker ook aan de verbindingsfunctie.

\subsection{INTERNE UITDAGING: SOCIAAL-CULTURELE DIFFERENTIATIE EN INDIVIDUALISERING}

Neem als eerste de categorie burgers. Toen de verzorgingsstaat in het begin van de vorige eeuw vorm begon te krijgen, waren zijn voorzieningen vooral gericht op mannen, met een lage opleiding, die fysiek sterk belastend werk deden en een groot gezin te onderhouden hadden. In het begin van de eenentwintigste eeuw gaat het om mensen (mannen en vrouwen), met een redelijke tot goede opleiding, die meestal inspirerend werk verrichten waarin ze eerder psychisch dan fysiek belast worden, en die leven in een klein samenlevingsverband waarin ook anderen voor inkomen zorgen. Hun levensloop is gedifferentieerder en minder voorspelbaar, ze zijn economisch welvarender, beter opgeleid, mobieler, individualistischer en mondiger, en over de hele linie ook ouder dan de typische burger van begin twintigste eeuw. De 'veranderende burger' vormt daarom een van de aanleidingen voor een herijking van de verzorgingsstaat.

Deze nieuwe burger is niet alleen een 'externe invloed op' de verzorgingsstaat. Hij is er net zo goed een product van. Leerplicht en scholen hebben immers bijgedragen aan het ontstaan van een hoger opgeleide en mondiger bevolking. Het socialezekerheidsstelsel heeft andere gezins- en familiepatronen gestimuleerd en bijgedragen aan de individualisering. Zonder de Algemene Bijstandswet van 1965 zouden veel vrouwen het niet hebben aangedurfd om te scheiden van hun man. Zonder gezinszorg zouden ouderen afhankelijker zijn van hun kinderen. Niet iedereen duidt dat overigens enkel positief. Vanaf de jaren tachtig groeide bij sommigen de bezorgdheid dat de zich voortzettende individualisering het sociale weefsel zozeer zou aantasten dat alle onderlinge betrokkenheid op termijn zou eroderen. Mensen zouden niet meer voor elkaar zorgen, of niet meer bereid zijn mee te betalen aan de voorzieningen van de verzorgingsstaat; en ze zouden ook andere vormen van asociaal gedrag gaan vertonen. Anderen waren beducht voor het gevaar dat burgers de diverse voorzieningen opportunistisch gingen gebruiken, en zichzelf niet langer zouden inspannen om dat gebruik tot een minimum te beperken. Deze thema's zijn sindsdien niet van de agenda geweest en vormen nog steeds oriëntatiepunten bij het ontwikkelen van beleid. Hoe deze weging ook uitpakt, op een aantal punten lijken zich blijvende veranderingen te hebben voorgedaan. Drie daarvan springen in het bijzonder in het oog, zeker in het licht van de consequenties die deze hebben voor de invulling van de verzorgingsstaat van de komende decennia. Burgers verrichten andere arbeid dan vroeger; ze horen in 
toenemende mate tot de middenklasse; en hun individualisme vertoont specifieke kenmerken: Nederlandse burgers zijn niet losgeslagen en zorgeloos, maar willen leven in een zachtmoedige samenleving.

\section{Andere arbeid}

Nederlandse burgers zijn ander werk gaan doen. In 1900 was het belangrijkste beroep voor mannen landarbeider en voor vrouwen - tot ze trouwden - dienstbode. In 1930 stond bij mannen bouwvakarbeider op de eerste plaats van de lijst beroepen, en bij vrouwen nog steeds dienstbode; in 196o bij mannen metaalarbeider en vrouwen winkelbediende; en in 1990 bij mannen medewerker groothandel en bij vrouwen verpleegster (Heerma van Voss 2002). Werk heeft bovendien een andere betekenis gekregen in het leven van mensen. Een eeuw geleden was werk boven alles een bron van inkomen. $\mathrm{Nu}$ is werk ook, en voor velen vooral, een manier geworden om zich te ontplooien en iets om identiteit aan te ontlenen. In het verlengde daarvan krijgen arbeidsrelaties een andere inhoud: het gaat niet meer om eenzijdig opgestelde contracten voor het leven, maar om tweezijdige afspraken voor een bepaalde periode. Verandering en ontwikkelen worden belangrijker. Deze omslag is in Nederland met name zichtbaar bij vrouwen. Was het in de jaren tachtig nog gewoon om huishouden en zorg voor kinderen als levensdoel te benoemen, inmiddels willen de meeste moeders graag ook buitenshuis werken. Ook veel ouderen willen zich niet voortijdig van de arbeidsmarkt terugtrekken. Tegelijkertijd is arbeid niet de enige sociaal-culturele waarde in Nederland. Veel mensen geven juist aan dat arbeid alleen de ontplooiing dient, als het niet de volledige werkweek in beslag neemt. Nederlanders hechten veel waarde aan tijd voor zorg en familie en aan 'vrije tijd' (SCP).

\section{Middenklasse}

Nederland is veranderd in een middenklassesamenleving. Het onderscheid naar stand is nagenoeg verdwenen, verschillen tussen klassen zijn verminderd. De meeste mensen hebben daardoor meer mogelijkheden dan hun grootouders, maar sommigen uiteraard minder. Vele grootmoeders waren immers dienstbode (tot ze trouwden) - anderen hadden een leven lang huishoudelijk personeel in dienst. Beide situaties zijn zeldzaam geworden. Dat we zijn omgevormd tot een middenklassesamenleving blijkt ook uit de inkomensontwikkelingen. Vanaf het eind van de Eerste Wereldoorlog profiteerden de lagere inkomensgroepen meer van de welvaartsgroei dan de hogere. Ook de vermogensongelijkheid verminderde, deels door de verplichte aansluiting bij pensioenfondsen. Kapitaalinkomsten vormden in 1939 nog 21 procent van het Nederlandse nationale inkomen, in 1977 was dat gedaald tot 4 procent. Arbeidsinkomen werd steeds belangrijker, net als inkomen uit socialezekerheidsregelingen. Binnen de categorie arbeidsinkomen namen de verschillen tussen hand- en hoofdarbeiders af, net als de verschillen tussen de (traditioneel slecht betaalde) landarbeiders en de industriearbeiders. Vanaf 1983 trad er overigens een kentering op. Inkomensverschillen groeien weer, naar Europese maatstaven gebeurt dat in Nederland echter relatief laat en gematigd. Naast de algehele nivellering treden er overigens verschuivingen in rijkdom c.q. armoede op tussen de bevolkingsgroepen. Zo is in Nederland, net als 
in de meeste OECD-landen, de afgelopen twintig jaar het risico op armoede verschoven van ouderen naar kinderen en de gezinnen waarin ze opgroeien.

\section{Kwalitatief individualisme}

Door de stijging van het onderwijsniveau en de aanwezigheid van een breed scala aan verzorgingsarrangementen, maar ook door de mogelijkheid om veelvormige sociale verbanden aan te gaan, zijn mensen zichzelf in toenemende mate gaan beleven als individuen die hun eigen levenspad vorm kunnen geven. Op dat laatste gaan we hier kort in. De sociale verbanden waarin Nederlandse burgers leven, zijn er anders uit gaan zien: ze zijn breder en wisselender geworden. Er is wel eens uitgerekend dat een boer in de achttiende eeuw in heel zijn leven even veel verschillende mensen tegenkwam als menig moderne Nederlander in een dag. De (fysieke en psychologische) afstand ten opzichte familieleden die elders wonen, is groter geworden; maar ook de betekenis van buren is afgenomen. De traditionele integratiekaders als kerk, leger en buurt hebben aan invloed ingeboet. De gemeenschappen waarin moderne burgers leven zijn groter, en bovendien kunnen ze in de loop der jaren wisselen. Het zijn, zoals sociologen dat noemen 'lichte gemeenschappen'. Burgers kunnen zich deze lichtheid permitteren omdat hun inkomen meestal verder strekt dan de meest noodzakelijke levensbehoeften en omdat ze in geval van nood kunnen terugvallen op verzorgingsarrangementen. Bij de lichtheid van de sociale verbanden hoort het idee dat men op zichzelf staat, individu is, en op unieke wijze vorm aan het leven kan en moet geven. Waar het nastreven van individualiteit enkele eeuwen geleden een privilege was voor een kleine bovenlaag, is het in de twintigste eeuw een mogelijkheid geworden voor brede lagen van de bevolking. Schnabel (1984) stelt in dit verband, in navolging van Simmel, dat kwantitatief individualisme (ieder kreeg in praktische zin de mogelijkheid om niet langer volledig afhankelijk van anderen te zijn) is overgegaan in kwalitatief individualisme (iedereen kan inhoud geven aan een eigen levensproject). De veelbesproken individualisering - een ambigue term - is dus mede een product van de verzorgingsstaat. Hij brengt overigens niet met zich mee dat individuen onderling grotere sociale verschillen gaan vertonen. Bij het vormgeven van het eigen levensproject blijken mensen vaak dezelfde idealen na te streven. De opvattingen van de Nederlandse autochtone bevolking zijn nu homogener dan in de jaren zestig, toen er nog een generatieconflict geconstateerd kon worden.

Nederland is dus een middenklasseland geworden, waarin zich een proces van individualisering heeft voorgedaan, maar meer in psychologische dan in sociale zin. Gelijkheid in rechten en (de mogelijkheid tot het verwerven van) bezittingen is een wijdverbreid ideaal geworden. Gelijkheid in culturele zin wordt minder positief geduid: flatgebouwen die uniformiteit uitstralen, figureren als afschrikwekkend. Waar rangen en standen verdwenen, werden pluriformiteit en het benadrukken van smaak en culturele verschillen van belang. Juridische, economische en sociale gelijkheid verschaft mensen de kans om zich te profileren op het punt van presentatie en leefstijl - iets waar allerlei nieuwe subtiele onderscheidingen en hiërarchieën bij komen kijken. 


\section{Consequenties}

De uitdaging voor de verzorgingsstaat is dus om in te springen op sociaal-culturele veranderingen die zich hebben voorgedaan en waar nodig als katalysator van gewenste toekomstige verandering optreden. Een vraag daarbij is in hoeverre individualisering en culturele differentiatie een plaats hebben in de moderne verzorgingsstaat. Toenemende diversiteit en individualisering zouden immers kunnen betekenen dat burgers andere eisen kunnen stellen aan de verzorgingsstaat, minder uit de voeten zouden kunnen met standaardvoorzieningen, kritischer tegenover de overheid staan, en ook meer keuzeopties willen hebben in hun sociale voorzieningenpakket (WRR 2005). Dat zou dan weer directe implicaties hebben voor de balans tussen rechten en plichten van de sociale zekerheid, tussen publieke en private voorzieningen, de mogelijkheid tot risicodeling, het politieke draagvlak voor de verzorgingsstaat en het vermogen van de overheid om de verzorgingsstaat aan te passen aan de eisen van de tijd.

Het valt echter te betwijfelen of de wensenlijsten van hedendaagse burgers zo gevarieerd zijn dat een zo groot mogelijke keuzevrijheid in collectieve en sociale voorzieningen het meest gepaste antwoord vormt. Uit onderzoek blijkt dat zelfs de moderne, geëmancipeerde, actieve, hoogopgeleide burger binnen toegenomen vrijheidsgraden in hoge mate voorspelbaar gedrag vertoont. Hij is eerder een 'optimaliseerder' dan een 'maximaliseerder', want kiezen en alle keuzemogelijkheden voortdurend tegen elkaar afwegen, kost nu eenmaal ook tijd en moeite. Hij "kiest voor de kudde" (Duyvendak en Hurenkamp 2004), en wil niet al te veel individuele keuzemogelijkheden op terreinen als pensioenen, verzekeringen en zorg. Keuzemogelijkheden waardeert hij vooral binnen het bestaande pakket van collectieve voorzieningen. Uit geen enkel onderzoek blijkt een groeiende neiging of verlangen om bijvoorbeeld het eigen pensioen of de eigen werkloosheidsverzekering te regelen. De 'veranderende burger' wordt dus het meest recht gedaan door hem een beperkt aantal opties aan te bieden aan de randen van de verzorgingsstatelijke arrangementen (denk aan de ziektekostenverzekeringen zoals we die nu hebben, met een basispakket én de mogelijkheid om bepaalde extra's bij te verzekeren).

Dat uit sociaal-culturele veranderingen niet op lineaire wijze conclusies voor de verzorgingsstaat te trekken zijn, komt ook omdat er, ondanks de algemene stijging van de welvaart en het opleidingsniveau, altijd specifieke groepen 'achterblijvers' blijven bestaan. Op dit moment gaat het dan vooral om autochtone en allochtone nieuwkomers op de arbeidsmarkt en in het onderwijs, dak- en thuislozen en anderen die voor hun bestaan direct afhankelijk zijn van de verzorgingsstaat. Deze groepen burgers passen niet in het beeld van de geïndividualiseerde burgers die op eigen kracht hun leven inrichten. Ze lopen onverminderd vrij voorspelbare hoge risico's op werkloosheid en uitkeringsafhankelijkheid. Dit betekent opnieuw dat waar er opties in verzorgingsstatelijke arrangementen worden ingebouwd, dit aan de randen van het systeem moet gebeuren, op zo'n manier dat verstandige afwegingen bevorderd worden, maar de bodem onder breed gedragen regelingen niet wordt weggeslagen. 


\subsection{CONCLUSIE}

Tot wat voor beeld leiden al deze ontwikkelingen als het gaat om de verzorgingsstaat van de komende decennia?

\section{De uitdagingen van buitenaf}

Allereerst tekent zich duidelijk af dat de marges om een eigen beleid te voeren met betrekking tot de verzorgingsstaat, smaller zullen worden. De internationale concurrentie (par. 3.2) zal steeds meer haar effecten hebben. De liberalisering van de kapitaalmarkten in de jaren tachtig is gevolgd door een grotere integratie van internationale product- en arbeidsmarkten. Nationale controle daarop is moeilijker en zwakker geworden. Ook het proces van Europese integratie heeft de ruimte voor nationale beleidskeuzes op het gebied van sociaal beleid ingeperkt (par. 3.3). Met de totstandkoming van de interne markt in de EU zijn nationale economische grenzen goeddeels verdwenen, en met de introductie van de Europese Monetaire Unie is het instrumentarium van nationale wisselkoers- en renteaanpassing opgehouden te bestaan. Op grond van het Stabiliteits- en Groeipact, ten slotte, is nationaal budgettair beleid aan banden gelegd. In het EU-kader zijn de nationale verzorgingsstaten van soeverein semi-soeverein geworden.

Een deel van het debat over de verzorgingsstaat zal zich dan ook verplaatsen naar de Europese vergaderzalen. De intensivering van economische internationalisering en de verregaande europeanisering van macro-economisch beleid (interne markt en EMU) stellen nieuwe eisen aan slagvaardig sociaal beleid. In een Europa met geïntegreerde markten is een goed werkende arbeidsmarkt en een deugdelijke sociale bescherming niet alleen een zaak van nationale overheden; grensoverschrijdende belangen vergen ook onderlinge beleidscoördinatie op nationaal gevoelige terreinen als arbeidsmarktbeleid, en beleid ten aanzien van de sociale zekerheid, pensioenen, en armoedebestrijding. Deze uitdaging aangaan is van belang willen nationale verzorgingsstaten hun verbindende functie kunnen blijven vervullen in een internationaliserende wereld. Als gezamenlijk kader voor de sociaal-economische toekomst van Europa heeft de EU vooralsnog ingezet op de 'Lissabonagenda', omdat voortgaande technologische ontwikkeling en het inzetten op een kenniseconomie de aandrijvers zijn van de internationale concurrentie. Een hogere arbeidsmarkt- en onderwijsparticipatie, een zo hoog mogelijke kwaliteit van onze onderwijssystemen, meer doen aan onderzoek en ontwikkeling, zijn belangrijke onderdelen van die agenda. In het analysekader van dit rapport doet die agenda vooral een beroep op de verheffingsfunctie van de verzorgingsstaat.

\section{De uitdagingen van binnenuit}

De veranderende demografische opbouw vraagt om antwoorden, zoveel is ook duidelijk, want de vergrijzing heeft grote gevolgen voor de houdbaarheid van de pensioenvoorzieningen. Mensen leven langer, maar het laatste kwart van de twintigste eeuw zagen we ook dat mensen op grote schaal eerder stopten met werken, met als gevolg dat het aantal jaren dat gebruik wordt gemaakt van pen- 
sioenvoorzieningen sterk is gegroeid, terwijl het aantal jaren dat men bijdraagt gelijk bleef of een tijd lang zelfs afnam. Dat belast de verzekeringsfunctie van de verzorgingsstaat met name voor zover die op een omslagsystematiek is gebaseerd.

Tegelijkertijd zullen zorg- en zekerheidsarrangementen (nog) meer rekening moeten gaan houden met gedifferentieerde leefstijlen en levenslopen. Processen van sociale differentiatie en individualisering, en veranderingen op de arbeidsmarkt, waaronder de massale toestroom van vrouwen op de arbeidsmarkt, stellen nieuwe eisen aan de stelsels van maatschappelijke dienstverlening. Vigerende stelsels van sociale zorg zouden overvraagd kunnen worden, omdat arbeidsmarkten en gezinshuishoudens, als traditionele sferen van zorg en welzijn, zijn verzwakt. Vrouwen zijn immers toegetreden tot de arbeidsmarkt terwijl mannen niet veel meer zijn gaan zorgen. Gezinnen worden kleiner, en ook later gevormd en mensen gaan ook steeds vaker en langer alleenstaand door het leven. Mensen krijgen minder kinderen die elk veel informele en formele zorg en aandacht krijgen.

De eisen met betrekking tot de zorg- en dienstverlening zullen ook toenemen. Met de ontwikkeling van een middenklassesamenleving is ook het verlangen gegroeid dat arrangementen kwalitatief voldoende van niveau zijn, en dat ze bovendien mogelijkheden bieden voor individuele kleuring. Dat impliceert niet dat burgers over ieder onderdeel weer opnieuw willen (en kunnen) kiezen, wel dat er aan de randen mogelijkheden zijn tot individuele invulling. Want dat is uiteindelijk wat de meeste mensen lijken te willen: zelfontplooiing en autonomie in de context van een gemeenschap (verheffing en verbinding). Zoals ook onderzoek van bijvoorbeeld het SCP en 21 minutes overduidelijk laat zien, willen Nederlanders het liefst wonen in een zachtmoedige samenleving. De voordelen van sociale cohesie, politieke stabiliteit en betrouwbare institutionele kaders zijn nog steeds manifest. 


\section{DE NEDERLANDSE VERZORGINGSSTAAT IN EUROPEES-VERGELIJKEND PERSPECTIEF}

\subsection{INLEIDING}

De verzorgingsstaat is geen louter Nederlandse aangelegenheid. Dat biedt de mogelijkheid om een vergelijking te maken met de wijze waarop elders verzorgingsstaten ingericht zijn en functioneren. Zijn er landen die het beter doen? Die vraag wordt al jaren gesteld, en ook in dit hoofdstuk zullen we pogen lessen te trekken uit een vergelijking van Nederland met andere landen. De wijze waarop die vraag nader gepreciseerd wordt, kent twee hoofdbenaderingen. De economische benadering gebruikt een dergelijke landenvergelijking veelal om economische prestaties en sociale prestaties met elkaar te vergelijken. Kan een uitgebreide verzorgingsstaat wel samengaan met hoge werkgelegenheid enerzijds en goede macro-economische prestaties anderzijds? Zou een afgeslankte verzorgingsstaat zoals de Amerikaanse niet veel beter bestand zijn tegen internationale concurrentie, meer banen scheppen en mensen prikkelen om hard te werken? De politicologisch/bestuurskundige benadering stelt de vraag vanuit een typologie van verzorgingsstaten. Doen we er goed aan om de blik richting het noorden te richten - het Scandinavische model - of is het beter om westwaarts te kijken - het Angelsaksische model? Het achterliggende idee is dat continentale verzorgingsstaten, waaronder Duitsland en Frankrijk, en volgens sommigen ook Nederland, hun langste tijd gehad zouden hebben: ze zijn te duur, de arbeidsmarkten zijn weinig flexibel en er zijn te weinig prikkels.

De Europese landenvergelijking die in het eerste deel van dit hoofdstuk wordt gemaakt, laat zien dat er geen uitruil plaats hoeft te vinden tussen sociale rechtvaardigheid enerzijds en economische groei en werkgelegenheid anderzijds. Getoond wordt dat de Nederlandse verzorgingsstaat - net als veel Scandinavische het relatief goed doet als het gaat om maatschappelijke ongelijkheid, werkgelegenheid en armoede, maar ook slaagt in het terugdringen van inflatie en het vergroten van economische groei. De Nederlandse verzorgingsstaat heeft zich aangepast aan de macro-economische en sociaal-structurele eisen die gesteld werden. Belangrijker is het dan ook om exacter te bezien waar specifieke structuren en arrangementen problematisch (kunnen) zijn.

Dat Nederland het relatief goed doet, maakt het debat over een nieuw model Scandinavisch of Angelsaksisch - ook minder urgent. Bovendien is het lastig om buitenlandse praktijken over te planten in de Nederlandse verzorgingsstaatlogica, laat staan om hele systemen te adopteren. Wel kan Nederland op onderdelen leren van andere landen. In het laatste deel van dit hoofdstuk wordt daarom geprobeerd specifieker en diepgaander te kijken naar de functies van de verzorgingsstaat. Hoe verzorgt, verzekert, verheft en verbindt de Nederlandse verzorgingsstaat? Kunnen we door een voorzichtige Europese vergelijking al een eerste duiding krijgen van typisch Nederlandse overschotten en tekorten? De Europese 
vergelijking maakt het mogelijk om alvast enkele knelpunten en uitdagingen voor Nederland te traceren.

\subsection{VERZORGINGSSTATEN TUSSEN ECONOMISCHE DOELMATIG- HEID EN RECHTVAARDIGHEID}

Verzorgingsstaten worden veelvuldig geclassificeerd in regimeclusters, gebaseerd op verschillende criteria. Zoals het niveau van publieke en private uitgaven voor sociale bescherming, de wijze van financiering van sociale zekerheid en maatschappelijke dienstverlening, de maatstaven voor de toekenning van sociale bescherming en ondersteuning, de mate van en vorm van arbeidsmarktregulering, en de aard van de arbeidsverhoudingen. Een aantal sleutelvariabelen en historische politieke preferenties blijken systematisch met elkaar verbonden te zijn (Ferrera e.a. 2000; Ferrera en Hemerijck 2003).

Allereerst het Scandinavisch model, waar we hier gemakshalve onder verstaan: Denemarken, Noorwegen, Zweden en Finland. Scandinavische verzorgingsstaten bieden relatief genereuze inkomenszekerheid, actief arbeidsmarktbeleid en een breed scala aan publieke maatschappelijke dienstverlening voor ouderen en gezinnen met jonge kinderen. Deze dienstverlening gaat verder dan gezondheidszorg en primair en secundair onderwijs, en bevordert de gelijkheid tussen de seksen. Historisch kent Scandinavië sterk gecentraliseerde systemen van arbeidsverhoudingen, waar loonovereenkomsten worden gesloten tussen nationale werkgeversorganisaties en federaties van vakbonden. Als nadeel geldt dat de financiering van de omvangrijke publieke sector leidt tot een hoge belastingdruk.

Een tweede model is het Angelsaksische cluster van het Verenigd Koninkrijk en Ierland. De hoogte van de sterk geïndividualiseerde en inkomensafhankelijke uitkeringen voor werkloosheid, ziekte, en ouderdom is relatief laag, met strikte regels ten aanzien van het recht op bijstand. Sociale bescherming weerspiegelt een nadruk op gerichte, op behoeften gebaseerde rechten van bescheiden omvang. Gezondheidszorg en sociale dienstverlening worden gefinancierd door belastingen en eigen bijdragen. Een middelentoets speelt een belangrijke rol bij de uitkeringen. Net als in Scandinavië is de bestuurlijke structuur van de Angelsaksische verzorgingsstaat (inclusief werkloosheidsverzekering) in hoge mate verstatelijkt. Ook is er sprake van een sterk gedereguleerde arbeidsmarkt en een relatief gefragmenteerd stelsel van arbeidsverhoudingen, en loononderhandelingen vinden plaats op bedrijfsniveau. Als gevolg is er sprake van hoge arbeidsdeelname, ook voor vrouwen.

Deze twee modellen worden vaak als alternatief gepresenteerd voor het derde regime, het continentale, waaronder de Beneluxlanden, Duitsland, Oostenrijk en Frankrijk vallen. Nederland wordt ook vaak onder dit cluster geschaard. Centraal kenmerk is hun Bismarcktraditie: verzekeringen en voorzieningen zijn gebaseerd op een sterke verbinding tussen arbeidsmarktpositie en/of familie- 
status, gebaseerd op traditionele (kostwinner)waarden. De continentale landen hebben een meer dan gemiddelde belastingdruk, en een beperkter scala aan maatschappelijke dienstverlening voor werkende gezinnen dan de Scandinavische. Duur en hoogte van de sociale verzekeringen zijn direct gekoppeld aan het arbeidsverleden en de gezinssituatie, en worden grotendeels gefinancierd door premies en afdrachten van werkgevers en werknemers. Inkomensherverdeling vindt met name plaats tussen de actieve beroepsbevolking en het niet-actieve deel. Het bismarckiaanse stelsel, waarin het kostwinnersbeginsel een belangrijke rol speelt, heeft lange tijd de arbeidsparticipatie van (gehuwde) vrouwen ontmoedigd. Wat betreft de loonvorming ligt het primaat bij het sectorale onderhandelingsniveau. Verder is de arbeidsmarkt strikter gereguleerd dan in de Scandinavische landen. Het gebrek aan stimulansen om te werken, de strikte arbeidsmarkt en de hoge verzorgingsstaatkosten gelden als nadelen.

Het mediterrane cluster - Italië, Spanje, Portugal en Griekenland - wordt zelden als een alternatief gepresenteerd. Dit regime volgt in de verzekeringslogica het continentale cluster, maar kenmerkt zich door specifieke institutionele structuren, die een gemengde oriëntatie weerspiegelen. Het mediterrane cluster is bismarckiaans wat betreft inkomensoverdrachten en pensioenen. Het is Beveridgiaans wat betreft gezondheidszorg, met universele nationale gezondheidszorg in zowel Italië en Spanje. De familie is erg belangrijk en compenseert de tekorten in het formele verzorgingsstaatsysteem, met name op het terrein van sociale bijstand. Het sociaal vangnet onder de sociale verzekeringen is beneden gemiddeld ontwikkeld. Daarnaast is er sprake van een sterk gereguleerde arbeidsmarkt en een politiek gepolariseerd systeem van arbeidsverhoudingen. Loononderhandelingen vinden vooral plaats op bedrijfsniveau.

\section{Afruil?}

Hoe presteert Nederland in Europa, met name als het gaat om klassieke verzorgingsstaatindicatoren zoals arbeidsdeelname en macro-economische prestaties? Bieden andere modellen inderdaad een wenkend perspectief? Hoe staat het bijvoorbeeld met de concurrentiekracht van de ruimhartige verzorgingsstaten van Noord-Europa? En welk vermogen hebben verschillende regimes van verzorgingsstaten om zich aan te passen aan zich wijzigende omstandigheden?

Bij de beantwoording van deze vraag zullen we ons in het bijzonder richten op de 'uitruil'-discussie. In de economische literatuur wordt de verzorgingsstaat veelal voorgesteld in het kader van een afruil tussen economische doelmatigheid en sociale rechtvaardigheid (Okun 1975; CPB 2006). Volgens deze redenering staan de herverdelende ambities van de verzorgingsstaat op gespannen voet met een soepel functioneren van de economie en arbeidsmarkt (the big trade-off). Verscherpte concurrentieverhoudingen, demografische vergrijzing en ontgroening, en een grotere maatschappelijke heterogeniteit, zetten de afruil tussen doelmatigheid en rechtvaardigheid zodanig op scherp dat bij ongewijzigd beleid - dat wil zeggen bij het vasthouden aan bestaande programma's en instituties - er niet veel anders resteert dan het afslanken van de verzorgingsstaat. Maar is er ook 
daadwerkelijk sprake van een afruil tussen economische doelmatigheid en sociale rechtvaardigheid in de verschillende Europese landen, waaronder Nederland?

\subsubsection{OVERHEIDSUITGAVEN}

De overheidsuitgaven van Nederland zijn de afgelopen kwart eeuw in relatieve termen sterk gedaald: van big spender in de jaren zeventig en tachtig naar een relatief gematigd niveau van overheidsuitgaven. Figuur 4.1 laat dat zien, waarbij de gegevens 'per regime' worden weergegeven op basis van enkel het meest typerende land voor dat regime - dat verhoogt de leesbaarheid. Voor Scandinavië is dat Zweden, voor continentale landen is dat Duitsland, voor mediterrane landen Italië en voor Angelsaksische landen het Verenigd Koninkrijk. De economische crisis in de nasleep van de Duitse hereniging, zo blijkt, heeft voor alle Europese verzorgingsstaten consequenties gehad. De recessie leidde tot een snelle stijging van de sociale uitgaven, maar daarna kregen de meeste landen de overheidsfinanciën ook weer relatief snel op orde. Gedurende de jaren negentig zijn de overheidsuitgaven in heel Europa geconsolideerd of marginaal gedaald. De daling was met drie procent van het nationaal inkomen het sterkst in de Scandinavische landen. Binnen het continentale cluster was er in Frankrijk en Duitsland sprake van een stijging van de overheidsuitgaven, net als in Italië. De mediterrane landen laten verder een stabiel beeld zien. In het Verenigd Koninkrijk stegen de overheidsuitgaven tussen 1995 en 2000 , na een lange periode van bezuinigingen. Dat betekent dat de overheidsuitgaven - hoewel sterk gedaald sinds de jaren tach-

Figuur 4.1 Totale publieke uitgaven als percentage van het bnp

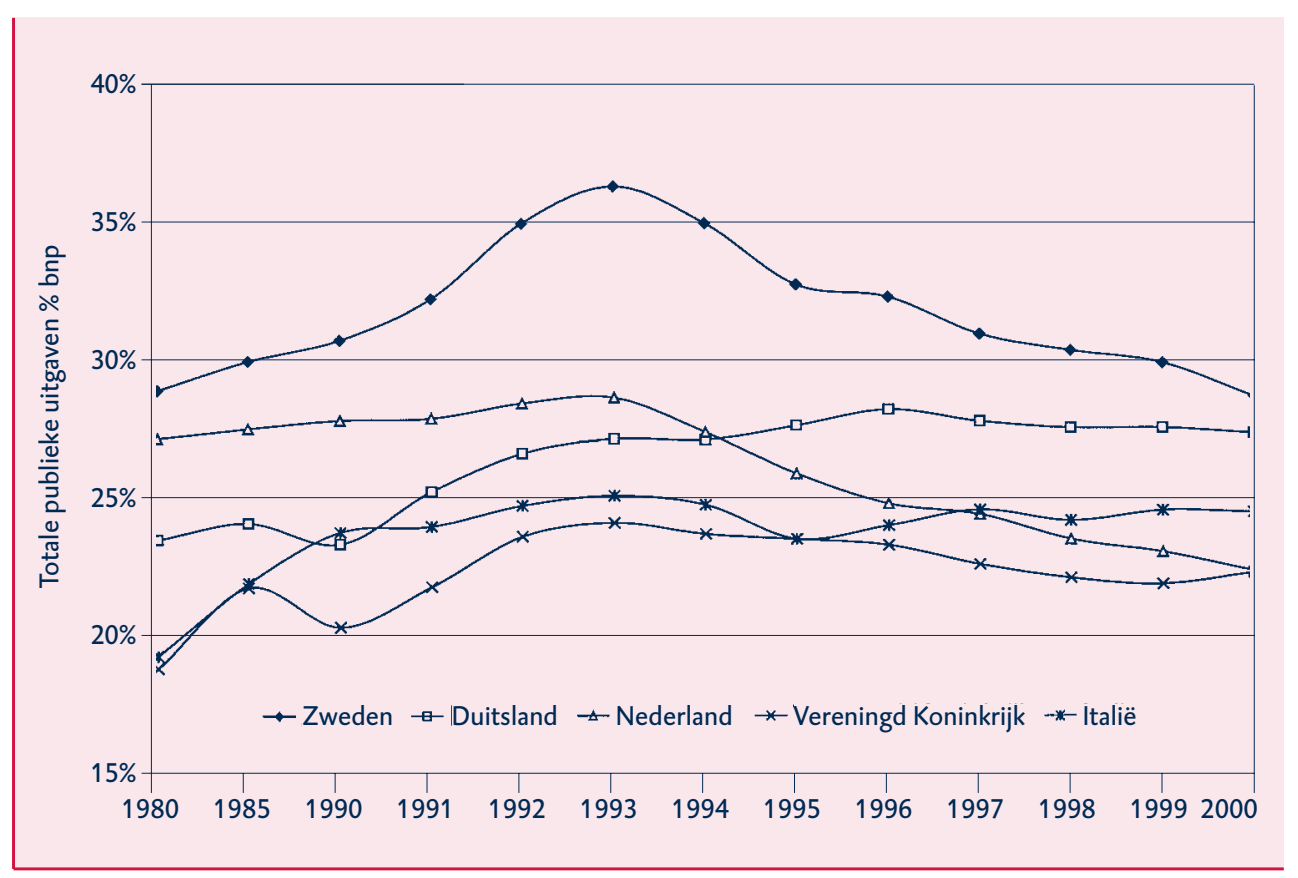


tig - het hoogst zijn in de Scandinavische en continentale verzorgingsstaten.

De overheidsuitgaven in Nederland zijn gedaald tot beneden het niveau van het mediterrane cluster en benaderen het niveau van het Verenigd Koninkrijk.

Behalve gedaald zijn de publieke uitgaven ook veranderd van samenstelling. Vanaf 1980 heeft een aanzienlijke verschuiving plaatsgevonden in het Nederlandse uitgavenpatroon (zie figuur 4.2). Wat vooral in het oog springt, is de sterke daling in de tweede helft van de jaren negentig van de publieke uitgaven aan arbeidsongeschiktheid (hoewel in vergelijkend perspectief nog steeds hoog), pensioenen, en werkloosheidsverzekeringen. Na een forse daling in de tweede helft van de jaren negentig stijgen uitgaven op het terrein van de gezondheidszorg en het onderwijs licht na 1997.

\section{Figuur 4.2 Ontwikkeling in publieke uitgaven in Nederland van 1980-2001}

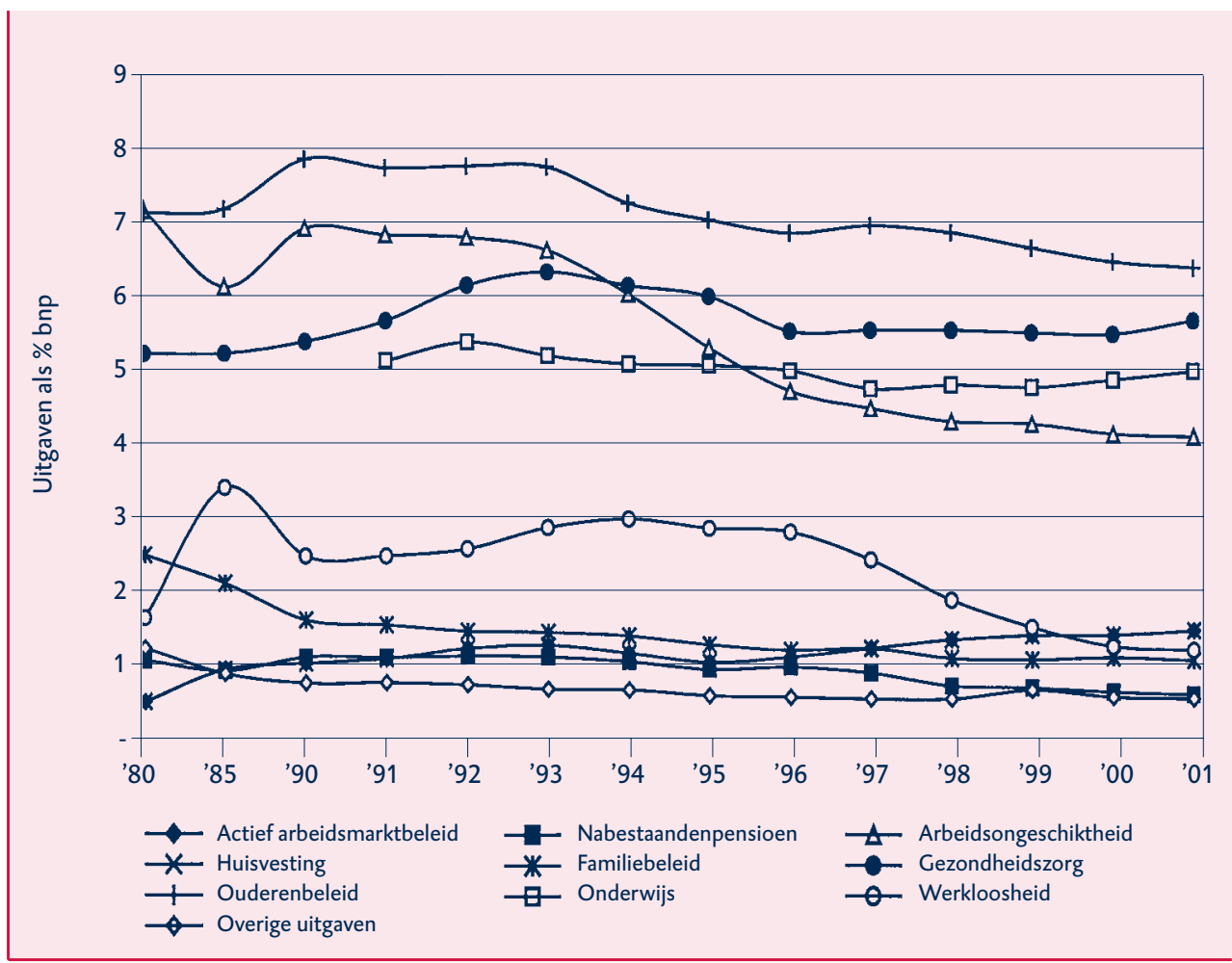

Bron: OECD

Noot: Cijfers voor onderwijs vanaf 1991 beschikbaar

De sociale uitgaven leiden niet meer tot een groot financieringstekort, integendeel. In bijna alle lidstaten van de Eu kunnen we een dalende trend zien in de jaren negentig (zie tabel 4.1). De mediterrane landen hebben hun tekorten vooral weten terug te brengen om deelname aan de EMU veilig te stellen. België, Frankrijk en Italië hebben hun overheidsfinanciën tussen 1993 en 2000 grosso modo op orde gebracht. In het Verenigd Koninkrijk was tot 2000 sprake van een over- 
schot; nu is er een financieringstekort van drie procent. Opmerkelijk is dat de Scandinavische verzorgingsstaten in korte tijd (forse) tekorten hebben weten om te zetten in overschotten. In 2001 - het 'topjaar' van de vorige hoogconjunctuur had niet een van de EU-lidstaten een tekort groter dan de EMU-norm van drie procent. Ook Nederland heeft zijn tekort in 2001 omgezet in een overschot. De overheidsschuld in de meeste Europese verzorgingsstaten varieert tussen de veertig en zestig procent van het bnp, met als uitschieters naar boven; Italië, Griekenland en België met om en nabij de honderd procent. Nederland heeft zijn staatsschuld met een omvang ter waarde van 75 procent van het nationaal inkomen teruggebracht naar 53 procent, ruim onder de EMU-norm van 6o procent.

Tabel 4.1 Financieringsoverschot of -tekort als \% van het bnp per jaar

\begin{tabular}{|l|r|r|} 
& Hoogste uitslag sinds 1990 & Waarde in 2001 \\
Scandinavisch & & \\
Finland & $-8 \%(1993)$ & $4,90 \%$ \\
Continentaal & & \\
Duitsland & $-3,4 \%(1996)$ & $-2,70 \%$ \\
Frankrijk & $-5,8 \%(1993)$ & $-1,40 \%$ \\
Nederland & $-5,1 \%(1990)$ & $0,20 \%$ \\
België & $-7,1 \%(1993)$ & $0,20 \%$ \\
Oostenrijk & $-5,1 \%(1995)$ & $0,10 \%$ \\
Angelsaksisch & & \\
lerland & $-2,5 \%(1992)$ & $1,70 \%$ \\
Mediterraan & & \\
Italië & $-7,1 \%(1995)$ & $-2,20 \%$ \\
Portugal & & \\
Spanje & & \\
\hline
\end{tabular}

Bron: IMF

\section{Bruto/netto sociale uitgaven}

De hoogte van de bruto publieke sociale uitgaven kan niet zonder meer beschouwd worden als de graadmeter van de generositeit van de verzorgingsstaat. In de Scandinavische landen worden uitkeringen belast, terwijl in veel Angelsaksische, continentale, en mediterrane Europese verzorgingsstaten belastingvrijstellingen en hypotheekrenteaftrek een gedeeltelijk substituut vormen voor sociale uitgaven. Wanneer de netto totale sociale uitgaven, dus inclusief verplichte en vrijwillige private sociale uitgaven, in ogenschouw worden genomen, dan lijken landen meer op elkaar (tabel 4.2). Opvallend is dat landen als Italië en het Verenigd Koninkrijk netto ongeveer evenveel besteden aan sociale uitgaven als Nederland. Blijkbaar hechten alle Europese verzorgingsstaten aan publieke 
zekerheid en publieke voorzieningen, maar worden die op verschillende wijze gefinancierd (zie ook Esping-Andersen 2006).

Tabel 4.2 Sociale uitgaven als percentage van het bnp in 2001

\begin{tabular}{|c|c|c|c|c|c|c|}
\hline & $\begin{array}{r}\text { Bruto } \\
\text { publiek }\end{array}$ & $\begin{array}{r}\text { Netto } \\
\text { publiek }\end{array}$ & $\begin{array}{r}\text { Netto } \\
\text { verplicht } \\
\text { privaat }\end{array}$ & $\begin{array}{r}\text { Netto } \\
\text { vrijwillig } \\
\text { privaat }\end{array}$ & $\begin{array}{l}\text { Netto } \\
\text { totaal }\end{array}$ & $\begin{array}{r}\text { Netto vrijwil- } \\
\text { lig privaat/ } \\
\text { Netto totaa }\end{array}$ \\
\hline \multicolumn{7}{|l|}{ Scandinavisch } \\
\hline Denemarken & $29,2 \%$ & $21,8 \%$ & $0,1 \%$ & $0,6 \%$ & $22,5 \%$ & $2,7 \%$ \\
\hline Finland & $24,8 \%$ & $19,2 \%$ & $0,1 \%$ & $0,7 \%$ & $20,0 \%$ & $3,5 \%$ \\
\hline Zweden & $29,8 \%$ & $23,7 \%$ & $0,3 \%$ & $1,9 \%$ & $26,0 \%$ & $7,3 \%$ \\
\hline \multicolumn{7}{|l|}{ Continentaal } \\
\hline Duitsland & $27,4 \%$ & $25,4 \%$ & $0,8 \%$ & $1,9 \%$ & $27,6 \%$ & $6,9 \%$ \\
\hline Frankrijk & $28,5 \%$ & $25,2 \%$ & $0,0 \%$ & $1,8 \%$ & $27,0 \%$ & $6,7 \%$ \\
\hline Nederland & $21,4 \%$ & $18,0 \%$ & $0,4 \%$ & $4,1 \%$ & $22,1 \%$ & $18,6 \%$ \\
\hline België & $24,7 \%$ & $21,2 \%$ & $1,4 \%$ & $0,6 \%$ & $23,2 \%$ & $2,6 \%$ \\
\hline Oostenrijk & $26,0 \%$ & $20,6 \%$ & $0,5 \%$ & $0,7 \%$ & $21,8 \%$ & $3,2 \%$ \\
\hline \multicolumn{7}{|l|}{ Angelsaksisch } \\
\hline lerland & $13,8 \%$ & $12,2 \%$ & $0,0 \%$ & $0,4 \%$ & $12,5 \%$ & $3,2 \%$ \\
\hline Ver. Koninkrijk & $21,8 \%$ & $19,8 \%$ & $0,4 \%$ & $3,2 \%$ & $23,3 \%$ & $13,7 \%$ \\
\hline \multicolumn{7}{|l|}{ Mediterraan } \\
\hline Italië & $24,4 \%$ & $20,9 \%$ & $1,1 \%$ & $0,1 \%$ & $21,9 \%$ & $0,5 \%$ \\
\hline Spanje & $19,6 \%$ & $16,7 \%$ & $0,0 \%$ & $0,3 \%$ & $17,0 \%$ & $1,8 \%$ \\
\hline
\end{tabular}

Bron: OECD

Wanneer we de overheidsuitgaven voor sociaal beleid per beleidsfunctie anno 2001 verder ontleden, dan valt een aantal zaken op. Ten eerste besteden de continentale verzorgingsstaten tegenwoordig bijna evenveel aan actief arbeidsmarktbeleid als de Scandinavische (zie tabel 4.3). Over de gehele linie valt op dat Nederland relatief hoge publieke sociale uitgaven kent op de terreinen van arbeidsongeschiktheid, volkshuisvesting, en actief arbeidsmarktbeleid, maar op de andere terreinen relatief weinig uitgeeft. De publieke uitgaven aan staatspensioenen (AOW), onderwijs, gezinsbeleid, en nabestaandenpensioenen liggen lager dan in vrijwel alle EU-15 landen. Uitgaven voor gezinsondersteuning zijn het hoogst in Scandinavische, op de voet gevolgd door continentale verzorgingsstaten. Achter deze cijfers zit echter een groot verschil tussen beide clusters verborgen: in continentale verzorgingsstaten wordt door financiële regelingen de arbeidsparticipatie van moeders ontmoedigd, terwijl in Scandinavische verzorgingsstaten het accent ligt op actieve maatschappelijke dienstverlening in publieke kinderopvangvoorzieningen en ruimhartige regelingen voor ouder- 
schapsverlof voor werkende ouders. Nederland blijkt schril af te steken tegen beide clusters: er wordt weinig geld besteed aan gezinnen.

Tabel 4.3 Publieke sociale uitgaven aan functies als percentage van het bnp in 2001

\begin{tabular}{|c|c|c|c|c|c|c|c|c|c|}
\hline & $\begin{array}{l}\bar{\pi} \\
\stackrel{\pi}{\pi} \\
0 \\
0\end{array}$ & 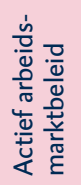 & 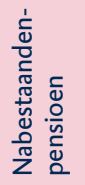 & 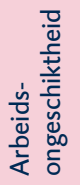 & 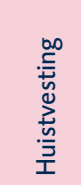 & 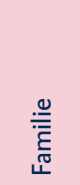 & $\begin{array}{l}\frac{\overline{0}}{0} \\
\frac{c}{0} \\
\overline{0} \\
0 \\
N \\
0\end{array}$ & $\begin{array}{l}\frac{c}{0} \\
\frac{d}{\frac{0}{0}} \\
\frac{0}{\partial} \\
0\end{array}$ & $\begin{array}{l}\frac{n}{3} \\
\frac{2}{d} \\
\frac{0}{0} \\
0\end{array}$ \\
\hline \multicolumn{10}{|l|}{ Scandinavisch } \\
\hline Denemarken & $29,2 \%$ & $1,5 \%$ & $0,0 \%$ & $3,9 \%$ & $1,5 \%$ & $3,8 \%$ & $7,1 \%$ & $8,3 \%$ & $8,5 \%$ \\
\hline Finland & $24,8 \%$ & $1,0 \%$ & $1,0 \%$ & $3,9 \%$ & $1,0 \%$ & $3,0 \%$ & $5,3 \%$ & $7,9 \%$ & $6,2 \%$ \\
\hline Zweden & $28,9 \%$ & $1,4 \%$ & $0,6 \%$ & $5,2 \%$ & $1,4 \%$ & $2,9 \%$ & $7,4 \%$ & $9,2 \%$ & $7,3 \%$ \\
\hline \multicolumn{10}{|l|}{ Continentaal } \\
\hline Duitsland & $27,4 \%$ & $1,1 \%$ & $0,4 \%$ & $2,3 \%$ & $1,1 \%$ & $1,9 \%$ & $8,0 \%$ & $11,7 \%$ & $4,6 \%$ \\
\hline Frankrijk & $28,5 \%$ & $1,3 \%$ & $1,5 \%$ & $2,2 \%$ & $1,3 \%$ & $2,8 \%$ & $7,2 \%$ & $10,6 \%$ & $5,8 \%$ \\
\hline Nederland & $21,8 \%$ & $1,5 \%$ & $0,7 \%$ & $4,1 \%$ & $1,5 \%$ & $1,1 \%$ & $5,7 \%$ & $6,4 \%$ & $5,0 \%$ \\
\hline België & $27,2 \%$ & $1,3 \%$ & $2,7 \%$ & $3,3 \%$ & $1,3 \%$ & $2,3 \%$ & $6,4 \%$ & $8,7 \%$ & $6,1 \%$ \\
\hline Oostenrijk & $26,0 \%$ & $0,5 \%$ & $2,7 \%$ & $2,5 \%$ & $0,5 \%$ & $2,9 \%$ & $5,2 \%$ & $10,7 \%$ & $5,7 \%$ \\
\hline \multicolumn{10}{|l|}{ Angelsaksisch } \\
\hline lerland & $13,8 \%$ & $0,7 \%$ & $0,8 \%$ & $1,4 \%$ & $0,7 \%$ & $1,6 \%$ & $4,9 \%$ & $2,7 \%$ & $4,4 \%$ \\
\hline Ver. Koninkrijk & $21,8 \%$ & $0,4 \%$ & $0,6 \%$ & $2,5 \%$ & $0,4 \%$ & $2,2 \%$ & $6,1 \%$ & $8,1 \%$ & $4,7 \%$ \\
\hline \multicolumn{10}{|l|}{ Mediterraan } \\
\hline Italië & $24,4 \%$ & $0,5 \%$ & $2,6 \%$ & $2,1 \%$ & $0,5 \%$ & $1,0 \%$ & $6,3 \%$ & $11,3 \%$ & $5,0 \%$ \\
\hline Griekenland & $24,3 \%$ & $0,2 \%$ & $0,9 \%$ & $1,8 \%$ & $0,2 \%$ & $1,8 \%$ & $5,2 \%$ & $12,7 \%$ & $3,9 \%$ \\
\hline Portugal & $21,1 \%$ & $0,6 \%$ & $1,5 \%$ & $2,5 \%$ & $0,6 \%$ & $1,2 \%$ & $6,3 \%$ & $7,9 \%$ & $5,9 \%$ \\
\hline Spanje & $19,6 \%$ & $0,8 \%$ & $0,6 \%$ & $2,4 \%$ & $0,8 \%$ & $0,5 \%$ & $5,4 \%$ & $8,3 \%$ & $4,4 \%$ \\
\hline
\end{tabular}

Bron: OECD

\subsubsection{ECONOMISCHE PRESTATIES EN WERKGELEGENHEID}

De Nederlandse verzorgingsstaat is wel afgeslankt, maar nog steeds stevig. Betekent dit dat Nederland slechte macro-economische en werkgelegenheidsprestaties levert? In macro-economische zin presteert Nederland met name in de jaren negentig bovengemiddeld vergeleken met de EU-15. Vanaf 196o tot 1980 liep de economische groei in Europa vrijwel gelijk op, met groeipercentages van rond de 3,5 procent (Aiginger en Guger 2005). Na in de jaren tachtig op een structureel lagere groeivoet te zijn gekomen, behoorde Nederland in de jaren negentig tot de groep kleine Europese landen die een hogere groei kende dan omringende grote economieën, zoals Duitsland, Frankrijk en Italië, hoewel er perioden van sterke schommelingen van oververhitting en recessie werden doorgemaakt (tabel 4.4). 
De beginjaren van de eenentwintigste eeuw vallen op door tegenvallende groeicijfers in bijna alle landen uit de eurozone, met uitzondering van Ierland en Finland. Mede als gevolg van de EMU is de inflatie in heel Europa bedwongen, ook in Nederland, en schommelt nu rond twee procent.

Tabel 4.4 Reële groei van het bnp, gemiddeld voor perioden van vijf jaar, in procenten

\begin{tabular}{|c|c|c|c|c|c|c|c|}
\hline & 70 - '75 & 75 - '80 & 80 - '85 & 85 - '90 & 90 - '95 & 95 - '00 & 00 - '05 \\
\hline \multicolumn{8}{|l|}{ Scandinavisch } \\
\hline Denemarken & 2,4 & 2,1 & 1,0 & 1,8 & 1,8 & 2,8 & 1,5 \\
\hline Finland & 5,1 & 2,7 & 3,3 & 3,9 & $-1,6$ & 4,6 & 2,8 \\
\hline Zweden & & & 1,8 & 2,7 & 0,4 & 3,1 & 2,6 \\
\hline Noorwegen & 4,7 & 4,7 & 3,1 & 2,4 & 3,4 & 3,9 & 2,1 \\
\hline \multicolumn{8}{|l|}{ Continentaal } \\
\hline Duitsland & & & & & 1,4 & 1,7 & 1,2 \\
\hline Frankrijk & & 2,3 & 2,0 & 2,9 & 1,4 & 2,6 & 2,1 \\
\hline Nederland & 4,4 & 2,3 & 1,0 & 3,1 & 2,3 & 3,6 & 1,3 \\
\hline België & & & 0,8 & 2,8 & 1,7 & 2,8 & 2,0 \\
\hline Oostenrijk & & 3,4 & 1,3 & 2,7 & 2,7 & 2,6 & 1,8 \\
\hline \multicolumn{8}{|l|}{ Angelsaksisch } \\
\hline lerland & & & & & 3,4 & 10,0 & 6,1 \\
\hline Ver. Koninkrijk & 2,7 & 2,1 & 0,9 & 3,8 & 1,3 & 3,0 & 2,8 \\
\hline \multicolumn{8}{|l|}{ Mediterraan } \\
\hline Italië & 4,2 & 3,2 & 1,8 & 3,1 & 1,7 & 1,7 & 0,9 \\
\hline Griekenland & 4,9 & 5,3 & $-0,2$ & 1,8 & 0,8 & 3,0 & 4,4 \\
\hline Portugal & & & & 6,4 & 1,7 & 5,2 & 1,3 \\
\hline Spanje & & & 1,2 & 4,2 & 1,7 & 4,1 & 3,5 \\
\hline
\end{tabular}

Bron: IMF

Economisch gezien is de Nederlandse verzorgingsstaat relatief gezond. Een volgende vraag is: kan een uitgebreide verzorgingsstaat samengaan met hoge werkgelegenheid? Werkgelegenheid is voor de houdbaarheid van de verzorgingsstaat een belangrijke toetssteen waaraan het succes van het sociaal-economisch beleid wordt afgemeten. In sociaal opzicht verschaft een baan mensen mogelijkheden tot zelfidentificatie en zelfontplooiing: werk draagt bij aan sociale cohesie in een samenleving. Het economische belang van werkgelegenheid is eveneens groot. Bij langdurige werkloosheid, arbeidsongeschiktheid en vervroegde pensionering gaan de uitgaven aan sociale zekerheid omhoog, terwijl tegelijkertijd de inkomsten dalen. Om aan ambities met betrekking tot sociaal beleid én gezonde overheidsfinanciën recht te doen, is het werkgelegenheidsaandeel van de bevolking van centraal belang voor de houdbaarheid van een ruimhartige verzorgingsstaat. 
De arbeidsparticipatie is traditioneel het hoogst in de Scandinavische verzorgingsstaten, gevolgd door het Verenigd Koninkrijk. In personen gemeten behoort Nederland inmiddels ook tot de voorhoede. Figuur 4.3 laat de Europese dynamiek in werkgelegenheidsprestaties van de verschillende verzorgingsstaattypes zien. Nederland heeft duidelijk een inhaalslag gemaakt en steekt goed af vergeleken bij andere continentale verzorgingsstaten. De Nederlandse prestaties zijn vergelijkbaar met de Scandinavische. Het werkloosheidscijfer in ons land is momenteel samen met dat van Denemarken het laagste in Europa (figuur 4.3).

Figuur 4.3 Werkgelegenheid in verzorgingsstaatregimes 1980-2003
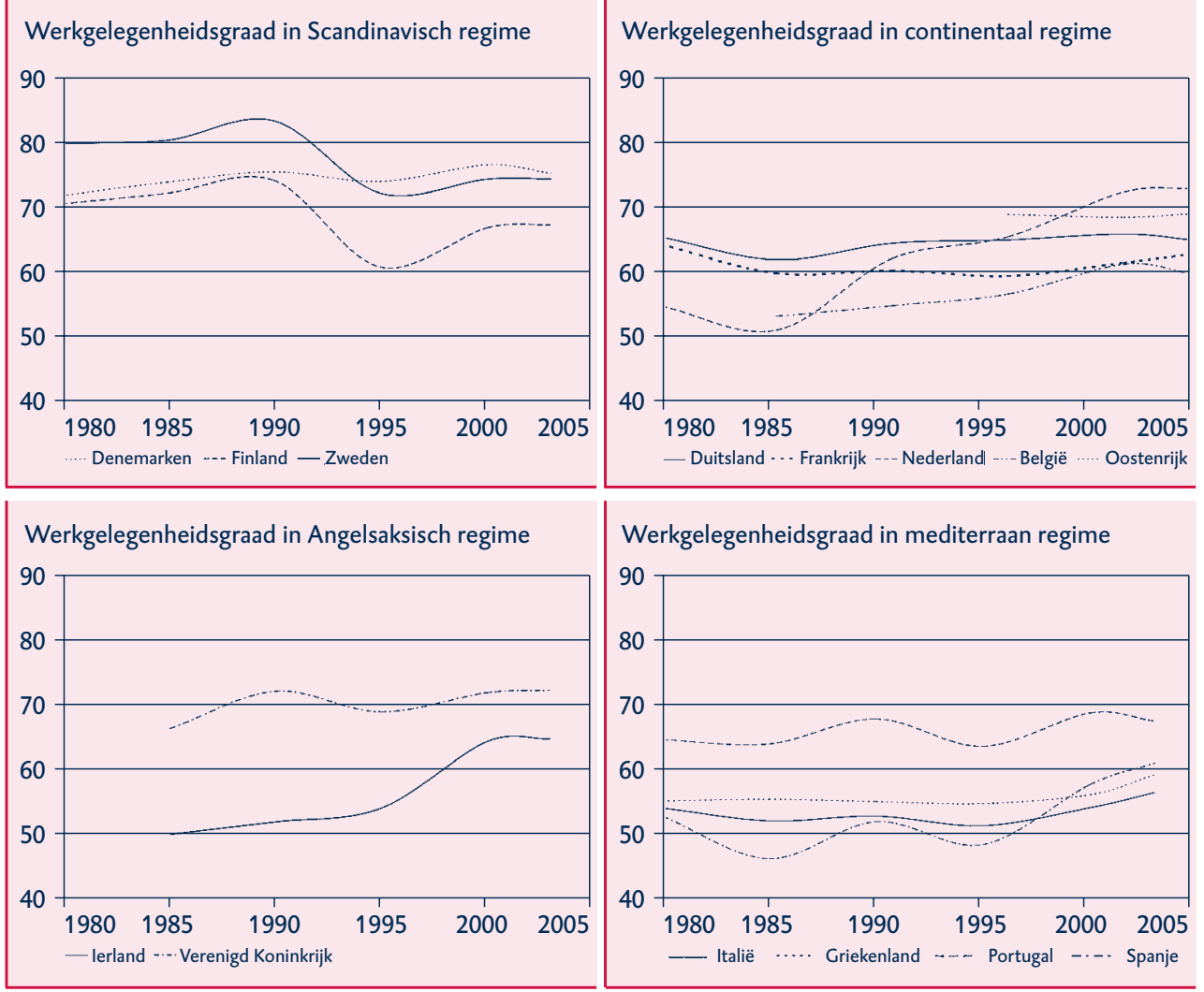

Noot: Gegevens van lerland en het Verenigd Koninkrijk vanaf 1985, Oostenrijk vanaf 1995

Bron: OECD

Deze cijfers zijn tot op zekere hoogte geflatteerd, omdat ze gebaseerd zijn op de arbeidsdeelname in personen, en niet in uren. Door de hoge vlucht die deeltijdarbeid hier heeft genomen, kent Nederland het laagste gemiddeld aantal gewerkte uren per werknemer in de EU. Overigens is in vrijwel alle landen sinds 1985 een dalende trend in het aantal gewerkte uren per jaar zichtbaar. Wanneer wordt gecorrigeerd voor FTE (full time equivalents) ontstaat er een relatief stabiel regimespecifiek beeld van een hoge en stijgende participatiegraad in Scandinavië 
(rond de 65 procent), gevolgd door de Angelsaksische landen (61 procent). De overige landen blijven steken onder de 60 procent, met Portugal en Oostenrijk als uitschieters naar boven (zie figuur 4.4). Nederland kent op deze manier gemeten een arbeidsdeelname die vergelijkbaar is met andere continentale landen.

\section{Figuur 4.4 Werkgelegenheidsgraad in FTE in 2004}

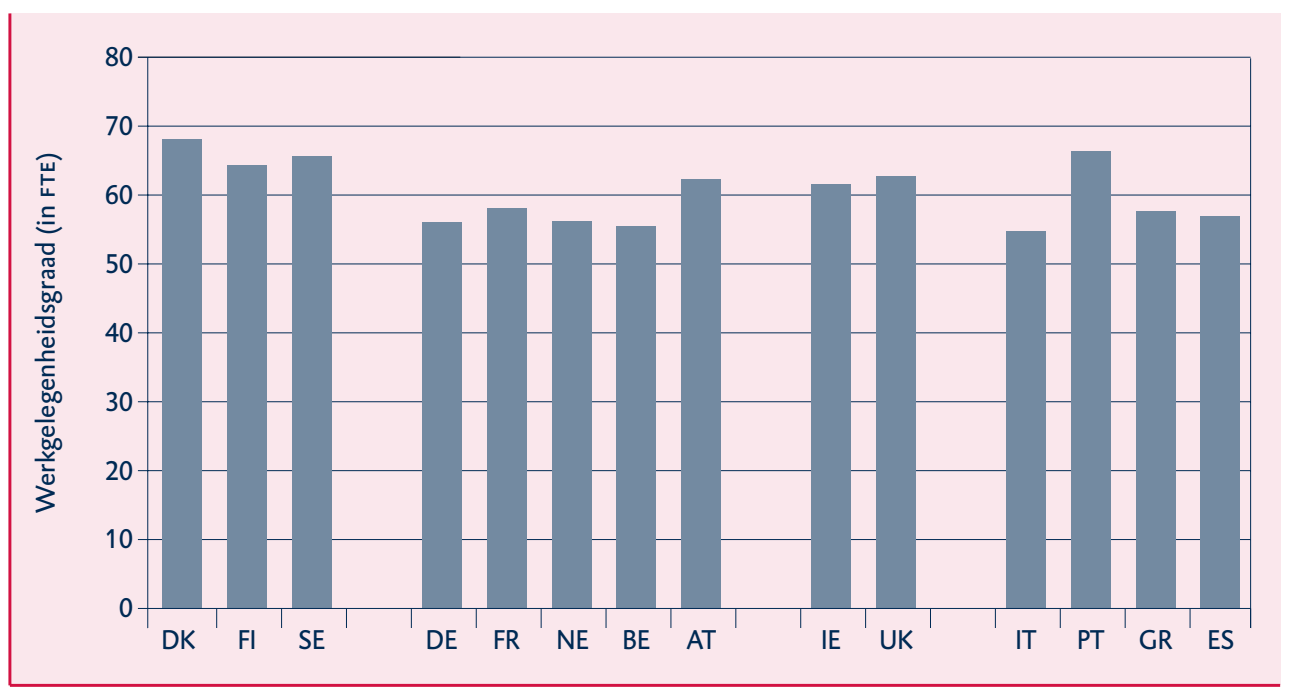

Bron: Eurostat

Achter deze verschillen in werkgelegenheidscijfers gaan andere verschillen schuil. In Scandinavië heeft de overheid een belangrijke rol als werkgever in de arbeidsintensieve maatschappelijke dienstverlening. Hierdoor schept de Scandinavische verzorgingsstaat naast werkgelegenheid voor hoogopgeleide professionals, ook veel overheidsbanen voor mannen en vooral vrouwen met een lagere opleiding. In Denemarken en Zweden werkt inmiddels een kwart van de - veelal vrouwelijke - beroepsbevolking in de maatschappelijke dienstverlening. De expansie van banen in de sociale dienstverlening, kinderopvang en ouderenzorg vanaf de jaren zeventig bracht een zelfversterkend mechanisme tot ontwikkeling. Meer vrouwen traden toe tot de arbeidsmarkt. Dit leidde tot een ontlasting van zorg binnen (werkende) gezinnen, en vervolgens ook weer tot een toename in de vraag naar professionele maatschappelijke zorg.

De reactie van de continentale en mediterrane verzorgingsstaten op het proces van economische herstructurering in de jaren zeventig en tachtig was gericht op beperking van het arbeidsaanbod via allerlei vormen van vervroegde uittreding. Een toenemend beroep op de sociale zekerheid leidde tot een verdere stijging van de lastendruk op arbeid. Vanaf het midden van de jaren tachtig gingen bedrijven in continentale verzorgingsstaten versneld over op arbeidsbesparende technologie en lieten minder productieve werknemers afvloeien via de sociale zekerheid. Hiermee sloeg de productiviteitsdruk (de druk op werknemers om productief genoeg te zijn om hun inkomen waar te maken) om in een inactiviteitsval: wie 
werkloos is geworden, heeft extra moeite om z'n productiviteit op peil te houden en terug te komen op de arbeidsmarkt. Werkgelegenheid nam af in sectoren waar de productiviteitsgroei stagneerde en waar de prijzen van goederen en diensten niet ter compensatie konden worden verhoogd. Een vicieuze cirkel van hoge brutoloonkosten, relatief lage nettolonen, de uittreding van minder productieve werknemers, en stijgende sociale lasten, bracht een spiraal op gang van dalende arbeidsdeelname en stijgende inactiviteit. Daarmee werd tevens het financiële draagvlak van de sociale zekerheid versmald.

Nederland neemt een bijzondere plaats in, omdat het als eerste continentale verzorgingsstaat zijn prestaties heeft verbeterd, en zich heeft ontwikkeld in de richting van Scandinavische niveaus. Figuur 4.5 laat zien dat Nederland niet langer een verzorgingsstaat zonder nieuwe banen is die het in de jaren tachtig nog was. Aan die banengroei liggen vier factoren ten grondslag: gematigde loonstijgingen, de ontwikkeling van arbeidsintensieve dienstverlening, de opkomst en verbreiding van deeltijdarbeid, en lastenverlichting (Visser en Hemerijck 1997). Vooral de arbeidsdeelname van vrouwen is sterk gestegen. De deelname van mannen tussen de 55 en 64 jaar was tot midden jaren negentig gedaald tot het laagste niveau in Europa, maar verbeterde eveneens snel. Veel van de nieuwe banen zijn

Figuur 4.5 Werkgelegenheid in Nederland, periode 1980-2003

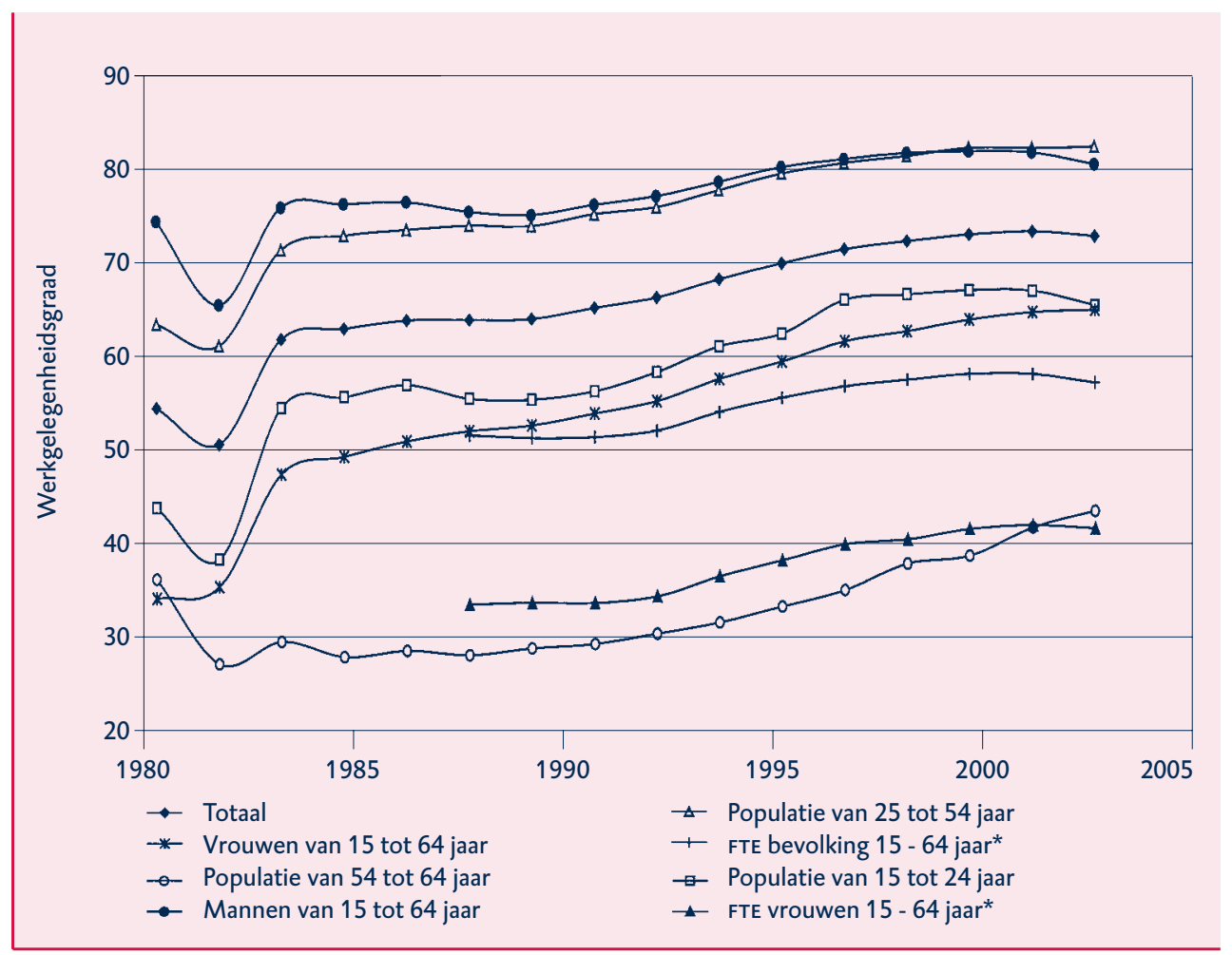

Noot: Werkgelegenheidsgraad in FTE beschikbaar vanaf 1993

Bron: OECD 
deeltijdbanen, soms met een beperkt aantal uren, die voor het overgrote deel door vrouwen worden vervuld. Zo lijkt Nederland zich als eerste continentale verzorgingsstaat te hebben ontworsteld aan de passieve bismarckiaanse beleidserfenis, met zijn neiging tot bescherming van de vaste banen van mannelijke kostwinners.

Figuur 4.6 Werkloosheid in EU-landen in mei 2006

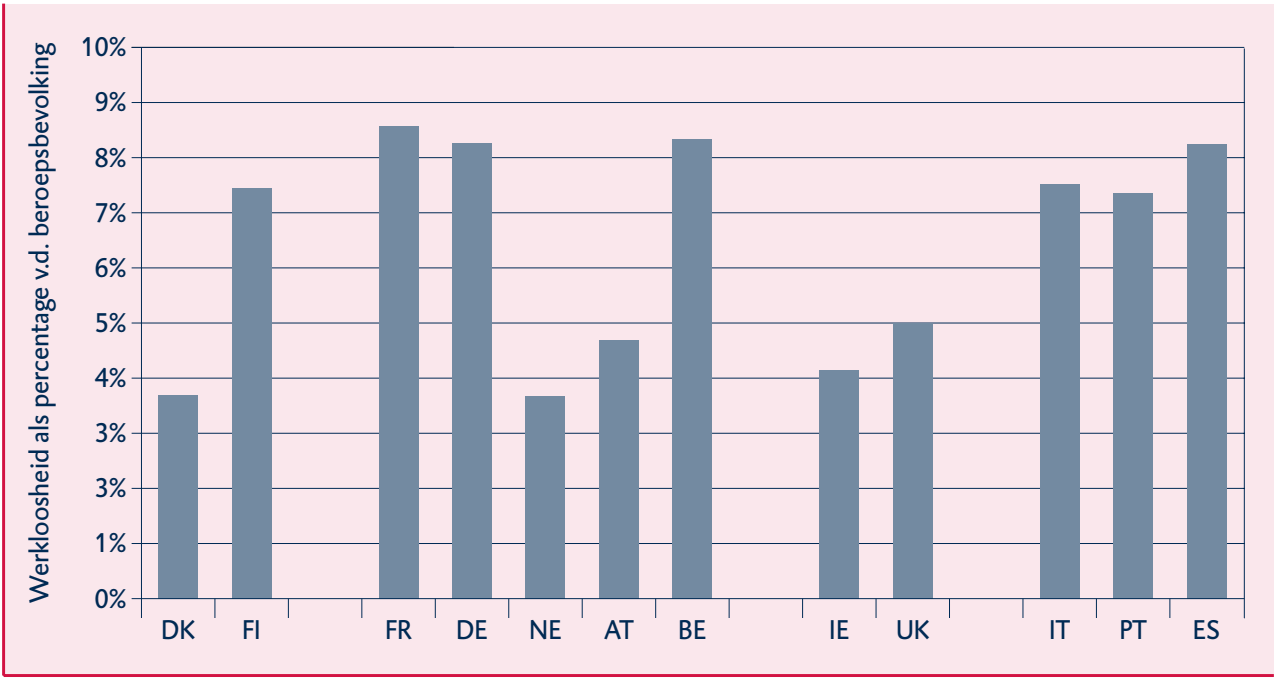

Bron: Eurostat

Vertalen de goede prestaties van Nederland op het gebied van werkgelegenheid zich ook in gunstige werkloosheidscijfers? Op dit moment varieert de werkloosheid in de EU-15 tussen de vijf en negen procent van de beroepsbevolking (zie figuur 4.6). Ook hier is sinds de jaren negentig sprake van convergentie, met een sterke daling van de werkloosheid in met name Spanje, en een stijging in de Scandinavische landen. De continentale verzorgingsstaten kennen een hoog werkloosheidscijfer met Oostenrijk en Nederland (waar langdurige werkloosheid deels 'verscholen' zit in de WAO) als gunstige uitzonderingen. De variatie in jeugdwerkloosheid is veel groter, met meer dan twintig procent in de meeste mediterrane verzorgingsstaten en Finland, en een relatief lage jeugdwerkloosheid van minder dan tien procent in Denemarken, Nederland, Oostenrijk en Ierland.

Groter nog zijn de verschillen ten aanzien van langdurige werkloosheid, hoewel sprake is van een daling van het aandeel van langdurige werklozen in de totale werkloosheidspopulatie sinds het midden van de jaren negentig in de meeste verzorgingsstaatclusters. Het percentage van de beroepsbevolking dat langer dan één jaar werkloos is, is bijzonder laag in Denemarken, Zweden, Nederland, Oostenrijk, het Verenigd Koninkrijk en Ierland. Langdurige werkloosheid is omvangrijk in met name Duitsland, Frankrijk, Italië, Griekenland en Spanje (zie figuur 4.7). 
Figuur 4.7 Werkloosheidstypen per regime, in procenten
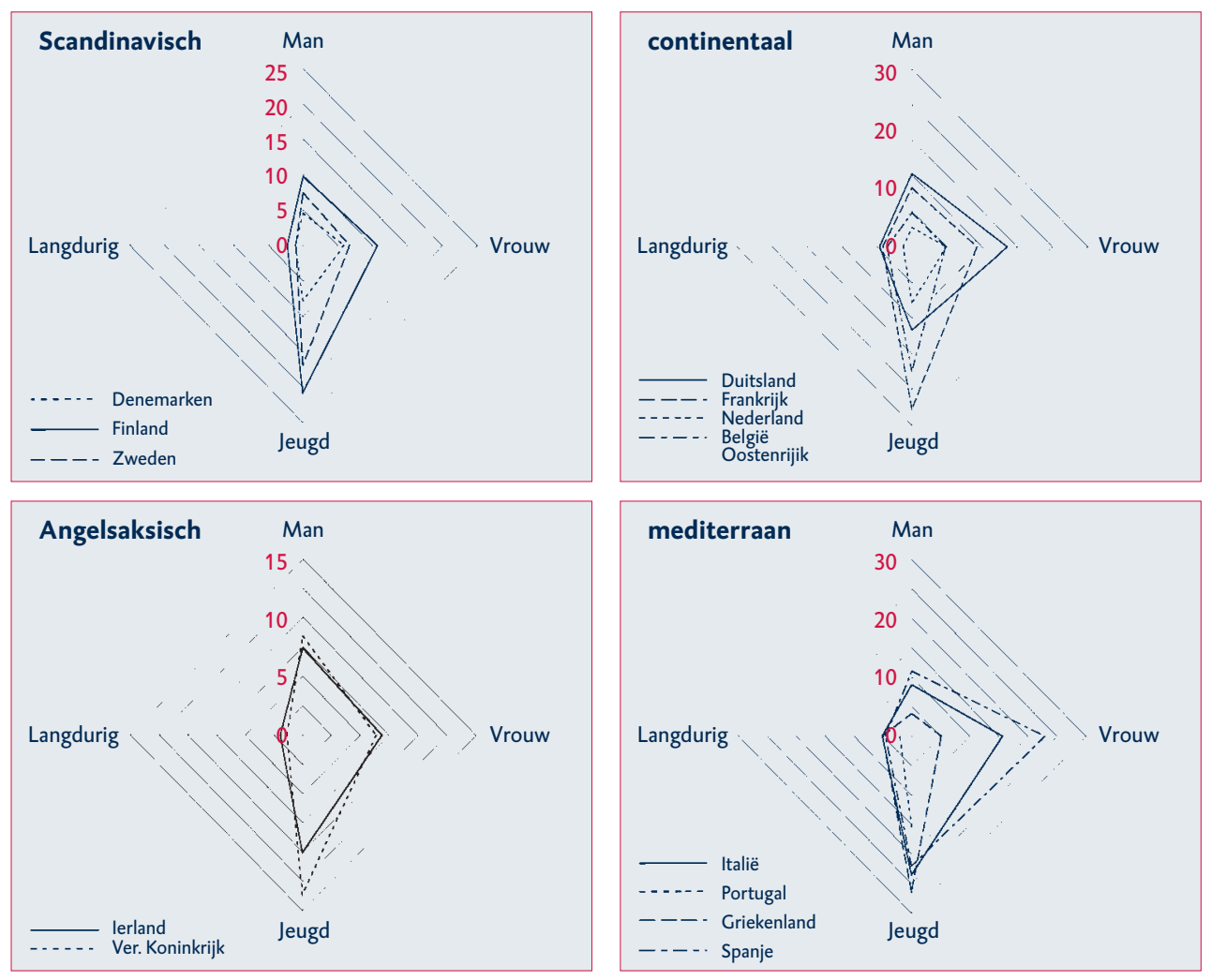

Noot: cijfers werkloosheid mannen uit 1999, vrouwen uit 1999, jeugd uit 2004, en langdurige werkloosheid uit 2003

Bron: Eurostat

Wat betreft armoede en inkomensongelijkheid scoort Nederland eveneens beter dan het gemiddelde. Figuur 4.8 laat zien dat armoederatio's en inkomensverdeling aanmerkelijk variëren tussen groepen landen: meer ongelijkheid in de mediterrane en Angelsaksische dan in de continentale en Scandinavische landen. Nederland lijkt overigens meer op de Scandinavische landen. Kortom: de Nederlandse werkgelegenheids- en werkloosheidscijfers, en ook de armoede- en inkomensstatistieken, zijn in internationaal vergelijkend opzicht uitstekend, en vormen op zichzelf dus geen argument om uit te kijken naar een totaal ander verzorgingsstaatmodel.

\subsubsection{NEDERLAND IN PERSPECTIEF}

De relatief hoge werkloosheid en lage economische groei in de EU-landen lijken, in vergelijking met de Verenigde Staten, het bewijs te leveren voor de stelling dat een uitgebreide verzorgingsstaat de economische doelmatigheid ondermijnt. Niettemin geldt voor een aantal van de meest ontwikkelde Europese verzorgingsstaten, waaronder Zweden, Denemarken en Nederland (met name in de jaren 
Figuur 4.8 Armoede en inkomensongelijkheid in EU-landen
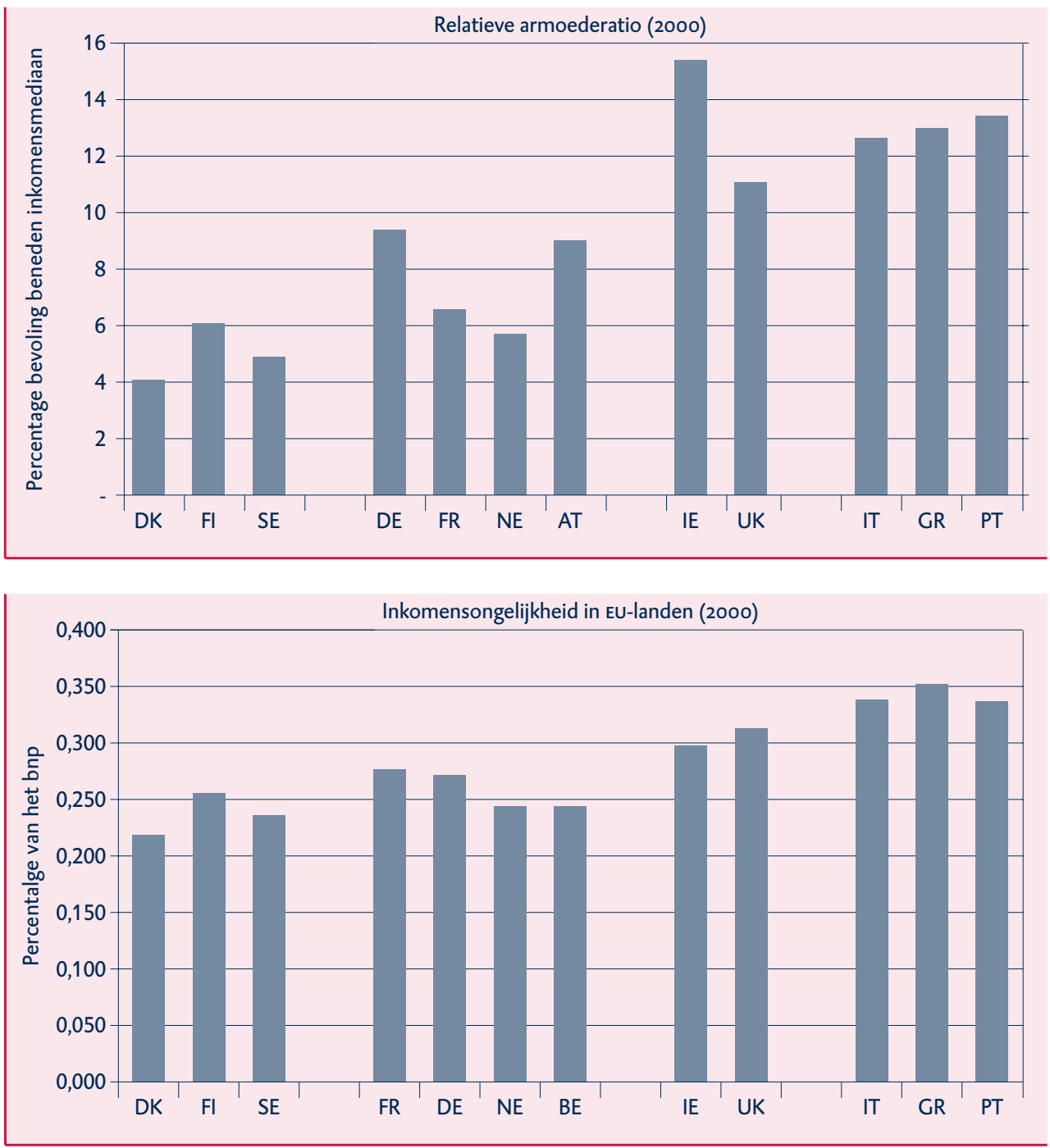

OECD 2005d

negentig), dat ze de Amerikaanse 'banenmachine’ vrijwel evenaren, terwijl ze tevens meer dan minimale standaarden hanteren voor inkomen, gezondheidszorg, werk, onderwijs en huisvesting. Bovendien presteert de (meest ruimhartige) Scandinavische verzorgingsstaatcluster beter dan de andere clusters ten aanzien van de doelstellingen van de Lissabonagenda van de EU, te weten werkgelegenheid, kennisintensivering en concurrentiekracht. Ook de Nederlandse macro-economische prestaties in de jaren negentig laten een zekere harmonie zien tussen sociale rechtvaardigheid en economische doelmatigheid.

Dit illustreert dat er beleid mogelijk is dat economische competitie en sociale rechtvaardigheid met elkaar verzoent. Het is dus zaak om niet rechtlijnig te 
denken over de spanning tussen economische en sociale prestaties. Dat blijkt ook uit andere zaken. Zo is een goede toegang tot opleidingen bevorderlijk voor de productiviteit, economische groei en sociale cohesie. Een sociaal vangnet reduceert armoede en sociale instabiliteit. Armoede is slecht voor elke economie, in het bijzonder wanneer de armoede van generatie op generatie wordt doorgegeven, waardoor sommige groepen worden uitgesloten van economische vooruitgang. Sociaal beleid kan dus ook een investering zijn in duurzame economische regelingen die een solide basis vormen voor flexibiliteit en het nemen van risico's. Het idee is dat mensen eerder van baan veranderen als ze zich geen zorgen hoeven te maken over hun sociale verzekeringen of pensioen. Actief arbeidsmarktbeleid draagt er verder aan bij dat werklozen in contact blijven met de 'normale' arbeidsmarkt. En sociale partners zorgen voor een zeker vertrouwen en arbeidsrust, hetgeen de productiviteit bevordert. Sociaal beleid, collectieve onderhandelingen en werknemersparticipatie kunnen bovendien zorgen voor een aantrekkelijk investeringsklimaat en voor hoogopgeleide, productieve arbeidskrachten.

Voor alle duidelijkheid: sociaal beleid is op zichzelf geen productiefactor. Om steekhoudende uitspraken te kunnen doen over de relatieve economische betekenis van sociaal beleid, is het steeds nodig om de aandacht te richten op specifieke combinaties van instituties en soorten beleid die worden toegepast in diverse constellaties van problemen. Sommige sociale regelingen hebben een negatieve invloed op economische groei. Te genereuze en te langdurige uitkeringen ondermijnen de neiging om weer aan het werk te gaan, dragen bij aan hoge belastingen, en leiden tot hoge loonkosten. Ook het beginnen van een eigen onderneming wordt erdoor ontmoedigd. Op eenzelfde wijze zorgen te rigide vormen van ontslagbescherming voor hoge kosten bij het aannemen en ontslaan van personeel, terwijl armoede en inactiviteit menselijk kapitaal vernietigen. Dit leidt tot de conclusie dat de verhouding tussen sociaal beleid en economische prestaties minder evident negatief is dan vaak wordt verondersteld, en dat het zaak is om te kijken naar de precieze vormgeving van verzorgingsstaatarrangementen.

\section{Modellen?}

Sapir (2005) heeft aan de hand van recente ontwikkelingen op macroniveau de volgende schematische conclusie getrokken. Zowel Angelsaksische als continentale landen lijken geconfronteerd te zijn met een uitruil tussen doelmatigheid en rechtvaardigheid. Angelsaksische verzorgingsstaten hebben een efficiënt model maar houden sociale ongelijkheid in stand, terwijl continentale verzorgingsstaten een sociaal rechtvaardiger maar minder efficiënt systeem hebben. Scandinavische en mediterrane verzorgingsstaten worden niet geconfronteerd met een dergelijke uitruil. Scandinavische verzorgingsstaten zijn grosso modo zowel doelmatig als rechtvaardig, terwijl mediterrane het moeten doen met sociale voorzieningen die noch efficiënt noch rechtvaardig zijn. Sapir komt tot de conclusie dat inefficiënte verzorgingsstaten op termijn niet te handhaven zijn. Zeker gezien de groeiende druk op de publieke middelen als gevolg van economische internationalisatie, veranderingen in gezinssituaties, en vergrijzing. 
Zowel Scandinavische als Angelsaksische verzorgingsstaten lijken dus houdbaar. De overeenkomst tussen de hoogten van de uitgaven in continentale en Scandinavische landen is opvallend. Het laat zien dat landen met vergelijkbare niveaus van sociale uitgaven uiteenlopende macro-economische prestaties kunnen leveren. De niveaus van totale uitgaven zeggen dus niet alles, het gaat om specifieke combinaties van instituties en reguleringen, inkomensoverdrachten en dienstverlening, passief en actief beleid, financiering en toekenningscriteria, de verdeling van de uitgaven over consumptie en investeringen.

Betekent dit dat de Nederlandse verzorgingsstaat zou moeten worden omgevormd tot een Scandinavische of een Angelsaksische verzorgingsstaat? Nee; de gegevens laten zien dat het niet raadzaam is om voor één model te kiezen. Ten eerste komt geen enkele verzorgingsstaat perfect overeen met één specifiek theoretisch geconstrueerd verzorgingsstaattype. Er is eerder sprake van historisch gegroeide idiosyncratische mengvormen van instituties en beleidserfenissen, afkomstig uit verschillende verzorgingsstaattradities. Op meso- en microniveau bestaan er binnen de clusters grote verschillen. In tegenstelling tot het Verenigd Koninkrijk worden de Ierse arbeidsverhoudingen bijvoorbeeld gekenmerkt door een hoge mate van sociaal overleg tussen werkgevers en werknemers, met georganiseerd vertrouwen als een fundamenteel onderdeel. Denemarken beschermt zijn arbeidsmarkt in veel mindere mate dan de andere Scandinavische landen, maar heeft daarentegen wel een uitgebreid en ruimhartig systeem van voorzieningen, gecombineerd met een sterk proactief arbeidsmarktbeleid.

De Nederlandse verzorgingsstaat kenmerkt zich wellicht het meest door een hybride beleidsrepertoire. Anders dan de archetypische continentale corporatistische verzorgingsstaten, combineert de Nederlandse verzorgingsstaat bismarckiaanse met beveridgiaanse kenmerken. Het Nederlandse pensioensysteem bijvoorbeeld is een hybride stelsel, waar het publieke basispensioen, de AOW, in de tweede pijler wordt aangevuld door verplichte bedrijfstakpensioenen. En naast arbeidsgerelateerde sociale verzekeringen, die inkomensafhankelijke uit-keringen voor zieken, werklozen, en arbeidsongeschikten genereren, bestaat er een publiek gefinancierd bijstandsstelsel als vangnet en generieke minimuminkomenbescherming. Bovendien heeft Nederland zich grotendeels ontworsteld aan de continentale traditie van passief arbeidsmarktbeleid en het ontmoedigen van vrouwen om te gaan werken.

Bovendien worden de verschillen tussen de modellen in de praktijk steeds minder scherp. Vanaf het midden van de jaren negentig, onder druk van de komst van de EMU, is er sprake van een opvallende toenadering tussen de verschillende verzorgingsstaten in de richting van een hoge(re) en brede(re) arbeidsdeelname met een grotere nadruk op flexibele arbeidsmarkten, actief arbeidsmarktbeleid, maatschappelijke dienstverlening, het uitfaseren van vervroegd uittreden en het versoberen van pensioenstelsels. In dit verband kan gesproken worden van contingente convergentie tussen verschillende regimes (Hemerijck 20o6). Landen worden met veel identieke uitdagingen geconfronteerd: de noodzaak van een 
activerend arbeidsmarktbeleid, de vergrijzing, het integreren van achterblijvende etnische groepen via de arbeidsmarkt, de wens om arbeid en zorg te combineren, en als gevolg van de globalisering toenemende interdependenties. Die internationale onderlinge afhankelijkheid noopt tot vormen van samenwerken, waarvan de EU een evident voorbeeld vormt. EU-beleid en het nationale beleid van lidstaten zijn geleidelijk meer met elkaar verweven geraakt, ook op terreinen waar landen hun eigen autonomie hebben behouden (vgl. Canoy en Smith 2006).

Ten slotte is het naïef om te menen dat geslaagd beleid probleemloos van één land overgebracht kan worden naar een ander land met een ander beleidsbestel. Dat ging niet met het Zweedse macro-economische beleidsmodel in de jaren zeventig, en ook niet met het Duitse Rijnlandmodel van de industriële ontwikkeling van kwaliteitsproducten in de jaren tachtig. In de jaren negentig speelde het Nederlandse werkgelegenheidswonder een prominente rol in het debat over de mogelijkheid van een soort 'derde weg': kapitalisme met een sociaal gezicht. Aan het begin van de eenentwintigste eeuw figureren in de internationale pers de 'Keltische Tijger' (Ierland; zie Hazeu 2005), het Deense 'Lego-model', en de Finse kenniseconomie als de nieuwe modelvoorbeelden. Maar iedere keer weer bleek de superieure werkzaamheid van een succesmodel vergankelijk te zijn. Verzorgingsstaten zijn evolutionaire systemen waarbinnen politieke prioriteiten, weerbarstige instituties, en (imperfecte) beleidsfuncties in de tijd onderwerp zijn van aanpassing; aanpassingen die niet vanzelf gaan. Verzorgingsstaten worden gekenmerkt door moeilijk uitwisselbare beleidstradities en institutionele vormgeving.

Deze conclusie betekent niet dat het zinloos is om geslaagde en minder geslaagde hervormingspogingen te bestuderen. Integendeel: een goed inzicht in vergelijkbare uitdagingen en ervaringen elders is onontbeerlijk in een periode van geïntensiveerde economische internationalisering, maatschappelijke differentiatie en Europese beleidsinnovatie. Dat kan echter beter gebeuren aan de hand van specifieke vragen, en beter niet op basis van grove modellen. In het volgende deel wordt daarom dieper en preciezer ingegaan op de verschillende Europese verzorgingsstaten, en op de mate en wijze waarop de vier functies vorm hebben gekregen. Met name wordt gekeken hoe Nederland verzorgt, verzekert, verheft en verbindt in vergelijking tot andere Europese landen. Hierdoor is het mogelijk om al voorzichtig een aantal knelpunten te identificeren, die in de hierna volgende hoofdstukken worden uitgewerkt.

\subsection{OP FUNCTIES VERGELEKEN}

Alle Europese verzorgingsstaten ondersteunen hulpbehoevenden en geven bijstand aan arme gezinnen (verzorgen), geven uitvoering aan meer of minder uitgebreide systemen van sociale verzekeringen (verzekeren), hebben zich gecommitteerd aan een doelmatige aanwending van talent en het ontwikkelen van menselijk kapitaal (verheffen), en dit alles in het kader van een bredere doelstelling van het bevorderen van sociale insluiting en maatschappelijke samenhang (verbinden). Daarbij zijn eerder gemaakte - padafhankelijke - inhoudelijke 
en institutionele keuzen mede van invloed op de precieze invulling van die functies in verschillende verzorgingsstaten.

\subsubsection{VERZORGEN}

Het merendeel van de Europese verzorgingsstaten biedt hulpbehoevenden (inkomensafhankelijke) bijstand en maatschappelijke ondersteuning, en kent een publiek gereguleerde gezondheidszorg. Traditioneel zijn de continentale systemen van gezondheidszorg gebaseerd op verplichte publieke en private zorgverzekeringen. In de Scandinavische en Angelsaksische landen domineren publieke systemen van nationale gezondheidszorg. Ze zijn echter van een andere aard: in de Angelsaksische landen bestaan, anders dan in Scandinavische landen, sterke prikkels voor de middenklasse om te opteren voor particuliere gezondheidszorg. In Europa zien we in de meeste landen overigens een stijging van de eigen bijdragen in kinderopvang, medische zorg en ouderenzorg.

De totale uitgaven aan langdurige zorg (voor ouderen en voor mensen met een fysieke of mentale handicap) verschillen sterk tussen landen: van o,6 procent van het bnp in Spanje tot een kleine drie procent in Zweden in 2000 (OECD 2005b). Nederland besteedt veel minder geld aan langdurige zorg dan de Scandinavische landen (figuur 4.9). Dit komt gedeeltelijk doordat de vergrijzing in landen als Zweden in een veel verdere fase is. Onze uitgaven zijn vergelijkbaar met die van het Verenigd Koninkrijk en Duitsland (vgl. ook Rostgaard 2004 en OECD 2005c). Er is echter ook een belangrijk verschil met deze laatste twee landen: in Nederland is er verhoudingsgewijs weinig sprake van private financiering van de zorg.

Figuur 4.9 Uitgaven aan langdurige zorg als percentage van het bnp, 2000

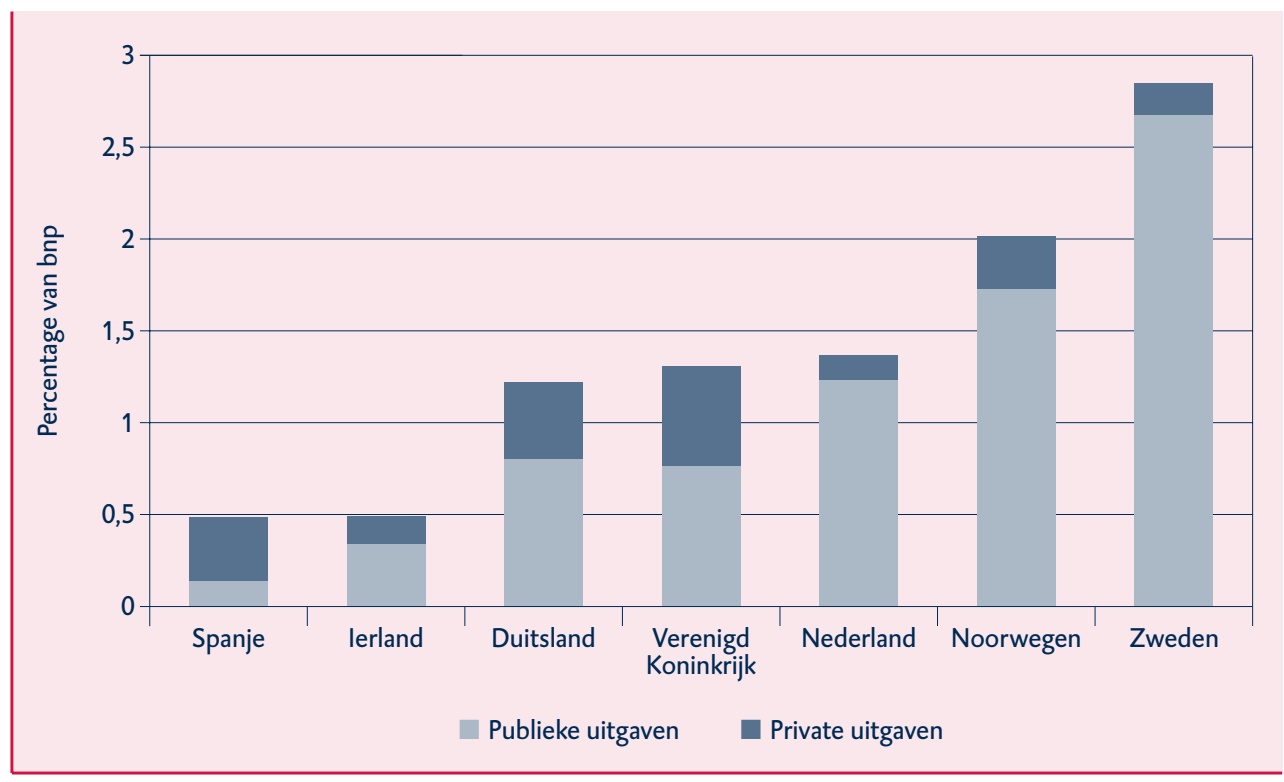

Bron: OECD 2005b 
Ouderen worden niet alleen door formele zorg verzorgd, maar ook informeel, met name door familieleden. Elk land kent een andere mix van formele en informele zorg, al dan niet ondersteund door financiële regelingen. Anders dan in continentale landen en het Verenigd Koninkrijk bestaat er in Nederland weinig (financiële) steun voor informele zorg, bijvoorbeeld via sociale zekerheid of verlofregelingen (OECD 2005C). In Nederland wordt door relatief veel mensen op informele wijze gezorgd, zoals tabel 4.5 laat zien. Er is overigens geen een-opeenverband tussen de hoeveelheid vrouwen die informeel zorgen en het bestaan van zorgvoorzieningen: informele zorg en formele zorg zijn geen communicerende vaten (Spiess en Schneider 2002; Sarasa 2005). Er is wel verband tussen formele zorg en het aantal uren dat informeel gezorgd wordt. In de continentale en Angelsaksische landen wordt door informele zorgers bijna een halve werkweek gezorgd. In Nederland wordt, net als in Scandinavië, minder intensief informeel gezorgd: het aantal uren per week is beperkt.

Tabel 4.5 Informele zorg in Europa, percentage dat informele zorg verleent

\begin{tabular}{|c|c|c|c|c|c|}
\hline \multicolumn{3}{|c|}{1994} & \multicolumn{3}{|c|}{2000} \\
\hline & mannen & vrouwen & $\begin{array}{l}>4 \text { uur } \\
\text { per dag }\end{array}$ & vrouwen & $\begin{array}{r}\text { uren } \\
\text { per week }\end{array}$ \\
\hline \multicolumn{6}{|l|}{ Scandinavisch } \\
\hline Denemarken & 4 & 9 & 8 & 7 & 12 \\
\hline Finland & - & - & - & 9 & 12 \\
\hline \multicolumn{6}{|l|}{ Continentaal } \\
\hline Duitsland & 7 & 14 & 22 & & \\
\hline Nederland & 6 & 13 & 14 & 10 & 17 \\
\hline Frankrijk & 3 & 8 & 17 & 5 & 15 \\
\hline België & 6 & 13 & 21 & - & - \\
\hline \multicolumn{6}{|l|}{ Angelsaksisch } \\
\hline Ver. Koninkrijk & 7 & 14 & 37 & - & - \\
\hline \multicolumn{6}{|l|}{ Mediterraan } \\
\hline Spanje & 5 & 16 & 47 & 13 & 38 \\
\hline Italië & 9 & 19 & 34 & - & - \\
\hline
\end{tabular}

Bron: Sarasa 2005; Dykstra 1994

Maatschappelijke dienstverlening wordt bijna overal in West-Europa van toenemend belang geacht, getuige de toegenomen uitgaven aan kinderopvang, onderwijs, gezondheid en ouderenzorg in het laatste decennium (Taylor-Gooby 2004). Tegelijkertijd komt de verzorgingsfunctie onder druk te staan, met name door vergrijzing als gevolg van een toenemende levensverwachting en dalende geboortecijfers. Kijken we naar het aantal mensen jonger dan 15 jaar en ouder dan 65 jaar in verhouding tot de beroepsbevolking (de age dependency ratio), dan is er 
in heel Europa een sterke stijging te zien, vooral in de mediterrane lidstaten. In Nederland ligt het hoogtepunt van deze grootheid rond 2040; dan bedraagt ze ruim zeventig procent. Dat zal leiden tot een stijging van het aantal zorgvragers.

\section{Figuur 4.10 Vruchtbaarheidsgraad in 1970 en 2003}

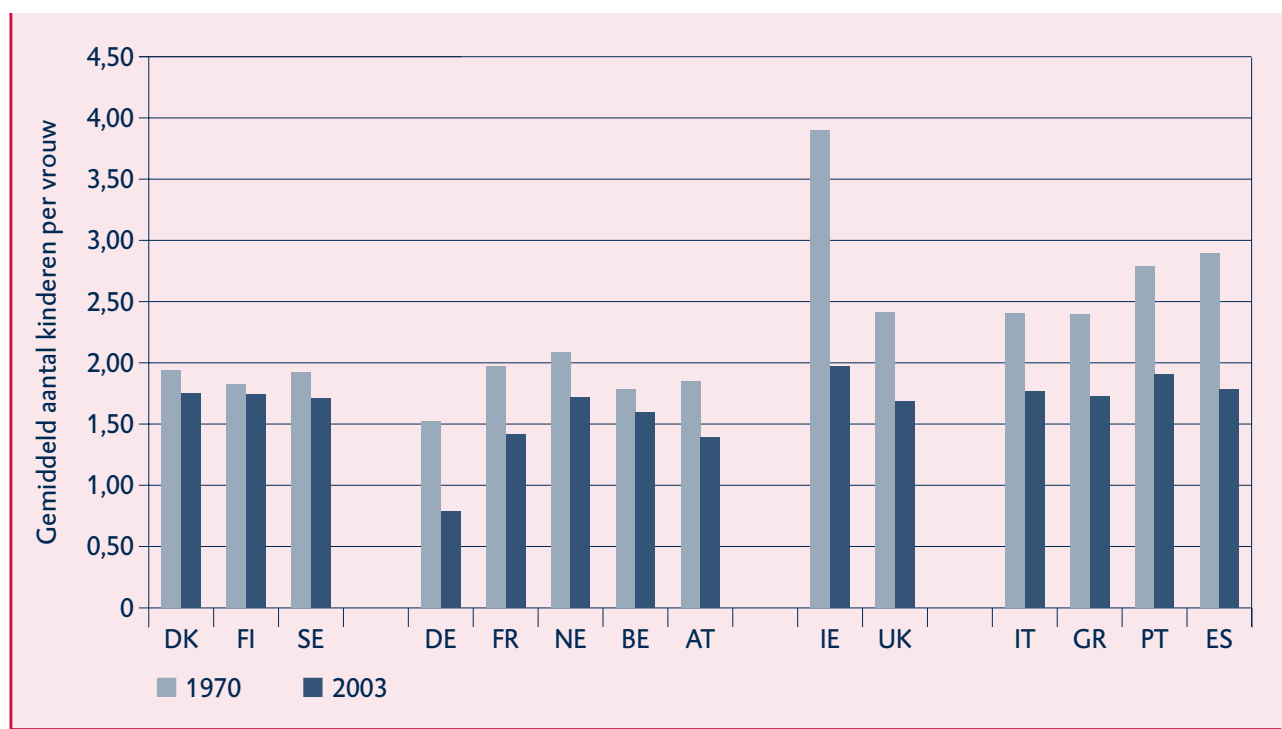

Noot: vruchtbaarheidsgraad: gemiddeld aantal kinderen per vrouw

Bron: OECD 2005a

Een tweede opgave voor de verzorgingsfunctie is omgaan met de toenemende arbeidsdeelname van met name oudere vrouwen. $\mathrm{Nu}$ is de arbeidsdeelname van oudere vrouwen in Nederland nog relatief laag (zie figuur 4.11), maar in de toekomst zullen vrouwen steeds meer blijven werken. Vooralsnog blijkt uit Europese vergelijkende studies naar informele zorg (Spiess en Schneider 2002; Sarasa 2005) en de Nederlandse praktijk (Knijn en Liefbroer 2002; SCP/De Boer 2005) dat mantelzorg en arbeidsdeelname best samen kunnen gaan. In heel verschillende landen als Finland en Engeland is de arbeidsdeelname van oudere vrouwen relatief hoog, maar ook het percentage mantelzorgers, zoals de tabel laat zien. Wel is het zo dat intensieve zorg moeilijk samen kan gaan met intensieve arbeid: voltijds werken en voltijds zorgen, zo blijkt uit de Europese praktijk, is lastig. Als gevolg van de lage vruchtbaarheidsgraad (zie figuur 4.10), de betaalbaarheid en het aanbod van formele zorg, de toenemende arbeidsdeelname van vrouwen en ouderen, en het afnemende belang dat de extended family speelt in onze moderne samenlevingen, zal er meer spanning ontstaan tussen informele zorg en arbeid.

\subsubsection{VERZEKEREN}

In Scandinavische verzorgingsstaten heeft iedereen die daarvoor in aanmerking komt, recht op een uitkering die negentig procent van het laatstverdiende loon kan bedragen, maar wel een bepaald plafond kent. De Angelsaksische sociale 
Figuur 4.11 Werkgelegenheid oudere vrouwen en oudere mannen (55-64 jaar) in 2004

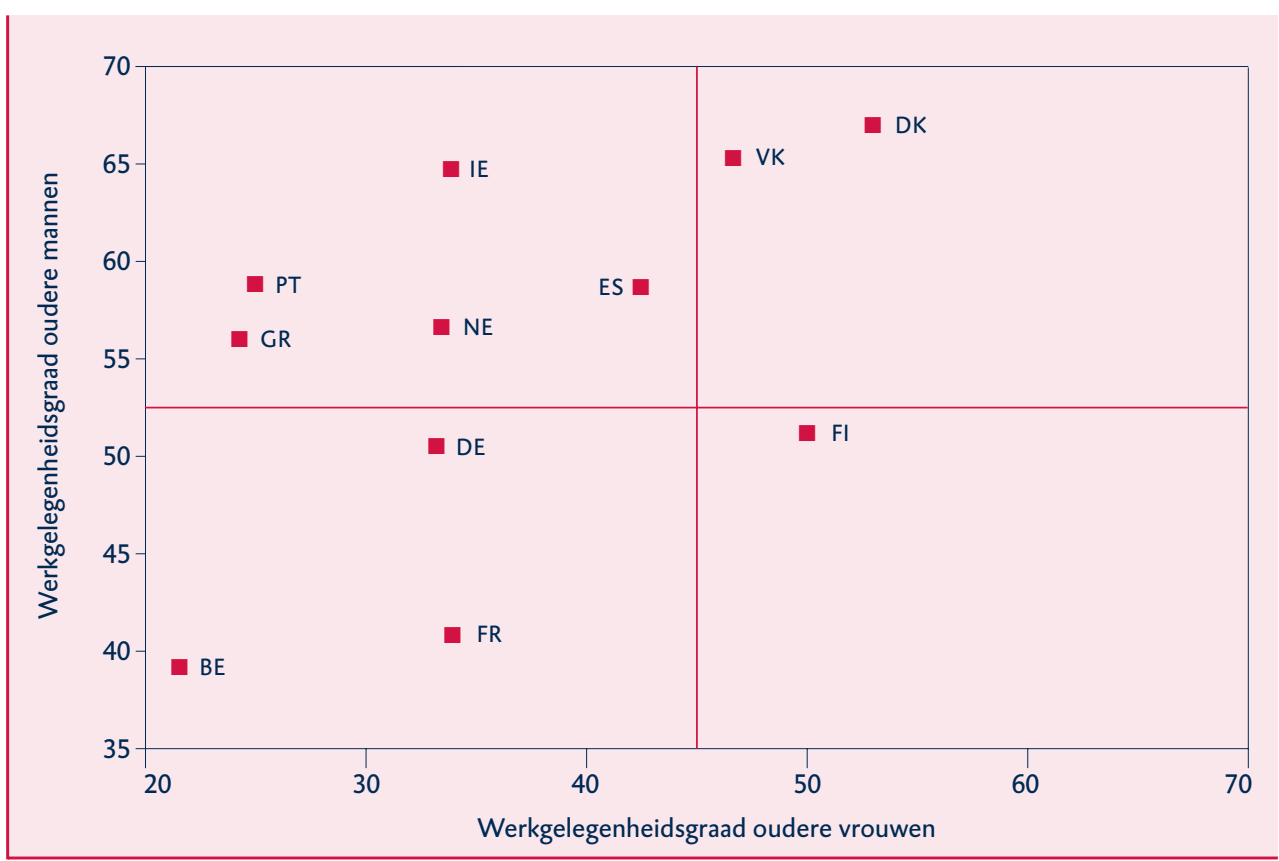

Bron: Eurostat, Structural Indicators

verzekeringen zijn inkomensafhankelijk, op behoefte gebaseerd, en bescheiden van omvang: ze bedragen minder dan 55 procent van het laatstverdiende inkomen. De hogere inkomensgroepen verzekeren hun arbeidsmarkt- en levenslooprisico's bij via private verzekeringen. De Continentale verzorgingsstaten worden gekenmerkt door hoge beroepsgroepgerelateerde inkomensvervangende uitkeringen die een verzekeringslogica weerspiegelen (financiering door sociale verzekeringsbijdragen). Uitkeringen benaderen het niveau van het laatstverdiende loon en de uitkeringsduur is relatief lang. Ook in de mediterrane landen zijn inkomensoverdrachten vooral passief van aard en is het sociale vangnet onderontwikkeld: Portugal en Griekenland kennen geen adequate bijstandsondersteuning. Ondanks deze verschillen in sociale verzekeringssystemen die sterk regimegerelateerd zijn, vertoont het aandeel van de beroepsbevolking dat voor zijn inkomen afhankelijk is van de sociale zekerheid (de benefit dependency rate) slechts een beperkte spreiding (zie tabel 4.6).

Binnen de sfeer van de sociale verzekeringen is een verschuiving gaande van een passief beleid gericht op een horizontale herverdeling van inkomen (van gezond naar ziek, van werkend naar werkloos) naar een beleid gericht op de activering en reïntegratie van kwetsbare groepen. Daartoe zijn in eerste instantie uitkeringen verlaagd, is de toegang tot de sociale zekerheid selectiever geworden, en is het voorwaardelijke karakter van rechten sterker benadrukt. De nadruk ligt nu meer op de wederkerigheid van rechten en plichten: om in aanmerking te blijven 
komen voor uitkeringen worden uitkeringsgerechtigden vaker verplicht om een baan te accepteren of een opleiding te volgen, terwijl de overheid meer dan voorheen de plicht op zich heeft genomen om uitkeringsgerechtigden te reactiveren voor de reguliere of gesubsidieerde arbeidsmarkt. Dat is nodig om de arbeidsparticipatie op een zo hoog mogelijk niveau te brengen in de continentale en mediterrane landen. Dat is noodzakelijk om de sociale zekerheid betaalbaar en de productiviteit en het concurrentievermogen op peil te houden. Ook in Nederland zijn de uitgaven voor actief arbeidsmarktbeleid sterk toegenomen, en steken ze gunstig af in vergelijking tot andere landen (zie tabel 4.3).

Arbeidsongeschiktheid, werkloosheid en vervroegde uittreding leidden in de jaren tachtig en negentig tot de meeste aanspraken op inkomensondersteuning. $\mathrm{Nu}$ ligt in Europa de focus meer op preventieve gezinsondersteuning: ouderschaps- en zwangerschapscompensatie worden belangrijker. Vergeleken met de rest van de EU kent Nederland een lage compensatie voor ouder- en zwangerschapsverlof, niet alleen ten opzichte van Scandinavische landen maar ook in vergelijking met Frankrijk en Oostenrijk.

Tabel 4.6 Benefit dependency rate. Percentage van populatie 15-64 jaar, afhankelijk van sociale zekerheid

\begin{tabular}{|c|c|c|c|}
\hline & 1980 & 1990 & 1999 \\
\hline \multicolumn{4}{|l|}{ Scandinavisch } \\
\hline Denemarken & 20,1 & 23,2 & 23,1 \\
\hline Zweden & 16,1 & 17 & 20 \\
\hline \multicolumn{4}{|l|}{ Continentaal } \\
\hline Duitsland & 15,2 & 18,1 & 22,4 \\
\hline Frankrijk & 13,9 & 20,2 & 24,2 \\
\hline Nederland & 15,9 & 19,9 & 17,8 \\
\hline België & 17,4 & 24,4 & 23,6 \\
\hline Oostenrijk & 15,5 & 18 & 21,5 \\
\hline \multicolumn{4}{|l|}{ Angelsaksisch } \\
\hline lerland & 12,4 & 18,9 & 19,3 \\
\hline Ver. Koninkrijk & 15,2 & 18,5 & 18,9 \\
\hline \multicolumn{4}{|l|}{ Mediterraan } \\
\hline Spanje & 8,3 & 12,3 & 11,2 \\
\hline
\end{tabular}

Bron: OECD 2004a 


\section{Oudedagsuitkeringen}

Het Nederlandse pensioenstelsel kent een hybride karakter. Ons stelsel kent, net als in de andere continentale landen, verplichte, inkomensafhankelijke en aan arbeid gerelateerde pensioenen (tweede pijler). Daarnaast kent Nederland een algemeen publiek gefinancierd ouderdomspensioen (AOW ). De AOW (eerste pijler) is vergelijkbaar met het Scandinavische omslagstelsel en voorziet alle inwoners vanaf 65 jaar van een basispensioen, net boven het bestaansminimum. De tweede pijler bestaat uit een meestal voor alle werknemers verplichte inkomensafhankelijke pensioenregeling, per bedrijf of sector georganiseerd. Werkgevers- en werknemersorganisaties beheren daartoe gezamenlijk de pensioenfondsen. De eerste en tweede pijler samen zorgen voor een pensioen dat zeventig procent van het laatstverdiende loon bedraagt, bij een volledige pensioenopbouw. De - in omvang - kleine derde pijler bestaat uit voor de belasting aftrekbare private aanvullende pensioenregelingen en lijfrentes, bedoeld voor wie niet of niet voldoende pensioen opbouwt in de tweede pijler.

Angelsaksische pensioenen zijn altijd gebaseerd geweest op het middelloon. Staatspensioenen die op de hoogte van het eindloon zijn gebaseerd, vergoeden minder dan vijftig procent van het laatstverdiende loon. Het pensioengat wordt hier gedicht door inkomensafhankelijke pensioenen, aangeboden door private pensioenfondsen. De Scandinavische pensioenen zijn evenmin genereus. De Zweedse en de Finse overheid verstrekken aan alle werkenden, in loondienst en zelfstandig, een inkomensafhankelijk pensioen. Het Zweedse en Deense middelloonsysteem heeft tot gevolg dat de inkomensafhankelijke pensioenpijler geen minimum- en maximumhoogten kent. Burgers zonder arbeidsverleden hebben recht op een staatspensioen, dat in Denemarken en Finland onderhevig is aan een inkomenstoets. De staatspensioensystemen van continentale verzorgingsstaten zijn gebaseerd op een omslagstelsel en worden georganiseerd via sociale verzekeringen. Verder is, met name in Nederland, het kapitaalgedekte tweedepijlerpensioen van groot belang. De totale hoogte van de Nederlandse oudedagsuitkeringen varieert tussen de vijftig en negentig procent van het laatstverdiende loon, vergelijkbaar met de Scandinavische verzorgingsstaten. Nederlandse ouderen zijn dus relatief goed verzekerd.

In de meeste EU-landen zijn in de afgelopen vijftien jaar belangrijke hervormingen in pensioenen doorgevoerd. In 1999 schakelde Zweden over van een eindloonnaar een middelloonsysteem (Schludi 2001). In Oostenrijk is de referentieperiode uitgebreid en zijn de indexeringsregels veranderd. Duitsland is overgegaan van bruto- naar nettoloonindexering, Frankrijk van loon- naar prijsindexering. In Nederland is rond de eeuwwisseling een belangrijke stap gezet met de ombouw van het eindloon- naar een middelloonstelsel. Duitsland is het verst gegaan. Teneinde het sparen in private pensioenfondsen en het gebruik van staatssubsidies op aanvullende pensioenen door mensen met een laag inkomen te stimuleren, zijn bonussen en belastingvoordelen in het leven geroepen. De afwezigheid van samenwerking en consensus onder grote politieke partijen en sociale partners in Frankrijk is een belangrijke oorzaak voor het gebrek aan voortgang in de hervor- 
mingen van het pensioensysteem en de arbeidsmarkt (Bonoli en Palier 1997; Levy 1999). Belangrijke pensioenhervormingen in Spanje, Portugal en Italië maakten deel uit van een hervormingspakket dat noodzakelijk was voor toetreding tot de EMU. Maar ondanks deze soms ingrijpende aanpassingen geeft een land als Italië nog steeds bijna zestien procent van zijn bnp uit aan pensioenen. Nederland kent een gemiddeld uitgavenpatroon als het gaat om pensioenen (figuur 4.12).

\section{Figuur 4.12 Pensioenuitgaven als percentage van het bnp, periode 1990-2003}

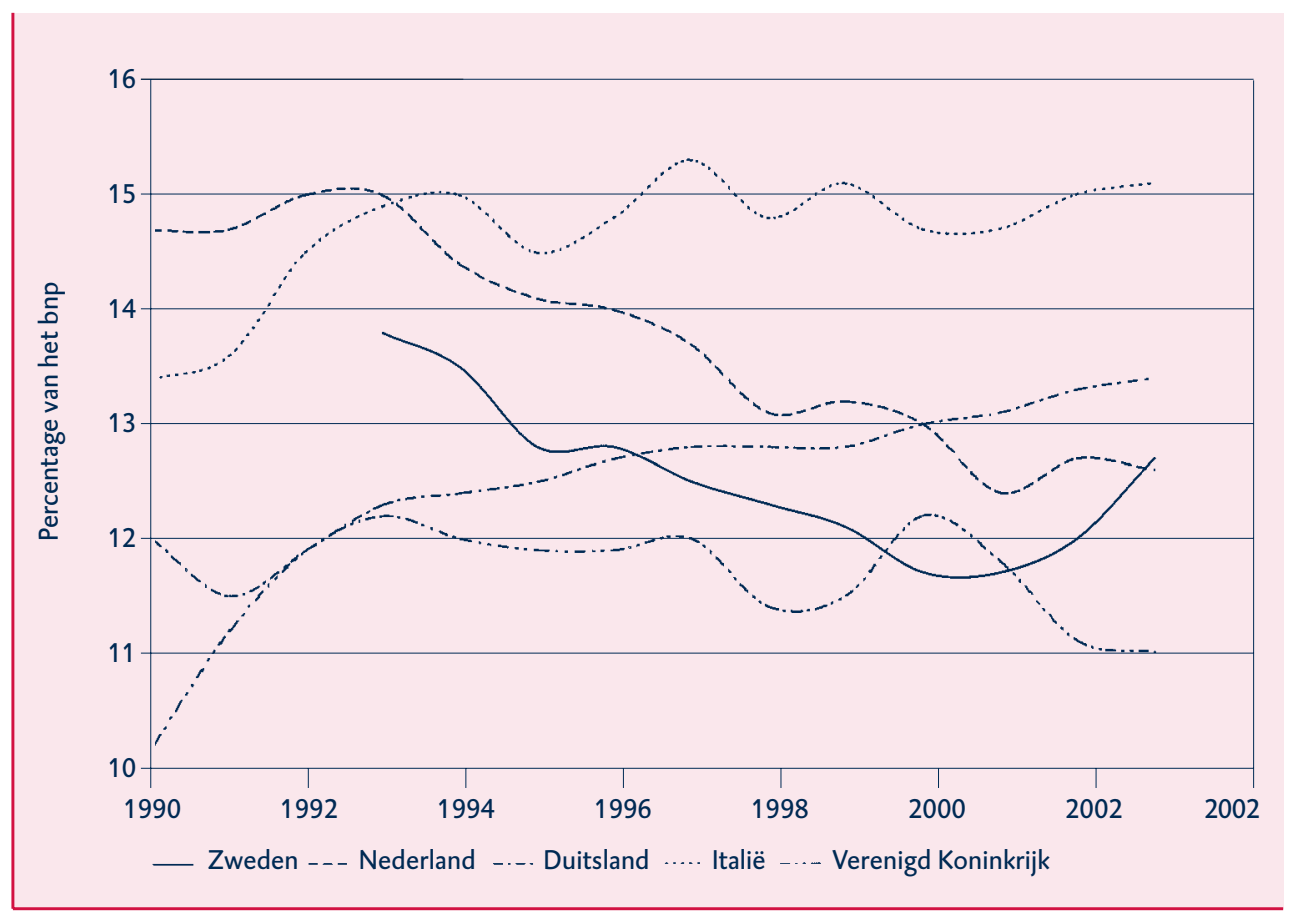

Bron: Eurostat, Sustainable Development Indicators

Een stijgende levensverwachting, een blijvend laag geboortecijfer en de babyboomgeneratie die de pensioengerechtigde leeftijd bereikt, zetten de houdbaarheid van de pensioenstelsels onder druk. Maar pensioenhervormingen komen slechts moeizaam van de grond, vooral in mediterrane en continentale stelsels. Dit geldt niet voor Scandinavische landen, waar de arbeidsdeelname van ouderen hoog is. De recente Nederlandse pensioenhervormingen, die voor een belangrijk deel relatief rustig zijn doorgevoerd, steken in dat opzicht gunstig af.

\subsubsection{VERHEFFEN}

Het onderwijs is gedurende de twintigste eeuw het belangrijkste middel geweest voor opwaartse mobiliteit. Het is de ambitie van de EU om ook in de huidige kenniseconomie op het hoogste niveau te kunnen concurreren (de 'Lissabonagenda'). Daarom wordt alom erkend dat investeren in menselijk kapitaal prioriteit heeft. Het verbeteren van het onderwijs over de gehele linie is hierbij het 
meest voor de hand liggende middel. Vrijwel overal in Europa ligt de arbeidsparticipatie van hoger opgeleiden boven de tachtig procent, terwijl lager opgeleiden aanzienlijk lager scoren. Een belangrijk probleem vormt het grote aantal 'voortijdige schoolverlaters'1 (zie figuur 4.13). In Portugal en Spanje verlaat ongeveer dertig procent de school voortijdig, in Nederland ongeveer dertien procent, maar in Denemarken en Zweden betreft het slechts ongeveer acht procent.

\section{Figuur 4.13 Vroegtijdige schoolverlaters in 2005}

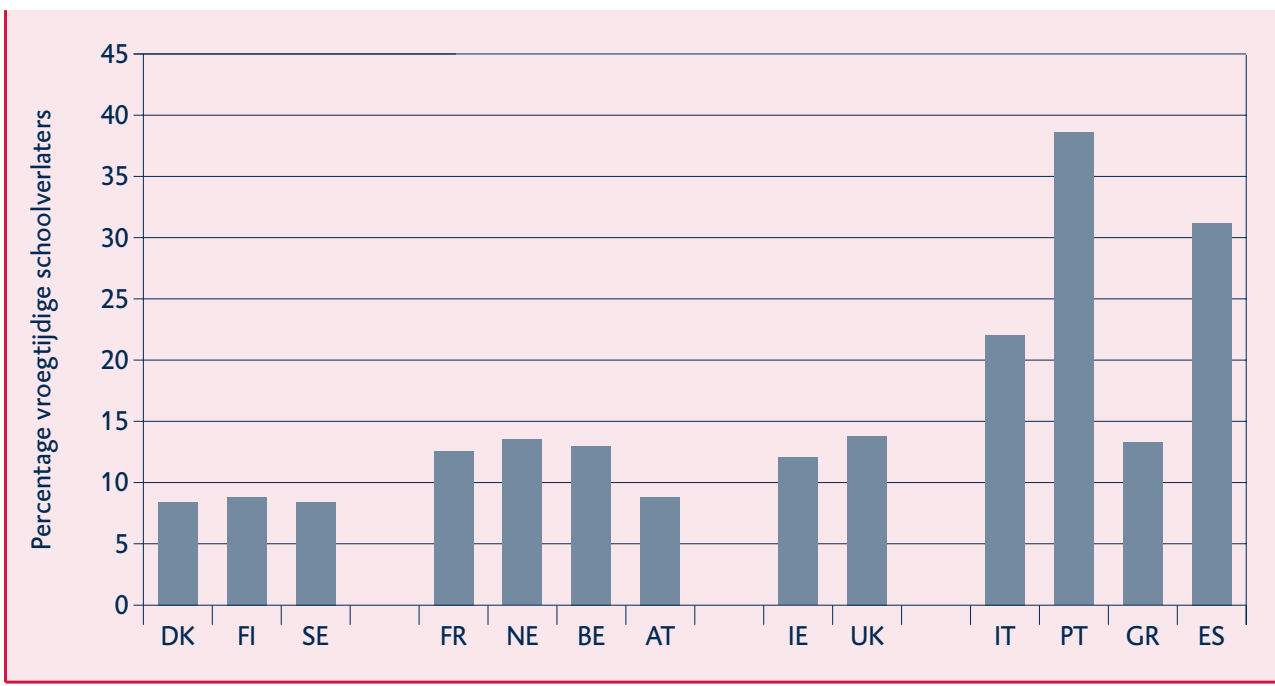

Bron: OECD

\section{Verschillende onderwijssystemen}

De Angelsaksische en de Scandinavische verzorgingsstaten worden gekenmerkt door brede, algemeen vormende, onderwijssystemen, waar leerlingen lang bij elkaar blijven en een gemeenschappelijk programma afronden. In de continentale en mediterrane verzorgingsstaten bestaan meer gedifferentieerde stelsels, met gescheiden algemeen vormende en categorale beroepsvoorbereidende trajecten, gericht op een goede aansluiting op de arbeidsmarkt. Het onderscheidende kenmerk van de continentale onderwijssystemen is de duale structuur. Zowel het Scandinavische systeem en het Duitse stelsel benadrukken het belang van intermediaire instituties tussen het onderwijs en de arbeidsmarkt. Dergelijke verbindingen blijven zwak in de meeste mediterrane landen, Frankrijk en het Verenigd Koninkrijk.

In Nederland bestond lange tijd een sterke koppeling tussen het algemeen vormende onderwijsdeel en het beroepsonderwijs. Hierdoor konden leerlingen gemakkelijk doorstromen van lager via middelbaar via hoger beroepsonderwijs naar de universiteit. Met de invoering van de basisvorming, geïnspireerd door Angelsaksische en Scandinavische voorbeelden, zijn deze doorstroommogelijkheden beperkt. Bovendien bestaat in Scandinavië - anders dan in Nederland - een tweedekans levenlanglerenbeleid; voorzieningen die een integraal onderdeel zijn 
van een beleidstraditie om arbeidsdeelname en productiviteit te bevorderen. De successen van bijvoorbeeld de Finse economie, maar ook de Ierse, zijn gedeeltelijk gebaseerd op een catch-up investeringsstrategie in het onderwijs, het voorkomen van voortijdig schoolverlaten en het vergemakkelijken van de overgang van school naar werk, vooral voor laaggeschoolden.

\section{Hoogte en financiering van onderwijsuitgaven}

Figuur 4.14 laat zien dat de totale uitgaven aan onderwijs het hoogst zijn in Scandinavië. Dat zijn vrijwel volledig publieke uitgaven; het private aandeel is hier het laagst. Denemarken geeft meer dan zeven procent van het bnp uit aan onderwijs. Nederland geeft, net als Spanje, veel minder uit, een kleine vijf procent. De grootste financieringsstroom in de EU is publiek van aard. In Duitsland en het Verenigd Koninkrijk wordt ook een aanzienlijk deel privaat gefinancierd. Het Verenigd Koninkrijk moedigt private scholen aan om zelfsturende trusts te vormen, om zich te ontworstelen aan de overheid.

Figuur 4.14 Uitgaven aan onderwijs als percentage van het bnp in 2002

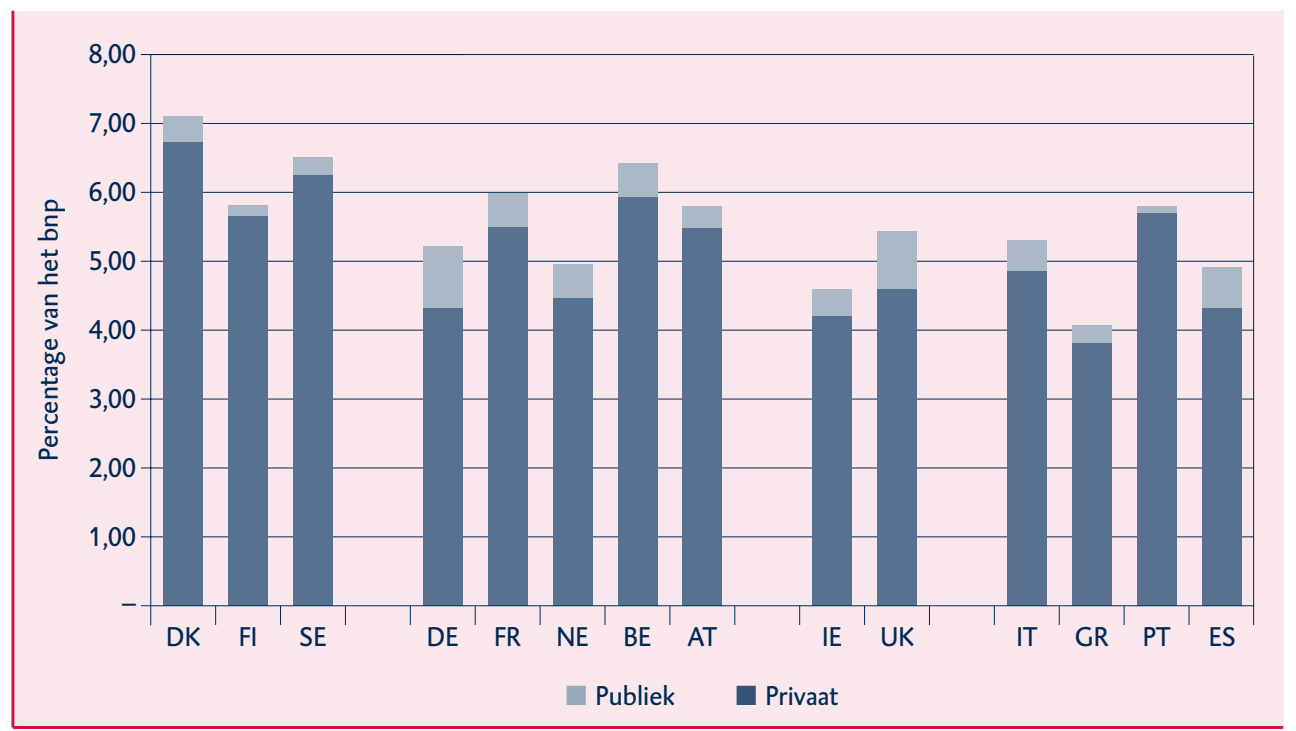

Bron: OECD 2004b

\section{Onderwijs en de Lissabondoelstellingen}

Om ook in de toekomst op het allerhoogste niveau economisch te kunnen presteren heeft de EU zich in Lissabon (2000) tot doel gesteld de kwaliteit en de kwantiteit van haar menselijk kapitaal te verhogen. De Europese Raad heeft deze ambitie omgezet in dertien doelstellingen, variërend van aanbevelingen rond voortijdige schoolverlaters, verhouding tussen mannen en vrouwen in exacte vakken, en het niveau van leesvaardigheid. Wat betreft dat laatste: in 2010 moet het percentage vijftienjarigen dat laag scoort op leesvaardigheid met ten minste twintig procent gedaald zijn ten opzichte van 2000. Op basis van de PISA Reading 
Scale scoren Nederlandse scholieren hoog (zie figuur 4.15), vergelijkbaar met Ierland en Zweden. Finland scoort als enige land significant hoger. De standaarddeviatie in PISA-scores in Nederland is een van de laagste in Europa, wat duidt op een homogeen gemiddelde. Dat betekent dat de meeste kinderen goed kunnen lezen, maar ook dat we weinig uitschieters naar boven kennen.

Figuur 4.15 Gemiddelde PISA-Score leesvaardigheden in 2003

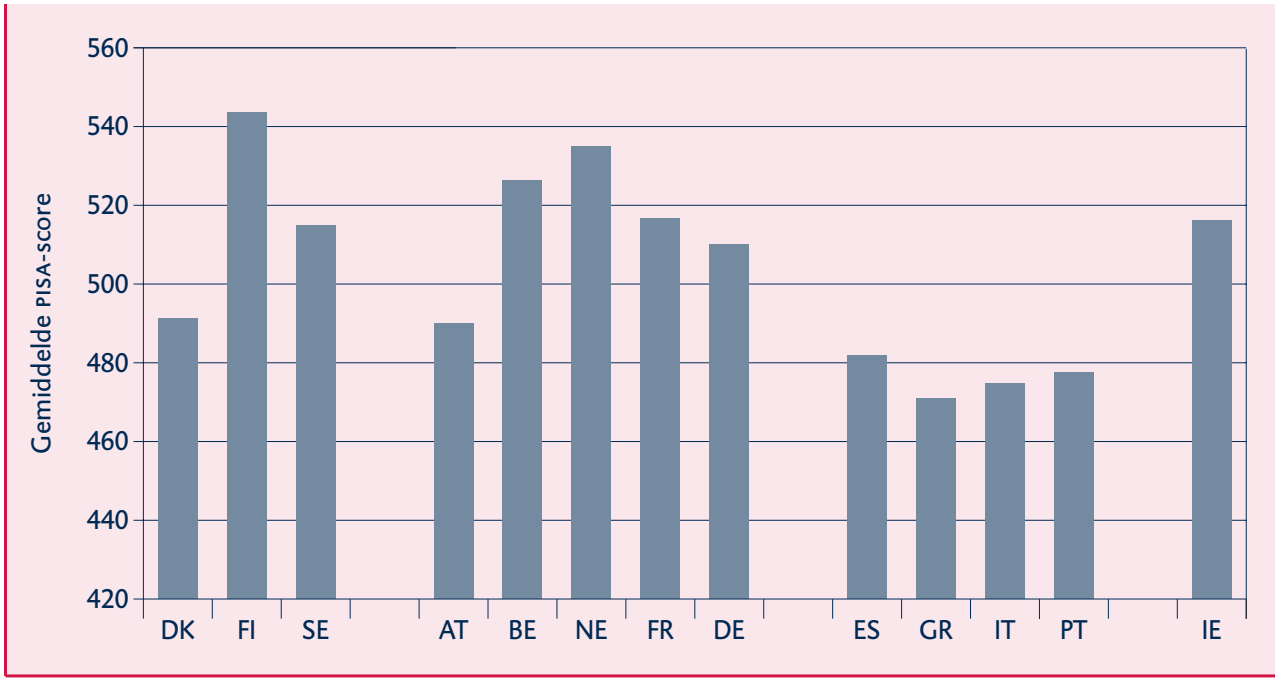

Bron: OECD

\section{Kinderopvang}

Vaak heerst de gedachte, en zeker in Nederland, dat kinderopvang een belangrijke manier is om voor vrouwen deelname op de arbeidsmarkt te vergemakkelijken. De pedagogische component wordt zelden of nooit aangevoerd als reden om een baby of peuter naar dagopvang te brengen. De kosten van kinderopvang zijn dan ook primair voor de ouders. Kinderopvang kan echter ook onderdeel zijn van de verheffingsfunctie van de verzorgingsstaat. Dergelijke verschillende visies op het belang van kinderopvang zijn terug te zien in figuur 4.16. In Denemarken en Zweden steekt het aantal kinderen in geregistreerde kinderopvang met kop en schouders boven de rest van Europa uit. De kosten van kinderopvang per kind zijn voor ouders dan ook beduidend lager dan elders in Europa (met uitzondering van Duitsland). In Nederland zijn de kosten van kinderopvang vergelijkenderwijs hoog. Dit past binnen de eerdere constatering dat in Nederland verhoudingsgewijs weinig geïnvesteerd wordt in gezinnen (zie tabel 4.5).

De verheffingsfunctie raakt ook de positie van vrouwen. In Nederland is de arbeidsdeelname van moeders sterk toegenomen, en is nu een van de hoogste in Europa, net na landen als Zweden en Denemarken (zie figuur 4.17). De meeste moeders in Nederland werken in deeltijdbanen. 
Figuur 4.16 Kinderopvang. Kosten en gebruik in 2001

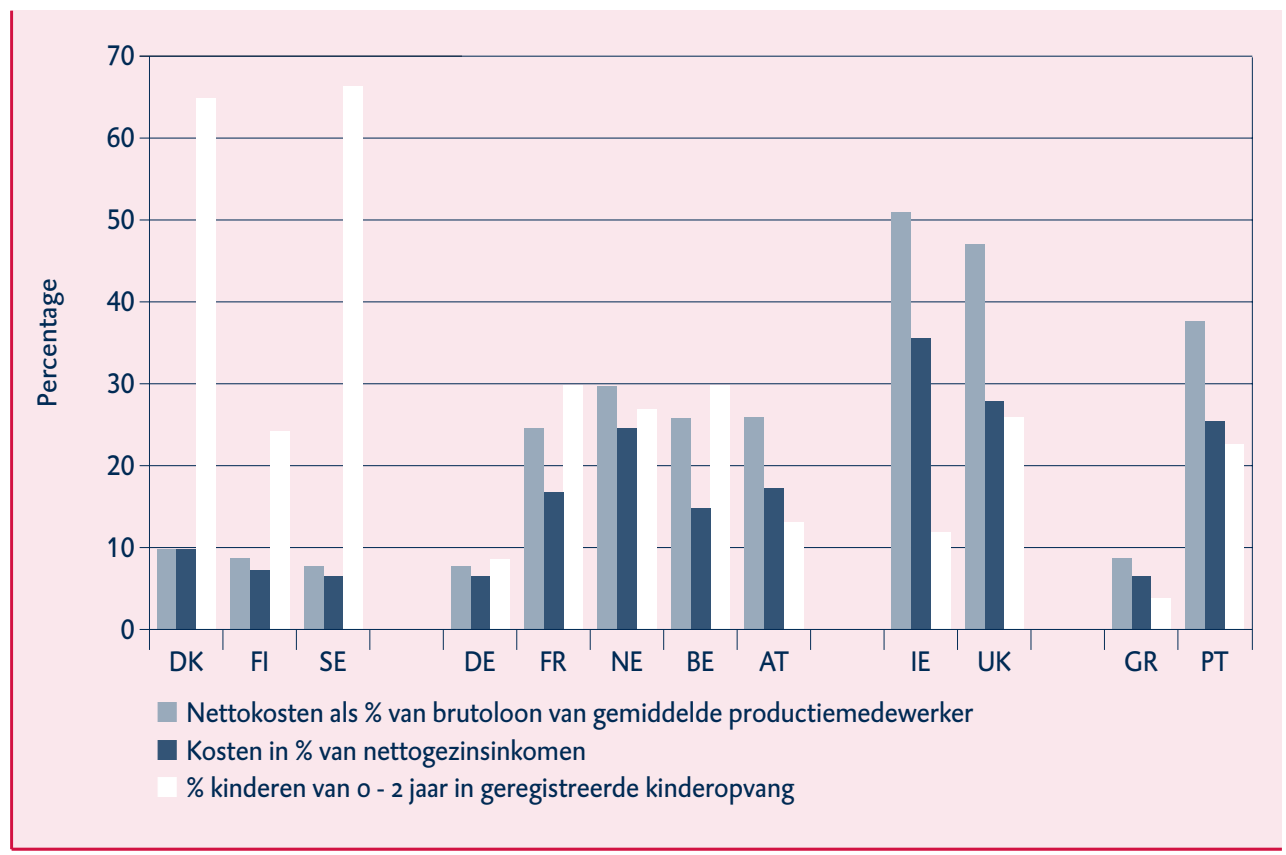

Noot: Data voor België, Frankrijk, Zweden en het Verenigd Koninkrijk betreft het jaar 2002

Bron: OECD 2005e

Figuur 4.17 Werkgelegenheid vrouwen met kind, per leeftijdscategorie kind

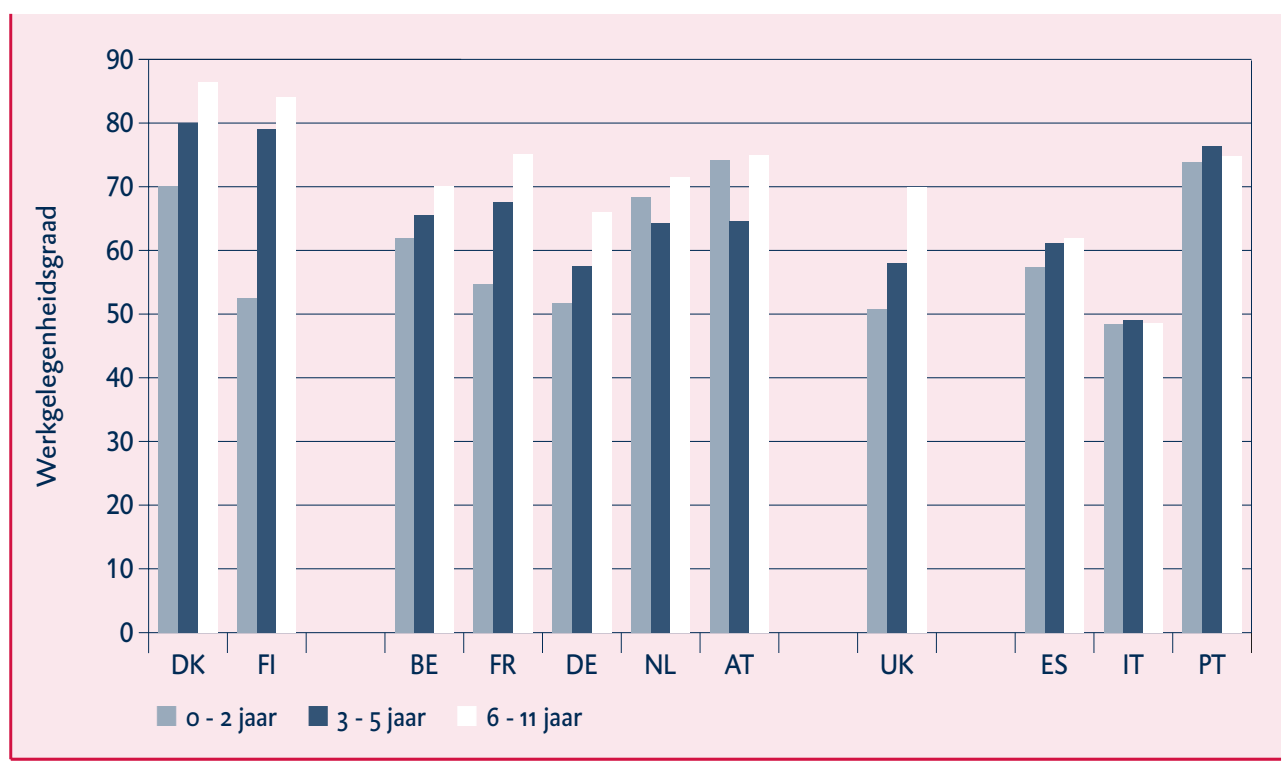

Noot: Gegevens van Zweden, lerland en Griekenland waren niet beschikbaar, of onbetrouwbaar Bron: Eurostat 
Het is opvallend dat de algemene tendens tot participatie door vrouwen hun vruchtbaarheid niet negatief beïnvloedt. Integendeel, figuur 4.18 suggereert zelfs een licht positieve correlatie tussen arbeidsdeelname en vruchtbaarheid. Met name landen waar het combineren van zorg en arbeid moeizaam verloopt (en meer economische onzekerheid heerst) zoals Italië en Spanje, laten lage vruchtbaarheidscijfers zien. Het lijkt erop dat kinderopvang, naast het verheffen van kinderen en het bevorderen van de arbeidsparticipatie, ook nog wel eens een ander (indirect) effect kunnen hebben.

\section{Figuur 4.18 Werkgelegenheid en vruchtbaarheid vrouwen in de EU in 2004}

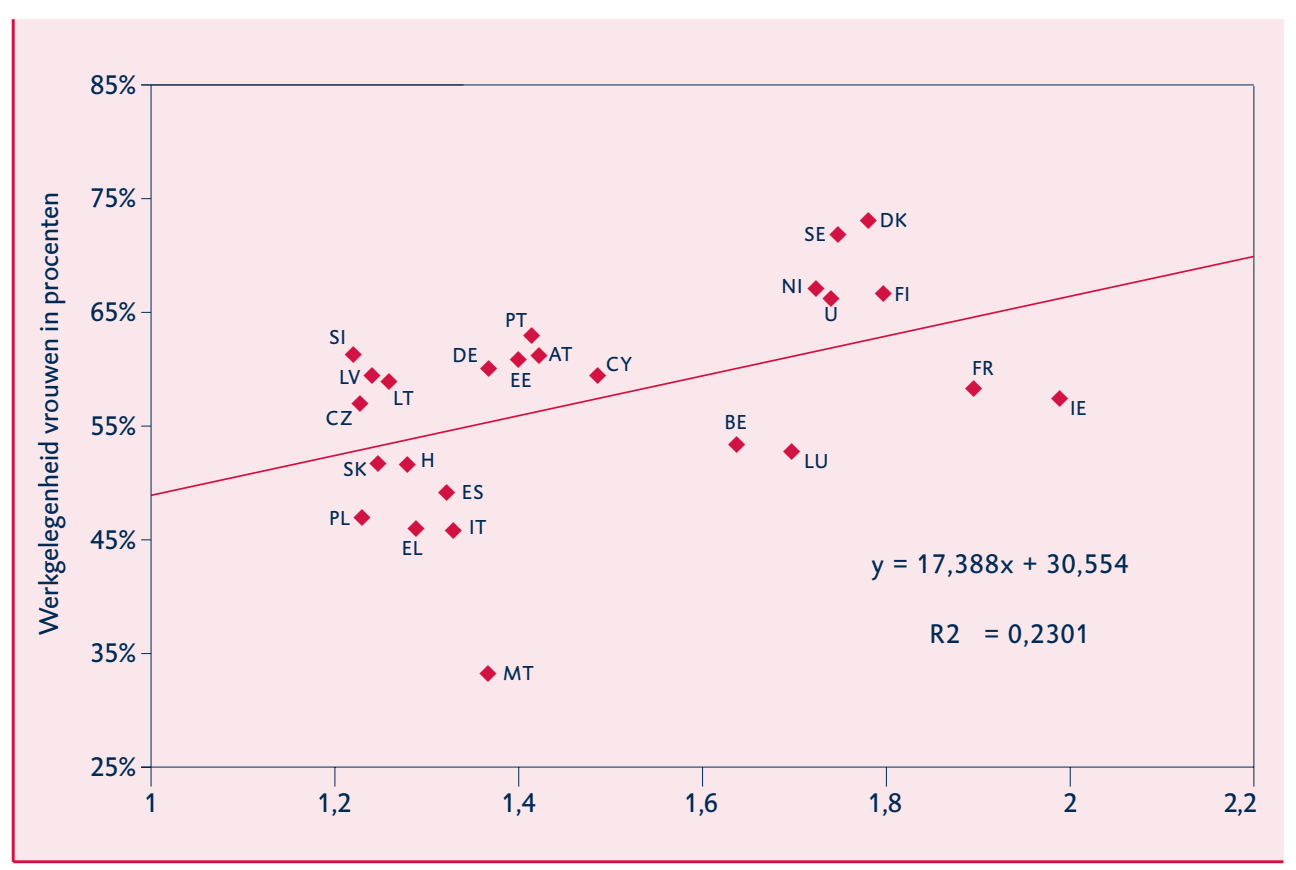

Bron: Saari 2006

\subsubsection{VERBINDEN}

Een belangrijke functie van de verzorgingsstaat is het creëren van sociale cohesie door middel van een gerichte insluiting van werknemers, vrouwen, etnischlinguïstische en religieuze minderheidsgroepen. De maatschappelijke verbondenheid in de rijke westerse samenleving kan onder druk komen te staan door processen van economische internationalisering, technologische innovatie, individualisering van samenlevingspatronen, vergrijzing en immigratie. Het is de vraag in hoeverre Europese verzorgingsstaten erin slagen de sociale verbinding tussen verschillende categorieën burgers te herijken. Is er in Europese landen sprake van verbindingstekorten wanneer we kijken naar zowel objectieve cijfers als subjectieve percepties van burgers over de verbindingskracht van de verzorgingsstaat tussen verschillende groepen: oud en jong, allochtoon en autochtoon, en hoog- en laagopgeleiden? 


\section{Oud en jong}

Een verouderende bevolking kan gevolgen hebben voor de verhouding tussen jong en oud, met als mogelijk resultaat een generatieconflict. De betaalbaarheid van de pensioenen en de gezondheidszorg staat onder druk, en daarmee ook de beleidsruimte voor kinderopvang en gezinsondersteuning. Vergeleken met andere Europese landen kennen Nederlandse ouderen significant minder armoede. Ook ten opzichte van de Nederlandse bevolking als geheel is het armoedecijfer van ouderen laag: 1,6 tegenover 6,o, afgemeten aan de ratio van figuur 4.19. Kinderarmoede vormt daarentegen een relatief groter probleem in Nederland.

\section{Figuur 4.19 Relatieve Armoederatio kinderen en ouderen in 2000}

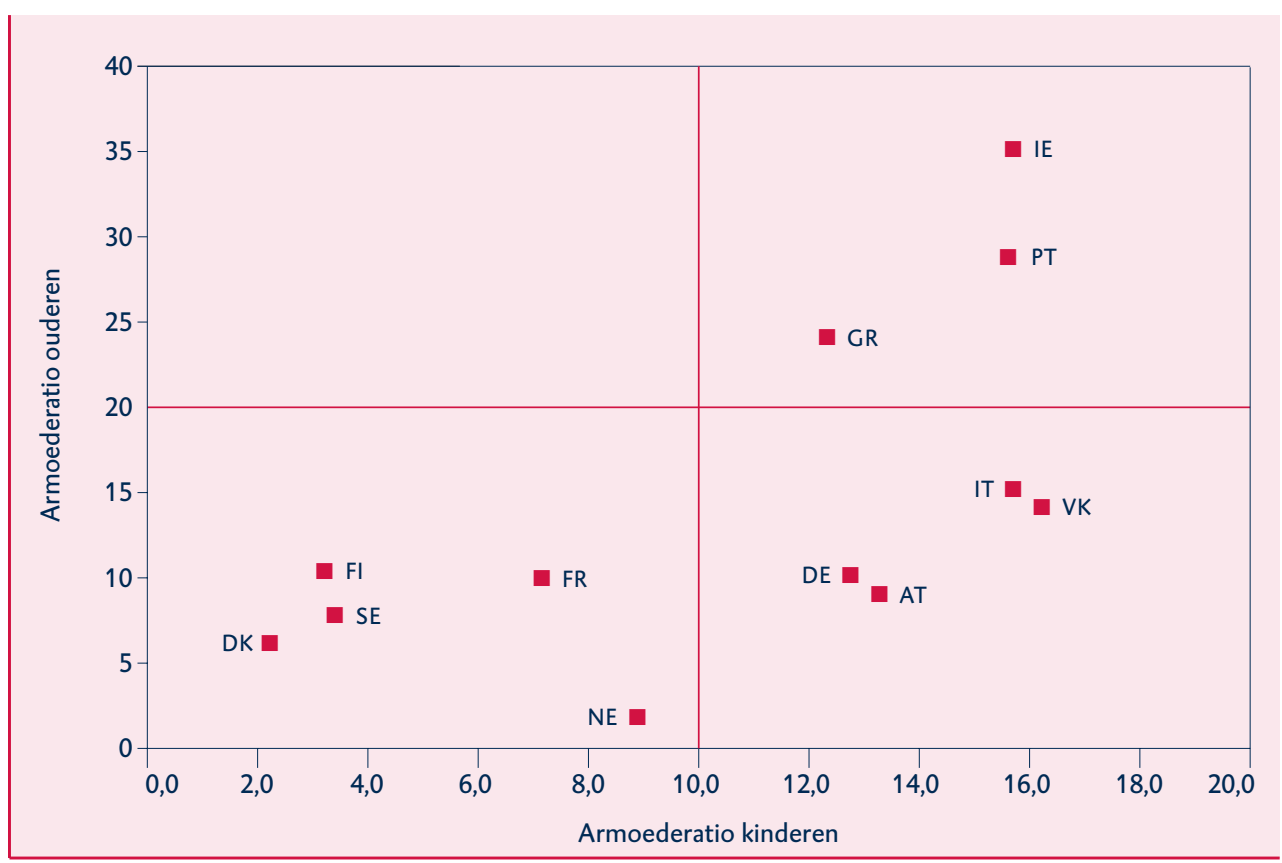

Bron: OECD 2005d

Vanaf de jaren tachtig is in de continentale en mediterrane verzorgingsstaten sprake van een dramatische daling van arbeidsparticipatie van oudere werknemers, met meer dan dertig procent. Dit komt met name door het vervroegd uittreden van vooral mannen. Sinds eind jaren negentig is er weer een toename van de arbeidsparticipatie van oudere werknemers in sommige continentale verzorgingsstaten. Nederland loopt hierbij voorop. Toch heeft zowel oud als jong een zwakke positie op de arbeidsmarkt: beide groepen kennen een hoge werkloosheid (oud iets meer dan jong). Er zijn echter belangrijke verschillen. Wanneer ouderen werkloos worden, blijven ze dit ook lange tijd, soms tot hun pensioen, al worden ze vaak ondersteund door relatief genereuze uitkeringen. Voor jongeren geldt dat niet: zij vinden relatief snel weer een andere baan (zie figuur 4.20). 
Figuur 4.20 Het aannemen van oude werknemers in 2004.

a) het percentage werknemers dat sinds minder dan 1 jaar een baan heeft, per leeftijdscategorie

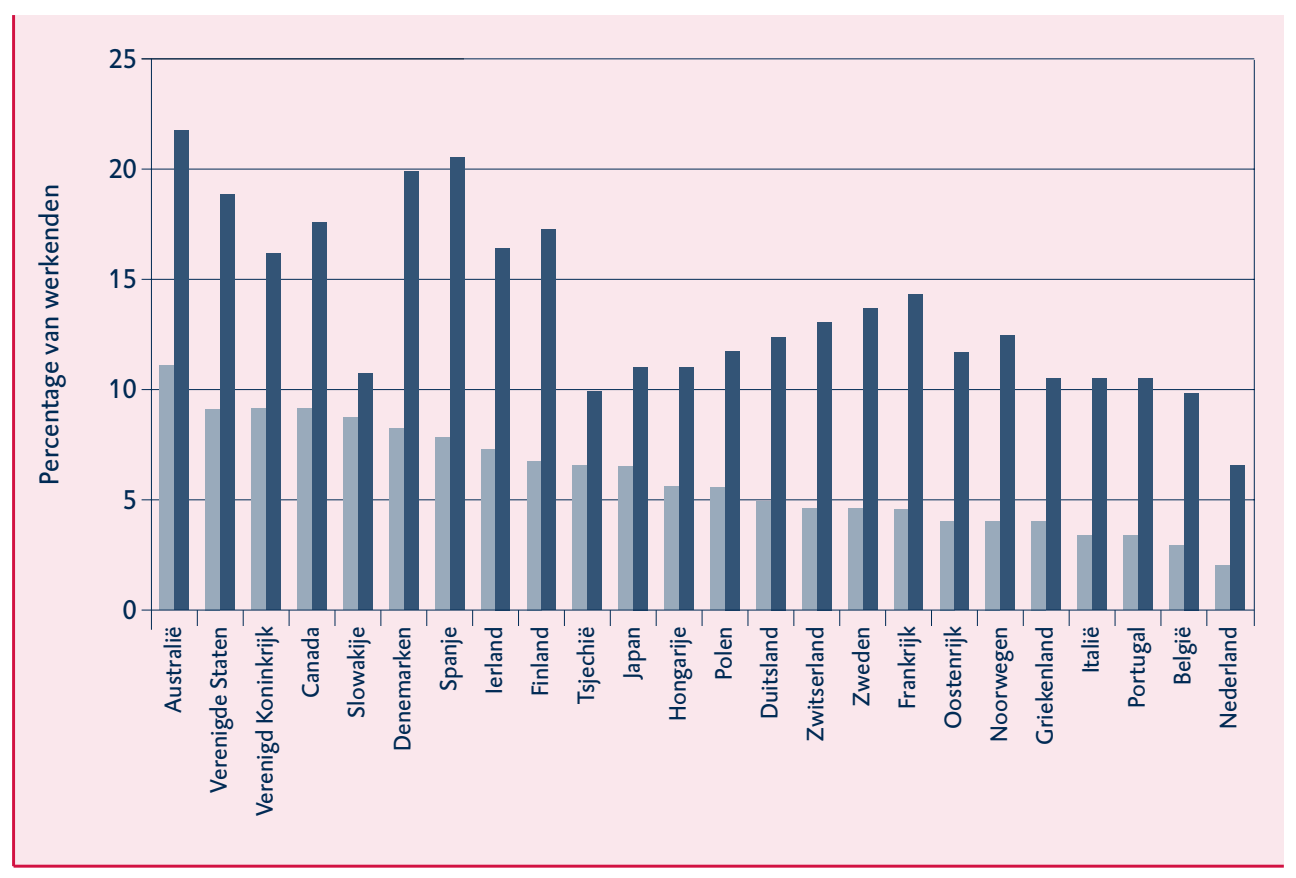

b) het percentage werknemers dat een jaar eerder werkloos was, per leeftijdscategorie

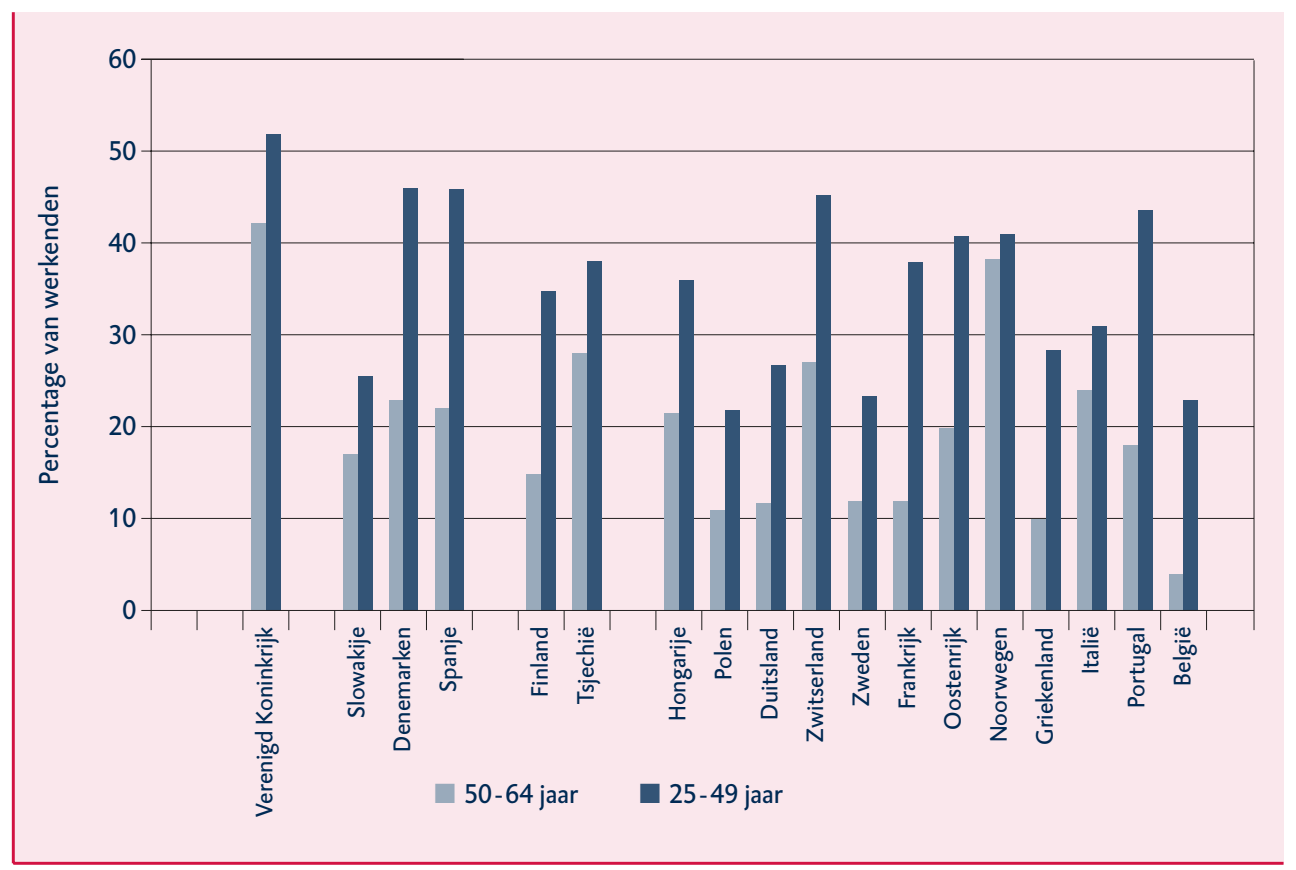

Noot: de gegevens voor Australië, de Verenigde Staten, Canada, lerland, Japan en Nederland ontbreken. Bron: OECD (2006) 
Verder blijkt dat werkgevers meer bereid zijn om in jongeren te investeren dan in ouderen: cursussen en trainingen worden over de hele economische cyclus meer aan jongeren gegeven (figuur 4.21). Overigens is Nederland, na de mediterrane landen, het land met de laagste investeringen op het terrein van bedrijfsspecifieke opleidingen. Vergelijkend onderzoek (zie tabel 4.7) laat zien dat vooralsnog de - subjectieve - gerapporteerde spanningen tussen jong en oud in Nederland niet uitzonderlijk groot zijn, maar wel groter dan in Scandinavische verzorgingsstaten.

Figuur 4.21 Training van werknemers naar leeftijdscategorie in 2006

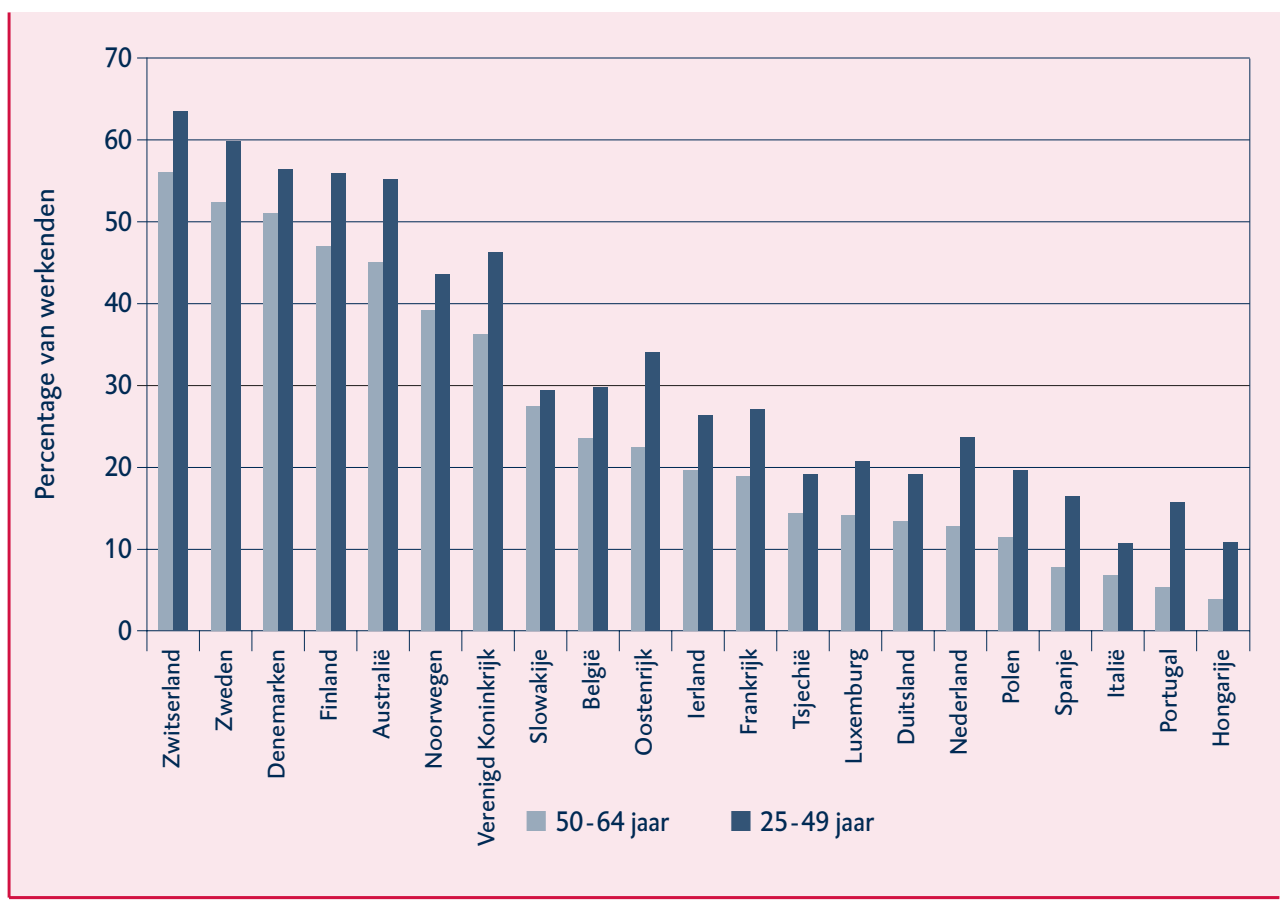

Bron: OECD (2006)

\section{Autochtoon en allochtoon}

Tabel 4.7 laat zien dat Nederland verhoudingsgewijs een grote spanning kent tussen allochtonen en autochtonen: samen met België en Frankrijk scoort Nederland het hoogst van Europa. Dat er sprake is van een gebrekkige solidariteit komt ook naar voren in het onderzoek van Van Oorschot (2005) naar percepties van deservingness in de verzorgingsstaat. Dit onderzoek laat zien dat de steun aan ouderen en zieken/gehandicapten door burgers van de gehele EU onverminderd sterk is, maar dat de solidariteit met werklozen en immigranten beduidend lager scoort. Uit onderzoek van Boeri (2006) blijkt dat de lage solidariteitsscores ten aanzien van immigranten - ongeveer de helft van de bevolking vindt dat minderheden de verzorgingsstaat uitbuiten - in het afgelopen decennium zijn geconvergeerd (figuur 4.22). Het is niet zo dat de ene Europese verzorgingsstaat beter is in de integratie van immigranten dan de ander. 
Tabel 4.7 Spanningen tussen sociale groepen, percentage dat spanning ervaart

\begin{tabular}{|c|c|c|c|c|c|}
\hline & $\begin{array}{r}\text { Arm } \\
\text { en } \\
\text { Rijk }\end{array}$ & $\begin{array}{r}\text { Manage- } \\
\text { ment en } \\
\text { werknemers }\end{array}$ & $\begin{array}{r}\text { Man } \\
\text { en } \\
\text { vrouw }\end{array}$ & $\begin{array}{r}\text { Oud } \\
\text { en } \\
\text { Jong }\end{array}$ & $\begin{array}{r}\text { Allochtoon } \\
\text { en Autoch- } \\
\text { toon }\end{array}$ \\
\hline \multicolumn{6}{|l|}{ Scandinavisch } \\
\hline Denemarken & 4 & 6 & 7 & 3 & 39 \\
\hline Finland & 21 & 17 & 8 & 9 & 37 \\
\hline Zweden & 24 & 16 & 10 & 10 & 45 \\
\hline \multicolumn{6}{|l|}{ Continentaal } \\
\hline Duitsland & 36 & 34 & 7 & 13 & 38 \\
\hline Frankrijk & 46 & 49 & 12 & 23 & 62 \\
\hline Nederland & 25 & 23 & 9 & 18 & 61 \\
\hline België & 36 & 34 & 16 & 21 & 60 \\
\hline Oostenrijk & 30 & 29 & 13 & 22 & 41 \\
\hline \multicolumn{6}{|l|}{ Angelsaksisch } \\
\hline lerland & 28 & 27 & 12 & 15 & 46 \\
\hline Ver. Koninkrijk & 23 & 26 & 17 & 17 & 48 \\
\hline \multicolumn{6}{|l|}{ Mediterraan } \\
\hline Italië & 21 & 30 & 7 & 8 & 40 \\
\hline Griekenland & 58 & 61 & 27 & 27 & 57 \\
\hline Spanje & 32 & 37 & 20 & 14 & 42 \\
\hline Portugal & 24 & 24 & 10 & 10 & 36 \\
\hline
\end{tabular}

Bron: The European Foundation for the Improvement of Living and Working Conditions (2003)

Ook feitelijk schieten de Europese verzorgingsstaten tekort, zoals de onderstaande figuur (4.23) laat zien. In Nederland, waar jeugdwerkloosheid relatief laag is, hebben jongeren die hier niet geboren zijn twee keer zoveel kans om werkloos te worden. In een land als de Verenigde Staten is werkloosheid onder jongeren die elders geboren zijn, juist laag.

Kortom: de lage solidariteit met immigranten, in combinatie met hun gemiddeld lagere sociaal-economische positie, en dat over verschillende generaties heen, vormen subjectieve en objectieve indicaties van een polarisatie tussen autochtoon en allochtoon. 
Figuur 4.22 Percepties misbruik verzorgingsstaat door immigranten, percentage dat misbruik door immigranten percipieert

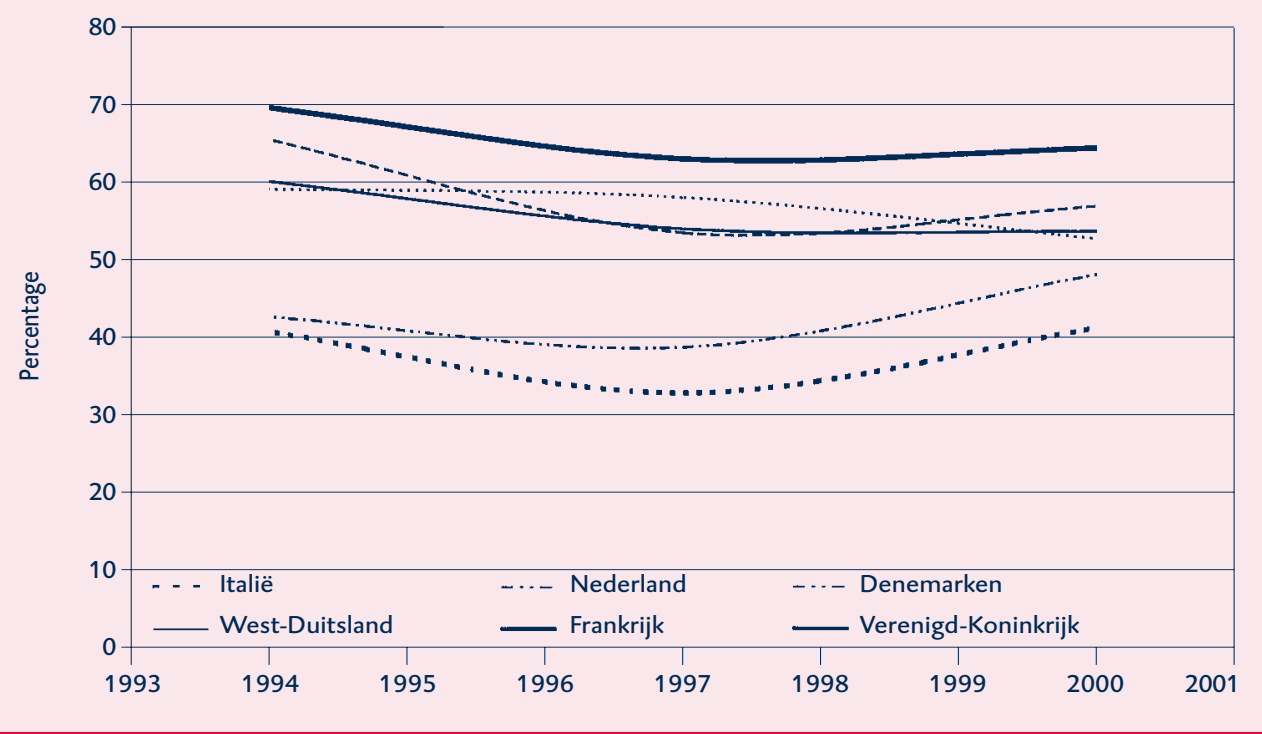

Bron: Boeri (2006)

Figuur 4.23 Werkloosheid van jongeren (15-24) naar geboorteplaats

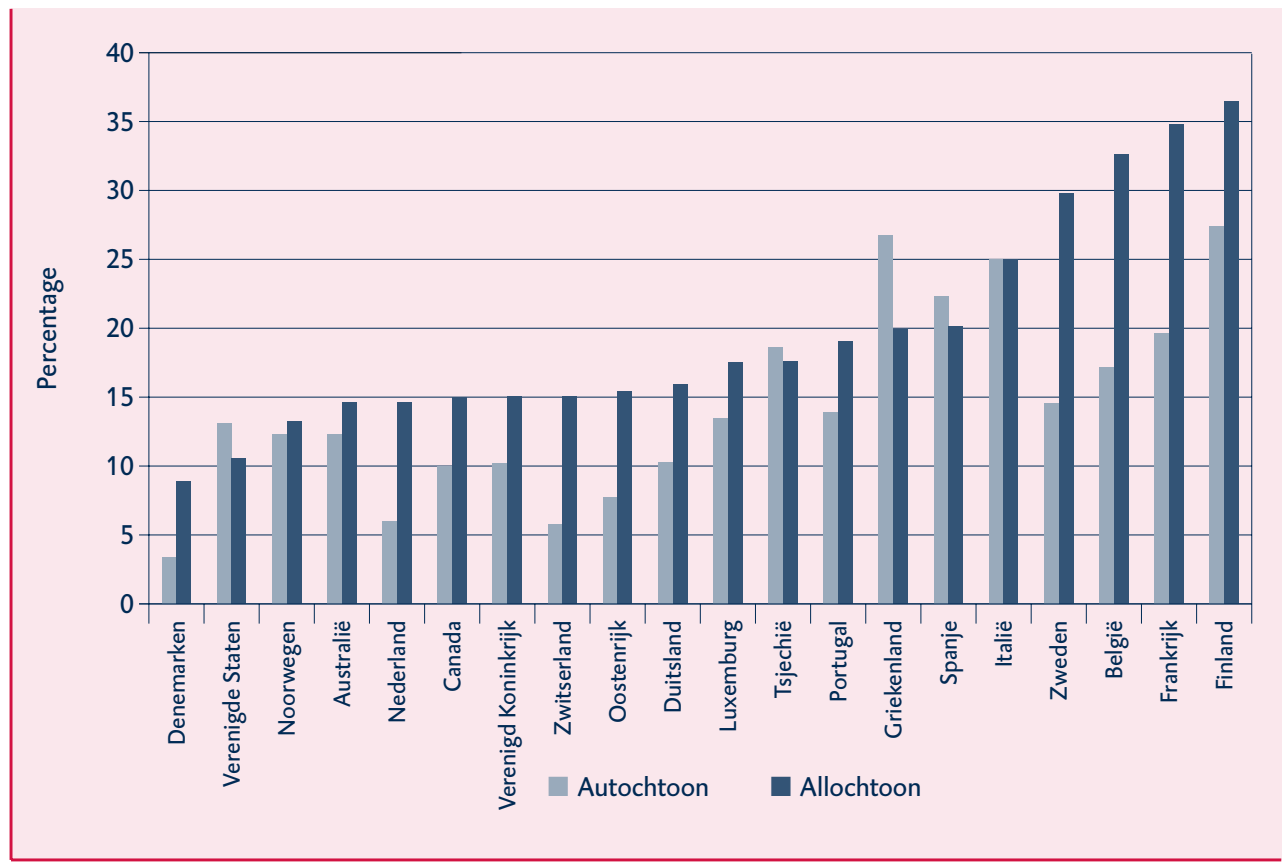

Bronnen: European Community Labour Force Survey (Eurostat) behalve Denemarken (Population Register), 2004; Australië: Survey of Education and Work; Canada: Survey of Labour and Income Dynamics; Verenigde Staten: Current population survey March supplement. 


\section{Hoog- en laagopgeleiden}

Algemeen geldt: hoe hoger het opleidingsniveau, hoe meer kans op werk. Figuur 4.24 laat zien dat in de Scandinavische verzorgingsstaten de kansen op werk voor de verschillende opleidingsniveaus nog het dichtst bij elkaar liggen. Ook in subjectieve zin, gezien bijvoorbeeld de lage deservingness-score die werklozen krijgen in het onderzoek van Van Oorschot (2005), is een verbindingstekort tussen hoog- en laagopgeleiden in de toekomst denkbaar.

\section{Figuur 4.24 Werkgelegenheidspercentage naar opleidingsniveau in 2003}

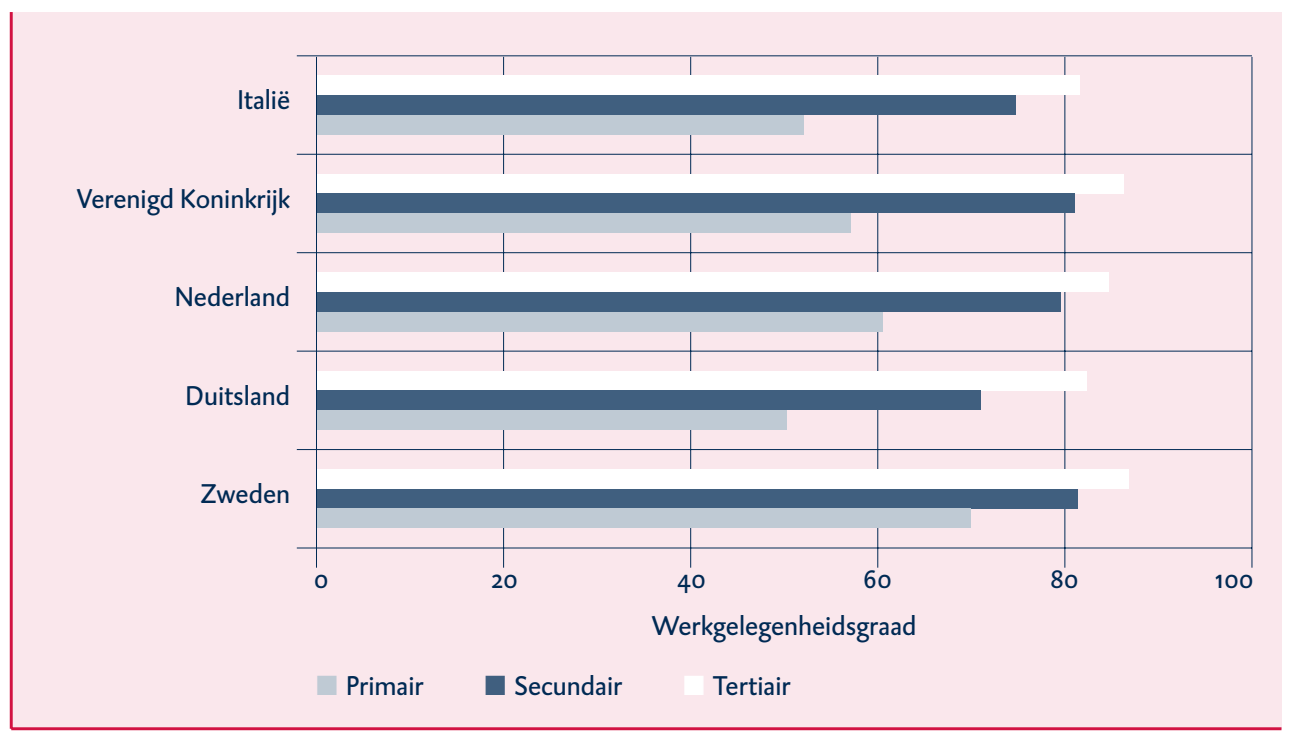

Bron: Eurostat

Ten aanzien van de verbindingsfunctie van de verzorgingsstaat leert de vergelijking dat Nederland een verhoudingsgewijs forse opdracht heeft in het tegengaan van een mogelijk generatieconflict. Dat geldt ook voor het tegengaan van mogelijk grotere ongelijkheden tussen hoog- en laagopgeleiden - vooral in de vorm van het vinden van een betere balans tussen insiders en outsiders op de arbeidsmarkt - en bovenal in het aanpakken van het verbindingstekort tussen autochtonen en allochtonen.

\subsection{CONCLUSIE}

In de meeste landen van de EU zijn in de afgelopen periode hervormingen in de sociale zekerheid, op de arbeidsmarkt, en in de maatschappelijke dienstverlening (met name in de gezondheidszorg, de gezinsondersteuning en onderwijs) doorgevoerd. Daarbij is er sprake van een convergente ontwikkeling. Die is echter nog niet afgerond. De belangrijkste elementen daarvan zijn: hoge(re) participatiecijfers als centrale beleidsdoelstelling, meer arbeidsmarktflexibiliteit, beter onderwijs, en een socialezekerheidstelsel dat mannen en vrouwen in staat te stelt om arbeid, zorg en gezinsleven te combineren. Er is sprake van een overgang van een 
reactieve en passieve verzorgingsstaat naar een meer proactieve verzorgingsstaat. Over de noodzaak van aanpassing van de Europese verzorgingsstaten aan veranderende economische en maatschappelijke omstandigheden bestaat weinig discussie meer. Wel zijn er grote verschillen in tempo, richting en karakter van de beleidsaanpassingen tussen de lidstaten.

De Nederlandse ervaring - en ook die van de Scandinavische landen - laat zien dat er geen eenduidige afruil is tussen sociale en economische prestaties. De Nederlandse verzorgingsstaat scoort vaak behoorlijk in economisch opzicht. De openbare financiën, het financieringstekort, de staatsschuld en de sociale zekerheidsuitgavenquote zijn in Nederland in de afgelopen kwart eeuw geleidelijk op orde gebracht. Afgezien van de periode 2002-2005 is ook de economische groei in ons land bovengemiddeld (Pestieau 2006). Op het terrein van de arbeidsmarkt valt de hoge participatie in personen op, hoewel vaak in deeltijd wordt gewerkt. De werkloosheid is, samen met die van Denemarken, de laagste in de EU. Nederland kent een gelijke inkomensverdeling. De Nederlandse Gini-coëfficiënt is, na die van de Scandinavische landen, de laagste in de EU. Hetzelfde geldt voor armoede onder ouderen.

De Nederlandse ervaring van de afgelopen twee decennia laat eveneens zien dat in een periode van de verdergaande Europese integratie, industriële herstructurering, vergrijzing en veranderde arbeids-, gezins- en samenlevingspatronen - de modernisering van de continentale verzorgingsstaat moeilijk, maar niet onmogelijk is. Toekomstbestendig sociaal beleid is echter niet alleen een kwestie van het herijken van de verzekeringsfunctie van de verzorgingsstaat en het flexibiliseren van de arbeidsmarkt, maar houdt ook meer aandacht in voor preventie, activering, en sociale dienstverlening in het kader van de verzorgings-, verheffings- en verbindingsfuncties.

Als we Nederland vergelijken op functies valt op dat in Nederland net als in Scandinavische verzorgingsstaten veel is geïnvesteerd in formele zorg. Informele zorg is in de praktijk ook belangrijk, maar wordt in Nederland relatief weinig vanuit overheidswege ondersteund. De uitdaging is om met het oog op de vergrijzing en ontgroening, en de toenemende arbeidsdeelname, de verzorgingsfunctie toekomstbestendig te maken. Wat betreft de verzekeringsfunctie heeft in Nederland een grote omslag plaatsgevonden naar actief arbeidsmarktbeleid. Daar besteden we ook veel geld aan. Ten opzichte van de werkzame beroepsbevolking zijn relatief weinig mensen inactief. Alleen de Scandinavische landen scoren voor de afgelopen decennia als geheel, beter in dit opzicht. Ten aanzien van de verheffingsfunctie blijkt dat Nederland minder geld uitgeeft aan onderwijs dan andere landen. Weliswaar zijn technisch gezien de leerprestaties bovengemiddeld, maar er zijn ook veel vroegtijdige schoolverlaters, waar andere landen beter presteren dan Nederland. Bovendien valt op dat kinderopvang in Nederland nog steeds het stiefkindje is vergeleken met een aantal andere Europese landen. De vergelijking van de verbindingsfunctie tot slot wijst met name naar interetnische spanningen. Nederlanders, samen met Belgen en Fransen, ervaren de meeste spanningen op dit 
terrein. Weinig Europese verzorgingsstaten lukt het om allochtonen te integreren, zeker op de arbeidsmarkt, en ook Nederland presteert op dit terrein niet goed.

Daarnaast zijn er forse verbindingsproblemen tussen generaties en tussen hoog en laag opgeleiden. 


\section{NOTEN}

I De term 'voortijdige schoolverlater' geeft overigens gemakkelijk aanleiding tot verwarring. Hij suggereert ten onrechte dat het hierbij alleen gaat om jongeren die ongediplomeerd op de arbeidsmarkt komen. Dat hoeft echter niet het geval te zijn. Met de term 'voortijdige schoolverlater' wordt bedoeld dat iemand geen basisberoepsopleiding heeft voltooid die als startkwalificatie op de arbeidsmarkt wordt beschouwd. In Nederland geldt het mbo2-diploma als minimaal niveau. 


\section{VERZORGEN: VEILIG STELLEN VAN VERZORGINGSCAPACITEIT}

\subsection{INLEIDING}

Dat de verzorgingsstaat zorgt voor zieken, zwakken, gehandicapten en ouderen is bijna een vanzelfsprekendheid geworden. Een fatsoenlijke, door de overheid georganiseerde of ondersteunde hulp aan mensen die niet (meer) voor zichzelf kunnen zorgen, is onderdeel geworden van ons beschavingsideaal. Het woord zorg is niet voor niets prominent aanwezig in de term verzorgingsstaat.

\section{Zorg voor kinderen}

Ondanks of dankzij die vanzelfsprekendheid valt op dat er weinig systematisch onderzoek is gedaan naar de vraag of er nu ook meer gezorgd wordt dan een eeuw geleden. Duidelijk is wel dat er een uitgebreid stelsel van professionele voorzieningen is ontstaan, maar de vraag is of dat per saldo tot een toename van de hoeveelheid zorg heeft geleid. Maar al te gemakkelijk kan het beeld ontstaan van een samenleving die zijn zorgtaken heeft geprofessionaliseerd, maar die ze daarmee ook heeft uitgebannen uit de interactie tussen familie en vrienden.

Het beperkt beschikbare materiaal laat echter een andere ontwikkeling zien: $\mathrm{Ne}-$ derland is een steeds zorgzamere samenleving geworden, en ook een samenleving die steeds meer waarde hecht aan zorg. Het meest manifest blijkt dat ten aanzien van de zorg voor kinderen. De functie van gezinnen is steeds meer komen te liggen bij de socialisatie van kinderen: kinderen zijn tegenwoordig gewenst en gepland, en de band van ouders met kinderen is - gemiddeld genomen - intensiever en vaak ook beter dan in vorige perioden. Goed kunnen koken, of het kunnen zorgen voor een goed inkomen, zijn daarmee relatief minder belangrijke eigenschappen van ouders geworden; het kunnen bieden van aandacht en affectie aan elkaar en aan de kinderen is daarentegen belangrijker geworden. Veel wijst erop dat de aandacht voor kinderen, met hun verder toenemende 'schaarste', verder groeit, en dat de regelmatig terugkerende beschouwingen over het gebrek aan aandacht van ouders voor kinderen eerder een teken is van het grotere belang dat we daar aan hechten dan van werkelijk afnemende aandacht - al zijn er ook nu groepen jongeren aan te wijzen voor wie die aandacht beslist te wensen overlaat.

Van belang is bovendien dat de zorg voor kinderen niet alleen is toegenomen, maar dat die ook meer als een gedeelde verantwoordelijkheid gezien wordt. Het merendeel van de kinderen onder de leerplichtige leeftijd gaat een aantal dagdelen naar een kinderdagverblijf of een peuterspeelzaal, en dat percentage zal nog toenemen. Bovendien wordt de school in toenemende mate aangesproken op haar brede socialiserende rol; het is steeds duidelijker niet louter een instantie die is gericht op kennisoverdracht. Veel scholen worstelen met deze rol, en de vraag in welke mate scholen deze rol ook effectief kunnen vervullen, is actueel. Dat neemt niet weg dat zorgverlening voor kinderen niet alleen belangrijker gevonden wordt, maar ook meer gezien wordt als een activiteit die verdeeld wordt over verschillende actoren. 


\section{Zorg voor ouderen}

Ook de zorg voor ouderen weerspiegelt deze trend, maar in een minder geprononceerde vorm. Dat heeft te maken met het feit dat de categorie ouderen zelf de afgelopen honderd jaar sterk is veranderd. Het is zelfs weinig productief meer om nu nog te spreken over één categorie ouderen. De groep mensen tussen de 55 en 75 jaar is, gemiddeld gesproken, energiek en voorzien van voldoende tijd en geld om hun leven op een prettige en betekenisvolle wijze in te vullen. De groep boven de 75 jaar vertoont daarentegen grosso modo een ander patroon: ze geven minder uit, blijven vaker thuis, en hebben meer lichamelijke gebreken die, zeker als ze boven de 80 jaar zijn gekomen, ook in toenemende mate om zorg vragen. Zorg voor de eerste categorie ouderen is maar beperkt nodig - als regel zijn ze per saldo nog zorggever; de tweede categorie heeft een veel intensievere behoefte aan zorg. En ook hier is het zoeken naar een manier om deze zorg een gedeelde verantwoordelijkheid te laten zijn.

In de naoorlogse periode betekende dit aanvankelijk dat er vooral gezorgd moest worden dat kinderen niet volledig voor hun ouders hoefden te zorgen. Tijdens de Tweede Wereldoorlog waren er veel huizen vernietigd, en na de oorlog was er sprake van een babyboom. De grootste huizen werden in die tijd bevolkt door oudere echtparen, terwijl pasgetrouwde stellen bij hun ouders moesten inwonen - of ouders bij hun kinderen. Dit leidde tot de snelle bouw van speciale woonvoorzieningen voor ouderen: de bejaardenhuizen. Begonnen als vervangende woonruimte, kregen ze vanaf de jaren zestig steeds meer het karakter van verzorgings- en dienstverleningsinstellingen. Gaandeweg deed de centrale keuken zijn intrede en ontstonden er nieuwe vormen van dienstverlening, zoals een kapper. In de jaren vijftig ontstonden eveneens de eerste verpleeghuizen; het eerste werd gehuisvest in een oud sanatorium, een voorziening waar steeds minder behoefte aan was. Ze werden aanvankelijk gemodelleerd naar het voorbeeld van een ziekenhuis en waren gericht op mensen die de hele dag zouden moeten liggen. Gaandeweg werd in de jaren zeventig meer afstand genomen van het ziekenhuismodel en kwam het woon- en leefklimaat centraler te staan. Zo kwamen beide sporen bij elkaar: de verzorgingshuizen die steeds meer zorgbehoeftige ouderen huisvesten (was eerder het aantal beperkingen een uitsluitingsgrond voor opname, nu is het een entree-eis geworden), terwijl de verpleeghuizen meer het accent op het woon- en leefkarakter leggen. Deze ontwikkelingen hebben geleid tot een relatief omvangrijk palet van intramurale voorzieningen voor ouderen dat duidelijk de sporen draagt van het streven om hen onafhankelijk van hun kinderen te maken, een streven waarin ook de invoering van de AOW in 1957 al paste.

Wie het Nederlandse zorgsysteeem dat zo ontstaan is, vergelijkt met andere Europese landen, valt een aantal zaken op. Allereerst heeft Nederland een vrij omvangrijk institutioneel zorgsysteem, maar niet omvangrijker dan bijvoorbeeld de Scandinavische landen. In tegenstelling tot het standaardbeeld van de zorg in Nederland - een sterk intramurale zorg - kent Nederland ook een van de meest uitgebreide vormen van extramurale zorg: thuiszorg. We hebben én veel intramurale én veel extramurale zorg. Bovendien is de Nederlandse zorg sterker 
publiek gefinancierd dan in de meeste andere landen. Wat verder opvalt is het contrast met de zorg voor kinderen. In vergelijking met andere Europese landen legt Nederland in de naoorlogse periode het accent vooral op de zorg voor ouderen, en weinig op de zorg voor kinderen. Nederland wordt vooral een ouderenzorgland, met een uitgebreid stelsel van opvangvoorzieningen voor ouderen, maar nauwelijks kinderopvang. Frankrijk en België daarentegen leggen vooral een accent op kinderen; denk aan de Franse colonies de vacances, maar ook aan de gebrekkige ouderenzorg in Frankrijk en België. Dit accentverschil komt ook tot uitdrukking in de onderhoudsplicht van ouders en kinderen. In Nederland zijn ouders wel onderhoudsplichting voor hun kinderen, maar kinderen niet voor hun ouders, in tegenstelling tot bijvoorbeeld Duitsland waar kinderen moeten meebetalen aan de zorg voor ouderen; daar ligt inmiddels zelfs de vraag voor of volwassenen zonder kinderen meer belasting moeten betalen.

Nederland is zo gaandeweg geëvolueerd tot een verzorgingssamenleving met steeds hogere ambities, in het bijzonder als het om ouderen gaat. Mensen zijn over de hele linie zorgzamer geworden en minder hard voor elkaar (Van den Brink 1999). Het woord 'zorg' heeft ook een steeds bredere betekenis gekregen. Zorg is, kortom, een steeds hoger gewaardeerd goed geworden in de hedendaagse samenleving.

\section{Zorg en de staat}

Nederland is ook een verzorgingsstaat geworden. De rol van de staat bij zorg is overigens niet vanzelfsprekend. Zorg is een activiteit die in belangrijke mate in de privésfeer vorm kreeg en krijgt. In meer georganiseerde vorm was zorg aanvankelijk vooral verbonden met organisaties met een charitatieve en confessionele inslag. De staat ging zich er vooral mee bemoeien toen zorg een probleem werd: besmettelijke ziekten waren een gevaar voor de gezondheid van allen, te veel onverzorgde zieken een aantasting van het straatbeeld, enzovoort. Het waren in het midden van de negentiende eeuw de gemeenten die de rol kregen om activiteiten te ondernemen; de landelijke overheid wilde wel een rol spelen, maar kon daar geen goede vorm voor vinden - ze had immers nauwelijks sturingsmogelijkheden ten aanzien van het particuliere initiatief. De rol van de landelijke overheid is dan ook vooral faciliterend geweest, en wel in drie fasen. De tweede helft van de negentiende eeuw was het vooral de opdracht om de kwaliteit gaandeweg mede tot een overheidsaangelegenheid te maken: de inspectie deed haar intrede, net als titelbescherming en opleidingseisen. De eerste helft van de twintigste eeuw stond vooral in het teken van het tot stand brengen van een stelsel van adequate financiering met als voorlopig sluitstuk de Ziekenfondswet van 1942. In de tweede helft van deze eeuw ging de overheid zich ook bemoeien met de aard en omvang van de voorzieningen. Het doel werd nu om een dekkend en adequaat stelsel van beroepsbeoefenaren en instellingen tot stand te brengen. Gedurende deze hele periode bleef de uitvoering vooral een zaak van particuliere organisaties; de rol van de overheid was randvoorwaardelijk, al werd die rol, via kwaliteit en financiering tot de planning van voorzieningen, wel steeds prominenter. 


\section{En straks?}

Zoals gezegd wordt zorg steeds belangrijker gevonden. De overheid heeft ook een actievere verantwoordelijkheid op zich genomen. Hoe kan en zal zich dat in de toekomst ontwikkelen? Duidelijk is dat alleen al om demografische redenen er een omvangrijke opgave ligt: hoe te zorgen dat de zorg die dan nodig is, ook gegeven kan worden? Daarnaast ligt er een kwalitatieve vraag. Het gaat immers straks ook om andere mensen dan tot nu toe: burgers zijn geëvolueerd, en hun verlangens zijn tot op zekere hoogte anders dan die van vijftig of honderd jaar geleden. En ten slotte is het de vraag bij wie welke opdracht ligt: heeft de overheid nog steeds de historisch gegroeide rol om kwaliteit, financiering en planning te organiseren?

Dit hoofdstuk probeert een antwoord te geven op de vraag hoe de functie 'verzorgen' in de toekomstige verzorgingsstaat zou kunnen worden ingevuld. Het hoofdaccent valt daarbij op de care-zijde van de zorg (verzorging, als regel langdurig van aard; ter onderscheiding van de cure-sector); de medisch-technische ontwikkelingen in engere zin blijven rusten, niet in de laatste plaats omdat ze lastig te voorspellen zijn. Verzorgen gaat in beginsel ook over de zorg voor kinderen; deze vorm van zorg wordt echter niet in dit hoofdstuk behandeld, maar in het hoofdstuk over de verheffingsfunctie van de verzorgingsstaat (hoofdstuk 7 ). Aan die indeling ligt een specifieke, inhoudelijke reden ten grondslag. In de kinderopvang in Nederland staat, zoals de term al suggereert, te veel de 'opvang' centraal en wordt er te weinig aandacht besteed aan de ontwikkeling van kinderen. Kinderzorg in Nederland heeft juist behoefte aan een verheffingsimpuls - vandaar dat kinderopvang in het hoofdstuk over 'Verheffen' wordt besproken. Dit hoofdstuk beperkt zich met name tot een analyse van de groter wordende groep hulpbehoevende ouderen. Die groep is getalsmatig en budgettair verreweg het belangrijkst.

\subsection{DE DUBBELE ZORGKLOOF}

Hoe groot wordt de zorgopgave de komende decennia? Er lijkt alle reden om aan te nemen dat er zich in de toekomst zorgtekorten zullen gaan voordoen; er is zelfs sprake van een dubbele zorgkloof. Het woord zorgkloof slaat op de afstand tussen wat er aan zorg beschikbaar is, en wat er nodig is of gewenst wordt. Het woord 'dubbel' slaat op het gegeven dat die zich in twee vormen zal voordoen. De eerste vorm, de kwantitatieve zorgkloof, betreft de afstand die er dreigt te ontstaan tussen wat er in financiële en personele zin wenselijk en mogelijk is. De tweede vorm is de kwalitatieve zorgkloof: de afstand tussen wat voor zorg gewenst is en wat er beschikbaar is. In beide gevallen is het de vraag hoe die kloof gedicht kan worden. Hieronder wordt eerst de omvang van beide kloven verkend en in een vergelijkend perspectief geplaatst.

\section{De kwantitatieve zorgkloof}

Hoeveel meer zorg is er in de toekomst nodig? We leven steeds langer. In 2020 zullen mannen gemiddeld ongeveer 78 , o jaar oud worden en vrouwen 81,1 jaar. Dat is een toename sinds 1970 van 7 jaar voor mannen en 'slechts' 4,5 jaar voor vrouwen; dat komt omdat vrouwen in hun (rook)gedrag meer op mannen zijn 
gaan lijken. In zijn meest recente studie naar de vergrijzing verwacht het $\mathrm{CPB}$ (СРВ 2006) een voortgaande stijging van de levensverwachting, alhoewel het bureau niet de Europese Eurostat-verwachting wil overnemen van 4,8 (voor mannen) en 4,3 jaar (voor vrouwen) als stijging van de levensverwachting tussen nu en 2050; het СРB - voorzichtiger - houdt het voor Nederland op een stijging van de levensverwachting van 2,9, c.q. 1,4 jaren (СРВ 2006, p. 34).

\section{Tabel $5.1 \quad$ Resterende levensverwachting naar opleidingsniveau}

\begin{tabular}{|c|c|c|c|c|c|}
\hline & $\begin{array}{l}: \\
\frac{n}{3} \\
\frac{0}{0} \\
\frac{c}{0} \\
0 \\
\frac{1}{0} \\
00 \\
0\end{array}$ & 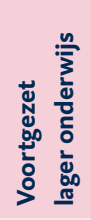 & 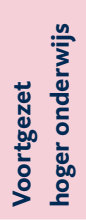 & 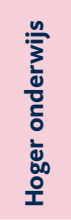 & 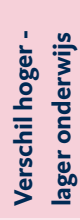 \\
\hline \multicolumn{6}{|l|}{ Levensverwachting mannen } \\
\hline resterend & 11,1 & 13,4 & 13,3 & 14,8 & 3,7 \\
\hline zonder beperkingen * & 8,0 & 10,5 & 10,6 & 12,6 & 4,6 \\
\hline in goede ervaren gezondheid ** & 6,3 & 7,9 & 8,4 & 11,3 & 5,1 \\
\hline in goede geestelijke gezondheid *** & 10,0 & 12,3 & 12,3 & 14,0 & 4,0 \\
\hline \multicolumn{6}{|l|}{ Levensverwachting vrouwen } \\
\hline resterend & 16,4 & 18,5 & 18,6 & 18,5 & 2,1 \\
\hline zonder beperkingen & 9,3 & 11,8 & 12,1 & 12,7 & 3,4 \\
\hline in goede ervaren gezondheid & 7,4 & 10,7 & 11,2 & 12,4 & 5,0 \\
\hline in goede geestelijke gezondheid & 14,1 & 16,1 & 16,3 & 16,4 & 2,3 \\
\hline
\end{tabular}

* bepaald op basis van 10 items (virusproblemen, gehoorproblemen, mobiltieit en ADL) / ** 'zeer goed' en 'goed' tezamen / *** bepaald op basis van de Affect Balance Scale

Noot: Resterende levensverwachting en gezonde levensverwachting (in jaren) naar opleidingsniveau voor mannen en vrouwen op 65-jarige leeftijd, 1995-1999, inclusief bewoners van verpleeg- en verzorghuizen

Bron: RIVM (2004)

Mensen boven de tachtig hebben nagenoeg allemaal (zware) zorgproblemen. Ze kunnen vaak het huishouden niet meer zelf doen, zich moeilijk verplaatsten en zich lastig zelf wassen.

Een hoogopgeleide leeft vandaag de dag ongeveer twee jaar lang met beperkingen (tabel 5.1). De vraag naar zorg zal dus stijgen, eenvoudigweg omdat het aantal ouderen sterk toeneemt. Het SCP/Timmermans (2005), die een raming van het potentiële zorggebruik over de periode 2000-2020 maakte, komt tot de conclusie dat de potentiële vraag naar verpleging en verzorging - informeel en formeel - met bijna 40 procent zal toenemen. Het RIVM, samen met het SCP, gaat uit van een stijging van 49 procent zoals tabel 5.2 laat zien. In de twee decennia daarna zal - wat verzwakt - die trend zich nog wel voortzetten. Pas na 2040 kan de vraag naar zorg enigszins gaan dalen; de babyboomgeneratie is dan grotendeels overleden.

De zorgkloof wordt verder vergroot door een andere demografische factor: de ontgroening. Tot 2020 zal de leeftijdscategorie die het meeste zorgt - tussen de 
45-65 jaar - nog met een kwart toenemen (SCP/De Boer 2005), maar daarna verandert dat. We zitten nu namelijk midden in de tweede demografische transitie (Lestheage en Van der Kaa 1986). De eerste demografische transitie had betrekking op de snelle daling van de sterftecijfers, gevolgd door een daling van het geboortecijfer, in de tweede helft van de negentiende eeuw. $\mathrm{Nu}$, een eeuw later, hebben we te maken met een grootschalige verandering in de vruchtbaarheid en veranderingen in de relatievorming en -ontbinding. $\mathrm{Na} 2 \mathrm{O} 2 \mathrm{O}$ zal het geboortecijfer - dat nu nog 1,75 is, en dat is nog redelijk hoog in vergelijking met het Europese gemiddelde van 1,4-mogelijk nog verder gedaald zijn. Verwacht wordt dat van de generatie vrouwen geboren na 1970 een vijfde geen kind zal krijgen (De Meesters et al. 2005; Hakim 2000). In 2005, rapporteerde het CBS, is voor het eerst sinds 1900 in Nederland de vervangingsratio kleiner dan één: de som van een (dalend) geboortecijfer en (stijgend) emigratiesaldo.

Tabel 5.2

Potentiële zorgvraag naar plaats (indexcijfers: $2000=100$ )

\begin{tabular}{|l|c|c|c|c|} 
Jaar & $\begin{array}{r}\text { Bevolkings- } \\
\text { omvang }\end{array}$ & $\begin{array}{r}\text { Potentiële } \\
\text { vraag }\end{array}$ & $\begin{array}{r}\text { Vraag naar } \\
\text { zorg thuis }\end{array}$ & $\begin{array}{r}\text { Vraag naar } \\
\text { opname }\end{array}$ \\
2000 & 100 & 100 & 100 & 100 \\
2005 & 106 & 108 & 108 & 110 \\
2010 & 116 & 118 & 117 & 119 \\
2015 & 134 & 132 & 134 & 129 \\
2020 & 149 & 149 & 153 & 142 \\
\hline
\end{tabular}

Noot: Potentiële vraag door personen van 65 jaar en ouder, naar plaats van de gevraagde hulp, 2000-2020 (index: $2000=100$ )

Bron: RIVM (2004)

Het dalende geboortecijfer is niet op alle fronten een probleem, maar wel op sommige (Derks e.a. 2006). Gezien het aantal vierkante kilometers dat ons land kent, kan een kleinere bevolking voor de leefomgeving en voor het fileprobleem een zegen zijn. En als de 'hobbel' van de generatie babyboomers in 2040/2050 is genomen, zal de bevolkingsafspiegeling naar leeftijd weer gelijkmatiger worden. Maar voor de zorg maakt het dalende geboortecijfer wél uit, en veel. Ten eerste wat betreft de betaalbaarheid van zorg op lange termijn. Voor Nederland zal in de periode tot 2040 het aandeel van 65-plussers in de bevolking toenemen van 14 procent nu tot 24 procent, terwijl de 'productieve' bevolking van 20-64-jarigen daalt van 61 naar 54 procent. Daarmee zullen we vanaf 2030 tot de 'oudste' landen van de OECD behoren (Van der Geest 2005, p. 13), terwijl we nu nog tot de jongere landen horen. De kosten van AOW en gezondheidszorg samen zullen - bij ongewijzigd beleid - tot 2040 stijgen van zo'n 12 naar 19 procent van het nationale inkomen (СРB 2006).

Ten tweede heeft het dalende geboortecijfer gevolgen voor de beschikbaarheid van zorgverleners. Het betekent allereerst dat de elderly dependency ratio (het aantal 
65-plussers gedeeld door de arbeidsgeschikte bevolking) in 2040 - wanneer hij op zijn top is -43 procent bedraagt; dat is precies het dubbele van wat die ratio nu is. Dat wil zeggen dat de leeftijdscategorie die potentieel zorgbehoeftig is, demografisch gezien twee maal zo zwaar zal drukken dan nu. Deze onafwendbare ontwikkeling kan ook omgekeerd worden uitgedrukt, bijvoorbeeld door het aantal vrouwen in de leeftijdscategorie van 50 tot 65 jaar per tachtigjarige te nemen (de 'dochterdichtheid'): tegen 2020 komt de teruggelopen vruchtbaarheid dan drastisch tot uitdrukking en is deze ratio ongeveer gehalveerd.

Mensen zonder kinderen - en die categorie groeit naar een vijfde van de bevolking - zullen bovendien vaker een beroep doen op formele zorg. En als je enig kind bent, kun je de zorg voor je ouders niet delen met broers of zussen, waardoor overbelasting op de loer ligt. Het dalende geboortecijfer betekent bovendien dat er minder mensen beschikbaar zijn op de arbeidsmarkt. Te verwachten valt dat op langere termijn de werkgelegenheid in de zorg met 30.000 arbeidsplaatsen per jaar moet toenemen. In het middenscenario van het СРВ (СРВ 2004) groeit het totale arbeidsaanbod in Nederland tot 2020 ook met 30.000 per jaar. Dit betekent dat de gehele groei van het arbeidsaanbod naar de zorg toe zou moeten gaan om te kunnen voldoen aan de behoefte in die sector. Daarna wordt de situatie nog lastiger: in 2025 zou volgens berekeningen van het ministerie van vws 22 procent van de beroepsbevolking moeten werken in de sector zorg en welzijn. Zelfs wanneer we een verhoging van de arbeidsproductiviteit in de zorg inboeken van een omvang die in de afgelopen jaren niet gehaald is, zoals het СРB in zijn scenariostudie doet, zal de zorg in 2040 nog zo'n 16,5 tot 18,5 procent van de totale werkgelegenheid voor haar rekening nemen.

Overigens heeft de ontwikkeling van een dalend geboortecijfer ook nog een negatief effect als het - zoals in Nederland het geval is - gepaard gaat met het op steeds latere leeftijd krijgen van kinderen. De gezondheidseffecten van uitstel van de eerste zwangerschap in termen van gestoorde vruchtbaarheid, ongewenste kinderloosheid, risicovolle zwangerschappen en een verhoogd risico op borstkanker, zijn substantieel en vaak onderschat (Hilders 2006).

\section{Financiële en personele opgaven in perspectief}

Er ligt dus een zeer forse opgave, zowel in financiële als in personele zin. Vooropgesteld zij dat die opgave vaak wordt aangeduid met de term 'vergrijzing', maar die term is maar beperkt adequaat. Het probleem is niet alleen dat mensen ouder worden; het probleem is vooral een onevenwichtigheid in de bevolkingsopbouw. Een geleidelijke verlenging van de levensverwachting van een demografisch evenwichtig opgebouwde bevolking hoeft niet problematisch te zijn. Maar onze demografie heeft zich niet stabiel ontwikkeld: de naoorlogse babyboom werd in de tweede helft van de jaren zestig gevolgd door een abrupte daling van de fertiliteit als gevolg van de 'pilknik'. Daardoor kent onze bevolkingsopbouw een 'hobbel' die de komende vier decennia een vergrijzings- en zorgprobleem veroorzaken. In financiële zin lijkt de opgave er vooral uit te bestaan om voldoende ruimte beschikbaar te maken om met deze hobbel om te gaan; in personele zin 
om voldoende capaciteit beschikbaar te krijgen. Als we de omvang van het financiële probleem in perspectief plaatsen, blijkt in ieder geval dat Nederland in vergelijking met de landen om ons heen een relatief klein probleem heeft. De nadruk ligt hierbij op het woord 'relatief'; er kan ook gesteld worden dat het probleem in andere Europese landen nog aanzienlijk groter is. Die relatief gunstige situatie heeft met een aantal zaken te maken.

Allereerst treedt de vergrijzingsgolf in Nederland relatief laat op. Wij hebben nu een vergrijzingsniveau dat in een land als Zweden al twintig jaar geleden bereikt was. In Nederland is nu 13 procent van de mensen boven de 65 jaar, in Frankrijk is dat 16,2 procent, in Duitsland 16,9 procent en in Zweden inmiddels 17,2 procent. Gevoegd bij een dalend kindertal heeft dat ertoe geleid dat in landen als Duitsland de omvang van de bevolking al afneemt, ondanks een positief migratiesaldo. In de meeste landen in Oost-Europa gaat deze ontwikkeling nog sneller: daar worden minder mensen geboren dan er overlijden, en is er bovendien sprake van netto-emigratie. Dat Nederland er relatief goed uitspringt, heeft alles te maken met het gegeven dat Nederland verhoudingsgewijs lang steunde op vrouwen die voltijds huisvrouw waren. Werden in Nederland in de jaren zestig tijdens de economische hoogconjunctuur mannelijke arbeidskrachten uit het mediterrane gebied gehaald, in de Scandinavische landen werd toen al uitgebreid ingezet op het verhogen van de arbeidsparticipatie van vrouwen. In demografische zin heeft dat ertoe geleid dat Nederlandse vrouwen lang doorgegaan zijn met het krijgen van relatief veel kinderen; in de jaren zestig bijvoorbeeld gemiddeld drie in plaats van twee. Dat heeft ertoe geleid dat het aandeel jongeren in de Nederlandse samenleving ten opzichte van het aantal ouderen relatief hoog is. Die dependency ratio die hier de uitdrukking van is, laat ook zien dat Nederland beter af is dan de meeste buurlanden. Onze vergrijzingsgolf komt relatief laat, en dat geeft ons de kans om ons goed te prepareren en te leren van de ervaringen elders.

Een tweede relativering ligt in het gegeven dat de Nederlandse bevolking wel ouder wordt, maar minder snel dan in de meeste landen om ons heen. Al sinds de jaren vijftig stijgt de levensverwachting, en wel behoorlijk fors: gemiddeld stijgt in de OECD-landen de levensverwachting iedere zes jaar met een jaar. Dat is op zichzelf al een opvallend - en nog niet helemaal verklaard - gegeven, want de verwachting was dat met het ouder worden van de bevolking de biologische grens van het menselijk lichaam in zicht zou komen, en dat de stijging van de levensverwachting dus niet in een lineaire lijn kan doorgaan. Opvallend is echter dat die stijgende trend zich tegenwoordig in Nederland minder duidelijk voordoet. In de recente vergrijzingsstudie van het СРВ (2006) wordt nu uitgegaan van een levensverwachting van mannen van 79,6 jaar (in de vergrijzingsstudie van het CPB van 2000 was nog uitgegaan van 81 jaar) en van vrouwen van 82,6 jaar (was eerder 83,6 jaar). Was Nederland tot 1964 nog koploper in de wereld als het ging om levensverwachting, die levensverwachting is hier minder gestegen dan elders, en nu bevindt Nederland zich op het niveau van het gemiddelde van de OECD (waarin zich ook landen als Mexico en Turkije bevinden). Deze ontwikkeling kan onvoldoende worden verklaard door bijvoorbeeld verhoogde perinatale 
sterfte van kinderen uit (een gegroeide) allochtone kring. De vraag is gerechtvaardigd of we dit moeten blijven beschouwen als een externe, onbeïnvloedbare grootheid, of dat hier sprake kan en moet zijn van een vraagstuk dat ook beleidsaandacht vergt. Hoe het ook zij, gegeven blijft dat de levensverwachting van Nederlanders minder stijgt dan die van vele andere Europeanen, en ook dat gaat de vergrijzingsgolf enigszins tegen.

Een derde factor is dat we wel ouder worden, maar we zullen door het stijgende opleidingsniveau en de nieuwe medische technologie niet langer, maar korter ziek zijn: het aantal ziektevrije jaren stijgt meer dan de levensverwachting. Volgens het gezamenlijk onderzoek van het RIVM en het SCP Ouderen nu en in de toekomst (2004) kregen mannen er tussen 1989 en 2000 1,0 jaar levensverwachting bij, maar steeg hun levensverwachting zonder lichamelijke beperkingen met 2,6 jaar, en die in goede geestelijke gezondheid met 2,o jaar. Voor vrouwen waren de gezondheidsresultaten (nog) spectaculairder: 0,3 jaar levensverwachting erbij, maar 3,8 jaar langer lichamelijk en 2,2 jaar langer geestelijk in goede conditie.

Ten slotte is goed nieuws dat het aantal alleenstaande ouderen niet verder zal toenemen. Dit komt doordat het scheidingspercentage niet meer groeit, ouderen steeds vaker met een nieuwe partner gaan samenleven, en de leeftijd waarop mannen en vrouwen sterven naar elkaar toegroeit (SCP /De Boer 2005; RVZ/Struijs 2006). Dit laatste geldt overigens nog niet voor allochtone vrouwen, die in dit opzicht kwetsbaar zijn; zeventig procent van de Marokkaanse vrouwen en vijftig procent van de Turkse is zes of meer jaar jonger dan hun echtgenoot, en ze zien dus een lange periode van weduwschap tegemoet.

Nederland zal al met al met een substantiële kwantitatieve opgave te maken krijgen als het gaat om de formele zorg in de komende decennia. Het goede nieuws is dat dit probleem wellicht beter beheersbaar is dan in veel landen om ons heen. Het slechte nieuws is dat het deel van het probleem waar de meeste aandacht naar uitgaat in de media - de betaalbaarheid - naar verwachting overschaduwd zal worden door een tot op heden nog minder belicht deel van het probleem: dreigende personeelstekorten. Alvorens in te gaan op de vraag hoe beide problemen hanteerbaar gemaakt kunnen worden, is het zaak om naast de kwantitatieve ook de kwalitatieve zorgkloof voor het voetlicht te brengen.

\section{De kwalitatieve zorgkloof}

Het idee over wat goede zorg is, heeft zich de afgelopen decennia verder ontwikkeld. Daarbij valt een viertal ontwikkelingen waar te nemen: (1) voortschrijdende professionalisering, (2) een voortgaand zoeken naar de beste institutionele vormgeving van de zorg, (3) hogere eisen aan een aanvaardbare kwaliteit van de dienstverlening, en (4) meer zorg op maat.

\section{Professionalisering}

Allereerst is er sprake van een voortschrijdende professionalisering. Voor de medische curatieve zorg is dat een proces dat al meer dan een eeuw gaande is -al 
brak de bloeiperiode van de genezing pas aan in de tweede helft van de vorige eeuw. Medisch specialisten - nu een vanzelfsprekendheid - kwamen pas in deze periode op. Nadat in de jaren voor de Tweede Wereldoorlog sommige huisartsen zich voorzichtig waren gaan specialiseren, kwam de grote doorbraak van de ziekenhuisgeneeskunde in de jaren vijftig - slechts enkele decennia nadat een ziekenhuis vooral was wat we tegenwoordig een verpleeghuis noemen: een plek waar mensen op humane wijze verpleegd werden, tot hun dood. De groei van de medisch-technische zorg is sindsdien systematisch doorgegaan. In vergelijking hiermee verliep de professionalisering van de care-sector veel trager. Lange tijd was het geven van zorg een vanzelfsprekende kundigheid van vrouwen. Het werd nauwelijks gezien als een activiteit waarvoor specifieke kwaliteiten nodig waren. Dat beeld verschoof maar voorzichtig. Zorgen vergt hoofd, hart en hand, zo werd steeds meer het idee. Zorg kan niet zonder empathie, sociale vaardigheden, kennis en reflectie vooraf en achteraf. En professionele zorg vraagt om beroepsontwikkeling, inhoudelijke kennis, professionele intervisie en consultatie.

\section{Institutionele vormgeving}

Ten tweede is het steeds zoeken naar de goede institutionele vormgeving van de zorg. Dat speelt met name in de care-sector. De zorg voor mensen met een fysieke, psychische of verstandelijke beperking staat veelal in het teken van het zoeken naar een beschaafde omgang met stoornissen die niet of nauwelijks te behandelen zijn. Het ideaal bleef lang hetzelfde, maar wat 'beschaafd' precies betekende, verschoof in de loop van de tijd. In grote lijnen werd aanvankelijk grootschalige institutionele hulp als vorm van vooruitgang gezien, en kwam er vervolgens een fase waarin het streven werd om deze hulp minder in aparte instituties onder te brengen. De zorg voor psychiatrische patiënten kende als eerste een intramuraliseringsfase: als uitvloeisel van de dolhuysen uit de Middeleeuwen werden er rond 1900 grootschalige voorzieningen voor hen gebouwd in dunbewoonde buitengebieden als de Veluwe en de duinstreek. Verstandelijk gehandicapten werden gaandeweg losgemaakt uit deze populatie en kregen in de decennia daarna eigen voorzieningen. Terwijl in de jaren zeventig voor deze beide groepen in brede kring de vraag gesteld werd hoe te deïnstitutionaliseren, werd op datzelfde moment juist een vergelijkbaar institutioneel arrangement opgezet voor ouderen met beperkingen: de verpleeghuizen doen dan op grote schaal hun intrede. Veertig jaar later is in deze sector de vraag aan de orde in welke mate het nog zinvol is grote intramurale voorzieningen te bouwen.

\section{Toenemende kwaliteitseisen}

De derde ontwikkeling heeft te maken met een verschuiving die aangeduid kan worden als de opkomst van een algemene middenklassenorm voor dienstverlening. Dat hangt samen met de verandering van de zorgvragers. Zorg was voor de meeste mensen lang vooral een gunst, verleend door hulpverleners die ze dankbaar moesten zijn en beschikbaar gesteld door een overheid die voor hen bepaalde wat goed was. Hoogbejaarden zijn vandaag de dag vaak nog de dankbaarheid zelve. En als 'zorgvragers' zijn ze eerder 'ondervragers' dan 'overvragers'. 
De babyboomers die straks zorg nodig zullen hebben, zijn echter veel beter geschoold - een gevolg van de verzorgingsstaat zelf. Een kwart van de ouderen heeft in 2000 havo of hoger als opleiding gevolgd; in 2020 zal dat de helft zijn (RIVM 2004). Zorg wordt dan ook gaandeweg steeds meer als een recht gepercipieerd, nog steeds verleend door een hulpverlener, maar een hulpverlener die zich te houden heeft aan specifieke regels die uiteindelijk zelfs door de rechter gesanctioneerd kunnen worden. Zorg lijkt dan ook een dienst geworden: een activiteit die beschikbaar is op een markt en daar tegen een bepaalde prijs ingekocht kan worden. Op dit moment bestaan overigens alle drie deze beelden nog door elkaar: afhankelijk van de generatie waartoe een cliënt behoort en het soort aandoening dat hij of zij heeft, prevaleert een van de beelden. Maar de verschuiving zal doorgaan. Daar komt bij dat toekomstige ouderen rijker zullen zijn. Door die trendmatige ontwikkelingen zullen zorgvragende burgers steeds assertiever en mondiger zijn en meer op hun rechten staan. Ouderen zullen meer verwachten van professionele zorg. Ze willen graag onafhankelijk zijn van dochters en partners. Ze willen dat de kinderen op bezoek komen, maar niet dat die meteen het huis moeten schoonmaken of de steunkousen helpen aantrekken (Van Gaalen 2005).

Hoe hoger de opleiding, hoe liever mensen professionele zorg ontvangen (Vollenga e.a. 2001). Dit betekent dat AWBZ-gefinancierde zorg en het gebruik van particuliere zorg volgens de ramingen stevig verder zal groeien. Vooral de behoefte aan verpleging (in Nederland redelijk geprofessionaliseerd) en begeleiding (meer een sociale functie) zal komende decennia toenemen. Er zal naar verhouding iets minder vraag zijn naar huishoudelijke hulp en persoonlijke verzorging (RIVM 2004; zie ook SCP 2004 en 2006). De vraag is of de professionele zorg wel zal kunnen beantwoorden aan deze hooggespannen verwachtingen. Met name de babyboomers zullen nog een lastige, want heel assertieve, generatie zorgontvangers worden.

Deze verschuiving, die nog volop gaande is, heeft al wel tot consequentie gehad dat de meeste burgers geen genoegen meer nemen met een kwaliteitsniveau van zorg dat onder een 'middenklassenorm' ligt. Voor een belangrijk deel wordt de zorg ook op dat niveau aangeboden. Nederlanders zijn dan ook over het algemeen tevreden over het niveau van de zorg, al is er over de hele linie wel een lichte afname van de waardering te zien (Alber en Köhler 2004). De curatieve zorgsector is het best in staat geweest om aan de middenklassenorm te blijven voldoen, al begonnen daar een aantal jaren geleden de wachttijden een associatie op te roepen met Oost-Europese dienstverleningsstandaarden. In de care-sectorgaven echter nietalleen de wachtlijsten, maarook de kwaliteitvan deaangeboden zorgaanleiding totklachten. Een substantieel deel van wat er in deze sector aan zorg word taangeboden, haalt niet meer helemaal de (zich steeds verder ontwikkelende) middenklassenorm. Personeel dat soms onvoldoende gekwalificeerd is, en ook de 'verkleuring' van de zorg, kunnen bijdragen aan een cultuurkloof tussen bewoners en verzorgenden.

Met name binnen de verpleeghuiszorg is deze ontwikkeling voelbaar. Uit een recent onderzoek van het SCP (2006) komt weliswaar naar voren dat negentig 
procent van de bewoners tevreden is met de hoeveelheid zorg en de bejegening van het personeel, maar ook blijkt dat veertig procent vindt dat de zorg gehaast plaatsvindt en dat er te weinig persoonlijke aandacht is. De meerderheid kan niet zelf bepalen wanneer hij of zij opstaat; dertig procent niet wanneer hij of zij naar het toilet gaat. Verpleeghuizen halen bovendien vaak de zelf gestelde doelen niet. Tekenend is dat ook het personeel ontevreden is. Ze vinden zelf dat ze tekortschieten (zie Brancherapporten Ministerie van vws 2005 en onderzoek Nivel 2003). Veel van het professionele tekort heeft te maken met de kwantitatieve en kwalitatieve achteruitgang van de personeelsbezetting, terwijl de 'zorgzwaarte' alleen maar is toegenomen. In tien jaar tijd is het aantal verzorgenden in een verpleeghuis gehalveerd, terwijl ze meer taken kregen (Van der Geest 2005, p. 44).

\section{Zorg op maat}

Een vierde ontwikkeling ligt in het verlengde van de vorige: er is sprake van een voortdurend zoeken naar hoe de cliënt een meer adequate plek kan krijgen binnen zijn of haar behandeling en verzorging. De medische ontwikkelingen geven wel aan wat tot de mogelijkheden behoort, maar lang niet in alle gevallen dicteren ze ook ondubbelzinnig wat er moet gebeuren; vaak is er sprake van ruimte voor verschillende invullingen van de behandeling. Dat geldt in sterke mate voor de care: cliënten in deze sector weten soms letterlijk beter wat goed voor hen is dan de hulpverleners met wie ze te maken hebben. Het geldt tot op zekere hoogte echter ook voor de curatieve zorg - ook daar gaat het er lang niet altijd om met de beste behandeling een ziekte te genezen: veel beslissingen zijn ook in deze sector gericht op het draaglijk maken van een fysieke beperking, en bij de vraag hoe dat moet, kunnen cliënten een belangrijke rol spelen. Eenvoudige schema's voldoen hier niet. Verzorgen gaat vaak over mensen wier leven dagelijks en langdurig onderhoud behoeft. Het gaat om de dagelijkse psychische, emotionele, praktische en sociale steun voor mensen die afhankelijk zijn van anderen (vgl. Daly en Lewis 1998; Knijn en Kremer 1997; Mol 2005; Heijst 2005). Nog anders gezegd: verzorgen is de zoektocht naar het goede leven van mensen met fysieke, mentale of sociale beperkingen. En goede professionele zorg wordt dan ook steeds meer een coproductie met de zorgbehoeftige. De professional weet nooit precies hoe een ander zich voelt en kan niet inschatten wat goede zorg is zonder de informatie en de welwillendheid van de patiënt (Sennett 2003). Omgekeerd kan de patiënt niet alles weten, en hij of zij weet het ook niet altijd beter.

De komende decennia zal het dus zaak zijn om de zorg mee te laten ontwikkelen met een verder stijgende kwaliteitsnorm, die zich ook zal vertalen in een roep om meer onderhandelingsruimte voor de cliënt.

\subsection{DE OPGAVEN}

\section{De financiële opgave}

Dat de aanstaande vergrijzing van de bevolking toekomstige generaties met oplopende lasten confronteert, was al langer duidelijk (o.a. WRR 1999). Om daarover 
berekeningen te kunnen maken, neemt de recente CPB-studie (2006) over dit onderwerp als uitgangspunt het zogenaamde Musgrave-criterium. Dit criterium zegt dat huidige generaties hun (stijgende) collectieve lasten in relatie tot hun levensinkomen niet mogen afwentelen op toekomstige generaties. Oftewel: iedere generatie wordt geacht eenzelfde saldo te hebben van overheidsprofijt en -lasten naar rato van het levensinkomen, en dus ook eenzelfde vergrijzingslast te dragen. Zoals dat in economische modellen gebruikelijk is, is dit geen normatieve keuze (van het СРВ of wie dan ook), maar een hypothetisch uitgangspunt (alsdan) om berekeningen te kunnen maken. Gegeven dit uitgangspunt zorgt de aanstaande vergrijzing voor een 'problematiek' van additionele collectieve voorzieningen - voor met name AOW en (gezondheids)zorg - die uitgedrukt in overheidsbestedingen neerkomt op een toename van 48 procent nu, naar 55 procent van het bbp in 2040: een toename van 7 procentpunt. Er is ook een inverdieneffect: door de consumptieve uitgaven uit uitgekeerd pensioenen stijgen de overheidsinkomsten met 4 procentpunt. Het saldo van de twee effecten is $(7-4=)$ 3 procentpunt nationaal inkomen, waarvoor beleidsaanpassingen gevonden zullen moeten worden. Overigens schat het СРВ de problematiek nu een stuk groter in dan nog maar zes jaar geleden (CPB 2OOO), met name door een structureel lagere rentestand, waardoor het vermogen in de pensioenfondsen minder rendeert, de toekomstige pensioenuitkeringen lager zullen zijn, en dus ook de consumptieve uitgaven en belastinginkomsten die daaruit voortvloeien.

Drie procentpunt nationaal inkomen is een forse opgave: het betekent dat huidige arrangementen niet houdbaar zijn. Daar staat echter tegenover dat deze problematiek speelt over een tijdspanne van 34 jaar (2006-2040), en het is in de Nederlandse openbare financiëngeschiedenis eerder vertoond dat een problematiek van een dergelijke omvang is opgelost. Verder zijn er de gebruikelijke onzekerheden, onder meer ten aanzien van de rentestand en levensverwachting. Al met al is het zaak om nu wel te gaan werken aan de aanpak van deze problematiek. In dat kader laat de СРB-studie zien dat het verder verhogen van de participatie van 55-plussers en van vrouwen (ontwikkelingen die al gaande zijn) een nuttige bijdrage levert, maar zeker niet voldoende soelaas biedt. Datzelfde geldt voor een even-tuele geleidelijke verhoging van de AOw-leeftijd. Een ander spoor is om een grotere bijdrage van (met name de meer draagkrachtige) ouderen te vragen. Dat kan bijvoorbeeld door evenwichtige vormen van verdere fiscalisering van de AOW, met compensatie voor wie geheel of grotendeels van de AOW moet leven. Het kan ook door het deel private betalingen in de zorg te verhogen. In Nederland wordt immers het grootste gedeelte van de zorg betaald uit publieke middelen; dat aandeel is groter dan in andere OECD-landen. Private betalingen spelen tot op heden geen grote rol: ouderen hoeven zelf beperkt mee te betalen, en hun kinderen al helemaal niet.

Het meest voor de hand ligt een traject waarbij in ieder geval wordt ingezet op het verhogen van de arbeidsparticipatie van de groep ouderen, met name de mensen tussen de 60 en 65 jaar (iets wat nog een complexe opgave is, want er is nauwelijks sprake van een arbeidsmarkt voor ouderen, en arbeidsorganisaties zijn er in het algemeen nog onvoldoende op ingericht om ouderen langer aan zich te 
binden), waarna de andere opties gaandeweg geagendeerd kunnen worden (vgl. Studiegroep Begrotingsruimte 2006, p. 31). Tegelijkertijd kan gezocht worden naar manieren om eigen betalingen in de zorg te relateren aan de prestaties van de zorgaanbieders; met name in de sfeer van wonen en dienstverlening kan aan een meer kostenconforme private financiering inhoud worden gegeven. Dat biedt tegelijkertijd de mogelijkheid om gaandeweg het palet aan zorg verder te differentiëren: een vastgesteld en collectief verzekerd basispakket voor de zorg, met private betalingen voor woon- en dienstverlening. Nederland lijkt - via het Persoonsgebonden Budget - vooral begonnen met een variant waarbij de huishoudelijke zorg in toenemende mate losgemaakt wordt uit het collectieve pakket. Het SCP (2004/Timmermans en Woittiez) verwacht dat in de toekomst deze vorm van zorg veel gebruikt zal gaan worden.

\section{De personele opgave}

In personele zin ligt de oplossing (nog) verder weg. We zagen al dat volgens de verkenningen op lange termijn bij ongewijzigd beleid alle schoolverlaters in de zorg zouden moeten gaan werken. Alsof dat al niet moeilijk genoeg is, komen er enkele complicerende factoren bij. Zo is er in algemene zin een opwaardering van het opleidingsniveau nodig. Steeds meer mensen zijn hoogopgeleid en willen graag zorg op maat. Door die ontwikkelingen zal de opleidingscapaciteit voor de totale groep met tien procent moeten toenemen, concludeert het onderzoeksbureau Prismant (2005). Complicerend is bovendien dat zorg een minder aantrekkelijke werkplek voor jongeren lijkt te worden; met name jonge vrouwen zijn minder enthousiast om in de zorg te gaan werken dan een tijd geleden. Nu al zien we dat veel mensen die wel een zorgopleiding volgen, uiteindelijk niet in de zorg gaan werken. Het werk wordt gepercipieerd als zwaar, en beloning en carrièreperspectief als beperkt. Daar komt nog bij dat de vergrijzing van het personeelsbestand in de zorgsector geleidelijk ook meer vervanging gaat vergen. Vanaf 2008 zijn er daarom kraptes aan personeel in de zorg te verwachten, een tendens die na 2015 versterkt zal doorzetten. Dit probleem zal zich in het bijzonder manifesteren in de ouderenzorg.

Voor deze situatie is geen eenvoudige oplossing voorhanden. Tot op heden wordt er langs verschillende lijnen geprobeerd om het probleem in ieder geval te adresseren. Een deel van de antwoorden wordt gezocht in de kwaliteit van het personeelsbeleid: de instroom verhogen door forse wervingsinspanningen en meer stageplaatsen, het zittende personeel behouden of later laten uittreden, het beroep aantrekkelijker maken door betere primaire en secundaire arbeidsvoorwaarden, het ziekteverzuim verminderen, en de deeltijdfactor vergroten. Een deel van het antwoord wordt ook gezocht in een andere beroepenstructuur: betere functiedifferentiatie en de introductie van nieuwe beroepen. Nog een deel van het antwoord wordt gezocht in efficiencyverbetering. Voor een deel is dat mogelijk door in de financieringsstructuur van de zorg meer prikkels tot innovatie in te bouwen; iets wat nu maar beperkt het geval is. Ten slotte liggen er mogelijkheden in de introductie van nieuwe technologie. In de cure-sector gaan de gedachten dan altijd onmiddellijk uit naar hightech, maar in de care-sector is 
waarschijnlijk meer te winnen met lowtech-maatregelen, als de introductie van wassen zonder water of het gebruik van internet- en kabelfaciliteiten om kwetsbare mensen die thuis wonen te kunnen bewaken en met ze te kunnen spreken.

Het is niet mogelijk de effecten van al deze maatregelen goed te kwantificeren, om nog maar te zwijgen over de effecten van eventuele nieuwe preventieve maatregelen. Zonder nieuwe preventieve methoden zal het aantal mensen met dementie stijgen van 175.000 nu naar 320.000 in 2030 . Substantiële doorbraken in medischtechnische zin zouden dit aantal kunnen veranderen, al zijn er weinig aanwijzingen voor dat daar op de korte termijn veel van te verwachten valt. Terwijl de hierboven genoemde maatregelen op het gebied van personeelsbeleid en efficiencyverhoging inmiddels de beleidsagenda al hebben gehaald, valt daarom te verwachten dat op korte termijn ook de roep om additionele maatregelen aan de orde zal zijn.

\section{Selectieve migratie?}

Een van de mogelijkheden die in discussie zal komen, is die van selectieve migratie. Dit debat speelt al levendiger in een aantal andere Europese landen waar de effecten van de vergrijzing (in Nederland vrij laat) en de ontgroening (in Nederland relatief beperkt) al meer merkbaar zijn. Men dient zich echter te realiseren dat om zowel kwantitatieve als kwalitatieve redenen hier slechts sprake van een partiële oplossing kan zijn. In kwantitatieve zin is de studie van Munz (2006) interessant, die in Europees verband het effect op het arbeidsaanbod naging van drie maatregelen: verhoogde arbeidsparticipatie, hogere pensioenleeftijd, en een actieve migratiepolitiek. Zonder beleidswijzigingen zou het aantal arbeidskrachten in de EU-25, nu zo'n 227 miljoen, tot 2025 dalen met 12 procent en tot 2050 zelfs met 29 procent, tot 160 miljoen. Zouden alle landen een arbeidsmarktdeelname hebben die nu de drie best presterende Europese landen hebben, dan zou de daling tot 2025 achterwege blijven, en in 2050 'slechts' 16 procent zijn. Verhoging van de pensioenleeftijd met vijf jaar in 2025 en tien jaar in 2050 mitigeert de daling slechts: in 2025 zou de daling dan 4 procent zijn en in 205016 procent. Een combinatie van beide scenario's zou in 2050 leiden tot precies hetzelfde aantal arbeidskrachten als in 2005. Wanneer, omgekeerd, de arbeidsparticipatie niet stijgt en de pensioengerechtigde leeftijd niet wordt verhoogd, zijn er 95 miljoen immigranten nodig om het arbeidspotentieel in 2050 op hetzelfde niveau te houden als in 2005, zo'n 20 procent van de nu aanwezige 474 miljoen inwoners. (Ter vergelijking: in dezelfde periode stijgt het arbeidspotentieel in het Nabije Oosten en Noord-Afrika met 118 miljoen.) Dit alles zou een instroom van migranten met zich meebrengen die ver boven de getallen ligt die de afgelopen 25 jaar gerealiseerd werden.

De mogelijkheden van migratie moeten ook om kwalitatieve redenen niet te hoog ingeschat worden; zo zijn in Nederland tot op heden alle formele experimenten ermee mislukt. Het blijkt niet goed mogelijk om verplegenden en verzorgenden met een andere culturele achtergrond over te planten naar de Nederlandse zorg. In Engeland is inmiddels een derde van de verpleegkundigen afkomstig van 
buiten dat land, maar die zijn wel bijna allemaal Engelssprekend. In andere landen waar sprake is van immigratie in de zorg, is ook sprake van een culturele overeenstemming. Spanje, Italië en de vs zijn voorbeelden van landen waarin migratie ten behoeve van de zorg (informeel) wordt toegestaan. Daarbij gaat het in Italië alleen om ouderenzorg; in de andere landen om zorg voor kinderen. In Europa zoeken mensen daarbij naar gelijkgestemden: in Spanje zijn LatijnsAmerikaanse vrouwen populair, en in Italië Poolse en Filippijnse (die immers ook katholiek zijn).

Bij de optie van (beperkte) migratie ter wille van de zorg speelt overigens ook nog een moreel vraagstuk: vaak laten migrerende vrouwen de zorgverantwoordelijkheden in het land van herkomst over aan andere (vaak nog minder betaalde) vrouwen. Ehrenreich en Hochschild (2002) spreken van een global heart transplantation, omdat de migrerende vrouwen vaak hun eigen kinderen achter (moeten) laten en hun affectie richten op andere kinderen. Anders geformuleerd, naar analogie met de braindrain ligt hier een risico van een caredrain. Arbeidsmigratie ter wille van zorg zou dan ook alleen vorm kunnen krijgen als die gepaard gaat met een Nederlandse rol in de ontwikkeling van de zorg in het exporterende land, inclusief afspraken over de terugkeer van arbeidskrachten.

Tot slot is het ook denkbaar dat niet de verzorgers gaan migreren, maar de te verzorgen mensen. Op beperkte schaal is dat al aan de hand, al leren de ervaringen met de naar Spanje verhuizende 'pensionado's' dat het hier vooral gaat om mensen tussen de 55 en 75 jaar, en dat het moment waarop ze echt zorgbehoeftig worden, voor hen vaak het moment is om weer terug te (willen) verhuizen naar Nederland, omdat dat land vertrouwder is en omdat ze daar meer steun van hun kinderen verwachten. In kwantitatieve zin is deze ontwikkeling dus hooguit van zeer beperkt belang.

De zorgvraag, zo blijkt, zal de komende decennia fors toenemen, naar schatting met bijna vijftig procent in de komende vijftien jaar. Dit brengt een omvangrijke financiële opgave met zich mee en een minstens zo omvangrijke personele. De financiële aspecten vergen dat er macro-economisch ruimte wordt vrijgemaakt. De personele oplossingen lijken nog lastiger te hanteren: zelfs als wordt ingezet op een veelheid van methoden om dit probleem hanteerbaarder te maken, dan nog dreigt er een fors zorgtekort. Dit betekent dat er ook gekeken zal (moeten) worden naar andere bronnen van zorg. Twee categorieën springen daarbij in het bijzonder in het oog. Allereerst is het zaak om na te gaan of een deel van de oplossing kan liggen in (uitbreiding van) informele zorg (paragraaf 5.4). Vervolgens is het de vraag of ook andere dan de traditionele zorgactoren een rol kunnen vervullen; daarbij kan met name gedacht worden aan de volkshuisvesting (paragraaf 5.5).

\subsection{INFORMELE ZORG}

In Nederland - en ook in de ons omringende landen - is de hoop voor het dichten van de zorgkloof voor een belangrijk deel gevestigd op informele zorgverleners. 
Die zouden de dubbele zorgkloof moeten helpen dichten, zeker als personeelstekorten uitbreiding van de professionele hulp onmogelijk (en wellicht ook onwenselijk) maken. Kan de zorgkloof overbrugd worden door uitbreiding van de informele zorg? En wat betekent dat voor de kwaliteit van de zorg?

\subsubsection{INFORMELE ZORG: NIET ALTIJD (EEN) IDEAAL}

Informele zorg is een onderwerp dat maar beperkte aandacht heeft gehad in publieke discussies. Het naoorlogse beleid stond immers in het teken van het vergroten van de onafhankelijkheid van (zorgbehoeftige) ouderen. Zo is er met de tijd een uitgebreid stelsel van voorzieningen voor ouderen ontstaan, bestaande uit verzorgings- en verpleeghuizen. Begin jaren tachtig leek dit bouwwerk, althans in kwantitatieve zin, voltooid. Budgettaire, zorginhoudelijke en normatieve overwegingen maken dan dat een uitgebreid intramuraal systeem niet langer wordt gezien als het enig mogelijke antwoord op de toekomstige ouderenzorg. De vraag wordt hoe een accentverschuiving aan te brengen van intramurale naar extramurale zorg. Thuiszorg is goedkoper, sluit beter aan bij de wensen van mensen, en appelleert meer aan hun eigen zorgvermogen, is het idee. De operatie van residentiële zorg naar thuiszorg gaat in Nederland overigens nauwelijks gepaard met budgettaire verschuivingen, zoals bijvoorbeeld in Denemarken - het is meer een ideologische dan een praktische operatie. Met de nadruk op thuiszorg komt in Nederland ook de familie weer in beeld. Waar de mate van de inzet van familieleden in de periode daarvoor werd overgelaten aan het onderhandelingsspel tussen gezinsverzorgster en cliëntsysteem, wordt met de komst van indicatiecommissies in de jaren negentig de vraag prangender: wat kan wel gevraagd worden van familieleden, en wat niet? Sindsdien zijn er voorzichtige pogingen gedaan dit vraagstuk verder te formaliseren, bijvoorbeeld via het concept van 'gebruikelijke zorg', maar in een context waarin het steeds gebruikelijker wordt om de zorg als een samenspel van formele en informele zorg te zien, is een dergelijke scheidslijn moeilijk te formaliseren.

Nederland heeft zich zo altijd wat afzijdig gehouden van het verder formaliseren en tot onderwerp van beleid maken van informele zorg. Dat paste niet bij een breed gedragen streven om ouderen zo onafhankelijk mogelijk te maken, en het paste niet bij de politieke opvatting dat informele zorg een sterk privékarakter heeft en dat de overheid zich daar niet in moet mengen, en het paste al evenmin bij een zorgtraditie van onderhandeling en samenspel die niet in formele schema's te vangen valt. De vraag blijft evenwel: wat voor mogelijkheden biedt informele zorg in de komende decennia?

\subsubsection{INFORMELE ZORG VERWAARLOOSD?}

Het beleid is lang gericht geweest op het zelfstandig maken van ouderen. Betekent dit een erosie van de (bereidheid tot) informele zorg? Dat beeld wordt vaak opgeroepen. Het beschikbare onderzoek leidt echter tot een andere conclusie. Het grootste aandeel in de zorgmix op dit moment wordt verleend door infor- 
mele zorgers, met name partners en kinderen (dochters). Samen geven die zo'n driekwart van alle zorg. De formele zorg is dus in de praktijk aanvullend op die informele zorg. In Nederland gaven in 2003 zo'n 1,6 miljoen Nederlanders (12,8 procent van de bevolking ouder dan achttien jaar) informele zorg aan mensen die het nodig hebben. Dat aantal informele zorgverleners is zelfs nog iets meer dan in 1991 toen 1,4 miljoen Nederlanders en 12,4 procent van de bevolking ouder dan achttien jaar informele zorg verleende (De Boer/SCP 2005). Bovendien is het aantal vrouwen ( 16,6 procent) dat zorg geeft de laatste decennia nauwelijks veranderd, en is ook het aantal mannen niet opvallend gestegen (van 8,1 in 1991 naar 8,8 procent in 2003). Wél is het zo dat de jongere leeftijdscategorie (tussen 18 en 34 jaar) minder is gaan zorgen, en ouderen (55-plus, en met name 65-plus) veel meer zijn gaan zorgen (De Boer/SCP 2005; Knijn en Liefbroer 2004). Mantelzorgers hebben ook vaker een betaalde baan dan vroeger.

De conclusie hieruit moet zijn dat de informele zorg in het afgelopen decennium niet is afgenomen. Wel is de informele zorg meer onder druk komen staan door de sterke toename van het aantal vrouwen op de arbeidsmarkt. Op dit moment werkt het merendeel van de Nederlandse vrouwen boven de 45 jaar niet, maar dat verandert in hoog tempo. Van de vrouwen tussen 45 en 49 jaar heeft al een kwart een voltijdse baan en bijna de helft een deeltijdbaan. Jongere vrouwen werken nu al minstens twee keer zoveel dan jonge vrouwen in de jaren tachtig.

\subsubsection{MINDER FORMELE ZORG, MEER INFORMELE ZORG?}

In het zorgbeleid werd lang niet te veel geleund op informele zorg, terwijl het altijd wel bestond. Is het reëel om aan te nemen dat de groeiende zorgbehoefte de komende decennia opgevangen zou kunnen worden door een toenemend beroep op de informele zorg? Er is een aantal redenen om aan te nemen dat dit hooguit heel beperkt mogelijk is.

De eerste reden is dat de wet van de communicerende vaten niet geldt: minder formele zorg betekent niet automatisch dat meer mensen informele zorg verlenen, en andersom (zie ook WRR 1999; Komter 2004). Verschillende Europees-vergelijkende studies laten zien dat er geen direct verband bestaat tussen het aantal vrouwen dat informeel zorg geeft en de aanwezigheid van zorgvoorzieningen (Spiess en Schneider 2002; Sarasa 2005; zie tabel 5.3). Op een vergelijkbare wijze is er overigens ook geen omgekeerde relatie tussen intramurale en extramurale zorg: voor zover er een verhouding tussen beide soorten zorg is, ligt die relatie precies omgekeerd: hoe meer intramurale, hoe meer extramurale zorg! Blijkbaar zijn landen beter te karakteriseren als meer of minder 'zorgminnend' dan als meer of minder 'intramuraal' of 'informeel'. Figuur 5.1 en tabel 5.3 laten dat zien. Het enige land waar er wel een duidelijke omgekeerde relatie is tussen de hoeveelheid intramurale en extramurale hulp, is Denemarken. Dat land heeft medio jaren negentig dan ook expliciet besloten om niet langer intramurale instellingen te bouwen - alle zorg wordt verleend in een extramurale context, ook intensieve zorg. De scheiding van wonen en zorg is daar dan ook ver doorgevoerd. 
Figuur 5.1 Informele zorg versus formele zorg

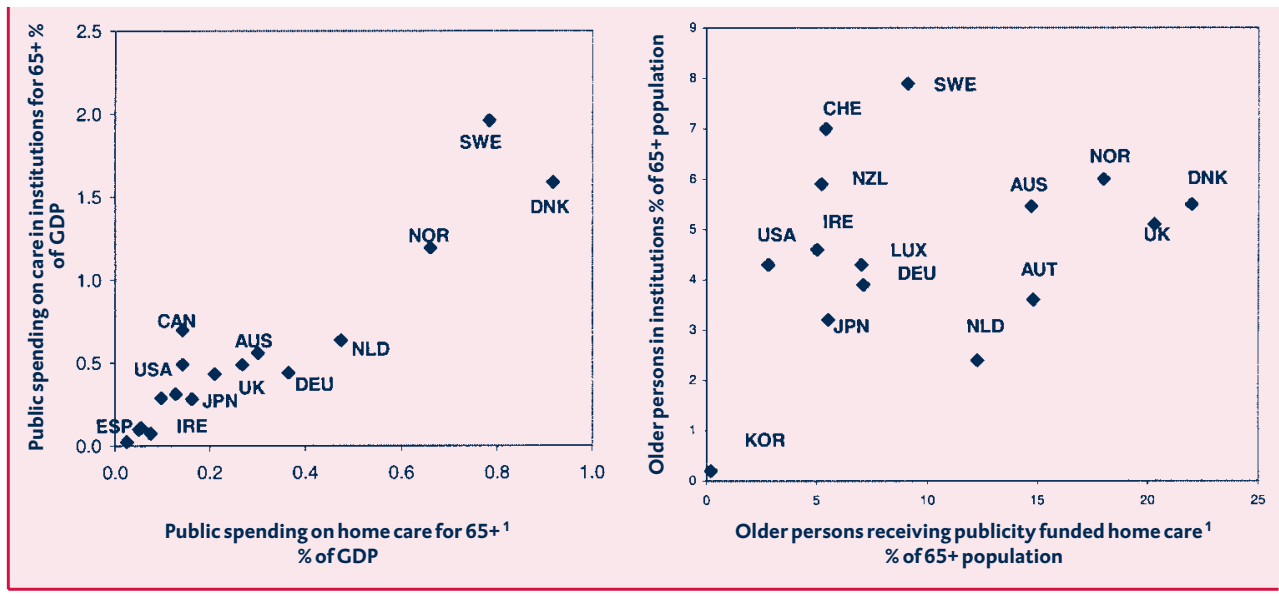

Bron: OECD/Lundsgaard 2005

Tabel 5.3 Informele zorg in Europa in 1994 en 2000

\begin{tabular}{|c|c|c|c|c|c|}
\hline & \multicolumn{2}{|c|}{1994} & \multicolumn{3}{|c|}{2000} \\
\hline & mannen & Vrouwen & $\begin{array}{l}\text { Meer dan } 4 \\
\text { uur per dag }\end{array}$ & vrouwen & $\begin{array}{r}\text { Gemiddeld } \\
\text { uren p. wk }\end{array}$ \\
\hline Nederland & 6 & 13 & 14 & 10 & 17 \\
\hline Denemarken & 4 & 9 & 8 & 7 & 12 \\
\hline Finland & & & & 9 & 12 \\
\hline België & 6 & 13 & 21 & & \\
\hline Duitsland & 7 & 14 & 22 & & \\
\hline Frankrijk & 3 & 8 & 17 & 5 & 15 \\
\hline Verenigd Koninkrijk & 7 & 14 & 37 & & \\
\hline Spanje & 5 & 16 & 47 & 13 & 38 \\
\hline Italië & 9 & 19 & 34 & & \\
\hline
\end{tabular}

Bronnen: Sarasa 2005; Dykstra 1994

Is er geen omgekeerde relatie tussen het aantal mensen dat informele zorg verleent en de aanwezigheid van voorzieningen, er is wél een verband tussen de omvang van de formele zorg en het aantal uren dat informeel gezorgd wordt. In Duitsland, België, Frankrijk, Engeland en de mediterrane landen wordt door informele zorgers bijna een halve werkweek gezorgd. In Scandinavische landen, en ook in Nederland, is de mantelzorg minder intensief. Tabel 5.3 geeft daar een indicatie van.

Een tweede reden dat informele zorg niet zonder meer als substituut voor formele zorg kan worden beschouwd, is dat mensen duidelijke ideeën hebben over wat ze aan formele zorg en wat ze aan informele zorg willen. Zorgontvangers willen liever goede professionele zorg wanneer het gaat om intensieve 
persoonlijke en verpleegkundige zorg. En die wens zal alleen maar sterker worden. Ouderen - vandaag en zeker in de toekomst - zijn graag onafhankelijk van hun familie (Ganesh 2006). Ze zien de rol van hun familieleden eerder in de ondersteuning bij 'lichte' activiteiten als het op orde houden van de administratie en het onderhouden van sociale contacten. Die preferenties hebben niet alleen te maken met het gevoel niet afhankelijk te willen zijn, maar ook met een reële inschatting dat veel intensieve zorg gemakkelijk leidt tot een overbelasting van de mantelzorg. Veel informele zorgverleners voelen zich belast, en hoe langer en intensiever (meer dan acht uur per week en langer dan drie maanden), des te eerder voelen ze zich overbelast. Dan dreigt de mantelzorger 'op te branden', met alle nadelige gevolgen van dien. In dat geval moet de professionele zorg immers alle zorg gaan overnemen (SCP/Timmermans e.a. 2005).

\section{Informele zorg én formele zorg!}

Het aantal mensen dat informeel zorgt, zo blijkt, is niet direct gecorreleerd met de omvang van professionele zorg; de mate waarin mensen informeel zorgen, kan wel door beleid worden gereguleerd. Gegeven het feit dat zorgontvangers sommige taken liever professioneel uitgevoerd zien, en andere door mantelzorgers, lijkt het verstandig om de verhouding tussen formele en informele zorg niet te benaderen in termen van of-of, maar van en-en. Om het potentieel aan mantelzorgers te behouden, is de aanwezigheid van formele zorg dan juist een vereiste. Het bestaan van formele zorg is een voorwaarde voor goede informele zorg. Ook geredeneerd in termen van kwaliteit lijkt dat een verantwoorde lijn: studies naar zorg laten zien dat informele zorg niet per se beter of slechter is dan formele zorg (Ungerson 2004; Twigg en Atkin 1994; RVZ/Struijs 2006; Van der Lyke 2000). Wel is duidelijk dat informele zorg alleen 'goed' is als de zorggever het zelf graag wil. Is dat niet het geval, dan kunnen spanningen ontstaan binnen de familie. Zorg in families kan de vorm aannemen van wat Land en Rose (1985) 'verplicht altruïsme’ hebben genoemd, met alle gevolgen van dien voor de kwaliteit.

Dit betekent dat professionele zorg niet alleen een belangrijke voorwaarde is om het informele zorgpotentieel te behouden, maar ook om te zorgen dat die zorg goed is. Meestal houden mantelzorgers het juist vol, en hebben ze voldoening bij het geven van zorg, als ze door de formele zorg goed worden ondersteund en als de professionele zorg zo nodig alternatieven biedt. Dit betekent ook een verandering in het denken in de organisatie van professionele zorg. Belangrijk is dat mantelzorgers niet alleen gezien worden als hulpbron om tekorten aan te vullen zoals nu als regel het geval is. Informele zorgers moeten door de professionele zorg serieus genomen worden, en wel op twee manieren. In de eerste plaats als medecliënt: informele zorgverleners hebben vaak ook hulp nodig, bijvoorbeeld in de vorm van respijtzorg - het tijdelijk overnemen van de zorg om een mantelzorger de gelegenheid te geven om op adem te komen en bijvoorbeeld op vakantie te gaan. In Engeland hebben mantelzorgers zelfs recht op een aparte indicatie voor zorg. De WMO die in Nederland in 2007 wordt ingevoerd, gaat die faciliteit ook kennen. 
In de tweede plaats moeten informele zorgers serieus genomen worden als medeprofessional. Hun ervaringen, mogelijkheden en ideeën verdienen een plaats in de wijze waarop de zorg verleend wordt. Het gaat dan niet louter meer om de relatie tussen professional en cliënt, maar om de driehoeksrelatie patiënt, professional en mantelzorger (zie Twigg en Atkin 1994: Kremer 2000; Van der Lyke 2000; RVZ/Struijs 2006). Kortom: voor het behoud en de kwaliteit van informele zorg past terugtreding van formele zorg niet, integendeel. Wat in de toekomst nodig is, is professionele zorg aangepast aan de noden van informele zorg. Minder formele zorg biedt dus geen oplossing voor de toekomst; informele zorg gedijt slechts als er daarnaast voldoende formele zorg bestaat.

\subsubsection{ARBEID EN ZORGBELEID}

Hoe zal informele zorg zich in de komende decennia ontwikkelen, en hoe is dat te beïnvloeden? Zoals gezegd, is het percentage mantelzorgers in Nederland sinds 1991 vooralsnog niet afgenomen. Ook zijn er weinig aanwijzingen van een afnemende bereidheid om te zorgen: zorg wordt met grote vanzelfsprekendheid gegeven (De Boer 2005; Bureau Veldkamp 2004). Ouders verwachten zelfs minder zorg van hun kinderen dan hun kinderen bereid zijn te geven (Van Gaalen 2005). Veel mensen willen graag zorgen, maar dan gaat het niet om langdurige, intensieve zorgtaken, maar om lichte taken die het dagelijks leven ondersteunen. Toch is de vraag reëel of er in de toekomst nog mogelijkheden zullen zijn om die zorg te geven, gezien de sterke toename van de arbeidsdeelname van vrouwen, en het belang van een toenemende arbeidsparticipatie van ouderen.

Vooralsnog blijkt uit Europese vergelijkende studies naar informele zorg (Spiess en Schneider 2002; Sarasa 2005) en de Nederlandse praktijk (Knijn en Liefbroer 2004; SCP/De Boer 2005) dat mantelzorg en arbeidsdeelname goed samen kunnen gaan. Dat valt ook te zien als de eerdere tabellen over het percentage zorgverleners worden vergeleken met tabel 5.4 over arbeidsdeelname van oudere vrouwen. In landen als Zweden, Denemarken, Noorwegen en met name Engeland is de arbeidsdeelname van oudere vrouwen relatief hoog, maar het percentage mantelzorgers ook. Vrouwen zijn blijkbaar bereid om naast werken ook zorg te geven.

Toch geldt ook hier dat er waarschijnlijk wel een negatief verband is tussen intensieve arbeidsdeelname en intensieve zorg. Hoe meer uren gezorgd wordt, hoe minder uren gewerkt. Zeker een hoge zorglast - bijvoorbeeld van meer dan veertien uur per week - heeft een effect op de hoeveelheid vrouwen die werken, en op het aantal uren dat gewerkt wordt (Spiess en Schneider 2002; Sarasa 2005). Deeltijdarbeid en deeltijdzorg kunnen goed samengaan, zo blijkt, mits er gezocht wordt naar manieren om de zorgtaken te verlichten en om zorgvragers minder te laten doen. Kan dat?

\section{Zorgende mannen}

Een eerste mogelijkheid ligt in de verhoging van de inzet van mannen. Zoals gezegd, zorgt slechts 8,8 procent van de mannen in 2003; dat is (slechts) 0,7 procent 
Tabel 5.4 Arbeidsdeelname van vrouwen tussen 45 en 65 jaar in 2003, in procenten

\begin{tabular}{|c|c|c|c|c|c|c|c|c|}
\hline \multirow[b]{2}{*}{ Leeftijdscategorie: } & \multicolumn{4}{|c|}{ Voltijd } & \multicolumn{4}{|c|}{ Deeltijd } \\
\hline & 45-49 & $50-54$ & $55-59$ & $60-64$ & 45-49 & $50-54$ & $55-59$ & 60-64 \\
\hline \multicolumn{9}{|c|}{ Landen met uitgebreide formele thuiszorgvoorziening en beperkte financiële steun informele zorg } \\
\hline Zweden & 71,7 & 70,0 & 62,3 & 37,1 & 13,5 & 13,7 & 14,8 & 16,4 \\
\hline Noorwegen & 59,9 & 57,1 & 46,9 & 31,0 & 21,5 & 23,8 & 25,2 & 21,3 \\
\hline Denemarken & 67,5 & 66,9 & 57,1 & 21,8 & 15,2 & 14,4 & 13,8 & 5,7 \\
\hline Nederland & 26,0 & 21,6 & 13,9 & 3,9 & 48,3 & 41,1 & 28,8 & 11,0 \\
\hline \multicolumn{9}{|c|}{ Landen met beperkte/gemiddelde formele thuiszorgvoorziening en uitgebreide financiële steun informele zorg } \\
\hline Verenigd Koninkrijk & 49,9 & 45,9 & 32,9 & 9,1 & 28,0 & 27,4 & 28,3 & 18,2 \\
\hline Duitsland & 46,7 & 42,7 & 30,5 & 6,8 & 29,2 & 26,8 & 21,3 & 8,2 \\
\hline Oostenrijk & 55,8 & 50,8 & 26,5 & 4,4 & 21,5 & 16,9 & 8,8 & 3,0 \\
\hline Luxemburg & 33,9 & 34,9 & 18,2 & 4,2 & 20,4 & 14,2 & 9,2 & 3,9 \\
\hline \multicolumn{9}{|l|}{ Overige landen } \\
\hline Nieuw-Zeeland & 55,1 & 51,9 & 41,9 & 24,5 & 25,0 & 23,1 & 23,2 & 18,7 \\
\hline Verenigde Staten & 66,1 & 63,3 & 54,3 & 33,8 & 9,4 & 8,7 & 8,7 & 9,9 \\
\hline Canada & 61,1 & 56,3 & 40,6 & 18,7 & 16,3 & 15,8 & 15,8 & 11,4 \\
\hline Japan & 38,0 & 36,8 & 31,7 & 18,4 & 32,3 & 29,2 & 25,0 & 19,1 \\
\hline Australië & 47,5 & 40,4 & 27,7 & 12,4 & 27,5 & 25,7 & 21,0 & 14,6 \\
\hline Korea & 55,4 & 49,4 & 42,6 & 35,9 & 5,0 & 5,3 & 5,8 & 6,4 \\
\hline Hongarije & 71,2 & 63,2 & 32,4 & 4,5 & 2,5 & 2,6 & 2,7 & 2,8 \\
\hline lerland & 33,2 & 28,3 & 18,3 & 9,3 & 25,7 & 24,0 & 22,5 & 14,8 \\
\hline Polen & 58,7 & 44,8 & 20,7 & 7,3 & 7,7 & 6,5 & 6,8 & 6,3 \\
\hline Mexico & 32,5 & 27,0 & 23,5 & 14,8 & 11,5 & 11,6 & 11,2 & 9,5 \\
\hline Spanje & 44,4 & 34,1 & 24,2 & 13,9 & 7,6 & 7,0 & 4,5 & 3,2 \\
\hline
\end{tabular}

Bron: OECD

meer dan een decennium daarvoor. De zorg die mannen verrichten, is meestal voor hun partner en veel minder voor hun ouders of anderen (De Boer/SCP 2005). Over de precieze inzet van mannen bij mantelzorg is weinig bekend. Als voor mantelzorg hetzelfde geldt als de zorg voor kinderen, zijn twee factoren relevant. In de eerste plaats geven mannen niet graag de band met de arbeidsmarkt op om zich voltijds te richten op zorg. Dit geldt in de eerste plaats voor zonen; de meeste mannelijke partners van hulpbehoevende ouderen zijn al uit het arbeidsproces. Mannelijke mantelzorg kan alleen groeien als de betrokkenen hun zorgtaken kunnen combineren met (deeltijd)arbeid. Ten tweede lijkt in ieder geval de huidige generatie mannen gehecht aan financiële middelen. Zonder betalingen zijn mannen moeilijk te verleiden tot zorg. Dat heeft niet alleen te maken met de financiële problemen die kunnen ontstaan bij verlies van inkomsten, maar ook met de betekenis van geld. Het Nederlandse betaalde ouderschapsverlof waarbij mannen een percentage van hun loon krijgen, bleek bij mannen veel populairder 
dan het Deense verlof waarbij mannen een flat rate kregen. Zo konden sommige mannen, zo bleek uit de Nederlandse evaluatie van verlof, aan hun collega's duidelijk maken dat het dom was als ze het niet zouden doen: niet werken en toch geld (Van Luyn en Keuzenkamp/sCP 2004).

\section{Jongere ouderen}

Een andere route, die nog relatief weinig aandacht krijgt, is het beter gebruiken van de mogelijkheden die 'jongere ouderen' bieden. $\mathrm{Nu}$ al blijkt dat een enorm reservoir van zorgverlening te zijn. Bij meer dan de helft van de kinderen in de leeftijd tot drie jaar die opvang krijgen, spelen de grootouders een substantiële rol, en circa veertig procent van de kinderen op de basisschool die opvang krijgen, krijgen dat alleen van hun grootouders. Dat maakt dat de kinderopvang die grootouders bieden, in dezelfde orde van grootte ligt als de officiële kinderopvang. Ook in termen van inzet in het vrijwilligerswerk zijn jongere ouderen een steeds belangrijkere leeftijdsgroep. Dezelfde leeftijdsgroep heeft vaak ook zorgbehoeftige ouders - iemand van 55 heeft gemiddeld gesproken ouders die begin tachtig zijn, de leeftijd waarop gebreken zich beginnen voor te doen. De vraag is hoe dit potentieel beter aan te spreken. Zo zou overwogen kunnen worden om een koppeling te maken tussen regelingen die voorzien in het gelijdelijk minder intensief werken vanaf het vijfenvijftigste levensjaar en regelingen die mensen meer mogelijkheden bieden tot het verlenen van mantelzorg.

\section{Tijd en geld}

En meer inzet van vrouwen? Tijd en geld zullen in de toekomst in ieder geval belangrijk zijn om mannen te verleiden om te zorgen. Maar dat geldt niet alleen voor hen. Ook vrouwen zullen gewend zijn om te werken en hechten aan een loopbaan. Er zal in de toekomst meer spanning ontstaan tussen arbeid en zorg. Daarbij speelt bovendien dat ons socialezekerheidsstelsel nog sterk geënt is op de afdekking van klassieke arbeidsrisico's, maar nog slechts beperkt rekening houdt met het 'nieuwe risico' van zorg (Driouichi 2004). En zorg zal financieel wel mogelijk moeten blijven. Informele zorg is namelijk niet 'gratis', en is dat nooit geweest. In het verleden werden vrouwen via kostwinnersbeginselen in de sociale zekerheid en belastingen deels gecompenseerd. Bovendien betalen mantelzorgers zelf ook een prijs. Het SCP (2005) berekende in zijn studie naar mantelzorg dat van mantelzorgers jonger dan 65 jaar zeventien procent inkomen derft door te stoppen met of minder te gaan werken. Samen verloren ze in 2001 één miljard euro. Bovendien kost helpen zelf ook veel geld, zoals kosten voor telefoon, transport, enzovoorts. Daardoor komt zeven procent van de mantelzorgers in financiële problemen (Van der Geest 2005).

Er zijn twee routes om informele zorg te ondersteunen met geld en tijd: (1) via de zorgontvanger, en (2) via de zorgverlener. Het Persoonsgebonden Budget is een variant van de eerste route. Varianten van de tweede route zijn verlofregelingen, een levensloopregeling, vrijstellingen in de sociale zekerheid en tijdelijke arbeidscontracten voor mensen die familieleden verzorgen. Beide routes hebben voor- en nadelen. In Europa volgen verschillende landen een verschillend spoor: 
Duitsland, Oostenrijk en Finland nemen de eerste route, de Scandinavische landen, Frankrijk en België de tweede, terwijl Engeland, net als Nederland, van beide mogelijkheden iets overneemt. Wat valt er van die ervaringen tot nu toe te leren?

\section{Via de zorgontvanger}

In een aantal landen in Europa zijn voorbeelden te vinden van betalingen aan zorgontvangers. Daarmee kunnen hulpbehoevenden zelf bepalen welke zorg ze het liefst willen. In Duitsland bestaat bijvoorbeeld Pflegegeld, in Engeland Direct Payments en in Canada een Compassionate Care Allowance. In Nederland kennen we het Persoonsgeboden Budget (PGB). Inmiddels is dit in ons land de meest gebruikelijke route om informele zorgverleners te betalen. Toen in 1991 het PGB werd geïntroduceerd (en het in 1995 na indicatie een recht werd), was het doel om een breekijzer te introduceren om de markt van thuiszorg open te breken. In 1997 werd het echter ook mogelijk om partner of kind te contracteren. Inmiddels betaalt meer dan de helft van alle budgethouders een informele zorger, en gaat 65 procent van het totale PGB naar informele zorg (Van den Berg et al. 2003; TK 2004-2005; Ramakers en Van den Wijngaart 2005). Meestal worden daar partners van betaald (37 procent); kinderen ( 22 procent) of ouders bij gehandicapte kinderen (17 procent) (Van den Berg et al. 2003). Mantelzorgers die betaald krijgen via het PGB verlenen bovenop hun PGB nog vele uren onbetaalde zorg. Gemiddeld verleent zo iemand circa acht uur betaalde en daarnaast nog eens veertien uur onbetaalde zorg. Betalingen zoals het PGB geven mensen de mogelijkheid om zorg met arbeid te combineren. Vooralsnog zijn de bedragen die gemoeid zijn met het PGB niet erg hoog: op jaarbasis gemiddeld zo'n zesduizend euro. Vaak is dat een bijverdienste voor middelbaar opgeleide vrouwen van een jaar of 45 die daarnaast nog een baan hebben van zo'n 22 uur.

Interfereert een PGB met de verhouding tussen zorgverlener en zorgontvanger? Met betalingen via de zorgontvanger komt een zorgverlener bij een oudere of gehandicapte in dienst. Kan er nog wel sprake zijn van een evenwichtige co-productie als de cliënt de financiële touwtjes in handen heeft? Uit het schaarse Nederlands onderzoek blijkt dat er weinig negatieve psychologische effecten zijn op de mantelzorger. Ook leidt deze betaalwijze niet tot een andere emotionele relatie, of meer overbelasting (Van den Berg 2005; Ramakers en Van den Wijngaart 2005). Uit Engels onderzoek komt echter naar voren dat door het contracteren van mantelzorgers meer van hen geëist wordt, en ze moeilijker nee durven zeggen (Ungerson 2004).

Tot slot geeft het PGB zorgverleners geen recht om te zorgen, integendeel. Er is zelfs sprake van een curieus verschil tussen mantelzorgers die wel via het PGB betaald krijgen, en mantelzorgers wier partner of ouder minder zorg geïndiceerd krijgen, juist omdat ze al onbetaalde zorg verleenden. Dit komt doordat indicatiecommissies mantelzorg die al gegeven wordt, kunnen zien als 'extra zorg' of als 'gebruikelijke zorg'. In dat laatste geval wordt de al gegeven mantelzorg afgetrokken van het totale zorgaanbod waarvoor iemand geïndiceerd wordt (Schut 2005; 
Yerden 2005). Kortom: betaald krijgen via het PGB is voor mantelzorgers op dit moment zeker geen recht.

\section{Via de zorggever}

In Nederland verloopt de betaling van mantelzorgers dus via de zorgontvanger, in de vorm van een PGB. In een aantal andere Europese landen is het gebruikelijker om mantelzorgers direct te betalen: via verlof, uitkeringen in het kader van de sociale zekerheid, via arbeidscontracten met gemeenten of via spaarvarianten zoals de levensloopregeling.

De eerste variant, zorgverlofregelingen, hebben als voordeel dat ze het mogelijk maken om zorg te verlenen terwijl het arbeidscontract met de bestaande werkgever gehandhaafd blijft. Zeker met het oog op de noodzaak dat mensen in de toekomst meer werken, is dat een voordeel. In Nederland bestaat deze variant al lang, maar is, vergeleken met België en Scandinavië, zeer beperkt. Nederland kent twee soorten verlof. Het eerste is gericht op kortdurende afwezigheid. Een werknemer kan in het kader van deze regeling tien werkdagen voor een ziek kind of een (in huis wonend) familielid zorgen. De vergoeding bedraagt zeventig procent van het loon. Daarnaast bestaat sinds kort het langdurig verlof, dat vergelijkenderwijs nog steeds relatief kort is en een beperkte reikwijdte heeft. In het geval van een levensbedreigende ziekte kan een werknemer twaalf weken verlof opnemen, maar alleen in deeltijd en onbetaald. In Nederland is voltijds verlof niet mogelijk (alleen als het binnen de CAO geregeld is, wat niet vaak het geval is). Zorgen voor bekenden, buren en vrienden én schoonouders is uitgesloten van de regelingen. Bovendien is er geen sprake van een recht: de werkgever moet er vooraf mee instemmen, al moet hij bij een negatieve beslissing bij de rechter wel kunnen aangeven welke zwaarwegende redenen er waren om het verlof niet te geven. In Nederland bestaat inmiddels wel de mogelijkheid voor werklozen en gedeeltelijk arbeidsongeschikten om onder voorwaarden tijdelijk een ontheffing te krijgen van de sollicitatieplicht wanneer ze mantelzorg verrichten.

Met een tweede variant, betalingen via de sociale zekerheid, is met name in Engeland ervaring opgedaan in de vorm van de Invalid Care Allowance (ICA). Het blijkt dat de ontvangers van deze uitkering verstrikt blijven in armoede, en dat ook de terugkeerkansen op de arbeidsmarkt minimaal zijn. De route van socialezekerheidsbetalingen lijkt dan ook niet te verkiezen. Dit neemt niet weg dat er wel aandacht besteed moet worden aan de opbouw van rechten voor zorgverleners in socialezekerheidsregelingen. Sinds 1987 wordt in Nederland bij de opbouw van WW-rechten rekening gehouden met een 'verzorgingsforfait'.

De derde variant is het afsluiten van een gemeentelijk contract, waarbij de gemeente (of andere zorgfinancier) een mantelzorgtoelage betaalt of iemand tijdelijk in dienst neemt. In met name Zweden en Finland is het gebruikelijk om een dergelijk arbeidscontract af te sluiten met mantelzorgers. Dit contract is dan onderdeel van een plan waarmee professionele zorg, cliënt en mantelzorg moeten instemmen. Het idee is niet alleen dat er zo een betere afstemming mogelijk is tussen de partijen, de gemeente heeft er ook (financieel) belang bij als 
informele zorg plaatsvindt. In Zweden is men overigens terughoudender geworden met deze vorm van betaling (Tjadens et al. 2005). De mantelzorgers zouden vaker overspannen en ziek worden door de druk van het reguliere arbeidscontract en het morele imperatief binnen de zorgrelatie. In Finland zullen er nationale regels geformuleerd gaan worden in verband met de grote lokale ongelijkheid.

Ten slotte wordt wel eens geopperd om mantelzorg te faciliteren via een spaarregeling, zoals nu via de levensloopregeling in principe ook mogelijk is. Bij een dergelijke modaliteit is het idee dat mensen individueel kunnen sparen om later voor een zieke partner of ouder te kunnen zorgen. De implicatie van zo'n grotendeels individuele regeling zou een fundamentele omslag betekenen in het denken over ouderenzorg. Van een collectieve verantwoordelijkheid in de jaren zestig en zeventig zou zorg voor ouderen zomaar weer een individuele beslissing en - vooral - een individuele investering worden. Gezien de ervaring met verlofregelingen die geen financiële compensatie bieden, moeten de verwachtingen ten aanzien van het feitelijke gebruik erg bescheiden zijn. De aan de levensloopregeling voorafgaande Wet op Verlofsparen - die sterk lijkt op de huidige - werd al nauwelijks gebruikt: slechts zes procent van de werknemers deed eraan mee. Meestal waren dat mensen die wat ouder waren - jonge mensen met kinderen spaarden zeker niet - en werd het verlof vooral gebruikt voor vroegpensioen en langere vakanties. Zorg werd nauwelijks genoemd als reden om het spaarsaldo op te nemen; tijd voor hobby's wel (Van Luijn en Keuzekamp/sCP 2004).

Vrouwen zullen daarbij nog vaker verlof opnemen om te zorgen dan mannen. Daardoor kunnen ze minder sparen voor vrije tijd of scholing. Mannen zullen hun spaartegoed vaker gebruiken om vervroegd te kunnen uittreden en van vrije tijd te genieten. De vraag is of dat een gewenste ontwikkeling is; het levert in ieder geval niet de gewenste zorgcapaciteit op die in de toekomst nodig is.

\subsubsection{ENKELE SUBCONCLUSIES}

Hoe de informele zorg in de toekomst te behouden? Dat lukt in elk geval niet door de hoeveelheid formele thuiszorg te verminderen: juist het bestaan van professionele zorg maakt het mogelijk ook informeel te zorgen. Het heeft de voorkeur om meer mensen bereid te vinden die minder zorgen. Dat betekent een formele thuiszorg die indien nodig de informele zorg overneemt en serieus neemt als mededeskundige, in combinatie met regelingen die in de toekomst de combinatie van zorg en arbeid (beter) mogelijk maken.

Al met al lijkt het Engelse systeem met een uitkering op basis van de sociale zekerheid een te magere regeling. De Nederlandse spaarloonregeling zal evenmin soelaas bieden om de toekomstige behoefte aan mantelzorg te helpen vervullen. Het Nederlandse zorgverlof is te beperkt vormgegeven om fundamenteel meer zorgcapaciteit te kunnen genereren. Dat laat de optie open om of deze regeling breder te maken, of over te gaan op een model waarbij er sprake is van tijdelijke 
'arbeidscontracten'. Die hebben in ieder geval twee voordelen: ze zorgen ervoor dat formele en informele zorg in één hand kunnen komen en dat afstemming over de zorg goed geregeld kan worden; iets wat, zoals eerder aangegeven, met nieuwe generaties cliënten steeds belangrijker zal worden. Bovendien bieden ze de mogelijkheid om ook de financiële winst (en verlies) van het inzetten van mantelzorg te verrekenen met die van de inzet van professionele hulp.

\section{5 .5 DE BIJDRAGE VAN VOLKSHUISVESTING AAN DE ZORGAGENDA}

In de voorafgaande paragrafen is al aangegeven dat de vergrijzing van de Nederlandse bevolking met zich meebrengt dat er tot 2020 ceteris paribus ongeveer vijftig procent extra zorgcapaciteit nodig is. Voor zover die zorg 'in mensen' geleverd zal moeten worden - en dat is en blijft in belangrijke mate het geval - kan die extra benodigde capaciteit komen uit informele danwel formele zorg. In par 5.4 is geanalyseerd dat door de kleinere gezinnen en de toegenomen arbeidsparticipatie het informele zorgpotentieel zeker niet veel zal kunnen toenemen. In essentie is dat potentieel al aangeboord en mogen we tevreden zijn als het in 2020 op hetzelfde niveau is gebleven als het nu is. Dit betekent in ieder geval dat de formele zorg dus flink zal moeten groeien komende decennia, en ruwweg op een groeipad van zo'n drie procent per jaar moet worden gebracht om de groeiende zorgkloof te kunnen dichten. Professionele, formele zorg is ook van belang, omdat ze ook als backing hard nodig is om de informele zorg goed te kunnen laten functioneren; formele en informele zorg zijn immers geen volledige substituten voor elkaar, maar vullen elkaar aan. Het is evenwel op dit moment nog zeer de vraag of de formele zorg ook op dit hoge groeipad gebracht kan worden; het betekent dat er snel meer middelen voor moeten worden vrijgemaakt en ook dat de instroom in de relevante opleidingen snel toeneemt. Op dit moment is van beide aspecten nog onvoldoende sprake.

Tegen deze achtergrond is het dan ook noodzakelijk om te onderzoeken of er buiten de personele bijdrage (formeel en informeel) vanuit de zorgwereld ook andere ontwikkelingen (gewenst) zijn die kunnen helpen om het dreigende verzorgingstekort tegen te gaan. De verzorgingsfunctie van de verzorgingsstaat komt immers niet alleen tot uitdrukking in de zorgsector, -instituties en -arrangementen zoals in de vorige paragrafen behandeld. Ook andere sectoren kunnen een rol spelen bij de invulling van de verzorgingsfunctie. De volkshuisvesting is er daar de belangrijkste van. Voor een belangrijk deel bestaat de bijdrage van die sector uit het zodanig bouwen of aanpassen van woningen dat veel zorg niet, of beter gezegd: later, gegeven hoeft te worden. In dit opzicht vervult de woningbouw een preventieve functie als het gaat om zorg. Voor mensen die zorgbehoeftiger zijn, gaat het er vooral om combinaties te maken tussen wonen en zorg. Hiervoor (par. 5.3.1) is al behandeld hoe bejaardenoorden in de jaren zestig werden beschouwd als ideale manier om ouderen welverdiende zorg te kunnen bieden. Maar de laatste decennia is het woon-zorgideaal voor ouderen gaandeweg verschoven naar zo lang mogelijk zelfstandig thuis wonen. Daarbij zijn autonomie, zelfstandigheid en privacy de dominante waarden. Dat mondt uit in 
een grotere waaier aan (woon-zorg)preferenties en meer maatwerk. Het zoeken is naar meer flexibiliteit, zonder dat dit leidt tot omvangrijke kostenstijgingen.

Intussen wordt in Nederland een dergelijke redenering wel gevolgd, maar is het in de praktijk nog tot (te) weinig substantiële initiatieven gekomen. Dat heeft ook te maken met de omvang van de opgave. Veel woningen zullen aanpassing nodig hebben of speciaal gebouwd moeten worden. Sinds de invoering van de Wet Voorzieningen Gehandicapten in 1994 zijn bij benadering 6oo.ooo woningen voor ouderen aangepast, vaak blijvend, maar niet altijd. In totaal zijn er nu ongeveer 500.000 voor ouderen bestemde woningen, waarvan er ongeveer 415.000 (83 procent) ook daadwerkelijk door ouderen met min of meer ernstige beperkingen worden bewoond (Ministerie van vws 2005, p. 30). Dat aantal voldoet echter niet aan de vraag, die behalve om demografische redenen ook zal groeien, omdat veel verzorgingshuizen niet meer beantwoorden aan de kwaliteitseisen van dit moment, en omgezet (moeten) worden in voorzieningen voor verzorgd wonen. Volgens een voorzichtige schatting van het ministerie van VROM zijn er op basis van woonbehoefteonderzoek tot 2015 alleen al zo'n 400 .0oo nultredenwoningen voor ouderen en gehandicapten nodig. Bij dat cijfer moeten de volgende gegevens in ogenschouw worden genomen: in Nederland werden er in 200567.000 nieuwe woningen opgeleverd; het nettosaldo was 55 .00o woningen, want er werden ook woningen gesloopt. Het streven is wel om de bouwproductie tot 2015 te verhogen, maar veel meer dan 400.000 woningen zullen er toch niet gerealiseerd gaan worden. Daar komt bij dat nultredenwoningen bouwen niet genoeg is voor ouderen: ook in traditionele woningen zijn aanpassingen nodig. Kortom, om in de komende decennia voldoende adequate huisvesting voor ouderen beschikbaar te krijgen, is een woningcapaciteit nodig die ongeveer gelijk is aan het totale bouwvolume dat in deze periode waarschijnlijk gerealiseerd gaat worden. Dit betekent dat vrijwel alle nieuwe huisvesting ouderenhuisvesting zou moeten worden - en wie de opkomst van de Vinex-locaties ziet, kan constateren dat ouderen niet de preferente doelgroep in de woningbouw zijn. Er lijkt een steviger beleid nodig te zijn dan nu aan de orde is. Twee varianten dienen zich aan: inzetten op een andere financieringsvorm in de zorg, of de woningcorporaties meer aanspreken op hun zorgrol.

\section{Andere financieringsvormen}

De eerste variant komt neer op het navolgen wat in landen als Duitsland en Oostenrijk gebeurt. In die landen worden er geen instellingen voor ouderen meer gefinancierd, maar burgers. Afhankelijk van een indeling in zorgzwaarte (in Duitsland worden zes categorieën onderscheiden) krijgt iemand een bepaald bedrag per maand. Met dat bedrag kan hij of zij zorg inkopen of een plaats in een voorziening inkopen. Voorzieningen zijn private ondernemingen, en het staat hen vrij een aanbod te ontwikkelen dat zich richt op het niveau van de vergoedingen, of om meer te bieden. De reden om dat laatste te doen ligt in de inschatting dat ouderen (of hun kinderen) vaak in staat en bereid zijn om een iets hoger kwaliteitsniveau te betalen omdat ze nog beschikken over privévermogen, al dan niet in de vorm van (deels) afbetaalde eigen woningen. Deze vorm van financie- 
ren, die in Duitsland sinds 1996 bestaat, heeft in ieder geval twee voordelen: hij sluit goed aan bij de wens tot differentiatie, en hij zet private partijen aan tot het ontwikkelen van nieuwe vormen van zorg. De praktijk blijft overigens, zo leren de ervaringen, enigszins achter bij deze theoretische voordelen. Wel heeft deze vorm van financiering een andere ontwikkeling mogelijk gemaakt die minder voorzien was: de opkomst van (veelal Poolse) vrouwen die als een soort au pair bij toerbeurt inwonen bij (dementerende) ouderen. Deze vrouwen wonen dan een paar maanden in, om dan afgelost te worden door iemand anders, meestal uit hun eigen kennissenkring.

\section{Rol wooncorporaties}

Een andere variant is om de wooncorporaties (meer) aan te spreken op hun zorgrol. Wanneer we kijken naar de Nederlandse volkshuisvestingssector, dan heeft hij ten minste één uniek aspect, namelijk de belangrijke rol die wooncorporaties spelen, al vanaf de ontstaansgeschiedenis van de verzorgingsstaat. De wooncorporaties hebben een belangrijke sociale doelstelling: het beschikbaar stellen van aanvaardbare en betaalbare woningen voor lage inkomensgroepen.

Dit heeft ook nadelige gevolgen gehad, omdat dit heeft geleid tot een in tweeën gedeelde woningmarkt, bestaande uit een grote sociale en een kleine private huursector enerzijds, en anderzijds de koopsector. De ene sector wordt gesubsidieerd via huursubsidiebeleid en - vroeger - objectsubsidies; de ander fiscaal gesubsidieerd via de hypotheekrenteaftrek. De Nederlandse woningmarkt in totaal wordt daardoor gekenmerkt door: zware publieke subsidiëring (ondanks de toename van private welvaartsniveaus); sterk gestegen grond- en woningprijzen (mede als doorwerking van de publieke subsidiëring), waardoor ook nieuwe huurwoningen een steeds hogere huuropbrengst moeten genereren dan vorige jaargangen, waardoor een gezonde doorstroming op de huurmarkt belemmerd wordt (wie blijft 'zitten' wordt immers niet geconfronteerd met al te sterke huurstijgingen). Het gevolg daarvan is weer dat gemeenten en wooncorporaties steeds vaker concluderen dat woningen die soms nog maar enkele decennia oud zijn en die nog in een heel redelijke staat (terug te brengen) zijn, tegen de vlakte moeten. De huuropbrengsten zijn (kunstmatig) te laag om deze woningen aantrekkelijk bezit te doen zijn; op de vrijgekomen grond kunnen dan dure huur- of koopwoningen worden teruggebouwd die dat wél zijn. Kortom, de kunstmatigheden van een verstoorde markt hebben zich opgestapeld. Dat is natuurlijk niet onopgemerkt gebleven. Het beleid is deze problemen al jarenlang aan het repareren en de hoofdzaak - een (zeer) geleidelijke afbouw van de fiscale subsidiëring van de koopsector in relatie tot een evenwichtig pakket voor het hele volkshuisvestingsterrein - zal de komende tijd naar alle verwachting op de agenda komen.

Ook de rol en positie van wooncorporaties is de laatste twintig jaar ingrijpend veranderd (Brandsen en Helderman 2006; Hazeu 2004). De corporaties (1) hebben een veel autonomere positie gekregen dan in het verleden, (2) hebben een ruimere taakopdracht, en (3) beschikken in het algemeen over forse financiële middelen om die taakopdracht ook in te kunnen vullen. In 1993 is het Besluit 
Beheer Sociale Huursector (BBSH) ingevoerd, dat tegenwoordig als de 'grondwet' voor de sociale huursector geldt. Het BBSH regelt dat wooncorporaties hun vermogen ook inzetten voor maatschappelijke vraagstukken, maar daarvoor zelf verantwoordelijk zijn. 'De politiek' heeft zichzelf in een (te) afstandelijke rol geplaatst en kan niet veel afdwingen in deze. De wooncorporaties bezitten zo'n 29 miljard aan eigen vermogen en jaarlijks (cijfer 2004) besteden ze 4,6 miljard aan maatschappelijke of sociale investeringen in de woningbouw of op andere terreinen. Dit investeringspotentieel maakt dat de huursector een belangrijke functie zou kunnen hebben in het mogelijk maken van een levensloopbestendige wooncarrière.

Brandsen en Helderman (2006) stellen vast dat de mogelijkheid tot 'maatschappelijk ondernemerschap' van de wooncorporaties er in de eerste fase van de jaren negentig toe leidde dat sommige zich inlieten met tamelijk buitenissige activiteiten (veelal luxediensten), terwijl andere min of meer slapend rijk werden. Anno nu constateren ze dat meer corporaties combinaties van wonen en zorg beginnen aan te bieden. Verder hebben veel corporaties allianties met zorginstellingen gesloten en bieden ze geïntegreerde woonzorgpakketten aan. Daarnaast ontwikkelen ze activiteiten gericht op versterking van de sociale structuur, vanuit het idee dat de corporaties met hun omvangrijke bezit in veel wijken en buurten een dominante speler zijn, die meer (zouden moeten) kunnen dan stenen stapelen en ook een bijdrage kunnen leveren aan de leefbaarheid. Niettemin is de bestuurlijke conclusie dat de overheid afhankelijk is van wat de wooncorporaties van hun 'maatschappelijke ondernemerschap' maken (Hazeu 2004); de overheid beschikt in de huidige bestuurlijke constellatie over (te) weinig harde instrumenten om bijvoorbeeld te bereiken dat er voldoende woningen komen waarin ook een zorgfunctie (beter) verdisconteerd wordt. Toch biedt juist ook dit gebied de corporaties mogelijkheden om een nieuw pact met de overheid te sluiten over hun maatschappelijke opdracht. In dat licht valt ook te denken aan het (her)bewerkstelligen van een betere 'ophanging' van wooncorporaties in relatie tot decentrale overheden op het brede volkshuisvestelijke terrein.

\subsection{CONCLUSIE: DE VERZORGENDE VERZORGINGSSTAAT}

\section{Verzorgingstekort}

De komende decennia heeft Nederland - net als alle andere westerse verzorgingsstaten - te kampen met de gevolgen van een vergrijzende bevolking. Ook als we ervan uitgaan dat het leeuwendeel van de mensen niet of nauwelijks een beroep hoeft te doen op de zorg van anderen, blijft staan dat de laatste levensjaren een onvermijdelijke zorgbehoefte met zich meebrengen. Dat kan ertoe leiden dat in 2020 een (formele en informele) zorgcapaciteit nodig is die bijna vijftig procent hoger is dan nu. Tot nu toe stond het debat daarover vooral in het teken van de stijgende kosten: die kosten zijn er, maar ze vormen nog het meest beheersbare deel het probleem. In personele en huisvestelijke zin is de opgave nog groter. Doorrekeningen leren dat binnenkort, maar zeker na 2015 als de vergrijzing versneld doorzet, zo ongeveer alle schoolverlaters en alle nieuw gebouwde wonin- 
gen beschikbaar zouden moeten komen voor de zorgsector. Dat is een weinig realistisch en weinig wenselijk scenario. Er is dus een offensiever beleid nodig om dit dreigende 'verzorgingstekort' te accommoderen. Dit verschijnsel is overigens niet uniek voor Nederland. Het is niet voor niets dat de OECD (2005) een offensief beleid op twee fronten bepleit: de kwantitatieve en kwalitatieve ontwikkeling van de formele zorg én de informele zorg.

\section{Randvoorwaardelijk beleid}

Een deel van de antwoorden zal gevonden kunnen worden in een scala van maatregelen die gericht zijn op het beter functioneren van de institutionele zorg. Technische oplossingen ('slimmer werken' door meer inzet van low- en hightech), infrastructurele oplossingen (zo bouwen dat ouderen beter voor elkaar kunnen zorgen), organisatorische oplossingen (herziening van de taakdifferentiatie), inhoudelijke oplossingen (voldoende aandacht voor preventieve activiteiten, met name voor ouderen), eventuele arbeidsmarkttechnische (selectieve migratie) en faciliterende oplossingen (selectieve emigratie van ouderen) zullen alle stuk voor stuk kleine bijdragen kunnen en moeten leveren aan het probleem van de dreigende zorgkloof.

Een belangrijk deel van het antwoord zal echter gevonden moeten worden door het beleid verder te richten dan alleen op de institutionele zorg. Werd in de inleiding van dit hoofdstuk al aangegeven dat het overheidsbeleid van de afgelopen honderdvijftig jaar de eerste vijftig jaar in het teken stond van kwaliteitswetgeving, toen van financiering van de zorg en daarna van de vormgeving van de institutionele zorg, de komende decennia lijkt de opdracht vooral te zijn om de randvoorwaarden te creëren voor het kunnen verlenen van zorg - en dat betekent dat de blik verschoven moet worden van de institutionele zorg naar de voorwaarden die het mogelijk maken dat er voldoende zorg verleend kan worden.

Een eerste stap die in dat opzicht overwogen zou kunnen worden, is het verder loslaten van de directe sturing van de care-sector via het huidige stelsel van aanbodfinanciering door dat verder om te bouwen naar een stelsel van vraagfinanciering. Persoonsgebonden budgetten zijn nu nog te veel een uitzondering. Ze leiden daarom nog onvoldoende tot het verder ontwikkelen van een gedifferentieerd aanbod in de care-sector en maken in deze sector nog geen einde aan eenvormigheid en categorale segmentatie. Er zal een divers palet tot ontwikkeling moeten komen van (private) voorzieningen die zich rechtstreeks richten op mensen met een chronische zorgbehoefte die daarvoor over een genormeerd bedrag beschikken, maar aan wie het ook vrij staat om uit eigen middelen extra geld toe te voegen ter wille van een hoger niveau van dienstverlening. Voor wie daar geen behoefte aan heeft, zou een standaardpakket beschikbaar moeten blijven. De rol van de overheid bij het realiseren van een stelsel van voorzieningen wordt zo afstandelijker - een belangrijk deel van de investeringsbeslissingen verloopt dan immer via private partijen en de kwaliteitsbeoordeling komt evenzeer in handen van de gebruikers te liggen. In plaats daarvan zou de overheid haar energie meer kunnen richten op randvoorwaarden die het mogelijk maken 
dat in een vergrijzende samenleving ook nog voldoende gezorgd kan worden. Een evident aandachtspunt daarbij is het faciliteren van informele zorg. Het is te eenvoudig om aan te nemen dat de geschatte toename van de zorgvraag door deze vorm van zorg kan worden opgevangen. De hoogopgeleide burgers van de toekomst wensen juist professionele zorg, en Nederlanders zijn wel bereid om te zorgen, maar niet zo intensief als nodig is. Met het oog op het lage geboortecijfer en de toenemende arbeidsdeelname van ouderen en vrouwen, is het al moeilijk genoeg om de informele zorg minstens op het huidige peil te laten blijven. Daarvoor zijn twee beleidsaccenten vereist. In de eerste plaats kan de informele zorg alleen in stand blijven en kwalitatief goed zijn als de keus om te zorgen in vrijheid wordt gemaakt. Dat betekent geen afname van de formele zorg, integendeel. Professionele zorg moet informele zorg kunnen overnemen en potentieel beschikbaar zijn. Bovendien is het zaak dat de formele zorg voldoende rekening houdt met de deskundigheid - maar ook met de noden - van informele zorgers. In de tweede plaats is het voor de instandhouding van informele zorg van belang dat mensen tijd en geld hebben om te kunnen zorgen, zeker in het licht van de toekomstige economie. Dit betekent niet alleen de mogelijkheid van deeltijdarbeid, maar ook goede verlofregelingen. Dat kan ook helpen om het potentieel aan mannelijke mantelzorgers en jongere ouderen aan te boren. Het is een illusie om te denken dat zoiets al vormgegeven is met de invoering van de huidige levensloopregeling: die is niet effectief genoeg om mensen in de toekomst een mogelijkheid te bieden om te zorgen. Een koppeling met regelingen voor minder intensief werken vanaf het 55 ste levensjaar ligt al meer voor de hand.

Tot slot is het zaak om tegelijkertijd voor de invulling van de verzorgingsfunctie ook verder te kijken dan de zorgsector. Er is bijvoorbeeld niet alleen sprake van een (dreigend) verzorgingstekort, maar ook van een 'overschot' aan ruime collectieve middelen (zowel in de vorm van publieke uitgaven als fiscale facilitering) voor de volkshuisvestingssector. Dat is vanuit de historie van de Nederlandse verzorgingsstaat wel verklaarbaar, maar in de huidige welvarende samenleving zal er ruimte moeten worden gemaakt om te zorgen. 


\section{VERZEKEREN: BALANCEREN TUSSEN ONDER- EN OVERVERZEKERING}

\subsection{INLEIDING}

De verzekeringsfunctie van de Nederlandse verzorgingsstaat is in de loop der tijd vormgegeven in een groot palet aan arrangementen. Dit hoofdstuk gaat over hoe we die verzekeringsfunctie hebben ingevuld, en welke veranderingen daarin wenselijk zijn gegeven de uitdagingen waar de (Nederlandse) verzorgingsstaat nu voor staat: vergrijzing, internationalisering, veranderende economie, veranderende burgers. In het licht van die uitdagingen (zie hoofdstuk 3 ), en door ons met vergelijkbare buitenlanden te vergelijken (zie hoofdstuk 4 ), is het zaak om te bepalen waar we wellicht onder- dan wel oververzekerd zijn.

Het hoofdstuk is als volgt opgebouwd. In paragraaf 6.2 wordt een karakterisering gegeven van de mate waarin en wijze waarop de verzekeringsfunctie in de Nederlandse verzorgingsstaat geleidelijk vorm heeft gekregen. In paragraaf 6.3 wordt vervolgens in beeld gebracht hoe de verzekeringsfunctie anno nu materieel uitpakt: welke groepen en risico's verzekert de Nederlandse verzorgingsstaat ruim of juist karig? Daarbij wordt zowel historisch als internationaal vergeleken. In paragraaf 6.4 wordt geschetst hoe we in de loop der tijd - door zowel externe invloeden als door de systeeminterne dynamiek - zijn gaan denken over de (sociale) verzekeringsfunctie en de vormgeving ervan. Dat veel 'verzekering' niet langer volledig vorm krijgt onder condities van een veil of ignorance, maar dat er zoiets als calculerend gedrag bestaat waarvan we het nodige weten, speelt een belangrijke rol in de verandering van opvattingen. Ook de ontwikkeling van de 'transitionele arbeidsmarkt' is van belang, omdat die een antwoord vraagt op de erbij behorende 'nieuwe risico's'. Dat brengt ons op vraagstukken van beïnvloedbaarheid van risico's, verdeling van verantwoordelijkheden en de bijbehorende besturingsvragen; die komen in paragraaf 6.5 aan de orde. In paragraaf 6.6 wordt de stand van zaken opgemaakt met betrekking tot de verzekeringsfunctie: waar verzekert de verzorgingsstaat - in het licht van de huidige en toekomstige noden en prioriteiten - onder of over? Hoe en wat zou er anders moeten? Welke 'uitruilen' binnen de verzekeringsfunctie zijn denkbaar? In paragraaf 6.7 ten slotte wordt de conclusie getrokken.

\subsection{RISICOMANAGEMENT IN DE NEDERLANDSE VERZORGINGSSTAAT: MATE EN VORMEN}

\subsubsection{VERZEKEREN: PUBLIEK EN PRIVAAT}

\section{Substituten voor verzekering}

Wanneer we de verzekeringsfunctie van de verzorgingsstaat in ogenschouw nemen, dienen we ons in de eerste plaats te realiseren dat we daarmee een component te pakken hebben van het ruimere fenomeen 'verzekeren': het 
menselijk zoeken naar zekerheid en vermijden van risico's in het algemeen. Er is, met andere woorden, ook veel 'verzekering' (arrangementen, zekerheidszoekend gedrag) buiten de collectieve sector. Zo zorgen gezin, familie en samenlevingsverbanden voor bepaalde zekerheden. Ook is er in beginsel substitutie mogelijk tussen (je) verzekeren en sparen (reserves achter de hand houden). Bij die keuze tussen verzekeren en sparen zijn de omvang en de spreiding van het risico belangrijke overwegingen. Verzekeren is een doelmatige vorm van inkomensbescherming voor risico's die kunnen leiden tot een omvangrijke schade en die ongelijk gespreid zijn over de populatie. Voor een groot risico als duurzame arbeidsongeschiktheid of langdurige werkloosheid is sparen een onhaalbare kaart. Sparen is eerder een optie voor risico's waar veel mensen ooit mee te maken krijgen, zoals aanvullende pensioenen, of voor kleine risico's die samenhangen met nalatig gedrag.

\section{Motieven voor sociale verzekeringen}

Naast sociale verzekeringen kennen we ook een omvattende particuliere verzekeringsmarkt waarin tal van verzekeringen worden aangeboden - niet alleen reis- en autoschadeverzekeringen, maar ook bijvoorbeeld verzekeringen tegen vormen van inkomensverlies. Dit impliceert dat er ook altijd een zekere substitutie (mogelijk) is tussen de publieke verzekeringen van de verzorgingsstaat en de eveneens omvangrijke private component. Private verzekeringen vormen een enorme bedrijfstak op wereldschaal; sociale verzekeringen een grote, bijna altijd nationaal georganiseerde activiteit. Waarom is er die splitsing tussen wat op de markt wordt verzekerd en wat door de overheid wordt geregeld?

In de eerste plaats neemt de overheid soms de rol van verzekeraar op zich omdat de markt het slecht kan. Dat is het geval bij gecorreleerd risico of systeemrisico. In een economische recessie verdubbelt bijvoorbeeld het werkloosheidsrisico vergeleken met het niveau tijdens een hoogconjunctuur. Alleen de overheid kan zulke risico's dragen en de kosten ervan omslaan en spreiden in de tijd, door het financieringstekort tijdens de recessie te laten oplopen en later weer af te bouwen. Een hypothetische private werkloosheidsverzekering daarentegen zou vermoedelijk leiden tot een verdubbeling van de premie tijdens een laagconjunctuur; uit oogpunt van een maatschappelijk gewenste evenwichtige macro-economische ontwikkeling in de tijd is dat ongewenst.

Verder speelt dat er twee belangrijke vormen van 'verzekeringsfalen' zijn: averechtse selectie (adverse selection) en het morele gevaar van oneigenlijk gebruik en misbruik (moral hazard). Averechtse selectie doet zich voor wanneer verzekeraars hun risicopopulatie willen selecteren, dat wil zeggen: sommige mensen uitsluiten van een verzekering. Sociale doelstellingen van verzekeringen, bijvoorbeeld solidariteit tussen allen, kunnen hierdoor niet gerealiseerd worden. Een ander probleem bij private verzekeringen is dat een verzekeraar de kenmerken van zijn verzekerde populatie vaak niet goed kan inschatten en - zekerheidshalve - de premie (te) hoog inzet, met als mogelijk 
gevolg dat hij alleen maar 'slechte risico's' aantrekt, en uiteindelijk de verzekeringsmarkt (voor iedereen) kan verdwijnen (Akerlof 1970; Hazeu 2000).

Moral hazard is de tweede inherente dreiging voor een verzekering. Het verzekeringsstramien houdt in dat er risico's worden gepoold met onbekende anderen. De basis daarvan is gedeelde kwetsbaarheid: het kan ons allemaal overkomen, en we weten van tevoren niet wie het zal overkomen. Bij (sociale) verzekeringen zijn die 'anderen' geen vrienden of familie, het zijn anonieme anderen. Dat gegeven verhoogt altijd het morele gevaar, zeker als het relevante collectief grootschalig is. De systemen moeten dus zó gemaakt worden dat dit moreel gevaar beheerst wordt. Verzekeringsequivalentie is er immers op gebaseerd dat individuen hun risico niet (kunnen) beïnvloeden. Als het moreel gevaar te groot en/of te zichtbaar wordt, kan dit de legitimiteit van verzekeringen ondergraven. Dat is de afgelopen drie decennia tot op zekere hoogte ook gebeurd. Vervolgens, maar wel vertraagd, zijn door het beleid maatregelen genomen. Regelingen werden minder aantrekkelijk gemaakt, controle en toelating werd strenger en de uittreding uit regelingen werd gestimuleerd. Een groot aantal herzieningsoperaties van sociale regelingen van de afgelopen decennia hebben in dat licht gestaan. Moreel gevaar is dus niet per se een onoplosbaar probleem; wél is het zaak dat het beleid hier permanente aandacht voor heeft.

Publieke, sociale verzekeringen waarin niet aan selectie wordt gedaan, vinden dus hun basis in het bestaan van gecorreleerd risico, averechtse selectie en moreel gevaar. Doordat iedereen is ingesloten in publieke verzekeringen, is er geen averechtse selectie: 'goede risico's' die zich niet snel voor een private verzekering zouden aanmelden, moeten immers ook meedoen. Dat geeft schaalvoordelen en spaart veel transactiekosten uit. Wanneer iedereen wordt ingesloten in publieke verzekeringen blijft het probleem van moreel gevaar wel bestaan, omdat mensen in de verleiding komen ten onrechte aanspraak op een uitkering te doen. Er zijn dus 'poortwachters' nodig om de toegang tot uitkeringen te reguleren. Verder zijn er, om aanspraken te beheersen, in private verzekeringen tal van praktische oplossingen bedacht die zijn ingebouwd in verzekeringscontracten en regelgeving, die in beginsel ook binnen publieke verzekeringsvormen een dergelijke functie kunnen vervullen. Hierbij kan gedacht worden aan eigen risico, onvolledige verzekeringen, of het wettelijk verplicht stellen (bij de autoverzekering).

\section{Verzekeringen en voorzieningen}

Het is hier van belang om het onderscheid tussen (sociale) verzekeringen en voorzieningen te stipuleren. Verzekeringen zijn er om risico's af te dekken die ex-ante alleen een verwachtingswaarde hebben. Voorzieningen (onderwijs, gezondheidszorg, kinderopvang, enzovoorts) leveren een dienst. Bij voorzieningen in overdrachtelijke zin wordt er soms wel gesproken van een verzekeringsfunctieonderwijs 'verzekert' mensen van goede opleidingsmogelijkheden. Maar anders dan echte verzekeringen, worden voorzieningen (nagenoeg) volledig betaald uit algemene middelen, en zijn er geen verzekeringspremies en -principes op van 
toepassing. Het onderscheid is overigens niet altijd waterdicht. De Bijstand is bijvoorbeeld een voorziening die gefinancierd wordt uit belastinggeld, maar die burgers wel van een inkomen 'verzekert'. Ook de volksverzekeringen (denk met name aan de AOw) zijn eigenlijk een hybride: hier is de sociale verzekeringsvorm gekozen om de kosten om te slaan over een grote groep van werkende premiebetalers. Het halen van de 65 -jarige leeftijd is tegenwoordig echter een goed voorspelbaar 'risico'. En wie niet vijftig jaar in Nederland heeft gewoond, en daarmee vanuit de gekozen verzekeringssystematiek geen volledige AOw heeft opgebouwd, krijgt die op zijn 65ste jaar tóch via aanvulling uit de Bijstand. Verder - en ook dat aspect maakt deze volksverzekering tot een hybride - geldt al langer dat een (toenemend) deel van de Aow betaald wordt uit algemene belastingmiddelen (fiscalisering).

\subsubsection{SOCIALE VERZEKERINGEN}

De verzekeringsfunctie is van oudsher een van de centrale functies van wat gaandeweg 'de verzorgingsstaat' is geworden. Die functie bestaat uit het helpen managen van de risico's van inkomensverlies waar het individu redelijkerwijs zelf niet de hand in heeft of kan hebben. Daarbij is de moderne verzorgingsstaat overgegaan tot decommodificatie (Esping-Andersen 1990). Ze komt mensen niet tegemoet met voedsel, voedselbonnen, een dak boven het hoofd, een baan(tje) of een andere in-naturavorm om hun inkomensverlies te compenseren, maar biedt hen een vrij besteedbare uitkering als (vervangend) inkomen. Zo blijft de 'moderne' autonome beslissings- en bestedingsvrijheid van het individu in tact. Het is geen bedeling, is het idee; je hebt immers premie betaald.

Sociale verzekeringen zijn gebaseerd op het idee om mensen compensatie te bieden voor de gevolgen van externe risico's. Dit basisidee draagt nog steeds de solidariteitsverbanden en legitimiteit van de erop gestoelde arrangementen in zich. Solidariteit in een sociale verzekeringscontext brengt dus tweerichtingsverkeer met zich mee: niet alleen ontstaan er rechten op aanspraken in een reeks nader omschreven gevallen, maar er zijn ook plichten om (oneigenlijke) aanspraken te voorkomen. Die wederkerigheid is ook altijd in de relevante wetsteksten expliciet tot uitdrukking gebracht: “. . . al datgene doen om te voorkomen dat..."

Dat mensen zich - tot op zekere hoogte, en onder bepaalde condities - verzekerd kunnen weten tegen inkomensverlies werd van toenemend belang in de opkomende industriële samenleving. Immers, met de trek van het platteland naar de stad bood de extended family steeds minder zekerheid. Dit heeft geleid tot 'bismarckiaanse' sociale regelingen: verzekeringen tegen risico's die verbonden zijn aan de moderne, industriële arbeidsrelaties. Deze regelingen vormen ook in Nederland de oudste wortels van onze verzorgingsstaat. Ze zijn in hun werkingssfeer beperkt tot (bepaalde groepen) van werknemers; vandaar de term werknemersverzekeringen. De gepoolde risico's betreffen met name de gevolgen van ziekte, arbeidsinvaliditeit en werkloosheid. 
De werknemersverzekeringen worden van oorsprong georganiseerd door gezamenlijkheden van werknemers- en werkgeversorganisaties: het (sectorale) 'middenveld'. In de loop van de twintigste eeuw zijn die regelingen qua financiering en besturing gaandeweg verstatelijkt (zie uitvoeriger par. 5.2). Dit hing samen met de wording van de moderne verzorgingsstaat, de groei van het stelsel, en daarmee ook de groeiende noodzaak om het totaal van de arbeidskosten en de collectieve lastendruk te beheersen in een steeds meer concurrerende wereldeconomie. De belangrijkste werknemersverzekeringen anno nu zijn de WW, ZW en WAO (sinds 2006 is de WAO voor nieuwe gevallen overgegaan in de WIA). De Bijstand is een uit de belastingen gefinancierd publiek sluitstuk ('restvoorziening') op de werknemersverzekeringen. De Bijstand verzekert van een basisinkomen, maar onder de strikte condities van een vermogens- en een partnertoets.

Na de Tweede Wereldoorlog is de verzekeringsfunctie verder uitgebouwd en veralgemeniseerd. Daarmee is de functie van zijn bismarckiaanse wortels (van werknemers in een branche of bedrijf die baan- en werkrisico's met elkaar delen) losgekomen. Als reactie op de verschrikkingen van die oorlog werd het gedachtegoed van Beveridge maatgevend. Het was voortaan een taak van de overheid om zijn burgers te vrijwaren van armoede. Voor het eerst in de moderne tijd werden nationale overheden zo sterk geacht dat ze die rol konden en moesten gaan spelen. Het gedachtegoed van Beveridge heeft ook in Nederland de inspiratie gevormd voor de (geleidelijke) opbouw en voltooiing van een stelsel van volksverzekeringen: AOW, AKW, ANW, AWBZ.

Naast de sociale werknemers- en volksverzekeringen en voorzieningen als de Bijstand, maar ook de huurtoeslag, bestaan er tal van andere belangrijke publieke dan wel private arrangementen die in ruime en overdrachtelijke zin een verzekeringsfunctie hebben: pensioen, ontslagbescherming, een 'vaste' baan met een jaarlijks stijgend inkomen, de zekerheid van hypotheekrenteaftrek, een (stabiel) samenlevingsverband, enzovoorts. Het in beeld brengen van dit hele palet is van belang, omdat daarmee zichtbaar gemaakt kan worden welke 'uitruil'relaties er te bedenken zijn tussen verschillende verzekeringsarrangementen in ruime zin.

\subsubsection{SUBCONCLUSIE: VERANDERENDE UITDAGINGEN; GEËVALUEERDE VERZE- KERINGEN}

De vormgeving van de verzekeringsfunctie van de verzorgingsstaat is, in reactie op veranderende noden en wensen, geëvolueerd in de tijd. Verzekeren als functie is dan wel een constante, maar hoe en in welke mate we er vorm aan geven, is veranderlijk en ook veranderd. Het veranderen van een sociale wet is als zodanig een moeizaam proces, maar als het nodig was, is er niettemin gerepareerd aan de verzekeringen. Daardoor is het systeem grosso modo bij de tijd gebleven. 


\subsection{WELKE RISICO'S ZIJN HOE VERZEKERD; EEN PLAATSBEPALING}

\subsubsection{INLEIDING}

Welke risico's en welke groepen zijn relatief goed sociaal verzekerd in Nederland, en welke minder? Het antwoord op die vraag geeft een handvat voor de beantwoording van de vraag of en zo ja waar we eventueel met minder verzekering toe kunnen, om ruimte te scheppen voor de andere functies van de verzorgingsstaat. Die plaatsbepaling komt tot stand op basis van een analyse van de historische ontwikkeling (6.3.2) en door internationaal te vergelijken (6.3.3).

\subsubsection{EEN HISTORISCHE PLAATSBEPALING NAAR RISICO'S EN GROEPEN: OUD VERSUS JONG}

Waar ligt in Nederland het accent als het gaat om sociale zekerheid? In hoofdstuk 5 werd al het beeld geschetst van Nederland als een land dat op het gebied van zorg altijd een sterk accent gelegd heeft op ouderen. Geldt dat ook voor verzekeringen? Een eerste oppervlakkige blik leidt in ieder geval tot die impressie. In Nederland is de afgelopen dertig jaar bijvoorbeeld veel gebruik gemaakt van de WAO. Die regeling is veelvuldig gebruikt om oudere werknemers voortijdig en blijvend te laten afvloeien van de arbeidsmarkt. Dit leidde ertoe dat ouderen (van onder de 65 jaar) relatief goed verzekerd zijn in de Nederlandse verzorgingsstaat: (1) als het tegenzit vervallen ze niet tot armoede, maar kunnen ze hun inkomen, status en levensstijl grosso modo handhaven, en (2) de 57-plus-categorie is decennialang feitelijk ontheven geweest van de wettelijke sollicitatieplicht. Deze situatie is de laatste jaren gaandeweg verschoven, mede door verschillende beleidsingrepen. Denk aan de herziening van de WAO en de ww, de afschaffing van de VUT, en - in het kader van de ww-herziening per 1 oktober 2006 - het herstel van de wettelijke sollicitatieplicht. De voorzieningen die de Nederlandse verzorgingsstaat biedt in de levensfase met (jonge) kinderen is onveranderd karig. Een - in vergelijking met veel landen - beperkte ouderschapsverlofregeling en een - in vergelijk de Scandinavische landen - beperkte omvang en late groei van kinderopvangvoorzieningen. Welk beeld rijst er als we specifieker kijken naar het gebruik van sociale zekerheid?

\section{Oud en jong in de werknemersverzekeringen en Bijstand}

Tabel 6.1 Aandeel van deelname van leeftijdscategorieën in de sociale zekerheid, 2006

\begin{tabular}{|lcc|} 
& $\mathbf{1 5 - 3 5}$ jaar & $\mathbf{4 5 - 6 5}$ jaar \\
Bijstandsuitkeringen & $30 \%$ & $43 \%$ \\
Werkloosheidsuitkeringen & $21 \%$ & $52 \%$ \\
Arbeidsongeschiktheidsuitkeringen & $12 \%$ & $71 \%$ \\
\hline
\end{tabular}

Bron: CBS 
Uit tabel 6.1 blijkt dat het beroep dat de leeftijdscategorie van 45 tot 65 jaar doet op de sociale zekerheid 1,5 (Bijstand) tot 6 (WAO) maal zo groot is als het beroep van de leeftijdscategorie van 15 tot 35 jaar. Omdat de beide leeftijdscategorieën zowel in de bevolking als in de beroepsbevolking vrijwel even groot zijn, gelden deze verhoudingen vrijwel ongewijzigd als het gaat om de verschillen per hoofd. De verschillen tussen 'jong' en 'oud' zijn nog groter als gekeken wordt naar het financiële beslag. De werknemersverzekeringen zijn immers gedurende de wwperiode loongerelateerd. In deze periode voorzien ze in een uitkering die afhankelijk is van het laatstverdiende inkomen. Omdat ouderen gemiddeld genomen meer verdienen dan jongeren, terwijl ouderen als regel ook een langer arbeidsverleden hebben, is het financiële beslag per oudere groter dan per jongere. Dat is inherent aan de aard van de regelingen.

\section{Pensioenen}

Pensioenen zijn een private (als regel via bedrijf of bedrijfstak geregelde) zaak, maar worden publiek opgelegd (pensioenplicht) en gefaciliteerd door de inkomstenbelasting. Als gevolg van de omkeerregel in de inkomensbelasting zijn betaalde pensioenpremies aftrekbaar en wordt er pas bij uitkering van de pensioenen inkomstenbelasting over geheven. De belastingderving die daarmee gemoeid is, kan op jaarbasis geschat worden op zo'n negen miljard euro (Caminada en Goudswaard 2004) - bijna twee procent van het nationaal inkomen. De daaruitvolgende - omvangrijke en groeiende - latente belastingschuld van toekomstige pensionado's draagt eraan bij dat de toekomstige betaalbaarheid van de Nederlandse verzorgingsstaat relatief gunstig afsteekt bij andere landen, die geen of een veel minder omvangrijk tweedepijler pensioenstelsel kennen. Nederland doet, vergeleken met de meeste andere landen, veel aan pensioenopbouw. In de beoordeling van de vraag waar we relatief goed verzekerd zijn, tikt die zware pensioenvoorziening stevig aan.

Om de relatieve positie van verschillende leeftijdsgroepen te beoordelen is het zaak verder te kijken dan het gebruik van sociale zekerheid en de opbouw van pensioenrechten. Ook het bezit van vermogen is van belang: van het fiscaal gepremieerde eigenhuizenbezit is als regel op rijpere leeftijd de hypotheeklast vrijgevallen. Ook dat bevordert een relatief ruime materiële welvaart op die leeftijd. Eigen huizen vormden vroeger een vorm van pensioenvoorziening, nu is er eerder sprake van 'dubbel op'. Op dit moment heeft ongeveer veertig procent van de 65-plussers een eigen woning. De schuld hierop bedraagt volgens het Woning Behoefte Onderzoek 2002 slechts dertien procent van de waarde (Ministerie van VWS 2005, p. 28). Daardoor hebben ouderen met een eigen woning een relatief veel groter vermogen dan anderen. Bovendien hebben ze vaak ook nog vermogen uit hoofde van andere bezittingen. Het totale vermogen (pensioenen + woningbezit + andere tegoeden - schulden) van alle Nederlanders samen bedraagt overigens anno 2005 zo'n 2.260 miljard euro (NRC, 11 maart 2006); dat is gemiddeld 140.00o euro per Nederlander. Dat is een behoorlijk hoog gemiddelde, maar dat zegt niets over de spreiding. Wat het onderdeel pensioenen betreft is er eerder een intragenerationeel probleem dan een intergenerationeel probleem. Anders 
gezegd, bij pensioenen is de lastenverdeling tussen generaties minder een probleem dan de lastenverdeling binnen een generatie. Het intragenerationele probleem is dat er bij de huidige ouderen mensen zijn die geen pensioen hebben opgebouwd of slechts een zeer onvolledig pensioen (met name vrouwen en kleine zelfstandigen). In de toekomst zal dit probleem geleidelijk kleiner worden, maar niet geheel verdwijnen (Ministerie van SZW/Thio 2002, p. 11).

Kortom, vergeleken met 'jong' (the spring season of human life; vgl. Bovenberg 2005) en 'middelbaar' (summer season) is 'oud' (fall en winter seasons) als groep goed verzekerd in de Nederlandse verzorgingsstaat. Dit algemene beeld verschilt echter per individu, en ook naar leeftijdscohort. Daarbij springt met name de generatie die geboren is tussen 1940 en 1950 er goed uit; de recente herzieningen in pensioen en VUT hebben het 'plaatje van profijt naar leeftijd' voor de generaties die daarna komen inmiddels minder gunstiger gemaakt.

\section{Oud versus jong gedynamiseerd}

Om het beeld verder te verscherpen is ook van belang of de inkomenspositie van ouderen in de komende jaren nog zal verbeteren ten opzichte van 65-minners. Dat blijkt, met name vanwege een toename van het inkomen uit aanvullend pensioen, in behoorlijke mate het geval. Het Ministerie van Szw/Thio (2002, p. 15) laat hierover de volgende te verwachten ontwikkeling zien (tabel 6.2). Daarbij is overigens de inkomensontwikkeling uit vermogensvorming nog onderschat, maar anderzijds zijn de recente pensioenherzieningen hier nog niet in begrepen. ${ }^{1}$

Tabel 6.2 Ratio gemiddeld besteedbaar inkomen huishoudens boven 65 jaar ten opzichte van inkomen van andere groepen huishoudens

\begin{tabular}{|lccc} 
& t.o.v. sociaal minimum & t.o.v. $65-$ & t.o.v. actief \\
2000 & 1,73 & 0,68 & 0,63 \\
2005 & 1,85 & 0,75 & 0,69 \\
2010 & 2,00 & 0,81 & 0,72 \\
2015 & 2,19 & 0,88 & 0,77 \\
2020 & 2,34 & 0,93 & 0,81 \\
\hline
\end{tabular}

Bron: SzW/Thio 2002

De tabel toont de ratio van het gemiddeld besteedbaar inkomen van de populatie ouder dan 65 jaar ten opzichte van een huishouden op het sociaal minimum, het gemiddeld besteedbaar inkomen onder 65 jaar, en het gemiddeld inkomen van huishoudens met inkomen uit arbeid. In 2000 bedraagt het gemiddeld besteedbaar inkomen van ouderen bijvoorbeeld 1,73 maal het sociaal minimum. In 2020 is het gemiddeld inkomen van ouderen gemiddeld waarschijnlijk meer dan 2,3 maal het sociaal minimum. De tabel laat ook zien dat het gemiddeld inkomen van 65-plussers tot 2020 snellertoeneemt dan dat van 65-minners. In 2000 is het gemiddeld besteedbaar inkomen van 65 -plussers gemiddeld 68 procent van dat 
van de leeftijdsgroep onder 65 jaar en dat neemt toe tot 93 procent in 2020 . Ten opzichte van huishoudens met inkomen uit arbeid neemt het besteedbaar inkomen van 65-plussers toe van gemiddeld 63 procent in 2000 tot 81 procent in 2020. $\mathrm{Bij}$ deze cijfers is ten dele sprake van (1) een inhaaleffect als gevolg van bijvoorbeeld de groei van het aantal huishoudens met inkomen uit aanvullend pensioen, (2) de toegenomen arbeidsparticipatie van vrouwen die leidt tot meer tweepersoonshuishoudens waarin beide partners inkomen uit aanvullend pensioen hebben, en (3) de groei van het inkomen uit aanvullend pensioen als gevolg van het volgroeien van pensioenregelingen. Hieruit volgt dat de sterke groei van de inkomenspositie van ouderen niet altijd zal doorgaan en na 2020 zal afzwakken.

\subsubsection{EEN INTERNATIONAAL-VERGELIJKENDE PLAATSBEPALING}

\section{De verzekering van arbeidsmarktrisico's internationaal vergeleken}

De verzekeringsfunctie - in de verzorgingsstaat vormgegeven - voor de risico's tijdens het werkzame leven heeft betrekking op inkomensverlies door werkloosheid en door ziekte/arbeidsongeschiktheid. Daarbij gaan we er voor Nederland dat hierin verschilt van bijvoorbeeld de vs - vanuit dat het wettelijk minimumloon garandeert dat werkenden geen armoederisico lopen. Bij het verzekeren tegen de gevolgen van werkloosheid gaat het overigens niet alleen om ww en

Bijstand, maar ook om het tegengaan van die werkloosheid zelf door middel van meer overdrachtelijke verzekeringsarrangementen. Denk hierbij aan de ontslagbescherming die werkenden hebben, en een actief arbeidsmarktbeleid waar werklozen en arbeidsongeschikten bij gebaat zijn.

In 2004 gaf Nederland 2,5 procent van het nationaal inkomen uit aan uitkeringen vanwege arbeidsongeschiktheid, en 0,8 procent aan uitkeringen vanwege werkloosheid. Het СРВ/De Mooij (2006, hoofdstuk 4, p. 89) geeft een tabel waarin de Nederlandse verzekering tegen deze arbeidsmarktrisico's wordt vergeleken met een tiental andere Europese landen en de vs. Die tabel laat zien dat de hoogte van de Nederlandse wW (7o procent) niet exceptioneel is vergeleken met andere landen (variërend van 50 tot 90 procent). Wél is de maximale uitkeringsduur (tot de wetswijziging van 1 oktober 2006 bedroeg die 60 maanden) lang; maar die is nu ingekort tot 38 maanden. De internationale vergelijking laat tevens zien dat Nederland een hoog WAO-uitkeringsniveau heeft; alleen Denemarken zit hoger.

De OECD heeft een maatstaf ontwikkeld om de mate van baanbescherming te kunnen vaststellen, de EPL-indicator (Employment Protection Legislation). Daaruit blijkt ( $\mathrm{CPB} /$ De Mooij 2006, p. 91) dat Nederland iets boven het gemiddelde niveau van bescherming van de andere landen zit, maar duidelijk onder het niveau van de omringende (grote) EU-landen. Daarbij wordt de indicatorwaarde voor Nederland bepaald door een relatief sterke bescherming voor de reguliere werkenden (insiders) en veel minder bescherming voor tijdelijke arbeidskrachten (outsiders). Dit weerspiegelt dat de Nederlandse 'uitvinding' van het uitzendwerk ooit het mechanisme is geweest om meer flexibiliteit op de arbeidsmarkt te bewerkstelligen. Als het gaat om actief arbeidsmarktbeleid, laat de vergelijking 
met het buitenland zien dat Nederland hier gemiddeld aan uitgeeft. Deze Nederlandse uitgaven gaan in ruime mate naar de reïntegratie van arbeidsongeschikten, van wie er in Nederland (nog) veel zijn.

\section{Macro-indicatoren vergeleken: i/a-ratio en uitgaven aan sociale bescherming}

Een andere belangrijke indicator in internationale vergelijkingen is de verhouding tussen het aantal economisch inactieven en het aantal werkenden: de i/a-ratio. De i/a-ratio is in Nederland sinds de jaren negentig sterk verbeterd, waardoor hij nu duidelijk lager ligt dan in andere EU-landen (De Kam en Goudswaard 2006, p. 54). Een andere indicator is het totaal aan publieke en private uitgaven $^{2}$ aan sociale bescherming (in procenten BBP). Op die indicator wijkt Nederland internationaal gezien niet meer af van andere EU- en OECD-landen; het is inmiddels twintig à dertig jaar geleden dat we in dat opzicht nog als de facto Scandinavisch land aangemerkt konden worden. De Kam en Goudswaard (2006, p. 55) verbinden hieraan de conclusie dat in verhouding tot het bruto binnenlands product veel landen ongeveer hetzelfde aan sociale bescherming uitgeven. Dit suggereert een breed gedeelde preferentie voor een bepaald niveau van sociale zekerheid, in welke vorm dan ook.

\subsubsection{SUBCONCLUSIE}

Nederland heeft de laatste jaren veel veranderingen doorgevoerd in zijn socialezekerheidsstelsel, en in internationaal perspectief is het geen buitenbeentje meer. Wel blijkt er binnen het stelsel verhoudingsgewijs weinig accent te liggen op verzekeringen die gericht zijn op de levensfase met kleine kinderen. Dat heeft de volgende consequenties: (1) een groot (ook steeds beter opgeleid) potentieel aan vrouwen bereikt de arbeidsmarkt niet, waardoor het draagvlak voor voorzieningen suboptimaal blijft (wat steeds meer zal gaan knellen naarmate de samenleving vergrijst), en (2) het vruchtbaarheidsniveau (in Nederland op 1,7 kind per vrouw3) blijft onder vervangingsniveau. De aanstaande vergrijzing van de bevolking, de vervangingsvraag op de arbeidsmarkt die daar het gevolg van is, de noodzaak om (meer) welvaart te genereren om die demografische last te kunnen dragen, en ook de professionalisering van de zorg (zie hoofdstuk 5), geven tezamen een argument om niet tevreden te zijn met de onvolledig gebleven arbeidsmarktdeelname van vrouwen. Een accentverlegging van de verzekeringsfunctie van de verzorgingsstaat naar de vroegere levensfasen kan helpen om dat tegen te gaan. Daarbij kan nog worden aangetekend dat de in 2006 ingevoerde levensloopregeling - gepropageerd om de combinatie van arbeid en zorg te vergemakkelijken - de facto (nog) niet zodanig vorm gekregen heeft dat ze als een antwoord kan worden beschouwd op deze problematiek. ${ }^{4}$ Daarbij geldt ook dat de levensloopregeling in haar huidige vorm voornamelijk aantrekkelijk is voor de hogere inkomens, omdat de fiscale premiëring bepaald wordt door het marginale IB-tarief van de inkomenscomponent die men door te sparen buiten de belastingheffing weet te houden. 


\subsection{ONTWIKKELINGEN IN HET DENKEN OVER DE VERZEKERINGS- FUNCTIE}

\subsubsection{INLEIDING}

De manier waarop de Nederlandse verzorgingsstaat verzekert, en meer in het bijzonder de manier waarop het socialezekerheidsstelsel in elkaar zit, is de afgelopen decennia uitgebreid onderwerp van maatschappelijk debat geweest. Een deel van het debat ging en gaat over de vraag hoe betaalbaar - en daarmee hoe houdbaar - de sociale zekerheid is. De vraag naar de houdbaarheid staat centraal in 6.4.2. Een ander deel van het debat ging over de vraag hoe adequaat de sociale zekerheid nog is. Sluit die nog aan bij het 'risicoprofiel' van de moderne Nederlander? Paragraaf 6.4.3 behandelt de opkomst van 'nieuwe risico's'. En is de sociale zekerheid niet te veel uitgegroeid tot een schadeverzekering zonder schadelastbeheersing? Paragraaf 6.4.4 behandelt de omslag in het denken over de verzekeringsfunctie: van werkloosheidsbestrijding naar participatiebevordering. En kunnen we eigenlijk nog wel spreken over een verzekering als risico's tot op zekere hoogte voorspelbaar zijn? Paragraaf 6.4.5 gaat in op het belang van verzekeringsequivalentie en de rol van informatie in relatie tot de legitimiteit van regelingen.

\subsubsection{VAN GROEI NAAR BEHEERSING VAN DE VERZEKERINGSFUNCTIE}

\section{Van groei naar beheersing}

Het aandeel van de publieke uitgaven (overheidsuitgaven + sociale verzekeringen) in het bbp bereikte in ons land in 1983 met 61 procent het hoogste niveau ( $\mathrm{CPB} / \mathrm{Bos} 2006$ ). Twintig jaar later, in 2003, is dit aandeel weer afgenomen tot 49 procent. Dit is deels het gevolg van ombuigingen, maar deels ook van het herstel van de economie. Hierdoor is de inactiviteit gedaald en daarmee ook het beroep op de sociale zekerheid. Zo varieerde het aandeel van de beroepsbevolking dat een beroep deed op Bijstand, WW en WAO van 4,6 procent in 1970 tot 18 procent in 1983 . In 2003 was dit percentage weer gedaald tot 13,7 procent (CPB/Bos 2006, p. 35).

De groei van de collectieve sector tot 1983, en de daling daarna, zijn niet elkaars spiegelbeeld. Met andere woorden: de terugdringing van de publieke sector was niet louter geconcentreerd op die posten die eerder de stijging veroorzaakten. Er is wat dat betreft een gemengd beeld. Sommige posten zijn sinds 1970 onafgebroken gestegen (zorg, openbaar bestuur), anderen zijn gelijk gebleven (infrastructuur), terwijl de sociale zekerheid de helft van de stijging in de periode 1970-1983 in 2003 weer heeft ingeleverd (СРВ/Bos 2006, p. 18). Bij dat laatste speelden vijf factoren een ongeveer even grote rol: (1) toegenomen werkgelegenheid, (2) het meer dan proportioneel achterblijven van het beroep op de sociale zekerheid, (3) privatisering, (4) doorwerking van loonmatiging, en (5) beleidsmatige ingrepen. De daling van de uitgaven aan sociale zekerheid was dus grotendeels nietselectief; alleen het zogenaamde volumebeleid en de beleidsmatige ingrepen in 
hoogte en duur waren dat. Ofschoon generieke ontwikkelingen zoals economisch herstel, loonmatiging en privatisering een grotere betekenis hebben gehad dan het totaal van de beleidsingrepen, kleuren deze laatste toch in hoge mate de maatschappelijk kijk op de ontwikkelingen in de sociale zekerheid. Het zogenaamde volumebeleid wordt, naast maatregelen met betrekking tot duur en hoogte van uitkeringen, vooral bepaald door het activeringsbeleid. Meer benadrukt wordt dat uitkeringen niet alleen een recht vormen, maar ook de verplichting met zich meebrengen om al het mogelijke te doen om betaalde arbeid te verrichten.

\subsubsection{HOE OM TE GAAN MET NIEUWE RISICO's?}

\section{Transitionele arbeidsmarkt accentueert 'nieuwe risico's'}

$\mathrm{Nu}$ de verzorgingsstaat, na een kwart eeuw van bezuinigings- en herstructureringsoperaties, in een nieuw evenwicht lijkt te zijn gekomen, dient de discussie zich aan hoe met een aantal 'nieuwe' risico's van het moderne leven moet worden omgegaan (bijv. Schmid 2005, 2006). Voor de 'traditionele' risico's (inkomensverlies doordat men niet meer kan werken door (1) werkloosheid, (2) ziekte/arbeidsongeschiktheid, of (3) ouderdom) kennen we stuk voor stuk sociale verzekeringen. Voor het armoederisico is er in aanvulling daarop een sociaal vangnet in de vorm van de Bijstand. Daarnaast echter zijn er als gevolg van de opkomst van de 'nieuwe burger' en de 'nieuwe economie' een aantal andere factoren die kunnen leiden tot een grotere kans op inkomensfluctuatie over de levensloop; deze worden wel aangemerkt als de 'nieuwe risico's' (zie box 6.1). Een andere term ervoor is manufactured risks, ter onderscheiding van externe (buiten het individu gelegen) risico's, maar bij nader inzien blijkt dit onderscheid minder scherp dan vroeger werd gedacht.

\section{Box 6.1 De nieuwe risico's volgens Günther Schmid (2006):}

(1) De van-school-naar-werk-transitie is gecompliceerder dan voeger. De carrièreloop, en dus de capaciteit om inkomen te verdienen, moet in een kortere periode (compressed career) waar worden gemaakt. Met name vrouwen lopen daardoor een (blijvend) inkomensrisico wanneer ze een periode verlet nemen voor het krijgen en verzorgen van kinderen.

(2) Hetzelfde geldt wanneer men 'tussentijds' aan (bij)scholing wil doen die verder gaat dan on the job training en men daarvoor uit zijn baan stapt.

(3) In 'het spitsuur van het leven' kunnen ook andere zorgplichten beslag leggen op mensen, zoals zorg voor ouders en anderen.

(4) Het tegenwoordig grotere risico dat op enig moment blijkt dat men een 'verkeerde' partner heeft geselecteerd, leidend tot een (echt)scheiding.

(5) Risico's voor laagopgeleiden aan de onderkant van de arbeidsmarkt dat hun werkgelegenheid structureel afneemt ${ }^{5}$; en

(6) Risico's voor vooral oudere werknemers, die boven hun productiviteit beloond worden en waarvoor de interne arbeidsmarkt stagneert. Zij lopen een verhoogde kans op werkloosheid en non-participatie. 
De eerste vier nieuwe risico's uit box 6.1 treffen met name vrouwen, omdat vooral hun carrière- en inkomensperspectieven erdoor in gevaar worden gebracht. De analogieredenering met de traditionele risico's volgend, is het dus zaak om ook deze nieuwe risico's en de gevolgen ervan te beperken. De afgelopen jaren is dat tot op zekere hoogte ook gebeurd. Zo werden er in CAO's afspraken over scholing en zorg gemaakt, aangevuld door fiscale facilitering (Commissie-Leijnse 2002).

\section{Nieuwe risico's? Betere voorzieningen!}

Een belangrijke vraag bij deze 'nieuwe risico's' is of ze wel als verzekeringsrisico's geframed moeten worden, of dat ze beter in de sleutel geplaatst kunnen worden van een van de andere functies van de verzorgingsstaat. Het idee van verzekeren is immers dat mensen zich indekken tegen risico's die hen eventueel kunnen treffen, onvoorzien, zonder dat ze er iets aan kunnen doen. Geldt dit wel voor het krijgen van kinderen of voor het ontbinden van een huwelijk? Op het eerste gezicht lijken het individuele keuzen, die men welbewust zelf maakt. Dat zou ook de bereidheid van medeburgers om mee te betalen aan kosten die verbonden zijn aan deze risico's danig onder druk kunnen zetten. In tweede instantie echter valt op het individuele karakter van deze gebeurtenissen heel wat af te dingen. Zo hebben we er collectief belang bij dat er voldoende vrouwen 'kiezen' voor het krijgen van kinderen - anders treedt er een nog verdere ontgroening op. Scheiden is iets wat mensen niet louter willen, maar wat ze veelal ervaren als iets wat op enig moment niet meer te vermijden is. En voor het geven van mantelzorg geldt al helemaal dat de grens tussen 'willen' en 'moeten' vanwege de familiale tradities en gevoelde solidariteit meestal niet werkelijk te trekken is. Al met al is het dan ook verstandig de nieuwe risico's wel van een collectief antwoord te voorzien, maar daarbij niet terug te grijpen op een typisch 'verzekeringsantwoord oude stijl': uitkeringen, fondsen, 'spaarpotten' en dergelijke. Gepaste voorzieningen, zoals calamiteitenverlof, goede kinderopvang, brede scholen met sluitende dagarrangementen, zijn een adequater antwoord. Daarom ook worden deze voorzieningen meer uitgebreid behandeld in de hoofdstukken over de verzorgingsfunctie (hoofdstuk 5) en verheffingsfunctie (hoofdstuk 7 ) van de verzorgingsstaat.

Behalve nieuwe risico's zijn er op dit moment ook nieuwe of betere of meer 'opvangmechanismen' bijgekomen. Met het stijgen van het inkomen heeft men niet alleen meer te verliezen bij het verlies, opschorten of halveren van een baan, maar heeft men in beginsel ook meer potentieel om zelf geld achter de hand te houden (sparen, vermogensvorming). Verder hebben tweeverdieners financiële steun aan elkaar als één van de partners zijn baan verliest. In beginsel heeft men daardoor wat meer tijd om zich te oriënteren, wat ook kan helpen om een ongelukkige baanmatch te voorkomen. Het vermogen om economisch zelfstandig te zijn, zal gaandeweg de norm worden, alleen al omdat relaties minder stabiel zijn dan vroeger en minder worden beleefd als 'gegeven voor het leven'. Dat maakt het voor partners onverstandig om zich bij elkaar te verzekeren. Het geeft, kortom, geen sterk argument voor een (verder) redress van de publieke verzekeringsfunctie. 


\subsubsection{VAN WERKLOOSHEIDSBESTRIJDING NAAR PARTICIPATIEBEVORDERING ALS NIEUW PARADIGMA}

\section{Activering}

Juist toen de verzorgingsstaat bijna 'klaar' was, ontstond begin jaren zeventig van de vorige eeuw de volgende keten: 'olieprijsschokken' (1973 en 1980), een wereldwijde sterk afnemende economische groei, monetaire en economische crisis, oplopende werkloosheid, en stijgende sociale lasten en arbeidskosten. Dit mondde uit in een beleidsconclusie die - soms iets vroeger, soms iets later - in alle Europese verzorgingsstaten werd getrokken, namelijk dat de omvang van de verzorgingsstaat uit de hand was gelopen en dringend betere beheersingsmechanismen behoefde. Onder die druk zijn de diverse Europese verzorgingsstaten vervolgens - ieder in zijn eigen tempo en vanuit zijn nationale 'eigenaardigheden' - geleidelijk van paradigma gewisseld. Door de verslechterde economische situatie verschoof de belangstelling van ontplooiing en verdelingsvraagstukken naar het bereiken en vergroten van materiële welvaart - en naar welke prikkels daarvoor nodig zijn in de samenleving en economie. Die paradigmawisseling hield ook in dat betaalde arbeid niet langer gezien werd als een gegeven, te verdelen koek, maar dat geprobeerd werd deelname aan de formele arbeidsmarkt te bevorderen om zo groei van de koek te genereren. Voor uitkeringsgerechtigden impliceerde deze omslag dat een passieve benadering plaats maakte voor activering. De dominante opvatting werd sindsdien - en is dat in zelfs nog oplopende mate dat zoveel mogelijk mensen in de arbeidsgeschikte leeftijd betaald werk dienen te verrichten. Dat is niet alleen nodig om de verzorgingsstaat betaalbaar te houden (verbeteren van de inactieven/actieven-ratio), maar bovendien omdat deelname aan de arbeidsmarkt mensen onafhankelijk maakt. Werk emancipeert; een uitkering of afhankelijkheidsrelatie binnen het gezin niet. Door werk wordt niet alleen armoede maar ook sociale uitsluiting voorkomen. De geleidelijke paradigmawisseling sinds de jaren tachtig wordt, kortom, gedragen door overwegingen van (1) betaalbaarheid/doelmatigheid, en (2) emancipatie. Achter het activeringsbeleid zit dus een dubbele strategie: vergroting van de beheersbaarheid van verzorgingsstatelijke regelingen, én bevordering van arbeidsmarktdeelname als emancipatieroute.

Hoe is Nederland erin geslaagd met deze opgave om te gaan? De volgende figuur (figuur 6.1) van de ontwikkeling van de beroepsbevolking tijdens afgelopen twee decennia laat het succes van de ingezette participatiestrategie zien. Wanneer we de groei van de beroepsbevolking schalen aan de ontwikkeling van de totale bevolking (van 14,5 miljoen mensen in 1985 naar 16,3 miljoen in 2006), zien we dat de beroepsbevolking in relatieve en absolute termen zelfs sterker is toegenomen dan de totale bevolking.

\section{Dynamisering verzekeringsfunctie}

De verschuiving van werkloosheidsbestrijding naar participatiebevordering als een 'betere verzekering' betekende dat het idee werd losgelaten dat werkloosheidsbestrijding ook tot stand kan worden gebracht door het arbeidsaanbod te 


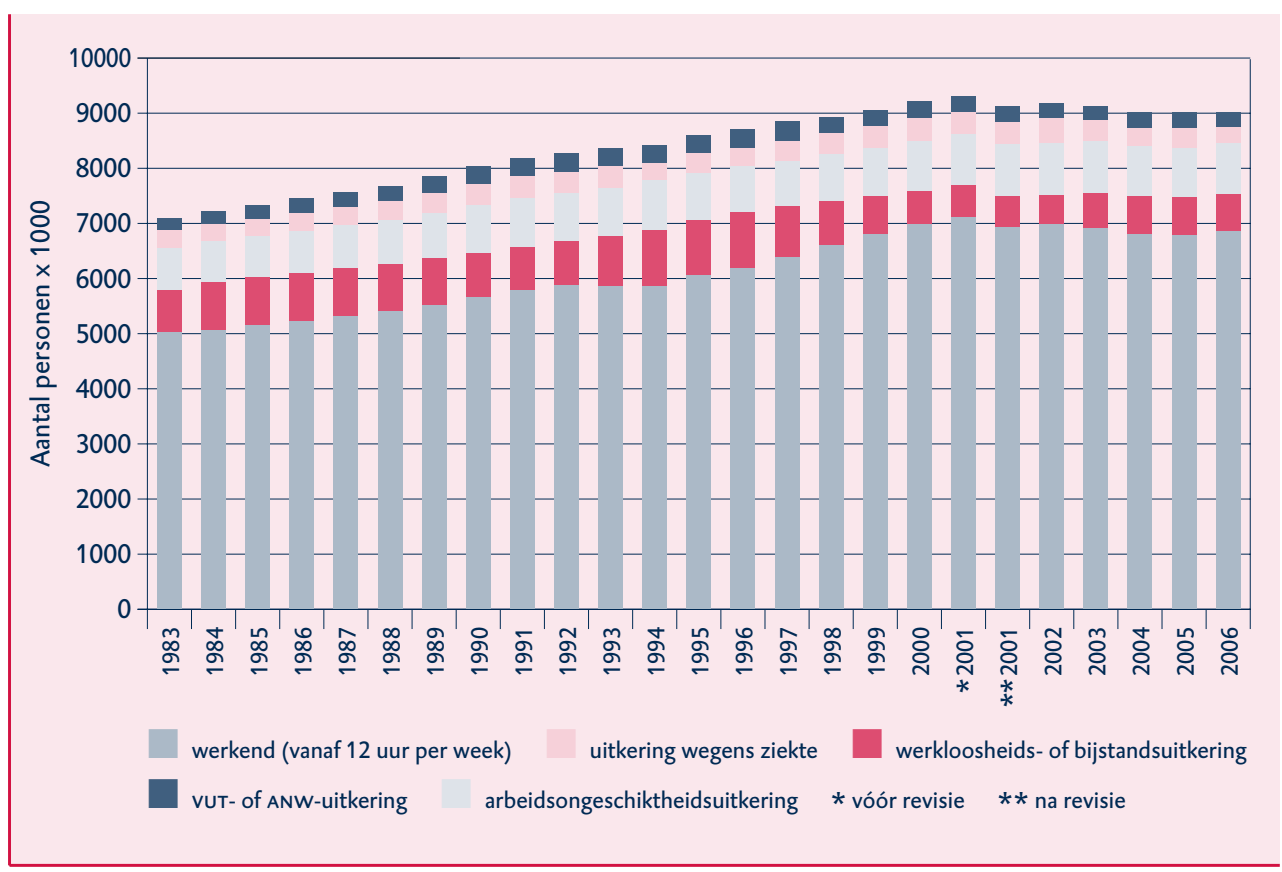

Bron: CPB 2006

beperken. Het maakte plaats voor het idee om het draagvlak van werkenden op de arbeidsmarkt te versterken zodat er een bredere basis kan groeien voor zowel private (consumptie) als publieke (verzorgingsstatelijke) uitgaven. De beoogde toename van de arbeidsparticipatie kreeg 'spontaan' vorm in de praktijk door de massale (maar als regel nog deeltijdse) toetreding van vrouwen tot de arbeidsmarkt - waarin Nederland nog een inhaalslag te maken had vergeleken met andere Europese landen. Verder kreeg het participatieparadigma vorm doordat de sociale zekerheidsregelingen (met name Bijstand, wW, zW en WAO) stap voor stap zodanig zijn hervormd dat ze een (snelle) terugkeer of toetreding tot de arbeidsmarkt bevorderden: activering en reïntegratie hebben een veel zwaarder accent gekregen.

\subsubsection{DE ROL VAN INFORMATIE IN RELATIE TOT DE LEGITIMITEIT VAN REGELINGEN}

In discussies over de verzorgingsstaat is gaandeweg de verzekeringsfunctie steeds centraler komen te staan. Het idee heeft postgevat dat de verzorgingsstaat bij uitstek gericht was op grootscheepse inkomensherverdeling. Van oorsprong was dat echter nooit de intentie van de bismarckiaanse werknemersverzekeringen: daarbij ging het om risicopooling tussen collega's in eenzelfde situatie in een bedrijf of bedrijfstak. ${ }^{6}$ Deze oudste verzekeringsarrangementen zijn in de publieke sfeer gekomen ter bestrijding van negatieve externe effecten: de opkomst van de - toen nieuwe! - risico's die waren verbonden aan de industriële, stedelijke samenleving. Die nieuwe samenleving dreigde immers te leiden tot een 
toename van vagebonden, zwervers, junks en criminelen waar heel de burgerij last van zou hebben. Iedereen van een bestaansminimum verzekeren was dus een kwestie van 'welbegrepen eigenbelang'.

Het misplaatste idee dat de verzorgingsstaat een 'herverdelingsproject' is, wordt in de hand gewerkt doordat het onderscheid tussen horizontale herverdeling (verzekeringsequivalentie: van gezond naar ziek, enzovoorts) en verticale herverdeling ('echte' inkomensherverdeling) niet altijd goed gemaakt wordt. Het voorkomen van negatieve externe effecten brengt herverdeling met zich mee. Maar veel regelingen van de verzorgingsstaat zijn horizontaal. Ze leiden tot een ex-post herverdeling: nadat het verzekerde feit zich heeft voorgedaan, vindt er een herverdeling plaats tussen 'geluksvogels' en 'pechvogels': niet-getroffenen en getroffenen. Ex-ante, vooraf, is ieders kans op pech of geluk onbekend. De kansverdeling gaat schuil achter een sluier van onwetendheid (veil of ignorance).

Niettemin kunnen regelingen natuurlijk wel beoordeeld worden op de mate waarin ze systematische, al dan niet beoogde, herverdelingseffecten hebben. Als er uniforme premies worden gehanteerd, ontstaat er bijvoorbeeld risicosolidariteit tussen mensen met een laag statistisch risico op werkloosheid, ziekte of arbeidsongeschiktheid, en mensen met een hoog risico. En inmiddels hebben we genoeg verzekeringsstatistiek beschikbaar om te kunnen weten dat laagopgeleiden systematisch vaker werkloos zijn, vrouwen vaker ziek, ouderen vaker arbeidsongeschikt, en ambtenaren niet in de ww terechtkomen - al betalen ze wel pseudo-ww-premie. In die zin bieden sociale verzekeringen de overheid wel een instrument om een beperkte mate van herverdeling (ex-ante) te organiseren of juist tegen te gaan. Dit is bijvoorbeeld relevant waar er op de arbeidsmarkt good jobs en bad jobs bestaan. Voor zover de bad jobs leiden tot 'herhaalwerklozen' hebben deze een groter dan gemiddeld profijt bij het bestaan van de ww; ze hebben immers meer kans om daarop een beroep te moeten doen. Dat kan verwelkomd worden - om mensen te stimuleren ook de bad jobs aan te pakken. Het kan echter ook worden gezien als ongewenste herverdeling. Zo worden er in Nederland in de wet nadere referte-eisen gesteld over de periode dat men aaneengesloten werk heeft gehad (in casu in de ww de 'wekeneis'? en de 'vier-uit-vijfeis'). Dit gebeurt om te voorkomen dat herhaal- en seizoenwerkloosheid ten laste komt van de ww. De referte-eisen dienen dus om zo dicht mogelijk bij verzekeringsequivalentie te blijven. En - behalve voor het tegengaan van oneigenlijk gebruik - is dicht bij verzekeringsequivalentie blijven ook nodig om een verzekering breed gelegitimeerd te houden. Want hoe meer (kennis over) systematisch herverdelende mechanismen, hoe groter de kans op afbrokkelende algemene legitimatie. Anderzijds geldt dat hoe meer informatie er beschikbaar is over 'kansen op' jonge vrouwen in de WAO bijvoorbeeld, hoe meer dit kan aanzetten tot een preventief beleid dat ertoe kan bijdragen dat deze 'kwade kansen' voor specifieke groepen zich niet langer zullen voordoen.

Hoewel inbreuken op verzekeringsequivalentie tot afbrokkeling van de legitimiteit kunnen leiden, hoeft dat niet. Neem het verschijnsel van ouderen of vrou- 
wen die systematisch vaker ziek of arbeidsongeschikt zijn zonder dat dit in een premieverschil tot uitdrukking komt. Zolang de - meer dan evenredig bijdragende - (jonge) mannen blijven denken: "Ik word ook ooit oud" en "Het is ook voor mijn vrouw" is dat geen probleem. Het zou kunnen gebeuren - door voortgaande individualisering - dat men niet meer mentaal de 'positie van de ander' kan of wil innemen. Dan ontstaan er wél problemen en kan de gedachte 'I want my money back' postvatten. Die mogelijkheid wordt soms in theorie wel gesignaleerd, maar is in Nederland tot op heden in de praktijk niet manifest gebleken (SCP 2004). Van Oorschot (2006) vindt in dit verband in zijn onderzoek op grond van de European Values Study dat identiteit en controle de cruciale variabelen zijn als het gaat om de deservingness vast te stellen van verschillende groepen (ouderen, zieken en invaliden, werklozen, en immigranten) op verzorgingsstatelijke verzekeringen en voorzieningen. Het belang van identiteit impliceert dat (te) veel migratie een potentiële bedreiging is van de solidariteitsverbanden van de verzorgingsstaat, omdat mensen aan migranten een andere identiteit toedichten. De factor controle impliceert dat instandhouding van de solidariteit vraagt om een strenge controle en toelating van 'ontvangers'. Het is dus zaak om de aanspraken en de toegang goed te bewaken om te voorkomen dat de kosten te hoog oplopen. De afgelopen kwart eeuw hebben achtereenvolgende kabinetten dit ook steeds in hun beleid verdisconteerd.

\section{Ziektekostenverzekering en informatie}

De RVZ (Jeurissen 2005; RVZ 2006) heeft er recent op gewezen dat door (1) de aanstaande vergrijzing, en (2) het (veel) duurder worden van de duurste diagnosegroepen, waar met name ouderen in vallen, ouderen als groep absoluut en relatief nog meer de gezondheidszorg gaan belasten dan ze nu al doen. In de curatieve zorg kostte bijvoorbeeld een halve eeuw geleden de duurste tien procent van de verzekerden 43 procent van het budget; vijftig jaar later is dat opgelopen tot 70 procent. En de verwachting van de RvZ is dat door de ontwikkelingen in de medische technologie dit aandeel verder zal oplopen. Een beperkte groep vergt dus een zeer hoog deel van de totale curatieve kosten. De oud-voorzitter van de RVZ (RVZ 2006; Sanders 2006) verbindt hieraan de verwachting dat de solidariteit tussen jong en oud sterk(er) onder druk komt te staan. Om dat tegen te gaan, en omdat het eigen gedrag van mensen ruwweg voor de helft van invloed is op ziekteprevalentie, beveelt hij aan dat het beleid meer gaat inzetten op de beïnvloeding van dat gedrag: stimulering van individuele preventie en gezond gedrag, premiedifferentiatie, 'gepast patiëntschap', enzovoorts. De - door de RVZ niet uitgewerkte consequentie hiervan is dat de overheid en de werkgever meer het privéleven van mensen zullen moeten betreden: immers, gezond gedrag zal dan op een of andere wijze gemeten, gemonitord en 'beloond' moeten worden.

Het gevaar van een afbrokkelende solidariteit tussen verzekerden, komt ook terug in de analyse van Rosanvallon (2000) die haarscheuren in de solidariteit voorziet als (gezondheids)risico's minder at random verdeeld blijken naarmate de voortgang van de medische wetenschap meer informatie over de risicoverdelin genereert. De redenering die de RVZ en Rosanvallon volgen, is dat verzeke- 
ringssolidariteit gebaseerd zou zijn op het idee dat alle participanten ongeveer een gelijke kans zouden hebben op het 'profijt' van de verzekering, en dat mensen minder willen meebetalen als ze het idee krijgen tot de 'goede risico's' te horen. De realiteit van de meeste verzekeringen - of ze nu privaat danwel publiek zijn - is evenwel dat mensen het prettig vinden om verzekerd te zijn als zodanig, en dat ze als regel geen al te nauwkeurig idee hebben van hun individuele kans om een beroep te moeten doen op een verzekering, en zich tot op heden ook niet erg laten leiden door dat motief. Wel hebben mensen globale noties over de 'groepskans', bijvoorbeeld dat wie jong is, minder kans loopt op ziekte en arbeidsinvaliditeit.

Tot slot is van belang dat een groot deel van de belastingen en sociale zekerheid geld herverdeelt van de ene levensfase naar de andere en niet van het ene individu naar het andere. Naar schatting bestaat zeventig procent van alle uitgaven van de verzorgingsstaat uit herverdeling over de levensloop naar dezelfde persoon. Zo bezien is men in de moderne verzorgingsstaat vooral solidair met zichzelf - en dat is een belangrijke voedingsbodem voor de bereidheid te blijven investeren in socialezekerheidsarrangementen.

\subsubsection{SUBCONCLUSIE: VERZEKERINGSFUNCTIE MEER VERBINDEN MET DE ANDERE FUNCTIES}

De ontwikkeling in het denken over de verzekeringsfunctie laat zich samenvatten in vier conclusies.

(1) Hoe meer verzekeringsequivalentie, hoe minder druk op solidariteit In het algemeen geldt dat de verzekeringsfunctie van de verzorgingsstaat en de onderliggende solidariteitsverbanden het minst onder druk komen te staan als de aanspraken op en kosten van sociale regelingen voldoende beheerst blijven. Dit is de ratio achter het beheersingsparadigma van afgelopen kwart eeuw. Verder zijn (referte-)eisen aan de potentiële 'ontvangers', en vormen van premiedifferentiatie voor de 'betalers' toegepaste en onverminderd toepasbare mechanismen om niet te ver van verzekeringsequivalentie verwijderd te raken (vergelijk de naar bedrijfstak gedifferentieerde premie in de WAO en voor de eerste zes maanden van de ww).

\section{(2) Hoe minder informatie, hoe minder druk op solidariteit}

Een tweede factor die aan sociale verzekeringen onderliggende solidariteitsverbanden kan ondergraven, is dat er (meer, veel, te veel) informatie bekend wordt over feitelijke risico's en kansen op profijt van regelingen. Zo is binnen sociale verzekeringen een zekere systematische herverdeling wel mogelijk, maar op voorwaarde dat die niet te groot is en niet te veel in het oog loopt. De solidariteitsverbanden blijven ook steviger naarmate mensen zich beter herkennen en meer verbonden voelen met de mensen waar het profijt van de regeling terechtkomt; die moeten liefst aanvoelen als 'eigen' ouders, kinderen, buren of anderszins groepsgenoten. Voor beleidsmakers kan een grotere beschikbaarheid aan 
informatie over groepskansen om op een regeling aangewezen te raken aanleiding zijn om specifiek preventief beleid te ontwikkelen gericht op de betreffende groepen.

(3) Toekomst: verzekeringsfunctie meer mengen met verheffingsfunctie In de vormgeving van de verzekeringsfunctie is steeds van belang dat deze zó wordt vormgegeven dat het individu geprikkeld wordt, c.q. blijft worden, om zelf een maximale inspanning te leveren om zijn bestaansrisico's te beheersen. Die gevraagde inspanning wordt ook 'preventiever' van karakter: het gaat niet alleen om de werkloze die blijft solliciteren, maar ook om de vraag of men voldoende doet en blijft doen aan scholing en schoolbaarheid om gedurende het (langer wordende) werkzame leven te kunnen blijven participeren op de arbeidsmarkt. Dit betekent dat de verzekeringsfunctie qua 'techniek' niet uitsluitend gericht moet worden op inkomenszekerheid, maar ook op baan- en werkzekerheid. Dan gaat het om de employability van mensen, wat in termen van de in dit rapport onderscheiden functies een (vruchtbaar) samengaan van de verzekerings- met de verheffingsfunctie behelst.

(4) Het antwoord op de nieuwe risico's

Ook vanuit de optiek van de 'nieuwe risico's' is het vooral de verheffingsfunctie van de verzorgingsstaat die impulsen moet krijgen, en waar de verzekeringsfunctie zich mee moet verbinden. Verder is het verstandig binnen het kader van de verzorgingsfunctie (hoofdstuk 5 ) meer en betere zorgvoorzieningen te organiseren als passend antwoord op 'nieuwe (zorg)risico's'.

\subsection{BEÏNVLOEDBAARHEID, VERANTWOORDELIJKHEIDSVERDELING EN BESTURING}

\subsubsection{INLEIDING}

De sociale zekerheid stond de afgelopen jaren niet alleen in het teken van de vraag naar de houdbaarheid, maar ook in het teken van de vraag naar de adequaatheid: past het stelsel nog bij het risicoprofiel van de moderne Nederlander, gaat het nog wel om te verzekeren risico's, en zijn er goede prikkels om aan risicobeheersing te doen? Achter dergelijke vragen gaat een vervolgvraag schuil: wiens sociale zekerheid is het eigenlijk? Die vraag is de afgelopen decennia eerder impliciet dan expliciet beantwoord. Het impliciete antwoord zit in de wijze waarop regelingen werden herzien, en dat was deels in een richting waarbij de verantwoordelijkheid van burgers en van (organisaties van) werkgevers en werknemers groter werd. In meer principiële zin is de vraag minder aan de orde geweest. Paragraaf 6.5.2 gaat daarom eerst in op de manier waarop de verantwoordelijkheid voor de sociale zekerheid zich de afgelopen eeuw ontwikkeld heeft. Daarna kunnen we de vraag stellen wie welke verantwoordelijkheden op zich zou moeten nemen in de verzekeringsfunctie van de verzorgingsstaat. 


\subsubsection{DE SOCIALE VERZEKERINGSFUNCTIE IN RELATIE TOT DE COLLECTIEVE SECTOR}

De werknemersverzekeringen worden van oudsher bekostigd uit sociale premies, die tegenwoordig, gemakshalve, worden geïnd door de Belastingdienst, maar die in aparte sociale fondsen zijn ondergebracht - bestuurd door werkgevers- en werknemersorganisaties. Die fondsen doen aan eigen fondsvorming en reserveopbouw, en stonden oorspronkelijk los van het macro-economische beleid van de overheid. Vanaf de jaren zeventig is dit drastisch anders geworden. Ruwweg liggen daar drie achtereenvolgende oorzaken aan ten grondslag: (1) de financieeleconomische crisis van de tweede helft van de jaren zeventig, (2) het 'WAOdrama', en (3) de komst van de EMU en de (vooraf)schaduwende werking daarvan.

Het eerste luik: de twee oliecrises van de jaren zeventig brachten scherp de nadelige gevolgen in beeld van de hoog opgelopen arbeidskosten. Daarbij kwam verder tot uitdrukking dat we geleidelijk een zeer volwassen verzekeringsfunctie hadden opgebouwd; het was niet langer 'klein bier', maar het totaal van de sociale premies was inmiddels een zeer wezenlijk onderdeel van de collectieve sector en van de arbeidskosten gaan vormen. Gevolg was dat de toenmalige minister van Financiën (Duisenberg; 1973-1977) vond dat een effectief macro-economisch beleid aan de lastenzijde zich niet kon beperken tot een verantwoordelijkheid voor louter de belastingdruk. Voortaan moest er gewerkt worden met de totale collectieve lasten, een - op dat moment - nieuwe grootheid: de druk van belastingen, niet-belastingmiddelen én de sociale premies.

Door de introductie van dat collectieve lastenbegrip is de manoeuvreerruimte van de beheerders van de sociale premies stevig ingeperkt. In de vijftien jaar daarop volgt het tweede luik: het WAO-drama kwam tot ontwikkeling. In een notendop kwam dat op het volgende neer: de werkgevers en werknemers gebruikten de WAO als afvloeiingsmechanisme van de arbeidsmarkt, waardoor in internationale vergelijkingen gemeten de arbeidsinvaliditeit in Nederland tweeà driemaal zo hoog was als in vergelijkbare landen. Toen die praktijk definitief en 'officieel' werd vastgesteld door de parlementaire enquêtecommissie onder voorzitterschap van Buurmeijer (1993), was de gevolgtrekking een verbetering van de beheersing door een (verdere) verstatelijking van de betrokken verzekeringen, ook van de werknemersverzekeringen. Werkgevers en werknemers zijn toen uit de uitvoering en het toezicht op de regelingen gehaald.

Het derde luik: in de tweede helft van de jaren negentig werd deze dus al twintig jaar eerder ingezette lijn van stapsgewijze verstatelijking van de verzekeringsfunctie nog versterkt doordat Nederland aan de EMU-criteria moest gaan voldoen. Dat vroeg om uitgavenbeheersing in de hele collectieve sector en werkte zo een door de centrale overheid beheerst en gestuurd macro-economisch beleid verder in de hand. Sindsdien maken werkgevers- en werknemersorganisaties, maar ook lagere overheden (die immers ook nog met de OzB aan eigen belasting- 
heffing doen), geen deel meer uit van het financieel-economische besturingscentrum van de verzorgingsstaat.

\subsubsection{VERZEKERINGSFUNCTIE IS EERST VERSTATELIJKT EN LATER DEELS GEPRIVATISEERD}

Sociale verzekeringen zijn historisch gezien begonnen met de werknemersverzekeringen. Deze waren gerelateerd aan de werknemerspositie, boden inkomenscompensatie aan kostwinners, en werden uitgevoerd door 'middenveld'organisaties. In de loop van de geschiedenis is de verzekeringsfunctie echter eerst over een lange periode geleidelijk aan verstatelijkt en onderdeel geworden van de collectieve sector en het macro-economische beleid. Recenter is er meer aandacht voor de mogelijkheid van aanvullende, partiële privatisering teneinde een doelmatige uitvoering van de verzekeringsfunctie te versterken. Dat is ook gebeurd: parallel lopend met het verstatelijkingsproces, is de uitvoering van de verzekeringsfunctie deels geprivatiseerd. Dit kwam vooral neer op het aanbrengen van 'private marges' aan publieke regelingen: burgers/werknemers en werkgevers zijn ook gedeeltelijk eigen verantwoordelijkheid gaan dragen in een poging de volumegroei te beperken.

Het belangrijkste element hiervan was de privatisering van het ziekterisico in Nederland, die sinds 1997 in drie stappen is doorgevoerd. De werkgever draagt eerst zes weken, vervolgens een jaar, en sinds 2004 maximaal twee jaar de kosten van een Ziektewetuitkering. Tegelijkertijd is het instrumentarium om het ziekteverzuim (beter) te beheersen bij de werkgever neergelegd. Het is zijn plicht om arbodiensten en reïntegratiebedrijven te contracteren. De achterliggende gedachte achter deze verschuiving in verantwoordelijkheden is dat ziekte niet een geheel objectieve, externe, niet te beïnvloeden zaak is. Het is niet louter een kwestie van door een 'slecht lot' getroffen worden. Ook gebrek aan motivatie en motivering kan zowel aan werknemers- als aan werkgeverzijde een rol spelen. Dat deze privatisering - met name de eerste stappen ervan - ook succesvol is geweest, kan worden afgelezen aan de daling van het $\mathrm{zW}$-percentage dat sindsdien heeft plaatsgevonden.

Ook in andere regelingen zijn dergelijke stappen gezet. De invoering van de WIA (als opvolger van de WAO) in 2006 die verschillende arbeidsongeschiktheidsregimes introduceert, maakt dat nu alleen nog de lasten van langdurige, onomkeerbare arbeidsongeschiktheid exclusief ten laste van het publieke systeem terechtkomen; bij gedeeltelijke arbeidsongeschiktheid hebben werknemer en werkgever een grotere verantwoordelijkheid te dragen gekregen. In de Bijstand komen de financiële consequenties bij de gemeenten en valt het beroep op Bijstand niet meer deels te verhalen op de rijksoverheid. De nieuwe, per 1 januari 2006 ingevoerde, ziektekostenverzekeringssystematiek, waarbij de publieke ziekenfondsen hun monopoliepositie voor de verzekering van de lagere inkomens hebben verloren en deel zijn gaan uitmaken van een concurrerend systeem van aanbieders van ziektekostenverzekeringspakketten, kent eveneens meer financiële prikkels, in 
dit geval vooral voor burgers - al krijgen werkgevers ook een financieel belang, omdat de mogelijkheid geïntroduceerd is om met korting collectieve contracten aan te bieden.

\subsubsection{NIEUWE VERANTWOORDELIJKHEDEN VOOR HET MIDDENVELD?}

De sociale zekerheid heeft dus een dubbele beweging meegemaakt. Enerzijds is ze verstatelijkt - de gelden van de sociale fondsen tellen bijvoorbeeld mee voor het EMU-saldo. Anderzijds is ze ook deels geprivatiseerd en zijn werkgevers en werknemers weer meer eigen risico gaan lopen. Is deze wat ambigue rol van werkgevers en werknemers en hun organisaties in de verzorgingsstaat toekomstbestendig? Er zijn goede argumenten om de vraag niet zozeer te benaderen in termen van principes (van wie is de sociale zekerheid?), als wel in pragmatische termen waarbij verantwoordelijkheden en de mogelijkheid tot beïnvloeding aan elkaar worden gekoppeld. Ook als de overheid principiële verantwoordelijkheid houdt om voor alle burgers een stelsel van inkomensdervingsverzekeringen te garanderen, ligt het immers voor de hand om de partijen die invloed hebben op het beroep dat op dergelijke verzekeringen wordt gedaan, prikkels te geven die bijdragen aan gepast gebruik.

Een relevante vraag is vervolgens wie die partijen precies zijn: individuele werkgevers en werknemers, of eerder hun organisaties op bedrijfstakniveau, of op het niveau van landelijke organisaties van werkgevers en werknemers? Relevant is hier dat in de moderne economie het belang van specifiek vakmanschap, uit te oefenen in een specifiek bedrijf, in een specifieke bedrijfstak, gradueel afneemt. Dit impliceert dat de materiële grenzen tussen bedrijfstakken enigszins vervagen, en de arbeidsmarktmobiliteit tussen sectoren toeneemt (Bovenberg 2005a, p. 126). Daardoor neemt de rol van sectoren/bedrijfstakken in onze economie eerder af dan toe. Werkgevers en werknemers zijn echter van oudsher op dit middenniveau het sterkst georganiseerd: hier worden CAO's afgesloten, pensioen- en andere regelingen uitgevoerd, enzovoorts. Een verdere verschuiving van verantwoordelijkheden naar individuele werknemers en werkgevers enerzijds en landelijke organisaties anderzijds ligt op termijn dan ook in de rede.

\subsection{DE VERZEKERINGSFUNCTIE GEËVALUEERD}

\subsubsection{INLEIDING}

Wanneer we de analyses uit de vorige paragrafen met elkaar in verband brengen, ontstaan de contouren van een schets van de verzekeringsfunctie voor de komende decennia. Zo moeten we de verzekering plaatsen in het licht van het feit dat Nederland steeds welvarender is geworden: hebben we nog wel dezelfde behoefte aan verzekering als in het verleden (par. 6.6.2)? Voorts moeten we de ontwikkeling van de verzekeringsfunctie evenzeer plaatsen in het licht van de huidige en toekomstige uitdagingen (par. 6.6.3). 


\subsubsection{DE VERZEKERINGSFUNCTIE IN EEN WELVARENDER SAMENLEVING}

\section{De functie van verzekering sui generis: afdekken van risico's}

Mensen sluiten verzekeringen af tegen ziekte, diefstal, stormschade, riskante investeringsprojecten, en nog veel meer. Het voordeel van 'verzekeren' sui generis is dat risico's worden gedeeld. Een verzekering is dus een economisch 'goed': veel mensen hebben er behoefte aan omdat ze risico's het liefst willen vermijden. Risico lopen wordt beschouwd als een disutility; een verzekering tegen een risico is daarmee een utility. 'Normale' mensen zijn nu eenmaal risicomijders, wat ook in veel economisch-psychologische experimenten is vastgesteld. Vanuit het oogpunt van risicomijding maakt het niet uit of die verzekering een private (vrijwillig afgesloten) of publieke verzekering betreft.

De functionaliteit van verzekeren is niet constant in de tijd, maar verandert mee met veranderende condities en configuraties. In dat licht valt te veronderstellen dat in een welvarender samenleving mensen meer eigen draagkracht hebben om bepaalde risico's zelf te dragen, waardoor de behoefte aan collectieve risicodeling afneemt. Feitelijk blijkt deze eerste intuïtie echter gelogenstraft te worden: ook in een welvarende(r) samenleving willen mensen hun risico's graag afgedekt hebben. Er zijn (ten minste) één sociologische en twee economisch-theoretische hypothesen ontwikkeld om die onverminderde risicoaversie te kunnen verklaren. Een eerste verklaring kan worden gevonden bij de socioloog Beck (1986) die analyseert hoe onze moderne samenlevingen steeds meer risico's percipiëren, terwijl de risicoaversie van mensen toeneemt als hun welvaart stijgt. Een tweede hypothese, afkomstig uit de economische theorie, is dat aan de mate van risicoaversie van mensen als zodanig niets verandert als ze welvarender worden, maar dat ze zich door hun stijgende welvaart (en het afnemende grensnut van die extra welvaart) meer verzekeringen kunnen permitteren. Een derde hypothese is gebaseerd op de economisch-psychologen Kahneman en Tversky (200o) en hun prospect-theorie: mensen hanteren een heel andere calculatie bij neerwaartse dan bij opwaartse risico's ('kansen'). Anders gezegd: de weerzin om door een bepaalde bodem te zakken is verhoudingsgewijs veel groter dan het nut dat men ontleent aan groei- en winstkansen. En het is met name die diepe risicoaversie die ertoe leidt dat mensen - ook als ze zich dat wel zouden kunnen veroorloven - geen afscheid nemen van verzekeringen, of die nu privaat of publiek zijn.

De implicatie van die breed gevoelde risicoaversie in onze samenleving is dat we eerder meer dan minder belang gaan hechten aan allerlei vormen van verzekering. ${ }^{8}$ Over mate en vormen vallen natuurlijk steeds (politieke) discussies te voeren (zie box 6.2), maar omdat markten nu eenmaal voor bepaalde risico's geen voor iedereen adequate verzekeringen aanbieden, is ook de verzekeringsfunctie van de verzorgingsstaat here to stay. 


\section{Box 6.2 Van (minder) verzekeren naar (meer) sparen als optie?}

De laatste jaren zijn (opnieuw) maatregelen genomen om het beroep op de sociale zekerheid terug te dringen. Op het terrein van de arbeidsongeschiktheid is een groot aantal maatregelen genomen met betrekking tot de verplichting tot loondoorbetaling bij ziekte gedurende twee jaren, de aanscherping van het schattingsbesluit, en de herinrichting van de WAO door middel van de nieuwe wet WIA.

In de $\mathrm{W} w$ is de maximale termijn gedurende welke men voor een $\mathrm{WW}$-uitkering in aanmerking kan komen, teruggebracht van vijf jaar naar 38 maanden. Verder is de wekeneis verhoogd en is het beleid ter zake van de vrijstelling van de sollicitatieplicht strenger geworden. Deze maatregelen hebben naar verwachting substantiële effecten op lange termijn.

Niettemin kan de vraag zich voordoen of met deze maatregelen een afdoend antwoord is gegeven op de wens tot het toekomstbestendig maken van de arbeidsongeschiktheidsregelingen en de werkloosheidsregeling. In principe zijn er immers altijd ontwikkelingen denkbaar die ertoe kunnen leiden dat de mate en vorm van de verzekeringsfunctie in de toekomst toch weer op de agenda zouden komen. Men kan hierbij denken aan internationale - met name Europese, demografische, en maatschappelijke ontwikkelingen. Met name die maatschappelijke ontwikkelingen, tot uitdrukking komend in de zogenaamde 'nieuwe risico's' (zie par. 6.4.3) en nieuwe preferenties, zouden kunnen leiden tot nieuwe initiatieven. In dit licht staat bijvoorbeeld het idee van spaarregelingen (bijv. Rezwani en Hendrix 2002; Sorensen e.a. 2006) die aan een - vermeende-behoefte aan keuzevrijheid tegemoet probeert te komen. Het idee is dat spaarvormen, bijvoorbeeld in de ww, tot een zuiniger gebruik leiden. Hierbij dient wel bedacht te worden dat sparen iets wezenlijk anders is dan verzekeren en verzekerd zijn. Spaarvormen zouden een deel van de sociale verzekering afschaffen en de sociale verzekeringspoortwachter als aansprakenbeheersende instantie vervangen door behoedzaamheid ten aanzien van het 'eigen' spaarsaldo als rem op gebruik. Als (een deel van) sociale verzekering door een spaarregeling (als bijvoorbeeld de levensloopregeling) wordt vervangen, komen mensen die hun spaargeld moeten aanspreken vanwege ziekte, werkloosheid, ouders die om zorg gaan vragen, enzovoorts al snel met een lege spaarrekening of een leeg 'rugzakje' te zitten. Het vervolg laat zich voorspellen: ongetwijfeld zal deze groep zich tot de overheid wenden, omdat men er immers voor het eigen gevoel niets aan heeft kunnen doen door het slechte lot getroffen te zijn (Jansweijer 2004). Zowel de ww als de arbeidsongeschiktheidsvoorziening worden gekenmerkt door een geconcentreerd gebruik: we lopen niet allemaal dezelfde kans om er een beroep op te moeten doen. Wellicht hangt dit deels samen met de mate waarin men zelf invloed kan uitoefenen op de omstandigheden die leiden tot werkloosheid en arbeidsongeschiktheid. Ook de toegang tot de arbeidsongeschiktheidsregeling die een medische en arbeidskundige toets kent, is moeilijk goed te objectiveren. Dit kan ertoe leiden dat nu vervroegd uittreden (ten laste van een collectief) voor nieuwe generaties feitelijk onmogelijk is gemaakt, de lastig objectiveerbare toelating tot de werknemersverzekeringen tot een niet-bedoelde instroom in deze regelingen leidt. Deze mogelijkheid kan er aan bijdragen dat de introductie van spaarelementen potentieel interessant blijft, bijvoorbeeld in de vorm van no-claim bonussen (zoals we die nu kennen in de nieuwe zorgverzekering), eigen risico's en/of wachtdagen. Dit in aanvulling op de zogenaamde referte-eis die een zekere vorm van sparen inhoudt, maar dan uitsluitend wat betreft de aanspraak op rechten.

Kortom, spaarelementen kunnen, als additionele toevoeging aan de vormgeving van sociale verzekeringen, nuttig zijn om aanspraken te beheersen. Spaarregelingen daarentegen als meer generieke vervanging van verzekeringen echter niet. Ze bieden dus geen antwoord op de risicoaversie die mensen onverminderd blijken te hebben. 


\section{De (veranderende) functies van sociale verzekering}

Dat er in de tweede helft van de negentiende eeuw, met de opkomende industrialisering en de afnemende functie van de extended family als fallback-optie, behoefte ontstond aan nieuwe vormen van risicopooling is (achteraf) goed te verklaren. Er zijn echter meer redenen waarom we een omvangrijk publiek verzekeringsstelsel hebben. Het komt ook omdat 'verzekeren' meer doet dan alleen beschermen of garanderen (van een inkomen, een baan, of een andere vorm van compensatie). Naast de primaire beschermende functie hebben verzekeringen een productiviteitsbevorderende functie: verzekerde mensen kunnen en durven meer risico's aan. Het bestaan van sociale verzekeringen maakt het ook mogelijk dat mensen met relatief minder risico op zoek kunnen gaan naar een volgende baan op weg naar een optimale baanmatch. Mensen kunnen bijvoorbeeld gemakkelijker een andere baan nemen die uitdaagt, ook al is bijvoorbeeld de werkdruk of de economische positie van de nieuwe werkgever niet goed in te schatten. De betere baanmatch die daardoor mogelijk is, is goed voor de productiviteit - op individueel en op macroniveau (WRR 200o). Dit mobiliteitsbevorderende effect wordt ook wel aangeduid met de 'smeeroliefunctie' van sociale verzekeringen. Zie ook de volgende box (box 6.3) over het 'Oostenrijkse model'.

\section{Box 6.3 Het 'Oostenrijkse model' als voorbeeld van smeerolie}

Deels ter vervanging, deels ter aanvulling op een werkloosheidsuitkering kunnen er bij ontslag arrangementen voor scholing, begeleiding bij sollicitatie, enzovoorts bedacht worden die helpen om langdurige werkloosheid tegen te gaan, en die wellicht een productievere werking hebben dan ons ontslagrecht/-vergoeding. In Oostenrijk past men bijvoorbeeld een constructie toe in een sociale verzekeringsvorm: elke werkgever is verplicht een bepaald percentage van de loonsom in een collectief fonds te storten, waaruit een onvrijwillig werkloze werknemer bij ontslag een bedrag ontvangt (los van zijn werkloosheidsuitkering) dat is gekoppeld aan de duur van zijn totale arbeidsverleden.

Voor de verdere toekomst van de verzekeringsfunctie van de verzorgingsstaat kan deze secundaire functie ook meer en bewuster vorm worden gegeven door deze beter te verbinden met de verheffingsfunctie.

\subsubsection{DE NOODZAKELIJKE VERANDERINGEN IN DE VORM VAN DE VERZEKERINGSFUNCTIE}

De vormgeving van de verzekeringsfunctie van de verzorgingsstaat is in de loop der tijd regelmatig aangepast en geherstructureerd als veranderende omstandigheden daarom vroegen. Ook nu doen zich ontwikkelingen voor waar de vormgeving van de verzekeringsfunctie op in moet spelen. Zo legt de vergrijzing die zich de komende decennia zal voltrekken extra druk op het systeem. Op de volgende hoofdpunten behoeft de vorm van de verzekeringsfunctie veranderingen; veranderingen die overigens deels al gaande zijn. 


\section{Meer nadruk op plichten en tweezijdigheid}

De in hoofdstuk 5 behandelde verzorgingsfunctie van de verzorgingsstaat is vooral gericht op zorgbehoeftigen: kinderen, ouderen, en enkele specifieke groepen. De zorgverlening aan hen kan niet afhankelijk worden gemaakt van een tegenprestatie. Bij de verzekeringsfunctie ligt dit anders. Verzekeren is altijd al deel van een tweezijdige relatie: burgers en/of bedrijven betalen premie of belasting en daar staat een recht tegenover voor het geval dat het verzekerde feit zich voordoet. Een uitkering of onkostenvergoeding zijn geen ongeclausuleerde rechten. Steeds vaker worden ze gecombineerd met een plicht of aansporing tot scholing, bemiddeling of activering. In die ontwikkeling weerspiegelt zich de al lang ingezette geleidelijke transformatie van een van oorsprong deels bismarckiaans regime naar een moderne, brede verzorgingsstaat.

$\mathrm{Nu}$ zijn verzekerde rechten altijd al geclausuleerd geweest: men werd en wordt geacht zelf het nodige te doen om te voorkomen dat men ziek of werkloos wordt of in de Bijstand terechtkomt. Echter, de mate waarin mensen ook daadwerkelijk op die eigen verantwoordelijkheid zijn aangesproken (bijvoorbeeld door weigering van de uitkering of strafboete als men tekort is geschoten), heeft gewisseld in de tijd. Wat de ww betreft vond de meest omvattende intensivering van het sanctiebeleid plaats in het kader van de invoering van de Wet boeten en maatregelen in 1996. Die wet benadrukt de wederkerigheid van rechten en plichten. Ook de Bijstand heeft de laatste jaren een sterke ontwikkeling in deze richting doorgemaakt.

Die ontwikkeling is niet uit de lucht komen vallen. In Nederland is er immers een onverminderd sterke maatschappelijke (en politieke) voorkeur voor het behoud van de kernelementen van ons stelsel dat een ruime (bovenminimale) verzekering kent tegen de traditionele risico's. Maar dat is niet 'zomaar' te realiseren. Gegeven de steeds straffere concurrentie in de wereldeconomie is een voldoende grote participatie op de arbeidsmarkt nodig, anders wordt de noemer te klein om de teller te kunnen dragen. Voor uitkeringsgerechtigden betekent dit dat ze zoveel mogelijk in werk- en leerprocessen betrokken moeten blijven, omdat langdurig werkverzuim of werkloosheid vaak funest is voor hun toekomstige kansen op de arbeidsmarkt. Deze combinatie van een binnenlandse, historisch en cultureel bepaalde voorkeur, met een harde externe conditie, dwingt met andere woorden tot een verplichtend, niet al te relaxed regime ten aanzien van de verzekeringsfunctie. Recent ingezette gemeentelijke praktijken bij de uitvoering van de Bijstand voor jongeren illustreren dat dit regime inmiddels serieus is ingezet. Die lijn zou doorgezet kunnen worden door het recht op een uitkering voor werkloze jongeren tot 25 jaar te vervangen door een recht op werk of opleiding.

\section{Meer nadruk op preventie en investering in plaats van recht op financiële compensatie}

De ontwikkelingen die op ons afkomen, zijn ten dele ook op te vangen door een verschuiving van 'verzekering tegen inkomensverlies' naar 'verzekering tegen baan- of werkverlies'. Daarbij verschuift de nadruk van financiële premies die, als 
ons een ongunstig lot treft, financiële compensatie garanderen naar het voorkomen van ongewenste situaties. De moderne burger, die tenslotte geen negentiende-eeuwse onontwikkelde 'loonslaaf' meer is, wordt geacht het nodige te kunnen doen om het dreigende 'slechte lot' te keren. Verzekeren verbreedt zich zo van 'beschermen' naar: (in je zelf) investeren; dus van financiële compensatie achteraf naar verstandige preventie vooraf. Daar moet die burger ook wel mogelijkheden voor krijgen. Zo kunnen consumptierechten (cash) verschuiven naar investeringsplichten en -rechten (in kind; voorzieningen). De verzekeringsfunctie gaat dan ook deels samenlopen met de verheffingsfunctie: een succesvolle verheffing is de beste verzekering tegen armoede, werkloosheid en sociale uitsluiting.

\section{Meer nadruk op activering binnen de verzekeringsfunctie}

Vanaf eind jaren tachtig is de route richting een meer activerende verzorgingsstaat ingeslagen. Dit gebeurde op verschillende niveaus tegelijkertijd en in wisselwerking: (1) op de arbeidsmarkt (met name door de grootscheepse toetreding van vrouwen), (2) door adviseurs die het als een nieuw paradigma muntten en polijstten, en (3) door het beleid, het meest expliciet vanaf 1994 toen het eerste paarse kabinet inzette op "werk, werk, werk" ter overbrugging van de verschillende opvattingen over de toekomst van de verzorgingsstaat tussen 'links' en 'rechts'. Een meer activerende verzorgingsstaat bleek een recept waar eigenlijk niemand tegen kon zijn. Het appelleert ook nog steeds; de opgave is om te zorgen dat het voldoende consequent wordt toegepast en waar nodig gemodificeerd. Als die offensieve lijn niet verder zou kunnen worden ingezet, ligt er nog slechts een route open naar een meer selectieve verzorgingsstaat die een aantal minimale niveaus waarborgt: het scenario van de residual welfare state van het СРВ (СРВ 2006).

\subsection{CONCLUSIE: NAAR MEER PREVENTIE ALS DE BESTE VERZEKERING}

\section{Van inkomensbescherming via participatie naar employability}

De historische beschrijving heeft laten zien dat het Nederlandse sociaal-economische beleid al zo'n twintig jaar geleden de omslag begon te maken van werkloosheidsbestrijding naar participatiebevordering. Met name de spontane, grootschalige toetreding van vrouwen tot de arbeidsmarkt speelde daarin een rol. De pendant van die omslag voor de verzekeringsfunctie van de verzorgingsstaat was een accentverschuiving van alleen financiële compensatie (voor baanverlies) naar ook het activeren en bevorderen van de uitstroom uit regelingen.

$\mathrm{Nu}$ is een volgende verschuiving aan de orde: van participatie naar employability; van activeren naar voorkomen. Ook daar zijn eerste stappen gezet, bijvoorbeeld waar gemeenten jongeren geen bijstand geven, maar mogelijkheden voor scholing of werk aanbieden. Die lijn kan verder doorgezet worden. Uiteraard is het effect op jongeren daarbij het grootst, zij hebben immers nog een heel werkzaam leven te gaan. Echter, daar kan en moet het niet bij blijven, zeker gezien het feit dat de aanstaande vergrijzing een scenario van toenemende tekorten op de arbeidsmarkt al op korte termijn waarschijnlijk maakt (Derks e.a. 2006). Immigratie biedt daar- 
voor geen oplossing. Deze verschuiving helpt ook om te voorkomen dat de verzekeringsfunctie een te zwaar financieel beroep doet op de verzorgingsstaat, waardoor onvoldoende financiële ruimte over zou blijven om nieuwe risico's met faciliterende voorzieningen tegemoet te treden en de andere verzorgingsstatelijke functies te vervullen.

\section{Oververzekerd}

Veel traditionele sociale zekerheid - werknemersverzekeringen en AOW - is erop gebaseerd dat als mensen ouder worden, ze minder productief worden, en een toenemend risico lopen van baan- en inkomensverlies. Die risico's worden niet alleen opgevangen door de AOW en pensioen, maar ook door VUT, WW, WAO, en ZW. In al deze regelingen zijn ouderen (zwaar) oververtegenwoordigd. De vraag is of deze oorspronkelijke rationale van productiviteitsverlies aan het einde van het (werkzame) leven nog volledig opgaat. In de eerste plaats worden mensen tegenwoordig gemiddeld zo'n vijftien jaar ouder dan sinds de invoering van deze regelingen, zo'n zestig tot honderd jaar geleden. Door de algehele verbetering van de levensstandaard en de (volks)gezondheidszorg hebben de meeste mensen niet alleen een langer leven, maar ook een langer leven in - grosso modo - goede gezondheid. Gevolg van de traditionele regelingen in de huidige tijd is: (1) dat er een groot productief potentieel onbenut blijft - wat steeds meer kwestieus wordt, zeker als over enkele jaren het arbeidsaanbod in Nederland gaat teruglopen (Derks 2006), en (2) - anders dan in ieder ander tijdperk van de menselijke geschiedenis - 55-plussers er gemiddeld genomen 'warmpjes' en goed verzekerd bijzitten. 'Warmer' dan functioneel is in een samenleving die tegelijkertijd verzekeringstekorten constateert bij met name mensen in het 'spitsuur van het leven', waarin tegelijkertijd baanrisico's, kinderen (of wensen daartoe), opleidingen, hypotheeklasten, en zorg voor ouders gecombineerd moeten worden. Daar komt bij dat Nederland meer aan tweedepijlerpensioen doet dan welk ander land ter wereld. Wat dat betreft lopen we zeker voor op de meeste andere (Europese) landen die veel grotere problemen gaan krijgen met de aanstaande vergrijzingsrekening. Die prioriteit concurreert echter met andere publieke en/of private uitgaven. Gezien de uitdagingen waar we nu voor staan, is 'oud' oververzekerd in onze verzorgingsstaat en 'jong' onderverzekerd.

\section{'Nieuwe risico's' vergen betere voorzieningen}

De Nederlandse overheid heeft zich van oudsher verre gehouden van het voeren van een bevolkingsbeleid. Dat stond na de Tweede Wereldoorlog in een kwaad daglicht (en daarvoor deden we het trouwens ook niet; er is eenvoudigweg geen traditie in). Verder was er, met een jonge bevolking, decennialang ook weinig reden om hierover na te denken: de demografische boom zag er goed uit. Juist deze relatief jonge bevolking maakte het na de oorlog mogelijk om een ruim pensioenstelsel (eerste en tweede pijler) op te bouwen. En vanaf de jaren zestig werden hoogconjuncturele tekorten op de arbeidsmarkt opgevangen door mediterrane arbeidskrachten aan te trekken. Het krijgen en opvoeden van kinderen is in Nederland tot op heden voornamelijk opgevat als een cultureel gegeven of een individuele keuze (met in de verzuilde tijd voor de katholieke zuil invloed van de 
kerk, maar niet van de overheid). Pas op dit moment ziet men een rol weggelegd voor de overheid bij het faciliteren van de mogelijkheid van mensen om kinderen te krijgen en op te voeden. Tot op heden heeft de overheidsrol ten aanzien van kinderopvangvoorzieningen en dergelijke zich voornamelijk beperkt tot enig financieel bijpassen, maar we zijn hier ver verwijderd van bijvoorbeeld de Scandinavische voorzieningenniveaus. Het krijgen van een kind vertaalt zich in Nederland dan ook direct in een beduidende afname van de koopkracht van de ouders: gemiddeld daalt hun bestedingsruimte met een vijfde (Bos en Hooghiemstra 2004, p. 66). Dit 'gezinsdal' wordt voornamelijk veroorzaakt doordat vrouwen in deeltijd gaan werken als ze moeder worden of helemaal stoppen met werken. Internationaal-vergelijkenderwijs kan gesteld worden dat de Nederlandse verzorgingsstaat hier onderverzekert (Kremer 2005, hoofdstuk 5). De conclusie ten aanzien van de zogenaamde nieuwe risico's is daarmee dat er hier nog ruimte is om voorzieningen te verbeteren.

\section{Vergrijzing stelt nadere eisen aan ons verzekeringssysteem én aan ons arbeidsstelsel}

Vergrijzing is een probleem dat we lang van tevoren kunnen zien aankomen: het is een trend die zeker is. Beleidsmatig 'niets doen' is dan ook onverstandig. Naarmate er tijdiger beleid op de vergrijzing wordt gevoerd, is het palet aan opties groter. Bovendien is er dan ook een lange periode beschikbaar om aan oplossingen te werken; die oplossingen hoeven dus niet allemaal morgen of volgend jaar ingevoerd te worden - er is geen reden voor paniek. Maar er is ook geen reden voor uitstel. Recente vooruitberekeningen van het СРВ (2006) laten zien dat de vergrijzing die ons tot 2040 - wanneer de vergrijzingslast maximaal is - te wachten staat, ingrijpende repercussies heeft. De kosten van pensioenen, AOW en gezondheidszorg zullen sterk stijgen als onderdeel van het nationaal inkomen. Zonder nadere en tijdige beleidsmaatregelen betekent dit dat het financieringstekort en de staatsschuld na 2010 sterk zullen gaan oplopen. De te nemen maatregelen kunnen in ten minste vier hoofdrichtingen worden gezocht: (1) ouderen gaan (weer) langer doorwerken, (2) geleidelijke afschaffing van het ouderentarief in de inkomstenbelasting (zodat ook AOW'ers mee blijven betalen aan collectieve voorzieningen), (3) een geleidelijke verhoging van de AOW-leeftijd (naar bijvoorbeeld 67 jaar9), en (4) in het algemeen de arbeidsparticipatie zo hoog mogelijk zien te krijgen (zie ook WRR 200o): een investering in het draagvlak van de samenleving.

Dat ouderen langer (moeten en kunnen) doorwerken is al langer in discussie. Door het aantrekken van de economie, en de beperking van de routes van vervroegde uittreding, stijgt de participatie van de groep tussen de 55 en 65 jaar ook weer. Die stijging is al zo'n tien jaar voorzichtig gaande, maar daar kan nog meer bereikt worden. Verder lopen er momenteel debatten over de Nederlandse pensioenleeftijd. Een afnemende productiviteit bij klimmende leeftijd - van oudsher, in een tijd met merendeels 'slijtende' beroepen, de ratio achter een pensioenleeftijd rond het 65 ste jaar - is niet meer vanzelfsprekend. Stratenmakers, vuilnisophalers en dergelijke beroepen hebben nog steeds met fysieke slijtage te maken, en dat geldt ook 
voor sommige beroepen in de dienstverlening (zorg, onderwijs). Maar voor andere beroepen geldt het optreden van productiviteitsverlies bij een klimmende leeftijd niet. Er zijn, integendeel, steeds meer creatieve beroepen en 'ervaringsberoepen' (management bijvoorbeeld) waarin mensen alleen maar 'beter' worden met de jaren.

Als we willen dat mensen langer doorwerken, is het strak vasthouden aan anciënniteit als belangrijkste basis van de beloningsstructuur wel een probleem. Van oudsher heeft dit anciënniteitbeginsel een institutioneel-economische ratio: het zet partijen aan tot 'investeren' in de arbeidsrelatie (vgl. Lazear 1995). Nu echter zou het gaan betekenen dat de even productieve of zelfs wat minder productievere ouderen voor een werkgever dubbel zo duur zijn als hun jongere collega's. Zoveel hoger komt de productiviteit in het algemeen met het klimmen der jaren niet te liggen. Bovendien brengt de huidige beloningsstructuur over het leven met zich mee dat er vanaf de leeftijd van 45 à 50 jaar nauwelijks mobiliteit is of zelfs maar een arbeids'markt' als zodanig. Dit illustreert overigens dat interne mechanismen (anciënniteit, beloningsstructuur) en externe mechanismen (arbeidsmarktmobiliteit, ontslagwetgeving) sterk met elkaar verweven zijn.

Waar het gaat om vergrijzing, langer doorwerken en de positie van oudere werknemers kan daarom de volgende drieslag gemaakt worden. In de eerste plaats is het een goede zaak als mensen in onderling overleg tussen werkgever en werknemer er vaker voor opteren om na hun 65 ste jaar nog - geheel of gedeeltelijk door te werken (Hazeu 1999, p. 12). De volgende slag is dat bedrijven eraan zullen moeten wennen om voor oudere werknemers een interessante werkgever te zijn. ${ }^{10}$ Hun productie en productiviteit zijn immers nodig: de schaarste op de arbeidsmarkt gaat structureel toenemen, er is breed gevoelde huiver in onze samenleving over verdere arbeidsmigratie, en de laagdrempelige uittreedroutes van VUT, WAO en WW zijn 'dichtgeschroeid'. Het vormgeven van goede manieren om als bedrijf om te gaan met oudere werknemers kan gestimuleerd worden door good practices naar voren te halen. Die good practices kunnen ook uit het buitenland komen, bijvoorbeeld uit de Scandinavische landen die zo'n jaar of twintig voorlopen op Nederland in demografische ontwikkeling. Daarbij is het natuurlijk zaak om niet een 'Deens model' of een 'Zweeds model' te kopiëren, maar om goed werkende mechanismen, arrangementen en instituties ook in de Nederlandse verhoudingen te beproeven. De mate waarin we komende jaren verder weten te komen in deze eerste twee 'slagen' (langer doorwerken op basis van vrijwilligheid, en een beter ouderenbeleid van werkgevers) geeft - zeg rond 2010 - ook een indicatie van de noodzaak om ook door het optrekken van de AOw-leeftijd nog een bijdrage te leveren aan het opvangen van het vergrijzingsprobleem.

Ten slotte: betere participatievoorzieningen voor jongeren betekent win-win voor allen

In dit hoofdstuk is geanalyseerd hoe de organisatie en beheersing van de verzekeringsfunctie van de verzorgingsstaat in de afgelopen twee decennia ruwweg op 
orde is gebracht. De komende tijd zal vooral de aanstaande vergrijzing nadere eisen stellen. Ouderen hebben daarbij als groep de afgelopen jaren al de nodige ingrepen ondergaan (afschaffing vUT, beperkte indexering pensioenen; van eindloon naar middelloon; de wW-duurbeperking en heractivering van de sollicitatieplicht) en zullen er mogelijk nog meer ondergaan; denk aan de debatten over fiscalisering van de AOW en over doorwerken na het 65 ste jaar. Hierbij dient wel in ogenschouw te worden genomen dat ouderen als groep in de Nederlandse verzorgingsstaat verhoudingsgewijs het sterkst verzekerd zijn, terwijl jongeren en mensen in 'het spitsuur van het leven' minder goed af zijn. Bovendien heeft een wat evenwichtiger profijt van de verzekeringsfunctie naar leeftijdscategorieën niet louter een herverdelend effect, maar juist een win-winkarakter. De macro-economische ruimte die ermee wordt gecreëerd, kan immers dienen ter financiering van betere voorzieningen om nieuwe risico's op te kunnen vangen. Het dient dan ook iedereen. Een hogere arbeidsparticipatie betekent immers een groter draagvlak voor het opvangen van de vergrijzingsproblematiek. 


\section{NOTEN}

1

November 2006 komt het ministerie van szw met een actualisering uit van deze studie over de toekomstige inkomenspositie van ouderen. Daarin zal onder andere gepoogd worden om ook rekening te houden met het inkomen van ouderen uit derdepijlerregelingen (lijfrentepolissen) en inkomen uit vermogen.

Een indicator die is ontwikkeld om rekening te houden met definitieverschillen, verschillen in belastingstelsels (krijgt een voorziening de vorm van een publieke uitgave of juist van een tax expenditure?) en verschuivingen van publieke naar private regelingen, die veel invloed hebben op wat in statistieken wordt gerapporteerd, maar juist een minder goed zicht bieden op de materiële kant van de zaak.

3 Dat lage vruchtbaarheidsniveau wordt ook beïnvloed door de late komst van het eerste kind, gemiddeld zo rond het dertigste jaar van de moeder. Verder geldt dat de vruchtbaarheid van allochtone vrouwen wel hoger dan gemiddeld ligt, maar dat die van tweedegeneratie allochtone vrouwen richting die van autochtone vrouwen tendeert.

$\mathrm{Nu}$ ook schoorvoetend door Bovenberg erkend: "De levensloopregeling moet meer worden gericht op scholing in plaats van vervroegde uittreding." (A.L. Bovenberg en B. Jacobs, 'Vele hervormingen nodig om vergrijzing op te vangen', de Volkskrant 21 maart 2006).

Overigens is het beeld hier niet geheel uitgekristalliseerd voor de toekomst. In ieder geval is er zowel sprake van een afname van het aanbod als van de vraag naar laagopgeleiden. De laatste jaren is de vraag sneller afgenomen dan het aanbod (Jacobs 2004), maar dat kan conjunctureel bepaald zijn. Naar de toekomst toe is het voorstelbaar dat een toenemende inkomensongelijkheid in het voordeel kan werken van de participatie van laagopgeleiden. Voor de lange termijn is ter voorkoming van structurele uitval en marginalisering van belang dat laagopgeleiden een fatsoenlijk leven kunnen leiden. Bij voldoende inzet van het bestaande beleidsinstrumentarium zou dit mogelijk moeten zijn. Verontrustend blijft met name dat er een groep gemarginaliseerden bestaat voor wie de aansluiting met de arbeidsmarkt blijvend verloren is gegaan.

En wanneer alle relevante publieke voorzieningen (ook bijvoorbeeld de batentoerekening van middelbaar en hoger onderwijs) en belastingsubsidies (bijvoorbeeld hypotheekrenteaftrek) bij elkaar worden genomen, resulteert de verzorgingsstaat ook niet in een grootscheepse herverdeling van hoog naar laag (vgl. SCP 2003). Vanaf de aanscherping van de toegangseis voor de ww per 1 april 2006 geldt dat men van de voorgaande 36 weken er 26 gewerkt moet hebben. Daarvoor lag de wekeneis op 26 van de laatste 39 weken.

In de Amerikaanse samenleving is bijvoorbeeld veel minder sociale verzekering, maar werken mensen gemiddeld meer uren, die ook nog productiever zijn, zodat hun nationaal inkomen per hoofd van de bevolking zo'n dertig procent boven het gemiddelde van de EU-15 ligt. In zekere zin is dat hun manier van verzekeren, of, anders gezegd, de compensatie voor het tekort eraan. 
9 De modaliteit 'fiscalisering van de AOW' levert volgens het СРв (СРВ/Van Ewijk e.a. 2006, p. 18) 1,5 à 2 maal zo 'n grote bijdrage aan de oplossing van de budgettaire problematiek ten gevolge van de vergrijzing dan de modaliteit 'geleidelijke verhoging van de AOW -leeftijd tot 67 jaar'. Hierbij moet wel aangetekend worden dat een en ander sterk afhankelijk is van hoe dergelijke modaliteiten worden ingevoerd (o.a. fasering). Zie ook de Studiegroep Begrotingsruimte (2006, p. 31) voor een uitvoeriger overzicht van mogelijke maatregelen.

10 Werkgevers - zoals de overheid bijvoorbeeld - die nog bezig zijn competities te organiseren wie de 'beste jonge ambtenaar van het jaar' is, en eenvoudigweg niet op het idee komen dat je zo'n competitie ook kunt organiseren voor de 50-pluscategorie, doen niet alleen aan leeftijdsdiscriminatie, maar zien vooral de bui nog niet hangen. 


\section{VERHEFFEN: INVESTEREN IN EEN ZACHTMOEDIGE MERITOCRATIE}

\subsection{INLEIDING}

De Nederlandse verzorgingsstaat heeft altijd (ook) in het teken van verheffen gestaan. Waar de wortels van de sociale zekerheid zoals die in het vorige hoofdstuk aan bod kwam, eerder in (het begin van) de twintigste eeuw liggen, gaat deze functie in sterke mate terug op de negentiende eeuw. In deze periode krijgt het Nederlandse onderwijsbestel contouren en neemt de arbeidsmarkt moderne vormen aan. In het verlengde daarvan vormen noties over kansen en mogelijkheden voor ontwikkeling een belangrijk onderdeel van het maatschappelijk discours. De vraag ligt voor hoe die noties inhoud te geven en wat het betekent voor de vormgeving van de verschillende instituties.

Kenmerkend voor moderne samenlevingen is het funderende idee van individuele gelijkwaardigheid. Het belang van dat idee wordt door alle grote politieke stromingen onderschreven. Minder overeenstemming is er lange tijd geweest over wat dat betekent, wanneer aan de norm van individuele gelijkwaardigheid recht is gedaan, en wie daarvoor de voornaamste verantwoordelijkheid heeft. Grof gezegd staan daarbij twee interpretaties tegenover elkaar: kansengelijkheid en uitkomstgelijkheid. Kansengelijkheid vereist een maatschappelijk bestel waarin vrije beroepskeuze wettelijk is gegarandeerd en waarin de overheid zich garant stelt voor de toegankelijkheid van het onderwijs. Uitkomstgelijkheid daarentegen is gebaseerd op een sociaal-wetenschappelijke analyse waarin de formele gelijkheden van de burgerlijke maatschappij vooral gezien worden als een toedekking van feitelijke ongelijkheden. De 'negatieve vrijheden' die bescherming bieden tegen overmatige staatsbemoeienis en burgers de mogelijkheid geven om via het schadebeginsel het civiele leven in goede banen te leiden, is in dit perspectief ontoereikend om recht te doen aan het beginsel van individuele gelijkwaardigheid. Naast 'negatieve vrijheden' zijn er dan 'positieve vrijheden' nodig die verdergaan dan contractvrijheid en formele toegangsgelijkheid (Berlin 1958).

Beide interpretaties zijn in het licht van de voortgaande heterogenisering van de samenleving achterhaald. Omdat verheffen in een geïndividualiseerde samenleving niet uitsluitend de verantwoordelijkheid van de overheid kan zijn, maar in toenemende mate toevalt aan het individu zelf, kan verheffen niet langer de vorm aannemen van het van overheidswege 'optillen' van mensen tot aan een politiek bepaald uitkomstenniveau. Daarvoor bestaan niet alleen redenen van politieke opportuniteit (We're all liberals now!), maar ook eigenstandige morele redenen. Een eigentijdse uitwerking van het beginsel van individuele gelijkwaardigheid moet namelijk zowel recht doen aan de notie van gelijkheid als aan de notie van handelingsverantwoordelijkheid die er via de band van moderne persoonsconcepties, waarin het autonoom denkende en handelende individu centraal staat, aan moet worden toegevoegd. Alleen een verdeling van hulpbronnen en posities die, 
om met de Amerikaanse filosoof Ronald Dworkin (200o) te spreken, tegelijk 'gevoelig' is voor verschillen in talent en inzet en 'ongevoelig' voor verschillen die buiten het bereik van de individuele verantwoordelijkheid liggen, voldoet aan deze twee eisen. Het ideaal dat hiermee wordt verwoord is er één waarin alle legitieme verschillen 'verdiende' verschillen zijn en alle niet-verdiende verschillen in principe moreel illegitiem.

Het amendement dat de Engels-Indiase econoom en Nobelprijswinnaar Amartya Sen hieraan heeft toegevoegd, luidt dat individuen zeer kunnen verschillen in de mate waarin zij erin slagen gelijke kansen ook daadwerkelijk te benutten. Oftewel, ongelijke uitkomsten zijn alleen dan moreel legitiem als de maatschappelijke kansen corrigeren voor mentale, cognitieve en fysieke verschillen tussen mensen. Daadwerkelijke kansengelijkheid vereist dan ook een verdeling van maatschappelijke hulpbronnen die mensen gelijke mogelijkheden verschaft om hun maatschappelijke kansen daadwerkelijk te realiseren. Het is vervolgens aan in-dividuen zelf om deze kansen ook daadwerkelijk te grijpen. Oftewel, effectieve kansengelijkheid is alleen dan gerealiseerd wanneer mensen over gelijke mogelijkheden beschikken om hun levensplannen te realiseren, ook al vereist dat een ongelijke verdeling van maatschappelijke hulpbronnen en mondt het uit in ongelijke uitkomsten (Sen 1995). Deze geïndividualiseerde kansengelijkheid wijkt in haar sensitiviteit voor individuele verschillen af van de uniforme kansenvrijheid à la John Rawls (1971), Will Kymlicka (1990) en Ronald Dworkin (200o), maar onderscheidt zich, evenals het liberaal-egalitarisme van Rawls en anderen, van uitkomstgelijkheid door haar gevoeligheid voor individuele verantwoordelijkheid voor de eigen levensuitkomsten. Ook al is de mens geen meester van zijn eigen lot, hij is evenmin het willoze slachtoffer van de omstandigheden.

Dit morele principe komt niet uit de lucht vallen. Het is een radicalisering van de voornaamste ontwikkelingslijnen in het moderniseringsproces zoals dat door de klassieke sociologie is beschreven en daarmee een voorbeeld van empirisch gefundeerde normativiteit. Een maatschappelijke orde waarin achievement het voornaamste verdelingscriterium is, is een maatschappij die via een uitgebalanceerd onderwijsbestel zorgt voor gelijke uitgangsposities en een optimale ontplooiing van ieder menselijk talent, ongeacht aard en omvang ervan. Ook is het een orde waarin het idee van vrije beroepskeuze serieus wordt genomen en waarin dus wordt gestreefd naar een arbeidsmarkt waarin alle drempels, schotten, plafonds en andere belemmeringen die niet gerelateerd zijn aan objectieve functie-eisen zijn weggenomen. Een maatschappij die daaraan voldoet, wordt ook wel een 'meritocratie' genoemd (Roemer 2000).

Hoewel een goed functionerende meritocratie een belangrijk element is van de verheffingsfunctie, is die functie daarmee niet uitgeput. Verheffen is niet alleen een instrument ter maximalisering van de economische groei, maar omvat ook het idee van ontwikkeling en ontplooiing omwille van zichzelf. Het vergroten van de verheffingscapaciteiten van onderwijsbestel en arbeidsmarkt is niet alleen 
een noodzaak om de Nederlandse verzorgingsstaat betaalbaar te houden, maar ook omdat ze zo meer tegemoet komt aan de grotere diversiteit aan wensen, verlangens en vermogens die hedendaagse Nederlandse burgers nu eenmaal hebben. Daarnaast omvat verheffen een element van zachtmoedigheid, gebaseerd op een fundamentele acceptatie van menselijke beperkingen die een meritocratie ontbeert. De hardvochtigheid van een samenleving waarin verschillen in uitkomsten niet langer hoeven te worden gecorrigeerd omdat ze nu eenmaal 'verdiend' zijn, wordt door de meeste Nederlanders afgewezen, zo leert ook recent onderzoek (SCP 2005; 21minuten.nl). Om deze redenen wordt in dit hoofdstuk het begrip 'verheffen' gebruikt en niet 'meritocratisering'.

Uiteraard klinkt in 'verheffen' ook de gedachte van culturele overdracht door. Hoewel recent het pleidooi weer klinkt om het Nederlandse onderwijs daarin een belangrijke rol te laten spelen (Onderwijsraad 2006), past daarbij wel bescheidenheid. Niet alleen is er geen duidelijkheid over wat die culturele overdracht zou moeten behelzen, ook ontbreekt het aan een moreel gezaghebbende elite die overtuigend kan vaststellen welke culturele canon eenieder zou moeten kennen. Om deze redenen beperken we ons in dit hoofdstuk tot een meer functionele invulling van verheffen, en beperken we ons tot het onderwijs en de arbeidsmarkt. In het volgende hoofdstuk (hoofdstuk 8 , over de verbindingsfunctie van de verzorgingsstaat) wordt uitvoeriger ingegaan op de kwestie van culturele verheffing.

In dit hoofdstuk wordt zowel het Nederlandse onderwijsbestel als de arbeidsmarkt doorgelicht op hun vermogen om mensen te verheffen. Daarbij kijken we niet naar sociale mobiliteit in Nederland in zijn algemeenheid, maar richten we ons vooral op de identificatie van verheffingstekorten (en eventueel overschotten) binnen het Nederlandse onderwijsbestel en de Nederlandse arbeidsmarkt. De vragen die in paragraaf 7.2 centraal staan zijn: slaagt het Nederlandse onderwijsbestel erin het aanwezige talent van de bevolking in voldoende mate te ontdekken en te (helpen) ontplooien? Biedt het verschillende talenten voldoende leertrajecten om zich maximaal te scholen? Is het onderwijssysteem in afdoende mate toegerust voor een arbeidsbestel waarin vaardigheden niet langer een leven lang meegaan?

Paragraaf 7.3 neemt vervolgens de arbeidsmarkt onder de loep en kijkt vooral naar de mate waarin recht wordt gedaan aan de norm van vrije beroepskeuze. Staan posities in de Nederlandse arbeidsmarkt open voor iedere getalenteerde of vallen er toch drempels en blokkades voor de instroom en doorstroom van specifieke groepen en individuen aan te wijzen? De kwaliteitsslag die in paragraaf 7.2 wordt bepleit voor het Nederlandse onderwijs, verliest immers aan effect wanneer de arbeidsmarkt haar verdelende functie niet naar behoren vervult. Dat is niet alleen een verspilling van middelen en menselijk kapitaal, maar kan ook, als die blokkades en drempels bovendien etnisch 'gekleurd' zijn, gemakkelijk leiden tot sociale 'ontbinding'. 
Paragraaf 7.4 beantwoordt de vraag Wat te doen? Hoe kunnen eventuele verheffingstekorten worden weggenomen? Welke aanpassingen en wijzigingen zijn er nodig om de Nederlandse samenleving voor te bereiden op een wereld van toenemende internationalisering, technologische verandering, heterogeniteit, en vergrijzing en ontgroening? Hoe de werking van de verheffingsfunctie te verbeteren, opdat de robuustheid en toekomstbestendigheid van de Nederlandse verzorgingsstaat wordt vergroot?

Paragraaf 7.5 beantwoordt de vraag hoe een 'zachtmoedige meritocratie' eruitziet en schetst in grove penseelstreken de arrangementen die benodigd zijn om een toekomstige meritocratie van zijn scherpe kantjes te ontdoen.

\subsection{VERHEFFEN IN HET ONDERWIJS}

Van oorsprong was het Nederlandse onderwijs vooral standenonderwijs. 'Hoger' en 'lager' duidden niet, zoals tegenwoordig, een temporeel onderscheid aan, maar verwezen naar twee verschillende opleidingstrajecten die primair bedoeld waren voor de reproductie van standsverschillen. Pas later daagde het besef dat dit om sociale en economische redenen onwenselijk was. Sociaal onwenselijk omdat een gesegregeerd onderwijssysteem niet paste bij een samenleving die werd gekenmerkt door groeiende wederzijdse afhankelijkheden en gedeelde risico's. En economisch onwenselijk omdat het onderwijsstelsel van de negentiende eeuw niet bij machte bleek het aantal hoger geschoolden af te leveren waar de veranderende economische structuur om vroeg.

Met de industrialisatie van de Nederlandse economie in de tweede helft van de negentiende eeuw namen ook haar kapitaalsintensiteit en schaalomvang toe. Als gevolg daarvan steeg de complexiteit van de bedrijfsvoering, kromp het aantal eenvoudige uitvoeringsfuncties, en werd de roep om gekwalificeerde ambachtslieden en geschoolde managers groter. Als gevolg van de mismatch tussen de kwaliteit van de gevraagde en de aangeboden arbeid groeide de druk op de overheid om de schotten tussen de onderwijstrajecten af te breken. In de tweede helft van de negentiende en het begin van de twintigste eeuw resulteerde dat in een aantal wetten die van de aanduidingen 'hoger' en 'lager' temporele aanduidingen maakten. Het lager onderwijs werd een publiek gefinancierde, zij het deels privaat georganiseerde, primaire onderwijsfase die ieder kind moest doorlopen. Differentiatie naar interesse en intellectuele vermogens vond na afloop van deze fase plaats en leidde ertoe dat kinderen werden uitgesorteerd over verschillende niveaus binnen de secundaire onderwijsfase. Met deze nieuwe institutionele structuur kreeg het onderwijs ook een expliciete verheffingstaak. Het streven werd om zoveel mogelijk leerlingen te laten doorstromen naar hogere onderwijsvormen door belemmeringen op instroom en doorstroom zoveel mogelijk weg te nemen. Dit kan worden geïnterpreteerd als de uitkomst van de politieke contestatie over de juiste vertaling van het principe van individuele gelijkwaardigheid, die vanaf het einde van de negentiende eeuw geleidelijk aan had geresulteerd in een groeiende lijst sociale grondrechten die moesten bijdragen aan de realisering 
van het ideaal van kansengelijkheid (Braggen en Weijers 1995). Gedurende de twintigste eeuw neemt individuele 'verdienste' als verdelingsprincipe geleidelijk de plaats in van geboorte, sekse, bezit of leeftijd (Meijnen 2005a).

Met de toenemende meritocratisering van arbeidsorganisaties en het verschralen van inkomenscompenserende regelingen van staatswege is het onderwijsstelsel uitgegroeid tot de 'verheffingsmachine' bij uitstek. In toenemende mate is het schooldiploma beslissend geworden voor de arbeidsmarktperspectieven en, via inkomen, relaties, status en de andere hulpbronnen die via arbeid worden verkregen, voor gezondheid, wooncarrière, gezinsvorming, vriendenkring, welzijn, geluk en zelfs mortaliteit. Om die reden is onderwijs voor de meeste politieke partijen dan ook uitgegroeid tot hét instrument voor de realisering van breed gedeelde emancipatiedoelstellingen. Opeenvolgende kabinetten hebben sinds de jaren zestig kleine en grote onderwijshervormingen doorgevoerd om de reproductie van sociaal-economische ongelijkheden te verminderen en de doorstroom van leerlingen uit lagere sociaal-economische klassen naar het hoger beroepsonderwijs (hbo) en het wetenschappelijk onderwijs (wo) te vergroten, in een impliciete en soms expliciete poging om Nederland om te vormen tot een meritocratie (Meijnen 2005a; Karsten en Sleegers 2005).

\section{Anno nu: onderwijs, arbeidsmarkt en de Lissabonagenda}

Als gevolg van economische internationalisering is er aan het eind van de twintigste eeuw onder politieke en economische elites een groeiend besef van economische kwetsbaarheid ontstaan. Ondernemingen staan in toenemende mate bloot aan concurrentie uit landen die of een lager loonpeil kennen of een kwalitatief superieur productieklimaat. Ook via belastingheffingsgrondslagen zijn landen met elkaar in concurrentie. Om deze concurrentie het hoofd te bieden, kunnen grofweg twee wegen worden ingeslagen: ofwel het pad van lage arbeidskosten, ofwel het pad van de kwaliteitsconcurrentie waarin ingezet wordt op innovatie en kapitaalintensivering van de productie, wat ook dwingt tot grotere investeringen in menselijk kapitaal (Finegold en Soskice 1988).

Door de Europese Unie (EU) is vanwege de relatief hoge bruto arbeidskosten expliciet die laatste strategie omarmd. Met het Lissabonakkoord van 2000 is de doelstelling geformuleerd om de Europese economie te transformeren tot de meest concurrerende en dynamische ter wereld. Onderwijs wordt daarbij gezien als het instrument bij uitstek om arbeidsvraag en arbeidsaanbod in termen van competenties en functie-eisen dichter bij elkaar te brengen. In een context van vrijwel continue economische structuurveranderingen vereist dat voortdurende scholing en dus een onderwijssysteem waarin initiële en postinitiële opleidingen goed op elkaar aansluiten. Zonder permanente educatie zijn de vaardigen van morgen immers de werklozen van overmorgen (Sennett 2006). Dat zien te voorkomen is niet alleen een kwestie van economische noodzaak, maar ook van een preventieve verzekering tegen sociaal-economische marginalisering. Daarnaast is de toenemende nadruk door de EU-lidstaten op verhoging van de onderwijsinspanningen ingegeven door demografische ontwikkelingen - vergrijzing en 
ontgroening - die zowel maximalisering van de arbeidsparticipatie afdwingen (extensieve groei) als maximalisering van de arbeidsproductiviteit (intensieve groei) en dus optimaal gebruik maken van het aanwezige talent. Als gevolg daarvan kunnen ontwikkelde economieën met vergrijzende bevolkingen het zich niet langer permitteren om burgers aan de kant te laten staan of burgers met achterhaalde vaardigheden de arbeidsmarkt op te sturen. Voortijdige uitval en ontoereikende competentieverwerving zijn in dit licht prangende problemen.

In deze paragraaf wordt het Nederlandse onderwijsbestel doorgelicht op zijn verheffende capaciteiten. Hoe presteert het Nederlandse onderwijsbestel in vergelijking met andere landen? Weet het voldoende uit de leerlingen te halen? Is er

Figuur 7.1 Spreiding wiskundescores van 15-jarige leerlingen in 2003

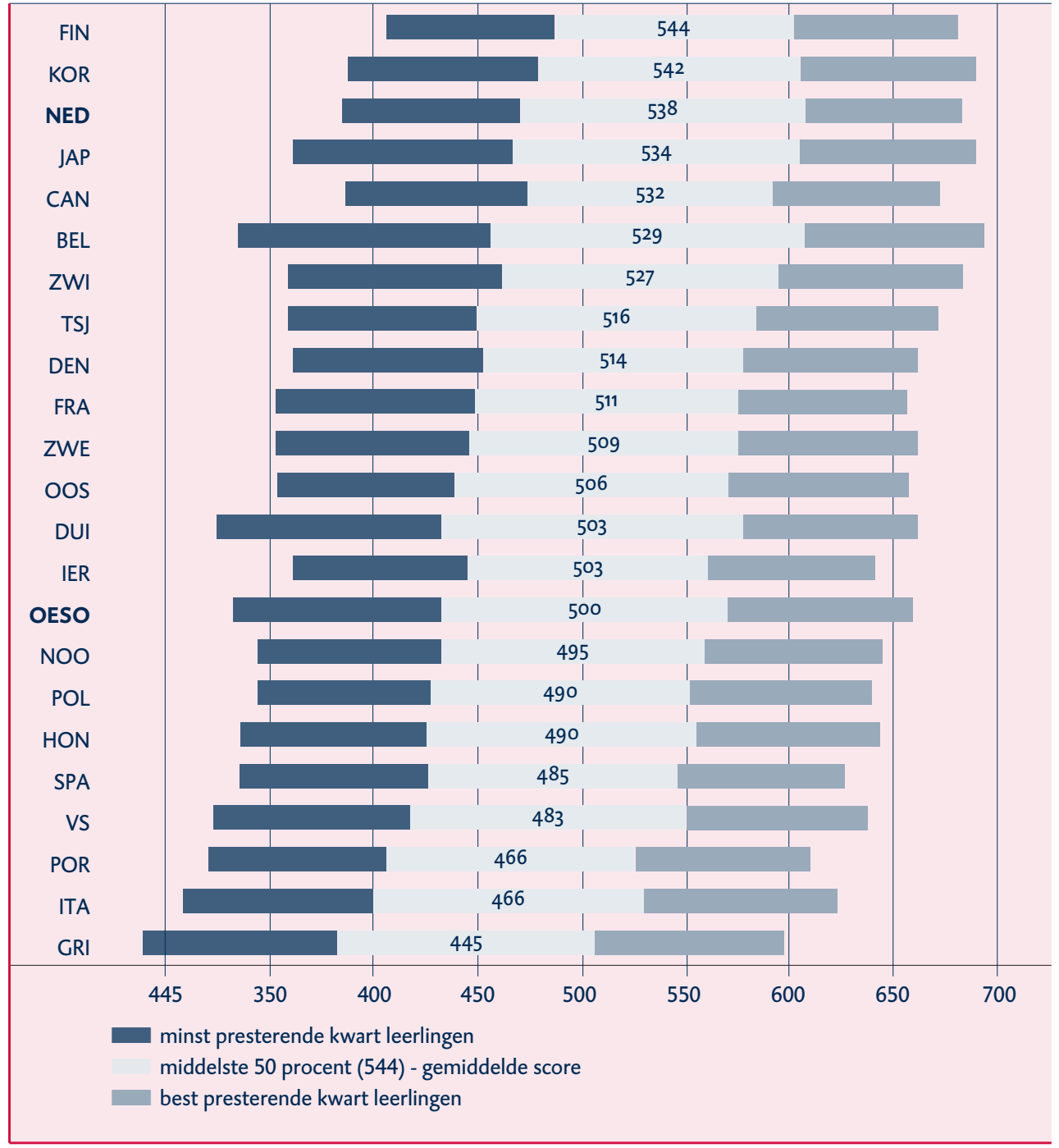


sprake van structurele onderbenutting, dat wil zeggen: zijn er bevolkingsgroepen die stelselmatig uitvallen of in de onderste regionen van het bestel terechtkomen? Maar niet alleen 'verheffingstekorten' zijn van belang, ook 'verheffingsoverschotten'. Waar kunnen inefficiënties en andere vormen van verspilling worden geïdentificeerd? Waar zou het onderwijsbestel in principe toe kunnen met minder publieke middelen omdat er meer private middelen in te zetten zijn?

\subsubsection{De PRESTAties VAN het NederLANDSE ONDERWIJS}

Hoewel het lastig is om de prestaties van verschillende onderwijssystemen internationaal te vergelijken, blijkt het Nederlandse onderwijsbestel op de enkele gestandaardiseerde internationale tests die er zijn, goed tot uitstekend te scoren. Uit de driejaarlijkse PISA-testen die de Organisatie voor Economische Samenwerking en Ontwikkeling (OECD) sinds 2000 onder 4.500 tot 10.000 leerlingen per deelnemend land afneemt om zicht te krijgen op de lees- en rekenvaardigheden van vijftienjarigen, scoort Nederland uitstekend. Op het vlak van wiskunde staat Nederland derde, achter Finland en Zuid-Korea.

Op het gebied van leesvaardigheden staan Nederlandse leerlingen op de zevende plaats, na respectievelijk Finland, Zuid-Korea, Canada, Australië, Nieuw-Zeeland en Ierland. En op het vaardigheidsgebied natuurwetenschap scoort Nederland een vierde plaats, na (weer) Finland, Zuid-Korea, Japan en Australië (OECD 2005; OCW 2005). Deze goede prestaties zijn des te opmerkelijker als wordt bedacht dat de Nederlandse uitgaven aan onderwijs relatief laag zijn. In 2004 bedroegen de totale uitgaven 5 procent van het bruto binnenlands product (bbp). Dit ligt onder het EU-gemiddelde (5,4 procent) en het OECD-gemiddelde (5,6 procent) en ook beduidend onder de uitgaven van landen als Frankrijk (6,1 procent), België $(6,4$ procent), en het Verenigd Koninkrijk (5,9 procent). Met recht kon de minister van OCW dus in haar reactie op de laatste Education at a glance van de OECD schrijven dat de effectiviteit van het Nederlandse onderwijs afgemeten aan de verhouding tussen kosten en opbrengsten groot is (Ministerie van OCW 2005).

Zo op het eerste gezicht is er dus weinig aan de hand. De kwaliteit van het Nederlandse primaire onderwijs (want dat is wat deze tests hoofdzakelijk meten) is internationaal gezien uitstekend en voldoet daarmee in grote lijnen aan onze verheffingseisen. Dat wil echter niet zeggen dat er niet ook (grote) knelpunten zijn in het Nederlandse onderwijs. Hieronder zullen wij deze per onderwijsfase langslopen.

\subsubsection{VOORSCHOOLSE EDUCATIE: VOORBIJ DE OPVANG}

Internationaal bestaat consensus over het belang van goede voorschoolse educatie (OECD 2001). Goede, kwalitatief hoogstaande voorschoolse educatie is niet alleen noodzakelijk om uitval en ontwikkelingsstoornissen in een vroegtijdig stadium te kunnen identificeren, maar ook om de reproductie van sociaal-economische ongelijkheden door (te) vroege sortering zoveel mogelijk tegen te gaan. 
Figuur 7.2 Verdeling (publieke en private) uitgaven naar onderwijsniveau als percentage van het bbp in 2002

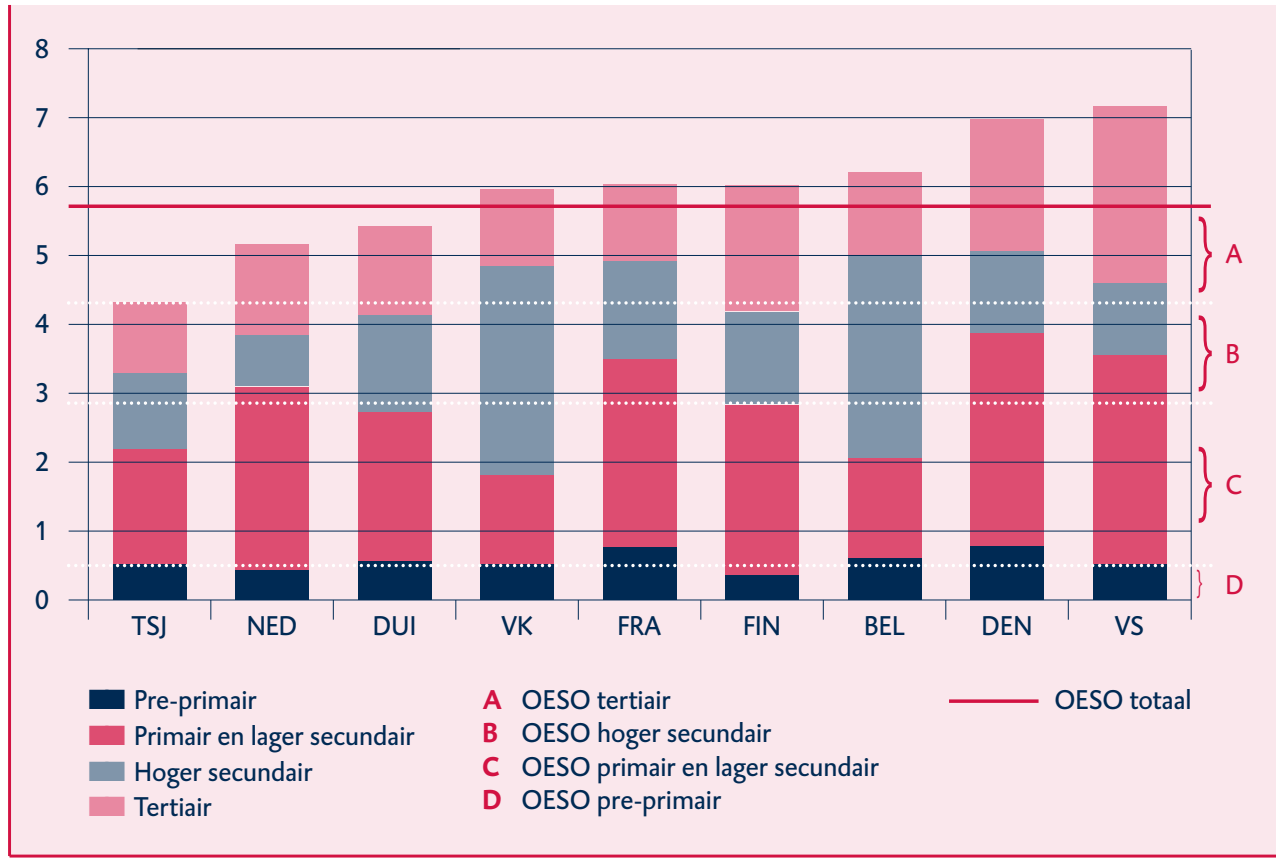

Bron: OECD

Onder ideale condities, dat wil zeggen bij consequente toepassing van de beste voorschoolse programma's, voldoende ouderbetrokkenheid, en doorlopende ondersteuning tijdens het basisonderwijs, kan de helft tot twee derde van de leerachterstand ongedaan worden gemaakt (Leseman 2005).

In Nederland bestaan er weliswaar instellingen voor Voor- en Vroegschoolse Educatie (VVE), maar deze zijn ten eerste relatief schaars en ten tweede expliciet bedoeld voor de bestrijding van de achterstanden van allochtone kinderen. In de reguliere kinderopvang, aan de andere kant, is relatief weinig aandacht voor de cognitieve en emotioneel-affectieve ontwikkeling, zo blijkt uit recent evaluatieonderzoek. Bovendien staat sinds het van kracht worden van de Wet op de Kinderopvang de kwaliteit van de crèches onder druk (NCKO 2005; Gevers DenooytSchaub 2006). Veelzeggend is dat er wordt gesproken van voorschoolse opvang in plaats van voorschoolse educatie, en dat met de nieuwe Wet op de Kinderopvang de crèches zijn gaan ressorteren onder het ministerie van Sociale Zaken en Werkgelegenheid in plaats van het ministerie van Onderwijs.

Momenteel ligt de nadruk bij het realiseren van voorschoolse opvang op een instrumentele redenering. Meer voor-, tussen- en naschoolse opvang is nodig om de relatief lage arbeidsparticipatie (in uren) van de Nederlandse beroepsbevolking, met name die van vrouwen, te vergroten. Hoewel er op het gebied van de arbeidsparticipatie van vrouwen in korte tijd grote winst is geboekt, blijken ze 
toch nog grotendeels te moeten opdraaien voor de zorgtaken. Het hebben van kinderen wordt door veel vrouwen als een reden gezien om de eigen arbeidsdeelname terug te schroeven. Ondanks pogingen van de overheid om het zogenaamde 'combinatiescenario' te propageren, waarbij man en vrouw gelijkelijk zorgen en werken, blijven mannen overwegend voltijds werken en ziet een toenemend aantal vrouwen de onmogelijkheid om gezin en carrière te verenigen als een belangrijke reden om te kiezen voor kinderloosheid (Koopmans en Schippers 2006). Gegeven deze analyse wordt kinderopvang vooral gezien als oplossing voor een demografisch probleem en in termen van beschikbaarheid (hoeveel crèches?) en toegankelijkheid (hoe duur?) bediscussieerd. Daaruit spreekt een grote onderschatting van het belang van kwaliteitsoverwegingen bij beslissingen om kinderen al dan niet naar de crèche te brengen en de eigen arbeidsdeelname te continueren (Kremer 2005; SCP 2006a).

Ervaringen in Denemarken en Zweden leren dat met het inbouwen van een pedagogische component in de voorschoolse opvang niet alleen de kwaliteit van de opvang kan toenemen, en daarmee het enthousiasme van ouders om hun kinderen daadwerkelijk naar de opvang te brengen, maar dat tevens vooruitgang kan worden geboekt in het terugbrengen van de invloed van sociaal-culturele gezinsverschillen op leerprestaties (Esping-Andersen 2006). Grof gezegd geldt dat hoe jonger ontwikkelingsachterstanden worden aangepakt, hoe meer de effecten van vroege ontwikkelingsverschillen ongedaan kunnen worden gemaakt en hoe beter de leerprestaties gedurende de schoolcarrière zullen zijn (Leseman 2005). Dit betekent niet alleen een effectievere identificatie en ontplooiing van talenten, maar biedt ook mogelijkheden om vormen van deviante socialisatie als gevolg van tekortschietende opvoeding vroegtijdig aan te pakken en daarmee het ontstaan van 'ontbindingsproblemen' in latere levensfasen te voorkomen. Hier bestaat dus een duidelijk verheffingstekort.

\subsubsection{PRIMAIR ONDERWIJS: OVER ONGELIJKHEID EN DIVERSITEIT}

Gezien de hoge lees- en rekenvaardigheidscores van Nederlandse kinderen is de conclusie dat de gemiddelde basisschool er uitstekend in slaagt om een goede basis te leggen voor het voortgezette onderwijs (Meijnen 2005a; 2005b). Het is echter niet alles goud wat er blinkt. Drie problemen met betrekking tot het Nederlandse basisonderwijs zijn het bespreken waard: (1) de spreiding van de kwaliteit, (2) de gevolgen van de frequentere individuele leertrajecten, en (3) de korte schooldagen en het korte schooljaar.

\section{Spreiding}

Een eerste probleem is dat hoge PISA-scores verhullen dat de spreiding tussen hoog en laag in Nederland relatief groot is in vergelijking met de in dit opzicht best presterende landen, de Scandinavische landen. Dat wil zeggen dat de hoge scores vooral het resultaat zijn van een betrekkelijk kleine groep excellente leerlingen, maar dat het basisonderwijs er veel minder in slaagt om de onderkant naar een hoger plan te tillen. Een oorzaak daarvan zou de sterke mate van segregatie in 
het Nederlandse basisonderwijs kunnen zijn, zeker in de grote steden, die prestatieverschillen tussen scholen in de hand werkt, en zwakke leerlingen het motiverende effect ontzegt van de confrontatie met leerlingen afkomstig uit sterkere sociaal-economische milieus. Een andere verklaring schuilt wellicht in de sterke mate van differentiatie in het Nederlandse onderwijssysteem, hoewel Nederland in vergelijking met andere 'gedifferentieerde' landen als Duitsland en België zo slecht nog niet scoort. Als gevolg van zo'n 'gedifferentieerd onderwijsbestel' slagen scholen er minder in om het effect van sociaal-economische verschillen op de individuele leerprestaties teniet te doen. Landen met zogenaamde 'omvattende onderwijssystemen', als de Scandinavische, die leerlingen meer mengen en langer bij elkaar houden, slagen daar beter in (OECD 2005; Leseman 2005). De derde mogelijke verklaring is hiervoor al gegeven en betreft de afwezigheid van een pedagogische invulling van de voorschoolse opvang, waardoor de mogelijkheid ontbreekt om leerachterstanden te bestrijden wanneer ze ontstaan, namelijk gedurende de eerste vier levensjaren. Of menging dan wel een stelselherziening de antwoorden zijn, zoals de eerste twee verklaringen suggereren, komt in paragraaf 7.4 aan de orde.

\section{Gevolgen frequentere individuele leertrajecten}

Een tweede probleem is dat op het merendeel van de Nederlandse basisscholen het individuele leertraject dat oorspronkelijk uit het 'vernieuwingsonderwijs' (montessori, jenaplan, dalton) afkomstig is, het traditionele klassikale onderricht grotendeels verdrongen heeft. Als gevolg daarvan zijn rust en orde in het klaslokaal schaars geworden. Voor het merendeel van de leerlingen is die gecontroleerde wanorde van de schooldag een goede voorbereiding op het moderne leven en de multitasking die een latere werkplek vraagt. Onderzoek leert echter dat voor leerlingen uit zwakkere sociaal-economische milieus een dergelijke leeromgeving juist negatief kan uitpakken (Meijnen 2005a; Dronkers 2006). Zeker wanneer als gevolg van etnische segregatie basisscholen worden geconfronteerd met de effecten van sociaal-economische marginalisering, etnische uitsluiting en de overgangsproblemen van migranten, levert dat leeromgevingen op die weinig bevorderlijk zijn voor het maximaliseren van de leerprestaties van zwakkere leerlingen.

\section{Korte schooldagen en een kort schooljaar}

Ten slotte is een probleem dat de Nederlandse schoolweek zich kenmerkt door een relatief groot aantal contacturen, maar tevens door relatief korte schooldagen en een relatief kort schooljaar. Enerzijds betekent dat een betrekkelijk hoge arbeidslast voor leerkrachten, wat de aantrekkelijkheid van de professie niet ten goede komt. Anderzijds impliceert het een 'privaat' aanbod van naschoolse activiteiten op het gebied van sport, lichamelijke opvoeding en cultuurconsumptie dat grotendeels de bestaande sociale stratificatie volgt. Ervaringen uit omringende landen die veel eerder al begonnen zijn met 'brede school'-achtige arrangementen, leren dat deze het beste functioneren wanneer ze voorzien in aansluitende combinaties van cognitieve en recreatieve blokken die beide onder leiding staan van pedagogisch geschoolde krachten. Zo kan niet alleen de arbeidsdag van de leerkracht worden verkort zonder dat dit ten koste gaat van de schooldag van 
de leerling, maar komt ook de motorische, sociaal-emotionele en culturele ontwikkeling die momenteel in grote mate afhankelijk is van het ouderlijke aanbod binnen het bereik van meer kinderen. Ook hier kan dus gesproken worden van een verheffingstekort.

\section{Naschoolse opvang}

Ook in termen van aandacht voor de vorming van kinderen buiten de schooluren, ligt er in Nederland nog een opgave. De ontwikkeling van de brede school en van dagarrangementen in en om de school komen maar voorzichtig van de grond. De eerste initiatieven ontstonden rond 1995 in Rotterdam en Groningen. Volgens de laatste rapportage (Jaarbericht 2003) waren er in 2003 inzake het primair onderwijs 500 operationele brede scholen, en werkte 54 procent van de gemeenten aan brede-schoolontwikkeling, tegen 36 procent in 2001 (Bakker en Van Oenen 2005). Inmiddels worden alle scholen wettelijk verplicht naschoolse opvang aan te bieden. Die opdracht staat echter nog veelal in het teken van 'opvang', zoals dat ook in de kinderopvang het geval is. Tot op de dag van vandaag wordt in beleid en regelgeving vermeden om pedagogische voorwaarden en kaders te stellen. De vraag die voor komt te liggen is hoe een samenhangend concept voor een sociaal-pedagogische infrastructuur voor kinderen van 0-12 jaar kan worden ontwikkeld.

\subsubsection{VOORTGEZET ONDERWIJS: OVER DOORSTROOM EN UITVAL}

Anders dan in veel ons omringende landen worden leerlingen in Nederland vroeg (op de leeftijd van twaalf jaar) gesorteerd over verschillende vervolgonderwijstrajecten. Dit is kenmerkend voor 'gedifferentieerde' onderwijsstelsels. Ondanks pogingen om kinderen uit verschillende milieus en met verschillende talenten langer bij elkaar te houden (denk aan de middenschool), is de praktijk er een van vroege selectie. Hoewel alle leerlingen die van de basisschool komen formeel in een gezamenlijke brugklas terechtkomen, fungeert de uitslag van de cito-toets in de praktijk als scherprechter en stromen de intellectueel sterkere leerlingen door naar de brugklas havo/vwo en worden de zwakkere toegeleid naar het vmbo (Karsten en Meijnen 2005). De samenhang die met de term 'brede scholengemeenschap' wordt gesuggereerd, verhult een werkelijkheid van gescheiden vestigingen en gescheiden organisaties die de leerlingen met de betere cito-scores (ongeveer 40 procent) voorselecteert voor het algemeen vormende traject (havo/vwo) en de leerlingen met de mindere cito-scores (zestig procent voor het beroepsvoorbereidende traject (vmbo/mbo).

In beide trajecten spelen verschillende verheffingsproblemen. In het algemeen vormende traject betreffen de klachten vooral de effecten van de zogenaamde Tweede Fase en de bijbehorende keuze voor het Studiehuis met zijn grote nadruk op de verwerving van sleutelcompetenties en werkhoudingen die de kloof met het vervolgonderwijs alleen maar vergroot zouden hebben. In het beroepsvoorbereidende traject betreffen de problemen vooral het gebrek aan verbindingen tussen het vmbo en het algemeen vormende traject, waardoor leerlingen die naar het vmbo gaan daar als het ware worden 'opgesloten' en 'verkeerd gealloceerde' 
leerlingen nauwelijks mogelijkheden hebben om door te stromen. Daarnaast is er toenemende aandacht voor het grote aantal uitvallers in het vmbo, waardoor teveel leerlingen zonder startkwalificatie op de arbeidsmarkt terecht komen en onvoldoende voorbereid aan hun arbeidscarrière beginnen. Omdat de problemen in het algemeen vormend onderwijs vooral samenhangen met het ontbreken van selectie in het hoger onderwijs, beperken wij ons hier tot een bespreking van de meest in het oog springende verheffingstekorten in het vmbo.

\section{Doorstroom}

Overgewaaid uit het Verenigd Koninkrijk, dat zich als gevolg van zijn decennialange economische statusdaling vis-à-vis landen als Frankrijk en vooral Duitsland, blind staarde op de rol van het befaamde Duitse leerlingenstelsel bij de wederopbouw van de Duitse economie (Crouch et al. 1999; Wolf 2001), groeide in de jaren negentig ook in Nederland de onvrede met het eigen beroepsvoorbereidende onderwijs (Van Lieshout 1996). Aanleiding voor deze onvrede was de observatie dat het onderwijs vooral industriële competenties overdroeg, terwijl de Nederlandse economie sinds de jaren zeventig was uitgegroeid tot overwegend een diensteneconomie. Daarnaast had het beroepsvoorbereidende onderwijs zich mede als gevolg van die gebrekkige aansluiting ontwikkeld tot het 'afvoerputje' van het Nederlandse onderwijsbestel waardoor steeds grotere groepen leerlingen de weg naar het algemeen voorbereidende onderwijs zochten en vonden. Dat was niet alleen problematisch omdat niet iedere leerling over de cognitieve vaardigheden beschikt die het algemeen vormende onderwijs vereist, met doublures, uitval en andere inefficiënties als gevolg, maar ook omdat de toekomstige arbeidsmarkt nu eenmaal niet alleen behoefte heeft aan dit soort talig georiënteerde vaardigheden.

Om deze redenen kwam vanuit politiek, maatschappij en bedrijfsleven een groeiende roep om herziening van de beroepsvoorbereidende onderwijskolom teneinde haar uit te bouwen tot een gelijkwaardig onderwijstraject naast het algemeen vormende. Midden jaren negentig mondde dit uit in het initiatief om het lagere beroepsonderwijs (lbo) en het middelbaar algemeen vormende onderwijs (mavo) samen te voegen tot wat is gaan heten het voorbereidend middelbaar beroepsonderwijs (vmbo). Het doel van deze operatie was het opvijzelen van de status van het beroepsonderwijs en het aanbieden van nieuwe leertrajecten die beter op het beroepsonderwijs (mbo) zouden aansluiten, zodat het gemakkelijker zou worden een zogenaamde startkwalificatie te behalen, dat wil zeggen een vmbodiploma met aansluitend een tweejarig Мво-certificaat of equivalenten daarvan. Dit alles paste in de poging om het beroepsvoorbereidende leerweg tot een sluitend, eigenstandig en gelijkwaardig verheffingstraject om te bouwen. Ondanks de goede intenties laat het zich aanzien dat de effecten ervan vanuit verheffingsperspectief bezien ongewenst zijn geweest.

Ten eerste is het niet gelukt om de status van het beroepsvoorbereidende onderwijs te verhogen. Een grote groep ouders is er veel aan gelegen om hun kind een als vernederend ervaren gang naar het vmbo te besparen. Als gevolg van negatief 
getoonzette berichtgeving is het imago van het vmbo ook bij werkgevers slecht. Veelzeggend is de gestage daling van het aantal leerlingen in de theoretische leerweg (de voormalige mavo) sinds de introductie van het vmbo in het schooljaar 1999/2000. Van de kleine 100.0oo leerlingen die destijds de mavo bevolkten, zijn er vier jaar later nog maar 78.ooo over. Dat is op grond van verheffingscriteria te betreuren. Juist de mavo fungeerde van oudsher als brug tussen het algemeen vormende en het beroepsvoorbereidende onderwijs, en maakte daarmee de stijging van leerlingen afkomstig uit lagere sociaal-economische milieus mogelijk. De fusie van lbo en mavo heeft ertoe geleid dat de kloof tussen beroepsvoorbereidend en algemeen vormend onderwijs juist gegroeid is en dat de doorstroming van leerlingen die om welke redenen ook ('laatbloeier', echtscheidingsproblemen ouders, off day tijdens cito-toets, ziekte, enzovoorts) ten onrechte in het beroepsvoorbereidende traject zijn beland, goeddeels tot stilstand is gekomen. De doorstroming naar de havo via het tweede jaar mbo die ervoor in de plaats is gekomen, is niet alleen langer en dus hoogdrempeliger; deze blijkt in de praktijk bovendien gepaard te gaan met achterstanden op theoretisch vlak die de succeskansen van doorstromers alleen maar schaden. Ook dat is vanuit verheffingsperspectief bezien onwenselijk. Tot slot blijkt de beroepsvoorbereidende leerweg in de praktijk een allesbehalve sluitend traject te zijn. Per vmbo-cohort gaat ongeveer zeventig procent verder in het mbo. Daarvan kiest vervolgens ongeveer een kwart voor een vervolgstudie in het hbo. Het gevolg is dat het merendeel van de leerlingen in het hbo niet afkomstig is uit de beroepsvoorbereidende leerweg, maar uit het algemeen vormende traject. Maar liefst tachtig procent van de afgestudeerde havo-leerlingen koos in het studiejaar 2002/2003 voor het hbo, tegen slechts zestien procent van de mbo-leerlingen (CBS 2006a, p. 14-15, 91). Zo bezien is het beroepsvoorbereidende traject slechts een half traject en loopt de toegang tot de hogere opleidingsvarianten ervan (hbo) nog altijd via het algemeen vormende onderwijs.

Een tweede probleem is de schaalvergroting in het voortgezet onderwijs. Was de gemiddelde schoolgrootte in het begin van de jaren negentig 520 leerlingen, in het schooljaar 2004/2005 bedroeg dat 1400 leerlingen (СBS 2006a, p. 13). Ook in het voorbereidende beroepsonderwijs zijn met het samengaan van mavo en lbo grote anonieme 'leerfabrieken' ontstaan waarin leerlingen gemakkelijk het overzicht verliezen en waar zij als gevolg van het ontbreken van sociale controle ook gemakkelijk uitvallen. Bovendien blijkt schaalvergroting, ondanks de voorspelde schaalvoordelen, in de praktijk te leiden tot een verplaatsing van een deel van de middelen van het primaire proces naar de aansturing ervan. Als gevolg daarvan is bij gefuseerde scholen vaak minder geld per leerling beschikbaar dan in de kleine, categorale scholen, met alle kwaliteitseffecten van dien. Onder ouders bestaat dan ook een duidelijke voorkeur voor kleinere scholen (Onderwijsraad 2005a; 2005b).

\section{Uitval}

Ook al is de problematiek van leerlingen zonder startkwalificatie breder dan die van de uitval uit het vmbo, en omvat ze bijvoorbeeld ook uitvallende havo'ers en vwo'ers, twee derde van de kwart miljoen jongeren tussen 15-24 jaar zonder startkwalificatie is afkomstig uit het vmbo (CBS 2005a). Volgens de OECD is Nederland, 
samen met enkele mediterrane landen, met een percentage van ongeveer twintig procent van ieder cohort koploper in het afleveren van leerlingen zonder startkwalificatie. In het Lissabonverdrag van de EU is vermindering van de groep jongeren die zonder startkwalificatie de arbeidsmarkt betreedt een van de beleidsprioriteiten. Voor Nederland betekent dit een halvering van het percentage in 2010. De achterliggende argumentatie is dat het ontbreken van een startkwalificatie niet alleen de toegang tot de arbeidsmarkt bemoeilijkt en daarmee kostbare ex-post compensatie vereist (uitkeringen, activeringsprogramma's, loonkostensubsidies, scholing en training), maar ook negatieve langetermijneffecten heeft voor de inzetbaarheid en de verdiencapaciteit en van deze jongeren. Er zijn echter wel redenen om aan de juistheid van deze redenering voor de Nederlandse context te twijfelen.

Het is kenmerkend voor gedifferentieerde onderwijssystemen dat de aansluiting op de arbeidsmarkt voor kwetsbare leerlingen juist door het bestaan van een apart beroepsvoorbereidend onderwijstraject relatief goed is. Enerzijds doordat de vaardigheden die in dit type onderwijs worden geleerd 'direct' inzetbaar zijn. Anderzijds doordat het bedrijfsleven meer betrokken is bij het beroepsvoorbereidende onderwijs en de kloof tussen school en arbeidsmarkt dus kleiner is. De arbeidsparticipatiecijfers die de OECD in haar laatste Education at a glance voor Nederland geeft, staven dit. Van de 21 procent die geen startkwalificatie heeft behaald, heeft maar liefst driekwart (17 procent van het geheel) een betaalde baan. Dat levert werkloosheidscijfers voor deze categorie jongeren op die lager zijn dan die van Zweden, Denemarken, België en Duitsland.

Figuur 7.3 Werkgelegenheid voor 20-24 jarigen die niet aan onderwijs deelnemen per onderwijsniveau 2002

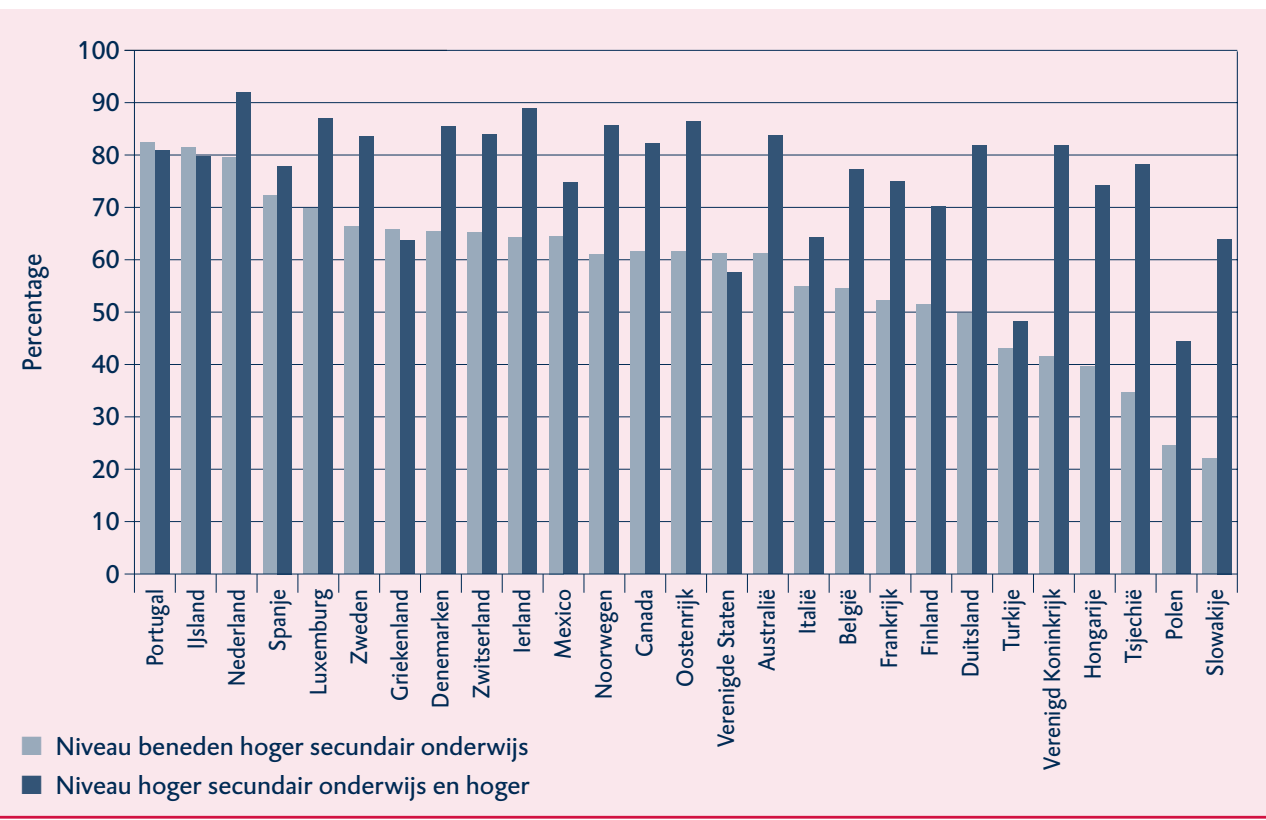

Bron: OECD 
Daar moeten echter twee kanttekeningen bij worden geplaatst. Ten eerste dat deze cijfers conjunctureel gekleurd zijn; meer recente cijfers van het CBs leren dat als gevolg van de sterk gestegen jeugdwerkloosheid van de laatste jaren het verschil in werkgelegenheidskansen tussen jongeren met en zonder startkwalificatie is verslechterd. Van de jongeren onder 24 jaar met startkwalificatie was in 2004 tien procent werkloos, tegen zeventien procent voor jongeren zonder startkwalificatie (CBS 2005b). Nu de conjunctuur aantrekt, daalt dit cijfer evenwel ook weer snel. Ten tweede blijkt een startkwalificatie eerder en beter toegang te geven tot vaste contracten (Houtkoop et al. 2004). Oftewel, het niet hebben van een startkwalificatie heeft weliswaar relatief weinig invloed op de baankansen van jongeren, maar bepaalt wel de kwaliteit van de banen waar jongeren toegang tot hebben.

\section{Startkwalificatie}

Hier is de geschiedenis van het begrip 'startkwalificatie' instructief. De commissie-Rauwenhof die het begrip in 1990 introduceerde, omschreef het "als het levenslange recht van alle werkenden en werkzoekenden om een beroepskwalificatie te behalen op ten minste het niveau van aankomend vakman/vakvrouw" (Tijdelijke Adviescommissie Onderwijs-Arbeidsmarkt 1990). Er zijn twee in het oog springende verschillen met de definitie die momenteel wordt gehanteerd. Ten eerste ging het bij de commissie-Rauwenhof niet om een statisch criterium ter beoordeling van de effectiviteit van het initiële onderwijsstelsel, maar hoorde het thuis in een perspectief van levenslang leren. Ten tweede valt op dat in vijftien jaar tijd de lat van een startkwalificatie is verschoven van minstens een vierjarig lbo-diploma naar ten minste een zesjarige beroepsvoorbereidende leerweg. Het is de vraag of hiermee de lat niet te hoog is komen te liggen, en of onderwijsveld en politiek hiermee niet een schijnprobleem hebben gecreëerd. Uiteraard is onderwijs een 'goed' waar je nooit genoeg van kunt hebben, maar dat laat onverlet dat de vraag gerechtvaardigd is of de publieke verontwaardiging over het grote aantal leerlingen dat zonder startkwalificatie de arbeidsmarkt betreedt wel op zijn plaats is. Zeker als bedacht wordt dat daar ook leerlingen onder vallen die het equivalent van de vroegere mavo, te weten de theoretische leerweg van het vmbo, succesvol hebben doorlopen. Bovendien moet worden bedacht dat de huidige invulling van 'startkwalificatie' haaks staat op het streven naar rehabilitatie van het beroepsvoorbereidende onderwijs. In feite wordt tegen alumni van het vmbo gezegd dat hun diploma's waardeloos zijn (Houtkoop et al. 2004).

Hoewel enige nuancering in het debat over vroegtijdig schoolverlaten dus op zijn plaats is, is de 'verkleuring' ervan zeker een zorgelijk aspect. Allochtone leerlingen hebben momenteel ruim anderhalf keer zoveel kans om uit te vallen als autochtone en hebben bovendien een veel grotere kans om na uitval werkloos te worden (SCP 2006b). Bovendien bezetten allochtone uitvallers in de arbeidsmarkt veelal de meer precaire plekken die gevoeliger zijn voor conjuncturele schommelingen. Die combinatie van verheffingstekorten is, mede in het licht van de actuele maatschappelijke verharding jegens migranten met een islamitische achtergrond, verontrustend. 
Figuur 7.4 Aandeel 20-34-jarigen met startkwalificatie naar etnische groep, generatie en geslacht, 2001-2003 (in procenten)

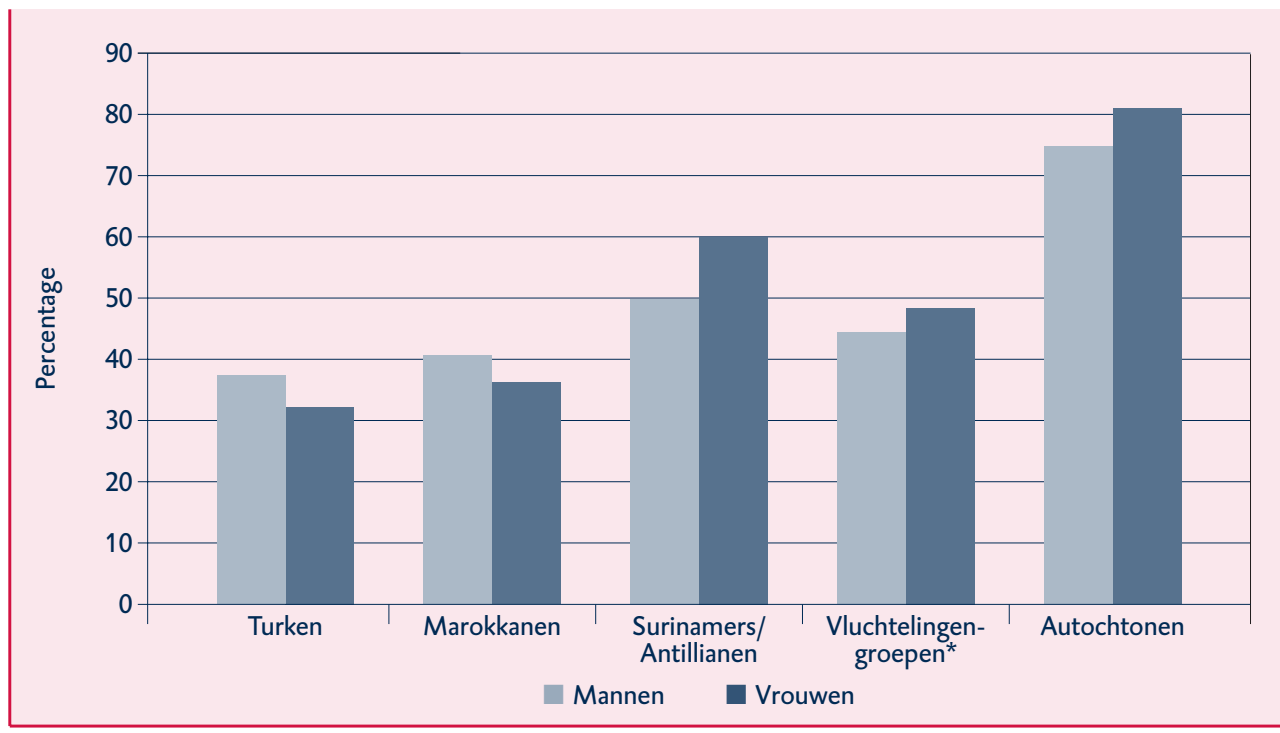

Noot: * voormalig Joegoslaven, Irakezen, Afghanen, Iraniërs, Somaliërs

Bron: SCP/WODC/CBS 2005, p. 51

\subsubsection{HOGER ONDERWIJS: TUSSEN KWANTITEIT EN KWALITEIT}

Internationaal luidt de consensus dat meer hoger onderwijs beter is dan minder. Onderwijs staat in deze redenering ten dienste van economische groei. Tegelijkertijd wordt de noodzaak benadrukt om de effectiviteit van het hoger onderwijs te vergroten (OECD 2005). Gegeven budgettaire beperkingen en een groeiende vraag naar onderwijsdiensten zullen instellingen voor hoger onderwijs meer moeten doen met minder (publieke) middelen. Uiteraard bestaat er een forse spanning tussen deze twee doelstellingen. Volgens de laatste redenering is meer immers niet noodzakelijk beter, maar kan het evengoed verspilling zijn: te lange studieduur per student; te veel studenten die niet in het hoger onderwijs thuishoren; te veel uitval; te veel studenten die 'makkelijke' studierichtingen volgen; te weinig studenten die kiezen voor natuurwetenschappelijke en technische studies. Oftewel, kwantitatieve doelstellingen bijten kwalitatieve, en omgekeerd.

Internationaal bezien ligt de deelname aan het hoger onderwijs in Nederland op het OECD-gemiddelde. Het percentage van de bevolking dat een tertiaire opleiding heeft voltooid (hbo of wo) ligt iets onder de 30 procent. Daarmee blijft Nederland duidelijk achter bij landen als Canada (55 procent), Japan (52 procent), Zweden (42 procent) en Finland (42 procent), maar ook bij omringende landen als Duitsland en Frankrijk. Daarbij dient evenwel aangetekend te worden dat deze ranglijst enigszins vertekend is, doordat elders onder tertiair onderwijs ook kortere, één- of tweejarige vervolgopleidingen worden gerekend, zoals de Franse IUT's en de Britse foundation degrees, waarmee in Nederland momenteel schoor- 
voetend geëxperimenteerd wordt. Verder is er in Nederland sinds 1995 sprake van een herstel in de deelnamecijfers van het hoger onderwijs, wat nog niet altijd (volledig) doorklinkt in de internationaal vergelijkende cijfers, die nu eenmaal met een zekere vertraging beschikbaar zijn.

Een andere indicator voor deelname is die van de verwachte onderwijsduur per leerling. Met gemiddeld 17 onderwijsjaren bevindt de Nederlandse leerling zich in het midden van de ranglijst. Uitschieters zijn Australië met 21 jaar en Zweden en het Verenigd Koninkrijk met 20 jaar.

\section{Figuur 7.5 Instroompercentages tertiair onderwijs 2003}

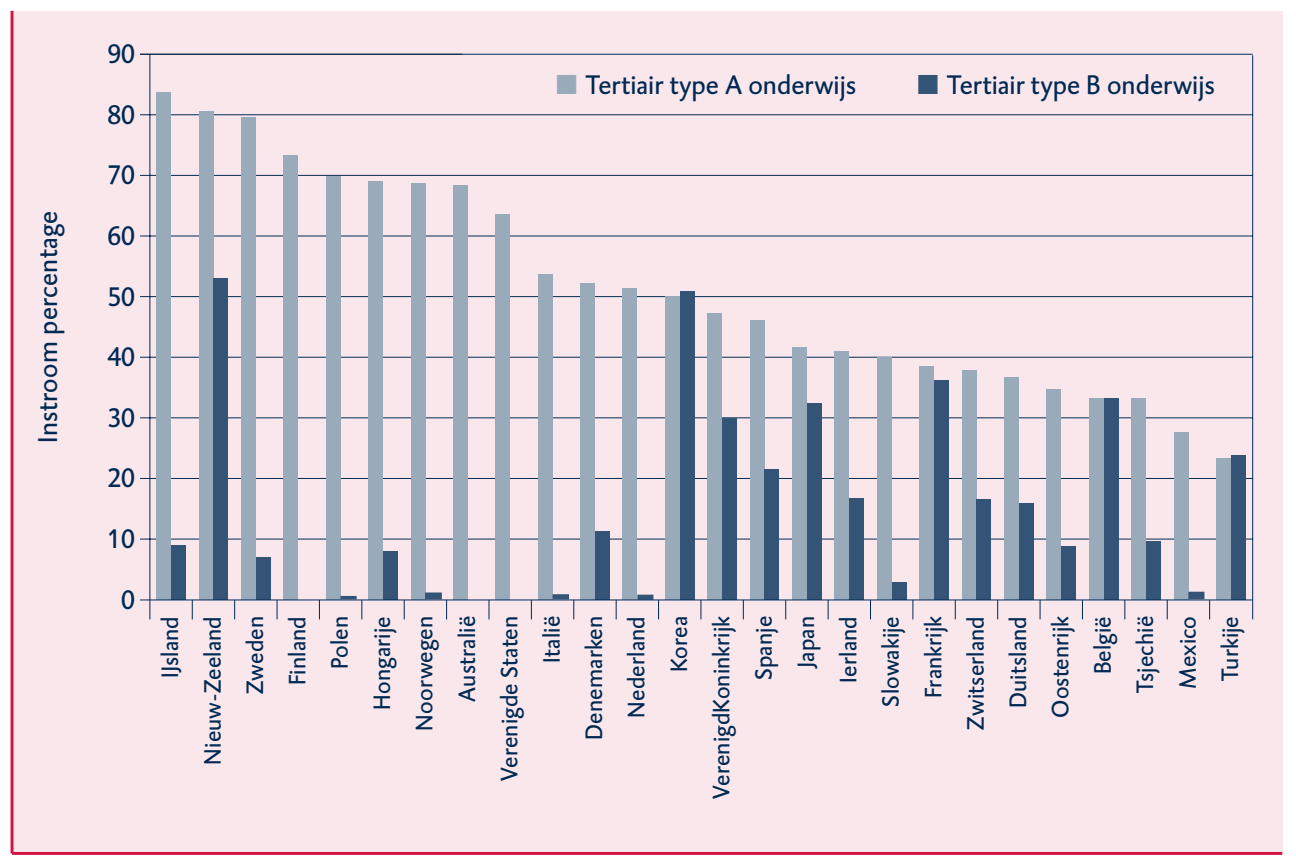

Noot: Tertiair onderwijs type a verwijst naar overwegend theoretisch hoger onderwijs, Tertiair onderwijs type b verwijst naar beroepsvoorbereidend hoger onderwijs Bron: OECD

Wat rendement betreft scoort het Nederlandse wo gemengd. Hoewel met de invoering van de vijfjarige studieduur begin jaren negentig het rendement is verdubbeld, heeft deze trend zich niet doorgezet. Na zeven jaar is slechts zestig procent van de vwo-instroom in het bezit van een bul, terwijl bijna vijftien procent de studie heeft stopgezet. Van het cohort dat in 2000 aan zijn studie begin haalde slechts achttien procent binnen de nominale duur zijn doctoraal of bachelor-diploma (CBS 2006a, p. 66). Wat dat betreft is er sprake van een sterke selectie in het voortgezet onderwijs en een zwakke selectie in het hoger onderwijs, en wordt de middelmaat uit de hogere klasse dus nog altijd institutioneel beschermd (Braggen en Weijers 1995). In het hbo ligt het rendement beduidend hoger. Daar haalt veertig procent van ieder cohort binnen de gestelde termijn zijn diploma (CBS 2006a, p. 6o). 


\section{Financiering hoger onderwijs}

In Nederland spitst het debat over het hoger onderwijs zich ook toe op de financiering ervan. Daarbij spelen drie kwesties: de hoogte van de publieke bijdrage, de wijze van financiering van het hoger onderwijs en de inrichting van de studiefinanciering. Om met de hoogte van de publieke bijdrage te beginnen: was de financiering van Nederlandse universiteiten in eerste instantie gekoppeld aan het aantal studerenden (inputfinanciering), sinds de jaren negentig is met het oog op rendementsverbetering meer en meer ingezet op outputfinanciering. Hoewel zo op het eerste gezicht een probaat middel om de doeleinden van brede toegankelijkheid, kwaliteitsverbetering en doelmatigheid met elkaar te combineren, groeien ook de indicaties van perverse neveneffecten. In universitaire kringen regent het klachten over een neerwaartse druk op de kwaliteitscriteria. Hierin weerspiegelt zich een spanning die het Nederlandse hoger onderwijs van meet af aan heeft gekenmerkt. In de loop van haar geschiedenis heeft de Nederlandse universiteit nooit een oplossing weten te vinden voor de spanning tussen haar twee primaire taken: het opleiden van onderzoekers en het opleiden van breed inzetbare professionals. Het eerste vereist hoge kwaliteitsstandaarden en dus vroege selectie, terwijl het tweede juist ruime toegankelijkheid en soepele certificering vereist. Met de introductie van een stelsel van outputfinanciering lijkt met name de eerste functie - de universiteit als onderzoeksinstituut - in de knel te komen, ten faveure van de tweede - de universiteit als beroepsopleiding. Dit is de structurele oorzaak voor de vele klachten over de kwaliteit van universiteit, opleiding, bul en student die door verschillende betrokkenen worden geformuleerd (Braggen en Weijers 1995).

Al anderhalf decennium klagen universiteiten over de gebrekkige financiële middelen waar zij van staatswege over kunnen beschikken en - zij het veel minder over de geringe speelruimte die ze hebben om private geldbronnen aan te boren. De massalisering van de Nederlandse universiteiten sinds de jaren zeventig is niet gepaard gegaan met een navenante stijging van het budget. De gevolgen van de gedaalde uitgaven per student zijn nergens systematisch bijgehouden, maar hebben wel geleid tot een verschraling van de voorzieningen, zowel voor studenten als voor personeel. Aansluitend bij de ambitie van de EU om de Europese economieën te laten uitgroeien tot kenniseconomieën proberen universiteiten al jaren om beleidsmakers en politici te overtuigen van het belang van grotere publieke investeringen. Het is echter de vraag of een grotere overheidsbijdrage wel te rechtvaardigen is vanuit het perspectief van economische groei. Hoewel lastig te kwantificeren als gevolg van gebrekkige data en problemen van multicausaliteit, wordt de bijdrage van hoger onderwijsinvesteringen aan de lange termijn economische groei geschat op niet meer dan een vijfde (Wolf 2001; Groot en Maassen van den Brink 2003). De consequentie hiervan is dat pogingen om een (veel) groter deel van ieder cohort tertiair onderwijs te laten volgen, zoals de helft van iedere cohort die het ministerie van ocw zich voor 2010 ten doel heeft gesteld (zie Onderwijsraad 2005c), wel eens eerder zouden kunnen leiden tot diploma-inflatie, eerder dan tot de gewenste verhoging van de kennisintensiteit van de economie. Het is om deze reden onduidelijk of hier een publiek verheffingstekort ligt. 
Ook verdient de vormgeving van de studiefinanciering aandacht. In de loop van de afgelopen decennia is die structuur een aantal keren herzien. De ratio achter die herzieningen werd vooral bepaald door de macrobudgettaire mogelijkheden en algemene noties over wat een rechtvaardige inkomensverdeling is. Veel minder voorop gestaan heeft de vraag hoe het stelsel zo ingericht kon worden dat het ook maximaal aanzette tot studeren: bijbaantjes werden eerder regel dan uitzondering, en studeren op latere leeftijd of het volgen van twee studies werd eerder ontmoedigd dan gestimuleerd.

\subsubsection{POSTINITIEEL ONDERWIJS: NAAR EEN LEVEN LANG LEREN?}

Als gevolg van snelle organisatorische, technologische en economische veranderingen is de houdbaarheid van vaardigheden en daarmee van kwalificaties afgenomen. Dit betekent dat niet langer kan worden volstaan met de concentratie van het leren in een bepaalde levensfase, maar dat werknemers gedurende hun hele carrière in de gelegenheid moeten worden gesteld om hun competenties op te vijzelen of nieuwe competenties te verwerven. Daar zijn niet alleen goede macroeconomische redenen voor - het bij de tijd houden van het menselijk kapitaal om de concurrentie het hoofd te bieden - maar ook micro-economische: het op peil houden van de eigen productieve inzetbaarheid ter voorkoming van economische overbodigheid.

Daarnaast geldt dat concentratie van de onderwijsinspanning in een bepaalde levensfase grote risico's over de levensloop met zich meebrengt voor diegenen die gedurende die levensfase, door wat voor oorzaak ook, niet ontvankelijk bleken voor het educatieve aanbod. Laatbloeiers, trage leerlingen, leerlingen met een afwijkend leerpatroon, of leerlingen met een tumultueuze thuissituatie zijn in een onderwijsstelsel met een geconcentreerd leermoment in het nadeel. Ook in een onderwijsstelsel zonder verheffingstekorten zullen leerlingen om onterechte redenen daardoor verkeerd over maatschappelijke posities worden verdeeld. Dat is niet alleen maatschappelijk gezien een vorm van verspilling, maar het is ook vanuit het perspectief van het individu bezien een vorm van gefaalde verheffing.

Ondanks fraaie plannen is van het ideaal van permanente educatie in de praktijk nog weinig terechtgekomen. Het ministerie van ocw is nog altijd eerst en vooral een ministerie van Jeugdonderwijs. Institutioneel bezien is het ministerie primair verantwoordelijk voor het zogenaamde 'funderende' onderwijs en vallen de vele cursussen en trainingen die daarbuiten plaatsvinden ofwel onder de verantwoordelijkheid van werknemers en werkgevers ofwel onder die van huishoudens en individuen. Als gevolg daarvan is ook de kennis over dit deel van de onderwijsmarkt gebrekkig. Dit geldt niet voor dat gedeelte van het postinitieel onderwijs, dat wordt aangeduid als 'volwasseneneducatie' en dat wordt bekostigd door de overheid. Het betreft hier het zogenaamde 'voortgezet algemeen volwassenenonderwijs' dat ook wel bekend staat als 'tweedekansonderwijs', alsmede de zogenaamde basiseducatie die breed maatschappelijk functioneren, sociale redzaam- 
heid en Nederlands als tweede taal (NT2) omvat. Het merendeel van de deelnemers aan dit type onderwijs, 95.00o, volgt NT2-cursussen, 38.0oo volgt de basiseducatie, terwijl slechts een kleine 14 .0oo voortgezet volwassenenonderwijs volgt, wat het eigenlijke tweedekansonderwijs is. Sinds 1990 is het aantal deelnemers aan dit type onderwijs met bijna 85 procent afgenomen. In dat jaar bezochten nog bijna 53.0oo deelnemers de zogenaamde 'moedermavo'. Nu zijn dat er nog maar 5.00o. Soortgelijke ontwikkelingen deden zich voor in de moederhavo en de moedervwo (CBS 2005, p. 129-130). Naar alle waarschijnlijkheid is dat een effect van de sterk gestegen arbeidsparticipatie van vrouwen, wat aangeeft dat het niet gemakkelijk is om werk en scholing te combineren.

\section{De postinitiële onderwijsmarkt}

Veel groter van omvang, maar ook veel slechter in kaart gebracht, is het postinitiële onderwijs dat niet door de staat wordt gefinancierd. Het gaat dan om alle korte en lange cursussen en trainingen die buiten het initiële onderwijsbestel worden gevolgd. Het beschikbare cijfermateriaal leert ten eerste dat het merendeel van de cursussen aan arbeid gerelateerd is ( 83 procent). Ten tweede is duidelijk dat deelname aan deze cursussen in hoge mate conjunctureel bepaald is. Tot 1999, de top van de vorige conjunctuurcyclus, steeg het aantal deelnemers aan arbeidsmarktgerelateerde cursussen; vanaf 2000 is dat aantal licht afgenomen. Ten derde blijkt dat het merendeel van de deelnemers aan het begin van de arbeidscarrière staat. Meer dan twintig procent van de 25-29-jarigen volgde in 2003 een postinitiële cursus, een percentage dat gedurende de loopbaan geleidelijk afneemt tot slechts vijf procent van de 6o-64-jarigen. Bovendien blijken werkenden meer cursussen te volgen dan werklozen, en bezit het merendeel van de deelnemers een hoger onderwijsdiploma (OSA 2005). Ten slotte scoort Nederland relatief laag op het percentage 25-64-jarigen dat deelneemt aan postinitieel onderwijs. Hoog scoren landen als Denemarken, de Verenigde Staten, Zweden, Finland en Zwitserland, met percentages die schommelen tussen de veertig en vijftig (SCP 2005b). Waarschijnlijk is dat een effect van verschillen in onderwijsbestel. Zoals gezegd sorteren gedifferentieerde stelsels als het Nederlandse, leerlingen eerder in de levenfase uit over algemeen vormende en beroepsvoorbereidende trajecten dan omvattende stelsels. Als gevolg daarvan beschikt een groter deel van ieder Nederlands leerlingencohort (circa zestig procent) over vaardigheden die direct inzetbaar zijn op de arbeidsmarkt. Dit betekent dat minder beroepsgerelateerde training nodig is om pas-afgestudeerden specifieke vaardigheden bij te brengen. Kortom, de omvang van de postinitiële opleidingsmarkt wordt mede bepaald door de kenmerken van het onderwijsbestel.

Ook in het postinitiële segment van het onderwijsbestel zijn verheffingstekorten aan te wijzen. Het voornaamste probleem is de gebrekkige aansluiting tussen het initiële en het postinitiële onderwijssysteem. Bij een verheffingsoffensief hoort niet alleen aandacht voor de kwaliteitsgebreken van het funderende onderwijs maar ook een volledig opgetuigd tweede- en derdekansonderwijs. Daaraan ontbreek het momenteel in Nederland. De postinitiële educatie staat nu hoofdzakelijk ten dienste van afgestudeerden uit het (hoge) algemeen vormende onderwijs 
en verschaft deze in aanvulling op algemene vaardigheden en houdingen bedrijfsspecifieke competenties. Het zijn echter de leerlingen uit het beroepsvoorbereidende traject die in een context van snelle economische structuurwijzigingen voor steeds snellere veroudering van hun vaardigheden moeten vrezen. Voor deze categorie werknemers is echter nauwelijks postinitieel onderwijs beschikbaar. De gebrekkige mogelijkheden van schoolterugkeer zijn een veel groter probleem dan dat van de schooluitval, ook al gaat de meeste publieke aandacht uit naar het tweede en krijgt het eerste punt nauwelijks aandacht.

\subsection{VERHEFFING OP DE NEDERLANDSE ARBEIDSMARKT}

Bij een onderwijsbestel dat tot doel heeft ieder talent te ontplooien - ongeacht etniciteit, geslacht of sociaal-economische herkomst, en ongeacht aard en omvang van de talenten - hoort een arbeidsmarkt die mensen verdeelt over arbeidsplaatsen op basis van competenties. Dat is niet alleen een kwestie van efficiënt omgaan met schaarse middelen, maar ook een kwestie van sociaal-economische verbinding. Er is immers geen beter recept voor sociale 'ontbinding' dan pedagogische verheffing te laten stranden op een arbeidsmarkt die wordt gedomineerd door 'citadellen van insidermacht'.

Zo bezien gaat het bij verheffen op de arbeidsmarkt om drie aspecten. Allereerst is de toegankelijkheid van de arbeidsmarkt voor schoolverlaters en (her)intreders van belang. Dit aspect wordt behandeld onder de noemer instroom. Ten tweede de mogelijkheid om al doende verworven menselijk kapitaal via een nieuwe functie (interne mobiliteit) of een nieuwe baan (externe mobiliteit) optimaal te kunnen inzetten. Dit aspect wordt besproken onder de noemer doorstroom. Ten derde speelt het probleem van de ondoorzichtige toekomst. Economische structuurwijzigingen als gevolg van technologische, organisatorische en internationale veranderingen laten zich moeilijk voorspellen. We weten niet welke specifieke vaardigheden de economie van morgen zal vragen, noch weten we hoe we die vaardigheden moeten bijbrengen en hoe de aanleg ervoor trefzeker kan worden herkend. Wat wel duidelijk is, is dat functie-inhouden en -eisen onder voortdurende aanpassingsdruk staan, waardoor zowel collectief als individueel continu het gevaar van 'overbodigheid' dreigt (Sennett 2006). Zo bezien is een robuuste arbeidsmarkt er een waarin voldoende aanpassingsruimte bestaat, zowel op macro- als op microniveau. Concreet gaat het dan om het vermogen van de Nederlandse arbeidsmarkt om de arbeidsoverschotten die ontstaan in neergaande sectoren en bedrijven door te sluizen naar expanderende sectoren en bedrijven. Uiteraard gaat dat in een groeiende arbeidsmarkt makkelijker dan in een krimpende. Dit aspect wordt besproken onder de noemer van dynamiek.

\subsubsection{DYNAMIEK}

Arbeidspatronen hebben zich gedurende de twintigste eeuw radicaal gewijzigd. De meest in het oog springende veranderingen zijn de drie grote structuurwijzigingen die de Nederlandse economie heeft ondergaan. Terwijl in de negentiende 
eeuw nog rond de veertig procent van de Nederlandse beroepsbevolking in de primaire sector werkzaam was, is dat aandeel aan het begin van de 21ste eeuw gedaald tot minder dan drie procent. De tweede wijziging betreft de groei en neergang van industriële werkgelegenheid in de Nederlandse economie. Hoewel geleidelijk gestegen van even boven de twintig procent in de vroege negentiende eeuw naar een top van 42 procent in de jaren zestig van de vorige eeuw, beslaat de industriële werkgelegenheid momenteel wederom slechts twintig procent. De derde grote wijziging die de Nederlandse economie heeft doorgemaakt is het sterk gegroeide aandeel van de dienstensector. Werkte in de jaren zestig nog 45 procent van de beroepsbevolking in de dienstensector, aan het begin van de eenentwintigste eeuw is dat aandeel gestegen tot rond de 78 procent, waarmee de Nederlandse economie, samen met de Amerikaanse, een van de meest verdienstelijke economieën ter wereld is.

Opmerkelijk aan de Nederlandse arbeidsmarkt is dat ze deze wijzigingen de laatste twee decennia relatief soepel heeft weten op te vangen; de arbeidsmarkt is de slechte periode van de jaren zeventig en vroege jaren tachtig duidelijk te boven gekomen. Nu bevindt de structurele werkloosheid in Nederland zich op een relatief laag niveau, zeker in vergelijking met buurlanden als Duitsland, België en Frankrijk. Een deel van de structurele werkloosheid hebben we in het verleden 'weggedefinieerd' via de WAO, maar in belangrijke mate kan de verbeterde arbeidsmarktsituatie ook op het conto worden geschreven van de sterke werkgelegenheidsgroei sinds 1985 . Sindsdien is het aantal banen namelijk met bijna anderhalf miljoen gestegen. Waren in 1990 nog circa 6 miljoen Nederlanders aan het werk, anno 2006 is dat aantal gestegen tot ruim 7,4 miljoen. Vrijwel deze hele aanwas is ten goede gekomen aan vrouwen. Hadden in 1990 nog 2,5 miljoen vrouwen een baan, in 2006 bedroeg dat aantal bijna 3,2 miljoen. Daarbij moet worden aangetekend dat het vrijwel volledig om deeltijdbanen gaat, dat wil zeggen banen met een omvang van tussen de 12 en 34 uur per week. Het aantal vrouwen dat voltijds werkt is al jaren constant en ligt rond de één miljoen. Daarnaast hebben circa 500.000 vrouwen een baan van minder dan 12 uur per week (CBS 2004; 2006b).

Het aantal baan- en functieveranderingen is een duiding van de dynamiek op de arbeidsmarkt. Afhankelijk van meetmethoden en databestanden ligt het aantal baan- en functieveranderaars in Nederland op circa één miljoen, wat wil zeggen dat van iedere zeven werkenden er jaarlijks één van functie of betrekking verandert, of van iedere zes er twee per twee jaar van baan of functie wisselen (SCP 2005b). Hoewel internationale mobiliteitsvergelijkingen omgeven zijn met voetangels en -klemmen, blijkt uit de beschikbare data dat de arbeidsmobiliteit in Nederland relatief groot is. Vergeleken met de meest mobiele arbeidsmarkt van Europa, de Britse, waar op tweejaarlijkse basis maar liefst 24 procent van de werkenden van baan verandert, scoort Nederland met 20 procent baanveranderaars niet veel lager. Zeker in vergelijking met Duitsland waar slechts 9,3 procent van de werkenden per twee jaar van baan verandert, is de Nederlandse arbeidsmarkt een toonbeeld van dynamiek (SCP 2005b, p. 68 e.v.). 


\subsubsection{INSTROOM}

Op basis van het voorgaande mag worden geconcludeerd dat de Nederlandse arbeidsmarkt relatief dynamisch is. Daardoor kunnen mensen betrekkelijk gemakkelijk een baan vinden en zijn er in principe geen duurzame blokkades die de verzilvering van menselijk kapitaal in de weg staan. Dit beeld verandert echter wanneer we kijken naar de aard van de banengroei. Als het gaat om functieniveaus valt op dat het merendeel van de groei aan de bovenkant van de functiehiërarchie plaatsvindt. Tussen 1994 en 2002 groeide het aantal banen met academische functie-eisen met bijna de helft, terwijl de categorie daaronder (hooggeschoold) met 43 procent groeide. Wat dat betreft lijkt de werkgelegenheidsgroei in Nederland het patroon te volgen dat op basis van de skill biased technological change-hypothese mag worden verwacht, namelijk een werkgelegenheidsgroei die zich beperkt tot de bovenkant van de banenladder (Marx 2006). Dit geldt echter niet voor de werkgelegenheidsontwikkeling aan de onderkant van de functiehiërarchie. In de laagste categorie (ongeschoolde arbeid) nam de werkgelegenheid sinds 1994 namelijk eveneens fors toe, en wel met 41 procent. Het gevolg is dat de werkgelegenheidsstructuur gepolariseerde trekken vertoont, met sterke groei aan boven- en onderkant en krimp in het midden (De Beer 2001, p. 53 e.v.).

Ook de aard van het arbeidscontract heeft sinds de jaren zeventig wijzigingen ondergaan. Bestond in 1970 meer dan twee derde van alle arbeidscontracten uit standaardcontracten, in 2004 is nog slechts iets meer dan de helft standaard. Deze ontwikkeling is meer het gevolg geweest van de sterke stijging van het aantal deeltijdbanen dan van een stijging van het aantal contracten van bepaalde duur. Momenteel heeft ruim 2,5 miljoen werkenden een deeltijdaanstelling tegen ongeveer 4,4 miljoen werknemers een voltijdsaanstelling, een aantal dat sinds de vroege jaren negentig nauwelijks is veranderd. Dit betekent dat het merendeel van de banenaanwas sinds 1990 deeltijdbanen betrof. De Wet Flexibiliteit en Zekerheid geeft deeltijdwerknemers sinds 1999 pro rato toegang tot dezelfde sociale rechten als voltijdwerknemers, waardoor deeltijdarbeid anders dan in ons omringende landen niet hetzelfde is als 'precaire arbeid'. Dit geldt wel voor werknemers met een afwijkend arbeidscontract (voor bepaalde duur, uitzendkrachten, op- en afroepkrachten). Dit aandeel is in Nederland echter al tijden relatief stabiel en bedraagt rond de tien procent van alle werkenden (WRR 2007).

\section{Vrouwen}

De banengroei van de laatste twee decennia heeft dus vooral aan de boven- en de onderkant van de functiehiërarchie plaatsgevonden, en betrof vooral deeltijdwerk. Hoe zijn deze banen onder werkenden verdeeld? De grootste groep die van de groei van de Nederlandse arbeidsmarkt heeft geprofiteerd, zijn vrouwen geweest. Dat houdt direct verband met de sterke stijging van het opleidingsniveau van vrouwen die heeft plaatsgevonden en nog plaatsvindt; zo is in het tertiair onderwijs inmiddels meer dan de helft van alle studenten vrouw, worden meer 
dan de helft van alle doctoraalbullen aan vrouwelijke studenten uitgereikt, en betreft meer dan veertig procent van alle promoties vrouwelijke promovendi (CBS 2004; SCP/CBS 2004, p. 44 e.v.). Problematischer is dat deze stijging van de arbeidsparticipatie van vrouwen vrijwel geheel voor rekening komt van deeltijdbanen. Ook hoogopgeleide vrouwen laten door hen verworven kenniskapitaal gedurende minder uren renderen dan hun mannelijke evenknieën doen. Dit is niet alleen vanuit collectief perspectief bezien een verheffingstekort, maar sluit evenmin aan bij de wensen van veel vrouwen zelf, die, zo blijkt uit survey-gegevens (SCP 2004), graag wat meer uren zouden willen werken (en mannen minder), zij het niet in voltijd.

Belangrijker is de vraag op welke plek binnen de functiehiërarchie (her)intredende vrouwen terechtkomen. Is dat overwegend aan de bovenkant of juist vooral aan de onderkant? In het eerste geval blijft het investeringsverlies beperkt tot kwantitatieve tekorten (meer uren), terwijl er in het tweede geval tevens sprake is van kwalitatieve tekorten (overscholing). Hoewel het opleidingsniveau van jongere vrouwen dat van mannen weinig ontloopt, geldt dat niet voor oudere generaties. Dat betekent dat het opleidingspeil van vrouwen op geaggregeerd niveau nog altijd lager is dan van mannen. Dit is een van de verklaringen voor de (geringe) oververtegenwoordiging van vrouwen in de lagere functiecategorieën en hun (forsere) onderrepresentatie in de twee hoogste functiecategorieën. Toch is sinds de jaren negentig sprake van een sterke verbetering van de benutting van het vrouwelijke kenniskapitaal. Was in 1995 slechts 26 procent van de wetenschappelijke beroepsbeoefenaren vrouw; in 2002 was dat percentage gestegen tot 33. Eenzelfde beeld vertoont het aantal vrouwelijke managers. Ook daar is sprake van een duidelijke stijging, en wel van 14 procent naar 25 . Hier moet echter bij worden aangetekend dat deze groei zich voornamelijk beperkt tot publieke sectoren als onderwijs, openbaar bestuur en gezondheids- en welzijnszorg. In de particuliere sector is het aandeel vrouwelijke managers nog altijd laag en staat de ontdekking van het kenniskapitaal van vrouwen dus nog in de kinderschoenen (CBS 2004; SCP/CBS 2004, p. 63 e.v.; Van Zanten 2006).

\section{Allochtonen}

De tweede groep die heeft geprofiteerd van de banengroei in de jaren negentig zijn de niet-westerse migranten die in groeiende getale Nederland bevolken. Bedroeg de werkloosheid onder migranten in 1990 nog zo'n 24 procent, in 2002 was dat gedaald tot circa negen procent (SCP 2003). Niet alleen absoluut, ook relatief was er gedurende de jaren negentig sprake van een duidelijke verbetering. Was de werkloosheid van migranten in het begin van de jaren negentig nog vier keer zo hoog als onder autochtonen, tien jaar later was dat verminderd tot het drievoudige. Anders dan in het geval van vrouwen wier arbeidsmarktpositie gedurende de recente recessie (2002-2005) verder verbeterde, lijken migranten echter zwaarder getroffen door de werkloosheid. Inmiddels bevindt het werkloosheidspercentage van niet-westerse allochtonen zich weer op het niveau van het midden van de jaren negentig, te weten 16,1 procent (SCP/WODC/CBS 2005; CBS 2006c). 
Tabel 7.1 Werkloze beroepsbevolking naar etnische groep en geslacht, 2003 en 2004 (in procenten)

\begin{tabular}{|c|c|c|c|}
\hline & Mannen & Vrouwen & Totaal \\
\hline Turken & 12 & 18 & 14 \\
\hline Marokkanen & 24 & 19 & 22 \\
\hline Surinamers & 10 & 13 & 12 \\
\hline Antillianen & 16 & 15 & 16 \\
\hline (vrm.) Joegoslaven & 20 & 21 & 20 \\
\hline Irakezen & 40 & 31 & 39 \\
\hline Afghanen & 34 & 50 & 37 \\
\hline Iraniërs & 25 & 25 & 25 \\
\hline Somaliërs & 34 & 44 & 36 \\
\hline Overige niet-westerse allochtonen & 20 & 16 & 18 \\
\hline Totaal niet-westerse allochtonen & 16 & 15 & 16 \\
\hline Autochtonen & 4 & 6 & 5 \\
\hline
\end{tabular}

Bron: SCP/WODC/CBS 2005, p. 85

De verklaring voor het verschil tussen vrouwen en niet-westerse allochtonen in de mate waarin hun arbeidsmarktsituatie conjunctuurgevoelig is, schuilt deels in de verschillen in conjunctuurgevoeligheid van de economische sectoren waarin ze werkzaam zijn (vooral publieke sectoren in het geval van vrouwen en vooral industriële sectoren en de persoonlijke en commerciële dienstverlening in het geval van migranten), in het opleidingspeil (gemiddeld in het geval van vrouwen en beduidend lager dan gemiddeld in het geval van migranten), de aard van het arbeidscontract (merendeel vast in het geval van vrouwen, tot een derde tijdelijk in het geval van migranten) en deels in een onverklaarbare rest die vermoedelijk te herleiden is tot discriminatie. Dit laatste wordt tevens gesuggereerd door het feit dat voor beide groepen geldt dat gelijke arbeid in de praktijk nog altijd geen gelijke beloning genereert, ook niet wanneer wordt gecorrigeerd voor verschillen in arbeidsduur, sector en opleidingsniveau (SCP/CBS 2004, p. 133 e.v.).

\section{$7 \cdot 3 \cdot 3$ DOORSTROOM}

Bij arbeidsmobiliteit gaat het niet zozeer om de toegangsdrempels tot de arbeidsmarkt, maar staan juist de carrièrekansen centraal. Doorstroom betreft de mogelijkheid van werknemers om hun arbeidsvoorkeuren te realiseren, zowel ten aanzien van salariëring, arbeidskwaliteit, arbeidsomstandigheden als de aansluiting tussen functie-inhoud en behaalde kwalificaties. Dat daarvoor mobiliteit vereist is, heeft vier redenen. Ten eerste kennen de meeste werknemers in het begin van hun arbeidscarrière een zoekfase die leidt tot een verhoogde mobiliteit. Dit kan een gevolg zijn van intransparantie: de werkzoekende heeft eenvoudig- 
weg onvoldoende informatie om gericht naar een passende betrekking te zoeken. Maar ook kan zo'n zoekfase het gevolg zijn van een weinig specifieke vooropleiding. In dat geval sorteert de opleiding de werkzoekende niet al voor een bepaalde betrekking voor, maar moet hij op eigen houtje al doende ontdekken welk type arbeid bij zijn talenten en voorkeuren het beste past. Ten tweede kunnen arbeidsvoorkeuren in het licht van ervaringen door de werknemer worden herzien. In een starre arbeidsmarkt kan dit leiden tot een groeiende ontevredenheid over de actuele betrekking; in een dynamische arbeidsmarkt daarentegen kunnen werknemers hun veranderende voorkeuren wel via baan- of functieveranderingen verwezenlijken. Ten derde doen veel werknemers al doende nieuwe vaardigheden en competenties op die de eisen van hun huidige functie te boven kunnen gaan. Ook dat kan een reden zijn om uit te gaan kijken naar een andere functie of baan. Ten vierde kan door technologische en/of organisatorische wijzigingen de huidige functie of baan komen te vervallen waardoor werknemers worden gedwongen om zich nieuwe vaardigheden en competenties eigen te maken teneinde een nieuwe functie te kunnen vervullen.

De vraag is hoe deze vormen van mobiliteit zijn verdeeld over verschillende groepen werknemers. Zoals gezegd is de arbeidsmobiliteit in Nederland relatief hoog. Deze mobiliteit betreft bovendien vaker baanveranderingen via de externe arbeidsmarkt dan functieveranderingen via interne arbeidsmarkten. De baanveranderingen zijn echter ongelijk over werknemers verdeeld. Oudere en hoogopgeleide werknemers die beschikken over veel bedrijfsspecifieke kennis zijn vaker functiewisselaars dan jongere en laagopgeleide werknemers. Baanwisselaars zijn vaker werkzaam in kleine bedrijven, in de persoonlijke en kleinschalige commerciële dienstverlening en beschikken vaker over een tijdelijk contract. Hoewel vrijwillige mobiliteit domineert, is een vijfde van de arbeidsbewegingen onvrijwillig van aard. Het zijn vooral laagopgeleiden en werknemers met een tijdelijk contract die gedwongen mobiel zijn. De mobiliteit van deze werknemers heeft ook een overwegend neerwaartse richting (SCP 2005 b, p. 68 e.v.).

\subsubsection{DE NEDERLANDSE ARBEIDSMARKTPRESTATIES GEWOGEN}

Hoe deze ontwikkelingen te beoordelen? Een eerste beoordelingscriterium is het vermogen van arbeidsmarktinstituties om bij te dragen aan werkgelegenheidsgroei. Als de werkgelegenheidsgeschiedenis van de twintigste eeuw namelijk iets leert, is het dat banengroei een belangrijke voorwaarde is voor het kunnen opvangen van de werkgelegenheidseffecten van economische structuurwijzigingen. Het verwerken van arbeidsoverschotten in een stabiele arbeidsmarkt neemt eerder de gedaante aan van een stoelendans. Juist door de sterke werkgelegenheidsgroei, zeker na 1985, heeft Nederland zo'n stoelendans succesvol weten te ontlopen. Op dit criterium scoort de Nederlandse arbeidsmarkt dan ook uitstekend. Datzelfde geldt voor het criterium van mobiliteit. Uiteraard bestaat er een relatie tussen de mate van werkgelegenheidsgroei en de mate van baan- en functiemobiliteit (SCP 2005b). Toch is het zinvol om groei en mobiliteit analytisch te onderscheiden. In een starre arbeidsmarkt - ongeacht of deze groeit, stabiel is of 
krimpt - komen immers minder stoelen (tijdelijk) vrij dan in een meer dynamische. Dat maakt het voor nieuwkomers (schoolverlaters, migranten) en oudkomers (herintredende vrouwen, werklozen) moeilijker om een plaats te vinden. Ook op het criterium van mobiliteit scoort de Nederlandse arbeidsmarkt, zoals we hiervoor al zagen, goed.

Dit betekent dat er wat betreft de dynamiek van de Nederlandse arbeidsmarkt geen reden is om te oordelen dat het Nederlandse arbeidsbestel (te) rigide zou zijn. Wie in Nederland van baan of functie wil veranderen, kan dat in de meeste gevallen doen zonder al te veel consequenties voor opgebouwde rechten. Verder is de omvang van de groep werknemers die gedwongen mobiel is, relatief klein en kunnen ze bovendien, als gevolg van de grote dynamiek van de Nederlandse economie, relatief gemakkelijk een nieuwe baan vinden. Bovendien moet steeds in gedachte worden gehouden dat een zekere mate van immobiliteit ten goede komt aan de verwerving van bedrijfsspecifieke kennis en dat het opbouwen van loyaliteit jegens de werkgever en economisch functioneel is; meer dynamiek op de arbeidsmarkt is dan ook niet per definitie beter dan minder. Daarnaast gaat mobiliteit gepaard met overstapkosten die moeten worden afgezet tegen de baten van een betere allocatie van menselijk kapitaal over maatschappelijke posities.

Sectorale dynamiek en mobiliteit zijn echter niet het hele verhaal. Zowel ten aanzien van groei als van mobiliteit moet ook worden nagegaan wat de kwaliteit van de banengroei is, voor welke groepen deze nieuwe banen zijn, om welk type mobiliteit het gaat, en hoe deze vormen van arbeidsmobiliteit zijn verdeeld. Een ongelijke verdeling van baan- en carrièrekansen is inherent aan het meritocratische verdelingsprincipe. Ongerechtvaardigd wordt deze ongelijke verdeling pas wanneer ze structureel van aard is en bepaalde werknemers definitief 'opsluit' in tweederangs arbeidsbetrekkingen. Wanneer deze verdeling ook nog eens etnische en geslachtelijke scheidslijnen volgt, dreigt het gevaar van sociale 'ontbinding'.

Op deze twee dimensies scoort de Nederlandse arbeidsmarkt beduidend minder goed. Ten aanzien van baankansen van nieuw- of oudkomers zijn er vier verheffingstekorten geconstateerd. In het geval van vrouwen bestaat er naast een kwantitatief verheffingstekort in termen van een achterblijvend aantal arbeidsuren per aanstelling ook een kwalitatief verheffingstekort dat zich enerzijds manifesteert als een scheve verdeling van vrouwelijk talent over de Nederlandse economie, en anderzijds als een nog altijd bestaande mismatch tussen de sterk gestegen kwaliteit van het vrouwelijke arbeidsaanbod en de daarbij achterblijvende kwaliteit van de vraag. Vrouwen werken, ondanks vrijwel identieke opleidingsprofielen, minder uren dan mannen, genereren suboptimale rendementen op hun opleidingsinvesteringen en zijn daardoor vaker economisch afhankelijk, wat inkomensrisico's met zich meebrengt in het geval van zwangerschap of scheiding. Daarnaast zijn vrouwen ondervertegenwoordigd in functies van academisch niveau en nemen ze weinig managementposities in. 
In het geval van migranten gaat het om een onwenselijke cumulatie van elkaar wederzijds versterkende verheffingstekorten. Bij gebrek aan in- en doorstroomkansen op de arbeidsmarkt ontbreekt het ook aan prikkels om gedurende het verblijf in het onderwijsbestel het eigen menselijk kapitaal te maximaliseren. Omgekeerd leidt een lage kwaliteit van het arbeidsaanbod van specifieke, gemakkelijk herkenbare groepen tot gemakkelijk legitimeerbaar uitsluitgedrag van de kant van werkgevers en daarmee tot een verdere afname van de in- en doorstroomkansen van ook die leden van deze groep die wel over voldoende menselijk kapitaal beschikken. De conclusie luidt dat in het geval van niet-westerse allochtonen de werkgelegenheidswinsten van de jaren negentig nog weinig structureel zijn en dat verheffingstekorten hier nog steeds manifest zijn. Anders dan bij vrouwen gaat het in het geval van niet-westerse allochtonen vooral om een te geringe arbeidsparticipatie en veel minder om een te gering aantal uren per betrekking. Een (te) groot percentage niet-westerse allochtonen is werkloos. En anders dan bij vrouwen gaat het in het geval van allochtonen niet zozeer om problemen van overscholing als wel om problemen van onderscholing. Het opleidingspeil van de gemiddelde allochtoon is nog altijd, ondanks sterke verbeteringen bij vooral de tweede (en derde) generatie, onvoldoende om voldoende baan- en carrièrekansen te kunnen garanderen. Bovendien zullen de kwaliteitseisen aan de vraagkant van de arbeidsmarkt als gevolg van technologische en organisatorische veranderingen en economische internationalisering alleen maar toenemen.

\subsection{VERBETEREN VAN DE VERHEFFINGSFUNCTIE}

In de voorgaande paragrafen is gezocht naar de voornaamste verheffingstekorten in onderwijsbestel en arbeidsmarkt. In deze paragraaf wordt onderzocht wat er aan deze tekorten kan worden gedaan. Daarbij worden eerst de oplossingsrichtingen besproken voor het onderwijsbestel en daarna die voor de arbeidsmarkt.

\subsubsection{BETERE VERHEFFING IN HET ONDERWIJSBESTEL}

In de discussies die nu al decennialang in het onderwijsveld worden gevoerd, passeren met regelmaat twee generieke oplossingen als panacee voor alle kwalen. De eerste is een radicale omvorming van het Nederlandse onderwijsbestel naar Scandinavisch model. De tweede luidt dat de problemen in het onderwijs vooral te wijten zijn aan bezuinigingen en dat meer geld de oplossing is. Voordat meer in detail wordt ingegaan op de oplossingen voor boven geïdentificeerde verheffingstekorten, worden eerst de merites van deze twee opties besproken.

\section{Naar een Scandinavisch onderwijsmodel?}

Sommigen bepleiten dat het model dat Nederland zou moeten navolgen dat van meer omvattende onderwijsstelsels als de Scandinavische is. Deze houden leerlingen zo lang mogelijk bij elkaar en verdelen de verschillende groepen pas bij de overgang van het secundaire naar het tertiaire niveau - meestal rond het zestiende à zeventiende levensjaar - over theoretische en praktische onderwijstrajecten. 
Centraal in dit stelsel staat het bijbrengen van basale vaardigheden op het gebied van taalbeheersing, wiskunde, geschiedenis en wereldoriëntatie, en veel minder is het gericht op het voorbereiden op de arbeidscarrière. Dat laatste is een verantwoordelijkheid die toevalt aan werknemer en werkgever. Doordat omvattende stelsels leerlingen met verschillende talenten langer bij elkaar houden, slagen ze er beter in om de verschillen in prestaties tussen leerlingen te verkleinen (OECD 2005; Leseman 2005).

Het Nederlandse onderwijsbestel vertoont ondanks enkele pogingen om het meer omvattend te maken nog altijd trekken van het standenonderwijs dat het ooit geweest is. De vroege sortering, de geringe effectiviteit van de pogingen om de cognitieve effecten van sociaal-economische verschillen te bestrijden, de hoge uitval uit het vmbo, de stokkende doorstroom naar het algemeen vormende onderwijs, de relatief geringe deelname aan het tertiaire onderwijs, de lage statuur van het vmbo: het zijn stuk voor stuk weeffouten die toe te schrijven zijn aan de institutionele restanten van het oude standenonderwijs. Als gevolg daarvan zijn goed op elkaar aansluitende en doorlopende 'leerlijnen' nooit van de grond gekomen, lopen leerlingen in het Nederlandse onderwijsbestel onnodige risico's op foutieve allocatie, wat leidt tot uitval, terwijl er tegelijkertijd te weinig wegen terug zijn (Onderwijsraad 2005d).

Niettegenstaande zijn er goede redenen om terughoudend te zijn met (nieuwe) ingrepen in het Nederlandse onderwijsbestel. Ten eerste omdat het op hoofdlijnen goed functioneert. De hoge scores op internationale vaardighedentests, bij relatief lage publieke bestedingen, zijn een compliment aan het adres van de Nederlandse leerkrachten. Ten tweede omdat vorige onderwijshervormingen hebben geleerd dat blauwdrukken op weinig steun van een goed georganiseerd veld kunnen rekenen en dus ook een geringe kans van slagen hebben (Prick 2006). Ten derde is de eenzijdige aandacht voor institutionele hervorming ten koste gegaan van reflectie op pedagogische doelen en instrumenten (De Rooy 2005). Zowel vanuit het onderwijsveld als uit het parlement klinkt de roep om bezinning op de voornaamste taken van het onderwijs, om pas daarna te zoeken naar de institutionele arrangementen die daarbij horen. Ten slotte kunnen de meeste verheffingstekorten vermoedelijk worden opgelost met aanvullende in plaats van vervangende maatregelen.

\section{Meer middelen?}

Daarnaast kan met enige regelmaat de roep om meer geld worden gehoord. Onder verwijzing naar de 8 à 9 procent van het bnp die de Scandinavische landen aan onderwijs besteden, wordt in Nederland wel gepleit voor het ongedaan maken van de bezuinigingen van de jaren tachtig en vroege jaren negentig. Het probleem met deze redenering is dat vergelijkende data leren dat meer geld wellicht een noodzakelijke, maar nog geen voldoende voorwaarde is voor betere onderwijsprestaties. Big spenders als Zweden en Denemarken scoren lager op gestandaardiseerde prestatiemetingen dan Nederland. Voorzichtig concludeert de OECD in de laatste Education at a glance dan ook dat verruiming van de budget- 
taire mogelijkheden geen panacee is, ook al is er wel een duidelijke ondergrens waaronder het budget niet kan zakken zonder aanmerkelijke kwaliteitsverslechteringen (OECD 2005).

De redenering dat meer onderwijs beter is dan minder onderwijs en dat verhoging van de publieke investeringen in het onderwijs dus de beste investering is die een samenleving kan doen, mag zich op grote populariteit verheugen. Hoewel het belang van economische competitiviteit een voorname reden is om te willen werken aan een kwaliteitsverbetering in het onderwijs, volgt daar niet een ongekwalificeerd pleidooi uit voor meer financiële armslag. Ten eerste zal door vergrijzing ook de komende decennia sprake zijn van budgettaire beperkingen, terwijl de mogelijkheden voor verruiming van de belastinggrondslag en verhoging van de belastingtarieven als gevolg van economische internationalisering evenzeer hun beperkingen kennen. Ten tweede levert niet iedere euro die in het onderwijs wordt gestoken evenveel op. Grof gezegd kan uit de onderwijseconomie de vuistregel worden afgeleid dat de maatschappelijke opbrengsten uit onderwijsinvesteringen afnemen naarmate ze hoger in de onderwijskolom terechtkomen. Oftewel, investeringen in goede voorschoolse educatie leveren meer rendement op dan investeringen in het primaire onderwijs, investeringen in het primaire onderwijs meer dan in het secundaire, en investeringen in het secundaire meer dan in het tertiaire (Heckman 2005; Wolf 2001). Immers, hoe jonger de leeftijdsgroep is waaraan de middelen gespendeerd worden, hoe langer de terugverdienperiode kan zijn en hoe hoger dus het rendement. Voor het individuele rendement geldt het omgekeerde. Hoe hoger in de onderwijsketen, hoe groter de individuele baten van onderwijsinvesteringen (Groot en Maassen van den Brink 2004).

Het ligt daarom voor de hand dat de primaire verantwoordelijkheid van de overheid zich toespitst op een goede algemene basisvorming en dat de verantwoordelijkheid voor hogere, beroepsgeoriënteerde opleidingen meer gelegd wordt bij individuen, huishoudens en (publieke en private) werkgevers. Daar staat tegenover dat universiteiten en hogescholen meer armslag zouden moeten krijgen om private financieringsbronnen aan te boren door verdere differentiatie in hun cursusaanbod en kostendekkende prijsstelling toe te staan. Het grote verschil met het Amerikaanse universitaire bestel schuilt niet zozeer in het verschil in hoogte van de publieke bijdrage als wel in de minimale particuliere bijdrage aan academisch onderwijs in het Nederlandse (en Europese) bestel. Om de toegankelijkheid te garanderen bij een grotere particuliere bijdrage zou ze gecombineerd moeten worden met een inkomensafhankelijk leningenstelsel (Jacobs en Van der Ploeg 2005; CPB 2006). Een variant daarop is de manier waarop in onder meer Australië en Schotland de studiefinanciering is geregeld. Studenten krijgen een relatief ruime beurs - die ook dient om studenten niet te dwingen een groot deel van de studietijd te spenderen aan baantjes naast de studie - en kunnen in de eerste fase van hun arbeidscarrière een extra belastingaanslag verwachten als hun inkomen boven een bepaald niveau uitkomt. Zo betalen veelverdieners de publieke investering die in hun kenniskapitaal is gedaan, maar die ze zelf renda- 
bel maken, voor een deel terug, terwijl modaalverdieners niet voor hun studielust worden gestraft met hoge restitutieverplichtingen. En door kostendekkende bedragen voor de studie te vragen worden studenten weer gedwongen te doen wat ze geacht worden te doen, namelijk studeren.

\section{Concrete verheffingstekorten}

Hiervoor is geconstateerd dat de voornaamste verheffingstekorten zich in het funderende onderwijs bevinden. Waar het allereerst aan schort, is een goed stelsel van universeel toegankelijke vroegschoolse educatie dat in de plaats zou moeten komen van de bestaande stelsels van kinderopvang en peuterspeelzalen. Gezien het belang van een stimulerende leefomgeving voor de ontplooiingskansen van het jonge kind en de publieke kosten die zijn gemoeid met de langetermijneffecten van tekorten op dit vlak, is de geringe aandacht voor de pedagogische kwaliteit van de voor-, tussen- en naschoolse opvang zorgwekkend. Nederland is internationaal gezien de laatste jaren weliswaar een meer oudervriendelijk land geworden maar een kindonvriendelijk land gebleven, wat blijkbaar een diepgewortelde maatschappelijke overtuiging weerspiegelt dat sociale reproductie de exclusieve verantwoordelijkheid is van de ouders.

Deze ontkenning van de publieke dimensie van de opvoeding, scholing en verzorging van nieuwe generaties moet worden doorbroken. Dat kan allereerst door alle ouders en verzorgers toegang te bieden tot goede, kwalitatief hoogwaardige voorschoolse educatie. Dit vereist een kostbare, maar hoognodige kwaliteitsimpuls in de bestaande voorschoolse kinderopvang naar Zweeds, Deens of Frans model. Daar worden kinderen niet zomaar beziggehouden ('opgevangen'), maar worden ze gericht begeleid bij hun sociaal-emotionele, sociaalculturele, fysieke en cognitieve ontwikkeling. In Zweden bijvoorbeeld is men in de jaren negentig massaal overgegaan op een systeem van brede scholen, waarin de opvang geheel geïntegreerd is. De ochtend staat in het teken van de schoolse vakken. Na het (gezamenlijke) eten is het's middags - voor de jongere kinderen tijd voor spelen, sporten en werken in verschillende ateliers en - voor de oudere kinderen - ook nog voor extra lestijd. Leerkrachten en pedagogische medewerkers werken samen als een team en assisteren elkaar over en weer. Dit impliceert de noodzaak van goed geoutilleerde kinderdagverblijven, een duidelijk pedagogisch plan, een gunstigere kind-stafratio, geringere mobiliteit en hoger opgeleide en dus beter betaalde leid(st)ers. Ondanks goede bedoelingen schieten Nederlandse kinderdagverblijven op al deze punten nog tekort.

Ten tweede dienen de beperkte arrangementen van tussen- en naschoolse opvang die momenteel nog bestaan à tempo te worden vervangen door brede scholen met sluitende dagarrangementen, geschoolde leid(st)ers en een breed scala aan vormende buitenschoolse activiteiten op het gebied van spel, sport en cultuur. De ongelijke toegang tot deze activiteiten die mede het gevolg is van te beperkte publieke bijdragen op dit vlak komt met name de ontplooiing van de sociaal-economische kwetsbaren niet ten goede. Bovendien zijn naschoolse activiteiten bij uitstek geschikt voor de cultuuroverdracht die eveneens bij verheffen 
hoort en die momenteel onvoldoende aandacht krijgt, als gevolg van de relatief korte Nederlandse schooldag en het zware cognitieve programma dat binnen die schooldag moet worden afgewerkt. In Nederland is inmiddels voldoende ervaring opgedaan met sluitende dagarrangementen in de context van de zogenaamde Brede School- en Vensterschool-experimenten, die ofwel zelf onderwijs, sport, spel, sociaal-emotionele ontwikkeling en hulpverlening bieden ofwel deze centraal organiseren. Het is nu tijd om de stap te zetten naar een geleidelijke uitbreiding van deze arrangementen als standaardvoorziening naar alle Nederlandse basisscholen. Dat vereist aanpassingen van de bebouwde omgeving en organisatorische inrichting die verdergaan dan de wettelijke regelingen die momenteel al zijn doorgevoerd of aanstaande zijn.

Door dit type opvoedkundige ondersteuning als universele maatschappelijke dienst aan te bieden, wordt erkend dat de opvoeding van nieuwe generaties (mede) een publieke verantwoordelijkheid is. Daar zijn substantiële kosten mee gemoeid, waar echter voldoende potentiële baten tegenover staan. Ten eerste die van preventie: bezien vanuit een levensloopperspectief geldt dat voorkomen beter en goedkoper is dan genezen. Hoe eerder ontwikkelingsstoornissen kunnen worden gesignaleerd, hoe beter ze kunnen worden bestreden. Dat voorkomt hoge uitgavenposten in latere levensfasen (Esping-Andersen 2006). Ten tweede op het gebied van ontplooiing: niet iedere leefomgeving biedt voldoende ontplooiingsprikkels. Als gevolg daarvan worden sommige kinderen al aan het begin van hun leven geconfronteerd met achterstanden die ze in de praktijk niet meer kunnen inhalen, met structurele onderbenutting van talent als gevolg. Dit type maatregelen zorgt voor een gelijkere toegang tot ontplooiingskansen en dus tot een betere benutting van talent. Ten derde stelt het ouders en verzorgers beter in staat om zorgtaken en carrière te combineren, wat de arbeidsparticipatie van vooral vrouwen ten goede komt.

Een tweede groot verheffingstekort bevindt zich in het secundaire onderwijs. Hoewel de publieke aandacht vooral uitgaat naar uitvalproblemen, is de kloof tussen het algemeen vormende en het beroepsvoorbereidende traject als gevolg van de samenvoeging van lbo en mavo in het vmbo bij nader inzien een ernstiger probleem. In het licht van de onvermijdelijke feilbaarheid van iedere vorm van selectie is het van belang dat leerlingen niet worden 'opgesloten' in leertrajecten waar ze niet thuishoren. Tegen die achtergrond verdient het aanbeveling om de bestaande doorstroommogelijkheden in de secundaire onderwijsschakel opnieuw tegen het licht te houden. Daarbij zijn ten minste twee zaken van belang. Ten eerste dat dit niet automatisch een terugdraaien van de vmbo-operatie hoeft te betekenen. Een duidelijkere differentiatie binnen het vmbo en dus een duidelijker verschil tussen de meer theoretische en de meer praktische leerwegen zou een eerste stap op de goede weg kunnen zijn. Dit impliceert een formeel afscheid van de in de praktijk al ten grave gedragen Basisvorming (Prick 2006). Ook zou het leerlingen gemakkelijker moeten worden gemaakt om direct van de theoretische leerweg naar de havo over te stappen. Nu slaagt maar vijf procent daar in (CBS 2006, p. 35). Ten tweede verdient het aanbeveling om de beoorde- 
lingscriteria die de onderwijsinspectie hanteert, zodanig aan te passen dat ze risicomijdend gedrag van de zijde van scholen niet langer stimuleert. In combinatie met wettelijke beperkingen op het aantal malen dat mag worden gedoubleerd, leiden de huidige beoordelingscriteria enerzijds tot koudwatervrees bij scholen om leerlingen van lagere scholingsniveaus toe te laten, en anderzijds tot een preventieve 'afstroom' van leerlingen naar lagere scholingsniveaus om de prestatiecijfers van de school niet negatief te belasten met doublures. Vanuit verheffingsperspectief bezien verdient het aanbeveling om leerlingen ruimere mogelijkheden te bieden om een juiste leerweg te vinden en tijdelijke tegenvallers op te vangen.

Ten aanzien van de uitvalproblematiek geldt dat het om een (deels) geconstrueerd probleem gaat. Bovendien staat de maatschappelijke beroering over het hoge percentage uitvallers haaks op de betrekkelijk soepele toegang tot werk die de Nederlandse arbeidsmarkt ook aan uitvallers biedt. Het verdient dan ook aanbeveling om de notie van een startkwalificatie weer te gebruiken zoals ze oorspronkelijk was gemunt, namelijk als een doel dat thuishoort in een perspectief van permanente educatie. Gezocht zou moeten worden naar een instrumentarium dat uitvallende leerlingen het recht geeft om in een later stadium van hun carrière alsnog een kwalificatie te behalen die gelijkwaardig is aan de huidige startkwalificatie. Daarmee wordt niet alleen beter beantwoord aan de vaak wat afwijkende leertrajecten die dit type leerlingen in de praktijk volgt, maar wordt ook tegemoet gekomen aan de grotere 'overbodigheidsrisico's' die lager geschoolde werknemers lopen. Een start zou gemaakt kunnen worden door in CAO's niet meer te spreken over een beloningsniveau dat gekoppeld is aan leeftijd, maar aan kwalificatieniveau. Jongeren die na enkele jaren mbo een aanbod krijgen om ergens te gaan werken - en dat gebeurt veelvuldig in perioden van hoogconjunctuur, terwijl dat in de statistieken verschijnt als schooluitval - hebben dan een prikkel om alsnog, bijvoorbeeld in deeltijd of na een paar jaar, hun opleiding af te maken. Kortom: niet 'schooluitval' is het probleem, de geringe 'schoolterugkeer' is dat.

Verder vereist verheffing via het onderwijs in een geïndividualiseerde en geïnternationaliseerde samenleving meer ruimte voor differentiatie en verschil dan momenteel als regel bestaat. Tegen de achtergrond van een toenemende diversiteit aan talenten en een groeiende onzekerheid over de effectiviteit van bestaande identificatie- en ontplooiingsinstrumenten past bescheidenheid. Een manier waarop deze bescheidenheid gestalte kan krijgen, is door het toestaan van een grotere diversiteit in pedagogische doelen en didactische methodieken. Naarmate de diversiteit van de Nederlandse bevolking als gevolg van migratie en individualisering groeit, dienen ook de instrumenten waarmee verschillende talenten worden geïdentificeerd en tot groei worden gebracht diverser te zijn. De relatief bescheiden mate waarin aandacht op maat voor zowel excellerende als achterblijvende leerlingen vorm krijgt, volgt deze ontwikkeling onvoldoende. Hoewel de decentrale structuur van het Nederlandse onderwijs zich in principe goed leent voor het entameren van proefondervindelijke experimenten met verschillende leermetho- 
den, aanpakken en organisatiemodellen ontbreekt het in de praktijk op de meeste scholen aan een experimenteercultuur. Dat is het effect van een traditie van centrale inhoudelijke aansturing, en van defensieve reacties daarop van de zijde van de schoolbesturen. Hier moet worden gebalanceerd tussen centralisme en decentralisatie, en tussen inhoudelijk gedreven onderwijsvernieuwing en pragmatische evaluatie: werkt het? Uiteraard vereist dit enige vorm van centrale coördinatie en sturing. Voor de hand ligt het om voor die rol de Onderwijsinspectie uit te bouwen van een primair controlerende instantie in een orgaan dat een geleide experimenteercultuur zou kunnen helpen vestigen (WRR 2004).

\subsubsection{BETERE VERHEFFING OP DE ARBEIDSMARKT}

\section{Vrouwenemancipatie en kindervoorzieningen}

Hoewel de Nederlandse arbeidsmarkt in termen van werkgelegenheidsgroei en baan- en functiemobiliteit in het algemeen naar behoren functioneert, betekent dat nog niet dat de banengroei gelijkelijk over de Nederlandse populatie verdeeld is. Ten aanzien van baankansen zijn eerder vier verheffingstekorten geïdentificeerd. Ten eerste dat Nederlandse vrouwen, ondanks een sterk gestegen arbeidsdeelname en sterk gestegen onderwijskwalificaties, nog altijd in grote meerderheid in deeltijdbanen werken. Hoewel deeltijdbetrekkingen dankzij de Flexwet toegang geven tot dezelfde sociale rechten als voltijdsbetrekkingen, garanderen zij niet de economische zelfstandigheid die uitgangspunt is van het Nederlandse emancipatiebeleid (SCP/CBS 2004). Het is de vraag of dit bezwaarlijk is, omdat het dikwijls om zelfgekozen afhankelijkheden gaat. Veel Nederlandse vrouwen bekennen zich om positieve redenen tot hun zorgtaken en zien dus vrijwillig af van maximalisering van hun arbeidsuren (Kremer 2005; SCP 2006a). Dit mag zo zijn, maar onderzoek leert ook dat het feitelijk gewerkte aantal uren van Nederlandse vrouwen achterblijft bij het door hun gewenste aantal uren, namelijk als regel een vierdaagse werkweek van circa 32 uur (SCP/CBS 2004).

De blokkades voor vrouwen om volwaardig deel te nemen aan het arbeidsproces zijn overwegend te herleiden tot combinatieproblemen, dat wil zeggen het onvermogen om zorgtaken te combineren met een volwaardige arbeidscarrière. Lange tijd was de analyse dat dit vooral een capaciteitsprobleem was: er waren eenvoudigweg te weinig opvangplaatsen voor jonge kinderen. Nu die capaciteitsproblemen goeddeels zijn verdwenen, maar de combinatieproblemen niet, moet worden geconcludeerd dat de oorzaken kennelijk dieper liggen. Steeds duidelijker wordt het dat de internationaal unieke zelfzorgideologie van Nederlandse vrouwen alleen kan worden doorbroken door een forse kwaliteitsimpuls in de voor-, tussen- en naschoolse opvang. Alleen wanneer de kinderopvang wordt opgetuigd tot een volwaardig educatief traject voor en naast de reguliere school, waarin het naast cognitieve ook om sociale en emotionele ontwikkeling gaat, zullen Nederlandse vrouwen met een gerust gemoed hun kind naar de crèche brengen. Hoewel dat forse investeringen vereist in bebouwing, outillage, salariëring en opleidingspeil, zijn dat investeringen die in tweeërlei opzicht kunnen renderen. Ten eerste door een verdere vergroting van de arbeidsparticipatie van 
vrouwen mogelijk te maken. En ten tweede door in een vroegtijdig stadium deficiënte socialisatie te kunnen identificeren en bestrijden (Esping-Andersen 2006).

\section{Segregatie}

Het tweede verheffingstekort betreft de segregatie op de Nederlandse arbeidsmarkt. Gezien de oververtegenwoordiging van vrouwen in sectoren als onderwijs, openbaar bestuur en gezondheidszorg en hun ondervertegenwoordiging in het bedrijfsleven kan met enige overdrijving worden geconstateerd dat de Nederlandse arbeidsmarkt voor vrouwen nog slechts partieel toegankelijk is. Deels is dit het effect van de 'gescheiden' leerwegen die jongens en meisjes nog altijd volgen. Meisjes zijn oververtegenwoordigd in sociaal-maatschappelijke, verzorgende en cultureel georiënteerde opleidingen, terwijl jongens de meerderheid vormen in technische opleidingstrajecten. Anderzijds zou in een sterk verdienstelijkte economie als de Nederlandse een hoger aandeel vrouwen in de particuliere dienstensector mogen worden verwacht. Gezien de tegenwoordig meer evenwichtige samenstelling in de relevante opleidingen, is de verwachting gerechtvaardigd dat deze onderrepresentatie geleidelijk zal afnemen. Hetzelfde effect gaat uit van het krimpende aandeel van typische mannensectoren als de bouw en de industrie in de Nederlandse werkgelegenheid (CBS 2004).

Toch zijn er redenen om dit al gaande proces te willen versnellen. Ten eerste omdat de selectieve toegankelijkheid van de Nederlandse arbeidsmarkt vrouwen minder kansen biedt om hun kenniskapitaal te verzilveren. Dat beperkt niet alleen de baankansen van vrouwen, maar versmalt ook de toegang tot een belangrijk kennispotentieel van de Nederlandse bevolking voor werkgevers. Ten tweede leert arbeidsmarktonderzoek dat er een relatie bestaat tussen de doorstroommogelijkheden van vrouwen en het aandeel van vrouwelijke werknemers in het personeelsbestand van de organisatie. Ruwweg geldt dat hoe meer vrouwen er in een organisatie werken, hoe groter het aantal vrouwelijke managers in die organisatie is (CBS 2004). Ook op grond van de doorstroomdimensie van verheffing valt er dus wat te zeggen voor een bespoediging van de 'feminisering' in het bedrijfsleven.

Daarvoor zijn er in ieder geval vier beleidsmogelijkheden. Ten eerste kan worden ingezet op voorbeeldwerking. Door ervoor te zorgen dat vrouwen met voorrang op gezichtsbepalende functies terechtkomen, wordt het signaal gegeven dat ook lager in de organisatie gestreefd moet worden naar grotere representativiteit. Ten tweede valt er een doorstroomeffect van vrouwen in lagere posities te verwachten door een effectief antidiscriminatiebeleid, het faciliteren van soepelere werk/ zorgcombinaties, het formaliseren van calamiteitenverlof en een verdere verruiming van de arbeidstijdenflexibiliteit. Verplichtende maatregelen à la Noorwegen, waar beursgenoteerde ondernemingen op straffe van fiscale sancties wettelijk verplicht zijn om een drempelwaarde aan vrouwen op managementposities te realiseren, of contract compliance naar Amerikaans of Canadees voorbeeld, liggen in Nederland minder voor de hand. In plaats daarvan kan worden ingezet op een serieuze mix van de bovengenoemde maatregelen om het 
doorstroomeffect te vergroten. Ten derde is denkbaar dat een assertieve vakbond of een andere maatschappelijk middenveldorganisatie, gebruik makend van internet en dergelijke, een effectief systeem van naming and shaming weet op te zetten dat vrouwvriendelijke bedrijven prijst en vrouwonvriendelijke berispt.

Ten vierde verdient het aanbeveling om na te denken over versterking van het bestaande Nederlandse antidiscriminatiebeleid. Hoewel grotendeels gemodelleerd naar de Britse Commission for Racial Equality ontbeert het de Nederlandse Commissie voor Gelijke Behandeling aan effectieve sanctiemogelijkheden. Naar het zich laat aanzien heeft dat negatieve effecten voor de effectiviteit van het antidiscriminatiebeleid (Singi Dami et al. 2006). Bij de verscherping van het Nederlandse discriminatiebestrijdingsbeleid kan als argument worden gehanteerd dat alleen wanneer er een hard maar fair antidiscriminatiebeleid gevoerd wordt, het aangaan van arbeidscontracten met een gerust hard kan worden overgelaten aan onderhandelingen tussen werkgever en werknemer.

\section{Arbeidsmarktpositie migranten}

De twee laatste verheffingstekorten ten slotte betreffen de achterblijvende baanen carrièrekansen van niet-westerse migranten. Ondanks een inhaalslag in de tweede helft van de jaren negentig, blijkt de werkgelegenheidskrimp van de laatste jaren disproportioneel bij deze groep terecht te zijn gekomen. Alhoewel de deelname van jongeren uit deze groep aan de hogere regionen van het onderwijs gelukkig stijgt, vormen instroomblokkades voor migrantenjongeren op de Nederlandse arbeidsmarkt niettemin nog steeds een ontbindingsgevaar. Daartegen zijn dan ook maatregelen vereist. Zoals lessen uit West-Europa en NoordAmerika leren moet daarbij tegelijk naar de aanbod- en de vraagkant van de arbeidsmarkt worden gekeken (Singh Dami et al. 2006). Beleid dat gericht is op een verruiming van de baan- en carrièrekansen van migranten is vergeefs wanneer niet tegelijkertijd via het onderwijsbestel wordt gewerkt aan vergroting van het kenniskapitaal, de sociale en culturele verheffing en de motivatie van migranten. Omgekeerd geldt dat een inzet op verheffing via het onderwijs verspilde moeite is wanneer migranten onvoldoende mogelijkheden hebben om hun menselijk kapitaal op de arbeidsmarkt te verzilveren.

De les van het werkgelegenheidssucces van de tweede helft van de jaren negentig is dat de economische integratie van migranten - zij het via werknemerschap, zij het via zelfstandig ondernemerschap - niet vanzelf gaat. Ondanks hoogconjunctuur en onstuimige banengroei waren initiatieven van derden nodig om de arbeidsmarktparticipatie van migranten te vergroten. Wat opvalt aan deze diverse initiatieven is dat ze zeer verschilden in effectiviteit. Weinig effectief waren de twee positieve-actie-wetten die in de eerste helft van de jaren negentig naar Canadees voorbeeld in Nederland zijn geïntroduceerd en in het nieuwe millennium weer zijn afgeschaft. Deels door hun controversiële aard en deels door het ontbreken van sancties hebben ze vooral gewerkt als oefeningen in etnische categorisering van het personeelsbestand, die echter weinig hebben bijgedragen aan de slechting van discriminatoire muren (Jonkers 2003). 
Wel succesvol daarentegen waren de convenanten die onder auspiciën van het ministerie van szW werden gesloten tussen arbeidsbureaus en мкв Nederland. $\mathrm{Na}$ een moeizame start zijn uiteindelijk in korte tijd meer dan veertigduizend werkzoekende migranten bij kleine en middelgrote ondernemingen geplaatst. Evaluatiestudies leren dat het succes vooral te danken was aan de intensieve begeleiding van de sollicitanten door ter zake kundige intercedenten (Berkhout et al. 2001). Hoewel de kritiek van het SCP en anderen op de passieve houding van het kabinet gedurende de jaren van recessie in grote lijnen terecht is (SCP 2003, p. 305 e.v.), is het niet zozeer het einde van de positieve-actie-wetgeving dat betreurd moet worden, alswel het projectmatige karakter van de convenanten. Als gevolg daarvan is de lokale kennis die de tijdelijk ingehuurde intercedenten van zowel de vraag- als de aanbodkant van een moeilijk segment van de Nederlandse arbeidsmarkt verworven hadden achteloos teloor gegaan, terwijl deze juist in een periode van economische neergang goede diensten had kunnen bewijzen. Het verdient dan ook aanbeveling om te zoeken naar meer structurele equivalenten van deze convenanten.

Daarnaast is ook hier een pleidooi op zijn plaats voor een serieuzer antidiscriminatiebeleid. Hoewel er voldoende indicaties zijn van discriminatie op de arbeidsmarkt, ontbreekt het aan een adequaat instrumentarium onterechte bevoordeling en benadeling bij de allocatie van posities over werknemers tegen te gaan. Een actiever opsporend en signalerend beleid, aangevuld met de mogelijkheid om effectieve sancties op te leggen, al dan niet in de vorm van een stevigere wettelijke basis voor de Commissie Gelijke Behandeling, zou kunnen bijdragen aan een verdere meritocratisering van de arbeidsmarkt.

Momenteel zien we een beleid dat vooral inzet op culturele integratie als oplossing van dreigende maatschappelijke 'ontbinding' zonder dat echter de sociaaleconomische voorwaarden daarvoor zijn gerealiseerd; het dreigende gevolg is dat culturele tegenstellingen eerder worden verscherpt, met 'ontbinding' als uitkomst. Dit geeft des te meer aan dat het zaak is om een goede analyse te maken en om daarop een evenwichtig beleidsprogramma te enten.

\subsection{CONCLUSIE: NAAR EEN ZACHTMOEDIGE MERITOCRATIE}

Ook al oogt het voorafgaande wellicht als een voornamelijk instrumenteel pleidooi voor de optimalisering van de verheffingsfuncties van de Nederlandse verzorgingsstaat, de ontwikkeling in de richting van een 'diplomacratie' die dat in de hand lijkt te werken, is om meerdere redenen ongewenst. In een 'diplomacratie' is het behaalde certificaat, als indicator van vaardigheden en competenties, in een groeiend aantal economische sectoren bepalend voor de toegang tot maatschappelijke posities, die op hun beurt inkomen, vermogen, residentie, sociaal netwerk, huwelijkspartner, status en zelfs het sociaal-economische succes van het nageslacht bepalen en daarmee van grote betekenis zijn voor welbevinden, gezondheid en mortaliteit. Oftewel, de beloningen in één specifieke maatschappelijke arena, namelijk diploma's in de onderwijsarena, fungeren als cruciale 
hulpbronnen ter verwerving van andere beloningen in andere maatschappelijke arena's, zoals die van werk, huisvesting, sociale relaties, prestige of huwelijkspartners. In een samenleving als de Nederlandse waarin de toegang tot cruciale hulpbronnen niet uitsluitend verloopt via inkomen, maar ook via beginselen van solidariteit en sociale rechtvaardigheid, is dat een onwenselijke ontwikkeling (Van Oorschot 2002).

Verder is het, gegeven de cognitieve beperkingen die menselijke actoren nu eenmaal eigen zijn, ten principale onmogelijk om 'de verheffingsmachine' perfect te laten functioneren. Er zal altijd talent niet of pas veel te laat worden ontdekt, en er zullen ook dan fouten worden gemaakt bij de verdeling van talenten over maatschappelijke posities. Om deze redenen is het van belang dat het idee van 'nieuwe rondes, nieuwe kansen' op een of andere wijze in de Nederlandse verzorgingsstaat gestalte krijgt. Een aanknopingspunt daarvoor is bijvoorbeeld de levensloopregeling, die in zijn huidige vormgeving onbevredigend functioneert. Wanneer het beleid ervoor opteert om door te gaan met deze regeling dient ze genereuzer te worden en moet ze met name ook voor kapitaal zwakkeren gemakkelijker toegankelijk worden gemaakt. Verder zouden de prikkels van de regeling zodanig moeten worden verlegd dat het doel ervan werkelijk het stimuleren van investeringen in het eigen menselijk kapitaal wordt in plaats van primair het kopen van vrije tijd. Zo'n levensloopregeling 'nieuwe stijl' zou een financiële infrastructuur kunnen bieden voor een adequaat vormgegeven stelsel van tweede- en derdekansonderwijs, waarmee 'laatbloeiers', 'uitvallers' en 'lastpakken' niet langer op grond van een mislukte cito-toets of een moeizame schoolcarrière veroordeeld zijn tot een bestaan in de marge van de Nederlandse arbeidsmarkt.

Tot slot zullen ook in een verzorgingsstaat die er meer werk van maakt om verheffingstekorten te bestrijden, voorzieningen nodig blijven om ook kansarme mensen (die dus niet goed te verheffen zijn) een menswaardig bestaan te garanderen. Door van het Nederlandse onderwijsbestel een effectievere 'ontdekkingsen ontplooiingsmachine' te maken, kan deze groep verkleind worden, maar ze zal niet verdwijnen. Tegenover het krimpende effect van een effectiever onderwijsbestel staat immers het groeiende effect van hogere functie-eisen als gevolg van economische, organisatorische en technologische vooruitgang (Tinbergen 1975). Een menswaardig bestaan voor deze kansarme groep zal vorm moeten krijgen via kwalitatief hoogstaande diensten op het gebied van onderwijs, activering, opvang en zorg, maar ook via de subsidiëring uit publieke middelen van functies die nimmer zullen kunnen rekenen op marktconforme opbrengsten. 


\section{VERBINDEN: OVERBRUGGEN VAN SOCIALE AFSTAND}

\subsection{INLEIDING}

Verzorgingsstatelijke arrangementen hebben een belangrijke rol gespeeld bij het verbinden van individuen en collectieven aan de vorming van de (Nederlandse) natiestaat. Dat was het meest zichtbaar toen de Nederlandse identiteit onder druk stond. En dat is vooral het geval geweest rond twee verschillende momenten van buitenlandse bezetting: de Franse bezetting in de eerste jaren van de negentiende eeuw en de Duitse bezetting van 1940-1945. Uit deze bezettingservaringen kwam een verbindingsopdracht voort: de toenmalige politieke en bestuurlijke elite richtte zich na de bevrijding op nieuwe publieke arrangementen. Om van een verzameling individuen, groepen, dorpen en provincies een hecht aaneengesmede nationale gemeenschap van risicodelers te maken, was het zaak om hen te verbinden aan een aansprekend 'project': het project van wederopbouw en modernisering (zie bijv. Knippenberg en De Pater 2002). Bovendien werkte het door de buitenlandse bezetting opgelegde centrale gezag in een voorheen nog erg gedecentraliseerd land als katalysator. Het bestendigde beide keren, met andere woorden, ook na de bezetting mogelijkheden en capaciteit van centraal bestuur.

De ontwikkeling van een verbindingsfunctie via de natiestaat speelt ook bij de tegenstelling tussen arbeid en kapitaal. Dat begon zich af te tekenen in het spoor van het eerste moderniseringsproject, en de bijbehorende industrialisatie en urbanisatie van het Nederland van de late negentiende eeuw. Zoals in alle kapitalistische economieën dreigde de sociale ontworteling waarmee de industrialisatie gepaard ging, en de verscherping van de tegenstelling tussen bezitters en bezitslozen, te leiden tot een erosie van het nationale saamhorigheidsgevoel. Was de arbeider primair arbeider en pas daarna Nederlander, of was het Nederlanderschap een afdoend integratiekader om de middelpuntvliedende krachten van de kapitalistische productiewijze tegen te gaan? De wetgeving die vanaf het einde van de negentiende eeuw werd ingevoerd (zie hoofdstuk 2) versterkte de integrerende werking van de natiestaat door haar duidelijker en universeler - alhoewel in de aanloop nog pover naar hedendaagse normen - een verzekerings- en een verzorgingsfunctie te geven. Tegelijkertijd nam het iets van de scherpte van de klassentegenstellingen weg.

De verzorgingsarrangementen die de Nederlandse inwoners samenbinden, hebben in de loop der decennia een vanzelfsprekend karakter gekregen. Ze zijn er nu eenmaal, net zoals de wegen, de riolering, het waterleidingnetwerk en andere fysieke infrastructuur er nu eenmaal zijn. Al doende hebben ze hun emotioneelaffectieve lading verloren (zoals die er ooit was voor de diamantslijpers die een eerste sociale regeling met elkaar organiseerden, of rondom de oprichting van de eerste ziekenfondsen om het ziekterisico met elkaar te delen, enzovoorts). De 
verbindende functie van de verzorgingsstaat heeft meestal in de schaduw gestaan van haar andere functies. Verzorgen, verzekeren en verheffen zijn altijd de meer in het oog springende functies geweest, waardoor het belang van 'verbinden' - zowel als voorwaarde voor en als gevolg van de andere functies - niet steeds de aandacht heeft gekregen die het verdient.

\section{Nieuwe verbindingsopdracht}

De samenleving is al lang niet meer dezelfde als direct na de Tweede Wereldoor$\log$, laat staan als die van de beginjaren van de verzorgingsstaat. Hoewel van een andere orde dan de calamiteiten en spanningen van destijds, is het door het ouder, diverser, hoger opgeleid en mondiger worden van burgers, noodzakelijk geworden om de verbindingsfunctie opnieuw tegen het licht te houden. Oftewel, na de historische verbindingsopdrachten die zojuist genoemd zijn, staat de Nederlandse samenleving nu voor een nieuwe verbindingsopdracht. De uitdagingen en de daaraan gekoppelde potentiële maatschappelijke tegenstellingen zijn beschreven in hoofdstuk 3 .

De eerste mogelijke scheidslijn die kan worden geïdentificeerd is die tussen rijk en arm. Belastingheffing en inkomensoverdrachten lijken er vooralsnog aan bij te dragen om het Nederlandse inkomensgebouw internationaal vergeleken redelijk egalitair te houden. De vraag is of ze daar in het licht van de ontwikkelingen in de (internationale) economie ook in de toekomst in zullen slagen. Skill-biased technological change zou tot een tweedeling op de arbeidsmarkt kunnen leiden. Terwijl de vraag naar hooggeschoolde werknemers naar verwachting verder zal toenemen, geldt dat niet voor de onderzijde van de arbeidsmarkt. Afhankelijk van de effectiviteit van het onderwijsbestel als 'verheffingsmachine' kan dat tot tekorten aan de bovenzijde en overschotten aan de onderzijde leiden, met opwaartse inkomenseffecten aan de bovenkant en neerwaartse aan de onderkant tot gevolg. De vraag is of zo'n scenario reëel is, en zo ja, wat er aan te doen valt.

De tweede tegenstelling is die tussen jong en oud. In hoofdstuk 6 is geconstateerd dat de Nederlandse verzorgingsstaat van oudsher relatief karig is voor kinderen en gezinnen, en relatief genereus voor ouderen en gepensioneerden. Dit intergenerationele contract kan redelijk stabiel blijven zolang de kosten ervan omgeslagen kunnen worden over een voldoende aantal jongeren, en zolang die jongeren er zich verzekerd van weten dat zij later ook zo bejegend zullen worden. Vergrijzing en ontgroening zetten dat contract echter onder druk. Een steeds geringer aantal jongeren zal in de toekomst moeten voorzien in de stijgende verzorgingskosten van ouderen - die bovendien naar verwachting nog een paar jaar ouder gaan worden. Bovendien vrezen jongere generaties dat de overheid het vergrijzingsvraagstuk zal aanpakken door onder meer de toegang tot voorzieningen, alsmede hun generositeit, te gaan beperken voor komende generaties. Ook hier is de vraag of dit een realistische verwachting is - zijn er al tekenen van intergenerationele conflicten waar te nemen? - en zo ja, wat valt er aan te doen? 
Ten derde is een urgent verbindingsprobleem de tegenstelling tussen autochtonen en niet-westerse migranten, en dan met name migranten uit islamitische landen. Veel Nederlanders geven momenteel in onderzoek aan bang te zijn voor moslims. Ze zien migranten als less deserving als het gaat om de verzorgingsstaat en hebben vaak het gevoel dat ze niet willen integreren. Bovendien voelen sommige groepen allochtonen zich ook steeds meer vervreemd van autochtonen (GPD/Motivaction 2006; SCP 2005a, p. 53 e.v.). Nationale overheden beschikken over relatief weinig beleidsinstrumenten om interetnische verbindingen te stimuleren. In belangrijke mate is dat een historische erfenis die te maken heeft met de eigenaardigheden van de migratiestroom in kwestie. De arbeidsmigranten van de jaren zestig en zeventig waren in eerste instantie als tijdelijke 'gasten' bedoeld. Het duurde tot het begin van de jaren tachtig voordat het besef doordrong dat deze migranten niet meer zouden vertrekken, maar eerder sterk in aantal zouden groeien. Sindsdien is er een zoektocht gaande naar instrumenten die kunnen worden ingezet om de omvang van de migrantenstroom af te zwakken; een zoektocht die soms sterk ideologische boventonen kreeg, waarbij eenzijdig van allochtonen gevraagd wordt zich te verbinden, en oplossingen niet altijd even goed doordacht zijn. Met enige urgentie wordt daarom ingegaan op de vraag wat de meest effectieve instrumenten zijn om de verbindingsfunctie van de verzorgingsstaat beter vorm te geven.

Vanwege bovengenoemde tegenstellingen staat de verbindingsfunctie van de verzorgingsstaat opnieuw in de belangstelling. In het licht van de toenemende functionele afhankelijkheden tussen mensen - kenmerkend voor het samenspel van ontwikkelingen dat sociologen aanduiden met 'modernisering' - zijn zowel 'verbindingstekorten' als 'verbindingsoverschotten' onwenselijk. Onder het eerste wordt verstaan een gebrek aan overstijgende groepsrelaties (bridging) en onder het tweede een te sterke groepsidentificatie die de groep voor buitenstaanders niet meer toegankelijk maakt (bonding). Het gaat dus in het vervolg niet om het stimuleren van hechte gemeenschappen tout court, maar eerder om het creëren van communities lite, bestaande uit een subtiele mix van 'sterke' en 'zwakke' banden, in de termen van dit hoofdstuk, van groepsidentificatie en groepsdoorlaatbaarheid. Dit betekent dat er feitelijk twee deelopdrachten zijn. Enerzijds gaat het om het 'verlichten' van zware gemeenschappen en anderzijds om het 'verdichten' van lichte gemeenschappen (Duyvendak en Hurenkamp 2004).

De opzet van dit hoofdstuk is als volgt. In paragraaf 2 wordt nader ingegaan op de aard van de verbindingsfunctie om er criteria uit te destilleren die kunnen helpen bij het identificeren van verbindingstekorten en -overschotten. In de paragrafen 3, 4 en 5 worden vervolgens de hiervoor geïdentificeerde potentiële breuklijnen langsgelopen in een poging om hun ernst en omvang vast te stellen, en om na te gaan welke beleidsopties er zijn om verdere verwijdering tegen te gaan en eventueel ontstane breuklijnen te helen. Het hoofdstuk wordt afgesloten met een conclusie (paragraaf 6). 


\subsection{DE VERBINDINGSFUNCTIE NADER BEPROEFD}

\section{Individu, modernisering en verbinding}

Individuele autonomie, ofwel de gedachte dat het individu in beginsel meester is in de zaken die hem aangaan, is zowel doel als reden van de 'bevrijding' van het individu uit ongekozen verbanden. Dit proces wordt aangeduid met de term 'modernisering'. Maar het gaat bij modernisering niet om een soort radicale autarkie. Tegen de achtergrond van de complexe arbeidsdeling die moderne samenlevingen kenmerkt, kan individuele autonomie alleen maar worden begrepen als 'autonomie in gebondenheid'. De Franse socioloog Emile Dürkheim (1893) formuleerde het als volgt: "We werken samen op grond van vrijwilligheid, maar onze vrijwillige samenwerking schept wederzijdse verplichtingen die we niet hebben gewild."

Individuen zijn dus op velerlei wijzen van bekende en onbekende anderen afhankelijk; afhankelijkheden die als gevolg van de groei van het grensoverschrijdende verkeer alleen maar zijn toegenomen, en in de toekomst verder zullen toenemen. In het verleden hebben banden met 'nabijen' altijd zwaarder gewogen dan banden met 'vreemden', maar wat voor nabij werd gehouden, is in de loop der tijden overigens wel verschoven. De clan, de stam en de familie als organisatie-eenheden hebben we in de loop van de geschiedenis ingeruild voor het gezin, de onderneming, de vrijwillige associatie en, last but not least, de staat. Hedendaagse Nederlanders zijn op deze manier onderdeel van een veelheid van overlappende verbanden, die niet alle in dezelfde mate emotioneel-affectief zijn en die ook niet alle in dezelfde mate functioneel zijn voor het eigen levensproject en dat van de eigen dierbaren. In de huidige Nederlandse context doet zich de situatie voor dat de verbanden die functioneel gezien het meest noodzakelijk zijn voor het individuele levensproject omdat ze toegang geven tot cruciale hulpbronnen - scholing, zekerheid, verzorging - tegelijk de verbanden zijn die het minst 'warm' lijken te zijn; denk aan de geformaliseerde instituties die onder onze brede definitie van de verzorgingsstaat vallen. Toch zijn ook deze verbanden belangrijk voor identificatie en affectie, zeker in tijden van maatschappelijke onrust en beroering. De vraag is dan ook in hoeverre in Nederland sprake is van verbindingstekorten of -overschotten, en daaraan voorafgaand op welke wijze verbinding vorm krijgt.

\section{Doordringbaarheid van groepsgrenzen}

Van belang is allereerst om modernisering niet exclusief individueel te duiden, en verbinding ook niet exclusief als groepsgericht. Verbinding staat ten dienste van individuele ontplooiing en zelfverwerkelijking (de realisatie van individuele concepties van het goede leven), maar heeft juist daarom baat bij sociale relaties die dat mogelijk maken. Het is niet productief om individu en groep met elkaar te contrasteren en de eerste te associëren met moderniteit en de tweede met premoderniteit, zoals soms gebeurt (bijv. Sandel 1982). Modernisering betekent zeker niet dat groepsverbanden er niet meer toe doen. Het cruciale verschil tussen premoderne en moderne groepen ligt veeleer besloten in de mate van doordringbaarheid van de groepsgrenzen. Waren groepen in een premoderne tijd exclusief 
van aard en ontoegankelijk voor buitenstaanders, moderne groepen zijn inclusief. Ze danken hun legitimiteit juist aan de mate waarin ze toegankelijk zijn voor derden. Gebrek aan identificatie - een verbindingstekort - ontstaat wanneer men het gevoel heeft niet te kunnen doordringen tot een andere groep (Verkuyten 2005; 2006). Dit betekent bijvoorbeeld dat een werkloze die het gevoel heeft overbodig te zijn en nooit meer werk zal vinden zich niet verbonden voelt met werkenden.

\section{Legitimiteit van verschillen}

Ten tweede is van belang de mate waarin individuen onderlinge verschillen als legitiem beschouwen. Aansluitend bij de notie van kansengelijkheid, als meest adequate vertaling van het moderne principe van individuele gelijkwaardigheid onder condities van wederzijdse afhankelijkheid, is niet 'ongelijkheid' als zodanig het probleem, maar illegitieme ongelijkheid. Uiteraard zijn de criteria om vast te stellen wat illegitieme ongelijkheden zijn tijd- en plaatsgebonden. Als vuistregel kan gelden: zolang de 'verliezers' de 'winnaars' hun winst niet misgunnen, is er sprake van legitieme ongelijkheden, en is er geen verbindingsprobleem. Dat lijkt in het huidige Nederland te gelden voor inkomensongelijkheden die herleid kunnen worden tot opleidingsverschillen. Het geldt echter niet voor inkomensongelijkheden die het gevolg zijn van discriminatie op basis van groepskenmerken, zoals sekse, leeftijd of etniciteit (Verkuyten 2005; 2006).

In dit hoofdstuk worden deze twee dimensies van verbinden - de doordringbaarheid van groepsgrenzen, en de legitimiteit van groepsongelijkheden - gebruikt om de ernst en omvang van de verbindingstekorten vast te stellen die rond de scheidslijnen tussen rijk en arm, jong en oud, en allochtoon en autochtoon zouden kunnen ontstaan. Uit het gebruik van deze verbindingsdimensies volgt ook welke instrumenten zouden kunnen worden ingezet om eventuele verbindingstekorten te bestrijden. Immers, waar verbindingstekorten het effect zijn van te sterk uitsluitende groepsgrenzen is er sprake van een te geringe sociale mobiliteit. In dat geval is een verbindingstekort tegelijkertijd een verheffingstekort. Voor een aantal verbindingsproblemen geldt dus dat de oplossing ervan gelegen is in het omvormen van het Nederlandse onderwijsbestel in een effectievere 'verheffingsmachine' langs lijnen die in het vorige hoofdstuk zijn uiteengezet. Omdat verheffen voor een deel van de dreigende verbindingstekorten de meest voor de hand liggende oplossing is, zij in dat geval verwezen naar hoofdstuk 7.

Dat geldt deels ook voor verbindingstekorten die kunnen worden herleid tot de (il)legitimiteit van groepsongelijkheden. Zoals het hiervoor gegeven voorbeeld van arbeidsdiscriminatie al duidelijk maakt, staat of valt verbinding met een allocatie van arbeidskansen op basis van functionele criteria. Bevoordeling of benadeling op basis van voor de functie irrelevante kenmerken - zoals sekse, huidskleur, seksuele voorkeur of geloof - passen daar niet in. Ook ten aanzien van deze verbindingstekorten geldt dat waar ze samenvallen met verheffingstekorten zij terugverwijzen naar hoofdstuk 7 . 
Wat hierbij echter wel moet worden bedacht, is dat individuen en groepen van opvatting kunnen verschillen over welke ongelijkheden legitiem zijn, en welke niet. Zo is een sterk gesegregeerde samenleving denkbaar waarin verschillende groepen er eigen morele opvattingen op na houden over wat al dan niet legitieme ongelijkheden zijn. Zolang er sprake is van een sterke mate van groepsautarkie hoeft dat niet tot al te grote conflicten te leiden. In zekere zin voldeed het traditionele Nederlandse zuilenstelsel aan dit beeld (Lijphart 1968). Maar dat is anders geworden in de hedendaagse Nederlandse samenleving; een samenleving van grote en groeiende individuele en collectieve functionele afhankelijkheden. Onder dergelijke omstandigheden is een zekere overeenstemming over verdelingscriteria noodzakelijk om verdelingsconflicten te voorkomen en afwendgedrag onder 'verliezers' of 'winnaars' tegen te gaan.

\section{Ontmoeting, contact en wederzijdse identificatie}

Culturele verheffingsinstrumenten zijn vaak controversieel. Daarom is het raadzaam om het proces van voorleven en corrigeren over te laten aan het maatschappelijke verkeer tussen burgers. Dat vereist wel dat burgers elkaar inderdaad ook ontmoeten. De overheid kan sociale overeenstemming het best vergroten door onderlinge contacten tussen de leden van verschillende maatschappelijke groepen te stimuleren. Daarmee kan een proces van wederzijdse identificatie in gang worden gezet en wordt uitwisseling (en daarmee transformatie) van inzichten en perspectieven mogelijk gemaakt (zie ook RMO 2005a; 2005b). Het gaat daarbij deels om de verheffende overdracht van de conventies en gedragsregels van de middenklasse aan lagere klassen en aan nieuwkomers, maar ook om de continue wederzijdse toetsing van onderliggende waarden en normen. Verbinden is immers, anders dan verheffen, een tweezijdig proces. Ook leden uit meerderheidsgroepen dienen zich in te leven en rekening te houden met anderen en waar nodig aan te passen. Contact zorgt ervoor dat men een genuanceerder beeld krijgt van de ander; het voorkomt stereotypering. Fysieke nabijheid maakt het overnemen van gedragsregels door voorbeeldwerking mogelijk, en vergroot daarmee de stijgingskansen van nieuwkomers. Maar het kan tegelijk ook de kennis van en het begrip voor andere praktijken, rituelen en gewoontes vergroten en daarmee bijdragen aan een groter wederzijds begrip. De achterliggende gedachte is dat identificatie ontstaat door gezamenlijk handelen en door fysieke nabijheid.

Om deze positieve effecten te kunnen genereren moeten de contacten aan drie voorwaarden voldoen, zo leert sociologisch onderzoek (Pettigrew 1998; Estlund 2003). Ten eerste moet er sprake zijn van een relatief gelijke status binnen de situatie in kwestie. Ten tweede moet er een gedeeld doel zijn. Ten derde moet er een functionele noodzaak tot samenwerken zijn. Aan deze voorwaarden voldoet slechts een beperkt aantal 'ontmoetingsplaatsen' in de Nederlandse samenleving. Vrijwilligerswerk speelt van oudsher hier een rol, en ook de rol van sportverenigingen wordt in dit opzicht in toenemende mate (h)erkend. De meest substantiële zijn echter de school, de werkplek en, wellicht, lagere territoriale schaalniveaus als de stad, de wijk of de buurt. In het vervolg van dit hoofdstuk wordt daarom nagegaan hoe het is gesteld met deze ontmoetingsplaatsen, hoe contact 
tussen verschillende sociale groepen op deze plaatsen kan worden vergroot, en wat daarvan wel en niet verwacht mag worden.

\subsection{RIJK EN ARM IN NEDERLAND}

Zoals empirisch onderzoek leert, laten de eerste drie naoorlogse decennia in vrijwel alle West-Europese economieën een daling van de inkomens- en vermogensverschillen zien (Pikketty en Saez 2006). De dominante verklaring daarvoor zijn de sterk progressieve belastingstelsels, met marginale belastingtarieven van zestig procent of meer, die in de eerste naoorlogse decennia werden geïntroduceerd, en die de kosten voor het opbouwen en onderhouden van grote vermogens sterk hebben verhoogd (Piketty 2005). Ook de deconcentratie van kapitaalbezit en daarmee van de inkomsten uit kapitaal in de naoorlogse jaren als gevolg van de opkomst van institutionele beleggers, hogere successierechten en de afnemende rol van familiebezit in de meeste economieën hebben daaraan bijgedragen (Afman 2005).

Een soortgelijk patroon laat de ontwikkeling van de inkomensverdeling in Nederland zien. Ook hier zien we een substantiële daling van de inkomens- en vermogensverschillen gedurende de eerste drie naoorlogse decennia. Anders dan in landen als de Verenigde Staten en het Verenigd Koninkrijk, waar zich sindsdien een duidelijke trendbreuk heeft voorgedaan (Atkinson en Salverda 2005; Duménil en Lévy 2004), is in Nederland de stijging van de inkomens- en vermogensverschillen beperkt gebleven. Dat heeft in de eerste plaats te maken met een minder vergaande hervorming van de inkomensgaranderende dimensies van de Nederlandse verzorgingsstaat. In de tweede plaats is deelname aan het tertiaire onderwijs (licht) toegenomen waardoor de prijsopdrijvende effecten van een grotere vraag naar hooggeschoolde arbeid als gevolg van technologiegedreven structuurveranderingen in de Nederlandse economie zijn gedempt (Afman 2005; Atkinson en Salverda 2005; SCP 2003).

Recent lijken echter ook in Nederland de inkomens- en vermogensverschillen toe te nemen, als gevolg van minder genereuze voorzieningen voor niet-werkenden, een groeiende vraag naar hoogopgeleiden, een afnemende vraag naar laaggeschoolden, en internationale belastingconcurrentie op het vlak van kapitaalinkomsten en winsten uit onderneming. Terwijl de primaire inkomensongelijkheid, uitgedrukt in termen van Gini-coëfficiënten, gedurende de eerste drie jaren van deze eeuw steeg van 0,495 in 2000 naar 0,504 in 2003, daalde de ongelijkheid tussen de besteedbare inkomens van 0,330 in 2000 tot 0,327 in 2003 (Irrgang en Hoeberichts 2006).

\section{Verbinding en de onderkant van de arbeidsmarkt}

De toenemende internationalisering en het kennisintensiever worden van de Nederlandse economie suggereren dat de sociale afstand tussen hoog- en laagopgeleiden, en daarmee tussen rijk en arm, in Nederland in de toekomst zou kunnen gaan groeien. Dat roept de vraag op hoe robuust de inkomensgarande- 
rende arrangementen van de Nederlandse verzorgingsstaat zijn, en of er op de scheidslijn tussen rijk en arm in de toekomst wellicht toch maatschappelijke breuken zijn te verwachten. Arbeidsdeelname wordt steeds meer als een cruciaal onderdeel van het goede leven gezien, en ook de eisen die aan een baan worden gesteld worden steeds hoger. Tegelijkertijd doemt in de nabije toekomst voor met name de lager opgeleiden het schrikbeeld op van overbodigheid (Sennett 2006). Voortgezette deïndustrialisatie en de introductie van nieuwe technologieën vragen van werknemers in toenemende mate om de beheersing van complexe en actuele kennis en vaardigheden. Als gevolg daarvan bestaat er een groeiende vraag naar hoger opgeleiden die ten koste gaat van lager opgeleiden en minder getalenteerden. Tegenover een te verwachten neerwaartse druk op de salarissen van laaggeschoolde werknemers staat een opwaarts effect op de salarissen van hooggeschoolden. Als dit een reële ontwikkeling is, zou ze aanleiding kunnen geven tot een toenemende disidentificatie tussen lager en hoger geschoolden. Zijn er al indicaties zijn van een dergelijke disidentificatie tussen hoog- en laagopgeleiden?

Vooralsnog is er van dit doemscenario geen sprake. Sinds 1975 is er geen structurele neergang in de relatieve arbeidsmarktpositie van laagopgeleiden waar te nemen (De Beer 2001). Evenmin is er sprake van een structurele toename van de langdurige werkloosheid onder laagopgeleiden (Marx 2004). De omvang van de echte onderkant van de arbeidsmarkt is juist opvallend constant: al decennia bevindt die zich rond de zeven procent. Het zijn vooral de banen daar net boven die verdwijnen. Lagere technische, bouwkundige en administratieve functies blijken het meest gevoelig voor technologische en organisatorische veranderingen. Sinds 1985 is er dan ook tien procent minder emplooi in dit segment van de arbeidsmarkt.

Daarnaast is er ook goed nieuws. Werkgelegenheidsgroei blijkt zich namelijk niet alleen aan de bovenkant van de arbeidsmarkt voor te doen, maar ook aan de onderkant. Dat is het gevolg van de voortschrijdende tertiarisering van de Nederlandse economie, die zelf in belangrijke mate het gevolg is van de outsourcing-strategieën van ondernemingen en huishoudens. Met name in het segment van de persoonlijke dienstverlening kan een groeiende werkgelegenheid worden verwacht. De vergrijzing en ontgroening van de Nederlandse bevolking, en de toenemende arbeidsdeelname van vrouwen zullen dit proces nog versterken. Hierbij dient men zich te realiseren dat dit geen ongeschoolde banen in de ware zins des woord zijn, omdat in veel van dit soort werk goede communicatieve en probleemoplossende vaardigheden worden vereist (SCP 2005c).

De vraag is dan of de groep mensen die niet of nauwelijks verhefbaar is aan de eisen zal kunnen voldoen die de diensteneconomie van morgen stelt. Volgens recent onderzoek is er nu al sprake van een groeiende mismatch aan de onderkant van de arbeidsmarkt tussen gevraagde en aangeboden vaardigheden (Gesthuizen 2004). De laagopgeleiden van vandaag beschikken weliswaar over praktische vaardigheden, maar missen de sociale competenties die in een dienstenecono- 
mie steeds belangrijker worden. Bovendien zijn diploma's uitgegroeid tot het toegangsbewijs voor de arbeidsmarkt, terwijl zeker aan de onderkant van de arbeidsmarkt de mogelijkheden om al doende te leren, en dus sociaal te stijgen, zijn afgenomen. Laagopgeleide mannen tussen de 25 en 34 jaar hebben daardoor meer kans op werkloosheid en minder kans op sociale stijging dan hoger opgeleide mannen en vrouwen.

\section{Verbinding en de bovenkant van de arbeidsmarkt}

Daarnaast rijst de vraag wat de verbindingseffecten zijn van schaarste aan de bovenkant van de arbeidsmarkt. De economische theorie voorspelt als gevolg daarvan een groeiende inkomensongelijkheid. Door marktintegratie en het reputatiemechanisme is bovendien een enkele niche van de arbeid getransformeerd in een zogenaamde winner-takes-all- markt (Frank en Cooke 1996). Voorbeelden zijn de markten voor topsporters, filmacteurs, televisiepersoonlijkheden, waar soms ook topmanagers en topbestuurders zich aan spiegelen. Voortschrijdende economische internationalisering zou kunnen leiden tot het ontstaan van een hoogopgeleide, kosmopolitische, mobiele kaste van urban professionals die zich minder gebonden weet door nationale banden van solidariteit. Gedurende de jaren negentig groeide het aantal ondernemingen sterk dat zeer hoge salarissen uitkeerde aan de eigen bestuursleden en de hiërarchische lagen daar net onder (Wilterdink 2002). Met name in de Verenigde Staten en het Verenigd Koninkrijk is als gevolg van deze ontwikkelingen sinds de jaren zeventig sprake van sterk gestegen inkomensongelijkheden (Atkinson en Salverda 2005; Duménil en Lévy 2004).

Hoewel de omvang van dit probleem in Nederland vooralsnog beperkt is, valt in het debat erover een opvallende tweedeling te ontwaren tussen veel beleidsmakers en politici enerzijds, en een meerderheid van het electoraat anderzijds. Terwijl de eerste de legitimiteit van inkomensverschillen ruwweg lijken te accepteren - het heeft immers ook een motiverend effect - lijkt dit voor de Nederlandse bevolking in afnemende mate te gelden. Volgens het SCP vond in 1980 nog 75 procent van de Nederlanders dat de inkomensverschillen kleiner moesten zijn, daalde dat naar 56 procent in 1991, om sindsdien weer te stijgen naar 70 procent in 2000 (SCP 2005b, p. 76-83). Vooral laagopgeleiden vinden de verschillen te groot; hoger opgeleiden vinden dat veel minder. Kennelijk wordt de steun voor egalisering van inkomensverschillen sterk beïnvloed door de mate waarin men zichzelf kansen toedicht om tot de hogere verdiepingen van het salarisgebouw door te dringen. Mocht als gevolg van economische structuurveranderingen de wederzijdse doordringbaarheid van de groep van 'verliezers' en 'winnaars' op de arbeidsmarkt afnemen, en bovendien de al aanwezige onenigheid over de legitimiteit van de verdelingscriteria verder groeien, dan dreigt hier, ondanks de prestaties van de Nederlandse verzorgingsstaat op het gebied van het verbinden van arm en rijk, niettemin opnieuw een verbindingstekort. Hoe dat te voorkomen? 


\subsubsection{WAT TE DOEN?}

\section{Arbeidsmarkt}

Allereerst is van belang om de omvang van de groep van 'onverhefbaren' zo gering mogelijk te maken. Succesvolle verheffing vermindert de ernst en omvang van de verbindingsopdracht. Maar zelfs als het onderwijsbestel zou functioneren als een 'geoliede verheffingsmachine', zou er een restgroep blijven. Een menswaardige plaatsmaken voor deze groep mensen vraagt aanpassingen op de arbeidsmarkt. Dat vereist van betrokken partijen - overheid, werkgevers en werknemers - een heroriëntatie op de voornaamste criteria die worden gehanteerd om bestaande arbeidsmarktinstituties de maat te nemen en nieuwe te ontwerpen. Stijgende kwalificatie-eisen en maximalisatie van het rendement op investeringen in menselijk kapitaal kunnen een te hardvochtige arbeidsmarkt tot gevolg hebben. Om die reden is het zinvol om arbeidsmarktinstituties, zoals gesubsidieerde arbeid, ook te beoordelen op basis van het criterium van 'zachtmoedigheid', zoals dat in de slotparagraaf van hoofdstuk 7 beschreven is.

Hoewel er in Nederland al geruime tijd ervaring bestaat met verschillende vormen van gesubsidieerde arbeid, is het van belang om deze interventies niet langer primair in de sleutel van in- en doorstroom te zetten. Ten eerste omdat wat reguliere arbeid kan zijn ook reguliere arbeid moet zijn. En ten tweede omdat daarmee te vaak valse verwachtingen worden gewekt, met mogelijk demotiverende effecten. De meeste instromers zijn nooit doorgestroomd en hebben als gevolg daarvan ook nooit de kans gehad om hun gesubsidieerde functies naar waarde te schatten. Het element van zachtmoedigheid waarvan gesubsidieerde arbeid een uitdrukking is, impliceert een ander type beoordeling dan de rendements- en productiviteitslogica die op de reguliere arbeidsmarkt prevaleert, en dient ook als zodanig te worden begrepen en gepresenteerd. Om te voorkomen dat sommige groepen laagopgeleiden zich overbodig voelen, zal aan de onderkant van de arbeidsmarkt permanente overheidsaandacht nodig zijn. Arbeid is immers in toenemende mate het belangrijkste integratiekader in Nederland. De vorm waarin dat gebeurt, moet mee kunnen bewegen met conjuncturele ontwikkelingen, maar wel uitdrukking geven aan de 'zachtmoedigheid' van de meritocratie.

Ook aan de bovenkant van de arbeidsmarkt dreigt een verbindingstekort als door schaarste aan hooggekwalificeerde werknemers de prijs van dit type arbeid sneller stijgt dan die van andere typen arbeid. Effectieve verheffing is waarschijnlijk het meest probate middel om dit verbindingstekort te verminderen. Dat wil immers zeggen dat alles in het werk wordt gesteld om talent maximaal te ontwikkelen en uitval zoveel mogelijk wordt tegengegaan. Hoe meer jongeren instromen in het tertiair onderwijs, hoe groter het aanbod van hoogopgeleide werknemers, hoe geringer de opwaartse druk op de beloning voor hooggeschoolde arbeid die wordt veroorzaakt door economische structuurveranderingen. Zo bezien schuilt er een spanning tussen de toegenomen rendementspressie waar het (hoger) onderwijs mee te maken heeft en de verhoogde toegangsselectiviteit waarin dat zou kunnen resulteren enerzijds, en anderzijds de verbindingsop- 
dracht die juist een relatief genereuze toegang tot en meer geduld van onderwijsinstellingen lijkt te vragen.

\section{Inkomensbeleid}

Daarnaast speelt het 'probleem' van de topinkomens in Nederland. Hoewel het soms heftige emoties oproept, is de schaal van dit probleem relatief beperkt. De salarissen van bestuursleden van beursgenoteerde ondernemingen bijvoorbeeld liggen nog altijd lager dan in Angelsaksische landen gebruikelijk is. Mede met dit argument heeft de overheid zich tot op heden terughoudend opgesteld ten aanzien van wettelijke ingrepen in de vorming van topinkomens. In de private sector is loonvorming immers primair een zaak van de marktpartijen. Opmerkelijk is wel dat de Nederlandse 'grootverdiener' veel minder dan aan het einde van de negentiende eeuw, en veel minder dan de grootverdienende Amerikaan, een verantwoordelijkheid ervaart voor prangende sociale kwesties. Ook hier werkt blijkbaar het bestaan van de verzorgingsstaat door. Een overheidsverantwoordelijkheid of -betrokkenheid voor de loonvorming ligt natuurlijk anders binnen de publieke en semi-publieke sector. Hier past een meer offensieve benadering.

\subsection{OUD EN JONG IN NEDERLAND}

\section{Demografische stress}

Intergenerationele verdelingskwesties komen vaak op scherp te staan in tijden van economische en demografische stress. Zolang ieder nieuwe cohort ongeveer net zo groot is als het vorige hoeft de leeftijdsgerelateerde aanwas van sociale rechten niet tot conflicten te leiden. Dat geldt ook voor een verzorgingsstaat als de Nederlandse waarin status- en positiebehoud na verlies van de mogelijkheden tot inkomensverwerving centraal staan. Dit kan veranderen wanneer de bevolkingsomvang stabiel is of krimpt. Op dat moment komt de logica van het stelsel in zijn tegendeel te verkeren. Krimpende cohorten van werkenden moeten dan in toenemende mate bijdragen aan de verzorgings- en onderhoudskosten van grotere cohorten niet-werkenden. Zeker wanneer dat ten koste gaat van investeringen in de eigen levenssituatie of die van het eigen nageslacht, of wanneer als gevolg van 'demografische stress' niet langer kan worden gegarandeerd dat toekomstige ouderen over dezelfde sociale rechten kunnen beschikken als de huidige ouderen, kunnen intergenerationele spanningen ontstaan.

In de huidige decennia treden er belangrijke verschuivingen op in de getalsmatige verhoudingen tussen de generaties. Dat leidt tot een debat over hoe de financiële consequenties van vergrijzing het beste kunnen worden opgevangen in een samenleving die tegelijk ontgroent. De verdeling van de kosten van vergrijzing in een ontgroenende wereld is potentieel conflictueus. Hoewel hier in principe geen doordringbaarheidsprobleem speelt - iedereen is per slot van rekening ooit jong geweest en zal meestal ook oud worden - hebben inmiddels veel mensen de verwachting gekregen dat de kwaliteit van de sociale rechten die de Nederlandse verzorgingsstaat op basis van leeftijd distribueert op den duur zal verschralen. Met name onder jongere generaties leeft de vrees dat men nu moet betalen voor 
voorzieningen waarop men zelf nooit aanspraak zal kunnen maken. Hierdoor rijst de vraag wat de legitimiteit is van de bestaande leeftijdsafhankelijke regelingen.

Onderzoek leert dat jongeren in toenemende mate vraagtekens plaatsen achter de statusverschillen die de Nederlandse verzorgingsstaat (re)produceert (Van Dalen en Henkens 2004; Bureau Veldkamp 2004). Wat daarbij opvalt, is dat 65-plussers en jongeren tot 35 jaar het vaak met elkaar eens zijn als het gaat om kwesties als langer doorwerken, verhoging van de pensioengerechtigde leeftijd, fiscalisering van de AOw, of een sollicitatieplicht voor ouderen (www.21minuten.nl). Het is de leeftijdscategorie daartussen die daar anders over denkt. Op de keper beschouwd tekent zich in Nederland dus niet zozeer een conflict af tussen 'jong' en 'oud', maar eerder een conflict tussen twee specifieke generaties, namelijk tussen de zogenaamde 'prestatiegeneratie' en de 'protestgeneratie'.

\section{Generatieconflict?}

De protestgeneratie is geboren tussen 1945 en 1955, en is nu tussen de vijftig en zestig jaar oud. Deze generatie groeide op onder condities van een snel stijgende welvaart, kende gunstige levenskansen en de leden ervan hechten sterk aan democratisering en een informalisering van sociale relaties (Becker 1997). De prestatiegeneratie zijn de mensen die geboren zijn na 1970 en die nu maximaal 35 jaar zijn. Gedurende de formatieve periode van deze generatie, grotendeels samenvallend met de jaren negentig, trok de arbeidsmarkt aan, stond de verzorgingsstaatdiscussie in het teken van bedrijfsmatiger werken en werd het klassieke liberale idee dominant dat iedereen zijn eigen kansen kan creëren en dat 'winst' of 'verlies' tijdens het leven dus primair te danken of te wijten zijn aan individuele verdienste en inzet, of het gebrek daaraan.

Vanuit het perspectief van de prestatiegeneratie bezien, is de verzorgingsstaat gaan samenvallen met die onderdelen ervan die ten dienste staan van inkomensbehoud van ouderen: de eerste en de tweede pensioenpijler, de gezondheidszorg, ontslagbescherming, hypotheekrenteaftrek en, meer recentelijk, de levensloopregeling. De verdelingen van baten en lasten die deze regelingen genereren, zouden door de jongste generaties steeds meer als illegitiem worden beschouwd. In deze paragraaf wordt onderzocht of er (1) objectieve indicaties zijn van een ongelijke intergenerationele verdeling van toegangs- en doorstroomkansen op de arbeidsmarkt, en (2) sprake is van een ongelijke inkomens- en vermogensverdeling die aanleiding zouden kunnen geven tot intergenerationale conflicten over de principes achter de verdeling van kosten en baten over generaties. En zo ja, wat zou daaraan gedaan kunnen worden?

\subsubsection{OUD EN JONG OP DE ARBEIDSMARKT}

Opmerkelijk aan de Nederlandse arbeidsmarkt is lange tijd geweest de relatief lage arbeidsparticipatie van zowel jongeren als ouderen. Beide groepen kennen een tamelijk hoge werkloosheid; bij jongeren is dat met name conjunctureel 
bepaald, terwijl de werkloosheid van ouderen meer langdurig van aard is (Bekker et al. 2005; OECD 2006). Dat heeft veel te maken met de geringe geneigdheid van werkgevers om (relatief dure) oudere werknemers aan te nemen of in dienst te houden. De voorkeur gaat als regel uit naar jongeren, ook als de arbeidsmarkt krap is (Bekker et al. 2005). De OECD suggereert dan ook dat de Nederlandse arbeidsmarkt in relatief sterke mate onderscheid maakt naar leeftijd (OECD 2006). Enerzijds is dat een kwestie van perceptie; werkgevers zouden de feitelijke arbeidsproductiviteit van ouderen onderschatten. Anderzijds is dat het gevolg van de structuur van het loongebouw dat via het senioriteitsprincipe leidt tot een 'inkomenssubsidie' van jongere aan oudere werknemers, waardoor oudere werknemers relatief duur zijn voor werkgevers. Zo bezien zijn eventuele klachten van jongere generaties over een ongelijke verdeling van toegangskansen op werk niet aan de orde, en zijn ze vergeleken met ouderen wat dat betreft juist in het voordeel.

\section{Mobiliteitskansen}

De volgende vraag is hoe dat met de mobiliteitskansen zit. Analoog aan de uiteenzettingen over de arbeidsmarkt in hoofdstuk 7 is het zaak om onderscheid te maken tussen vrijwillige en onvrijwillige mobiliteit en tussen opwaartse, zijwaartse en neerwaartse mobiliteit. De klacht van de zijde van de prestatiegeneratie luidt dat de toegang tot arbeidscontracten van onbepaalde duur en posities met een hoge mate van autonomie in sterke mate is voorbehouden aan ouderen. Jongeren zouden zich daardoor meer dan evenredig gedwongen zien om genoegen te nemen met betrekkingen in het tijdelijke segment van de arbeidsmarkt. Ofwel, waar het hier om gaat is een ongelijke verdeling van onvrijwillige mobiliteit en een onvoldoende toegang tot vormen van vrijwillige mobiliteit.

Uit empirisch onderzoek blijkt dat de kwaliteit van de banen van ouderen over het algemeen genomen inderdaad beter is dan die van jongeren (Bekker et al. 2005). Meer dan jongeren hebben ouderen de mogelijkheid om zelf te bepalen welke werkzaamheden ze verrichten en ze beschikken over meer vrijheden om hun werk naar believen in te delen. Ook klopt het dat ouderen - zeker na hun vijftigste - honkvast zijn. Vergeleken met de Angelsaksische verzorgingsstaten kent Nederland een goede contractbescherming voor werknemers met een vast arbeidscontract (OECD 2004). Toch kan daar niet zonder meer uit geconcludeerd worden dat mobiliteitskansen ongelijk over de generaties zijn verdeeld. Berekeningen op basis van CBS-gegevens laten zien dat in 200591 procent van de 25 tot 34 -jarigen een vaste baan had. Van de 55 tot 64 -jarigen was dat 95 procent. Dat zijn kleine verschillen, die bovendien relatief ongevoelig zijn voor conjuncturele ontwikkelingen. Kortom: ouderen en jongeren nemen wel een iets andere positie op de arbeidsmarkt in, maar vertonen grosso modo meer overeenkomsten dan verschillen. In plaats van een intergenerationeel verbindingstekort zou wat betreft de arbeidsmarktpositie dus eerder een nieuw intergenerationeel verbond verwacht kunnen worden. 
Een tweede klacht die wel wordt vernomen, is dat ouderen niet bereid zouden zijn om hun verworvenheden op het gebied van vroege pensionering op te geven om op die manier een deel van de vergrijzingskosten op zich te nemen (Vos 2005). Lange tijd was deze klacht gegrond. Daaraan is echter recent een einde gekomen. Sinds de jaren negentig is de arbeidsdeelname van ouderen door de aantrekkende conjunctuur spontaan al sterk toegenomen, mede als gevolg van de sterk verhoogde arbeidsmarktparticipatie van oudere vrouwen (SCP 2006; 54 e.v.). Hoewel vooral jongeren en 65 -plussers vinden dat ouderen langer moeten blijven doorwerken, beginnen ook werkende ouderen zelf meer heil te zien in langer doorwerken, waarbij ze wel aangeven een voorkeur te hebben voor werken in deeltijdverband en dus voor deeltijdpensionering (www.21minuten.nl).

Kortom, voor dreigende intergenerationele conflicten tussen jong en oud op de arbeidsmarkt bestaat weinig aanleiding. Sterker nog, door technologiegedreven economische structuurveranderingen kan een sterke verbetering worden verwacht van de positie van nieuwe generaties, die niet alleen kleiner in aantal, maar ook beter opgeleid zullen zijn dan vorige generaties. Uiteraard is dat laatste niet een natuurlijk gegeven, maar een variabele die mede wordt bepaald door de mate waarin het Nederlandse onderwijsbestel als een effectieve 'verheffingsmachine' weet te functioneren. Wél schiet de Nederlandse arbeidsmarkt tekort als het gaat om het tegengaan van leeftijdsdiscriminatie van ouderen.

\subsubsection{INKOMEN EN VERMOGEN VAN OUD EN JONG}

In welke mate kan ook de verdeling van inkomens en vermogens tussen de generaties een potentiële bron van ongelijkheid en conflict zijn? Een derde van de Nederlanders onder de veertig vreest dat de ouderen van nu 'de pot verteren', waardoor er niets over blijft als ze zelf oud zijn en meer dan de helft van de Nederlanders vindt daarnaast dat rijke ouderen best minder AOW zouden mogen krijgen, zo leert een opinieonderzoek (Bureau Veldkamp 2004). Klopt dit beeld?

\section{Inkomen en vermogen protestgeneratie}

Zoals gezegd heeft de protestgeneratie het in Nederland relatief goed. De armoede onder 65-plussers is relatief laag en de pensioenen zijn relatief genereus, zeker vergeleken met eerdere decennia en met andere Europese landen. De goede inkomenspositie van ouderen heeft in de eerste plaats te maken met de toename van de aanvullende pensioenen. Niet alleen is die tweede pijler van het pensioensysteem zeer omvangrijk en kent hij weinig 'witte vlekken' (meer), ook ligt de arbeidsmarktparticipatie hoger dan vroeger (SCP 2006a, p. 86). Als gevolg daarvan heeft het leeuwendeel van de werknemers een aanvullend pensioen boven op de AOW. In 2020, zo laat de nevenstaande figuur (figuur 8.1) zien, zullen de aanvullende pensioenen een groter deel uitmaken van het totale inkomen van gepensioneerden: van 34 procent in 2000 naar 47 procent in 2020. Ook de inkomsten uit de derde pijler, de individuele lijfrenten, zullen stijgen. De grootste toename is herleidbaar tot de sterk gestegen arbeidsparticipatie van vrouwen en het grotere aanvullende pensioen waarin dat resulteert. Overigens zullen de 
verschillen tussen de cohorten na 2020 snel afnemen, omdat het effect van generatiegerelateerde participatieverschillen dan grotendeels uitgewerkt zal zijn (SZW/Thio 2002; Caminada en Goudswaard 2003; SER 2005).

\section{Figuur 8.1 Besteedbaar inkomen (in guldens) naar inkomensbron en huishoudtype}

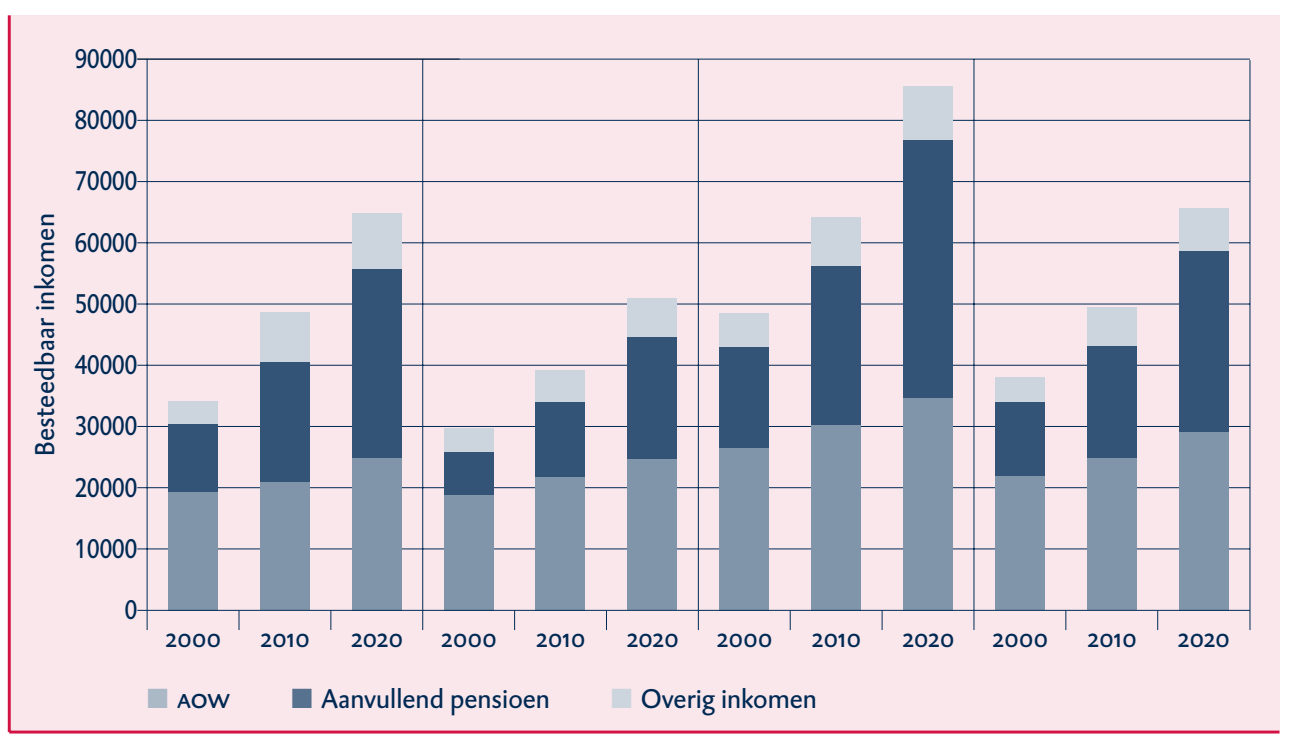

Bron: szw/Thio (2002)

Ook de vermogenspositie van de protestgeneratie is vergelijkenderwijs goed te noemen. Deze wordt in belangrijke mate bepaald door gunstige resultaten op de kapitaalmarkt en vooral de woningmarkt. Gegeven de vrij sterke fluctuaties op deze markten sinds de jaren zeventig kan worden gesproken van 'gelukkige' en 'minder gelukkige' generaties. Wie eind jaren tachtig of begin jaren negentig een woning heeft gekocht, heeft sindsdien kunnen profiteren van een grote waardestijging. Als gevolg van verkeerd gerichte financiële prikkels, zoals beschreven in hoofdstuk 5 , is er in Nederland sprake van een structurele mismatch tussen vraag en aanbod op de woningmarkt, zowel op de huur-als op de koopmarkt. Dit heeft ook sterk ongelijke vermogenseffecten voor verschillende generaties tot gevolg gehad (SEO 2006; REA 2006).

Dit geldt in mindere mate voor beleggingen in aandelen en andere eigendomstitels. Omdat in Nederland vermogen sterk correleert met leeftijd zijn het vooral de oudere generaties die direct (dividenden, koersstijgingen) dan wel indirect (lagere pensioenpremies of zelfs 'premievakanties') van de sterke stijging van de aandelenkoersen gedurende de tweede helft van de jaren negentig hebben kunnen profiteren. Daar staan echter grote verliezen tegenover na het uiteenspatten van de 'ICT-bel' in 2001. Deze lotgevallen weerspiegelen zich in de vermogensposities van verschillende generaties. Het gemiddelde vermogen van Nederlanders tussen de 55 en 64 jaar groeide tussen 1993 en 2000 van 82.00o naar 171.000 euro; een groei van 109 procent. Over dezelfde periode groeide het vermogen van 
Nederlanders onder de 25 jaar van 17.000 naar 19.000 euro; een groei van 12 procent. Het vermogen van Nederlanders tussen de 25 en 34 jaar groeide gedurende deze periode van 28.0oo naar 37.0oo euro, wat neerkomt op een groei van 32 procent (Haffner 2005).

\section{Inkomen en vermogen prestatiegeneratie}

Zo bezien heeft de prestatiegeneratie meer reden tot klagen als het gaat om de intergenerationele verdeling van inkomens en vermogens. Daarbij kunnen echter twee kanttekeningen worden gemaakt. Ten eerste is het van belang om na te gaan wat er met dat vermogen gebeurt. Uiteraard wordt een deel ervan gebruikt als inkomstenbron gedurende het post-arbeidzame leven. Dat geldt in ieder geval voor de spaargelden die in de vorm van pensioenpremies worden beheerd door pensioenfondsen en deels ook voor particuliere aandelenbeleggingen. Een groot deel van deze vermogens wordt echter niet door de spaarders zelf geconsumeerd, maar als erfenis aan volgende generaties overgedragen. Door de ontgroening betekent dit een overdracht van vermogens naar jongere generaties; een overdracht die veel groter en geconcentreerder is dan de overdrachten tussen voorgaande generaties. Afgezien van (gedeeltelijke) ouderlijke bekostiging van de universitaire studie, biedt dit weinig soelaas bij leniging van actuele financieringsnoden van leden van de prestatiegeneratie, bijvoorbeeld als ze een huis willen kopen, omdat het merendeel van deze besparingen pas vrijkomt als de bezitters ervan overlijden en de ontvangers ervan tussen de 40-64 jaar oud zijn (Kohli 1999).

Ten tweede moet niet uit het oog worden verloren dat er grote financiële verschillen binnen generaties (zullen blijven) bestaan. Hoewel op geaggregeerd niveau kan worden gesteld dat de financiële positie van de protestgeneratie rooskleurig is, verhult zo'n uitspraak een grote ongelijkheid binnen die generatie. Sinds 1994 is het percentage ouderen van boven de 75 jaar met een laag inkomen weliswaar gedaald van ruim dertig naar 7 procent in 2003; voor ouderen tussen 55 en 64 jaar geldt juist een gestegen kans op armoede (SCP 2006a, p. 93).

Ondanks de gestegen arbeidsparticipatie en de aanvullende pensioenaanspraken die daarbij horen, moet bedacht worden dat werknemers aan de onderkant van de arbeidsmarkt een veel minder riante inkomensopbouw kennen en om die reden ook veel minder in de vermogensgroei delen. Onderzoek leert dat de meest verdienenden ook over ongeveer vier keer zoveel vermogen kunnen beschikken dan de minst verdienenden. Daarnaast is onder minvermogenden ook in veel geringere mate sprake van familiale overdrachten tussen de generaties (Kohli 1999). Als gevolg daarvan zullen mensen in het laagste inkomensdeciel ook in 2020 in hoge mate afhankelijk zijn van de AOW (szW/Thio 2002).

\subsubsection{WAT TE DOEN?}

\section{Disfunctionerende woningmarkt aanpakken}

De financiële autonomie van de Nederlandse wooncorporaties leidt tot onvoldoende aanbod in het huursegment van de Nederlandse woningmarkt, terwijl de regressieve fiscale stimulering van de koopwoning en de opwaartse prijsdruk 
waarin dat resulteert, ertoe leidt dat dit segment moeilijker toegankelijk is voor nieuwkomers, met weer als gevolg dat het sociale huursegment veel 'scheefwoners' bevat. Waar de gemiddelde starter in 1985 nog met ongeveer 25 procent van zijn maandelijks besteedbare inkomen de woningmarkt kon betreden, moet hij tegenwoordig ruim 40 procent reserveren, ondanks de huidige lage rentestand (Brouns, 2006). Vanuit het perspectief van intergenerationele rechtvaardigheid bezien, verdient het dan ook aanbeveling om te zoeken naar instrumenten die het onderscheid tussen de beide woningmarktsegmenten kunnen slechten, en de toegang tot vermogensopbouw gelijkmatiger kunnen spreiden over generaties, zonder de toegang tot goede, betaalbare huurwoningen te verslechteren (SEO 2006).

\section{Bevorderen dat ouderen langer doorwerken}

De Nederlandse arbeidsmarkt is in termen van toegangs- en doorstroomkansen even vriendelijk (of onvriendelijk) voor jong en oud. Sterker nog, als het gaat om arbeidsmarkttoegang hebben ouderen meer reden tot klagen dan jongeren; klachten die bovendien, in het licht van vergrijzing en ontgroening, ernstiger zouden moeten worden genomen dan momenteel gebeurt. Enerzijds zullen werkgevers moeten leren inzien dat oudere werknemers niet per definitie minder productief zijn dan jongere; een toenemende vergrijzing en ontgroening zullen werkgevers hopelijk een sterkere prikkel geven om dat te leren. Anderzijds is de relatief hoge betaling van ouderen een effect van de vormgeving van het Nederlandse loongebouw en het ontslagrecht. Daarbij wordt pensionering nog te veel als een binaire kwestie gezien. Hier verdient het aanbeveling om te experimenteren met vormen van deeltijdpensionering. Het senioriteitsprincipe in het Nederlandse loongebouw is lastiger aan te pakken. Gezocht moet worden naar fiscale mogelijkheden om de bruto-arbeidskosten van oudere werknemers naar beneden te brengen om werkgevers te stimuleren om hun oudere werknemers in dienst te houden. Verder dienen de netto-opbrengsten van ieder doorgewerkt uur voor gepensioneerden hoog genoeg te zijn om ook hen te prikkelen om zich (deels) beschikbaar te houden voor de arbeidsmarkt.

\section{Vergrijzing en financieringsaspecten van pensioen en AOW}

Oudere werknemers blijken wel degelijk gevoelig voor het argument dat de vergrijzingskosten evenredig over de generaties moeten worden verdeeld. Uiteraard dient bij die verdeling door de wetgever prudentie te worden betracht en moeten argumenten van geleidelijkheid en partialiteit zwaar wegen. Ook om die reden verdient het aanbeveling om de mogelijkheden voor deeltijdpensionering te verruimen. Verder ligt het in de lijn van een verbindingsperspectief om mogelijke veranderingen in de financieringsmodus van de AOW niet als onbespreekbaar af te wijzen. Dat geldt eveneens voor het zwijgen over de omvorming van de tweede pensioenpijler van een eindloon- in een middelloonstelsel die is aangezet door de implosie van de beurskoersen in 2001. In beide gevallen gaat het immers om een herziening van het contract tussen generaties in het licht van gewijzigde financiële omstandigheden, en beiden raakt het verschillende generaties. De verbinding tussen generaties vraagt juist om aandacht voor een inkomenspolitiek waarbij er aandacht is voor inkomensverschillen binnen generaties. 


\subsection{INTERETNISCHE VERBINDINGEN}

De toon van het Nederlandse integratiedebat is de laatste jaren een zekere schrilheid gaan vertonen. Hoewel het duidelijk is dat de Nederlandse instituties een groot deel van de niet-westerse migranten en hun kinderen onvoldoende bij de Nederlandse samenleving weten te betrekken, is het overdreven om te stellen dat de integratie in Nederland is mislukt, zoals sommige opiniemakers menen. Wel zit er onvoldoende schot in de integratie van allochtonen via werk, wonen en onderwijs (SCP/WODC/CBS 2006). Tegen de achtergrond van toenemende internationale spanningen rond het islamitische terrorisme groeit bovendien de vrees voor introspectieve groepsidentificatie. Dit proces speelt zowel aan de zijde van de autochtonen als aan de zijde van islamitische migranten; een proces dat naarmate het verder doorzet ook lastiger te doorbreken zal zijn. Het gaat hier allereerst om een doorlaatbaarheidsprobleem. Over en weer luidt het verwijt dat men ofwel te weinig integratiekansen krijgt, ofwel de integratiekansen te weinig grijpt. Een tweede probleem is hier nauw mee verbonden: er bestaat onenigheid over de legitimiteit van de betreffende groepsverschillen. Volgens sommigen zijn deze verschillen het resultaat van verschillen in verdienste en dus legitiem, terwijl ze volgens anderen gevoed worden door racisme en discriminatie, en dus ongewenst zijn. Een derde probleem is het gebrek aan interetnisch contact: segregatie begint nog voor de basisschool en werkt door in de arbeidsmarkt.

\section{De verbindingsstrategie}

Ten aanzien van het eerste vraagstuk - het doorlaatbaarheidsprobleem - ligt het voor de hand om een verbindingsstrategie te volgen die is gebaseerd op het doorlaatbaar maken van groepsgrenzen via de verheffingsinstrumenten die in hoofdstuk 7 zijn beschreven. Gebrek aan doorlaatbaarheid is immers een gebrek aan sociale mobiliteit, en sociale mobiliteit verloopt ook in een 'zachtmoedige meritocratie' vooral via onderwijs en arbeid. Dat is echter niet voldoende. Verheffing betekent immers ook identificatie met de waarden en normen die in het ontvangende land de verdeling van maatschappelijke hulpbronnen en posities bepalen. Wie bijvoorbeeld het principe van individuele autonomie niet onderschrijft, en bijvoorbeeld kinderen geen ruimte biedt om individuele concepties van het goede leven te realiseren, kan botsen met wettelijke en institutionele arrangementen. Ditzelfde geldt voor de conventies van de middenklasse die men moet leren beheersen om met enig succes zijn weg te vinden op de markt van arbeid, huwelijk en sociale relaties. Oftewel, verbinden vooronderstelt niet alleen effectieve verheffing, maar de causaliteit loopt ook omgekeerd: daadwerkelijke verheffing vooronderstelt een zekere verbinding.

Verbinding is bovendien geen eenzijdig, maar een tweezijdig proces. Dat betekent ook dat niet alleen allochtone, maar ook autochtone burgers een verbindingsopdracht hebben. Sociale afstand ontstaat immers ook wanneer autochtonen weinig kennis en begrip hebben voor de sociale praktijk van allochtonen. Ongenuanceerde, stereotype beelden staan die integratie in de weg. In een cohesieve samenleving leert ook de (blanke) middenklasse om met verschillen om te 
gaan, en zich te verdiepen in de anderen in plaats van andersdenkenden en andersvoelenden uit te sluiten.

In complexe samenlevingen, die worden gekenmerkt door secularisering en individualisering, neemt de functionele afhankelijkheid van derden weliswaar sterk toe, maar krijgt deze afhankelijkheid tegelijkertijd nog maar op weinig plaatsen 'een gezicht'. We kennen de bakker die ons brood bakt en de brouwer die ons bier brouwt niet. Op de keper beschouwt zijn alleen school en werk nog 'locaties' waar we ons in de onmiddellijke nabijheid bevinden van niet-verkozen derden die net zozeer van ons afhankelijk zijn als wij van hen. Bovendien voldoen school en werk aan de drie condities die - volgens de theorie van de contacthypothesenodig zijn voor succesvolle doorbreking van stereotypering: gelijke status, een gedeeld doel, en de noodzaak tot samenwerken. Om deze redenen wordt in deze paragraaf nagegaan in welke mate deze 'locaties' in Nederland als effectieve interetnische ontmoetingsplaatsen fungeren, en hoe hun bijdrage aan het verbinden van diverse etnische groepen kan worden versterkt. Ook wordt nagegaan wat initiatieven op het niveau van buurt of wijk aan interetnische verbinding kunnen bijdragen.

\subsubsection{DE SCHOOL ALS ONTMOETINGSPLAATS}

Gemengde scholen zijn cruciaal voor de overdracht van de normen en houdingen van de middenklasse. De tweede socialisatie die de school jonge mensen biedt, verloopt immers maar ten dele via het officiële curriculum en de rol die de leerkracht bij de overdracht ervan speelt. Minstens zo belangrijk zijn de handelingen en leerhoudingen van medeleerlingen in de lesuren, maar ook daarbuiten. Deze kunnen positieve effecten hebben op de individuele leerprestaties, maar ook negatieve. De materiële en mentale ondersteuning die middenklassenouders hun kinderen bewust en onbewust bieden, predisponeert deze kinderen over het algemeen tot een grotere leerbereidheid, concentratievermogen en discipline, en dus tot betere leerprestaties, dan kinderen afkomstig uit lagere sociale klassen. Scholen met een gemengde populatie en een stevig contingent middenklassenleerlingen kunnen sociaal zwakkere kinderen derhalve een gunstiger leerklimaat bieden dan scholen die uitsluitend bevolkt worden door sociaal zwakkere leerlingen, zonder dat dit ten koste hoeft te gaan van de leerprestaties van de middenklassenleerlingen (Paulle 2005). Oftewel, menging komt ten goede aan verheffing, terwijl segregatie effectieve verheffing juist afremt. Dit geldt vooral voor het voorschoolse traject en het primaire onderwijs, maar in mindere mate ook voor het secundaire en tertiaire onderwijs. Bovendien kunnen middenklassenkinderen op een gemengde school leren anderen niet over één kam te scheren. Nu al zijn scholen verplicht om leerlingen verdraagzaamheid en de omgang met etnische verschillen bij te brengen. Maar dat lukt vanzelfsprekend beter in een gemengde omgeving waar de theorie geoefend kan worden, dan in een geheel 'witte' of geheel 'zwarte' omgeving. In welke mate vindt in het Nederlandse schoolbestel die menging ook plaats? 


\section{Segregatie}

Het antwoord luidt: nauwelijks. Segregatie begint in Nederland al in het voorschoolse traject. Ten eerste is de arbeidsmarktparticipatie van Turkse en Marokkaanse moeders (veel) lager dan die van autochtone (en Surinaamse) moeders. Als gevolg daarvan zijn peuters van Turkse en Marokkaanse afkomst veel minder te vinden in de reguliere kinderopvang (zie tabel 8.1).

Tabel 8.1 Gebruik van kinderopvang door werkende ouders (anderhalf- en tweeverdieners en alleenstaande) met kinderen van 0-3 jaar naar etnische groep, 15-64 jarigen, 2004/2005 (in procenten)

\begin{tabular}{|c|c|c|c|c|c|}
\hline & Turken & Marokkanen & Surinamers & Antillianen & Autochtonen \\
\hline kinderdagverblijf & 22 & 7 & 46 & 62 & 41 \\
\hline gastouder & 0 & 2 & 3 & 2 & 7 \\
\hline $\begin{array}{l}\text { betaalde oppas } \\
\text { (thuis of buitenshuis) }\end{array}$ & 5 & 11 & 8 & 4 & 11 \\
\hline grootouders & 26 & 20 & 10 & 11 & 19 \\
\hline $\begin{array}{l}\text { onbetaalde oppas } \\
\text { (familie of vrienden) }\end{array}$ & 19 & 7 & 7 & 4 & 7 \\
\hline peuterspeelzaal & 5 & 14 & 16 & 4 & 11 \\
\hline $\begin{array}{l}\text { totaal regelm. gebruik van } \\
\text { een of meerdere soorten }\end{array}$ & 53 & 40 & 66 & 76 & 69 \\
\hline
\end{tabular}

Bron: SCP (Keuzenkamp en Merens) 2006

Daar staat tegenover dat de programma's voor Voor- en Vroegschoolse Educatie (VVE) wel goed bezocht worden door migrantenkinderen, maar nauwelijks door kinderen van autochtonen, laat staan hoogopgeleide autochtonen. Dat heeft alles te maken met de doelstelling van deze programma's - het verkleinen van taal- en rekenachterstanden — en de bijbehorende financieringssystematiek.

Tabel 8.2 Deelname aan voor- en vroegschoolse voorzieningen van kinderen naar etnische groep, schooljaar 2002/2003 (in procenten)

\begin{tabular}{|r|r|r|r|r|r|r|}
\multicolumn{2}{|r|}{ Turken } & Marokkanen & Surinamers & Antillianen & $\begin{array}{r}\text { Autochtoon } \\
\text { laag }\end{array}$ & $\begin{array}{r}\text { Autochtoon } \\
\text { hoog }\end{array}$ \\
\multicolumn{2}{|r|}{ VVE-programma } & & & & \\
1996 & 32 & 26 & 11 & 19 & 3 & 1 \\
1998 & 42 & 24 & 10 & 22 & 6 & 2 \\
2000 & 39 & 28 & 12 & 30 & 4 & 13 \\
2002 & 51 & 41 & 24 & 17 & & 5 \\
\hline
\end{tabular}

Bron: SCP (Gijsberts en Hartgerts) 2005 
Deze segregatie wordt voortgezet in het vervolg van de onderwijsketen. Sinds 1985 is het percentage basisscholen in de vier grote steden met meer dan zeventig procent leerlingen afkomstig uit niet-westerse gezinnen met een lage opleiding gestegen van vijftien naar vijfendertig. De 'zwartste' scholen zijn de scholen met een islamitische en hindoeïstische grondslag. De 'witste' scholen, daarentegen, zijn algemeen bijzondere scholen op pedagogische grondslag, zoals het montessori-, het jenaplan- en het daltononderwijs, en niet, zoals wel eens wordt gedacht, het bijzonder christelijke onderwijs. Slechts een kleine minderheid van alle basisscholen kent momenteel een gemengde leerlingenpopulatie, ook al zegt het merendeel van de ouders dat te wensen. Op de meeste scholen is één leerlingengroep dominant. Zo zijn er scholen met vooral Turkse leerlingen, scholen met vooral autochtone leerlingen met laagopgeleide ouders, en scholen met vooral Marokkaanse leerlingen.

Hoewel minder scherp, geldt iets soortgelijks voor het secundaire onderwijs. Kinderen afkomstig van niet-westerse migranten komen in overgrote meerderheid terecht in het beroepsvoorbereidende traject, en weten binnen dat traject minder dan autochtone kinderen de weg naar de theoretische leerweg op kleinschalige scholen te vinden. Daardoor worden de meest massale leerfabrieken, in ieder geval in de grote steden, overwegend bevolkt door allochtone leerlingen, terwijl de 'oude' mavo's in meerderheid 'witte' bolwerken zijn (Latten 2005).

De segregatie in het onderwijs wordt hoofdzakelijk veroorzaakt door de grote verschillen in het woongedrag van autochtonen en allochtonen. In Nederland is de etnische segregatie op wijkniveau aanzienlijk (Musterd en Van Kempen 200o). Dat komt met name door de 'witte vlucht': autochtonen vertrekken uit allochtone buurten en verhuizen naar de omliggende gemeenten. Nieuwe groepen migranten nestelen zich vervolgens op de leeggekomen plekken. Deze verschuivingen worden veroorzaakt door de verschillende financiële mogelijkheden waarover deze groepen beschikken en de mismatch die er bestaat tussen de woonwensen van kapitaalkrachtigen en het woningenprofiel van achterstandsbuurten. Ook sociaal-economisch stijgende Turken en Marokkanen blijken dan ook het liefst de autochtone middenklasse te volgen, omdat ze de grotere woningen en het middenklasseklimaat van de omliggende forensengemeenten prefereren (Musterd en De Vos 2005). Gecombineerd met de breed gedeelde wens van ouders om hun kinderen zoveel mogelijk in de buurt naar school te laten gaan, resulteert dat in een grote overlap tussen school- en woonsegregatie. Toch kan woonsegregatie niet de gehele schoolsegregatie verklaren. In 2002 was 33 procent van de Nederlandse basisscholen 'te wit', en 22 procent 'te zwart' vergeleken met de samenstelling van de wijkbevolking. Ofwel: wijksegregatie verklaart slechts circa twee derde van de schoolsegregatie. De rest is het effect van de keuzes van autochtone ouders die slecht bekendstaande 'zwarte' buurtscholen vermijden en hun kinderen buiten de buurtgrenzen op school te doen op beter bekendstaande 'witte' scholen (Onderwijsraad 2005, p. 83; Peters 2006). 


\subsubsection{WAT TE DOEN?}

\section{Gemeentelijk onderwijsachterstandenbeleid}

De verbindingsstrategie die hier wordt voorgesteld is tweeledig: het omsmeden van het Nederlandse onderwijsbestel tot een effectieve 'verheffingsmachine' wellicht relatief de makkelijkste opgave (Onderwijsraad 2005) - en het bevorderen van (vrijwillige) interetnische ontmoeting. De vraag die daarop volgt, is hoe dit het beste kan gebeuren.

Vroeg geleerd is oud gedaan. Het ligt voor de hand om jonge kinderen al vroeg samen te laten spelen en leren. Zo krijgen ook hun ouders een 'ontmoetingskans'. $\mathrm{Al}$ eerder - in hoofdstuk 7 - is gesteld dat het van groot belang is dat jonge kinderen gebruik kunnen maken - zeker voor een aantal dagen per week - van kwalitatief goede kinderopvang met aandacht voor zowel cognitieve als sociale ontwikkeling. Nu zijn voorschoolse educatie en kinderopvang strikt gescheiden en kennen verschillende financieringsstromen, wettelijke kaders en verantwoordelijkheidsverdelingen. Integratie van deze voorzieningen kan helpen om etnische segregatie tegen te gaan.

Discussies over 'witte' en 'zwarte' scholen lopen al snel vast op het constitutioneel verankerde recht van ouders om hun kind te plaatsen op de school van hun keuze. Daarnaast beschikken ouders over het recht om eigen scholen op te richten die, mits zij voldoen aan overheidseisen ten aanzien van faciliteiten, curricula en kwalificaties van het personeel, in aanmerking komen voor publieke financiering. Om deze redenen is het in de Nederlandse context lastig om de segregerende effecten van ouderlijke schoolkeuzes via dwang en/of stimulering tegen te gaan. Dwang vereist aanpassing van het grondrecht van vrije schoolkeuze. In toenemende mate gaan dan ook stemmen op om de constitutionele verankeringen van vrijheid van schoolkeuze uit de grondwet te halen, of in ieder geval nader te kwalificeren. Omdat het om grondwettelijke artikelen gaat, vereist dit een verzwaarde en langdurige procedure - met een groot conflictpotentieel en een onzekere kans op resultaat. Om die reden lijkt dit niet de meest productieve oplossingsrichting.

Een andere oplossingsrichting is de zogenaamde 'gewichtenregeling' geweest. Volgens deze regeling krijgen scholen extra middelen (tot 1,9 maal het 'normale' bedrag per leerling) voor leerlingen die extra begeleiding behoeven, ofwel vanwege sociaal-economische achterstand (klasse) ofwel vanwege cultureelsociale achterstanden (etniciteit). Het bezwaar tegen deze vorm van 'compensatie' is dat ze de segregatie vergroot of in ieder geval bestendigt. 'Zwarte' scholen hebben hierdoor immers geen prikkel om de samenstelling van de leerlingenpopulatie te 'verwitten' als hen dat geld gaat kosten en zij als gevolg daarvan in hun personeelsbestand zullen moeten snijden. De 'herziene' gewichtenregelingen die in augustus 2006 van kracht is geworden, bevat weliswaar geen etnisch criterium voor compensatierechten meer, wat nadelig is voor de verheffing van allochtonen, maar leidt onder hetzelfde euvel als zijn voor- 
ganger, namelijk dat het concentratie reproduceert (Bosker en Guldemond 2004; Peters 2006).

Beter lijkt het daarom om gemeenten meer vrijheden te verstrekken in het aanwenden van de gelden die zijn gereserveerd voor het gemeentelijke onderwijsachterstandenbeleid. Zolang de inzet van extra middelen op het niveau van individuele scholen segregatie slechts bestendigt, moet worden gekozen voor het hogere schaalniveau van het stadsdeel of zelfs de stad om met deze middelen niet alleen bestaande achterstanden te bestrijden, maar ook ouders en hun kinderen te kunnen verleiden tot desegregerende schoolkeuzes (zie ook RMO 2005a; 2005b; Schillemans en Verhagen 2005). Onderzoek wijst uit dat de effectiviteit van dit soort 'verleidende' achterstandsbestrijding staat of valt met steun van schoolbesturen en ouders. In een context van schoolkeuzevrijheid werkt 'verleiden' met extra middelen in ieder geval beter dan het dreigen met sancties en verplichtingen die toch omzeild kunnen worden, zowel door ouders als door schoolbesturen. Het falen van veel van het bestaande antisegregatiebeleid in het onderwijs is daar op terug te voeren (Peters 2006). Gemeenten dienen daardoor meer vrijheid te krijgen om extra middelen in te zetten om zowel verheffing als verbinding te bevorderen. Dat kan bijvoorbeeld door een premie op menging te geven.

\section{Wonen en mengen}

Ten slotte ligt het - gezien de grote overlap tussen woon- en schoolsegregatie voor de hand om te interveniëren in de woonvariabele. Door wijken te herstructureren kan de bevolkingssamenstelling worden beïnvloed, en daarmee ook de samenstelling van de leerlingenpopulatie in wijkscholen. Het nadeel van deze strategie is dat ze een lange adem vereist. De gewenste aanpassingen van de stedelijke morfologie kunnen alleen geleidelijk worden aangebracht, waarna het nog geruime tijd zal duren voor de effecten ervan op de samenstelling van de wijkpopulatie zichtbaar worden.

Daarnaast stuit deze mengstrategie in de vier grootste steden in Nederland al snel op numerieke grenzen gezien de bevolkingssamenstelling. In steden bestaan de jongste cohorten immers voor meer dan de helft uit kinderen afkomstig van nietwesterse migranten. Waar de 'witte' middenklasse schaars wordt, valt van mengingsbeleid weinig te verwachten. Positieve effecten van menging doen zich immers alleen voor wanneer kinderen afkomstig van de 'witte' middenklasse in de meerderheid zijn (Paulle 2005). Zodra het aandeel zwakke leerlingen richting 50 procent tendeert, zijn de positieve effecten op sociaal zwakkere leerlingen verdwenen, terwijl de leerprestaties van 'witte' middenklassenkinderen er beduidend op achteruitgaan. In de vier grote steden geldt daarom de noodzaak van andere soorten van verbinding, bijvoorbeeld die tussen de nieuwe allochtone middenklasse en de allochtone onderklasse, en tussen etnische groepen onderling. Zoals gezegd bestaan veel zwarte scholen uit enkel één etnische categorie. Deze noodzaak tot differentiatie is des te meer reden om de verbindingsfunctie in het onderwijs als een belangrijke opdracht bij de gemeenten neer te leggen, en daar ook de middelen voor vrij te maken. 


\subsubsection{VERBINDEN OP DE WERKVLOER}

De werkvloer voldoet bij uitstek aan de drie voorwaarden die eerder zijn geïdentificeerd als de mogelijkheidsvoorwaarden voor wederzijdse identificatie. Ten eerste geldt voor de werkvloer per definitie dat er een functionele noodzaak tot samenwerken is. Ten tweede staat deze samenwerking ten dienste van een 'hoger' doel, te weten van het doel organisatie. En ten derde is er in een arbeidscontext enigszins sprake van een gelijke status; alleen de voor de functie relevante verschillen doen ertoe, alle overige verschillen zijn in principe irrelevant. Amerikaans onderzoek leert dat binnen dit soort contexten interetnisch contact leidt tot een meetbare afname van wederzijdse stereotypering, en een toename van de democratische gezindheid, waaronder deugden en vaardigheden worden verstaan als luisterbereidheid, empathie, geduld en tolerantie voor andere gezichtspunten (Estlund 2003). De vraag is hoe het op Nederlandse werkvloeren met de mate van interetnisch contact staat.

Zoals hoofdstuk 7 al liet zien, is de dynamiek op de Nederlandse arbeidsmarkt groot, zowel in termen van in- als van doorstroom. Niet alleen vrouwen hebben daar de afgelopen decennia van geprofiteerd, ook allochtonen zijn erin geslaagd om hun positie op de arbeidsmarkt te verbeteren. In hoofdstuk 7 is echter ook geconstateerd dat allochtonen meer dan andere groepen getroffen zijn door de economische teruggang tijdens de achterliggende laagconjunctuur. Dat heeft om te beginnen te maken met de grotere conjunctuurgevoeligheid van de sectoren waarin allochtonen in overgrote mate werkzaam zijn, en vervolgens met de aard van hun arbeidscontract: relatief veel allochtone werknemers bevinden zich in de buitenste ring van de interne arbeidsmarkt van grote ondernemingen, en verliezen bij economische tegenwind dan ook eerder hun baan dan hun meer gevestigde collega's. In sommige gevallen had het bovendien te maken met tekorten op het gebied van vaardigheden. Het gaat dan niet in de eerste plaats om vakinhoudelijke kennis, maar vaak om lastig te kwalificeren eigenschappen als kennis van geaccepteerde sociale omgangsvormen, gedisciplineerdheid, arbeidsethos, orde en netheid en meer van dergelijke soft skills. Oftewel, niet-westerse migranten hebben minder in- en doorstroomkansen op de arbeidsmarkt dan autochtone Nederlanders en concentreren zich in de meer kwetsbare sectoren van de economie, waar zij in het algemeen ook nog eens een keer beschikken over de meer kwetsbare arbeidscontracten (SCP 2005).

\subsubsection{WAT TE DOEN?}

Het verbindende potentieel van gemengde werkvloeren moet in Nederland dus verder worden aangesproken. Ook hier geldt dat een belangrijke randvoorwaarde daarvoor wordt gevormd door een verdere stroomlijning van het Nederlandse onderwijsbestel, wat vroegtijdige uitval onder met name allochtone jongeren moet terugdringen, en hun doorstroom naar hogere scholingsniveaus moet zien op te voeren. In combinatie met de technologiegedreven structuurverandering van de economie, en de ontgroening die de omvang van nieuwe cohorten ver- 
kleint, zal dit leiden tot een groeiende schaarste aan hoogopgeleide werknemers, wat de kansen op doorstroming op de arbeidsmarkt van allochtone jongeren zal vergroten. Ook hier is effectieve verheffing dus een goede verbindingsstrategie. Naast deze algemene strategie zijn er echter specifieke aandachtspunten, zoals de ontwikkeling van soft skills en een stringenter antidiscriminatiebeleid op de arbeidsmarkt.

\section{Ontwikkelen soft skills}

Cognitieve en manuele vaardigheden zijn niet voldoende. Van even grote waarde zijn de hiervoor genoemde soft skills die iemand tot een betrouwbare en gewaardeerde werknemer en collega maken. Zowel in het primaire als in het secundaire onderwijs zal met name op zogenaamde 'zwarte' scholen meer aandacht moeten worden besteed aan het bijbrengen van deze soft skills. Arbeid vereist in moderne, complexe, dienstverleningsgeoriënteerde economieën als de Nederlandse een uitgebreide 'infrastructuur' die in belangrijke mate door de individuele werknemer zelf opgezet en onderhouden moet worden. Deze structuur is nodig om tot effectieve arbeid te komen, en omvat zaken als huishoudelijke planning, een stabiele woonomgeving, kledingonderhoud, voedselbereiding, zorgdragen voor voldoende rust en ontspanning, het in stand houden van een goede lichamelijke conditie, mentale weerbaarheid, enzovoorts. Een te groot deel van de allochtone jongeren mist als ze van school komen de complexe vaardigheden die hiervoor vereist zijn. Hoewel dit beschouwd kan worden als de verantwoordelijkheid van het gezin waartoe de jongere behoort, en er dus via publieke interventies naar zou kunnen worden gestreefd om de 'private leverantie' van deze arbeidsgerelateerde 'training' af te dwingen, past het meer in de lijn van het hier ontvouwde betoog om deze training te socialiseren en meer in schools verband te brengen.

\section{Stringenter antidiscriminatiebeleid}

Ten slotte - zeker gezien de tweezijdigheid van de verbindingsopdracht - verdient het aanbeveling om ook na te denken over middelen die werkgevers ertoe zouden kunnen aanzetten om over hun bezwaren tegen allochtone werknemers heen te stappen. Gedacht kan worden aan een dwingender beleid ten aanzien van een bijdrage van werkgevers aan de opleiding van nieuwe generaties werknemers, zeker als het gaat om beroepsvoorbereidende leertrajecten. Dit kan de vorm aannemen van een grotere financiële bijdrage van werkgevers, maar aantrekkelijker is het om te denken aan gezamenlijke opgezette leer-werktrajecten, die schoolgaande jongeren het vooruitzicht op betaalde arbeid kunnen bieden en werkgevers het vooruitzicht op goed opgeleide werknemers die ze bovendien risicoloos gedurende deze trajecten kunnen uitproberen. In combinatie met het stringentere antidiscriminatiebeleid dat in hoofdstuk 7 is bepleit, is het zo wellicht mogelijk om op een niet-confronterende, niet-verwijtende wijze de arbeidsintegratie van nieuwe generaties allochtone jongeren te bevorderen, en de Nederlandse werkvloer sterker dan momenteel het geval is, te maken tot een diverse werkvloer, waar, binnen functioneel verband, door werknemers geëxperimenteerd kan worden met ongeplande en onverwachte vormen van wederzijdse sociale aanpassing. 


\subsubsection{VERBINDEN IN WIJK EN BUURT}

Tegenwoordig zijn ook 'de wijk' en 'de buurt' (her)ontdekt als locatie van interetnische verbinding (bijv. WRR 2005). Een groeiend aantal stadsbestuurders heeft het tegengaan van territoriale segregatie tot een politieke en bestuurlijke opdracht verklaard, en biedt bestuurders en organisaties op wijk- en buurtniveau ruimte om initiatieven te ontplooien zodat buurtbewoners (meer) met elkaar in contact komen. Eén van de 'lichte' verschijningsvormen van deze ontwikkeling zijn buurtfestijnen, buurtbarbecues en andere buurtgerelateerde evenementen waarmee de laatste jaren wordt geëxperimenteerd. Het doel is - als regel in kansarme wijken (waar het probleem als meest prangend wordt beschouwd) - dat anonieme buurtbewoners elkaar gaan 'ontmoeten', waarmee de condities worden gegenereerd die wederzijdse identificatie bevorderen. Evaluaties van de ervaring die inmiddels is opgedaan, leren evenwel dat, hoewel goed bedoeld, hier niet te veel van verwacht mag worden. Het nadeel van dit soort initiatieven is immers dat ze niet voldoen aan de eisen van functionele noodzakelijkheid, herhaalbaarheid en relatieve gelijkwaardigheid die noodzakelijk zijn voor het in gang zetten van wederzijdse identificatieprocessen. Bij ontstentenis daarvan zullen de effecten ten hoogste tijdelijk en als regel vluchtig zijn (RMO 2005).

Wellicht bieden de bestuurlijke decentralisatieoperaties in het kader van de Wet Werk en Bijstand (WWB) en de Wet op de Maatschappelijke Ondersteuning (WMO) mogelijkheden. Ook al is het zo dat voor burgers met veel sociaal, cultureel en menselijk kapitaal de straat of de buurt een weinig relevant integratiekader is, voor mensen die zijn aangewezen op WMO-voorzieningen of die via de WBB in gesubsidieerde banen terecht zijn gekomen, is de wijk of buurt wel degelijk een relevant schaalniveau, in ieder geval voor specifieke categorieën bewoners. Afhankelijk van de beleidskeuzen van gemeenten zouden nieuwe mogelijkheden kunnen ontstaan voor lokale zorg- en welzijnsinstellingen die in het voorgaande decennium onder bezuinigingsdruk hun lokale bruggenhoofden, inclusief die lokale kennis die daarbij hoorde, hebben zien wegkwijnen. Ook geeft de aanwezigheid van middelen en verantwoordelijkheden op het schaalniveau van wijk of buurt structuur aan vormen van 'straatburgerschap' die anders niet van de grond zouden zijn gekomen, of een eenmalig karakter zouden hebben gehad (Uitermark en Duyvendak 2006).

De mogelijkheden van dergelijke benaderingen kennen echter hun grenzen als het gaat om de mate waarin ze verbinden dichterbij brengen. Behalve de sterk categorale invalshoek van de WBB en de WMO speelt ook het probleem dat zeker in de grote steden een vrij hoge mate van woonsegregatie bestaat. Oftewel, ook al worden wijk of buurt tot functioneel schaalniveau opgewaardeerd door er wat meer middelen en verantwoordelijkheden aan toe te delen, dan nog zal als gevolg van de grote mate van segregatie op dat niveau nauwelijks interetnisch contact plaatsvinden. Beleid gericht op het bevorderen van straatburgerschap zal dus alleen integratieve effecten kunnen hebben wanneer tegelijkertijd wordt ingezet op het beïnvloeden van de samenstelling van buurten en wijken. In dat kader 
moet vermeld worden dat de 'scheefwoners' die de schaarste aan goedkope huurwoningen veroorzaken, tegelijkertijd ook een verdergaande woonsegregatie voorkomen.

\section{Verbindingsstad}

De mogelijkheden van gemeenten om verbinding te thematiseren, zijn dus gelimiteerd. Op het terrein van onderwijsbeleid hebben ze beperkte instrumenten, terwijl juist daar grote opgaven liggen. Dat geldt ook voor het huisvestigingsbeleid. En waar ze andere bevoegdheden hebben, zoals in het kader van de WMO, is dat meestal eveneens beperkt; ze delen de verantwoordelijkheid voor de zorg voor mensen met langdurige beperkingen met zorgkantoren, voor de verslaving met zorginstanties en justitiële instanties, voor de jeugd met de jeugdzorg en met justitiële instanties, enzovoorts. Tegelijkertijd benoemen de afgelopen jaren burgemeesters en wethouders - over het hele politieke spectrum heen - het als hun kernopdracht om verbinding tot stand te brengen, ondanks hun beperkte instrumentarium. Het lijkt zaak deze ontwikkeling verder te ondersteunen.

Uit onderzoek blijkt dat zelfs transnationale bindingen heel goed samen kunnen gaan met nationale bindingen, maar vaker nog met verbindingen op het niveau van een stad. Migranten voelen zich nog het meest verbonden met de stad. "Wij zijn allemaal Rotterdammers" biedt daarom een vruchtbaarder identificatieperspectief dan "Wij zijn allemaal Nederlanders" (Phalet e.a. 2004; Verkuyten 2006). Kortom: het lokale niveau biedt kansen om functionele verbindingen tot stand te brengen, zeker in een globaliserende wereld waarin migratie zal blijven bestaan (hoofdstuk 3). Een stad zou de opdracht moeten hebben - en de meeste gemeenten willen dat maar al te graag - om dergelijke lokale verbindingen te bemoedigen.

Bovendien is de mate en vorm van verbinding die vereist is, niet alleen veranderlijk maar ook verschillend per lokaliteit. In grootstedelijke gebieden is inmiddels het merendeel van de jongeren allochtoon, spelen er vooral interetnische conflicten (bijvoorbeeld tussen Antillianen en Turken), is er minder sprake van 'zwarte scholen' en 'witte scholen' maar veeleer van 'Turkse scholen' en 'Marokkaanse scholen' en ontwikkelt zich er een allochtone middenklasse. Menging kan hier bijvoorbeeld betekenen het vasthouden van de allochtone middenklasse in achterstandswijken. In kleinere provinciesteden of dorpen daarentegen vormen allochtonen nog een kleine minderheid en ondervinden met name weerstand van een blanke middenklasse. De verbindingsopdracht noopt tot een gedifferentieerd beleid, beleid dat kan inspelen op verschil in dynamiek. Gemeenten zijn bij uitstek geschikt om verschil te maken in beleid (WRR 2006).

Dat betekent dat de verbindingsopdracht veel nadrukkelijker op de gemeentelijke agenda kan staan. Het is zaak dat één instantie zich verantwoordelijk acht voor de verbindingsopdracht en daarop aanspreekbaar is. Vervolgens moet het instrumentarium op maat worden gesneden. Zo ligt het voor de hand om de verantwoordelijkheid voor jeugdigen niet te verspreiden over vele partijen, maar deze primair te beleggen bij de gemeente. Verantwoordelijkheid is daarbij niet hetzelf- 
de als uitvoering: uitvoering kan goed aan partijen worden gedelegeerd, ook op een hoger schaalniveau dan dat van de gemeente. Het ligt voor de hand dat vrijheid ontstaat om middelen op het terrein van kinderopvang, onderwijs en huisvesting zo in te kunnen zetten, dat ze daadwerkelijk bijdragen aan verschillende vormen van menging. Dat kan de vorm hebben van een gemeentelijk verbindingsbudget. Op deze wijze wordt verbinding een duidelijker gemeentelijke beleidsopdracht, en wordt de rol van de gemeente, die in de ogen van veel gemeenten te veel die van uitvoeringskantoor van Den Haag is, meer eigenstandig en ontwikkeld in de richting van een 'verzorgingsstad' -in tegenstelling tot een verzorgingsstaat. Of, om het nauwkeurig uit te drukken, een 'verbindingsstad'.

\subsection{CONCLUSIE: DE VERBINDENDE VERZORGINGSSTAAT}

Verbinden is een functie van de verzorgingsstaat, en tegelijk een bestaansvoorwaarde. Verzorgingsstatelijke arrangementen kunnen alleen in stand blijven als mensen zich verbonden voelen met elkaar. Gegeven veranderende economische en politieke condities, zowel buitenslands als binnenslands, moeten verzorgingsarrangementen verder blijven strekken dan een louter equivalentieprincipe.

Dat betekent dat noch generaties, noch individuen een gegarandeerde aanspraak kunnen maken op verzorgingsstatelijke bijdragen die exact overeenkomen met hun 'eigen inleg'. Collectieve verbondenheid draagt bij aan een gedeeld besef van de billijkheid van individuele bijdragen die het directe eigenbelang overschrijden, en die gebaseerd zijn op een breder, maar niet altijd expliciet beredeneerd, besef van wederzijdse kwetsbaarheid en afhankelijkheid.

Daarnaast heeft 'verbinden' een morele waarde. In verschillende politiek filosofische tradities is geprobeerd om recht te doen aan twee antropologische constanten. De ene luidt dat mensen een diepgeworteld verlangen hebben naar vrijheid, zelfcreatie en individuele zelfverwerkelijking. Dat verlangen heeft bij uitstek zijn thuis in het moderne liberalisme. Daarnaast kent de mens een al even diepgevoeld verlangen naar gemeenschap, verbondenheid en bescherming (Unger 1984). De christen-democratie, de sociaal-democratie, sommige vormen van republikanisme, de vroegere romantiek en het recente communitarisme zijn verwoorders van deze antropologische constante (Taylor 1989). De nadruk op individuele verheffing waar het in het vorige hoofdstuk om ging, zou kunnen doen vergeten dat succesvolle verheffing alleen mogelijk is tegen de achtergrond van een vitaal collectief vlechtwerk dat niet alleen de hulpbronnen die benodigd zijn voor effectieve verheffing ter beschikking stelt, maar dat ook individuele verheffing eerst ook betekenis geeft. We zijn niet wie we zijn op grond van een louter individuele zelfbeschrijving, maar tegen de achtergrond van collectieve conversatie die ons bestaan betekenis geeft.

Verbinding zal in de toekomst meer onder druk komen te staan door een globaliserende wereld, een vergrijzende bevolking en voortdurende migratie en dif-ferentiatie tussen burgers. Goede verbinding komt tot stand wanneer groepsgrenzen doordringbaar zijn, verschillen tussen mensen als legitiem worden 
beschouwd, en als er (fysiek en/of verbaal) contact is tussen mensen onderling zodat niet voortdurend in stereotypen over elkaar gedacht wordt.

De verbinding tussen hoger en lager opgeleiden in Nederland lijkt op dit moment redelijk goed. Anders dan veel ons omringende landen slaagt de Nederlandse verzorgingsstaat er redelijk in om groeiende ongelijkheden in de primaire inkomensverdeling via belasting- en premieheffing te neutraliseren, en dat zonder al te geprononceerd verzet van de meest verdienenden. In het licht van toekomstige veranderingen op de arbeidsmarkt - skill biased technological change - kunnen wel verbindingstekorten ontstaan: met name voor lager opgeleide mannen ligt overbodigheid op de loer. Dat wijst niet alleen op de noodzaak van een verheffingsimpuls gericht op de ontwikkeling van vaardigheden (soft skills), maar ook naar het vanuit overheidswege blijven volgen van de onderkant. Dit vermindert het gevoel van sociale uitsluiting.

Een tweede potentiële breuklijn is die tussen jong en oud. Onze bevolking groeit komende decennia niet meer, en wordt gemiddeld ouder. De daarmee samenhangende vergrijzingskosten zullen moeten worden opgevangen, waarbij de verschillende generaties hun bijdrage zullen moeten leveren. De gevolgen van het vergrijzingsprobleem zijn omvangrijk; het relatieve voordeel van dit probleem is dat het een langzaam proces betreft, dat lang van tevoren te voorzien valt (zie ook Studiegroep Begrotingsruimte 2006). Het verbindingstekort dat langzaamaan dreigt te ontstaan tussen jong en oud is met name een legitimiteitsprobleem: jongeren hebben het gevoel dat ze aan de verliezende kant staan en de kosten van de verzorgingsstaat moeten dragen zonder daar rechten voor in de plaats te krijgen. Als het gaat om de positie op de arbeidsmarkt lijkt dat een onterechte aanklacht te zijn, omdat beide categorieën een steun in de rug kunnen gebruiken. In termen van toegang tot de woningmarkt ligt hier echter een opgave. Jongeren zien een generatie van steeds vermogendere ouderen opkomen die tegen hun pensionering ruime rechten hebben opgebouwd en over een bijna afgelost huis beschikken, terwijl ze zelf zelfs met een redelijk inkomen geen toegang tot de woningmarkt krijgen. Dat zet verbinding onder druk.

Een derde potentiële breuklijn is die tussen allochtonen en autochtonen. Er is sprake van een steeds groter geworden disidentificatie tussen allochtonen en autochtonen, zeker in vergelijking tot andere Europese landen (hoofdstuk 4). Op dit tekort aan bridging heeft de verzorgingsstaat nog geen goed antwoord geformuleerd. Naast problemen rond doordringbaarheid van groepsgrenzen - allochtonen stromen onvoldoende door in het onderwijs en de arbeidsmarkt bestaan er ook legitimiteitsproblemen (discriminatie) en is er sprake van een sterke fysieke segregatie tussen allochtonen en autochtonen. Verheffing van allochtonen via (voorschools) onderwijs lijkt daarbij de belangrijkste route, alsmede het tegengaan van discriminatie en het bevorderen van ontmoeting zowel in het onderwijs als op de werkvloer. Het gevoel van verbinding is immers sterk wanneer mensen elkaar kunnen treffen in functionele contexten, zoals in een arbeidsorganisatie of op school of kinderopvang. Ontmoetingsmomenten 
kunnen immers stereotyperingen verminderen en inlevingsvermogen vergroten, zowel aan de allochtone als ook aan de autochtone zijde.

Dergelijke vormen van identificatie kunnen bijdragen aan het 'verdichten' van de al te lichte gemeenschap die allochtonen en autochtonen onderling vormen. Verbinding ligt niet (langer) louter of primair op het niveau van de natiestaat, maar ook of meer op dat van de straat, de wijk, de buurt en de stad. Waar de wereld globaliseert en in die zin steeds groter wordt, moeten de antwoorden juist gezocht worden in het kleine. Onze primaire betrokkenheid gaat immers uit naar het nabije, en dat kan zowel het cultureel nabije, het functioneel nabije als het territoriaal nabije zijn. Vandaar dat in de globaliserende verzorgingsstaat van de 21ste eeuw een zwaar accent zal liggen op de 'verbindingsstad'. 


\section{CONCLUSIE}

\subsection{ANDERE BELEIDSORIËNTATIE}

De laatste eeuw kwamen er in Nederland drie keer zoveel mensen bij, zes keer zoveel huizen, en zijn we vijf keer zo rijk geworden, de levensverwachting is met twee derde toegenomen, het sterftecijfer is met een derde afgenomen, en huishoudens zijn gehalveerd in omvang. Een goed huis, goede voeding, goede kleding, goede gezondheidszorg en goed onderwijs zijn nu in principe voor iedereen bereikbaar. Moest een eeuw geleden nog de helft van het inkomen uitgegeven worden aan eten en drinken, nu is dat nog slechts een achtste (Schnabel 2004). De verzorgingsstaat heeft veel aan deze veranderingen bijgedragen: hij geeft bijna de gehele bevolking een hoge mate van zekerheid op vele levensterreinen, maakt een breed scala aan voorzieningen voor velen beschikbaar en toegankelijk, en vormt een voedingsbodem voor economische, maatschappelijke en culturele ontwikkeling. De verzorgingsstaat kan dan ook rekenen op een breed draagvlak onder de bevolking, hetgeen in het bijzonder blijkt in perioden dat hij onder economische, politieke of morele druk staat.

Toch kan het niet het streven zijn om de komende decennia de verzorgingsstaat zoals die gegroeid is, onveranderd te laten of slechts kleine ondoelmatigheden weg te werken of incrementele aanpassingen aan te brengen. Dat zou een strategie van blijvend klein onderhoud zijn, terwijl wijzigingen in de omstandigheden juist nopen tot groot onderhoud.

Ten eerste verandert de omgeving van de verzorgingsstaat. Niet langer is er sprake van een relatief gesloten natiestaat die ooit aan het begin stond van de verzorgingsstaat die op zijn beurt een reactie vormde op het ongepolijste kapitalisme van de negentiende eeuw. De industriële productiewijze vroeg om bescherming van werknemers, terwijl conjunctuurgolven moeilijk te beheersen waren. Zo begon de twintigste eeuw met het meer gesloten maken van allerlei markten en het ontwikkelen van een stelsel van verzekerings- en verzorgingsarrangementen op nationaal niveau. In de laatste decennia van de twintigste eeuw treedt echter weer een periode van grotere economische openheid op. Alles wijst erop dat dit proces van globalisering doorgaat, en dat het ook door moet gaan. Het is immers de voedingsbodem voor (verdere) welvaartsgroei, en zal, hopelijk, bijdragen aan een stabielere wereldorde. Nederland is er, als relatief open economie, zelfs extra bij gebaat dit proces te accommoderen. Voortgaande globalisering veronderstelt samenlevingen die voldoende flexibel zijn om constructief met de bijbehorende ontwikkelingen om te springen. De afgelopen decennia lieten zien dat-alhoewel dit proces vaak met horten en stoten gaat - Nederland over voldoende adaptief vermogen beschikte om dat ook te doen. Zo scoort de Nederlandse arbeidsmarkt goed in vergelijking met de meest mobiele arbeidsmarkt van Europa, de Britse. In het Verenigd Koninkrijk verandert per twee jaar 24 procent van de werkenden van baan, in Nederland 20 procent, terwijl in Duitsland dat percentage op 9 ligt. Als Nederland de ambitie heeft om zich verder te ontwikkelen tot kennisecono- 
mie, is een efficiënte allocatie van talenten over posities een noodzaak. Dat stelt eisen aan de mate waarin burgers zich kunnen ontwikkelen en scholen, aan de opvang van mensen die daarin onvoldoende meekomen en aan het voorkomen dat de spanning tussen die twee groepen te groot wordt.

Behalve de omgeving zijn ook de inwoners van de verzorgingsstaat zelf veranderd. De samenleving is - mede door migratie - heterogener geworden en de burgers mondiger. Bij zijn ontstaan was de verzorgingsstaat afgestemd op mensen die leefden in een voorspelbaar samenlevingsverband (dat van het gezin met een kostwinner), volgens een voorspelbaar patroon (de kostwinner ging na school werken en bleef dan vaak bij dezelfde baas jarenlang ruwweg hetzelfde werk doen; zijn vrouw kreeg en verzorgde de gezamenlijke kinderen), in een voorspelbare context (buurt, kerk, verenigingsleven) en met voorspelbare anderen (mensen van gelijke achtergrond en cultuur). Gezin, werk, sociaal netwerk en samenleving: het zijn allemaal begrippen die in de loop van de twintigste eeuw andere betekenissen hebben gekregen. Mensen zijn niet alleen onderling meer verschillend, maar leven ook in de loop van hun levens op telkens weer wisselende wijze, en op steeds meer verschillende plekken. Dat manifesteert zich ook in een ander verwachtingspatroon ten aanzien van de verzorgingsstaat. Burgers verwachten van de verzorgingsstaat dat deze hen niet alleen garanties biedt in de vorm van verzekerings- en verzorgingsarrangementen, maar hen ook helpt kansen te nemen, stimuleert tot verdere ontwikkeling en ruimte laat voor ontplooiing.

De consequentie van deze veranderingen is dat er een nieuwe invulling moet worden gegeven aan de verzorgingsstaat: een verzorgingsstaat waarin verheffen en verbinden meer aandacht krijgen dan nu het geval is. De afgelopen decennia is er ruimschoots aandacht besteed aan hervormingen van de onderdelen van de verzorgingsstaat die vooral gericht zijn op verzekeren en verzorgen; het wordt nu tijd om de beleidsinspanningen te concentreren op die onderdelen die gericht zijn op verheffen en verbinden. Het streven om verheffen en verbinden te voorzien van een eigentijdse en hoogwaardige invulling, moet nadrukkelijk herkenbaar worden in de toekomstige beleidsontwikkeling. Dat is niet hetzelfde als beweren dat verzekeren en verzorgen onbelangrijk zijn - ze zijn van groot belang. De vier functies constitueren samen het raster waarlangs de instituties van de verzorgingsstaat vorm krijgen en zijn dus alle vier noodzakelijk. De functies veronderstellen en versterken elkaar ook. Zo is verbinden een randvoorwaarde voor verzekeren: sociale verzekeringen zijn alleen mogelijk als er ten minste een minimaal gevoel van wederzijdse verbondenheid is. Omgekeerd produceert een verzekering ook verbondenheid. Functies zijn tot op zekere hoogte ook substitueerbaar. Verzekeren is een manier om inkomensverlies wegens werkloosheid tegen te gaan, terwijl verheffen (betere opleidingen) werkloosheid juist tracht te voorkomen en op die manier ook 'verzekert' tegen inkomensverlies. Functies komen ook samen in instituties: kinderopvang kan in het teken staan van het verzorgen van kinderen, maar tegelijk ook in het teken van verheffen en verbinden. Wat dit rapport demonstreert, is dat er goede argumenten zijn om de 
komende decennia verheffen en verbinden nadrukkelijker van een forse, gerichte en herkenbare beleidsinspanning te voorzien.

\subsection{ANDERE WEGING VAN DE FUNCTIES VAN DE VERZORGINGS- STAAT}

\section{Verzekeren}

Dat de beleidsaandacht voor een specifieke functie van de verzorgingsstaat in bepaalde periodes kan en moet groeien, maar ook weer in intensiteit kan afnemen, blijkt het meest duidelijk bij de functie verzekeren. Die functie heeft voor een belangrijk gedeelte gestalte gekregen via het stelsel van sociale zekerheid. De transformaties die in het stelsel mogelijk en wenselijk waren, zijn voor het grootste deel gerealiseerd. De kosten zijn verminderd, de doelmatigheid van het stelsel is verhoogd en een beter evenwicht in rechten en plichten is tot stand gebracht. Zo is het budgettaire beslag dat de ww, wAO en Bijstand op het bruto binnenlands product leggen, fors gedaald: dat percentage is sinds medio jaren tachtig - de hoogtijdagen van de kritiek op de sociale zekerheid - bijna gehalveerd. Van een land dat gekenmerkt werd door een relatief hoge mate van inactiviteit en een ruimhartig stelsel van sociale zekerheid, is Nederland een land geworden dat in arbeidsparticipatie (in personen gemeten) alleen door Denemarken voorbij wordt gestreefd. De afgelopen twintig jaar wisten we het aantal werkzame mensen met twee miljoen te verhogen, terwijl het aantal inactieven in absolute zin niet steeg. Kortom: de Nederlandse werkgelegenheids- en werkloosheidscijfers, de verhouding tussen het aantal inactieven en actieven, en de omvang van de armoede steken in Europees vergelijkend perspectief inmiddels goed af.

Tegelijkertijd is de werking van de verzekeringen wezenlijk gewijzigd: ze omvatten nu allemaal substantiële prikkels om het beroep op voorzieningen te beperken. De eerste twee ziektejaren komen bijvoorbeeld volledig voor rekening van de werkgever, terwijl deze zich ook nog voor een periode van vijf jaar moet verzekeren voor de mensen die na die twee jaar nog gedeeltelijk arbeidsongeschikt zijn. Preventie van ziekteverzuim staat dan ook nadrukkelijk op de agenda. Met de Wet Werk en Bijstand hebben gemeenten veel sterke prikkels gekregen om mensen naar werk te geleiden - en dat wordt in de praktijk ook energiek opgepakt. De ww is inmiddels in duur teruggebracht en sociale partners hebben nadrukkelijker een verantwoordelijkheid voor de invulling. In de uitvoering van al deze wetten valt wellicht nog het een en ander te verbeteren, en een enkele regeling behoeft nog nadere aandacht (de Algemene NabestaandenWet is bijvoorbeeld nog weinig activerend, en daarmee niet geheel meer van deze tijd), maar grosso modo naderen de belangrijkste systeemtransformaties in de sociale zekerheid voor dit moment hun voltooiing. Socialezekerheidsbeleid kan in plaats van in het teken van stelselwijzigingen in het teken van de implementatie komen te staan. 


\section{Verzorgen}

Het verzorgingsprogramma is veel minder dan het verzekeringsprogramma beland in de fase van verfijning van de uitvoering: de sterke nadruk op de uitvoering van de zorg moet eerder ingeruild worden voor een nieuwe. Ruim een eeuw geleden stond het verzorgingsprogramma primair in het teken van de verantwoordelijkheid die de overheid had om maatregelen te treffen om ziektes te voorkomen. Dat leidde bijvoorbeeld tot een uitgebreid stelsel om voedselveiligheid te waarborgen. Daarna werd in de twintigste eeuw de financiering van de zorg steeds meer een zaak die de overheid diende te regelen. Ten slotte werd ook de organisatie en het functioneren van instellingen een overheidsverantwoordelijkheid. Die beide onderdelen zijn zeker nog niet in de fase van 'klein onderhoud' beland. De fase waarin bijna de gehele verantwoordelijkheid voor de organisatie en uitvoering bij de overheid ligt, lijkt echter wel achter de rug. Deze onderdelen van het programma komen steeds meer in het teken te staan van een beheerste overdracht van verantwoordelijkheden aan burgers, aanbieders, professionals en marktpartijen. De afgelopen jaren stond daarbij de curatieve zorg centraal. Het ligt in de rede om de komende jaren deze ontwikkeling verder vorm te geven in de langdurige zorg.

Wat voor deze afnemende directe betrokkenheid van de overheid in de plaats zou moeten komen, is gerichte aandacht voor de personele, ruimtelijke en sociaal-culturele randvoorwaarden waaronder zorg wordt verleend. De demografische ontwikkelingen - die we vaak ten onrechte aanduiden als 'vergrijzing', maar die vooral ook te maken hebben met een lange onevenwichtigheid in de bevolkingsopbouw als gevolg van de naoorlogse geboortegolf - brengt het gevaar met zich mee dat er straks onvoldoende capaciteit zal zijn om ouderen adequaat te verzorgen. De toekomstige generatie ouderen is niet alleen talrijk, maar ziet zorg bovendien steeds minder als een gunst en steeds meer als een recht. Dat betekent dat niet alleen de kwantiteit, maar ook de kwaliteit van de professionele zorg aan hoge eisen zal moeten voldoen. Aan deze eisen kan alleen tegemoet worden gekomen als in het komende decennium alle schoolverlaters in de zorg gaan werken en alle nieuwbouw speciaal op ouderen wordt afgestemd. Dat is wenselijk noch realiseerbaar. Geen enkele maatregel is op zichzelf afdoende, zelfs geen grootscheepse arbeidsmigratie. Daarom is een samenhangend pakket van maatregelen: adequatere mogelijkheden om werk en zorg te combineren, technologische innovatie, een financieringsstructuur die meer prikkelt tot differentiatie en klantoriëntatie, en meer ruimte voor informele zorg. 'Tijdspolitiek' zal een nadrukkelijker thema in het beleid moeten worden. Zorgbeleid moet in het licht van de vergrijzing dan ook niet teruggebracht worden tot een louter financieel vraagstuk - betaalbaar is de zorg te houden: er is vooral sprake van een verdelingsprobleem tussen rijke en minder rijke ouderen. De personele en infrastructurele (en op termijn: sociaal-culturele) opdrachten die aan de vergrijzing kleven, zijn nog veel taaier en vergen een heroriëntatie binnen het verzorgingsprogramma. 


\section{Verheffen}

Tegenover de afgenomen noodzaak om het verzekeringsprogramma verder te herzien en de noodzaak tot heroriëntatie binnen het zorgprogramma van een uitvoerings- en betaalbaarheidsprobleem naar een beschikbaarheids- en tijdsvraagstuk, staat de (nog) grotere uitdaging om de verheffingsfunctie nieuw leven in te blazen. Nederland is een land dat in de opbouw van zijn verzorgingsstaat het accent heeft gelegd op ouderen: zij hebben, verhoudingsgewijs, genereuze voorzieningen en inkomensregelingen. Dat geldt voor de publieke regelingen, zoals blijkt uit de omvang van de ouderenzorg en de AOw, maar vooral ook voor de (semi-)private bezittingen, zoals huizenbezit, vermogen en pensioenaanspraken. Vergeleken met andere Europese landen kennen Nederlandse ouderen ook significant minder armoede.

De zorg voor kinderen steekt daar, in internationaal opzicht, echter mager bij af. De omvang van verlofregelingen voor ouders is beperkt, en kinderopvang is in Nederland laat en inhoudelijk weinig ambitieus van de grond gekomen. Het Nederlandse onderwijs presteert alleszins redelijk, maar de publieke uitgaven aan onderwijs en gezinsbeleid liggen hier lager dan in vrijwel alle EU-15 landen, en zelfs twintig procent lager dan in Frankrijk, het Verenigd Koninkrijk en België. Klachten over personele bezetting, leermiddelen, de matige kwaliteit van schoolgebouwen en onderhoud zijn in Nederland dan ook veelvuldig te horen. In vergelijkend perspectief is het gemiddelde opleidingsniveau van de Nederlandse bevolking niet hoog en blijft de duur van onderwijsdeelname achter bij de ons omringende landen. Nederland staat met enkele mediterrane landen bovenaan de OECD-lijst als het gaat om het aantal jongeren dat zonder startkwalificatie de school verlaat. Om de Lissabondoelstellingen te halen zou dit percentage in 2010 gehalveerd moeten zijn. Alhoewel veel van deze jongeren op enig moment toch wel werk weten te vinden - zeker in perioden van hoogconjunctuur - blijft de kwaliteit van de banen waar ze toegang toe hebben beperkt, zeker omdat tweedeen derdekansonderwijs in Nederland onvoldoende ontwikkeld is. Nederland investeert - na de mediterrane landen - het minste in bedrijfsspecifieke opleidingen. Meer nog dan hoge schooluitval is in Nederland de lage schoolterugkeer het probleem. Kortom, onze ambitie op dit vlak moet omhoog en kan omhoog.

Aan ambitie heeft het in de tweede helft van de vorige eeuw te veel ontbroken. We zijn genoegen gaan nemen met middelmaat - op individueel niveau, maar ook op het niveau van het onderwijssysteem als geheel. Het is dan ook zaak om de hele onderwijskolom opnieuw te bezien vanuit de vraag of deze mensen maximaal aanzet om hun capaciteiten te ontwikkelen. Er zijn namelijk substantiële verheffingstekorten aan te wijzen. De meeste aandacht dient daarbij uit te gaan naar kinderen, vaak van allochtone afkomst, die aan de basisschool beginnen met leerachterstanden van vaak meer dan een jaar. Vergelijkend onderzoek leert dat hun achterstand voor een belangrijk deel te voorkomen valt. Goede stimuleringsprogramma's blijken voorschoolse achterstand met de helft tot twee derde terug te kunnen brengen, mits ze voldoende intensief worden aangeboden en ouders er bij worden betrokken. De inzet moet dan ook zijn om te zorgen dat kinderen die 
voor voorscholing in aanmerking komen, er ook gebruik van gaan maken. De vorm die daarvoor het meest geëigend lijkt, is de integratie van de stimuleringsprogramma's (voor- en vroegschoolse educatie) in de reguliere kinderopvang. Daartoe dient kinderopvang voor minstens een aantal dagen per week voor alle kinderen een basisvoorziening te worden.

Ook de ambitie voor kinderen in de basisschoolleeftijd moet omhoog. Investeringen in het onderwijs zelf zijn daarvoor een eerste vereiste: een toename van het aantal uren dat lesgegeven wordt, maar ook verbetering van de kwaliteit van de docenten. Bovendien kan de tussen- en naschoolse opvang minder in het teken van opvang geplaats worden, en meer in het teken van vorming. Kinderen zouden een breed palet aan sociale, culturele, sportieve en cognitieve mogelijkheden aangeboden moeten krijgen. Op termijn ligt het voor de hand de aparte tussenen naschoolse opvang te integreren met de reguliere school. Maar al voordien zal het te ontwikkelen aanbod voor alle kinderen beschikbaar moeten zijn: het gaat er immers om niet alleen een oudervriendelijk land te worden, maar ook een kindvriendelijk land.

Dat menselijk talent wordt ook onderbenut in het (voorbereidend) beroepsonderwijs. De opdracht is om deze onderwijsvorm (weer) een positieve uitstraling te geven. Dat zal voor een belangrijk deel moeten gebeuren door het onderwijsconcept achter het vmbo en mbo substantieel te verbeteren. De belangrijkste ingrediënten daarvoor zijn: meer ruimte voor soepele doorstroom en voor differentiatie - zowel door variatie in intensiteit, niveau en inhoud van het onderwijsaanbod als door flexibilisering van eindtermen. De jongeren waarop dit onderwijs zich richt, bevinden zich in een lastige en turbulente levensfase. Vaak zijn ze niet goed in staat om keuzes te maken - zowel door de veelheid aan mogelijkheden en verlokkingen als door gebrek aan steun en structuur van hun ouders. Dat brengt met zich mee dat scholen naast kennisoverdracht ook individuele begeleiding moeten kunnen bieden. Het (weer) overbruggen van de afstand tussen school en ouders enerzijds, en tussen de school en instanties op het gebied van de jeugdzorg anderzijds, vergt aandacht en creatieve oplossingen, van het afleggen van huisbezoeken door docenten tot het huisvesten van jeugdzorginstellingen in scholen.

Ook universiteiten en het hogere beroepsonderwijs, ten slotte, schieten tekort in het vervullen van hun verheffingsopdracht. Ze bieden vooral massale opleidingen met een uniform karakter. Universiteiten hebben de spanning tussen hun twee kerntaken, het opleiden van onderzoekers en het opleiden van professionals, nooit goed tot een oplossing weten te brengen. Meer differentiatie naar inhoud en niveau zal nadrukkelijker gezocht moeten worden. In dat kader verdient ook de studiefinanciering bijstelling. De verheffingsfunctie serieus nemen betekent dat studiefinanciering zo is ingericht dat ze studeren maximaal bevordert en bijbaantjes ontmoedigt. Het tegenovergestelde is nu het geval: studenten hebben massaal baantjes en het netto aantal studie-uren is laag. Mensen van dertig of ouder worden ontmoedigd en voor mensen die een tweede studie willen doen, is geen regeling getroffen. 
Verheffen is een functie die vorm kan krijgen via het onderwijs, maar ook langs andere wegen. De arbeidsmarkt en de sociale zekerheid zouden meer in dit teken moeten komen te staan. Op de arbeidsmarkt is 'een leven lang leren' nog steeds te veel een credo en te weinig realiteit. De bestaande levensloopregeling zou omgevormd moeten worden tot een regeling die mensen motiveert om zich te blijven ontwikkelen. Investeren in scholing moet zijn vervolg krijgen in de mogelijkheid van mensen om hun talenten ook daadwerkelijk op de arbeidsmarkt tot uitdrukking te brengen. In dat opzicht is er nog steeds sprake van verheffingstekorten. Vrouwen werken minder uren buitenshuis dan mannen en vrouwelijk talent is nog steeds scheef verdeeld over de Nederlandse economie. Voor jongeren uit allochtone kring speelt het tegenovergestelde: ze zijn niet overschoold, maar onderschoold en worden bovendien onvoldoende snel opgenomen in de arbeidsmarkt. Een strakker antidiscriminatiebeleid, vormen van naming and shaming, goede voorbeeldwerking en een stevige inzet van de onderhandelingsinstrumenten van de overheid in overleg met werkgevers (voor eerdere periodes zijn er succesvolle convenanten afgesloten!) zijn een deel van het antwoord.

Ook in de sociale zekerheid zijn er mogelijkheden om verheffen nadrukkelijker inhoud te geven. In de vormgeving en uitvoering van de verzekeringsfunctie is het accent de afgelopen jaren steeds meer verschoven van inkomenscompensatie naar tegenprestatie. In de jaren negentig ging het vooral om activeren. Een volgende stap is wenselijk: voor wie werkloos wordt, is werk of scholing beschikbaar. Omdat het organiseren van een dergelijke omslag tijd vergt, zou begonnen kunnen worden door voor de groep jongeren tot 25 jaar het recht op een bijstandsuitkering te vervangen door het recht op werk of scholing. Een dergelijke maatregel zou vastleggen wat in veel steden in het kader van Wet Werk en Bijstand gaandeweg al vorm heeft gekregen.

Tot slot is het zaak om ook allerlei vormen van zelforganisatie en vrijwilligerswerk te koesteren. Dat geldt in het bijzonder de wereld van de 'jongere ouderen' de mensen tussen de 55 en 75 die al lang niet meer passen in het plaatje van de passieve en zorgbehoeftige 'bejaarde', maar die zich in toenemende mate willen en kunnen ontwikkelen in plaats van zich tevreden te stellen met het teren op oude inzichten, vaardigheden en bezigheden.

\section{Verbinden}

Wellicht de lastigste opgave waar de Nederlandse verzorgingsstaat voor staat, is om een nieuwe invulling te geven aan de verbindingsfunctie. Verbinden is een functie die niet gemakkelijk te vertalen valt in een welomschreven repertoire voor instituties. Het is bij uitstek ook een functie die niet alleen een overheidstaak is. Het is zoeken langs welke lijnen deze functie inhoud gegeven kan worden. Het heterogener en individueler worden van de Nederlandse bevolking maken dat 'de' Nederlandse samenleving minder vanzelfsprekend geworden is, en ook minder vanzelfsprekend zal blijven. Dit betekent dat 'verbinden' meer actief onderhoud vereist. Het ideaal kan daarbij niet zijn om terug te keren naar een relatief gesloten en homogene samenleving. Een passender ideaal - en een ideaal dat 
ook sterk leeft in Nederland - is om voor iedereen mogelijkheden te scheppen om bindingen aan te gaan, dan wel zich er uit los te maken en ze in te wisselen voor andere. In de termen van dit advies: 'zware gemeenschappen' moeten 'licht' gemaakt worden, en 'lichte gemeenschappen' voldoende 'zwaar'.

Verbinden is bij uitstek een functie die niet alleen als overheidstaak aangemerkt kan worden. Ook van andere actoren - binnen het maatschappelijk middenveld mag verwacht worden dat zij zich inzetten. De overheid kan daaraan bijdragen door te zorgen dat tegenstellingen niet zo structureel worden dat ze op termijn ontwrichten. Dat stelt zware eisen aan de instituties van het onderwijs en de arbeidsmarkt. Die moeten niet alleen beter leren verheffen dan ze tot op heden hebben gedaan, maar bovendien leren omgaan met nieuwe tegenstellingen. De oorspronkelijke tegenstelling die de verzorgingsstaat hielp overbruggen, die tussen arm en rijk, heeft veel van haar scherpte verloren. Het overbruggen van nieuwe tegenstellingen komt daarvoor in de plaats. De verbinding tussen hoogen laagopgeleiden is daarbij nog het geringste probleem. Anders dan veel ons omringende landen slaagt de Nederlandse verzorgingsstaat er redelijk in om groeiende ongelijkheden in de primaire inkomensverdeling via belasting-en premieheffing te neutraliseren, en dat zonder al te geprononceerd verzet van de meest verdienenden. De verbinding tussen generaties is lastiger. Dat valt weliswaar mee op de arbeidsmarkt, die zeker niet vriendelijker is voor ouderen dan voor jongeren, maar op een aantal andere terreinen voelen jonge generaties zich wel degelijk uitgesloten. Zo zijn de bezuinigingen in de sociale zekerheid in belangrijke mate wel van toepassing op jongeren, maar niet op mensen die nu ouder zijn dan vijftig. Verder is de toegang tot de koopwoningmarkt voor jongeren zeer moeilijk geworden. In sommige regio's is de woningmarkt voor starters zelfs geheel gesloten. Dat kan gaan knagen aan de verhouding tussen de generaties.

Het overbruggen van verschillen langs etnische lijnen is echter ongetwijfeld de grootste opgave. Samen met België en Frankrijk scoort Nederland in Europa het hoogst als het gaat om de spanning die mensen voelen tussen allochtonen en autochtonen. Veel allochtonen in Nederland percipiëren de klassieke instituties (scholing, huisvesting, arbeid) als ondoordringbaar, en voor een deel van hen zijn ze dat ook. Dat kan zich vertalen in een (versterkt) zoeken naar eigen identiteiten of in het terugtrekken in eigen kring, wat de verbindingsopgave alleen maar lastiger maakt. Bovendien trekken ook autochtonen zich terug en lijken niet te willen delen in arbeid, inkomen en macht. Voor de tweezijdige verbinding tussen allochtonen en autochtonen is een brede strategie nodig. Aandacht voor de culturele dimensie van verbinding is, zo is in de jaren tachtig en negentig gebleken, een onvoldoende voorwaarde voor integratie; het gaat er ook om verbinding te realiseren in 'harde' aspecten van de samenleving. Arbeidsorganisaties zijn in dat kader van evident belang. Evenzeer is het voorschoolse en (basis)onderwijs een cruciale factor, omdat dit in de huidige samenleving de plaats bij uitstek is waar kinderen (en hun ouders) elkaar kunnen ontmoeten zodat stereotypering vermindert. 
Het ligt voor de hand om gemeenten nadrukkelijker een verbindingsopdracht te geven, en om ze daartoe ook wettelijk en financieel in staat te stellen. Al langer wordt geconstateerd dat voorschools en basisonderwijs etnische segregatie in de hand werken. Tot nu is er echter grote terughoudendheid om daar ook duidelijke consequenties aan te verbinden, hoewel sommige gemeenten initiatieven namen, net als ouders en scholen. Van systematisch beleid is geen echter sprake. Het komt daarbij vooral aan op het ontwikkelen van lokale, op specifieke situaties toegesneden oplossingen. Gemeenten kunnen zelf het beste bepalen hoe ze een premie op menging kunnen zetten. In kleinere gemeenten zou het zwaartepunt kunnen liggen op voldoende gemengd onderwijs. In de grote steden, met een hoge concentratie van allochtonen en een gebrek aan voldoende autochtone kinderen, zal het antwoord vooral gevonden moeten worden in interetnisch mengen - dus ook tussen allochtone groepen onderling - en extra aandacht voor de kwaliteit van het onderwijs; verheffen is immers ook een sleutel tot verbinden.

\section{Herwegen}

Wie de bovenstaande analyse van functies volgt, moet constateren dat de verzorgingsstaat in zijn twintigste-eeuwse vorm - dat wil zeggen sterk geënt op een homogene populatie, de natiestaat, en een verzoening van arbeid en kapitaal vooral goed is geweest in het ontwikkelen van een breed verzekerings- en verzorgingsstelsel. Het verzekeringsstelsel werd op sommige punten zelfs te breed, terwijl de verheffings- en verbindingsfunctie er te bekaaid afkwamen. Dat heeft ertoe geleid dat Nederland een land is geworden dat goed geïnvesteerd heeft in ouderen, maar veel minder in kinderen. We hebben een goed zorgaanbod voor ouderen, terwijl ook hun inkomen verhoudingsgewijs goed is geregeld. Het in internationaal opzicht zeer goede Nederlandse pensioenstelsel maakt, met de vermogensvorming die ouderen door huizenbezit en anderszins hebben verkregen, dat ook hun financiële positie verhoudingsgewijs zo goed is dat je voor sommige ouderen zelfs kunt spreken van 'oververzekerd'. Het is niet voor niets dat de armoede onder ouderen in Nederland het laagste is van Europa. Daar staat tegenover dat de zorg voor kinderen relatief beperkt is. Nederland heeft verhoudingsgewijs korte verlofperiodes rondom geboorte, een traag van de grond komende kinderopvang, die ook nog steeds vooral in het teken van opvang staat en niet van vorming, en een schoolsysteem dat redelijk presteert gemeten naar de hoeveelheid geld, maar dat niet de ambitie uitstraalt over de hele linie tot de Europese top te willen behoren. De 'verzekeringsstaat' van gisteren moet worden getransformeerd in de 'verheffingsstaat' van morgen.

\subsection{ANDERE VERWACHTINGEN EN AMBITIES}

De relatieve onderweging van verheffen en verbinden behoeft bijstelling. Dat die bijstelling nodig is, heeft te maken met het veranderen van de (internationale) context van de verzorgingsstaat en met het veranderen van zijn burgers. Maar behalve nodig is zo'n bijstelling ook wenselijk. De ambities ten aanzien van hun eigen leven en van de samenleving, en de verwachtingen die burgers van de 
verzorgingsstaat hebben, zijn immers gaandeweg ook veranderd. Drie verschuivingen in het bijzonder springen in het oog.

\section{Van compenseren naar voorkomen}

De verzekerings- en verzorgingsoriëntatie die de opbouw van de verzorgingsstaat in belangrijke mate kenmerkte, hing samen met de behoefte van werknemers aan bescherming tegen de scherpe kanten van de kapitalistische productiewijze, variërend van grote conjunctuurgolven tot gevaarlijke arbeidsomstandigheden, en de snelle wijziging van de productiestructuur. Mede dankzij de verzorgingsstaat zijn burgers nu beter in staat om voor zichzelf te zorgen en zijn de bedreigingen gemitigeerd. Dat heeft geleid tot andere verwachtingen ten aanzien van inkomensbescherming. Die had een sterk compenserend karakter: wie om welke reden ook niet kon werken, werd daar tot op zekere hoogte financieel voor gecompenseerd. In de loop der tijd bleek dat echter disfunctioneel. Te veel mensen namen te snel en te gemakkelijk genoegen met de financiële gunsten van de verzekeringsstaat. In antwoord daarop werd in toenemende mate het ex-postbeleid waar mogelijk veranderd in een ex-antebeleid. In plaats van het compenseren van tegenslagen werd het voorkomen van uitsluiting de primaire doelstelling. Dit moest, zo was het idee, mogelijk zijn in een samenleving met een hoog algemeen inkomensniveau en een goed opgeleide bevolking. De verzorgingsstaat geeft in deze gedaante niet zozeer rechten, maar biedt contracten aan, met een accent op wederkerigheid. Zijn politieke en burgerrechten onvervreemdbaar, sociale rechten zijn weer conditioneel geworden. Op papier waren ze dat overigens altijd al, maar de uitvoeringspraktijk gaf daar soms te weinig uitdrukking aan. Dat is aan het veranderen.

Bovendien zijn burgers meer in dienstverlening geïnteresseerd geraakt, zeker leden van de middenklasse (en die is heel breed in Nederland). Zij zijn de verzorgingsstaat in toenemende mate gaan zien als een stelsel van voorzieningen. Het is voor hen steeds belangrijker dat de dienst waaraan ze behoefte hebben, beschikbaar is en voldoet aan de eigen kwaliteitsnormen. Daarbij wordt het minder belangrijk gevonden wie die diensten (onderwijs, zorg, kinderopvang, arbeidsbemiddeling) verleent. Klantgerichtheid en responsiviteit bij de uitvoering en een heterogener aanbod zijn daarentegen steeds belangrijkere onderscheidende kenmerken geworden.

\section{Van verzekeren naar investeren}

De verzorgingsstaat moet mensen ook kansen bieden om zich verder te kunnen ontwikkelen - die verwachting wordt steeds manifester. Lang sprak die ambitie bijna vanzelfsprekend. Ergens in de jaren zeventig van de vorige eeuw verdween ze echter naar de achtergrond. De ontwikkelingsdimensie kwam toen in het teken te staan van een soms zeer ruim opgevat ontplooiingsideaal. In reactie daarop groeide de overtuiging dat ontplooiing vooral een kwestie is van persoonlijke en niet van collectieve ambitie en verantwoordelijkheid. De verzorgingsstaat stelde herziening van de sociale zekerheid voorop. Op basis van zowel budgettaire als morele argumenten ging de aandacht uit naar een doelmatige 
uitvoering van en reductie van het beroep op socialezekerheidsregelingen. Toch blijven de traditionele ontwikkelingsnoties - goed onderwijs en zinvolle arbeid onverminderd relevante categorieën. De laatste jaren neemt de overtuiging zelfs toe dat deze categorieën aan een herwaardering toe zijn. De verzorgingsstaat is zo weer meer een 'investeringsproject' aan het worden: ze dient te investeren in menselijk kapitaal. Dit betekent dat het herverdelingsaspect een ander object krijgt: minder gericht op de herverdeling van inkomen en vermogen, en meer op de herverdeling van kansen. Of, met andere woorden, waar in verzorgen en verzekeren is voorzien, verschuift de nadruk naar verheffen. Dit brengt met zich mee dat er in plaats van over verzekeringsrechten en -plichten ook gesproken zou moeten worden over investeringsrechten en -plichten. Een belangrijk aandachtspunt daarbij is dat de instituties van de verzorgingsstaat zo moeten zijn ingericht dat iedereen ook het gevoel heeft dat er reële kansen zijn: toegang en doordringbaarheid zijn van steeds groter belang. Het wordt steeds belangrijker om te voorkomen dat mensen vast blijven zitten in achterstandssituaties.

Armoede of leerachterstand zijn op zichzelf niet het probleem, er niet bij weg kunnen komen wél.

\section{Van gelijkheid van uitkomsten naar gelijkheid van kansen}

De verzorgingsstaat komt ook steeds meer in het teken te staan van gelijkheid van kansen, en minder in het teken van gelijkheid van uitkomsten. Een moderne verzorgingsstaat moet zowel recht doen aan de gelijkheid tussen individuen als aan hun handelingsverantwoordelijkheid. Een verdeling van hulpbronnen en posities voldoet pas aan deze norm als ze, om met de Amerikaanse filosoof Ronald Dworkin (2000) te spreken, tegelijk 'gevoelig' is voor verschillen in talent en inzet, en 'ongevoelig' is voor verschillen die buiten het bereik van de individuele verantwoordelijkheid liggen. Gelijkheid betekent dan niet 'iedereen hetzelfde', maar 'iedereen gelijke ontplooiingskansen' al naar gelang vermogens en voorkeuren, ook al impliceert dat, door verschillen in talent en inzet, 'grote' verschillen in uitkomsten.

Daarnaast is een voldoende mate van wederzijdse betrokkenheid gewenst. Een verzorgingsstaat zonder voldoende wederzijdse betrokkenheid verliest geleidelijk zijn legitimiteit en daarmee zijn bestaansrecht. Om die te garanderen moeten de verschillen in uitkomsten niet alleen binnen collectief onderschreven grenzen blijven, maar moet ook ernst worden gemaakt met het idee van doordringbaarheid dat ten grondslag ligt aan de verheffingsfunctie. Nogmaals, tijdelijke achterstand is niet altijd te vermijden. Het is structurele achterstand die met alle middelen moet worden bestreden. Geen enkel verschil mag tenslotte zo groot zijn dat het een basaal gevoel van gemeenschapszin ondermijnt. Over deze pijlers onder de westerse verzorgingsstaten bestaat grote - vaak impliciete - consensus. In termen van dit advies heet dat een 'zachtmoedige meritocratie': een samenleving met gelijke kansen en voldoende prikkels om talenten maximaal te (kunnen) ontwikkelen, maar met de acceptatie van menselijke beperkingen die een zuivere meritocratie ontbeert. Om een samenleving, kortom, waarin verheffen niet ten koste gaat van verbinden. 


\subsection{ANDERE VERANTWOORDELIJKHEIDSVERDELING}

Het is nodig en wenselijk om meer werk te gaan maken van verheffen en verbinden, zo is de boodschap. Dat geeft richting aan het te voeren beleid, maar heeft ook implicaties voor de verantwoordelijkheidsverdeling. Verzorgen en verzekeren moeten en kunnen weer meer een verantwoordelijkheid van burgers worden, waarbij de overheid vooral een kaderstellende rol vervult, terwijl verheffen en verbinden vragen om een actiever en offensiever optredende overheid.

Bij verzorgen en verzekeren zal de overheid een kaderstellende taak moeten behouden, maar veel van de invulling kan aan anderen worden overgelaten. Dat moet leiden tot meer ruimte voor individuele variatie, tot differentiatie in arrangementen en tot minder uniforme regelingen. In de zorg betekent dit bijvoorbeeld dat de komende jaren een grotere speelruimte kan ontstaan voor betrokkenen in de langdurige zorg voor ouderen (AWBZ), opdat er een breder en diverser scala van voorzieningen (woon-zorgcombinaties) komt. Die voorzieningen zullen zich directer moeten richten op gebruikers en zich ook tegenover hen moeten verantwoorden. Dat zou bijvoorbeeld kunnen door de financiering een minder centralistisch karakter te geven, meer ruimte te scheppen voor private betalingen en verder te gaan op de weg van vraaggebonden financiering, een weg die in landen als Oostenrijk, Finland en Duitsland al langer ingeslagen is.

In de sociale zekerheid zou de vorm en mate waarin de oude dag verzekerd is, meer ruimte moeten bieden voor individuele preferenties. In Nederland is een sterk accent komen te liggen op het verzekeren van de oude(re) dag. Dat paste bij een generatie die niet over eigen middelen beschikte, en aan wie het maken van langetermijnkeuzes ook niet goed toevertrouwd kon worden. Dat beeld is aan het veranderen. De inkomens- en vermogenssituatie van oudere mensen vertoont een grotere heterogeniteit (sommigen hebben inmiddels een ruim pensioen en een huis met een afgeloste hypotheek, terwijl anderen louter zijn aangewezen op de AOw). Het verdient dan ook aanbeveling om niet langer aan iedereen de plicht op te leggen de oude dag zo zwaar te verzekeren als nu de standaard is geworden. Een iets minder zwaar regime, en de mogelijkheid om daarbinnen meer individuele keuzen te maken, zijn passender bij deze tijd. In het verlengde daarvan ligt het ook voor de hand om de uitvoering en de maatvoering van de sociale zekerheid weer meer in handen te leggen van de partijen die daar het meeste belang bij hebben - werknemers en werkgevers en hun representatieve organisaties - in het bijzonder voor zover het gaat om risico's die ze zelf kunnen beïnvloeden.

Tegenover deze overheid die zich meer beweegt in de richting van een kaderstellende rol bij verzekeren en verzorgen, staat een overheid die als het gaat om verheffen en verbinden nadrukkelijk aanwezig is, initiatief neemt en aanspoort. De publieke verantwoordelijkheid voor opvoeding, scholing en sociale samenhang moet weer nadrukkelijker gevoeld worden en de overheid moet zich daarop ook laten aanspreken. Het klassieke beleidsinstrumentarium van wetten, regels en financieringsbronnen is daarbij vaak wel een noodzakelijke voorwaarde, maar 
meestal niet voldoende. Tal van maatschappelijke actoren hebben hier een rol. De overheid moet de opdracht juist een gedeelde opdracht maken waarbij ze intelligente coalities met maatschappelijke organisaties aangaat. De overheid speelt daarbij soms de rol van aanjager en coach, soms die van regisseur, en af en toe die van opdrachtgever.

De mate van verantwoordelijkheid van de overheid met betrekking tot verheffen is omgekeerd evenredig met de leeftijd van de betrokkenen. Het vermijden van grote achterstanden op jonge leeftijd door het tot stand brengen van een breed palet van kinderopvangvoorzieningen waarin de voor- en vroegschoolse educatie is geïntegreerd, is daarbij urgent. Ook het verbeteren van de kwaliteit van het basisonderwijs en het (v)mbo, past in deze lijn. Het universitair onderwijs kent behalve maatschappelijke ook duidelijk grote persoonlijke baten. Het ligt dan ook in de rede dat de extra investeringen die nodig zijn voor de jongere leeftijdsgroepen, tot op zekere hoogte gefinancierd worden door in het tertiair onderwijs het profijtbeginsel nader inhoud te geven. Dat kan bijvoorbeeld langs lijnen die daarvoor in Schotland en Australië zijn ontwikkeld, waar academici die dankzij hun studie boven een bepaald inkomensniveau komen, via additionele belastingen een deel van hun studiekosten terugbetalen.

De gewenste verantwoordelijkheidsverdeling voor verbinden is zo mogelijk een nog complexer vraagstuk. Een probleem is dat in dit geval de verantwoordelijkheid niet alleen diffuus ligt, maar ook weinig gevoeld wordt. Voor een deel komt dat doordat vele (publieke en private) partijen hierbij een rol spelen, en de overheid slechts zelden een formele (doorzettings)macht heeft. Het is daarom van belang om de publieke verantwoordelijkheid helderder te gaan benoemen. Juist omdat verbinden gaat om het met elkaar in verband brengen van zoveel verschillende personen, instituties en regelingen, ligt het voor de hand hier vooral een meer ruimtelijke benadering te kiezen. Daarbij zou aangesloten kunnen worden op de manier waarop de laatste jaren op lokaal niveau burgemeesters en wethouders het als hun taak definieerden om verbinding tot stand te brengen. $\mathrm{Zij}$ ervaarden niet alleen een maatschappelijk gemis op dat gebied, maar meenden ook dat zij die taak verder inhoud moesten geven, ook al hadden ze daarvoor geen dekkend wettelijk instrumentarium. Tekenend is dat deze ambitie door alle partijen heen valt terug te vinden en vaak gedragen werd door colleges die breed waren samengesteld. Opdat deze ontwikkeling meer kracht krijgt, zou ten behoeve van de verbindingsfunctie verder inhoud gegeven kunnen worden aan de verzorgingsstad, ter aanvulling van de verzorgingsstaat. Of, om het adequater uit te drukken: de 'verbindingsstaat' vereist een 'verbindingsstad'. Zo ligt het voor de hand om de verantwoordelijkheid voor jeugdigen niet te verspreiden over vele partijen, maar deze primair te leggen bij de gemeente. Verantwoordelijkheid is daarbij niet hetzelfde als uitvoering: uitvoering kan goed aan partijen worden gedelegeerd, ook op een hoger schaalniveau dan dat van de gemeente. Het ligt ook voor de hand dat vrijheid ontstaat om middelen op het terrein van kinderopvang, onderwijs en huisvesting zo in te zetten dat ze daadwerkelijk bijdragen aan verschillende vormen van menging. Dat kan de vorm aannemen 
van een gemeentelijk verbindingsbudget. De praktijk kan dan een grote variëteit aan invullingen laten zien. Een bijkomend voordeel van deze werkwijze is dat ze goed past bij een globaliserende wereld: het blijkt dat transnationale bindingen juist heel goed samen kunnen gaan met verbindingen op het niveau van een stad. Migranten voelen zich nog het meest verbonden met de stad. 'We zijn allemaal Rotterdammers' biedt vaak een vruchtbaarder identificatieperspectief dan 'we zijn allemaal Nederlanders'.

\subsection{VERANDERINGSSTRATEGIE}

\section{Elan, niet angst regeert}

De kernboodschap van dit advies is dat in de verzorgingsstaat een verschuiving van aandacht gewenst is van de functies verzekeren en verzorgen naar de functies verheffen en verbinden. Hoe valt aan een dergelijke doorontwikkeling van de verzorgingsstaat naar meer offensieve patronen vorm te geven? Van belang is allereerst om een voldoende ambitieus klimaat te creëren. De transformatie van de verzorgingsstaat vergt een specifieke stijl: de stijl van wenkende idealen. Incrementele, bijna technische aanpassingen met een hoog no-regret-gehalte en een lage mate van politieke kleuring werken onvoldoende. Wanneer dat de overheersende stijl van besturing wordt, verdwijnt de vraag naar de urgentie en vooral ook de vraag naar de richting. Het is dan ook niet verwonderlijk dat de verzorgingsstaat de laatste jaren herhaaldelijk is afgeschilderd als een wees. Het is blijkbaar onhelder geworden wie hem geloofwaardig als 'project' kan neerzetten. Idealen articuleren is lastig gebleken. Toch zijn ze nodig willen we tot een toekomstgericht, toekomstbestendig en breed gedragen programma komen voor de verzorgingsstaat van de eenentwintigste eeuw.

\section{Voorbij de modellendiscussie}

Het weer nadrukkelijker formuleren van ambities moet vooral gebeuren in termen van inhoudelijke doelstellingen, niet in termen van archetypische modellen van de verzorgingsstaat. Uit hoofdstuk 4 kwam naar voren dat er geen uitruil bestaat tussen economische prestaties en stelsels van sociale zekerheid. Prestaties van verzorgingsstaten zijn wel te vergelijken, maar lastig causaal te verklaren. Wie andere tijdsperioden kiest, komt tot andere conclusies. In de jaren tachtig deden de Scandinavische landen het minder goed, terwijl Duitsland nog als Wirtschafswunder werd geprezen, met als voornaamste argument dat de arbeidsmarkt zekerheid bood: werkgevers konden hun medewerkers niet of nauwelijks ontslaan, en dat bracht hen ertoe, zo was de redenering, om te investeren in scholing en productinnovatie. Vooralsnog lijkt de conclusie van het vele internationale vergelijkende onderzoek dat er geen superieur model for all times is. Daar komt bij dat het verschil tussen de landen in Europa steeds kleiner wordt - landen nemen steeds meer beleidsinstrumenten van elkaar over. In alle Europese landen is er vanaf de jaren negentig een beweging waar te nemen om activering en preventie beter in de sociale zekerheid verankeren. Ook zijn alle Europese landen vanaf het begin van de eenentwintigste eeuw meer gaan investeren in scholing. Een benadering in termen van modellen miskent ten slotte ook de specifieke 
geschiedenis van de typisch Nederlandse instituties. Het lijkt vruchtbaarder om Nederland niet, zoals nu vaak gebeurt, te bekritiseren omdat het een hybride land is dat zich ergens tussen een Continentaal en een Scandinavisch model bevindt, maar om het te zien als een land met een eigen geschiedenis en ontwikkelingsrichting.

\section{Naar gedeelde ontwikkelingsrichtingen}

De benadering die de raad in dit rapport gekozen heeft, is er een die redeneert in termen van grote bewegingen: de gekozen tijdshorizon is die van enkele decennia. Vanuit dat perspectief is het veranderingsprogramma als het gaat om verzekeren een fase van afronding aan het bereiken, heeft het zorgprogramma een andere focus nodig, is het zaak de aanzetten voor een verheffingsprogramma krachtig verder ter hand te nemen en is het zoeken naar een verbindingsprogramma nog volop gaande. Het is de uitdaging om met name aan de verheffingsen verbindingsprogramma's meer inhoud te geven. Dat proces moet vooral gestuurd worden vanuit doelstellingen, en niet te snel worden vertaald in stelselherzieningen. Stelselwijzigingen zijn specifieke manieren om een programma invulling te geven. Ze verliezen echter al snel hun legitimiteit als niet helder is welk doel ze dienen. Of het nu gaat om het onderwijs, de gezondheidszorg of de sociale zekerheid: in brede kring bestaat het gevoel dat deze sectoren niet weer moeten worden opgezadeld met grote systeemwijzigingen. De prijs daarvan is ook altijd hoog, niet alleen vanwege de zichtbare transformatiekosten, maar juist ook door de onzichtbare vermindering van motivatie bij de betrokken professionals, terwijl het effect vaak gering is, soms zelfs averechts, of pas op termijn te zien. Dit probleem is wellicht het meest nijpend in het onderwijs: de sector is duidelijk moe van schaalvergroting en andere organisatieveranderingen, nieuwe onderwijsconcepten en nieuwe taken voor scholen en leerkrachten, terwijl de school tegelijkertijd meer dan ooit een belangrijk scharnierpunt is in de inrichting van de moderne samenleving. Een veranderingstraject vormgeven dat rekening houdt met al deze elementen, vergt stuurmanskunst. Het creëren van voldoende commitment aan de ontwikkelingsrichting, en het geven van ruimte aan de betrokkenen om zelf oplossingen aan te dragen, zijn daarbij essentieel. In dit advies - dat uit zijn aard een advies aan de regering is - is met name gespecificeerd wat een veranderingsprogramma impliceert voor de activiteiten van de overheid, maar de uiteindelijke kracht van zo'n programma schuilt in de mate waarin het vorm weet te geven aan een maatschappelijke agenda.

\section{Managen van langetermijnveranderingen}

Het trekken van lange lijnen verhoudt zich lastig tot het vaak door kortetermijnoverwegingen gedomineerde politieke spel. De opdracht is daarom om een manier te vinden om veranderingen die langer duren dan een kabinetsperiode politiek te managen. Neem het debat over de kosten van de vergrijzing. Wijzigingen van pensioensystemen, flexibilisering van de AOW-leeftijd, verdere fiscalisering van de AOw, bevorderen van het doorwerken na het zestigste levensjaar: het zijn allemaal veranderingen die alleen geleidelijk doorgevoerd kunnen worden. In dit opzicht zou inspiratie geput kunnen worden uit de herziening van het pensioen- 
stelsel in Zweden. In dit land - dat twintig jaar vooroploopt op Nederland in de mate van vergrijzing - is al in de jaren tachtig een breed maatschappelijk debat gevoerd dat leidde tot een voorstel voor een geleidelijke bijstelling van het pensioenstelsel in de decennia die zouden volgen. Het voorstel bevatte met opzet elementen afkomstig van de verschillende politieke richtingen, zodat het bij volgende kabinetsformaties op hoofdlijnen overeind zou blijven. Het feit dat het voorstel ook voorzag in automatische bijstellingen als bijvoorbeeld bevolkingsopbouw of beleggingsopbrengsten zouden fluctueren, bevorderde de acceptatie en voorkwam permanente politisering en de daarmee gepaard gaande gevoelens van onzekerheid bij burgers. Op een vergelijkbare wijze zou ook het (weer) breed toegankelijk maken van de woningmarkt van een langetermijnperspectief voorzien kunnen worden.

\section{Tot slot}

De verzorgingsstaat moet worden herwogen. Meer aandacht voor verheffen en verbinden moet de nieuwe ambitie vormen voor de verzorgingsstaat van de komende decennia. Het is de vraag of de term 'verzorgingsstaat' hier nog wel bij past - hij sluit in ieder geval niet goed aan op wat er in dit advies bepleit wordt. In diverse buitenlanden is het tegenwoordig gebruik om te spreken over een enabling state, een social investment state of een developmental welfare state - het zijn stuk voor stuk termen die in de richting komen, maar geen van alle drukken ze de vereiste functieverschuivingen adequaat uit. Welke term de boventoon gaat voeren, zal wel blijken. Een fixatie op termen is in ieder geval weinig vruchtbaareen helder beeld hoe we de verschillende functies van de verzorgingsstaat wegen, is dat wel. 


\section{LITERATUUR}

Afman, E. (2005) 'Income distribution dynamics in the Netherlands in the 2oth century Long run developments and cyclical properties', A IAS-working paper 2005-38 Amsterdam: Universiteit van Amsterdam.

Aiginger, K. en A. Guger (2005) 'The European socio-economic model', Working paper 266/2005, Österreichisches Institut für Wirschaftsforschung, Wenen.

Akerlof, G.A. (1970) 'The market for "lemons": quality uncertainty and the market mechanism', Quarterly Journal of Economics, 84: 488-50o.

Alber, J. en U. Köhler (2004) Health and care in an enlarged Europe, European Foundation for the Improvement of Living and Working Conditions, Luxemburg: Europese Commissie.

Arts, W., H. Entzinger en R. Muffels (red.) (2004) Verzorgingsstaat vaar wel, Assen: Van Gorcum.

Atkinson, A.B. en W. Salverda (2005) 'Top incomes in the Netherlands and the UK over the twentieth century', Journal of the European Economic Association, 3, 4: 883913 .

Bakker, K. en S. van Oenen (2005) Vernieuwing van de pedagogische infrastructuur o-12 jarigen, Manuscript WRR.

Bannier, G.W. (1936) Grondwetten van Nederland, Zwolle: W.E.J. Tjeenk Willink.

Barr, N. (2004) The economics of the welfare state, Oxford: Oxford University Press (fourth edition).

Beck, U. (1986) Die Risiko Gesellschaft. Auf dem Weg nach einem anderen Moderne, Frankfurt: Suhrkamp.

Becker, H. (1997) De toekomst van de verloren generatie, Amsterdam: Meulenhof.

Beer, P. de (2001) Over werken in de postindustriële samenleving, Den Haag: SCP.

Beer, P. de (2006) 'Zin en onzin van arbeidsmigratie. Schrikbeeld of wondermiddel', Internationale Spectator, juli-augustus: 343-346.

Bekker, S., A. Gielen, M. Kerkhofs, H. Meihuizen, A. Román, J. Schippers en A. de Voogd (2005) Trendrapport: Vraag naar arbeid 2004, OSA-publicatie A215, Tilburg: OSA.

Berg, B. van den (2005) Informal care: an economic approach, dissertatie Erasmus Universiteit.

Berg, B. van den et al. (2003) Mantelzorg en persoonsgebonden budget, Bilthoven: RIVM.

Berkhout, A., A. Odé en H. Weening (2001) Minderheden gevraagd. Evaluatie van het convenant instroom etnische minderheden in het midden- en kleinbedrijf, Den Haag: Ministerie van Sociale Zaken en Werkgelegenheid.

Berlin, I. (1958) Two concepts of liberty, Oxford: Clarendon Press.

Boeri, P. (2006) 'Migration policy and the welfare state', Paper Netsparconferentie, Den Haag, 27-28 april 2006.

Bonoli, G. en B. Palier (1997) 'Reclaiming welfare: the politics of French social protection reform', South European Society and Politics, 1, 3: 241-259.

Bos, J. en E. Hooghiemstra (2004) 'Het gezinsdal: verandering van koopkracht na het krijgen van kinderen', CBS-Bevolkingstrends, vierde kwartaal 2004: 61-67.

Bovenberg, A.L. (2005) 'Balancing work and family life during the life course', De Economist, 153, 4: 399-423. 
Bovenberg, A.L. (2005a) 'Nieuwe pensioencontracten', Tijdschrift voor Openbare Financiën, 37, 3: 118-128.

Braggen, P. en I. Weijers (1995) De toekomst van de universiteit, Amsterdam: Amsterdam University Press.

Brandsen, T. en J.K. Helderman (2006) 'Wonen; ruimte voor sociale investeringen', in Jaarboek Beleid en Maatschappij 2006.

Brighouse, H. (2005) On education, London: Routledge.

Brink, G.J.M. van den (2004) Schets van een beschavingsoffensief. Over normen, normaliteit en normalisatie in Nederland, WRR-Verkenning no. 3, Amsterdam: Amsterdam University Press.

Brink, G.J.M. van den (1999) Een schaars goed: de betekenis van zorg in de hedendaagse levensloop, Utrecht: NizW.

Brounen, D. (2006) 'Starters in het nauw', in: Christen Democratische Verkenningen, lente 2006: 35-46.

Bureau Veldkamp (2004) Vergrijzing in Nederland, Onderzoek uitgevoerd in opdracht van de Rijksvoorlichtingsdienst/Publiek en Communicatie ten behoeve van het Ministerie van Volksgezondheid, Welzijn en Sport, Amsterdam.

Caminada C.L.J. en K.P. Goudswaard (2003) Verdeelde zekerheid. De verdeling van lasten en baten van sociale zekerheid en pensioenen, Den Haag: Sdu Uitgevers.

Caminada, C.L.J. en K.P. Goudswaard (2004) 'The fiscal subsidy on pension savings in the Netherlands', Tax Notes International, 33, 13: 1231-1240.

Canoy, M. en P.M. Smith (2006) 'A social and economic model for Europe', Intereconomics. Review of European Economic Policy (te publiceren).

Castles, F. (2004) The future of the welfare state. Crisis, myths and crisis realities, Oxford: Oxford University Press.

Centraal Bureau voor de Statistiek (2004) Vrouwen op de arbeidsmarkt. Sociaal-economische trends, derde kwartaal 2004, Voorburg: CBS.

Centraal Bureau voor de Statistiek (2005a) Statistisch onderwijsjaarboek 2005, Voorburg: CBS.

Centraal Bureau voor de Statistiek (2005b) 'Met een startkwalificatie betere kansen op de arbeidsmarkt', С ВS Webmagazine, 7 november 2005, Voorburg: СВS.

Centraal Bureau voor de Statistiek (2006a) 'Vrouwen in opmars op de arbeidsmarkt', Webmagazine, 6 februari 2006, Voorburg: CBS.

Centraal Bureau voor de Statistiek (2006b) Werkloosheid niet-westerse allochtonen nauwelijks toegenomen in 2005, Persbericht 06-15, Voorburg: CBS, 13 februari 2006.

Centraal Bureau voor de Statistiek en RIVM - MNP, in samenwerking met CPB, RPB, SCP en NIDI (A.H. de Jong en H.B.M. Hilderink) (2004) Lange-termijn bevolkingsscenario's voor Nederland, Bilthoven: RIVM.

Centraal Planbureau (2000) Ageing in the Netherlands, Den Haag: CPB.

Centraal Planbureau (2006) Kansrijk kennisbeleid, СРB-document nr. 124, Den Haag: СРB.

Centraal Planbureau (F. Bos, R. Douven en E. Mot) (2004) Vier toekomstscenario's voor overheid en zorg, Den Haag, СРB-document no. 72, november 2004, Den Haag: CPB.

Centraal Planbureau (F. Huizinga en B. Smid) (2004) Vier vergezichten op Nederland. Productie, arbeid en sectorstructuur in vier scenario's tot 2040, Den Haag: СРВ. 
Centraal Planbureau (H. Roodenburg, R. Euwals en H. ter Rele) (2003) Immigration and the Dutch Economy, Den Haag: CPB.

Centraal Planbureau (R. de Mooij e.a.) (2006) Reinventing the welfare state, Den Haag: CPB.

Centraal Planbureau (A. van Vuren) (2003) Financiële consequentie PVK-regels, CPBMemorandum, Den Haag: CPB, 7 februari 2003.

Centraal Planbureau (C. van Ewijk, N. Draper, H. ter Rele en E. Westerhout, in cooperation with J. Donders) (2006) Ageing and the sustainability of Dutch public finances, СРВ-Bijzondere Publicatie no. 21, Den Haag: СРВ.

Centraal Planbureau (F. Bos) (2006) De Nederlandse collectieve uitgaven in historisch perspectief, СРВ-document no. 109, Den Haag: СРВ.

Commissie-Leijnse (Denktank Anders denken over zekerheid) (2002) Levenslopen, risico en verantwoordelijkheid, Rapport voor de minister en de staatssecretaris van Sociale Zaken en Werkgelegenheid, Den Haag, 25 september 2002.

Crouch, C., D. Finegold en M. Sako (1999) Are skills the answer? The political economy of skill creation in advanced industrial economies, Oxford: Oxford University Press.

Dalen, H.P. van, en C.J.I.M. Henkens (2004) 'Scheuren in het contract tussen generaties; over langer doorwerken en solidariteit', Demos, Bulletin over bevolking en samenleving 20, 1: 1-4.

Daly, M. en J. Lewis (1998) 'Introduction: Conceptualising social care in the context of welfare state restructuring', in J. Lewis (red.) Gender, social care and welfare state. Restructuring in Europe, Aldershot: Ashgate: 86-103.

Derks, W.M., P. Hovens en L.E.M. Klinkers (2006) Structurele bevolkingsdaling. Een urgente nieuwe invalshoek voor beleidsmakers, Rapport voor de Raad voor Verkeer en Waterstaat en de VRom-Raad, Den Haag.

Doorn, J.A.A. van (1977) 'De verzorgingsmaatschappij in de praktijk', in: J.A.A. van Doorn en C.J.M. Schuyt (red.) De stagnerende verzorgingsstaat, Meppel: Boom: 17-46.

Doorn, J.A.A. van en C.J.M. Schuyt (red.) (1977) De stagnerende verzorgingsstaat, Meppel: Boom.

Driouichi, F. (2004) Inkomensbescherming bij zorgverantwoordelijkheid. Sociale zekerheid van een zorgende werknemer tijdens transities van arbeid en zorg (dissertatie Universiteit van Utrecht), Meppel: Boom Juridische Uitgevers.

Dronkers, J. (2006) 'Hoe kan het onderwijs voor elkaar krijgen dat meer talenten benut worden? Meer effectieve scholen en betere leerkrachten!', de Volkskrant, www.volkskrant.com/bijlagen/dronkers.pdf.

Duménil, G. en D. Lévy (2004) 'Neoliberal income trends,' New Left Review 30: 105-134.

Dürkheim, E. (1893) De la division du travail social: Étude sur l’organisation des sociétés supérieures, Paris: Félix Alcan.

Duyvendak, J.W. en M. Hurenkamp (red.) (2004) Kiezen voor de kudde: lichte gemeenschappen en de nieuwe meerderheid, Jaarboek Tijdschrift voor de Sociale Sector, Amsterdam: Van Gennep.

Dworkin, R. (200o) Sovereign virtue: the theory and practice of equality, Cambridge, MA: Harvard University Press.

Dykstra, P. (1994) Employment and caring, Working paper 1997/7, Den Haag: NIDI.

Ederveen, S., R. de Mooij en A. Soude (2003) Social Europe, Occasional Paper 5. ENEPRI 
Eerste Kamer der Staten-Generaal, I mei 2006 Werknemersverkeer met de nieuwe EUlidstaten.

Ehrenreich, B. en A.R. Hochschild (red.) (2002) Global women: nannies, maids, and sex workers in the new economy, New York: Holt.

Ellison, N. (2006) The transformation of welfare states?, London: Routledge.

Entzinger, H. (2002) 'Arbeidsmigratie in de eenentwintigste eeuw: noodzaak of last?' in: F. Becker, W. van Hennekeler, M. Sie Dhian Ho en B. Tromp (red.), Transnationaal Nederland. Drieëntwintigste jaarboek voor het democratisch socialisme, Amsterdam: De Arbeiderspers.

Esping-Andersen, G. (1990) The three worlds of welfare capitalism, Cambridge: Polity Press.

Esping-Andersen, G. (2006) 'De toekomst van ons sociale stelsel - deel II (I). Investeer in kinderen', Socialisme \& Democratie, 63, 6: 12-24.

Esping-Andersen, G. (2006) Putting the horse in front of the cart: towards a social model for mid-century Europe, WRR-Lecture 2005, Amsterdam: Amsterdam University Press.

Estlund, C. (2003) Working together: How workplace bonds strengthen a diverse democracy, Oxford: Oxford University Press.

European Foundation for the Improvement of Living and Working Conditions (2005) First European Quality of Life Survey: Families, work and social networks, Luxemburg: Office for Official Publications of the European Communities.

Europese Commissie (2005) The EU economy 2005 review. Rising international economic integration. Opportunities and challenges, Brussel: DG ECFIN.

Europese Commissie (2006) The European economy. Special report no.1. The impact of ageing on public expenditure: projections for the EU25 member states on pensions, health care, long term care, education and unemployment transfers (2004-2050), Brussel: Economic Policy Committee en DG ECFIN.

Ewald, F. (1986) L'etat providence, Paris: Grasset.

Ferrera, M. (2005) The boundaries of welfare. European integration and the new spatial politics of social protection, Oxford: Oxford University Press.

Ferrera, M. en A. Hemerijck (2003) 'Recalibrating Europe’s welfare regimes', in: J. Zeitlin en D.M. Trubek (red.) Governing work and welfare in the new economy: European and American Experiments, Oxford: Oxford University Press.

Ferrera, M., A. Hemerijck en M. Rhodes (2000) The future of social Europe: recasting work and welfare in the new economy, Lissabon: Celta Editora.

Finegold, D. en D. Soskice (1988) 'The failure of training in Britain: Analysis and prescription', in Oxford Review of Economic Policy, 4: 21-53.

FORA (2005) Dutch capacity for productivity growth. From benchmarking to policy priorities,www.foranet.dk/upload/from-benchmarking-to-policy-priorities-final. pdf

Frank, R.H. en P. Cook (1996) The winner-takes-all society: why the few at the top get so much more than the rest of us, New York/London: Penguin.

Frieden, J. (2006) Global capitalism. Its fall and rise in the twentieth century, New York: Norton.

Gaalen, R. van (2005) 'Verwachtingen van ouderen ten opzichte van hun kinderen omtrent mantelzorg', in: Geron, Tijdschrift voor Sociale Gerontologie, 7, 3: 25. 
Ganesh, K. (2006) 'Made to measure. Dutch elder care at the intersections of policy and culture', in: C. Risseeuw, R. Palriwala en K. Ganesh (eds.) Care, culture and citizenship. Revisiting the politics of the Dutch welfare state, Amsterdam: Spinhuis Publishers.

Geest, L. van der (2005) Blijvende zorg. Economische aspecten van langdurige ouderenzorg, Achtergrondstudie NYFER uitgebracht door de Raad voor Volksgezondheid en Zorg, Zoetermeer.

Gesthuizen, M. (2004) The life-course of the low-educated in the Netherlands: Social and economic risks, dissertatie Nijmegen.

Gevers Deynoot-Schaub, M. (2006) Young children's behavior and experiences in child care centers: A longitudinal study, dissertatie Universiteit Leiden.

Gijsberts, M. en M. Hartgers (2005) 'Minderheden in het onderwijs', pp. 57-8o in: SCP/WODC/CBS Jaarrapport integratie 2005, Den Haag: SCP/WODC/CBS.

GPD/Motivaction (2006) Racismeonderzoek, http://www.motivaction.nl/153/d:188/Nieuws/Nieuws/Antwoorden- GPD -en-Motivaction-op-meest-gesteldevragen-over-racismeonderzoek.

Griffith, R. en A. Klemm (2005) 'What has been the tax competition experience of the last 20 years?’, Working Paper 04/05, Londen: Institute for Fiscal Studies.

Groot, W. en H. Maassen van den Brink (2003) Investeren en terugverdienen. Kosten en baten van onderwijsinvesteringen, Den Haag: SBO.

Haffner, M.E.A. (2005) Appel voor de dorst? Vermogen van ouderen op de woningmarkt, Utrecht: GPD/Nethur, no 29.

Hakim, C. (200o) Work-lifestyle choices in the 21st century: preference theory, Oxford: Oxford University Press.

Hazeu, C.A. (1999) 'Is er toekomst voor ouderen op de arbeidsmarkt?’, Geron. Tijdschrift voor Sociale Gerontologie, 1, juni: 5-13.

Hazeu, C.A. (2000) Institutionele economie. Een optiek op organisatie- en sturingsvraagstukken, Bussum: Coutinho.

Hazeu, C.A. (2004) 'Woningcorporaties: arm leven, rijk sterven?', Tijdschrift voor Openbare Financiën, 36, 4: 188-198.

Hazeu, C.A. (2005) Het voortdurende succes van het Ierse superpoldermodel, ESB, 90, 17: 278-279.

Hazeu, C.A. (2006) ‘Wet Maatschappelijke Ondersteuning', in: C.A. de Kam en A.P. Ros (red.) Jaarboek Overheidsfinanciën 2006, Den Haag: Sdu Uitgevers: 163-176.

Heckman, J.J. (2006) 'Skill formation and the economics of investing in disadvantaged children', Science, 5782: 1901-1902.

Heijst, A. van (2005) Menslievende zorg. Een ethische kijk op professionaliteit, Kampen: Klement.

Held, D. en A. McGrew (red.) (2004) Governing globalization. Power, authority and global governance, Oxford: Polity.

Hemerijck, A.C. (2006) Recalibrating Europe's semi-sovereign welfare states, wZB Discussion Paper 103.

Hilders, C. (2006) 'Het goede moment. Vrouwen wachten te lang met kinderen krijgen', Medisch Contact, 61, 31: 1244-1246.

Hoogenboom, M. (2003) Standenstrijd en zekerheid. Een geschiedenis van oude orde en sociale zorg in Nederland (1880-1940), dissertatie Universiteit van Amsterdam. 
Houtkoop, W., R. van der Velden en T. Brandsma (2004) De waarde van de startkwalificatie, Amsterdam: Max Goote Instituut.

Huber, E. en J. Stephens (2001) Development and crisis of the welfare state. Parties and policies in global markets, Chicago: Chicago University Press.

Idenburg, Ph.A. en W. Albeda (red.) (1983) De nadagen van de verzorgingsstaat, Amsterdam: Meulenhoff.

Irrgang, E. en M. Hoeberichts (2006), 'Inkomensongelijkheid in de eenentwintigste eeuw', in: ESB, 91, 4483: 152-153.

Jacobs, B. (2004) 'The lost race between schooling and technology', De Economist, 152, 1: 47-78.

Jacobs, B. en R. van der Ploeg (2005) Guide to reform of higher education. A European perspective, manuscript.

Jansweijer, R.M.A. (2004) 'Te mooi om waar te zijn', ESB, 89, Dossier levensloopbeleid, 26 februari 2004: D25.

Jeurissen, P.P.T. (2005) Houdbare solidariteit in de gezondheidszorg, RVZ-Signalement, Zoetermeer.

Jonkers, P. (2003) Diskwalificatie van wetgeving. De totstandkoming en uitvoering van de Wet bevordering evenredige arbeidsdeelname allochtonen, Amsterdam: Spinhuis.

Kahneman, D. en A. Tversky (red.) (200o) Choices, values, and frames, Cambridge: Cambridge University Press.

Kam, C.A. en K.P. Goudswaard (2006) 'Sociale zekerheid en arbeidsmarkt', Hoofdstuk 2 in: C.A. de Kam en A.P. Ros (red.) Jaarboek Overheidsfinanciën 20o6, Den Haag: Sdu Uitgevers: $35-56$.

Karsten, S. en P. Sleegers (red.) (2005) Onderwijs en ongelijkheid: grenzen aan de maakbaarheid?, Antwerpen: Garant.

Karsten, S. en W. Meijnen (2005) Leergeld. Sociaal-democratische onderwijspolitiek in een tijd van nieuwe verschillen, Amsterdam: Mets en Schilt.

Katzenstein, P.J. (1985) Small states in world markets. Industrial policy in Europe, Ithaca.

Kaufmann, F. (2003) Varianten des Wohlfahrtstaats. Der deutsche Sozialstaat im internationalen Vergleich, Frankfurt am Main: Suhrkamp.

Knight, F. (1936) The ethics of competition and other essays, London: Allen and Unwin.

Knijn, T. en M. Kremer (1997) 'Gender and the caring dimension of the welfare states: Towards inclusive citizenship’, Social Politics, 4, 3: 328-361.

Knijn, T. en A. Liefbroer (2004) 'De helpende hand', Demos, 20, 10: 84-85.

Knippenberg, H. en B. de Pater (2002) De eenwording van Nederland. Schaalvergroting en integratie sinds 1800 , Nijmegen: sun (zesde druk).

Kohli, M. (1999) Private and public transfers between generations: Linking the family and the state. European Societies 1: 81-104

Komter, A. (2004) Solidariteit en de gift, Amsterdam: Amsterdam University Press.

Koopmans, Y. en J. Schippers (2006) 'De combinatie van betaalde arbeid en zorg in Europa: instituties, regelingen en verzorgingsstaten', in Beleid en Maatschappij, 33, 1: 16-32.

Kremer, M. (2000) Geven en claimen. Burgerschap en informele zorg in Europees perspectief, Utrecht: NIZW.

Kremer, M. (2005) How welfare states care. Culture, gender and citizenship in Europe, dissertatie Universiteit Utrecht. 
Kymlicka, W. (1990) Contemporary political philosophy, Oxford: Clarendon Press.

Land, H. en H. Rose (1985) 'Compulsory altruism for some or an altruistic society for all?', in: P. Bean, J. Ferris en D. Whynes (red.) In defence of welfare, London: Tavistock.

Latten, J. J. (2005) Zwanger van segregatie, oratie Universiteit van Amsterdam.

Lazear, E.P. (1995) Personnel economics, Cambridge Mass./London: The MIT Press.

Leseman, P. (2005) Achterstandenbeleid in de voor- en vroegschoolse periode: discussiepunten, manuscript Wetenschappelijke Raad voor het Regeringsbeleid.

Lesthaeghe, R. en D.J. van de Kaa (1986) ‘Bevolking: groei en krimp’, Boekaflevering Mens en Maatschappij, 61, Deventer: Van Loghum Slaterus: 9-24.

Levy, J.D. (1999) Tocqueville's revenche. State, society, and economy in contemporary France, Cambridge, MA: Harvard University Press.

Lewis, J. en R. Surender (2004) Welfare state change. Toward a third way?, Oxford: Oxford University Press.

Lieshout, H. van (1996) Duaal monopolie. Een analyse van het Duits duale stelsel van beroepsonderwijs vanuit Nederlands perspectief, Amsterdam: Max Goote Instituut.

Lijphart, A. (1968) The politics of accommodation. Pluralism and democracy in the Netherlands, Berkeley: University of California Press.

Lyke, S. van der (200o) Georganiseerde liefde: politieke bemoeienis met zorg in de privésfeer, Utrecht: Jan van Arkel.

Mannoury, J. en I.P. Asscher-Vonk (1987) Hoofdtrekken van de sociale verzekering, Alphen aan den Rijn: Samsom Tjeenk Willink.

Marx, I. (2004) The labour demand shift against the less skilled and minimum income protection, proefschrift Universiteit van Antwerpen.

Meester, E. de, I. Esveldt, C.H. Mulder en G. Beets (2005) 'De invloed van levensloopkenmerken en waardeoriëntaties op vrijwillige kinderloosheid', Mens en Maatschappij, 80, 2: 119-142.

Meijnen, W. (2005a) Onderwijs en het meritocratisch ideaal, Amsterdam: sco Kohnstamm Instituut.

Meijnen, W. (2005b) Vermaatschappelijking van het onderwijs. Enkele suggesties, manuscript Wetenschappelijke Raad voor het Regeringsbeleid.

Metzler, G. (2003) Der Deutsche Sozialstaat. Vom Bismarckschen Erfolgsmodell zum Pflegefall, München: Deutsche Verlagsanstalt.

Minister Hoogervorst (2005) Werken aan houdbaarheid, Tinbergen-lezing voor de Koninklijke Vereniging voor de Staathuishoudkunde, 21 oktober 2005.

Ministerie van Economische Zaken en Ministerie van Sociale Zaken en Werkgelegenheid (2004) Kiezen voor groei. Welvaart voor nu en later, Den Haag: Ministerie van Economische Zaken.

Ministerie van Financiën (2005) De lessen uit de Nordics. Een verkennende studie door het Ministerie van Financiën, Den Haag.

Ministerie van Onderwijs, Cultuur en Wetenschap (2005) Onderwijsprofiel van Nederland. Analyse en samenvatting van 'Education at a glance 2005', Den Haag.

Ministerie van Sociale Zaken en Werkgelegenheid (2004) Nieuwe accenten op sociale zekerheid en arbeidsmarkt, Den Haag.

Ministerie van Sociale Zaken en Werkgelegenheid (2005) Arbeidsmigratie en sociale zekerheid, Den Haag. 
Ministerie van Sociale Zaken en Werkgelegenheid (2005) Beleidsverkennende notitie arbeidsmigratie, Den Haag.

Ministerie van Sociale Zaken en Werkgelegenheid (2006) Ontwikkelingen en keuzes in het stelsel van werk en inkomen, Brief aan de Tweede Kamer 28 juni 2006.

Ministerie van Sociale Zaken en Werkgelegenheid (V. Thio) (2002) De inkomenspositie van ouderen: toekomstige ontwikkelingen en fiscalisering van de AOW -premie, Werkdocument no. 230, Den Haag.

Ministerie van Volksgezondheid, Welzijn en Sport (2005) Brancherapporten, http://www.brancherapporten.minvws.nl, 18 mei 2005.

Ministerie van Volksgezondheid, Welzijn en Sport (2005) Ouderenbeleid in het perspectiefvan de vergrijzing, Den Haag.

Mol, A. (2005) De logica van het zorgen. Actieve patiënten en de grenzen van het kiezen. Amsterdam: Van Gennep.

Musterd, S. en R. van Kempen (200o) The spatial dimensions of urban social exclusion and integration: a European comparison, Urbex Series, No. 8, Amsterdam: Amsterdam Study Centre for the Metropolitan Environment.

Musterd, S. en S. de Vos (2005) 'Woondynamiek in concentratiewijken', blz. 123-138 in: H. Nicolaas, A. Sprangers en A. Zorlu, (red.) 'Migranten op de arbeidsmarkt. Meeste vluchtelingen hebben binnen vijf jaar werk', Demos, 21, maart: 17-20.

Myles, J. (2002) 'A new social contract for the elderly?', in: G. Esping-Andersen, Why we need a new welfare state, Oxford: Oxford University Press: 130-172.

Nederlands Consortium Kinderopvang Onderzoek (2005) Kwaliteit van Nederlandse kinderdagverblijven: Trends in kwaliteit in de jaren 1995-2005, Amsterdam: SCOKohnstamm Instituut.

Nederlands Instituut voor Onderzoek van de Gezondheidszorg (2003) 'Quick scan' kwaliteit van zorg vanuit cliëntenperspectief in de care-sector, Utrecht: NIVEL.

Okun, A.M. (1975) Equality and efficiency. The big trade-off, Washington: Brookings.

Onderwijsraad (2005) Spreidingsmaatregelen onder de loep, Den Haag: Onderwijsraad.

Onderwijsraad (2005a) Groot groeien in het onderwijs, Den Haag: Onderwijsraad.

Onderwijsraad (2005b) Variëteit in schaal, Den Haag: Onderwijsraad.

Onderwijsraad (2005c) De helft van Nederland hoogopgeleid, Den Haag: Onderwijsraad.

Onderwijsraad (2005d) Betere overgangen in het onderwijs, Den Haag: Onderwijsraad.

Onderwijsraad (2006) Onderwijs in cultuur, Den Haag: Onderwijsraad.

Oorschot, W. van (2002) 'Individual motives for contributing to welfare benefits in the Netherlands', in Policy and politics: studies of local government and its services, 30, 1: 31-46.

Oorschot, W. van (2006) 'Making the difference in social Europe: deservingness perceptions among citizens of European welfare states', Journal of European Social Policy, 16, 1: 23-42.

Organisatie voor Strategisch Arbeidsmarktonderzoek (2005) Postinitiële scholing: van patstelling naar pact, Tilburg: OsA.

Organisation for Economic Cooperation and Development (2001) Starting strong. Early childhood education and care, Parijs: OECD.

Organisation for Economic Co-operation and Development (2004) Employment outlook 2004, Parijs: OECD. 
Organisation for Economic Cooperation and Development (2004b) Education at a glance 2004, Parijs: OECD.

Organisation for Economic Cooperation and Development (2005) Ageing and employment in the Netherlands, Parijs: OECD.

Organisation for Economic Cooperation and Development (2005) Education at a glance 2005, Parijs: OECD.

Organisation for Economic Cooperation and Development (2005) Long-term care for older people, Parijs: OECD.

Organisation for Economic Cooperation and Development (2005a) Health at a glance, Parijs: OECD.

Organisation for Economic Co-operation and Development (2006) Live longer, work longer. Ageing and employment policies, Parijs: OECD.

Organisation for Economic Co-operation and Development (H. Immervoll en D. Barber) (2005e) 'Can parents afford to work? Childcare costs, tax-benefits and work incentives', OECD Social Employment and Migration Working Papers, no. 31, Parijs: OECD.

Organisation for Economic Cooperation and Development (J. Lundsgaard) (2005c) 'Consumer direction and choice in long-term care for older persons, including payments for informal care: How can it help improve care outcomes, employment and fiscal sustainability', OECD Health Working Papers, no. 20, Parijs: OECD.

Organisation for Economic Co-operation and Development (M. Förster en M. d'Ercole) (2005d) 'Income distribution in OECD countries in the second half of the 1990's', OECD Working Paper, no. 22, Parijs: OECD.

Oud, P.J. (1970) Het constitutioneel recht van het Koninkrijk der Nederlanden, Zwolle: W.E.J. Tjeenk Willink.

Parlementaire Enquêtecommissie-Buurmeijer (1993) Enquête naar het functioneren van de organen belast met de uitvoering van de sociale-verzekeringswetten, Tweede Kamer, 1992-1993, 22 730, 7 september 1993.

Paulle, B. (2005) Anxiety and intimidation in the Bronx and the Bijlmer. An ethnographic comparison of two schools. Amsterdam: Dutch University Press.

Peper, A. (1972) Vorming van welzijnsbeleid. Evolutie en evaluatie van het opbouwwerk, (proefschrift Rotterdam), Meppel: Boom.

Pestieau, P. (2006) The welfare state in the European Union. Economic and social perspectives, Oxford: Oxford University Press.

Peters, D. (2006) Tot elkaar veroordeeld. Een analyse van de vooralsnog vrijblijvende aanpak van etnische segregatie in het basisonderwijs, Utrecht: Sardes.

Pettigrew, T.F. (1998) 'Intergroup contact theory,' in: Annual Review of Psychology, 49: $65-85$.

Phalet, K. e.a. (2004) Islam in de multi-culturele samenleving. Opvattingen van jongeren in Rotterdam, Utrecht: Ercomer.

Pierson, C. (1998) Beyond the welfare state? The new political economy of welfare, Cambridge: Polity Press (second edition).

Pierson, P. (red.) (2001) The new politics of the welfare state, Oxford: Oxford University Press.

Piketty, T. (2005) 'Top income shares in the long run. An overview', in: Journal of the European Economic Association, 3, 2: 1-11. 
Piketty, T. en E. Saez (2006) 'The evolution of top incomes. A historical and international perspective', in: NBER Working Paper Series no. 11955.

Powell, M.A. en M. Hewitt (2002) Welfare state and welfare change, Buckingham: Open University Press.

Prick, L. (2006) Drammen, dreigen, draaien. Hoe het onderwijs twintig jaar lang vernieuwd werd, Amsterdam: Mets en Schilt.

Prismant (2005) De arbeidsmarkt voor verpleegkundigen, verzorgenden en sociaal-pedagogen in de zorgsector 2004-2008, Utrecht.

Raad van Economisch Adviseurs (2006) De woningmarkt uit het slot, Advies aan de Tweede Kamer, 28 maart 2006.

Raad voor de Volksgezondheid en Zorg (2005) Mensen met een beperking in Nederland. De AWBZ in perspectief, Zoetermeer.

Raad voor de Volksgezondheid en Zorg (A.J. Struijs) (2006) Informele zorg. Het aandeel van mantelzorgers en vrijwilligers in de langdurige zorg, Achtergrondstudie uitgebracht door de Raad voor Volksgezondheid en Zorg bij het advies Mensen met een beperking in Nederland, Zoetermeer.

Raad voor de Volksgezondheid en Zorg (F.B.M. Sanders) (2006) Briefadvies Duurzame solidariteit, Zoetermeer, 18 januari 2006.

Raad voor Maatschappelijke Ontwikkeling (2005a) Eenheid, verscheidenheid en binding. Over concentratie en integratie van etnische minderheden in Nederland, Den Haag: Sdu.

Raad voor Maatschappelijke Ontwikkeling (2005b) Niet langer met de ruggen naar elkaar. Een advies over verbinden, Den Haag: Sdu.

Ramakers, C.C. en M. van den Wijngaart (2005) Persoonsgebonden budget en mantelzorg. Onderzoek naar de aard en omvang van de betaalde en onbetaalde mantelzorg, Nijmegen: ITs.

Rawls, J. (1971) A theory of justice, Harvard: Harvard University Press.

Rele, H. ter (2006) 'Intergenerationele herverdeling bij afschaffing hypotheekrenteaftrek', ESB, 91, 4490: 330-331.

Rezwani, N., en P. Hendrix (2002) Verplicht sparen voor het werkloosheidsrisico, Den Haag: Ministerie van szw.

Rijksinstituut voor Volksgezondheid en Milieu/Sociaal en Cultureel Planbureau (A. van den Berg Jeths, J.M. Timmermans, N. Hoeymans en I.B. Woittiez) (2004) Ouderen nu en in de toekomst. Gezondheid, verpleging en verzorging 2000-202O, Bilthoven: RIVM.

Rodrik, D. (1997) Has globalisation gone too far?, Washington D.C.: Institute for International Economics.

Roemer, J. (2000) 'Equality of opportunity', in K. Arrow, S. Bowles en S. Durlauf (red.) Meritocracy and economic inequality, Princeton: Princeton University Press.

Rooy, P. de (2005) 'O zaal'ge tijd. Sociaal-democratie en onderwijs', in S. Karsten en W. Meijnen (red.) Leergeld. Sociaal-democratische onderwijspolitiek in een tijd van nieuwe verschillen, Amsterdam: Mets en Schilt.

Rosanvallon, P. (2000) The new social question. Rethinking the welfare state, Princeton Princeton University Press.

Rostgaard, T. (2004) With due care: social care for the young and the old across Europe, dissertatie, The Danish National Institute of Social Research. 
Rutten, S. (2004) Een eindeloze haastklus. Een halve eeuw gelijkekansenbeleid in het Amerikaanse onderwijs, Utrecht: Sardes.

Saari, J. (2006) The Europeanisation of social protection, Ministry of Social Affairs and Health, prepublicatie voor Europees Voorzitterschapsconferentie 8-9 november 2006 te Helsinki (te publiceren).

Sandel, M. (1982) Liberalism and the limits of justice. Cambridge: Cambridge University Press.

Sanders, F.B.M. (2006) 'Bekijk de cijfers en oordeel dan over solidariteit in de zorg', de Volkskrant, 24 februari 2006.

Sapir, A. (2005) Globalisation and the reform of European social models, achtergrondpublicatie voor informele ECOFIN-bijeenkomst in Manchester, september 2005.

Sarasa, S. (2005) How do midlife women manage adult care and labour in different welfare regimes?, Paper presented at the ESPAnet Conference 2005, University of Fribourg, Switzerland, 22-24 September 2005.

Sassen, S. (2005) The state and globalization: denationalized work and international power shifts, WRR-lecture 2005, Den Haag.

Scharpf, F.W. (200o) Globalization and the welfare state. Constraints, challenges and vulnerabilities, Paper The Year 2000 International Research Conference on Social Security, Helsinki, 25-27 September 2000.

Scharpf, F.W. en V.A. Schmid (eds.) (200o), Welfare and work in the open economy, 2 Volumes, Oxford: Oxford University Press.

Schillemans, T. en S. Verhagen (2005) 'Van spreidingsbeleid naar verleidingsbeleid', in: Socialisme \& Democratie, 9: 13-22.

Schludi, M. (2001) 'Pension reform in European social insurance countries', paper gepresenteerd op tweejaarlijkse bijeenkomst European Community Studies Association, Madison, Wisconsin 31 mei-2 juni 2001.

Schmid, G. (2005) Sharing risks: on social risk management and the governance of labour market transitions, Amsterdam: Hugo Sinzheimer-Lecture 10 november 2005.

Schmid, G. (2006) 'Social risk management through transitional labour markets', SocioEconomic Review, 4: 1-33.

Schnabel, P. (2004) Een eeuw van verschil: van achterstelling tot zelfontplooiing: de dynamiek van het gelijkheidsideaal, inaugurele rede Universiteit Utrecht, Den Haag: Sociaal en Cultureel Planbureau.

Schut, F.T. (2005) Gereguleerde concurrentie in de planbare curatieve GGZ? Een economische analyse, Amersfoort: GGZ Nederland.

Sen, A. (1995) Inequality re-examined, New York: Russell Sage Foundation.

Sennett, R. (2003) Respect in an age of inequality, New York: Norton.

Sennett, R. (2006) The culture of the new capitalism, New Haven: Yale University Press.

Singh Dami, R., J. Squires en T. Modood (2006) Developing positive action policies. Learning from the experiences of Europe and North America, Bristol: Centre for the Study of Ethnicity and Citizenship.

Sociaal en Cultureel Planbureau/WODC/CBS (2005) Jaarrapport Integratie 2005, Den Haag: SCP/WODC/CBS.

Sociaal en Cultureel Planbureau (2002) Zelfbepaalde zekerheden. Individuele keuzevrijheid in de sociale verzekeringen: draagvlak, benutting en determinanten, Den Haag: SCP. 
Sociaal en Cultureel Planbureau (2003) De sociale staat van Nederland 2003, Den Haag: SCP.

Sociaal en Cultureel Planbureau (2003) Profijt van de overheid. De personele verdeling van gebonden overheidsuitgaven en -inkomsten, Den Haag: SCP.

Sociaal en Cultureel Planbureau (2003) Rapportage minderheden 2003, Den Haag: SCP.

Sociaal en Cultureel Planbureau (2005) De steun voor de verzorgingsstaat in de publieke opinie, 1977-2002. Een analyse van trends in meningen, Den Haag: SCP.

Sociaal en Cultureel Planbureau (2005a) Uit elkaars buurt. De invloed van etnische concentratie op integratie en beeldvorming, Den Haag: SCP.

Sociaal en Cultureel Planbureau (2005b) Arbeidsmobiliteit in goede banen. Oorzaken van baan- en functiewisselingen en gevolgen voor de kenmerken van het werk, Den Haag: SCP.

Sociaal en Cultureel Planbureau (2005c) De sociale staat van Nederland 2005, Den Haag: SCP.

Sociaal en Cultureel Planbureau (2006) Hoe het werkt met kinderen. Moeders over kinderopvang en werk, Den Haag: SCP.

Sociaal en Cultureel Planbureau (2006a) Rapportage Ouderen 2006, Den Haag: SCP.

Sociaal en Cultureel Planbureau (2006b) Hoge (jeugd)werkloosheid onder etnische minderheden, Den Haag: SCP.

Sociaal en Cultureel Planbureau (A. de Boer, red.) (2005) Kijk op informele zorg, Den Haag: SCP.

Sociaal en Cultureel Planbureau (H. van Luyn en S. Keuzenkamp) (2004) Werkt verlof? Het gebruik van regelingen voor verlof en aanpassing van de arbeidsduur, Den Haag: SCP.

Sociaal en Cultureel Planbureau (J. Timmermans en I. Woittiez) (2004) Verpleging en verzorging verklaard, Den Haag: SCP.

Sociaal en Cultureel Planbureau (J. Timmermans, A. de Boer en J. Iedema) (2005) De mantelval. Over de dreigende overbelasting van de mantelzorger, Den Haag: SCP.

Sociaal en Cultureel Planbureau (S. Keuzenkamp en A. Merens) (2006) Sociale atlas van vrouwen uit etnische minderheden, Den Haag: SCP.

Sociaal en Cultureel Planbureau/Centraal Bureau voor de Statistiek (2004) Emancipatiemonitor 2004, Den Haag: SCP.

Sociaal-Economische Raad (2004) Met Europa, meer groei, Den Haag: SER.

Sociaal-Economische Raad (2005) Van alle leeftijden, Advies 05/O2, Den Haag: SER.

Sorensen, P.B., M.I. Hansen en A.L. Bovenberg (2006) Individual savings accounts and the life-cycle approach to social insurance, Paper for the Netspar-Conference on Reinventing the welfare state, Den Haag, 27-28 april 2006.

Spiess, C.K. en U. Schneider (2002) Midlife caregiving and employment: an analysis of adjustments in work hours and informal care for female employees in Europe, Economics Working Papers 9, februari 2002, European Network of Economic Policy Research Institutes, Brussels: ENEPRI CEPS.

Stichting voor Economisch Onderzoek (2006) Een nieuw fundament. Borging van publieke belangen op de woningmarkt, Amsterdam: SEO.

Streeck, W. (1997) 'Beneficial Constraints: on the economic limits of rational voluntarism', in: J. R. Hollingsworth en R. Boyer (eds.) Contemporary capitalism: the embeddedness of institutions, Cambridge: Cambridge University Press: 197-219. 
Studiegroep Begrotingsruimte (2006) Twaalfde rapport. Vergrijzing en houdbaarheid, Den Haag: Ministerie van Financiën.

Swaan, A. de (1989) Zorg en de staat. Welzijn, onderwijs en gezondheidszorg in Europa en de Verenigde Staten in de nieuwe tijd, Amsterdam: Bert Bakker.

Taylor, C. (1989) Sources of the self. The making of the modern identity, Cambridge: Cambridge University Press.

Taylor-Gooby, P. (red.) (2004) New risks, new welfare: the transformation of the European welfare state, Oxford: Oxford University Press.

Thoenes, P. (1962) De elite in de verzorgingsstaat. Sociologische proeve van een terugkeer naar domineesland, Leiden: Stenfert Kroese.

Tijdelijke adviescommissie Onderwijs-Arbeidsmarkt (1990) Onderwijs-arbeidsmarkt: Naar een werkzaam traject, Alphen aan den Rijn: Samsom Tjeenk Willink.

Tinbergen, J. (1975) Income distribution, Amsterdam: North-Holland Publishing Company.

Tjadens, F. et al. (2005) De AWBZ internationaal bekeken. Langdurige zorg in het buitenland, Achtergrondstudie uitgebracht door de Raad voor de Volksgezondheid en Zorg bij het advies Mensen met beperkingen in Nederland, Zoetermeer.

Twigg, J. en K. Atkin (1994) Carers perceived. Policy and practice in informal care. Buckingham/Philadelphia: Open University Press.

Uitermark, J. en J.W. Duyvendak (2006) Ruimte maken voor straatburgerschap, Rotterdam: Projectbureau Sociale Integratie Gemeente Rotterdam.

Unger, R.M. (1984) Passion. An essay on personality, New York: Free Press.

Ungerson, C. (2004) 'Whose empowerment and independence? A cross-national perspective on cash for care schemes', in Ageing and Society 24: 189-212.

Veen, R. van der (2005) Nieuwe vormen van solidariteit, Amsterdam: WBS.

Verkuyten, M. (2005) The social psychology of ethnic identity, Hove: Psychology Press.

Verkuyten, M. (2006) 'Groepsidentificaties en intergroeprelaties onder Turkse Nederlanders', in: Mens en Maatschappij, 81, 1: 64-84.

Visser, J. en A.C. Hemerijck (1997) 'A Dutch miracle'. Job growth, welfare reform and corporatism in the Netherlands, Amsterdam: Amsterdam University Press.

Vollenga, I., M. Duijnstee, L. Tielen en J. Keesom (red.) (2001) Mantelzorg van morgen. Een verkenning van toekomstbeelden, Utrecht: NIZW.

Vos, M.L. (2005) 'Geen generatiestrijd als de babyboomers eerlijk delen', in: Waterstof, 8, http://www.waterlandstichting.nl, november 2005.

Vries, G. de. (1994) Het pedagogisch regime. Amsterdam: Bert Bakker.

Wetenschappelijke Raad voor het Regeringsbeleid (1994) Belang en beleid. Naar een verantwoorde uitvoering van de werknemersverzekeringen, Rapporten aan de regering nr. 45, Den Haag: Sdu Uitgevers.

Wetenschappelijke Raad voor het Regeringsbeleid (1999) Generatiebewust beleid, Rapporten aan de regering nr. 55, Den Haag: Sdu Uitgevers.

Wetenschappelijke Raad voor het Regeringsbeleid (2000) Doorgroei van arbeidsparticipatie, Rapporten aan de regering nr. 57, Den Haag: Sdu Uitgevers.

Wetenschappelijke Raad voor het Regeringsbeleid (2003) Slagvaardigheid in de Europabrede Unie, Rapporten aan de regering nr. 65, Den Haag: Sdu.

Wetenschappelijke Raad voor het Regeringsbeleid (2004) Bewijzen van goede dienstverlening, Rapporten aan de regering nr. 7o, Amsterdam: Amsterdam University Press. 
Wetenschappelijke Raad voor het Regeringsbeleid (2005) 'Notitie toekomstbestendige arbeidsmarkt en sociale zekerheid', in: Vaste Commissie voor Sociale Zaken en Werkgelegenheid van de Tweede Kamer der Staten-Generaal, Syllabus nieuwe accenten op het terrein van werk en inkomen, 18 april 2005.

Wetenschappelijke Raad voor het Regeringsbeleid (2005) Vertrouwen in de buurt, Rapporten aan de regering nr. 72, Amsterdam: Amsterdam University Press.

Wetenschappelijke Raad voor het Regeringsbeleid (2006) Lerende overheid, Rapporten aan de regering nr. 75, Amsterdam: Amsterdam University Press.

Wilterdink, N. (2002) 'De ongelijkheid van inkomens: trends en ontwikkelingen', in: J.C. Vrooman (red.) Sociale ongelijkheid: breuk of continuïteit?, Actualiteitencollege van de Nederlandse Sociologische Vereniging, Amsterdam: siswo/Nsv.

Wolf, A. (2001) Does education matter? Londen: Penguin.

Yerden, I. (2005) Allochtone mantelzorg. Van traditionele plicht naar financiële verplichting, in: M. Hurenkamp en M. Kremer (red.) Vrijheid verplicht. Over tevredenheid en de grenzen van keuzevrijheid, Amsterdam: Van Gennep: 162-185.

Zanten, M. van (2006) Mevrouw, mijne heren... 25 vrouwen over de weg naar de top Amsterdam: Uitgeverij Archipel.

Zijderveld, A.C. (1999) The waning of the welfare state. The end of comprehensive state succor, New Brunswick/London: Tranasaction Publishers. 


\section{RAPPORTEN AAN DE REGERING}

\section{Eerste raadsperiode (1972-1977)}

1 Europese Unie

2 Structuur van de Nederlandse economie

3 Energiebeleid

Gebundeld in één publicatie (1974)

4 Milieubeleid (1974)

5 Bevolkingsgroei (1974)

6 De organisatie van het openbaar bestuur (1975)

7 Buitenlandse invloeden op Nederland: Internationale migratie (1976)

8 Buitenlandse invloeden op Nederland: Beschikbaarheid van wetenschappelijke en technische kennis (1976)

9 Commentaar op de Discussienota Sectorraden (1976)

10 Commentaar op de nota Contouren van een toekomstig onderwijsbestel (1976)

11 Overzicht externe adviesorganen van de centrale overheid (1976)

12 Externe adviesorganen van de centrale overheid (1976)

13 Maken wij er werk van? Verkenningen omtrent de verhouding tussen actieven en niet-actieven (1977)

14 Interne adviesorganen van de centrale overheid (1977)

15 De komende vijfentwintig jaar - Een toekomstverkenning voor Nederland (1977)

16 Over sociale ongelijkheid - Een beleidsgerichte probleemverkenning (1977)

Tweede raadsperiode (1978-1982)

17 Etnische minderheden (1979)

A. Rapport aan de Regering

B. Naar een algemeen etnisch minderhedenbeleid?

Plaats en toekomst van de Nederlandse industrie (1980)

Beleidsgerichte toekomstverkenning

Deel 1: Een poging tot uitlokking (1980)

Democratie en geweld. Probleemanalyse naar aanleiding van de gebeurtenissen in Amsterdam op 30 april 1980

Vernieuwingen in het arbeidsbestel (1981)

Herwaardering van welzijnsbeleid (1982)

Onder invloed van Duitsland. Een onderzoek naar gevoeligheid en kwetsbaarheid in de betrekkingen tussen Nederland en de Bondsrepubliek (1982)

Samenhangend mediabeleid (1982)

\section{Derde raadsperiode (1983-1987)}

Beleidsgerichte toekomstverkenning

Deel 2: Een verruiming van perspectief (1983)

Waarborgen voor zekerheid. Een nieuw stelsel van sociale zekerheid in hoofdlijnen (1985)

Basisvorming in het onderwijs (1986)

De onvoltooide Europese integratie (1986)

Ruimte voor groei. Kansen en bedreigingen voor de Nederlandse economie in de komende tien jaar (1987)

Op maat van het midden- en kleinbedrijf (1987)

Deel 1: Rapport aan de Regering

Deel 2: Pre-adviezen

31 Cultuur zonder grenzen (1987) 


\section{Vierde raadsperiode (1988-1992)}

Activerend arbeidsmarktbeleid (1987)

Rechtshandhaving (1988)

Allochtonenbeleid (1989)

Van de stad en de rand (1990)

Technologie en overheid (1990)

De onderwijsverzorging in de toekomst (1991)

\section{Vijfde raadsperiode (1993-1997)}

Duurzame risico's. Een blijvend gegeven (1994)

Besluiten over grote projecten (1994)

47 Hoger onderwijs in fasen (1995)

De financiering van de Europese Gemeenschap. Een interimrapport (1987)

Overheid en toekomstonderzoek. Een inventarisatie (1988)

Een werkend perspectief. Arbeidsparticipatie in de jaren '90 (1990)

Milieubeleid. Strategie, instrumenten en handhaafbaarheid (1992)

Grond voor keuzen. Vier perspectieven voor de landelijke gebieden in de Europese Gemeenschap (1992)

Ouderen voor ouderen. Demografische ontwikkelingen en beleid (1993)

Belang en beleid. Naar een verantwoorde uitvoering van de werknemersverzekeringen (1994)

48 Stabiliteit en veiligheid in Europa. Het veranderende krachtenveld voor het buitenlands beleid (1995)

Orde in het binnenlands bestuur (1995)

50 Tweedeling in perspectief (1996)

51 Van verdelen naar verdienen. Afwegingen voor de sociale zekerheid in de 21e eeuw (1997)

52 Volksgezondheidszorg (1997)

53 Ruimtelijke-ontwikkelingspolitiek (1998)

54 Staat zonder land. Een verkenning van bestuurlijke gevolgen van informatie- en communicatietechnologie (1998)

\section{Zesde raadsperiode (1998-2002)}

Generatiebewust beleid (1999)

Doorgroei van arbeidsparticipatie (2000)

Ontwikkelingsbeleid en goed bestuur (2001)

Naar een Europabrede Unie (2001)

60 Nederland als immigratiesamenleving (2001)

61 Van oude en nieuwe kennis. De gevolgen van ICT voor het kennisbeleid (2002)

62 Duurzame ontwikkeling. Bestuurlijke voorwaarden voor een mobiliserend beleid (2002)

63 De toekomst van de nationale rechtsstaat (2002)

64 Beslissen over biotechnologie (2003)

65 Slagvaardigheid in de Europabrede Unie (2003)

66 Nederland handelsland. Het perspectief van de transactiekosten (2003)

67 Naar nieuwe wegen in het milieubeleid (2003) 


\section{Zevende raadsperiode (2003-2007)}

Waarden, normen en de last van het gedrag (2003)

De Europese Unie, Turkije en de islam (2004)

71 Focus op functies. Uitdagingen voor een toekomstbestendig mediabeleid (2005)

72 Vertrouwen in de buurt (2005)

73 Dynamiek in islamitisch activisme. Aanknopingspunten voor democratisering en mensenrechten (2006)

$74 \quad$ Klimaatstrategie - tussen ambitie en realisme (2006)

75 Lerende overheid. Een pleidooi voor probleemgerichte politiek (2006)

Rapporten aan de Regering nrs $1 \mathrm{t} / \mathrm{m} 67$ en publicaties in de reeks Voorstudies en achtergronden zijn niet meer leverbaar. Alle studies van de WRR zijn beschikbaar via de website www.wrr.nl.

Rapporten aan de Regering nrs $68 \mathrm{t} / \mathrm{m} 75$ zijn verkrijgbaar in de boekhandel of via Amsterdam University Press, Prinsengracht 747-751, 1017 JX Amsterdam (www.aup.nl). 


\section{VERKENNINGEN}

\section{Zevende raadsperiode (2003-2007)}

1 Jacques Pelkmans, Monika Sie Dhian Ho en Bas Limonard (red.) (2003) Nederland en de Europese grondwet

2 P.T. de Beer en C.J.M. Schuyt (red.) (2004) Bijdragen aan waarden en normen

3 G. van den Brink (2004) Schets van een beschavingsoffensief. Over normen, normaliteit en normalisatie in Nederland

4 E.R. Engelen en M. Sie Dhian Ho (red.) (2004) De staat van de democratie. Democratie voorbij de staat

5 P.A. van der Duin, C.A. Hazeu, P. Rademaker en I.J. Schoonenboom (red.) (2004) Vijfentwintig jaar later. De Toekomstverkenning van de WRR uit 1977 als leerproces

6 H. Dijstelbloem, P.L. Meurs en E.K. Schrijvers (red.) (2004) Maatschappelijke dienstverlening. Een onderzoek naar vijf sectoren

7 W.B.H.J. van de Donk, D.W.J. Broeders en F.J.P. Hoefnagel (red.) (2005) Trends in het medialandschap. Vier verkenningen

8 G. Engbersen, E. Snel en A. Weltevrede (2005) Sociale herovering in Amsterdam en Rotterdam. Eén verhaal over twee wijken

9 D.J. Wolfson (2005) Transactie als bestuurlijke vernieuwing. Op zoek naar samenhang in beleid en uitvoering

10 Nasr Abu Zayd (2006) Reformation of Islamic Thought. A Critical Historical Analysis

11 J.M. Otto (2006) Sharia en nationaal recht. Rechtssystemen in moslimlanden tusssen traditie, politiek en rechtsstaat

12 P.L. Meurs, E.K. Schrijvers en G.H. de Vries (2006) Leren van de praktijk. Gebruik van lokale kennis en ervaring voor beleid

Alle Verkenningen zijn verkrijgbaar in de boekhandel of via Amsterdam University Press, Prinsengracht 747-751,

1017 JX Amsterdam (www.aup.nl). 


\section{WEBPUBLICATIES}

\section{Zevende raadsperiode (2003-2007)}

WP 1 Opvoeding, onderwijs en jeugdbeleid in het algemeen belang

WP 2 Ruimte voor goed bestuur: tussen prestatie, proces en principe

WP 3 Lessen uit corporate governance en maatschappelijk verantwoord ondernemen

WP 4 Regulering van het bestuur van maatschappelijke dienstverlening: eenheid in verscheidenheid

WP 5 Een schets van het Europese mediabeleid

WP 6 De regulering van media in internationaal perspectief

WP 7 Beleid inzake media, cultuur en kwaliteit: enkele overwegingen

WP 8 Geschiedenis van het Nederlands inhoudelijk mediabeleid

WP 9 Buurtinitiatieven en buurtbeleid in Nederland anno 2004: analyse van een veldonderzoek van 28 casussen

WP 10 Geestelijke gezondheid van adolescenten: een voorstudie

WP 11 De transitie naar volwassenheid en de rol van het overheidsbeleid: een vergelijking van insitutionele arrangementen in Nederland, Zweden, Groot-Brittanië en Spanje

WP 12 Klassieke sharia en vernieuwing

WP 13 Sharia en nationaal recht in twaalf moslimlanden 


\section{Deverzorgingsstaat herwogen}

Aan het begin van de eenentwintigste eeuw staat de verzorgingsstaat voor nieuwe uitdagingen: internationalisering van de economie, europeanisering van het bestuur, vergrijzing en ontgroening van de bevolking, en een grotere sociaal-culturele differentiatie van burgers. Met dit rapport schetst de Wetenschappelijke Raad voor het Regeringsbeleid hoe de verzorgingsstaat met die uitdagingen op een productieve wijze kan omgaan.

De WRR start zijn analyse met het determineren en doordenken van de vier hoofdfuncties van de verzorgingsstaat: verzorgen, verzekeren, verheffen en verbinden. Voor alle vier functies schetst dit rapport de uitdagingen, de invulling die ze moeten aannemen en de beleidsprogramma's die nodig zijn om ze toekomstbestendig te maken. Bovendien presenteert de WRR een weging van de functies ten opzichte van elkaar. De hoofdconclusie is dat de verheffings- en verbindingsfunctie een duidelijke impuls behoeven. De afgelopen jaren is er al ruimschoots aandacht besteed aan hervormingen die gericht zijn op verzekeren en verzorgen; het wordt nu tijd om de verheffings- en de verbindingsfunctie van een geconcentreerde en samenhangende beleidsinspanning te voorzien.

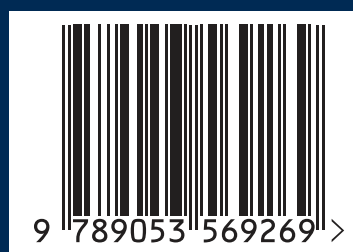

ISBN-13978-90-5356-926-9 I S B N - $1090-5356-926-\mathrm{X}$ 